


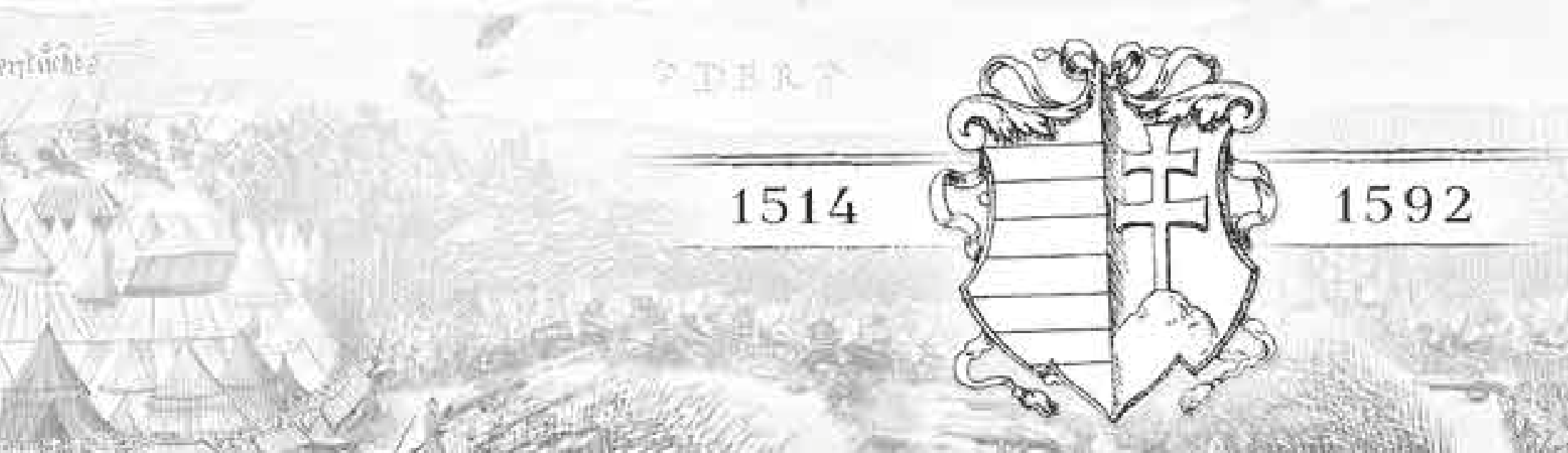

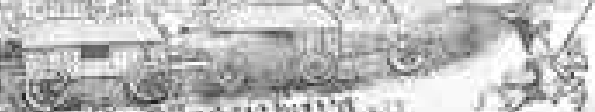 \\ Ixtrition 5 a \\ 2. \\ Pan}

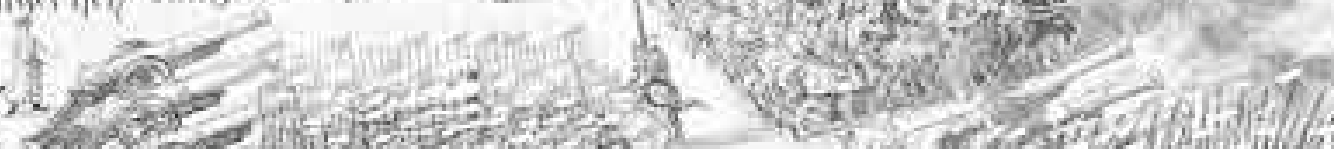

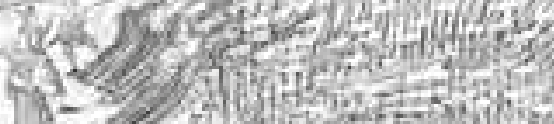

$\rightarrow \rightarrow x^{2}$

11. $x$, the $x=0$

s.

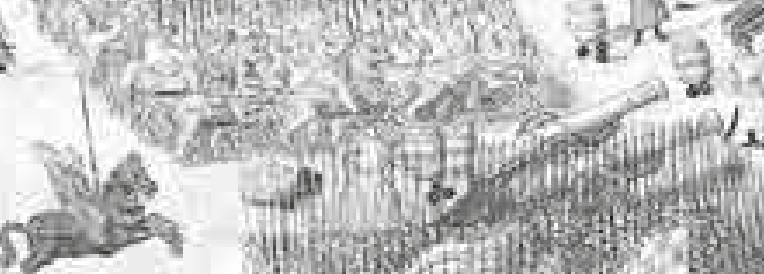
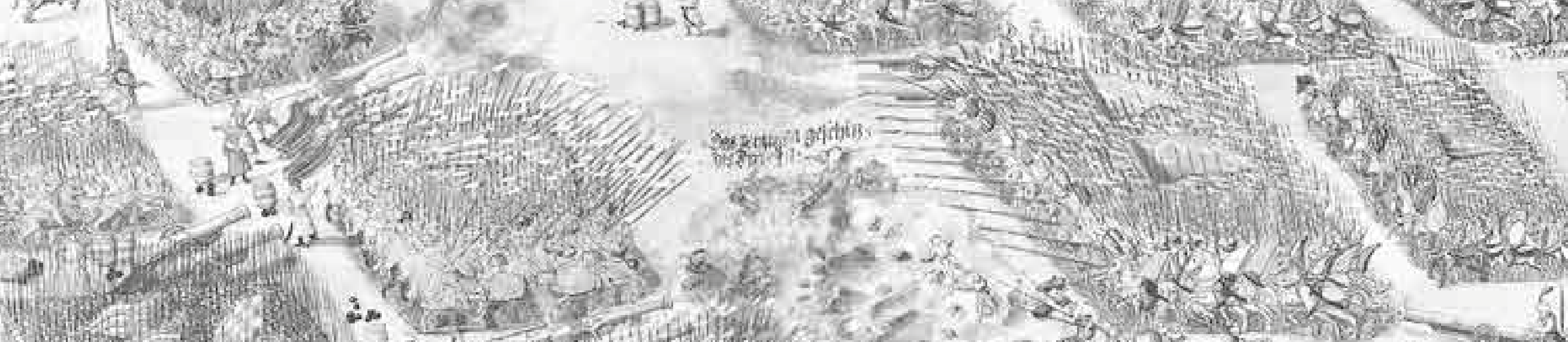

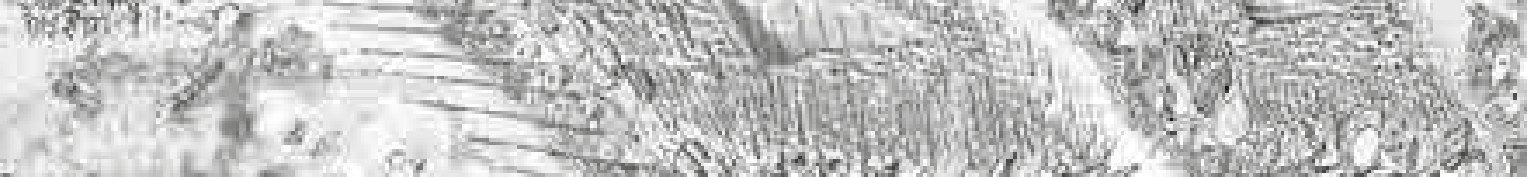
h

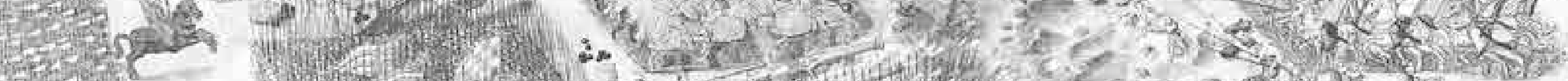
(1)

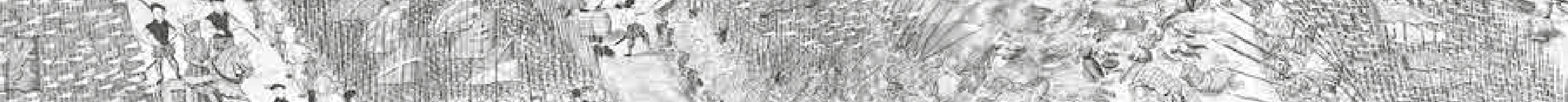

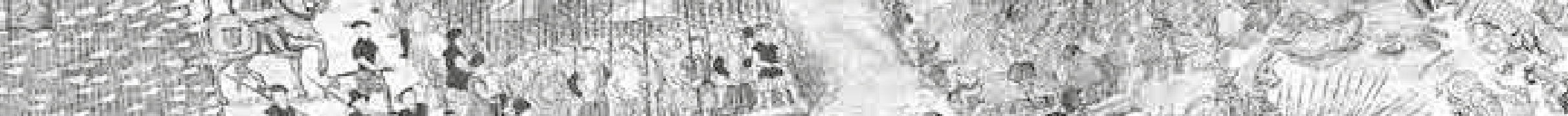

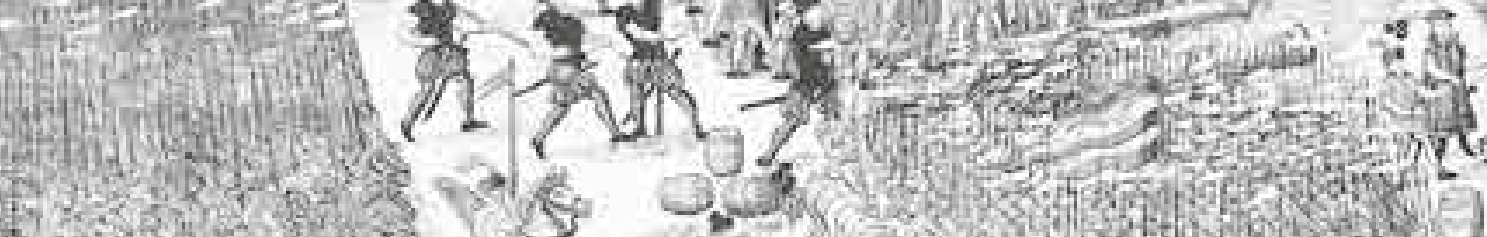

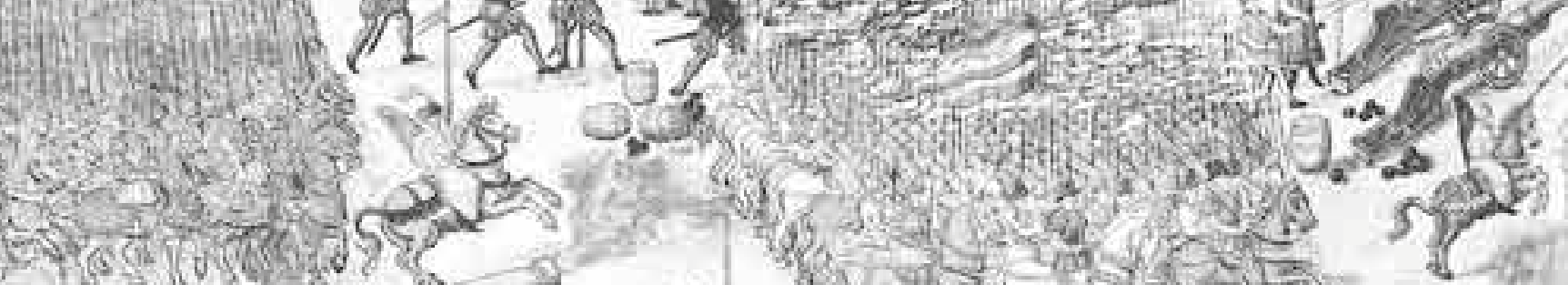
H.

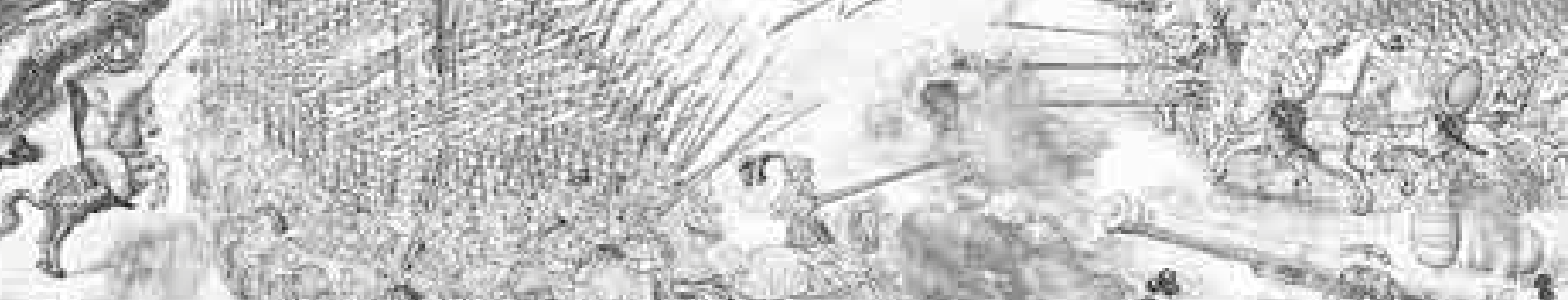

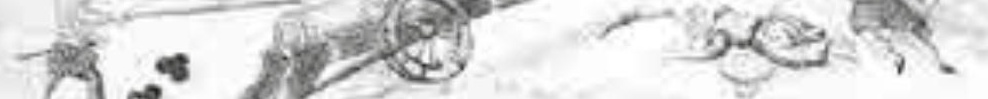

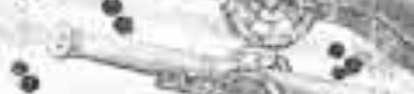


Köszönet mindazoknak a magyar és külföldi közgyüjteménynek és gyüjtőknek, akik hozzájárultak az általuk ôrzött metszetek képének közléséhez. 


\title{
SZALAI BÉLA
}

\section{Igy tudták, így hitték, igy képzelték}

\author{
A magyar történelem kortárs metszeteken

$$
1514 \text { - } 1592
$$

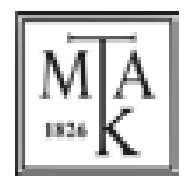


Tördelôszerkesztô

Madár Réka

Képszerkesztő

Csikszentsimoni Veress Péter

Lektorálta

Farkas Gábor Farkas

A könyvben lévő képek egyedi rejtett jelöléssel védettek az engedély nélküli másolás ellen

Progresszív Nyomda Kft Békéscsaba

(C) Szalai Béla 2021

(C) MTA KIK

Minden jog fenntartva

Felelős kiadó

Monok István, az MTA KIK fóigazgatója

ISBN 978-963-508-977-2

DOI 10.36820/metszetek.2021.szalai.2

A könyv megjelenéséhez hozzájárult a Herczeg Alapítvány /Temesvár/ támogatása

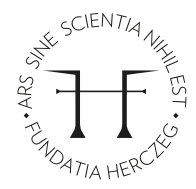




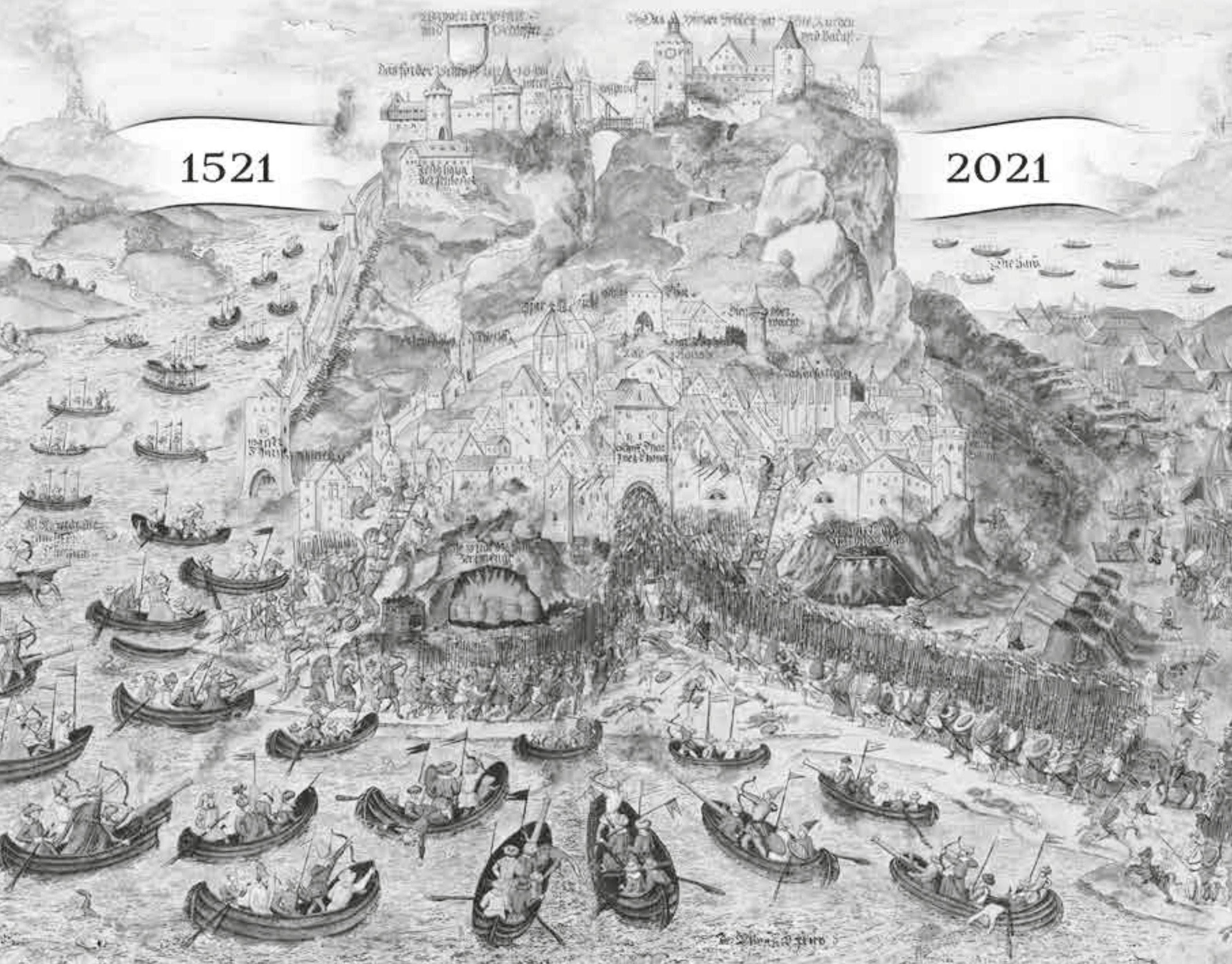




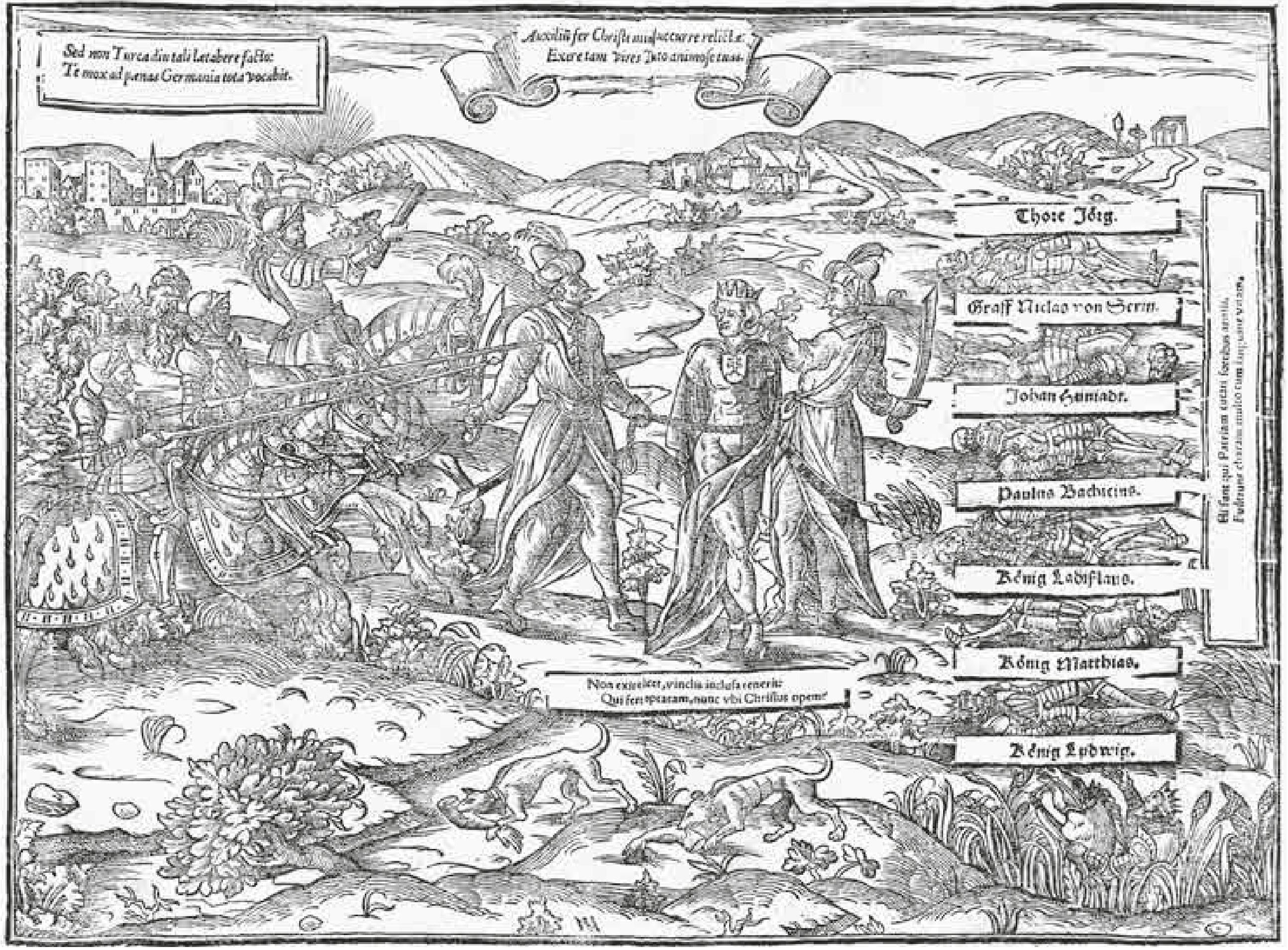

Hungária vértanúsága (Johann Nel, 1581) 


\section{E LőSZÓ}

A 2020. és a 2021. esztendők minden bizonnyal az elmúlt évtizedek legkülönösebb évei voltak. A járvány és a vele járó korlátozások megváltoztatták az életünket, és nagy valószínűséggel hosszabb távon is hatással lesznek - többek között - a tudományos közösség életére, a tudományművelés kereteire és módszereire is. Sok mindenről kiderült, hogy voltaképpen nélkülözhető, sok mindenről viszont éppen az, hogy nem. A kényszerpihenőt szinte valamennyien igyekeztünk kihasználni, leginkább azzal, hogy az időhiány miatt régóta elakadt terveinket próbáltuk tető alá hozni. A jelen kötet, a szerző vallomása szerint, igazából ennek a sajátos időszaknak az eredménye. A szerző, Szalai Béla elmúlt években publikált köteteinek ismeretében azonban biztos vagyok benne, hogy ez a mű a járvány nélkül is megszületett volna. A sokévtizedes gyűjtői tapasztalatot, könyvtári kutatást összegző könyvek az elmúlt években ütemesen követték egymást, járvány nélkül is.

Szalai Béla műveinek tematikája már első közelítésre is egy pontos és átgondolt tudományos program szerint formálódik. 20 évvel ezelőtt kezdte meg a magyarországi településekre vonatkozó metszetanyag publikálását, először területi bontásban, majd pedig tematikai és kronológiai szempontok szerint rendezve. Mindkét megközelítési mód elsődleges kutatói érdeklődést szolgál. A topográfiai rendezés egy adott település vagy vár ábrázolásainak együttes vizsgálatára nyújt alkalmat, míg a tematikus és időbeli rendezés az ábrázolások belső összefüggéseire világít rá, lehetővé teszi a művészek és műhelyek vizsgálatát, az képtípusok elkülönítését. A két megközelítés tehát szervesen kiegészíti egymást, és az elsőből következik a második, amely a metszetek összegyűjtésén túl sokszor alapos kutatómunkát is igényel, mint azt a szerzőnek a Matthias Greischer rézmetsző életét és munkásságát bemutató monográfiája igazolja. A magyar történelemre vonatkozó metszetanyag kronológiai és tematikai feldolgozását a tizenötéves háború idején készített ábrázolások bemutatásával kezdte, az ezt megelőző időszak sokszorosított grafikáinak gyűjteménye a jelen kötet.

Magyarország talán sohasem volt annyira Európa érdeklődésének központjában, mint a török háborúk idején. Izgalmas szempont, hogy ez a kiemelt figyelem pontosan egybeesik a sokszorosított grafika, a nyomtatott hírlevelek és röplapok születésének időszakával. Ezzel magyarázhatjuk, hogy a magyarországi eseményekről viszonylag gazdag képanyag áll rendelkezésünkre, amelyet a történetírás az elmúlt időszakban egyre inkább forrásként (és nem csak illusztrációként) is felhasznál. A metszetek történészi vizsgálata ugyanakkor csakis szisztematikus összegyüjtésük, katalogizálásuk, egymáshoz való viszonyuk tisztázása után lehetséges. Pontosan ezt a fáradságos és nagy tapasztalatot igénylő munkát végezte el Szalai Béla. A korábbi és a mostani könyvével a 16. századra vonatkozó, 1514 és 1606 közötti metszetanyag válik közkinccsé.

A jelen munka időbeli határait a legkorábbi magyarországi vonatkozású metszetek megjelenése és a tizenötéves háború kezdete jelöli ki. Az elsô ábrázolások a Dózsa-féle parasztháborúhoz (1514) kötődnek, ezt követik a Habsburg-Jagelló házassági szerződéssel (1515), Nándorfehérvár bevételével (1521), a mohácsi csatával és közvetlen következményeivel (1526-1528) kapcsolatos metszetek. Ezt követően a metszetek túlnyomó többsége a török hadjáratokhoz kötődik, ugyanakkor meglepő, hogy a századforduló hosszú török háborújához képest mennyivel kevesebb ábrázolás maradt ránk a várháborúk korából. Az első komolyabb metszetanyaggal képviselt esemény az 1566. évi hadjárat, elsősorban Gyula és Szigetvár török kézre kerülése. Ezek a metszetek nemcsak mennyiségileg, hanem a képanyag minősége szempontjából is jelentős ugrást jelentenek a korábbi ábrázolásokhoz képest, és sok szempontból megelőlegezik a tizenötéves háború képanyagának színvonalát. Az úgynevezett háborús békeévekből elsősorban a szikszói csatáról (1588), illetve jelentős magyarországi végvárakról maradtak ránk metszetek. A kötet a korábbi összeállításokhoz képest erősebben válogat a közölt anyagból, nyilván nem függetlenül attól a körülménytől, hogy a 16. századi metszetek a későbbiekhez képest sokkal elnagyoltabbak és kevésbé kvalitásosak, forrásértékük is csekélyebb. Ezzel a szemponttal magyarázható, hogy a válogatás a metszetlapok és röplapok esetében valóban a teljességre törekedett, míg a tudósításokon közölt képek között erősen válogatott. A nem sokszorosított müvészi grafika képei kimaradtak a gyüjteményböl.

Az alapos tanulmányában a szerző az ábrázolt történelmi eseményekre füzi fel a képanyag elemző ismertetését, ami több szempontból is hasznos döntésnek bizonyult. Egyrészt ezzel az eljárásával a korszakkal nem hivatásszerűen foglalkozó olvasók számára is elhelyezi a metszeteket 
a történeti összefüggésrendszerben. A szakemberek számára is nagyon fontosak a metszetek készítőiről, a műhelyekről, a képek keletkezéséről és hitelességéről írott elemzések. Az ábrázolások szisztematikus összegyűjtése mellett az óriási anyagismeretre és tapasztalatra alapuló megfigyelések, a metszetekkel való évtizedes foglalkozás során leszűrt tanulságok jelentik a könyv legnagyobb értékét. Úgy is fogalmazhatunk, hogy egy tudatos és tudóssá váló gyűjtői életmű során felhalmozott tudásanyag válik közkinccsé ebben a kötetben. Olyan ismerethalmaz, amelyet a képi forrásokkal foglalkozó történészek és művészettörténészek sem nélkülözhetnek ezután.

Szalai Béla topográfiai szempontból rendezett metszetkatalógusai, a kiegészítő kötetekkel együtt, immár a teljeségre törekednek, ha a teljességet, miként azt ő maga többször leírta, nem is érhetik el. A magyarországi témájú metszetanyagot kronológiai és tematikai szempontból bemutató két kötet után joggal merül fel az olvasóban az igény: örömmel forgatnánk a 17. századi metszetanyag tematikai szempontú gyüjteményeit is, még ha az anyag mennyisége miatt nem is a teljeset, de legalábbis bizonyos nagy történelmi eseménysorozathoz, mint az 1663/1664. évi hadjárathoz vagy a visszafoglaló háborúkhoz kapcsolódókat. Szalai Béla ügyszeretetét és munkabírását ismerve reményünk talán nem is annyira megalapozatlan.

Budapest, 2021. június 21.

Molnár Antal

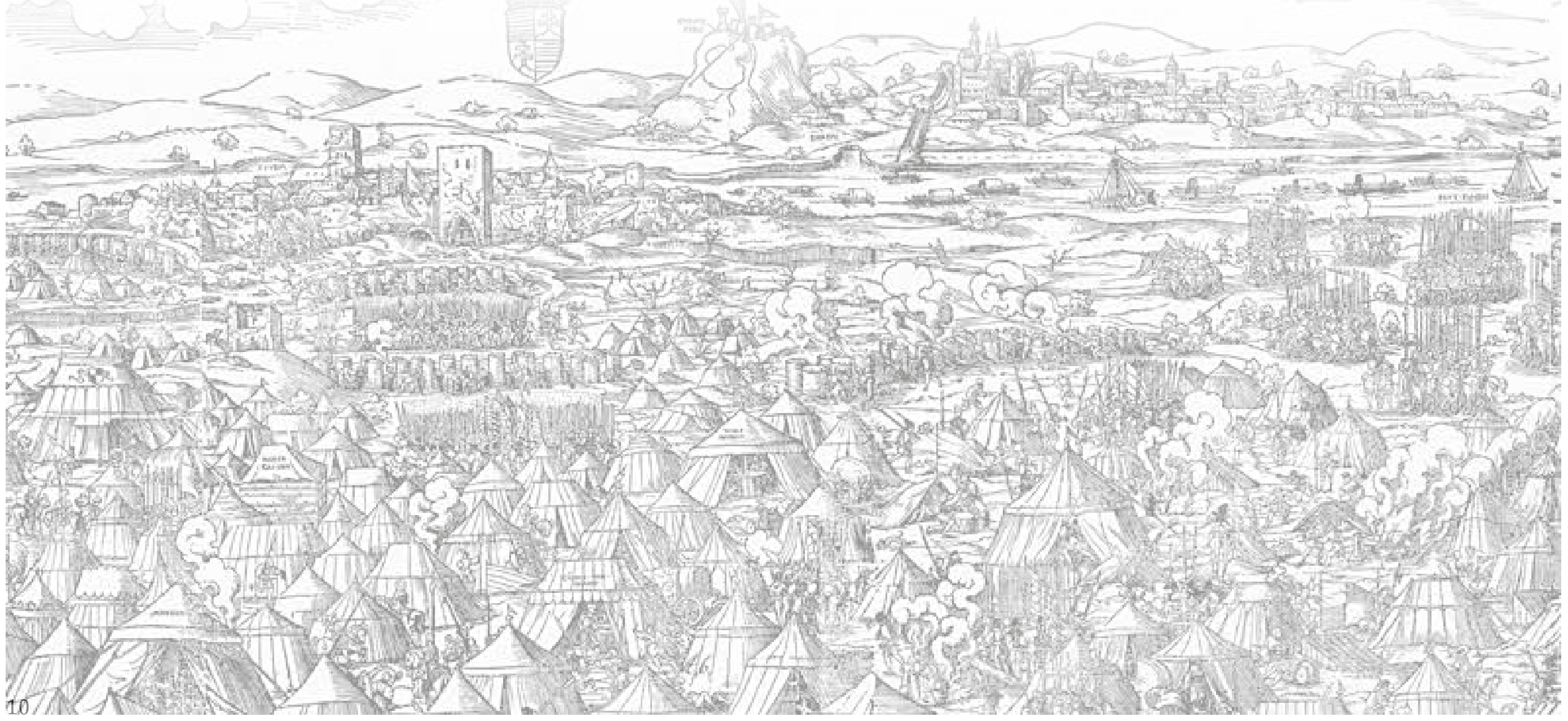




\section{TARTALOM JEGYZÉK}

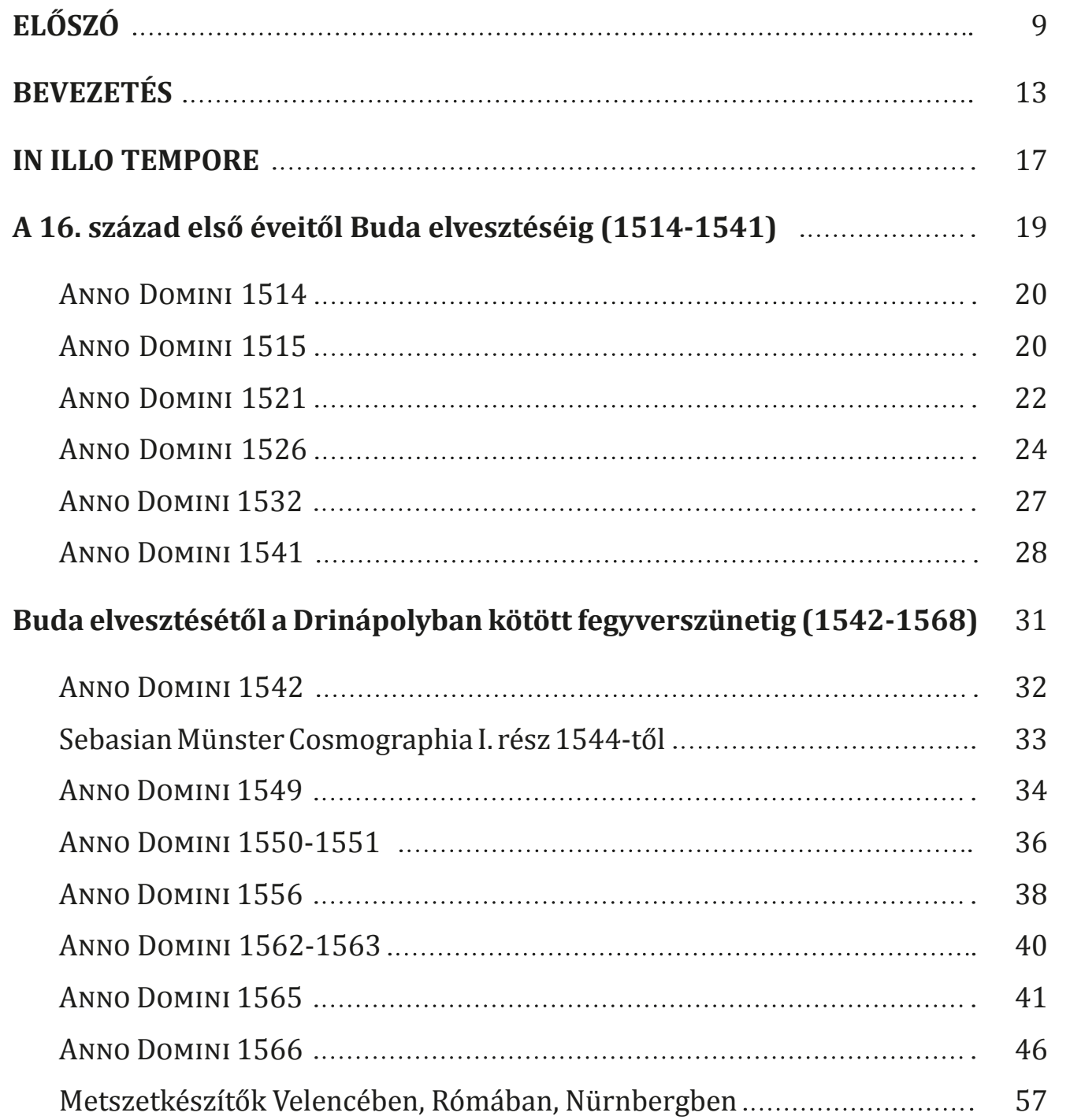

A háborús békeévek első fele (1569-1580) ……............................ 61

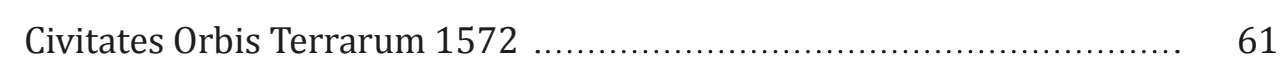

Sebasian Münster: Cosmographia II. rész 1574-től ………...................... 63

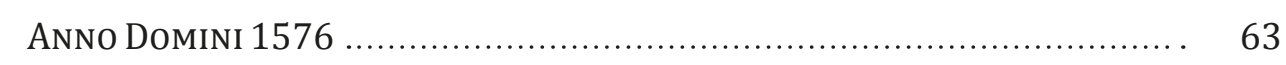

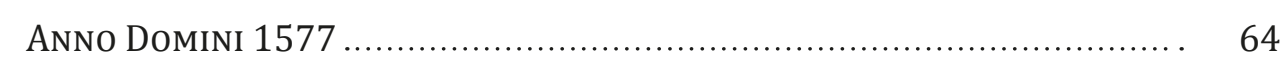

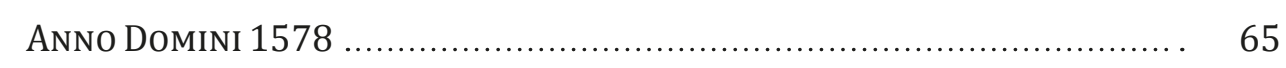

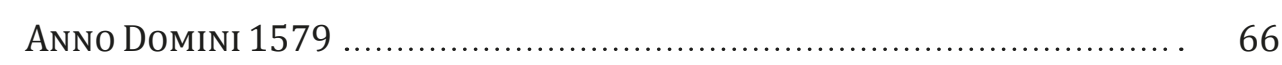

A háborús békeévek második fele (1581-1592) ………………........... 66

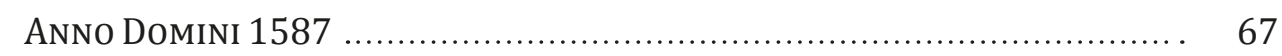

ANno Domini 1588 ............................................................................ 68

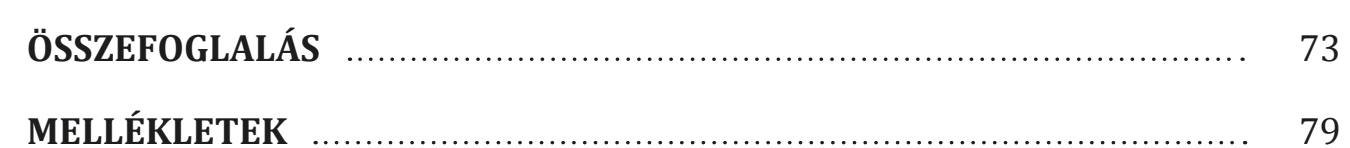

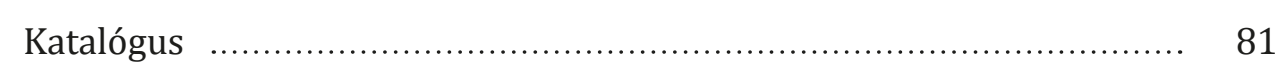

Az 1566. évi hadjárat Itáliában készült metszetei .......................... 96

Sebastian Münster Cosmographia metszetei …............................ 100

Művészek, metszetkiadók ………….............................................. 104

Egyesített irodalomjegyzék ..................................................... 106

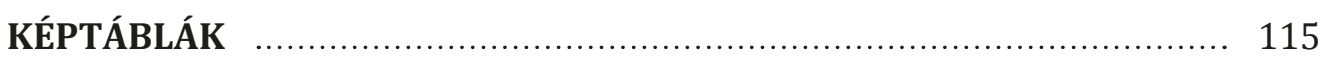

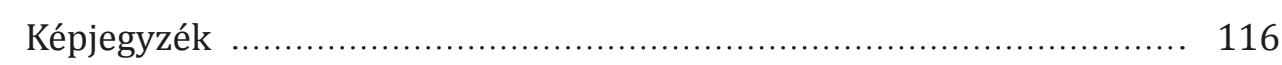

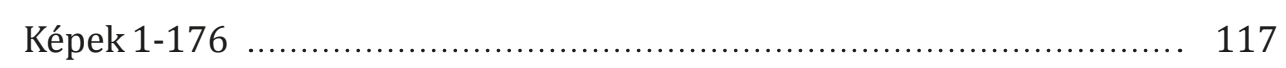




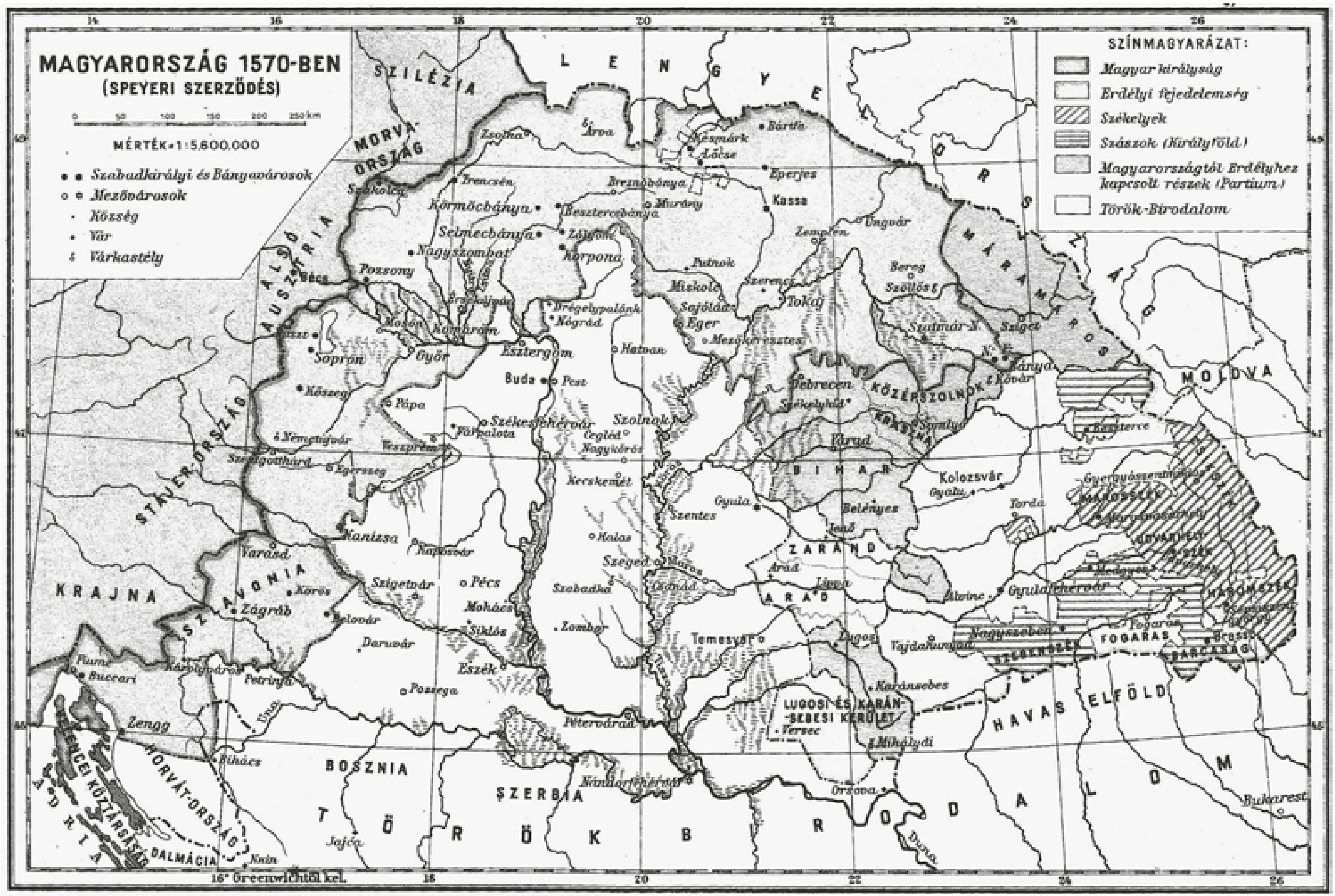




\section{BEVEZETÉS}

A 16. század a magyar történelem egyik tragikus, ha nem a legtragikusabb százada. A Mátyás király halálakor még európai középhatalomnak tekinthető, önálló Magyar Királyság száz évvel később szinte már csak nevében létezett. Területének mintegy harmadán török megszálás és közigazgatás volt. A közel hasonló kiterjedésű Erdély az időről-időre változó területű Partiummal önálló fejedelemség volt, de adót fizetett a török szultánnak, mert az oszmán hatalommal szemben nem tudta volna magát megvédeni. Ezért az isztambuli Portának Erdély külpolitikájában döntő beleszólása volt. A létező Magyar Királyság joghatósága Felső-Magyarországra és a Dunántúl északi részére korlátozódott. A Habsburg királyok a 16. század közepétől már nem csak cseh királyok, de a Német-római Birodalom császárai is voltak, akiknek ez a királyság volt a legkevésbé fontos országuk.. Nem jár messze a valóságtól az a vélemény, hogy a Habsburgok csak azért ragaszkodtak a Magyar Királyság birtoklásához, hogy annak területén tudják megállítani birodalmuk többi országa és Nyugat-Európa ellen támadó Oszmán Birodalom hadait. A történészek a mai napig vitatkoznak azon, az ország széthullásban mekkora szerepe volt a Mohács utáni kettős királyválasztásnak és Szapolyai Jánosnak vagy az ellenkirályként trónra kerülő Habsburg Ferdinándnak nagyobb ebben a bűne (mi ez utóbbit valljuk). Az viszont tény, hogy az Oszmán Birodalom, és annak képviselőjeként Szulejmán szultán ragyogóan használta ki az ország megosztottságát minél nagyobb területek megszerzésére.

Az ország széthullása valójában 1521-ben kezdődött Nándorfehérvár elfoglalásával, ami attól kezdve a Magyarország és esetenként a Bécs elleni támadások kiinduló pontja volt. A Mohácsnál 1526-ban történt csatavesztés után Szulejmán szultán hadai a Duna mentén feldúlták az országot Budáig, majd Budát és Pestet is, de eltekintve a déli végektől a kirabolt területeket nem szállták meg. Tényleges megszállásra János király haláláig nem is került sor, csak 1541ben Buda elfoglalása után szervezték meg a magyarországi török közigazgatást, amelynek székhelye az egykori főváros lett. Ennek a budai vilajetnek a területét az 1540-es évek első felében Esztergom, Tata, Székesfehérvár és pár további hely elfoglalásával jelentősen megnövelték. 1552-ben az Alföld nagy részét hódították meg, ekkor esett el Temesvár és Szolnok is. Az idős Szulejmán szultán utolsó hadjárata alatt meghalt 1566-ban Szigetvár ostrománál. Ebben az évben Gyula elfoglalásával gyakorlatilag a teljes Tiszántúl Nagyváradig, Szigetvár bevételével pedig a Balatontól délre eső területek is török kézre kerültek. A Drinápolyban 1568-ban megkötött és többször meghosszabbított fegyverszünet papíron kitartott a 15 éves háború kezdetéig (1592), ám a nagyobb hadjáratok közötti években az egész század során szinte nem volt olyan év, amelyben a török vagy királyi-császári csapatok ne portyáztak (és pusztítottak) volna egymás sérelmére.

Az ország pusztulását növelte János király haláláig a Ferdinánd és közte zajló hadakozások, majd János király halála után a Habsburgok Erdély bármi áron történő megszerzése érdekében folytatott harca. Erről a törekvésükrôl annak ellenére sem mondtak le, hogy legkésőbb 1552 után tisztában kellett lenniük azzal, hogy Erdélyt nem tudják megvédeni az Oszmán Birodalommal szemben. Báthory István lengyel királlyá választása után a Habsburgok Erdély politikája egy időre megváltozott.

Mindezek ismeretében érthető, hogy a Magyar Királyság megmaradt területein (az elvesztettekről nem is szólva) nem történt olyan gazdasági és kulturális fejlődés, mint a tőle nyugatra lévő, viszonylag békésebb időket megélő, eleve kedvezőbb adottságú országokban. Kivételként csak a reformáció terjedésével felpezsdült szellemi életet, a hitvitázó irodalommal a magyar nyelv fejlődését és nyomtatásban való elterjedését említhetjük.

Ebben a munkánkban a Magyar Királyság történetének 16. századi megmaradt tárgyi emlékei közül kívántuk összegyüjteni azokat a sokszorosított grafika (metszet) formájában fennmaradtakat, amelyek a történéseket, azok szereplőit és helyszíneit őrizték meg a mai kornak.

Mindenilyen fennmaradt metszet külföldön készült, hiszen a hazai viszonyok nem biztosították az ilyen alkotások létrejöttéhez szükséges társadalmi-gazdasági környezetet, még Erdély és Felső-Magyarország viszonylag fejlett városaiban sem. Ha tárgyilagosak maradunk, azt is el kell mondani, hogy hazánkban valójában jelentősebb igény sem mutatkozott az ilyen termékekre.

A városiasodásban messze a Magyar Királyság előtt járó Német-római Birodalomban, Itáliában és Európa más, tőlünk nyugatra lévő területein azonban más volt a helyzet. Az iskolázottság - elsősorban a városokban - megnőtt, ami együtt járt a közvetlen környezeten túli világ megismerésének vágyával. A reformáció eszméinek terjesztése során különös fontosságot tulajdonított a könyveknek, vallásos röpiratoknak, ami hozzájárulhatott a nyomdák gomba módra 
történt elszaporodásához. A nyomdák ontották a könyveket, a vallásos témájúak mellett a klasszikus szerzők írásait, a különböző tudományokat és általában az akkor ismert világ dolgait, történéseit bemutató műveket.

Ez utóbbiak közé tartoztak azok az igénytelen, gyakran borító nélkül megjelent pár oldalas kiadványok is, amelyek egy-egy valahol Európában történt rendkívüli eseményről, legtöbbször háborúkról, ostromokról, csatákról adtak - nem mindig hiteles - tájékoztatást. Az ilyen alkalmi kiadványoknak több gyưjtőneve is volt, a német nyelvterületen általában Zeytungként emlegették, nálunk a tudósítás a legelfogadottabb elnevezés. A kelendőség fokozására ezek címlapjára egy kicsi fametszetet nyomtattak, amely a tartalomra utalt. Ezek köre rendkívül változatos, legtöbbször csatajelenet, képzeletbeli várostrom, egy harcos képe, de bármi más is előfordulhatott, köztük arcképek, címerek. Már 1514-ben több olyan tudósítás jelent meg, mely címlapján egy keresztes katona látható, utalva a Bakócz Tamás esztergomi érsek által meghirdetett hadjáratra.

A könyvkiadók hamar rájöttek arra, hogy a képeket tartalmazó könyvek nagyobb sikerre számíthatnak, tudva azt is, hogy azok előállítása viszont költségesebb. A könyvekben megjelent képeket meg kellett rajzoltatni, majd egy fametszővel el kellett készíttetni a nyomtatáshoz szükséges fadúcot. Maga a nyomtatás nem jelentett különösebb nehézséget, hiszen a szöveg és a fametszet egyaránt magasnyomású eljárást igényelt, így együtt tudták nyomtatni a könyvet a benne lévő fametszetekkel.

Kifejezetten a „képes tudósítás” érdekében született meg az általában röplapnak nevezett /németül Einblattdrucke vagy Flugblatt/ sajtótermék, amelyen nagyobb méretű képpel együtt jelent meg az eseményről hírt adó beszámoló. A kép a 16. század végéig szinte mindig fametszet volt. Ha ráfért a kép és az ismertető szöveg egy lapra, akkor együtt nyomtatták, ha nem, akkor külön és a kép alá ragasztották a képen ábrázolt esemény szöveges (gyakran versformában írt) ismertetését. A legkorábbi ismert magyar vonatkozású röplap a Mohács melletti tragikus csatavesztésről jelent meg 1526-ban.

A rézkarc-rézmetszet tömeges elterjedése a 16. század második felében kezdődött. Ezek elsősorban önálló lapok formájában, ritkábban könyvekben (mint a Braun-Hogenberg mű) jelentek meg. Témájuk lehetett művészi indíttatású (ideértve az arcképeket is), de a témaválasztás valójában a megrendelő kiadótól függött. Az eseményekről (például várostrom) vagy városokról készített metszetek - és ez igaz a könyvekben megjelent életképekre is - a metszetkészítő napi megélhetését szolgálták. Ezen a téren nem volt különbség a fametszetek és a rézmetszetek rajzolóinak, azok dúcainak és rézlemezeinek készítői között.

A 16. század előbbiekben felsorolt nyomtatott termékei (tudósítás, röplap, képeket tartalmazó könyv, önálló metszetlap) azok, amelyek között kereshettük a magyar történelem eseményeit megörökítő sokszorosított grafikai alkotásokat vagyis a metszeteket.

Mint korábban írtuk, célunka 16. század magyar eseményeiről és helyszíneirôl megjelent metszetek összegyűjtése, rendszerbe foglalása és feldolgozása. A feladat elvégezhetősége érdekében ki kellett jelölni gyűjtésünk tér- és időbeli, valamint tematikai határait is, ami sokféle szempont mérlegelését kívánta. Utólag úgy látjuk, a tér- és időbeli korlátok meghatározása volt a könnyebb feladat.

A térbeli elhatárolás következtében nem foglalkoztunk azokkal a képes híradásokkal, amelyek a Magyar Királyság területén kívül történtekről adtak hírt. Ilyenek a század Horvátországban, illetve az attól délre, a Balkánon lejátszódott hadi események híradásai, noha azoknak a mindenkori horvát bán szerepe miatt magyar vonatkozása is volt. Kivételt tettünk olyan esetekben, amikor az adott esemény szorosan kötődött a magyar történelemhez, mint a Habsburg-Jagelló házassági szerződés megkötése vagy I. Ferdinánd temetése, mindkettő Bécsben .

Munkánk időbeni határai megegyeznek a 16. századdal. Az első, képekben is fennmaradt esemény azonban az 1514. évi Dózsa György féle parasztháború volt. Csak azokat a korabeli ábrázolásokat gyűjtöttük össze - függetlenül megjelenésük formájától (önálló metszetlap, képes röplap vagy könyv melléklete) -, amelyek a 15 éves háború kezdetéig megjelentek. Ezért nem szerepelnek munkánkban a későbbi visszaemlékezésekben vagy történeti feldolgozásokban megjelent képek. Mivel a 15 éves háború kezdetének pontos időpontja nem határozható meg, ezért az 1592. év első felének eseményeiről készült képes beszámoló gyűjtésünkben még szerepel. Egy kivételt itt is tettünk, ez Fráter György meggyilkolásának képe. Közismert, hogy a gyilkosságot elrendelő Habsburg hatalom sikeresen megakadályozta (cenzúrázta) ennek a hírnek korabeli elterjedését.

$\mathrm{Az}$ előzőknél jóval többrétű feladat volt gyűjtésünk tárgykörének meghatározása. Ennek ismertetése egyszerűbb, ha azt vesszük sorra, amikkel nem foglalkoztunk.

A 16. század magyar történelmének szereplőiről szép számmal jelentek meg saját korukban is metszetek. Ezek között a magyar királyok, erdélyi fejedelmek, híres magyar és külföldi hadvezérek, török szultánok, nagyvezírek nem egy esetben képzelt arcképei is megtalálhatók. Közülük csak azokkal foglalkoztunk, amelyen a portréval együtt megjelenik annak az eseménynek a képe is, amely az illetőt híressé tette (például Zrínyi Mikós arcképe Szigetvár képével).

A 16. században számos képekkel díszített könyv jelent meg az Oszmán Birodalom és annak szultánjai történetéről, a török elleni háborúkról. Ezekben és néhány tudósításban is a város- és ostromképek mellett fametszetek jelentek meg csatajelenetekkel, török és tatár harcosokról, fegyverekről, harci vagy egyéb eseményekről. Ezek közül csak azokat vettük figyelembe, ahol a kép megnevezése 
egyértelműen kötődött egy adott történéshez vagy helyhez. Ha egy könyv a Mohácsnál lezajlott csatát ismerteti és a közelében van egy csatakép, akkor azt csak akkor tekintettük a Mohács melletti csata képének, ha az kép megnevezéseként is szerepel. Nem voltunk ennyire szigorúak a tudósítások címlapján szereplő fametszetek esetében, ahol a város vagy vár képét (szinte kivétel nélkül képzeletbeli képeként) elfogadtuk, ha a város neve a tudósítás címében szerepelt. Több mint száz ilyen tudósítást gyűjtöttünk össze, de azokat csak válogatva közöljük munkánkban. Tisztában vagyunk azzal, hogy mint minden válogatás, ez is kifogásolható. Igen, a válogatásunk egyéni megfontolásokat, ízlést és szemléletet takar. Viszont bárkinek lehetősége van másféle, adott esetben ennél jobb (bár tárgyilagos mérőrendszert erre nehezen tudunk elképzelni) válogatást közzétennie.

Megismételjük, nem foglalkozunk a nem sokszorosított múvészi grafika képeivel (említveazEhrenspiegeldes Hauses Österreich című könyv Nándorfehérvár és Mohács rajzát, vagy a Zürichben lévő Wickiana gyűjtemény Buda, Szikszó stb. rajzait), bár közülük néhánynak képét szemléltetésként bemutatjuk.

Kezdetben úgy terveztük, hogy munkánkban a Buda metszeteket önálló fejezetben szerepeltetjük. Erre Rózsa György Budapest ábrázolásait feldolgozó munkássága iránti tisztelet késztetett. Ám az összegyűjtött anyag ismeretében úgy ítéltük meg, hogy a 16. század bemutatásának szerves egységét, időbeni folyamatosságát és áttekinthetőségét egy ilyen szétválasztás akadályozná, ezért a Buda ábrázolások elkülönített bemutatást elvetettük.

A metszetek - ha nem fantázia szülte ábrázolásokat mutatnak - mindig előképek után készültek. Ezek lehettek korábban megjelent metszetek vagy a helyszínen - elsősorban hadmérnökök által - készített rajzok. Nagyon kevés ilyen maradt fent, a korszak jellemzésére párat ezek közül is közzéteszünk.

Az összegyűjtött metszetek megnevezésére helyszínek esetében az általunk korábban kidolgozott azonosító rendszert használjuk (helynév, készítés éve, sorszám: például Tokaj 1565/2. A csak eseményeket ábrázoló metszeteknek (például eljegyzés, temetés) hasonló rendszerű azonosítókat kellett adnunk (esemény neve például Habsburg-Jagelló szerződés, I. Ferdinánd temetése), készítés éve, sorszám (például Mohács 1526/6).

A feldolgozás során felhasználtuk a 16. század metszeteiről az elmúlt két évtizedben készült tanulmányainkat is. Ezekben egyebek mellett foglalkoztunk Virgil Solis 1542-es Buda keleti nézetű látképével, Augustin Hirschvogel két magyar ostromképével, Domenico Zzenoi és Paolo Forlani munkásságával.

Munkánkban a 16. század magyar történelmére felfüzve ismertetjük az összegyűjtött ábrázolásokat. Ezzel elkerüljük, hogy a metszetek ismertetésénél az azok megértéséhez nélkülözhetetlen történelmi háttér egy önálló történelmi összefoglalás ismétléseként jelenjen meg. Hangsúlyozzuk, munkánk nem a
16. század történetírása, hanem annak egy összefoglalása, amely a fontosabb események mellett azokra a történésekre összpontosít, amelyekről képi emlékek fennmaradtak. Ezek között vannak olyanok is (pl. természeti csapások Magyarországon, vagy kultúrtörténeti események), amelyeknek alig van, vagy nincs is nyoma a szakirodalomban (mint a csodás égi jelenségek Kassánál 1579ben). Nem szerepel viszont történeti összefoglalónkban például Buda 1529. évi rövid török ostroma, amelyről semmilyen képi emléket nem ismerünk.

Könyvünkben a kortárs metszetek ismertetését a Mellékletek követik, benne első helyen a Katalógus, amelyben metszetek azon adatait tesszük közzé, amelyek a képekről ránézéssel nem állapíthatók meg (például méret, megjelenés formája, helye, ideje). Minden metszet leírásánál közöljük annak képszámát is. Önálló munkarészekben közöljük az 1566. évi hadjáratról Itáliában megjelent valamennyi metszet cím- és egyéb feliratainak fordítását és a Sebastian Münster Cosmographia című műve különböző kiadásaiban megjelent metszetek jegyzékét.

A könyvet mutatókkal (például művészek, metszetkiadók) igyekeztünk használhatóvá tenni. A felhasznált irodalom és hivatkozott ikonográfiai alapművek és egyéb kézikönyvek bibliográfiai adatait az irodalomjegyzékben szerepeltetjük.

A könyv utolsó részét jelentő Képtáblákon minden ismertetett metszet képét közöljük, képszámmal és a metszet elnevezésével együtt. A szöveges részekben a képtáblákon lévő képszám egyúttal a metszet hivatkozására szolgáló azonosító is (pl. lásd 24. kép), neve pedig a már említett metszetazonosító (például Buda 1592/1). Sajnos az eltérő méretek miatt a képtáblákon a metszetekkel nem mindig tudtuk követni az események szigorú időrendiségét. A képek keresését egy ABC sorrendben összeállított képjegyzék is segíti.

Munkánkban az olvasmányosság és az esztétikai megjelenés érdekében (és egyéb elvi megfontolásokból) kerültük a jegyzeteket. Ugyancsak tudatosan kerültük a divathóbortként elterjedt újonnan gyártott kifejezések (csata táj, katonai táj, hadi táj stb.) használatát, amelyek az angol „Military Landscape” hibás fordítása és téves fogalmi értelmezése nyomán születtek. Az ezzel a névvel fémjelzett, Angliából kiindult irányzat a történészek figyelmét - mint lehetséges forrásokra - az eddig meglehetősen mellőzött, történelmi eseményeket bemutató korabeli metszetekre kívánja irányítani. Ez a törekvés, kutatási irányzat nagyon helyes, de nem járhat a magyar nyelv megrontásával. A roppant gazdag magyar szókincsben minden kifejezés megtalálható, amely az ilyen feldolgozásokhoz szükséges.

Ezért is teljességében egyetértünk a magyar nyelv védelmében indítandó Kazinczy nyelvtisztítási mozgalom céljaival, amely elsősorban a kereskedelem és a szellemtudományi körökben elburjánzott idegen szavak, kifejezések használata ellen kíván fellépni. Semmiképpen nem szeretnénk elnyerni a figyelemfelhívás (és részben megszégyenítés) eszközeként havonként odaítélendő „Kazinczy 
szomorúsága díj”-at, amivel a legtöbb idegen kifejezést tartalmazó kereskedelmi kiadványt és tudományos művet fogják „elismerni”. Idézem boldogult Söveges Dávid magyartanárom életre szóló útmutató véleményét: „Az a magyar anyanyelvű, tudományt múvelő vagy hivatali ember aki egy idegen szó, kifejezés megértése után nem találja meg, vagy nem tudja megalkotni annak magyar megfelelőjét, és írásában, beszédében nem azt használja, hanem Kárpáthy Abellinóként a külföldet majmolja, az nem szereti, nem tiszteli, hanem lenézi saját anyanyelvét."

Anyaggyűjtésünket rendkívüli mértékben megkönnyítette, hogy a nagyobb könyvtárak, múzeumok világszerte, de főleg a minket érdeklő Európában egyre nagyobb mértékben teszik megismerhetővé gyűjteményeik anyagát a világhálón (sajnos, ezen a téren a hazai gyűjtemények még csak a kezdeteknél járnak). Ahányszor egy-egy addig előttünk ismeretlen metszetet vagy röplapot találunk a világhálón, mindig eszünkbe jut, hogy Szabó Károly Régi magyar könyvtár anyagának vagy Rózsa György Budapest látképeinek összegyűjtése postai levelezéssel, utazásokkal zsúfolt évtizedeket igényelt. A mai kor szinte mindent készen kapó, elkényelmesedett embere pedig morog, ha egy közgyűjteménynél nehezen kezelhető, elavult keresési lehetőséggel találkozik.

Ez a munkánk a koronavírus járvány idején készült el. Közismert, hogy a járvány a társadalom egészének és minden egyes tagjának mindennapi életét is meghatározta, és nem csak az átmeneti korlátozó intézkedések miatt. A járvány miatti korlátozott mozgási lehetőségek és az elővigyázatosság a kijárási tilalom időszakán kívül is otthon tartották mindazokat, akik ezt körülményeik miatt megtehették. Ez a mindennapokban számunkra azt jelenttette, hogy az otthon töltött hosszabb idő alatt több időt fordítottunk erre a munkánkra. Ironikusan azt is mondhatnánk, ez a könyv a járvány szüleménye. De bármennyire is segítette a kényszerű otthonlét a munka gyors befejezését, összességében a járvány mégis több hátrányt, mint előnyt jelentett. A bezárt múzeumok és könyvtárak, különösen az utóbbiak sokszor megoldhatatlannak tűnő kérdéseket vetettek fel. Munkánk jellegéből adódóan rengeteg adat ellenőrzéséhez kell kézikönyvet használnunk és ezek töredéke sem található meg a világhálón megnézhető formában. Különösen igaz ez a világszerte nagyon drága művészeti könyvekre (The Illustrated Bartsch, Hollstein's German Engravings, Robert Paas German Broadsheet, W. Strauss German Single-Leaf Woodcut stb.), amelyekből itthon nem hogy magánkézben nincs, de még a nagyobb könyvtárakban is alig találni példányt. Még szerencse, hogy pár angol és német könyvtárban a járvány időszakában működött az a szolgáltatás, hogy könyvekből pár oldal másolatot meg lehetett rendelni. Egyszerübb lett volna itt helyben bemenni egy könyvtárba és alaposabban utánanézni a keresetteknek.

Nem egy korábbi munkánkban írtunk már arról, hogy az ilyen jellegű gyűjtéseknél a teljességre való törekvés elvárható, maga a teljesség azonban nem. Mostani munkánknál a tudósítások esetében azonban eleve eldöntöttük, hogy nem a teljes körűségre, hanem azokból egy jellemző, színvonalas és lehetőleg érdekes válogatás közzétételére törekszünk. Természetesen tudtuk, minél szélesebb körből tudunk választani, annál jobb lehet az eredmény. Úgy hisszük a teljességhez legközelebb az önálló és könyvekben megjelent metszetlapok esetében kerültünk, a röplapok esetében talán kevésbé.

Munkánk során nagyon sok segítőnk volt: könyvtárosok, történészek, antikváriusok, muzeológusok, gyűjtők, művészettörténészek, nyelvészek, digitális képszerkesztő és még sokféle más dologban jártas ember. Senkit nem akarunk név szerint említeni (vanitatum vanitas), mert anélkül is tudjuk, hogy kiknek tartozunk most és a jövőben is köszönettel, hálával.

\section{KÖSZÖNET MINDEN SEGÍTŐNEK!}

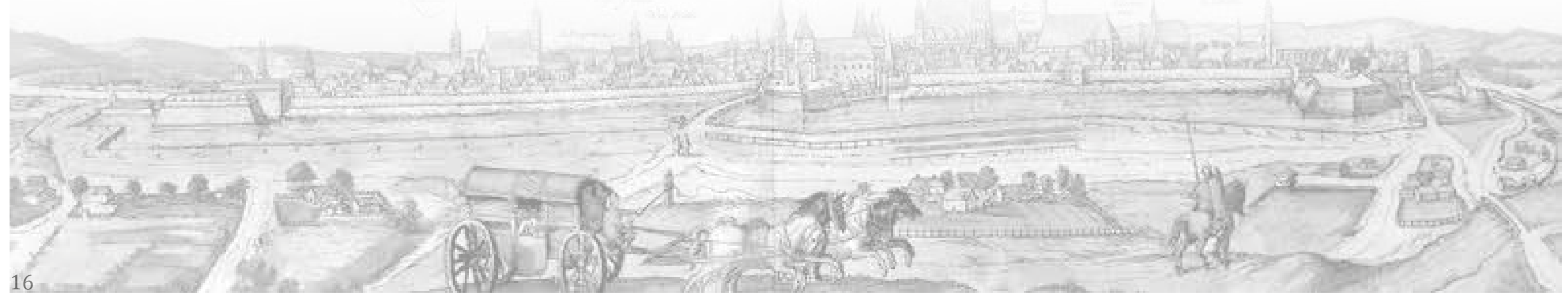


IN ILLO TEMPORE 


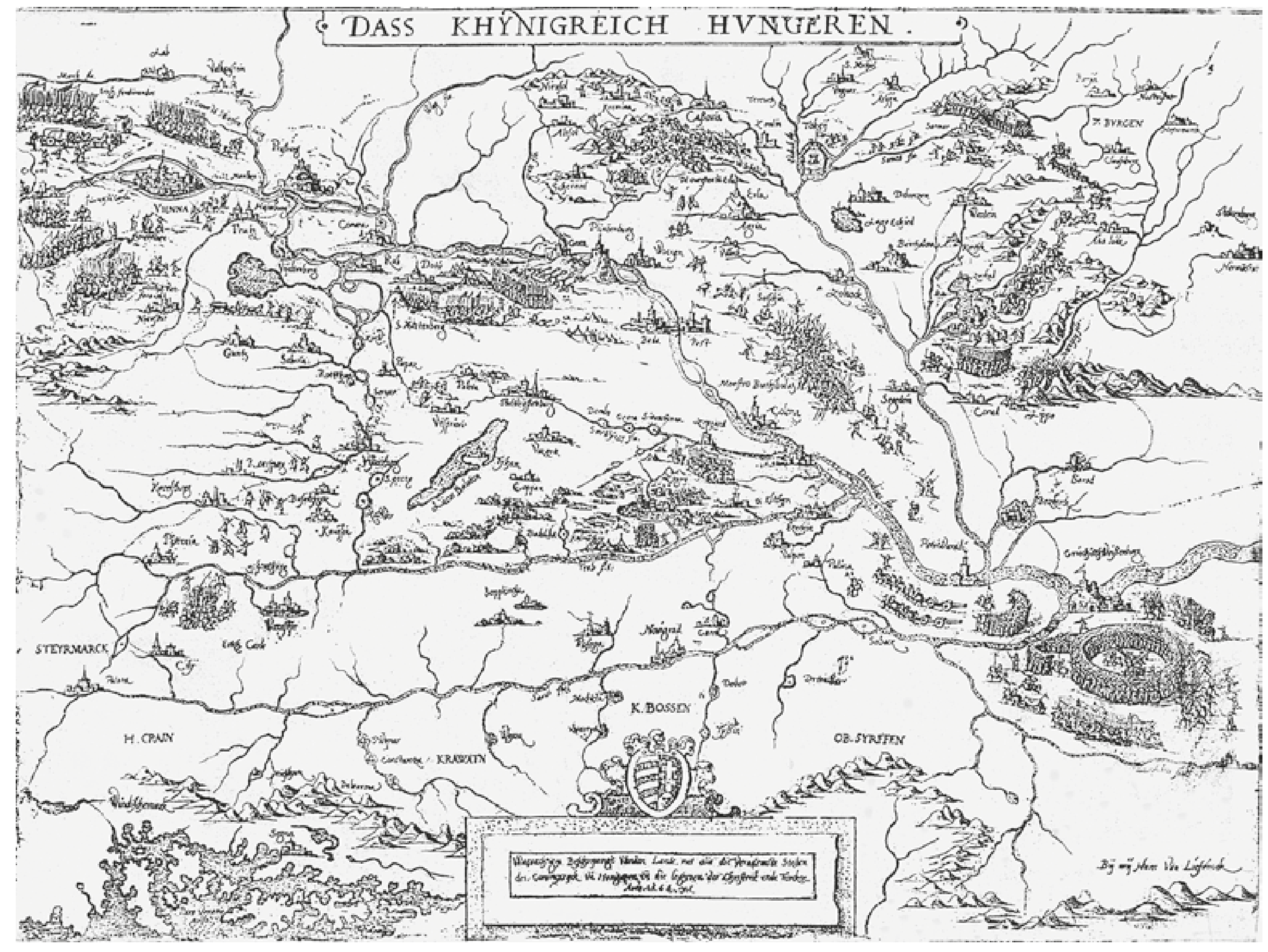




\section{ESEMÉNYEK, METSZETEK ÉVRŐLÉVRE}

\section{A 16. század első éveitől Buda elvesztéséig (1514-1541)}

A 16. század elejére a Balkán félsziget nagy részét már elfoglalt Oszmán Birodalom további terjeszkedése komoly fenyegetést jelentett a Magyar Királyság és a Velencei Köztársaság részére. A fenyegetett országok közé tartozott még a Lengyel Királyság is, hiszen a már megszállt török területektől csak a katonailag jelentéktelen Havasalföld és Moldva választotta el. Mivel az oszmán hatalom terjeszkedésének meghirdetett célja volt a mohamedán vallás terjesztése a „hitetlenek világában”, így az Európa keresztény létét is fenyegette. Mindez arra a felismerésre vezette az európai országok nagy részét, hogy a „törökök” néven emlegetett Oszmán Birodalom további hódításait egy széles körú összefogással kell megakadályozni, kiszorítva őket a Balkán félszigetről, visszafoglalva az időközben Isztambul névre átkeresztelt Konstantinápolyt is. Volt olyan elképzelés is, hogy ezt egy újabb keresztes hadjárattal lehetne elérni, a Pápai Állam tevékeny részvételével. Ezzel elvileg a harcias II. Gyula pápa is egyetértett, ám a pápai székbe kerülve idejét és energiáját a pápaság Itálián belüli világi hatalmának megerősítésre fordította. Miután ezt megvalósította, 1511 őszén a törökök elleni összefogás érdekében összehívta a következő év tavaszára a Lateránba az ezzel érintett országok képviselőit. II. Gyula pápa terveiből azonban nem lett semmi, mert még 1511 végén súlyosan megbetegedett.

II. Gyula pápa betegségének hírére 1511 novemberében Bakócz Tamás bíboros, esztergomi érsek, címzetes konstantinápolyi pátriárka Rómába utazott a várható pápaválasztásra. Nem titkolt célja volt, hogy az itthon szinte királyi tekintéllyel bíró és nagyhatalmú, nemzetközileg is elismert fôpapként pápává választassa magát. Mint leendő pápának, egyik fő célja volt a török Európából történő kiűzésére erős szövetséget létrehozni. II. Gyula pápa betegsége azonban elhúzódott. Ezt az időszakot a Rómában fejedelmi pompával élő Bakócz Tamás népszerűségének növelésére használta fel.

II. Gyula pápa 1513. február 20 án meghalt. A pápaválasztó konklávé háromfós elókészítő testületének Bakócz Tamás is tagja lett, ami választási esélyét mutatta. Ám a március 4-én kezdődött konklávé első szavazásakor csak 8 szavazatot kapott a 25-ből, majd a következő fordulóban, március 11-én a 35 éves, ám betegeskedő Giovanni di Medici bíborost választották pápának. A megválasztott új pápa felvette a X. Leó nevet.
A csalódott Bakócz Tamás úgy tervezte, Rómában telepedik le, talán még reménykedett egy következő lehetőségben is. Ám az új pápát feszélyezhette korábbi vetélytársa jelenléte. Egyes vélemények szerint ennek is szerepe lehetett abban, hogy X. Leó pápa 1513. szeptember 3-án kiadott pápai bullájában teljes búcsúval járó keresztes hadjáratott hirdetett a török ellen. Ugyanez a pápai bulla Bakócz Tamás bíboros esztergomi érseket összesen 16 északi, keleti és közép európai országra kiterjedő rendkívüli hatáskörrel pápai legátusként megbízta keresztes hadjárat szervezésével. Mindeközben a nagyobb nyugat-európai országok uralkodói, I. Miksa német-római császár, Ferdinánd aragóniai király és VIII. Henrik angol király egymással folytatott háborúikkal voltak elfoglalva.

Ezt a kinevezést nem lehetett visszautasítani, hiszen Bakócz Tamás annak idején azt hangoztatta, hogy a török elleni összefogás létrehozása miatt jött Rómába. Valójában csalódott lehetett, mert amit remélt, a pápai széket nem tudta megszerezni, viszont hetven éves korában kapott egy nagyon nehéz feladatot. Nem biztos, hogy tudott arról, hogy az 1512-ben trónra lépő Szelim szultán 1513ban békességet keresve fegyverszünetet kötött II. Ulászlóval. Bakócz Tamás november 7-én indult haza, az országhatáron egy győzedelmes keresztes hadjárat reményében ünnepélyesen fogadták. A télies időben a hazautazás több köztes pihenő miatt elhúzódott, ezért egyenesen érseki székhelyére, Esztergomba ment kipihenni az utazás fáradalmait.

\section{Anno Domini 1514}

Bakócz Tamás 1514 márciusában ismertette az összehívott országtanácsban a pápai bullát és terveit a keresztes hadjárat megvalósítására. Ennek lényege az volt, hogy az adott körülmények között a keresztes hadjárat meghirdetése csak a Magyar Királyság területén lehetséges (II. Ulászló öccse, Zsigmond lengyel király éppen béketárgyalásokat folytatott a törökökkel), és a hadjárathoz további anyagi támogatásra még X. Leó pápától sem lehet számítani. Bejelentette, hogy a kereszteseket egy általa kinevezett hadvezér fogja fegyverforgatásra kiképezni, majd a török ellen vezetni. Javaslata szerint a hadjáratban a főúri bandériumoknak nem kell részt venni és a birtokos nemességnek sem kell fegyveres jobbágyokat 
hadba állítania. Egyébként az ország hadvezetésben járatos főurai, katonái közül senki nem vállalkozott egy kiképzetlen „paraszthad” vezetésére.

Az országtanácsban Bakócz Tamás javaslata azonban kemény ellenállásba ütközött. Az ország pénzügyileg katasztrofális helyzetben volt, és sokan ellenezték a Szelim szultánnal nem régen kötött megállapodás (béke? fegyverszünet?) egyoldalú felmondását is. Hivatkozás hangzott el, mint intő példára I. Ulászló király hasonló eljárására 1444-ben és annak következményére, a Várna melletti véres vereségre. De voltak olyan vélemények is, ha a jobbágyok tömegesen beállnak a keresztes hadba, nem lesz aki betakarítsa a termést. Mások az országban már több helyen csapatosan kóborló szökött jobbágyoknak a keresztesek közé történő beállásától tartottak. De végül II. Ulászló és Bakócz akarata győzött, az országtanács március 24-én hozzájárult a keresztes hadjárat meghirdetéséhez a Magyar Királyság területén.

Virágvasárnap, 1514. április 9-én, Budán a Szent György téren Bakócz Tamás ünnepélyesen felolvastatta a pápai bullát, és ezzel meghirdette a keresztes hadjáratot. Április 16-án a püspöki székhelyeken (Erdély kivételével), majd a plébániákon tették közzé az önkéntes csatlakozás lehetőségét a keresztes hadjárathoz, amely teljes búcsú elnyerésével járt. A birtokos nemesség köteles volt eltűrni jobbágyaik keresztesnek jelentkezését, ellenkezés esetén egyházi átok fenyegette. A legfőbb gyülekezőhely a Rákos mező és Pest külvárosa volt, de erre kijelölt hely volt Várad, Kalocsa, Bács és egyéb helyek is. A gyülekezés lassan indult, április 24-én még csak mintegy háromszáz keresztes jött össze Pestnél.

Április 24-én Bakócz Tamás ünnepélyesen Dózsa Györgyöt nevezte ki a keresztes hadak vezetőjének, akinek köpenyére felvarrták keresztesek jelképét, a vörös keresztet. Május elejétôl a gyülekező keresztesek és a helyi nemesség között több helyen kisebb összecsapásokra került sor. Május 10-én Bakócz Tamás elrendelte a keresztesek elindulását azzal, hogy a fehér alapon vörös keresztes zászlók alatt vonulva csatlakozzanak Szapolyai János erdélyi vajda Bulgária felé nyomuló seregéhez. Május 15-én az országos zavargások hatására Bakócz Tamás betiltotta a keresztesek további toborzását és újabb kereszteseknek a meglévőkhöz való csatlakozását. Dózsa György Bakócz Tamás rendelkezését figyelmen kívül hagyta, ugyanúgy, mint május 24-én kiadott utasítását, amely elrendelte a keresztes hadjárat befejezését és a keresztesek hazatérését. Ezzel kezdetét vette az 1514. évi parasztháború.

A keresztes háború története, következményei jól ismertek, nem is foglalkozunk ezzel a továbbiakban, ismertetésünk az események visszhangját helyezi a középpontjába.
A legutolsó keresztes hadjárat óta több száz év telt el, így érthető, hogy Európa szerte érdeklődés kísérte az eseményeket, különösen a hadjárat kudarcát. Tucatnyi városban jelent meg tudósítás a hadjárat meghirdetéséről, és történéseiről. Ezek többségének címlapján egy keresztes vitéz szerepel a keresztesek zászlajával. A keresztesek öltözéke eltérő a különböző kiadások képein: van ahol egyszerű hétköznapi viseletben, de van ahol szinte páncélba öltözötten vagy buggyos nadrágban láthatók. Érdekes a zászlókon megjelenő

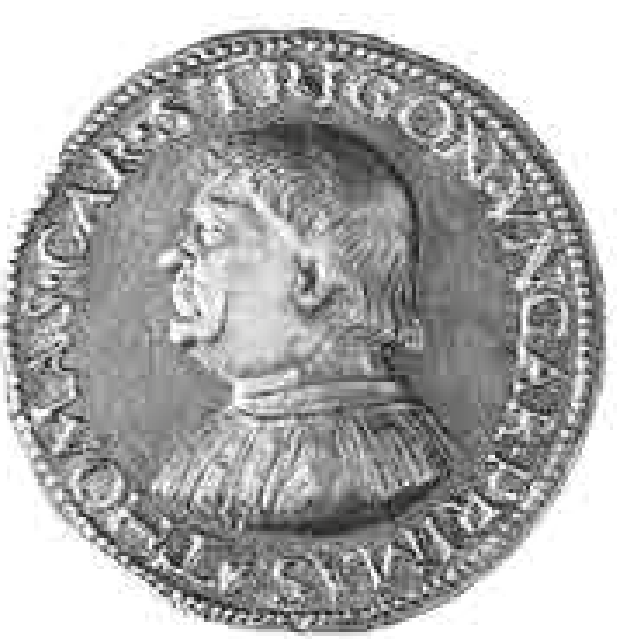
kereszt képe. Tudjuk a korabeli írásos forrásokból, hogy a keresztesek jele egy vörös kereszt volt. A tudósításokon megjelenő zászlókon azonban nem kereszt van, hanem feszület a megfeszített Jézussal és a kereszt alatt álló Szŭz Máriával és Szent Jánossal. (Keresztes katona 1, 2, és 3. kép)

Egyetlen 1514-ben megjelent tudósítást ismerünk, amelynek címlapján Dózsa György kivégzése látható. A meglehetősen nyersen ábrázoló képen ugyan nem lehet érzékelni, hogy a korona izzana, de az látható, hogy muzsikaszó mellett egy férfi kiharap egy darabot a trónszéken ülő Dózsa György vállából. (Dózsa György kivégzése 1514/1, 4. kép)

1519-ben Bécsben jelent meg Stephanus Taurinus (Stephan Stieröchsel) gyulafehérvári kanonok, erdélyi történetíró munkája az 1514.évi keresztes felkelés történetéről. A verses formában megírt mủ Dózsa Györgyöt és a kegyetlenkedő nemeseket egyaránt ellenszenvesen mutatja be. A könyv címlapján látható fametszet az 1514-ben megjelent kép ismeretéről árulkodik (ezen is megjelenik a Dózsa György vállából kiharapó férfi), ám több rajta a szereplő. A képen azt is látni, ahogyan fogókkal a lángoló koronát Dózsa György fejére helyezik. (Dózsa György kivégzése 1519/1, 5. kép)

\section{ANNo Domini 1515}

1515 júliusában, Bécsben fontos események történtek, ahol I. Miksa császár hívására találkozott II. (Jagelló) Ulászló magyar és cseh király valamint öccse, (Jagelló) Zsigmond lengyel király. A hármas megbeszélésre eredetileg 
Pozsonyban került volna sor, de I. Miksa császár több ok miatt (egyebek mellett Pozsonyt „szegényesnek” vélte egy ilyen fontos eseményhez, panaszkodott, hogy nem találna méltó szálláshelyet) kérte a tárgyalások helyszínének és időpontjának megváltoztatását. Bécsben megkötötték a Habsburg-Jagelló házassági szerződést, amely értelmében II. Ulászló akkor kilenc éves Lajos fia a felnőtt kort elérve egy éven belül feleségül veszi I. Miksa császár unokáját, Habsburg Máriát, Ulászló lánya, Jagelló Anna pedig a császár egyik unokájának, Habsburg Károlynak vagy Habsburg Ferdinándnak lesz a felesége. Halála esetére Ulászló fia, Lajos gyámjának I. Miksa császárt és I. Zsigmond királyt kérte fel. Egy másik, titkos szerződésben biztosították a kölcsönös örökösödét a két uralkodó háznak. Ezt II. Ulászló annak ellenére vállalta, hogy ismerte az 1505. évi rákosi országgyúlés döntését, amely állást foglalt az idegen trónkövetelőkkel szemben és kinyilvánította ragaszkodását a nemzeti király személyéhez és kimondta, hogy a Jagelló háznak nincs leányági örökösödési joga.

1515. július 22-én a bécsi Szent István székesegyházban Bakócz Tamás bíboros esztergomi érsek vezette a Lajos és a nála egy évvel idősebb Mária, illetve az unokáját helyettesítő I. Miksa császár és Anna eljegyzési szertartását. Anna már nem tért vissza Budára, Máriával együtt Innsbruckba került további neveltetésre. Az örökösödési szerződés kitudódott, az ellen Perényi Imre nádor a rendek nevében hivatalosan tiltakozott. A nádor ellenkezését azonban II. Ulászló Siklós adományozásával leszerelte és Perényi Imre végül a megállapodást aláírta. Az országgyűlés elé azonban a szerződés nem került, így az hivatalosan nem lett lépett érvényes.

A bécsi találkozóról több tudósítás is megjelent, ami érthető, hiszen Európa két fontos uralkodóházának vezetői jöttek össze és kötöttek egész Európa jövőjére is kihatható megállapodásokat. Hármat említünk meg ezek közül. Az elsőnek szerzőjét is ismerjük, Johannes Cuspinianus császári történészt, aki híresen nem kedvelte a magyarokat. A találkozóról írt latinul és németül is megjelent tudósításának címlapján a kép akár politikai hitvallásának tekinthető: középen a hatalmas kétfejű sas felette a császári koronával, körötte mintegy a császárság holdudvaraként a négy sarokban a cseh (kétfarkú oroszlán), a lengyel (sas), a Jagelló és a pólyás magyar címer (Habsburg-Jagelló szerződés 1515/1, 6. kép). Egy másik tudósítás címlapján I. Miksa császár a trónján ülve vesz át egy iratot egy térden álló ifjútól, talán valamelyik szerződést adják át neki. (Habsburg-Jagelló szerződés 1515/2, 7. kép)

A harmadik tudósítás két képet is tartalmaz. A címlapon két koronát viselő lovas üdvözli egymást egy város előtt, vélhetően a Bécshez érkező II. Ulászló és I.
Zsigmond király. Ugyanennek a tudósításnak a végén még egy kép van, amelyen két „kislány”, vagyis Anna és Mária királykisasszonyok és a lóháton feléjük tartó gyermek II. Lajos látható. Nem eldönthető, hogy a rajzoló a gyermek Lajos vagy a ló méreteit rontotta el, avagy a ló egy póniló. (Habsburg-Jagelló szerződés 1515/3 és 1515/4, 8, 9. kép)

I. Miksa császár élete utolsó két évtizedében tudatosan törekedett arra, hogy írásban és képekben megörökítse életének és uralkodásának fontosabb eseményeit az utókornak. Ehhez megvoltak az adottságok is: a császári udvarban császárhű és felkészült történetírók, eszközként a korban már elterjedt fametszet, a költségek fedezéséhez pedig a szükséges pénz. A császárnak rendelkezésére álltak a korai német reneszánsz kiváló művészei, köztük Albrecht Dürer, Albrecht Altdorfer, Hans Burgkmair és Hans Springinklee. I. Miksa császár életében azonban a tervezett hatalmas fametszetek közül (a Diadalmenet, az eredetileg annak részeként tervezett Diadalkocsi és a Diadalkapu) a maga teljességében azonban csak a Diadalkapu (Ehrenpforte) készült el. Ez a fametszet is több múvész közös alkotása, Dürer mellett Hans Springinklee és Wolfgang /Wolf/ Traut készítette a rajzokat és a fadúcokat. A metszetet 195 fadúcról 36 lapra nyomtatták és azokat ragasztották össze, mérete 295x357 cm.

A diadalkapun lévő történelmi jelenetek közül három kötődik a magyar történelemhez, közülük kettő Mátyás király halálát (1490) követő eseményekhez kötődik: Miksa főherceg visszafoglalja a Mátyás király által megszállt AlsóAusztriai területeket, köztük Bécset (ez kívül esik kötetünk határain), és Miksa főherceg zsoldoshadserege elfoglalja Székesfehérvárt. A harmadik jeleneten az 1515-ben Bécsben tartott kettős eljegyzés szerepel.

Az eljegyzési jelenet a jobboldali kapuív felett négy sorban elrendezett összesen 12 jelenet között az alsó sorban középen látható. A kép közepén Ulászló király áll, aki kezeit az előtte balra álló Lajos és jobbra álló Anna vállaira helyezi. A kép bal szélén áll I. Miksa császár, jobb szélén Zsigmond király. I. Miksa előtt áll unokája, Mária, szorosan Lajos mellett. A részletkép felett szótekercsen az esemény és a megszületett egyezségek jelentőségének méltatása olvasható, hangsúlyozva, hogy mindez az egész kereszténység érdekeit is szolgálja. A kép latin és német nyelvü felirattal is megjelent. (Habsburg-Jagelló szerződés 1515/5 [latin és német], 10, 11. kép)

A Diadalkapu másik „dicsőség” képe egy tragikusan szomorú eseménynek állít emléket. 1490-ben az I. Ulászló király ellen trónigénnyel fellépő Habsburg Miksa főherceg német és cseh zsoldos csapatokkal tört be Magyarországra és 
1490. november 17-én elfoglalta a védtelen Székesfehérvárt. Miksa főherceg az ostrom megkezdése elött a zsoldosoknak az elmaradt zsoldfizetés fejében szabad rablást engedélyezett. A sváb és cseh zsoldosok a várost egyetlen rohammal elfoglalták, majd nekiálltak a fosztogatásnak, pontosabban, házról házra járva minden fehérvári lakost, aki útjukba akadt, öreget, fiatalt, gyereket, férfit, nőt válogatás nélkül legyilkoltak, kiraboltak, a holttestekről még a ruhákat is lerángatták. Behatoltak a székesegyházba, kifosztották az egyházi kincstárat, meggyalázták és kirabolták a királysírokat. A másnap ünnepélyesen bevonuló Miksát az utcákon heverő holttestek százai fogadták, még a székesegyház belsejében is halottak feküdtek. Ezeket látva, Habsburg Miksa szigorú büntetést kilátásba helyezve betiltotta a fosztogatást, amit korábban maga engedélyezett. Eső után köpönyeg. Nincs ebben semmi meglepő, ez volt a magukatálszent módon buzgó keresztényeknek, a kultúra és a művészet pártolóinak valló, de valójában csak hataloméhes és hitszegő Habsburgok igazi arca (tisztelet a ritka kivételnek).

A metszeten mindebből érthetően semmi nem látszik. A kép előterét csapatok töltik ki, amelyek megkezdik behatolásukat a városkapun keresztül egy fallal kerített városba. A kép feletti felirat szerint Miután túlerejét kimutatván [ti. Miksa] bevonult Magyarországra, elfoglalta Magyarország egyik legerősebb és leggazdagabb városát, Székesfehérvárt és ezzel az országnak közel felét a háború jogán magáévá tette. A latin nyelvű szövegben tévesen Alba Graeca (Nándorfehérvár) szerepel a helyes Alba Regia helyett. (Székesfehérvár 1515/1 [latin és német], 12, 13. kép)

\section{$>>>><<<<<$}

II. Ulászló félévvel a bécsi egyezségek megkötése után, 1516 márciusa elején meghalt. A trónt a még kisgyermek korában megkoronázott II. Lajos foglalta el. Apjától egy mindenféle értelemben széteső félben lévő országot örökölt a Cseh Királysággal együtt. A Magyar Királyság a király, a főurak és a köznemesség folyamatos hatalmi harca miatt korábbi európai középhatalmi szerepét gazdasági és katonai értelemben egyaránt - elveszítette. A Szelim szultánnal 1516-ban megkötött hároméves fegyverszünet egy szultáni hadjárat veszélyét ugyan elhárította, de ettől az ország déli határaival szomszédos török várak katonaságának pusztító betörései nem szüntek meg. Szelim halála után 1520ban fia, a fiatal Szulejmán szultán ismét a nyugat felé hódítás politikáját tervezte (a kelet felől fenyegetést jelentő mameluk birodalmat apja megsemmisítette).
II. Lajos és az ország helyzetét tragikussá fokozta, hogy az időközben végletekig elfajult Habsburg-francia viszony miatt egy várható török támadás esetén semmilyen nyugat-európai segítséget nem várhatott. Nagybátyjára, Zsigmond lengyel királyra sem számíthatott, aki nem akarta a törökkel kötött békéjét felmondani. Nem is tehette, hiszen a Lengyel Királyság az állandó orosz fenyegetettség árnyékában élt, a kétfrontos orosz és török háborút pedig nem volt képes felvállalni.

\section{ANNo Domini 1521}

Szulejmán szultán 1521 májusában megindította csapatait a Magyar Királyság ellen. A cél Nándorfehérvár, illetve az attól mintegy hatvan kilométerre nyugatra, a Száva partján fekvő Szabács elfoglalása volt. Nándorfehérvár európai ismertségét még Hunyadi János 1456-ban a török felett itt aratott diadalának köszönhette.

Szabács, ez a fontos átkelési hely a Száván a 16. század elején elhanyagolt állapotú és rosszul felszerelt volt. Szabács vára Mátyás király korában vált ismertté, előbb a török elfoglalta, majd Mátyás király visszavette és erődjét megerősítette. A 16. század első évtizedeiben azonban további fejlesztésére vagy legalább karbantartására nem jutott pénz, védelmi rendszere elavulttá vált.

Szabács elfoglalása Ahmed ruméliai pasa feladata volt, aki pár napi ostrom után július 7-én bevette a várat. Közben Szulejmán szultán a sereg zömével Szabácshoz vonult, hogy ott átkelve a Száván benyomuljon a Dunántúlra. Ám a folyó áradása elvitte a frissen épített hajóhidat, így a szultán a fő erőkkel nem tudott átkelni a Száván, azon csak kisebb csapatok tudtak áthajózni. A szultán a Száva déli oldalán vonult Nándorfehérvár ostromához.

Július 15-én II. Lajos király pár száz katonával elindulta török ellen, de megtudva, hogy nem számíthat útközben sem Báthori István nádor, sem Szapolyai János erdélyi vajda seregeinek csatlakozására, egy nap után visszafordult.

Július elején az első török csapatok már körülzárták Nándorfehérvárt, ám az ostrommal az első hetekben szinte semmi eredményt nem értek el. Móré Mihály és Oláh Balázs parancsnoksága alatt mindössze hétszáz katona védte a várat. Szulejmán július végén ért Nándorfehérvárhoz. Az ostromtáborban mintegy 170 ezer ember volt, ebből 70 ezer lehetett a kiképzett katona. Augusztus elején II. Lajos újra megindult, seregével Tolnáig jutott. Augusztus 22-én a tolnai táborban, a nádor seregében Péterváradnál és az erdélyi vajda seregében Futaknál mintegy 50 ezer fegyveres gyúlt össze.

Augusztus 27-én a török aknászoknak sikerült felrobbantani a fellegvár legerősebb, Nebojsza nevű (más néven Köles-torony) tornyát. Móré Mihály 
időközben kiszökött a várból a törökökhöz. Oláh Balázs a megmaradt 70 katonájával szabad elvonulásuk fejében átadta a rommá lőtt várat augusztus 29-én Szulejmán szultánnak. A szultán mintegy két hetet időzött még Nándorfehérvárnál, (a megmaradt teljes lakosságát áttelepíttette Isztambulba), ezalatt csapatai a környéket kirabolták és felégették, majd haza indult. Ennek hírére II. Lajos elhatározta Nándorfehérvár azonnali visszafoglalását, ám a mohácsi táborában kitört súlyos járvány miatt október elején seregeit szélnek kellett engednie. Nándorfehérvár 1689-ig az oszmán hatalom nyugati hadjáratainak legfontosabb utánpótlási központja lett.

Nándorfehérvár ostromáról a Nürnbergben született, akkor még nagyon fiatal és vándor festőként dolgozó Hans Sebald Beham készített fametszetet. Nem tudjuk mikor és hol készítette, de úgy gondoljuk, a fametszet Nürnbergben nem sokkal az események után, talán még 1521-ben, de legkésőbb 1522-ben már megjelent. Beham biztosan nem járt Nándorfehérvárnál, annak lehetőségét pedig, hogy hozzájutott egy helyszínen készült vázlatrajhoz nagy valószínűséggel szintén kizárhatjuk. A történtekről azonban nagyvonalakban pontos értesülések jutottak el Nürnbergbe, amint azt a későbbiekben látni fogjuk. Az, hogy Beham Nándorfehérvár rajza rendkívül életszerű (de nem valós!) jó képzelőtehetségének és rajzkészségének legalább annyira köszönhető, mint az események ismeretének.

Hans Sebald Beham Nándorfehérvár képe az első olyan metszete a magyar történelmi ikonográfiának, amely kifejezetten egy város ostromának bemutatására készült. Jelentőségét csak növeli, hogy az elkövetkezendő közel kétszáz évben a város minden (német nevén Griechische Weissenburg vagy szláv elnevezéssel Belgrad) megjelent ábrázolásának kizárólagos ősforrása volt.

Nándorfehérvár a Duna és az abba ömlő Száva által közrefogott dombra épült város, a legmagasabb részén lévő fellegvárral kiváló védelmi adottságokkal rendelkezett. Beham képe azzal, hogy a várost domboldal helyett egy meredek hegy lejtőjére helyezte, a fellegvár pedig egy sziklás hegytetőre kerül, ezeket a védelmi adottságokat hangsúlyossá tette. A törökök még csak a várost támadják, és nem látni a képen ágyúkat se. Nem tudjuk, hogy az ágyúk hiánya tudatos-e Beham részéről (akkor az ostrom kezdeti szakaszát mutatná, amikor azok még nem érkeztek meg), de nem hisszük. Inkább az lehet ennek az oka, hogy nem talált a képen helyet az ágyúállásoknak. A mindkét folyót ellepő csónakok a török katonákkal élővé teszik a képet. [Nándorfehérvár 1521/1,14. kép)

Hans Sebald Beham metszete megjelent 1522-ben Nürnbergben is. A fametszet képmezőjét felfelé megnövelve az így nyert helyre nyomtatták a történtek részletes ismertetését. Ez a metszetlap Wolfgang Resch nyomdájában készült, egykor megvolt a híres Szántai gyűjteményben (Párizs), ma egy másik ismert példánya a bécsi Albertina gyưjteményében található. Az ismertetés Nándorfehérvárt német nevén Griechische Weyssenburgnak (Görögfehérvár, Hunyadi János győzelme előtt ez volt a hely magyar neve) nevezi, részletesen ismertetett várát a nürnbergi várkastélyhoz hasonlítja. Megemlíti, hogy a városban van egy ferences kolostor (parfuser closter) és egy „rác püspök” (Raczischer Bischoff) is, de nem szól az 1456. évi ostromról. Az ismertetésben olvashatunk Szabácsról, ahol megemlítik Mátyás király várépítését, Szabács és további erősségeknek, Zimony, Pétervárad és Szalánkemén elfoglalását. A nyomtatott szöveg egy lényegre törő összefoglalása az 1521. évi török hódításoknak. (Nándorfehérvár 1522/1, 15. kép)

Hans Sebald Beham Nándorfehérvár látképének egy másik Nürnbergben megjelent kiadását is ismerjük. Ez is 1522-ben jelent meg, kiadója Jost Denecker. Ez a lap valamivel kisebb méretű, az ismertető szövege azonos tartalmú a másik látképével, de más szedéssel és csak 15 soros. (Nándorfehérvár 1522/2, 16. kép)

A Hans Sebald Beham metszetén lévő ismertetés nem csak az elfoglalt várakat sorolta fel, de utalt a meghódított terület kifosztására is. A lakosság szenvedésének és Nándorfehérvár elfoglalásának egyszerre állít emléket az a vers, amely 1522 év elején jelent meg Augsburgban. A vers felidézi Kapisztrán Szent Jánost, Hunyadi János társát az 1456- évi győzelemben, akire most is szükség lett volna. A vers szerzőjét nem ismerjük, de a kiadó Otmar Silvan munkáiban mindig igényes fametszetek jelentek meg. Ezek közé sorolhatjuk azt a képet is, amely a vers címlapján jelent meg és a törökök pusztítását mutatja. A kép egyébként a Thuróczy krónika (Augsburg, 1488.) tatárjárás képe nyomán készült. (Török fosztogatás 1522, 21. kép)

Beham Nándorfehérvár képe, immár Griechicsche Weyssenburg néven lett Sebastian Münsternek köszönhetően széles körben ismert Európában. Münster Cosmographia című munkája az akkor ismert világ országainak történelmiföldrajzi ismertetését tartalmazta, folyamatosan bővülő tartalommal több nyelven 


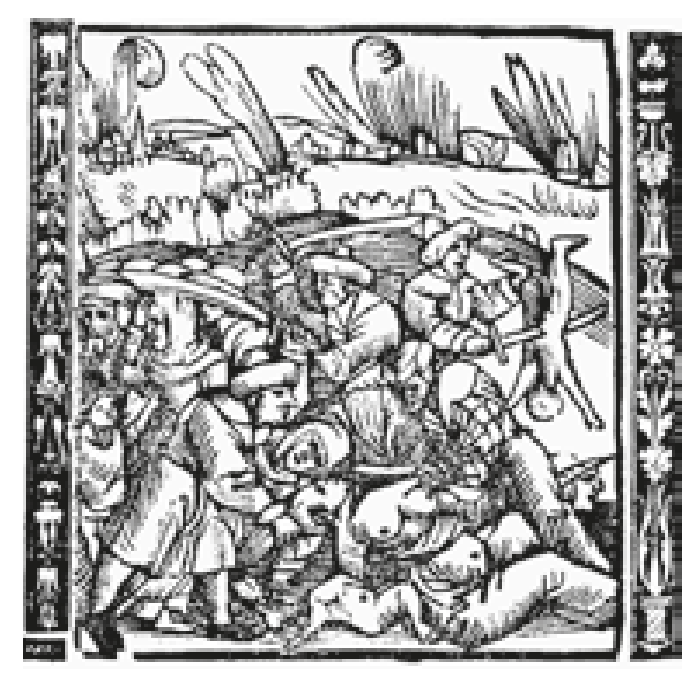

több tucat kiadása volt (ezekről később részletesen is szólunk). Az 1550. évi kiadásában jelent meg először szövegközti fametszetként Beham metszetének kicsinyített, de hűséges másolata. A metszet Jakob Clausen műve, akinek az egybefonódó I és $C$ jelzése a metszeten is látható. A látkép Hunyadi János és Kapisztrán Szent János Nándorfehérvárnál 1456-ban aratott győzelme leírásánál szerepel (téves 1457 évszámmal).

Csak a Cosmographia legutolsó, 1628. évi kiadásában került át a kép az 1521. évi ostrom ismertetéséhez. 1550-től ez a kép a Cosmographia valamennyi latin, német, francia és olasz nyelvű kiadásában megjelent, egy-egy képet közlünk is belőlük. (Nándorfehérvár 1550/1 [latin, német, francia és olasz], 17-20. képek)

$>>>><<<<$

Nándorfehérvár és környékének török meghódításával Szulejmán szultán csapatai előtt gyakorlatilag szabaddá vált az út egy újabb hadjárat esetén egészen Budáig. Ezt felismerve az 1521. november 19-ére összehívott országgyúlés a védekezés megszervezését és új adók kivetését tűzte ki maga elé. Emellett haderőreformot is előterjesztettek, mely alapvetően egy új (Mátyás királyéhoz hasonló) zsoldossereg felállítására törekedett.

Habsburg Ferdinánd főherceg még 1520-ban feleségül vette Jagelló Annát Linzben. Habsburg Mária főhercegnő II. Lajos jegyese 1521 tavaszán érkezett Magyarországra, Szokatlan módon őt még az esküvő előtt, 1521 decemberében Székesfehérváron magyar királynévá koronázták. 1522. január 13-án volt Budán a nagy ünnepséggel összekötött házasságkötés. A két házasságkötéssel teljesült az 1515-ben Bécsben kötött kettős házassági szerződés. Feltehetően ezek az események késztették a humanista tudós orvos-történetíró Joseph Grünbecket, hogy a török veszélyről írt asztrológiai munkáját II. Lajosnak és Máriának ajánlja, akiknek az álló alakos, koronás képe múvének címlapján meg is jelent. Lajos király lába alatt egy legyőzött török hever és a török elleni harchoz szükséges fegyvereket jelképesen egy égből alászálló angyal nyújtja át neki. (II. Lajos és Mária 1523/1, 22. kép)

II. Lajos és Mária tavasszal Prágába ment a cseh királyság ügyeit intézni. Máriát júniusban cseh királynévá koronázták, ugyanakkor II. Lajos letette a cseh királyi esküt, amit gyermekkori koronázásakor nem tehetett meg. Közel egy éves ott tartózkodása alatt azonban nem sikerült rábeszélnie a cseh rendeket, hogy segítséget szavazzanak meg egy jövőbeni török elleni hadjárathoz. Közben idehaza az 1521. évi országgyűlés döntéseit vagy nem tudták vagy csak részben tudták végrehajtani, egyeseket figyelembe se vettek. A király minden központi hatalmat erősítő terve a nemesség ellenállásán elbukott, a főurak és a köznemesség közötti feszültségek pedig az ellenségeskedésig fajultak.

Mindezek a jó irányba történő változtatásokat lehetetlenné tették. Az adók behajtása nem történt meg, így a zsoldos sereg felállítására nem volt pénz. Ez lett a sorsa következő évek országgyűlési döntéseinek is. 1521-től a még el nem vesztett déli végvárak erősítésére semmit nem fordítottak, védőik többsége a zsoldfizetés elmaradása miatt elszökött. Az 1514-ben történtek után a jobbágyság hadba hívása és fegyveres kiképzése szóba se kerülhetett. A tervezett török elleni hadjárat hadvezérének kinevezett Tomori Pál kalocsai érsek és Báthori István nádor, majd leváltása után Werbőczy István nádor, illetve Szapolyai János között a személyes vetélkedés rontotta a kapcsolatot, emiatt Tomori hamarosan le is mondott tisztségéről. Erdélyben Szapolyai János vajda szinte teljes önállóságot élvezett, viszonylag jelentős 10-15 ezer fős hadseregével.

Kudarcba fulladtak II. Lajos nyugati segítségszerzési kísérletei is. Ígéretek voltak, de tényleges anyagi vagy katonai segítség nem érkezett. A Habsburgfrancia háború V. Károly császár minden erejét lekötötte. II. Lajos király körében még a törökkel adófizetés ellenében kötendő béke is felmerült, ám ez nem csak itthon nem talált támogatásra, hanem VII. Kelemen pápa és V. Károly császár is kifejezetten ellenezte. 1525 őszén a lengyelek újabb fegyverszünetet kötöttek a Portával, így segítségre tőlük sem lehetett számítani.

\section{ANNo Domini 1526}

Szulejmán szultán 1526 áprilisában megindult hadai élén a Magyar Királyság ellen. Az ugyanekkor összehívott országgyűlés azonban elsősorban a rendi sérelmekkel foglalkozott, a háború ügyében csak erőtlen intézkedéseket 
tett. A nemesség fegyverfogásának feltételeként ragaszkodott ahhoz, hogy a fiatal és mindenféle hadi tapasztalat nélküli II. Lajos király személyesen vezesse a hadjáratot. Külföldi segítség csak VII. Kelemen pápától érkezett 25 ezer arany formájában, amit azonban De Burgio pápai nuncius óvatosságból nem adott át a magyar kincstárnak, hanem maga állított ki ebből 4000 zsoldost, akik többsége aztán ott veszett a csatatéren.

II. Lajos egy kisebb csapat élén 1526. július 20-án elindult Budáról Tolnára, a csapatok kijelölt gyülekezési helyére. Augusztus elején Szulejmán szultán csapatai egymás után szerezték meg Újlakot, Erdődöt, Eszéket. Szapolyai János az egymásnak ellentmondó utasítások miatt seregével ekkor még el sem indult az erdélyi Tordáról. A haditanács Tomori Pált és Szapolyai Györgyöt (János vajda öccsét) nevezte ki az összegyült hadak fővezérévé. Augusztus 18-án Szulejmán csapatai megkezdték Eszéknél az átkelést a Dráván. A haditanács úgy döntött, visszavonulás helyett nyílt csatában megütközik Szulejmán szultán jóval nagyobb létszámú és sokkal jobban felkészült hadseregével.

1526. augusztus 29-én lezajlott Mohácsnál a csata. A magyar hadsereg megsemmisült, II. Lajos is holtan maradt a csatatéren. A csatavesztés következtében a teljesen önálló és független Magyar Királyság valójában örökre megszűnt.

A mohácsi vereség híre augusztus 30-án ért Budára, majd pár nappal később Bécsbe, illetve Prágába, szeptember közepén pedig már Itáliában és a németrómai birodalom nagyobb városaiban is tudtak a tragikus csatavesztésről.

A Mohács melletti csatavesztésnek hatalmas irodalma van, ezek közül csak a legfrissebbekre utalunk, amelyek a közelgő 500. évfordulóra történő felkészülés jegyében a „Mohács 1526-2026 Rekonstrukció és emlékezet” sorozatban jelentek meg. A történészek figyelme, mint lehetséges forrásokra kiterjedt a vesztes csatáról és Lajos király haláláról Európa szerte megjelent korabeli tudósításokra is. Ezek pontos száma talán még ma se ismert. Farkas Gábor Farkas, aki II. Lajos halálának kutatásakor ezekkel a tudósításokkal tartalmilag is a legrészletesebben foglalkozott (kimutatva többségük magyarellenességét és Habsburg-pártiságát) számukat több tucatra becsülte. Már az első tudósításokban is szerepelnek a csata leírása mellett a csatatéren holtan maradt fôpapok és főurak neveinek listaszerű felsorolásai. A tudósítások címlapján, ha van kép - érthető módon az mindig csatajelenet. Közöttük egyetlen olyan fametszetet ismerünk, amelyen a harcosok között feltúnik maga a király, vagyis egy koronát viselő vitéz. Nem tartjuk véletlennek, hogy ez a koronás vitéz kifejezetten „gyerekképü", hiszen a benne lévő bányászének (amely lehet, hogy Hans Sachs műve?) rögtön az elején

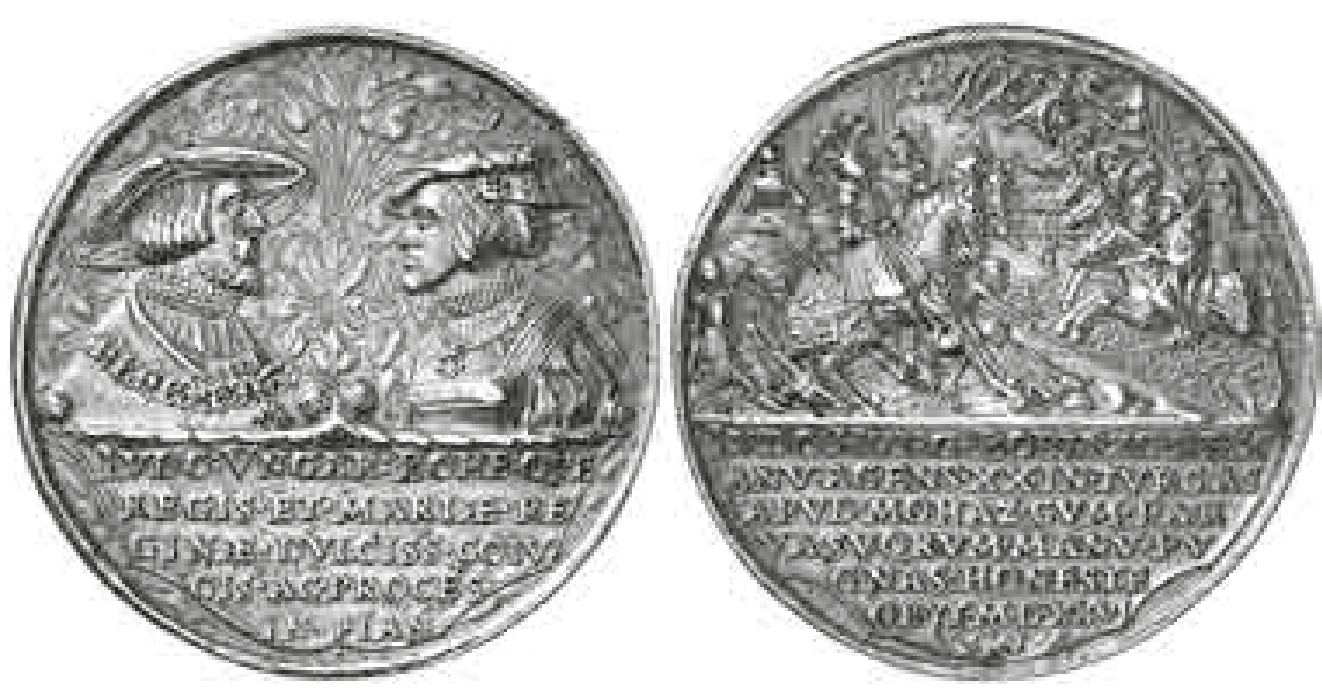

elmondja, hogy Lajos király mindössze 20 éves volt, amikor holtan maradt a csatatéren (Mohácsi csata 2, 23. kép). A csataképek közül bemutatunk néhány továbbit is, amelyeken a csatajelenet talán igényesebb munkának tekinthető. (Mohácsi csata 3-7, 24-28. képek)

A csatáról egyetlen nagyméretű korabeli sokszorosított ábrázolást ismerünk. Ezt a színezett fametszetet (amelyet az őrző helyén tévesen 1626. évi eseményként tartottak nyilván) pár éve a Seláf Levente-Tóvizi Ágnes szerzőpáros fedezte fel és ismertette. A négy fadúcról nyomtatott metszet alatt párrímes versformában olvasható a csata leírása. A kép alsó részén lovasok küzdelme van, a háttérben gyalogosok csatáznak, mindkét helyen a törökök láthatóan visszaszorítják a keresztény katonaságot. Figyelemre méltó, hogy a gyalogosok és lovasok egyaránt cseh oroszlános zászló alatt küzdenek, ami utalás lehet a versben említett (egyébként soha nem volt) húszezer fős cseh segítségre. Sem a fametszet készítőjét, sem a verses röplap nyomdászát nem ismerjük. (Mohácsi csata 1, 29. kép)

Mária királyné híveivel és legnagyobb értékeivel még a vereség híre megérkezésének éjszakáján Pozsonyba menekült. A Budán őrzött királyi kincsekből és értékekből, amit és amennyit tudott összecsomagoltatott és magával vitt, illetve azok legnagyobb részét mintegy hatvan hajóval a Dunán menekítette el.

Szulejmán szultán csapataival mindenféle ellenállás nélkül dúlva és rabolva haladt a védtelenül hagyott Budáig, ahova szeptember 12-én vonult be. Csapatai innen egészen Győrig pusztították a Dunántúlt, közben Pilismarótnál (vagy 
Pusztamarótnál?) egy szekértáborban védekező több ezer magyart mészároltak le. Szulejmán szultán szeptember 25-én hagyta el Budát, magával vitt minden mozdítható értéket (a Corvina könyvtár könyveiből, szobrokat, a Hagia Szophia templomban ma is látható két hatalmas bronz gyertyatartót, a templomok aranyezüst tárgyait stb.). A Dunán felvert hajóhídon átkelt Pestre, azt is kirabolták majd felgyújtották. A török katonák kivonulásuk közben Pesttől Péterváradig pusztították a vidéket, majd október 10-én Nándorfehérváron keresztül haza indultak. Török helyőrség csak az elfoglalt szerémségi várakban maradt.

A késő ősszel megjelent tudósítások már Buda elfoglalásáról és az elfoglalt területek kirablásáról, elpusztításáról valamint a lakosság elhurcolásáról is beszámoltak. Az egyik ilyen tudósítás címlapján egy jelképes várkép felett megjelenik Buda német neve Ofen (Buda 1526/1, 30. kép). Egy másik beszámoló Buda szeptember 8-án történt megszállásával kezdi híreit és részletesen leírja Buda és Pest szomorú sorsát. Ennek címlapján is szerepel egy városkép, amely lángokban ál. Ez a képzeletbeli városkép lehet Buda vagy Pest, bár inkább az utóbbi, mert azt valóban felgyújtották. De lehet, hogy ez a kép nem köthető egy meghatározott városhoz, hanem a pusztítást általánosságban jelképezi (Buda 1526/2, 31. kép). Megjegyezzük, ugyanez a fametszet 70 évvel(!) később, 1598ban egy tudósítás címlapján Győr képeként jelent meg!

Egy harmadik híradás címlapján egyesek a Buda utcáin történt vérengzés képét vélik felfedezni (Buda 1526/3, 34. kép), egy másik tudósítás pedig a kisgyermekekkel

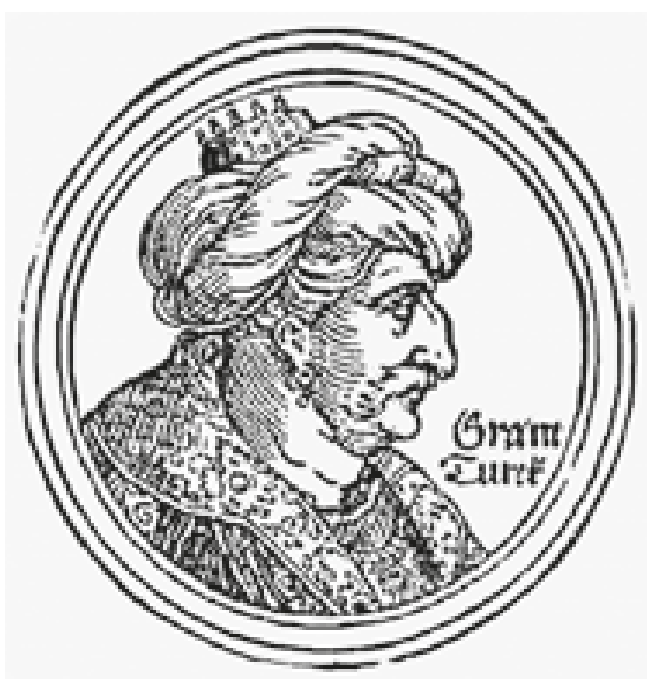
történt kegyetlenkedéseket mutatja. (Török vérengzés 1526, 35. kép)

Rózsa György Budapest ikonográfiáját feldolgozó alapvető művében szerepeltet egy fametszetet (Rózsa 1999/296), amely a kísérő szöveg szerint Buda 1526. évi képét mutatja. A látkép a Jeruzsálemi Szent János Ispotályos Lovagrend, mai nevükön a Máltai Lovagrend történetét feldolgozó könyvben jelent meg az 1526. év török ellenes harcai ismertetésénél. A látkép ugyan tetszetôs, de semmi köze nincs a valósághoz. (Buda 1581/1, 32. kép)
$>>>><<<<<$

1526. november 10-én, a Székesfehérváron tartott országgyúlés Szapolyai Jánost magyar királlyáválasztotta, akit másnap aSzent Koronával azéletben maradt kevés püspök között rangidős Podmaniczky István nyitrai püspök megkoronázott. Habsburg Ferdinánd fóherceget október végén cseh királlyá választották. Hivatkozva az 1515-ben kötött Habsburg-Jagelló házassági szerződésre - bátyja V. Károly császár és húga az özvegy Mária királyné támogatásával - Habsburg Ferdinánd bejelentette igényét a Magyar Királyságra is. Mária királyné és a mohácsi csatavesztésből elmenekült Báthori István nádor hamis keltezéssel országgyủlést hívott össze előbb Komáromba, majd a helyszínt áttették Pozsonyba. December 17-én ezen a pozsonyi „ellen-országgyűlésen”, ahol csak néhány Habsburg párti főúr jelent meg, Ferdinánd főherceget magyar királlyá választották. A választás nem volt, nem is lehetett törvényes, mivel volt már törvényesen megkoronázott király, így I. Ferdinánd csak ellenkirály volt.

1527 tavaszán Habsburg Ferdinánd pénzzel támogatta Cserni Jovánt, hogy a Dél-Alföldön menekült rácokból összegyűjtött seregével támadja meg János király területeit. Mialatt János király ellenük harcolt az Alföldön, Habsburg Ferdinánd júliusban tizenötezer fős seregével Pozsonynál betört az országba. A Duna mellett haladva sorra foglalta el a városokat, várakat, végül Budát is. János király szeptemberben Tokajnál vereséget szenvedett az idősebb Niklas von Salm császári hadvezértől és Erdélybe vonult vissza.

Habsburg Ferdinánd október elején országgyưlést tartott Budán, amelyen a köznemesség nem jelent meg, de nélkülük is döntöttek Ferdinánd megkoronázásáról. Az eseményekről folyamatosan beszámoltak a német nagyvárosokban megjelent tudósítások, közülük egy Nürnbergben kiadott már címében is arról értesít, hogy Habsburg Ferdinánd Székesfehérvárra megy, ahol megkoronázzák. A tudósítás címlapján a serege élén lovagló Habsburg Ferdinánd látható, sisakján kicsi koronával. (I. Ferdinánd koronázása 1, 36. kép)

A koronázás 1527. november 3-án történt. Perényi Péter koronaőr jutalom reményében (I. Ferdinánd ki is nevezte a koronázás után erdélyi vajdának) ismét elhozta a Szent Koronát és Podmaniczky István nyitrai püspök egy éven belül ismét koronázott, ezúttal Habsburg Ferdinándot. Így a Magyar Királyságnak már megkoronázott ellenkirálya volt. A koronázásról több tudósítást is kiadtak (mélyen hallgatva az előző évi koronázásról), közülük két francia nyelvüt említünk, illetve azok képeit ismertetjük. Az Anversben megjelent tudósítás címlapján egy zenés- 
zászlós felvonulás van, bizonyára koronázási menetet mutatja. A tudósításban olvashatunk is arról, hogy a koronázási menet trombitások vezetésével vonult át a Nagyboldogasszony bazilikából a „kétszáz lépésre lévô" Szent Péter templomba. Lehet, hogy ez ihlette a fametszet készítőjét. (I. Ferdinánd koronázása 2, 37. kép)

A másik tudósításnak (feltehetően ez is Habsburg birodalomhoz tartozó Németalföldön jelent meg) a címlapján és az utolsó oldalán is szerepel egy-egy fametszet. A címlapon egy hajó köt ki egy városban, feltehetően a beszámoló tengermelléki kiadója úgy hitte, hogy Székesfehérvárra is el lehet jutni hajóval. (I. Ferdinánd koronázása 3, 38. kép)

A tudósítás másik metszete talányosabb. A képen egyházi öltözékủ, ám fején koronát viselő férfi térdel széttárt karokkal egy oltár előtt, oldalán egy-egy egyházi emberrel. A kép akár a koronázás egy pillanatképe is lehet, amikor (és ez szerepel a tudósításban) a Szent Péter templom után I. Ferdinánd a Budai külvárosban lévó Szent István kápolnában imádkozott, majd ott letette a királyi esküt. A tudósítás egyébként nagyon részletesen, ám zavarosan írja le a koronázás menetét, nagy figyelmet fordítva a koronázást követő étkezés ülésrendjére és azt követő táncra. Szól arról is, hogy a király az egyházi jellegű, barna selyemből készült díszes koronázási ruházatot viselte. Egy művészettörténész látván a fametszetet azon Szent Istvánt vélte felfedezni, egy másik megtekintő szerint a képen egy szent pápa látható. Az alkotója a megfejtést franciás lazasággal az utókorra bízta, akárcsak a címlapon a hajó megjelenését. Összefoglalva a tudósítás képeiről leírtakat, nem hinnénk, hogy ördögtől való az a gondolat, hogy a tudósítás kiadója nem közölte volna ezeket a képeket, ha nem lett volna meggyőződve, hogy azok illenek a közzétett eseményekhez. (I. Ferdinánd koronázása 4, 39. kép)

1528 májusában I. Ferdinánd követséget küldött Szulejmán szultánhoz és éves adófizetést ajánlott fel, ha elismeri magyar királyságát és békét köt. Szulejmán szultán a követeket elfogatta és hadüzenetnek számító választ küldött. János király sokak megdöbbenésére a Habsburgok elleni további küzdelemhez Szulejmán szultántól kért segítséget. Szulejmán szultán János királlyal, mint egész Magyarország egyetlen királyával szövetséget kötött (Habsburg Ferdinánd magyar királyságát viszont soha nem ismerte el), és ígéretet tett katonai segítségre országa visszaszerzéséhez. 1528 év végére János király teljesen kiszorult az országból, Lengyelországba menekült.

1529-ben a szultán vezetésével hatalmas hadsereg indult Magyarországra. János király Mohácsnál felkereste táborában Szulejmán szultánt szövetségük megerősítésére. A törökök rövid ostrom után megszerezték I. Ferdinánd katonaságától Budát, majd Bécset fogták ostrom alá, sikertelenül. Szulejmán átadta János királynak a Perényi Péterrel kezére került Szent Koronát, Budát, a fogságába esett főurakat és visszatért Isztambulba. Az év végén VII. Kelemen pápa V. Károly császár kényszerítésére (akinek zsoldosai 1527-ben gyalázatosan kirabolták Rómát, vérfürdőt rendezve lakosai között) János királyt kiközösítette.

\section{AnNo Domini 1532}

Az elkövetkező két évben mindkét oldal eredménytelen kísérleteket tett egyfajta megbékélésre. 1532 tavaszán I. Ferdinánd a következő Bécs elleni török támadás elkerülése érdekében felajánlotta Szulejmán szultánnak, hogy a béke fejében egész Magyarországot átengedi János királynak, ám ajánlatát a szultán elutasította és a követeket nem engedte visszatérni Bécsbe. Szulejmán százezres sereggel megindult Bécs ellen. Elóbb szlavóniai várakat foglalt el, majd a DélDunántúlon átvonulva ért Kőszeghez. Augusztus 10-én a török csapatok Ibrahim pasa nagyvezér irányításával megkezdték Kőszeg ostromát. A várost és a várat a korábban követként a szultáni udvarban többször megfordult Jurisics Miklós védte mintegy ezer katonájával. A hatalmas török túlerőnek nem sikerült Kőszeget ostrommal elfoglalnia (ebben valamennyi szerepe lehetett a szinte megállás nélküli esőzésnek is). Tény, hogy Jurisics Miklós és a vár védői már reménytelen helyzetben voltak, amikor augusztus 26-án Ibrahim nagyvezér Jurisics Miklósnak (akit még isztambuli követsége idejéből ismert) tárgyalásokat ajánlott a vár békés átadásáról. A tárgyalások eredményeként Jurisics meghódolt a szultán előtt és jelképesen átadta a várat szultáni kegyelemre. Ez a valóságban úgy valósult meg, hogy a várvédők pár török katonát - túszok visszatartása mellett - beengedtek a várba, akik kitűzték a várfalra a török zászlót.

A szultáni sereg azonban Kőszegnél több mint három hetet vesztett, aminek feltehetően szerepe volt abban, hogy nem vonult tovább Bécs ostromára. Helyette a következő hetekben több csapatra szétoszolva Alsó-Ausztria és Stájerország keleti részeit dúlta, majd Marburgnál (ma Maribor, Szlovénia) átkelt a Dráván és annak mentén elhagyta az országot. Szulejmán szultán nagy hírnévvel megindított hadjárata komolyabb katonai siker nélkül ért véget.

Kôszeg hősies ellenállását a jelképes megadással együtt a kor elismerően ítélte meg, amint erről a korabeli tudósítások is tanúskodnak. Közülük az egyiken egy jelképes várkép Kőszeget mutatja, egy másikon török küldöncök adnak át levelet egy sátor bejáratában ülő török méltóságnak (talán Jurisics üzenetét Ibrahim pasának?). (Köszeg 1532/2 és Köszeg 1532/3, 40, 41. kép) 
Hans Sachs, a kor ismert versírója még 1532-ben dicsőítő költeményt írt Kőszeg ostromáról. A kőszegi esemény híre és Hans Sachs verse egyaránt késztethette a nürnbergi Erhard Schönt fametszetének elkészítésére. 1533-ban Schön hatalmas fametszete $(25,1 \times 114,3 \mathrm{~cm})$ megjelent Hans Sachs kép alá nyomtatott versével is, de ezt csak leírásból ismerjük, ilyen példány nem maradt fenn az utókorra. Erhard Schön ma ismert egyetlen Kőszeg fametszetét a British Museum gyűjteménye őrzi.

Erhard Schön metszetének címe Ein Klag zu Gott vber die grausamliche manigfaltigen wütery deß Blutdürstigen Türcken vmb gnedige Hilff (Siralmas ének Istenhez kegyes segítségét kérve a vérszomjas török iszonyatos dúlása ellen) utal az Európában a török hódításról kialakult egységes véleményről. Nem egyértelmű, hogy a kép Szulejmán szultán megérkezését mutatja a már ostrom alávett Kőszeghez (mi ezt valljuk), vagy a török szultán elvonulását a Jurisics jelképes meghódolása után. Ez utóbbinak ellent mond, hogy Kőszeg körül állnak az ostromlók sátrai, és az ostromló törökök létrákon hágnak fel a városfalra.

A kép középpontjában mindesetre Szulejmán szultán ül díszes hordszékén. Előtte lovasok visznek levágott keresztény fejeket lándzsára tűzve, őket zenészek követik. A szultán mögött török lovasok vezetik a rabszíjra füzött foglyokat. A kép hátterének többségét távolban lángoló falvak, városok látványa tölti ki. A kép jobboldali hátterében Güns felirat alatt láthatjuk Kőszeg látképét. A képen minden pontosan olyan, amilyennek Erhard Schön elképzelte. (Köszeg 1532/1, 42. kép)

Szulejmán szultán 1532. évi hadjáratát egy Rómában megjelent metszet is megörökítette. Kiadója egy spanyol származású római könyvkereskedő és rézmetsző, Antonio Salamanca, aki metszet-, térkép- és könyvkiadással is foglalkozott. A metszet megjelenésének okát a kép alatti hosszú leírás egyértelmúsíti: abban a római Hippolit Medici bíboros a főszereplő, akit VII. Kelemen pápa küldött pápai legátusként Regensburgba a török hadjáratra történő felkészülésről tanácskozó birodalmi gyűlésre. Küldetésének legfontosabb része volt, hogy a törökök elleni harchoz katonaságot vitt és a pápa pénzbeli támogatását. A címből megtudhatjuk a küldött katonaság létszámát is: ezerszázhúsz gyalogos és ezerhuszonöt lovas. A metszet címe szerint azon Ausztria és Magyarország azon helyei láthatók, ahol 1532 szeptemberében V. Károly császár, I. Ferdinánd és Hippolito Medici csapatai, illetve Szulejmán szultán megszámlálhatatlan (innumerabile) seregei vannak. A képen a rézmetsző Agostino de Musi detto Veneziano jelzése (A. V. 1532) is szerepel.

A metszet nehezen áttekinthető. Ami egyértelműen felismerhető, az a Duna folyásának ábrázolása Regensburg (Ratisbona) és Buda között, a folyóparton
Passau, Linz, Krems, Ens, Bécs, Hainburg, Esztergom jelképes feltüntetésével. Bécs alatt hatalmas török tábor, Bécs felett pedig keresztény tábor látható. Bécstől keletre a Lajta ömlik a Dunába. Esztergom és Buda között egy dombvonulat indul délre, amely a kép alján már hatalmas hegységgé változik. A hadjáratra emlékeztetnek a Dunán Budánál állomásozó török hadigályák. A metszeten egyébként harci cselekmény nem látható. (Buda 1532/1, 43. kép)

A földrajz tudós és térképész Sebastian Münster ferences szerzetesből lett a protestáns hitre tért Bázelben az egyetem héber nyelvi professzora. 1536-ban jelent meg Mappa Europae című munkája, amely Európa térképe mellett Európa országainak rövid földrajzi leírását is tartalmazza. A Sebastian Münster életművével foglalkozó irodalom ezt a munkáját mintegy előkészületi tanulmánynak tekinti az 1544-ben megjelent hatalmas munkájához, a Cosmographia-hoz (erről később részletesen is szó lesz). A Mappa Europae-ban pár jelentősebb város kisméretű szövegközti városképe is megjelent, azonban ezek a fametszetek mind képzeletbeli látképek. Magyarország leírása (Hungaria das ist Ungerland) mindössze egy oldal (az egész könyv kevesebb, mint ötven oldal), de azon két kis városkép is szerepel. Rózsa György szerint ezek Buda, illetve a Császár-fürdő (Rózsa 1999/289 és 290) nem hiteles ábrázolásai (Buda 1536/1 és 1536/2, 44, 45.kép)

\section{AnNo Domini 1541}

1538-ban I. János magyar király és I Ferdinánd ellenkirály Váradon békét kötött. Ebben megegyeztek, hogy I. János halála után az általa birtokolt területek I. Ferdinánd uralma alá kerülnek, és addig is egymást kölcsönösen királynak ismerik el. A szerződésben I. Ferdinánd vállalta, hogy a békekötés miatt várható török támadás kivédésére katonai segítséget nyújt I. János királynak. Megállapodtak abban is, hogy a békekötést nem hozzák nyilvánosságra mindaddig, amíg a várható támadásra fel nem készülnek. Miután I. Ferdinánd nem volt képes a török támadás elleni védekezéshez kellő nagyságú seregeket küldeni, I. János király megüzente, mindaddig nem tarja érvényesnek a megállapodást, amíg I. Ferdinánd a beígért katonai segítséget rendelkezésére nem bocsájtja.

1539 márciusában János király megnősült, I. Zsigmond lengyel király Izabella nevü lányát vette feleségül. 1540 júliusában megszületett gyermekük János Zsigmond, akinek születését János király csak tíz nappal élte túl. Halála után bizalmasa és kincstárnoka, Fráter György azonnal követséget küldött Szulejmán szultánhoz kérve, támogassa a gyermek János Zsigmond magyar 
királlyá választását és katonai segítséget kért I. Ferdinánd várható támadása ellen. János Zsigmondot szeptemberben királlyá választották a Rákos mezején tartott országgyúlésen, de sohasem koronázták meg. Hivatalosan a II. János választott magyar király címet viselte, amit a Habsburgok nem ismertek el. Habár valójában Erdély uralkodója volt, az erdélyi fejedelem címet soha nem viselte, mert az önálló Erdélyi Fejedelemség csak halála után jött létre. Az egyszerűség kedvéért a továbbiakban János Zsigmond névvel említjük

I. Ferdinánd hadat indított Leonard Wells generális vezetésével és októberben sorra foglalta el a korábban János király uralta Visegrádot, Tatát, Vácot és Székesfehérvárt. Eközben I. Ferdinánd követe Hieronym Laski bevádolta János királyt a szultánnál, hogy annak tudta nélkül kötött békét Váradon. A követség adófizetés fejében egész Magyarországot kérte. Szulejmán válaszként megüzente, hogy a következő évben személyesen vezet hadjáratot I. Ferdinánd ellen. Izabella királynő János Zsigmonddal Budán maradt, amit Wels generális október közepén ostromolni kezdett. Buda védelmét Fráter György irányította eredményesen, az ostromcsapatok november 21-én elvonultak.

1541. év május elején I. Ferdinánd harmincezer fôs sereget küldött Buda ostromára Wilhelm Freiherr von Roggendorf generális vezetésével. Szulejmán szultán június közepén indul el hadseregével Buda felmentésére. Roggendorf augusztus közepéig ostromolta Budát, ám ekkor tartva a török túlerőtől, megkezdte az elvonulást. Augusztus 21-22-én a török sereg megérkezett előhadai és a vár védői összehangolt támadásában Roggendorf csapatai megsemmisültek. Szulejmán szultán csak augusztus 26-án ért Buda alá, akit másnap Fráter György vezette küldöttség keresett fel és mondott köszönetet Buda felmentéséért. A küldöttség az ostromlók közül elfogott hatszáz katonát és zsákmányolt ágyúkat ajándékozott a szultánnak (sorsukról később). Augusztus 29-én Szulejmán kérésére a gyermek János Zsigmondot az Óbudán felvert szultáni táborbavittékbemutatniaszinte valamennyi Budán lévőfoúr kíséretében.Alátogatás során Szulejmán mintegy fiává fogadta János Zsigmondot, de a küldöttségben lévő Török Bálintot elfogatta és fogolyként magával vitte Isztambulba. A látogatás alatt a békés városnézés ürügyén Budára beszivárgott törökök lefegyverezték Buda

őrségét. Szulejmán Buda megszállása után közölte Izabella királynővel, hogy a továbbiakban Erdélyt, a Tiszántúlt és a Temesközt tekinti János Zsigmond uralma alatt álló területeknek, ezek megvédésében mindenkor számíthatnak rá, de ezért évi tízezer arany adót kell fizetniük. A csalódott Izabella királynő a gyermek János Zsigmonddal Fráter György kíséretében Lippára ment, amely egy ideig székhelyük volt.

Szulejmán szeptember 2-án ünnepélyesen bevonult Budára, a Nagyboldogasszony templomot dzsámivá nyilvánította és ezzel hivatalosan is kezdetét vette Buda török megszállása. Az elfoglalt területeken megszervezték

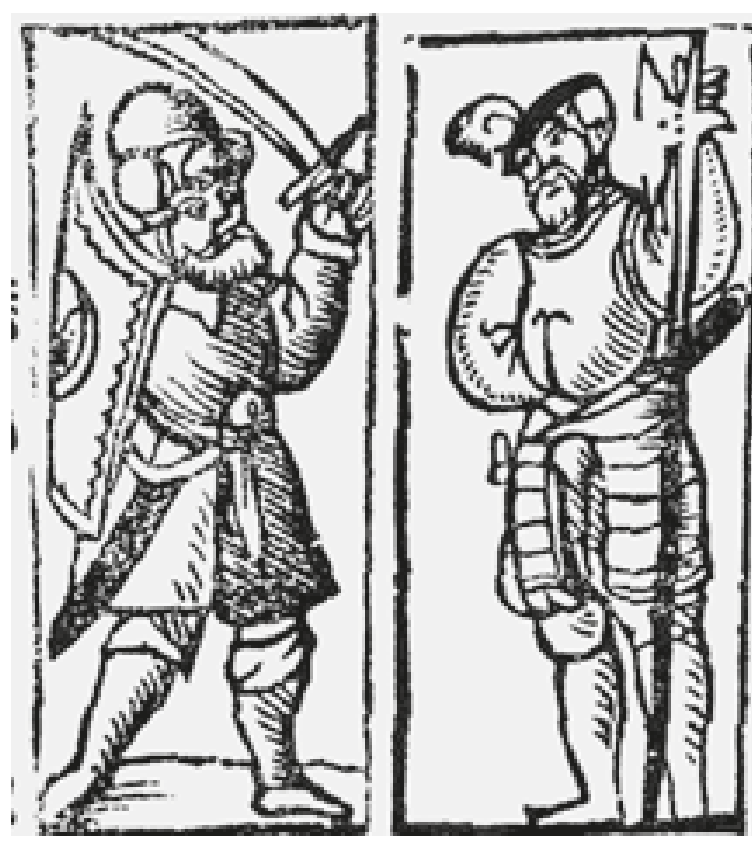
első, helyszínen készült vázlatrajzok alapján készített, összességben látványában hűnek nevezhető Buda metszetet (Rózsa 1999/1). Ez Erhard Schön öt fadúcról nyomtatott fametszete, amely alá Hans Sachs Buda ostromáról írt versét nyom tatták.

$\mathrm{Az}$ egyetlen eredeti példányban ismert metszetről és Hans Sachs Buda ostromáról írtverséről számos ismertetés látottnapvilágot,történeti és helytörténeti forrásértékét többen alaposan vizsgálták és megírták, közülük csak az időben utolsó Végh András, Gödölle Mátyás és Andrew Alchin nevét említjük. Andrew Alchin Buda ábrázolásait bemutató könyvében közli Hans Sachs versének magyar fordítását is. Abban a vitában nem kívánunk állást foglalni, hogy Erhard Schön Buda metszetét 
Hans Sachs verséhez készítette, vagy Hans Sachs találta alkalmasnak Erhard Schön Buda látképét arra, hogy arra a versében leírt ostromesemények is rákerüljenek. Csak azt állíthatjuk, hogy Erhard Schön Buda látképének önmagában (a rárajzolt ostromjelenetek nélkül) is jelentős helytörténeti forrásértéke van. De ez nem egyedül Erhard Schön művészi képességeinek köszönhető.

Erhard Schön Buda látképének a műfaj keretein belül elképzelhető valóság tükrözése csak helyszínen készült rajzok alapján lehetséges. Erhard Schön nem volt ott Buda ostrománál, tehát ő ilyeneket nem rajzolhatott. A Buda ostrománál jelenlevő ismeretlen rajzolónak a munkáját - még ha futólag említik is - azonban soha nem méltatják a metszettel foglalkozók, pedig a látkép megbízhatósága alapvetően neki köszönhető. Róla semmit nem tudunk, amint azt sem ismert részletesen, hogyan jutott Erhard Schön a szükséges Buda rajzokhoz. A következőkben ehhez kívánunk pár adalékot bemutatni.

Minden német-római birodalmi városnak, így Nürnbergnek is a török elleni harcok birodalmi támogatásához hozzá kellett járulnia, amit gyűjtő néven Türkenhilfe-nek neveztek. Ennek összegét mindig a birodalmi gyưlés határozta meg. A támogatás történhetett pénzzel, vagy zsoldosok felfogadásával, fegyverek beszerzésével vagy más módon is, de ezekről tételesen el kellett számolni. Ezeket pontosan könyvelték és az adatok a városok gazdasági iratai között fennmaradhattak. Nürnberg város levéltári forrásaiból ismert, hogy a városnak két megfigyelője is tartózkodott Buda 1541. évi ostrománál, Jeronimus von Hall és Philip Hermann. Ez utóbbi Nürnberg tüzérségi és tűzijáték alkalmazottja volt. A város számadási könyveiből arról is értesülünk, hogy májusban indultak Budához, onnan visszatérve november 2-án kiadásaikkal elszámoltak és az utazáshoz kapott két lovat is visszaadták. Az elszámolt költségeik között szerepel az ostromról készített és magukkal hozott élethű rajzokért fizetett összeg is. A város tehát rendelkezett Budáról megbízható rajzokkal, de sajnos, a rajzoló nevét nem jegyezték fel.

De nem csak a Philip Hermann és társa hozott rajzok készültek Budánál. 1542 januárjában jelentkezett egy festő Nürnberg városánál és felajánlotta némi tiszteletdíj reményében - a Budáról és Pestről(!) készített rajzait. A város visszaszolgáltatta a felajánlott rajzokat mondván: „A csodált budai és pesti mappákat (képeket) visszaadják a festőnek, jelezve, hogy már több is van a birtokukban." Ennek a festőnek se tudjuk a nevét, egyike lehetett a korszak vállalkozó lelkületú vándorfestőinek (Hans Sebald Beham is vándorfestőként kezdte pályáját) aki csatlakozott valamelyik birodalmi sereghez és elment Budához.

Erhard Schön bizonyára nagyon közeli ismeretségben lehetett Philip Hermannal, hiszen Schön 1542-ben történt halála után ő lett kiskorú gyermekeinek gondozója. Hermanntól Schön mint szemtanútól nem csak hiteles értesülésekhez juthatott, hanem talán az általa hozott rajzokhoz is, vagy megkaphatta azokat

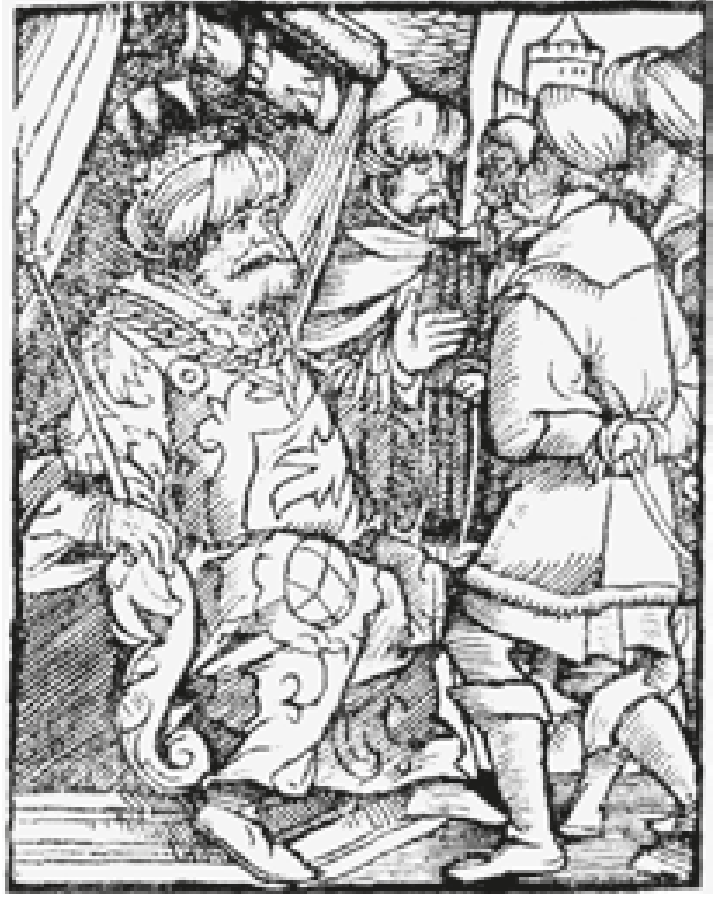
Nürnberg városától. De a nürnbergi városi bejegyzés azt is igazolja, hogy egy vándorfestőtől is hozzájuthatott a Buda metszetéhez szükséges rajzokhoz.

Ez az ismeretlen rajzoló több rajzot is készített, mert ilyen nagy látószögből Buda városa és vára, a Szent Gellérthegy és attól délre eső kelenföldi síkság egyetlen helyről se be nem látható, se meg nem rajzolható. A több részletrajzból történt egybeszerkesztés (ezt végezhette a rajzoló maga vagy Erhard Schön, de akár közösen is) lehet az oka a látkép egyetlen jelentősebb hibájának: a budai Várhegy a metszeten enyhén észak felé lejt, legmagasabb pontja a déli vége a királyi palotával. A valóságban ez pont fordítva van, a királyi palota a Várhegy legalacsonyabb, déli végén van, legmagasabb pontja pedig valahol a volt Mária Magdolna templom környékén. A több nézőpontból készült helyszíni vázlatok egybeszerkesztése okozhatja a Várhegy déli vége és a Szent Gellért-hegy közötti terület szurdokszerủ megjelenését is: ahogy haladunk északra a Nap hegy oldalában úgy szúkül egyre jobban össze az Ördögárok völgye és lesz egyre meredekebb a Szent Gellért-hegy oldala.

Az a meggyőződésünk, ez az ismeretlen rajzoló Budáról a Duna keleti oldaláról is készített rajzot, amit később Virgil Solis felhasznált Pest 1542. évi ostromát bemutató metszetéhez (lásd később).

Erhard Schön metszetének másik kifogásolt részére, a Déli-bástyától a Duna partra lefutó sarokbástyás, kettős védőfal bemutatására (ez a valóságban nyugati nézőpontból nem látható) megfelelő magyarázatnak tartjuk, hogy Erhard Schön (vagy az ismeretlen rajzoló) azt hadászati szempontból annyira fontosnak tartotta, hogy nem törődve a valóság hiteles tükrözésével, rárajzolta a látképre. 
A képen egyszerre látni az ostrom egymást követő, Hans Sachs versében részletesen leírt különböző történéseit. A látképre így se fért rá minden esemény, ami Hans Sachs versében szerepel, ami érthető: ha ugyan annál a falszakasznál több egymást követő esemény volt, akkor azok közül csak egyet lehetett rárajzolni a képre. Az eseménysorozatok egyszerre történő ábrázolása egyébként a korban (de később is) általánosan elfogadott volt. A képen szereplő események sora a kép jobb oldalán az augusztus 20-21-én történt csata bemutatásával végződik, amikor a visszavonuló Roggendorf generális csapatai megsemmisítő vereséget szenvedtek.

Erhard Schön látképének nagy értéke, hogy nem csak ábrázolja (egymáshoz viszonyítva térben jól elhelyezve) Buda látvány szempontjából meghatározó épületeit, a templomokat és a királyi palota épületeit, hanem közülük öt templomot meg is nevez. Még az is lehet, hogy ezeknek tornyai nagy távlatból ilyennek látszottak. Véleményünk szerint ez azonban nem mondaható el a Várnegyed egyéb épületei rajzáról, hanem azok a korra jellemző városi épületek formáját és kinézetét tükrözik.

A ma is meglévő eredeti fadúcokról (amelyekről azonban pár felirat az idők során, mint például Pest neve elveszett) a 20. században utánnyomatok készültek. (Erhard Schön Buda ostroma 1541/1, 46. kép)

Alig ismert azonban Erhard Schön egy másik, szintén 1541-ben Budánál történt eseményről készített fametszete. Wilhelm von Roggendorf Budát ostromló csapatai a vár felmentésre érkező török sereg Mohamed szerdár vezette előcsapatai és a Budából kitört védők egyidejű támadásában augusztus 20-21-én gyakorlatilag megsemmisült. Szulejmán szultán 1541. augusztus 26-án ért Buda alá, Cserepesnél ütött tábort. Ünnepélyes üdvözlésére Fráter György, Török Bálint, Petrovics Péter és Izabella királynő udvarából több más főembere felkereste Szulejmánt és ajándékul Roggendorf generális seregéből elfogott 600 zsoldost (20 fős csoportokba összekötözve) és zsákmányolt ágyúkat vittek (mindezt már említettük). Szulejmán a foglyokat azonnal lefejezette, mondván a halott katona nem háborúzik többé. Más források szerint csak 400 foglyot öletett meg, 200 katonát harci naszádokra vitetett evezősnek. Megint más források szerint csak 400 fogoly volt összesen. A források egyben megegyeznek, hogy Szulejmán szultán pár tisztet életben hagyott.

Hans Sachs a 600 keresztény fogoly lemészárlásáról és Buda csellel történő elfoglalásáról is írt 1542 tavaszén egy elbeszélő költeményt Ein tyrannische that des Türcken, wie er sechshundert gefangne knecht ellendiglich hat laszen niederhawen, auch die künigin ins ellend verschickt im 1541. jar. címmel. Hans Sachs versében az események időpontját összekeveri, szerinte Buda megszállása augusztus 27-én történt (valójában 29-án) és csak ezt követően, szeptember 2-án végezték ki a foglyokat. A vers végén Hans Sachs felszólítja és lelkesíti a német fejedelmeket, hogy fogjanak össze és győzzék le törököket - ezeket bizonyára már a Buda visszavételére szerveződő 1542. évi hadjárat ismeretében írta.

Erhard Schönnek ebből a metszetéből egyetlen sérült és Hans Sachs verse nélküli példány ismert. A képen semmilyen felirat vagy cím nincsen és azon Buda látképe sem tűnik fel, csak az elfogott katonák kivégzését mutatja, két részletben. A háttérben egy kisebb török lovascsapat előtt három oszlophoz kötözött katonát nyíllövésekkel végeznek ki, előttük földbe szúrva három félbetörtzászló, az egyiken a császári sas. Ez a jelenet Hans Sachs verse szerint a három zászlótartó kivégzése lehet. A képen jobbra Szulejmán szultán ül sátra bejáratánál, előtte török katonák gyűrűjében pár keresztény katona, talán ítéletükre vagy netán kegyelemre várva. A kép baloldalán két csoportban a foglyok lemészárlása látható. (Erhard Schön Buda, zsoldosok kivégzése1541/2, 48. kép)

Az 1526. év eseményeinél említettük a máltai lovagok történetéről írt könyvet, amelyben megjelent Buda képzeletbeli látképe a mohácsi csatával összefüggésben. Ebben a könyvben szerepel Buda 1541-ben történt török megszállása is (Rózsa 1999/297), egy hasonlóan légből kapott fametszetes Buda látképpel. (Buda 1581/2, 33. kép)

\section{Buda elvesztésétől a Drinápolyban kötött fegyverszünetig (1542-1568)}

Nem sokkal Buda elfoglalása után, szeptember végén I. Ferdinánd már sokadik követségét küldött Isztambulba, felajánlva, hogy a teljes Magyarország átengedéséért vagy legalább békekötés fejében éves adót fizetne. Szulejmán szultán az előbbit elutasította, a béke fejében pedig Esztergom, Visegrád, Székesfehérvár és Tata átadását követelte. I. Ferdinánd ezután egy következő évi hadjárathoz kezdett segítséget gyűjteni. December elején Prágában a cseh és osztrák tartományok együttes országgyűlésükön nagy összegű adót szavaztak meg egy török elleni hadjárat költségeire. 1542 februárjában a birodalmi gyűlés Speyerben 48 ezer katona küldését határozta el Buda visszafoglalásához.

Időközben még 1541 decemberében a csalódott Izabella királynő elhatározta, hogy fia nevében lemond az általa uralt országrészről és azt a Szent Koronával együtt átadja I. Ferdinándnak (Gyalui egyezmény). Ezt a szándékát 1542 augusztusában az erdélyi országgyűlés jóváhagyta. 


\section{Anno Domini 1542}

1542-ben Joachim brandenburgi választófejedelem vezette az osztrák, magyar és itáliai csapatokkal kiegészült, összesen ötvenötezer fős birodalmi hadsereget Budához. A választófejedelem csapatai a szeptember végén és október elején mindössze két hétig tartó ostrom során azonban hatalmas kudarcot vallottak. Pest városát ugyan hevesen ostromolták, de Buda ostromához gyakorlatilag hozzá se kezdtek. A Buda felmentésére induló török sereg még messze járt Budától, amikor ennek hírére - a magyar és itáliai csaptok ellenkezése dacára - a birodalmi seregek felhagytak az ostrommal és október 9-én elvonultak. A török felmentő csapatok ekkor még Bajáig sem értek el.

Pest ostromáról a szintén Nürnbergben élő és alkotó Virgil Solis készített egy fametszetet. Ez a négy fadúccal készített, ránézésre is hiányosnak látszó metszet csak fényképről volt ismert és azt a Buda ikonográfiájával foglalkozók nem tartották hiteles látképnek, mert a keleti nézetből készült Pest ostromképen a háttérben Buda városa ugyan helyesen szerepel, de a királyi palota markáns épületegyüttesét csak egyetlen tornyos épület ábrázolja (Rózsa 1999/378). Pár évvel ezelőtt azonban felfedeztük a metszetnek egy másik, ugyancsak csonka példányát, amelyről a fényképről ismert metszet bal szélső, egy fadúcnak megfelelő része hiányzik. Viszont ennek a metszetnek teljes az a része, ami a korábbi fényképről ismerten hiányzik. Ezen a hiányzó, mintegy öt centméter széles részleten a hiányolt budai Várpalota valósnak tűnő ábrázolása látható. A két képből összeállított metszet - noha a Szent Gellért-hegy (Geretzberg) kissé mesebelinek tűnik - megbízható képet ad Budáról, sőt azon a Margit-sziget és Óbuda (ALT OFEN) is megjelenik.

A kép Pest ostromát mutatja az azt körülvevő hatalmas ostromtáborral. A Pest városfalát rohamozó katonák ostromlétrákon másznak fel, a várost az ostromlók ágyúi lövik. A Szent Gellért-hegy tetején lévő török erődből ágyúval lövik az ostromlókat. Erhard Schön képéhez hasonlóan ezen is név jelöli az Alhévízen lévő fürdőt (PAADT) és szerepel a koronás magyar címer. (Virgil Solis Pest ostroma - Buda 1542/1, 47. kép)

Említettük már a metszeten megjelenő királyi palota képét, amely egyes részei azonosíthatóan megfelelnek az Erhard Schön metszetén láthatókkal. Azonban a Dunára lefutó kortinafal képe más. A déli várfal mellett futó „kurtina” a végén az egymás melletti két bástyával itt is megjelenik, de a „kurtina” törésében lévő két bástyától egy kettős várfal egyenesen vezet tovább a Dunáig, ahol egy nagyobb méretű építményben (Vízi-rondella?) végződik. Ez a rajz elfogadható a valóban létező déli kortinafal kissé elnagyolt ábrázolásának. Az északi kortinafal azonban nem látható a metszeten, feltehető helyén egy hosszúkás, téglatest alakú bástya ugrik ki a Duna irányába, amelyből éppen ágyúval lőnek Pest felé.

Erhard Schön metszetével egyezően itt is tévesen, északról déli irányba lejt a Várhegy. A mindkét látképen megjelenő négy beazonosítható templomtoronynak nemcsak az egymáshoz való térbeli elhelyezése egyezik, de közülük háromnak a formája is azonos.

Virgil Solis metszete is biztosan helyszíni vázlatrajzok alapján készült, azok rajzolója szintén ismeretlen. Nem tarjuk elképzelhetetlennek, sőt, valószínűsítjük, hogy Erhard Schön és Virgil Solis képeihez ugyanaz a rajzoló készítette a helyszíni vázlatokat. Ezért is gondoljuk, hogy Buda keleti nézetú rajza is még 1541-ben készült, amire utólag az ostromtábort és az ostromjeleneteket egyszerú lehetett rárajzolni.

Kevésbé ismert, hogy Hans Sachs Pest 1542. évi sikertelen ostromáról is írt egy 12 versszakból álló verset (OSZK Röplap/192). Mivel Virgil Solis 1542. évi metszete 4 fadúcról készült, a metszet alatt pontosan elférhetett (a dúcokról nyomtatott 4 lap mindegyikén 3-3 versszak) Hans Sachs verse. Heinrich Röttinger Virgil Solis metszetének ismertetésénél a „szöveg nélküli példány” (Textlose) megjegyzést teszi, ennek alapján az is feltételezhető, hogy metszet megjelenhetett Hans Sachs versével is.

Pest ostromáról a fiatal Enea Vico Rómában készített látképet. Munkája

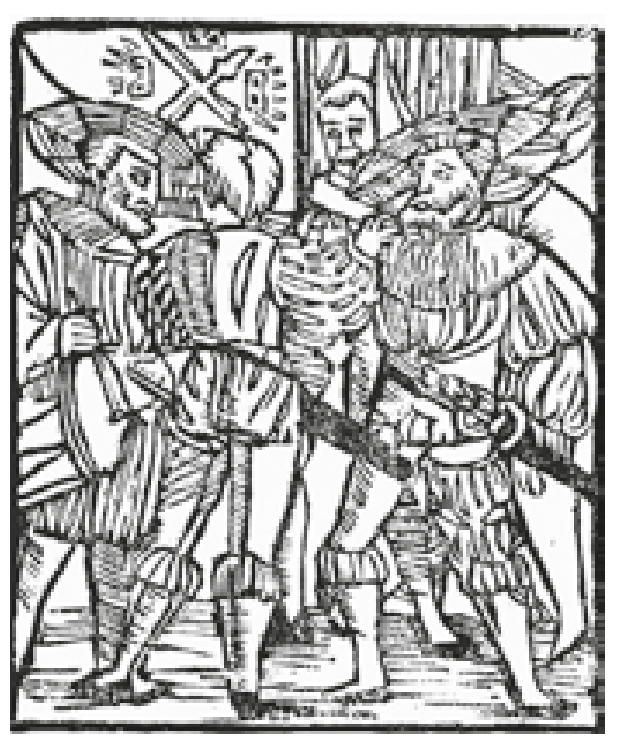
az első rézmetszet technikával készített sokszorosított magyar látkép. Nem tudjuk, mi keltette fel érdeklődését az esemény iránt, talán a Pest ostromában részt vett pápai sereg valamelyik katonájától (Virgil Solis metszetén feltünteti az Itáliából, Rómából és Milanóból érkezett katonák táborát) értesülhetett az ostromról és annak képét is elbeszélés alapján készíthette el. Ha nagyon kritikusan értékeljük a képen láthatókat, azokból annyi biztosan megfelel a valóságnak, hogy Buda és Pest a Duna két oldalán fekszik, tőlük északra van a Margit-sziget, Buda pedig egy kisebb hegyen helyezkedik el. Pár apróbb részlet helyismeretre, 
pontosabban szóbeli közlésre utal: a királyi palota és a polgárváros markáns elkülönítése, Pest városánál a Porta d’Agria (Egri kapu) és Porta di Vaccia (Váci kapu) név feltüntetése, a Margit-szigeten a domonkos kolostor és templom, a várból a Dunára lefutó kettős kortinafal a Vízi-rondellával.

A metszet legérdekesebb részlete a Dunán keresztül húzott, a hajózást elzáró vaslánc rajza. Úgy hisszük, Enea Vico ennek létéről is az ostromban résztvevő pápai katonáktól vagy a Giuseppe Melignani vezette olasz naszádosok valamelyikétől értesülhetett. Az Alessandro Vitelli irányította pápai csapatok főszereplői voltak a szeptember 1-én a pesti Duna parton, a hajózást elzáró lánc közelében lezajlott véres ütközetnek, a naszádosok pedig részt vettek a lánc felderítésében. (Buda 1542/2, 53. kép)

Ennek a dicstelen hadjáratnak érthetően alig volt visszhangja a Németrómai Birodalomban. Alig pár tudósítás jelent meg hírt adva minderről, de azok is inkább a törökök kegyetlenkedéseiről számoltak be, mint a birodalmi seregek kudarcáról. (Török vérengzés 1542, 52. kép)

\section{$>>>><<<<<$}

Buda visszafoglalási kísérletének kudarca után Izabella királyné felbontotta a Gyalun kötött megállapodást és nem volt hajlandó területeit átadni I. Ferdinándnak. 1543-ban Szulejmán szultán ismét hadat vezetett Magyarországra és egymás után foglalta el Esztergomot, Tatát, majd Székesfehérvárt. Esztergomot július 24-én zárták ostromgyűrűbe, pár nappal később elkezdték a vár folyamatos ágyúzását. A várfalak nem sokáig álltak ellen a heves ágyútűznek. Augusztus 8-án a várból két olasz katona kiszökött a vár átadásáról tárgyalni a török táborba. Kedvező ígérettel tértek vissza (bántatlanul elvonulhatnak) és rábeszélték az átadásra parancsnokukat, Francisco Salamancát. Az ostrom alatt megsebesült Martino Lascano várkapitányt Salamanca győzte meg a vár feladására. A védőkkel előbb az összes halottat eltemettették, majd teljesen kirabolva, szinte ruhájuktól is megfosztva hajókkal átszállították a Duna túlsó partjára és onnan szabadon elvonulhattak. I. Ferdinánd osztrák és birodalmi csapatai ezalatt tétlenül várakoztak Győrnél. Szeptember elején egy négyezer fős erősítést küldtek Székesfehérvárra, majd a sereg többi része szeptember végén egyetlen harci esemény nélkül szétoszolt. A következő évben Mehmed budai pasa elfoglalt három további kulcsfontosságú helyet, az Esztergomba vezető hajóutat védő Visegrádot és a Felvidék felől érkezhető támadások miatt fontos Nógrádot és Hatvant.
Az 1543. évi hadjáratnak alig volt visszhangja, egyedül Esztergom, mint korábbi királyi székhely elfoglalásáról jelent meg pár tudósítás, címlapjukon a szokásos várostromot vagy csatajelenetet mutató fametszetekkel. Néhány tudósítás címében is közölte, hogy a várat az itáliai katonaság adta át a törököknek. (Esztergom 1543/1/b és 1543/1/c, 54, 55. kép)

\section{Sebasian Münster: Cosmographia (1544-től)}

A Bázelben élő tudós Sebastian Münster Cosmographia című műve az akkor ismert világ teljes földrajzi, történelmi bemutatását térképekkel - köztük Johannes Honterus Erdély térképének másolatával - és számtalan fametszettel (városképek, uralkodók, címerek, állatok és növények stb.) kívánta szemléletesebbé tenni. Könyve első kiadása német nyelven jelent meg 1544-ben Bázelben. Műve hihetetlenül népszerűvé vált és az a történelmi eseményeket, az újabb földrajzi felfedezéseket követő bővülő tartalommal 1628-ig a német mellett latin, olasz, francia és cseh nyelven is kiadták. Összesen 36 különböző kiadását ismerjük. A különböző nyelvú könyvek legtöbbször ugyanazt a térkép- és képanyagot közölték, egyedül a prágai cseh nyelvű kiadásban nem jelentek meg térképek és képek. Természetesen a bővülő tartalomhoz az idők során újabb térképek és képek is készültek, illetve amit elavultnak tartottak (elsősorban térképeket), azt átjavították vagy elhagyták.

Münster könyvében már a kezdetektől szerepelt a Magyar Királyság ismertetése és térképe (hol Lengyelországgal együtt, hol Sarmatia néven egyedül). A szöveges ismertetésbe illesztve láthatjuk Attila hun fejedelem és Mátyás király portréját, olvashatjuk Nándorfehérvár 1456. évi ostromát (téves 1457 évszámmal), Hunyadi János diadalát, szerepel a magyar címer valamint több szövegközti életkép is. A müben viszonylag terjedelmes leírás olvasható Erdélyről is. A szászok lakta területekről két várost, Nagyszebent és Brassót részletesebben is leír. Az írásos ismertetést kiegészíti egy egész oldalas Erdélytérkép, amely a brassói Jonhannes Honterus művének másolata (ez a későbbi kiadásokban lekicsinyítve szövegközti térképként jelent meg). Ismerve, hogy a humanista brassói Honterus nemcsak Bázelben tanult, hanem térképkészítőként is volt kapcsolata Münsterrel (lásd az előbbi példát), alaposan feltételezhető, hogy Erdély ilyen mértékű szerepeltetése a Cosmographiában ennek köszönhető. Ne felejtsük, I. János magyar király a Habsburgok befolyása alatt álló NyugatEurópában persona non grata volt, beszélni se illett róla. Ez lehetett egyébként az oka annak, hogy Münster művében II. Lajos halálával a magyar történelem 


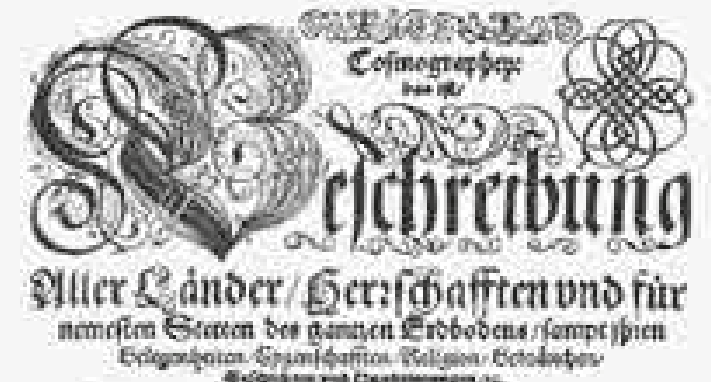

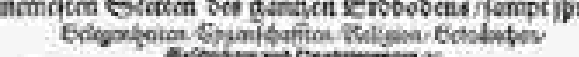

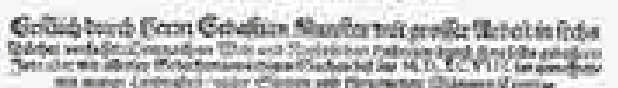

entom

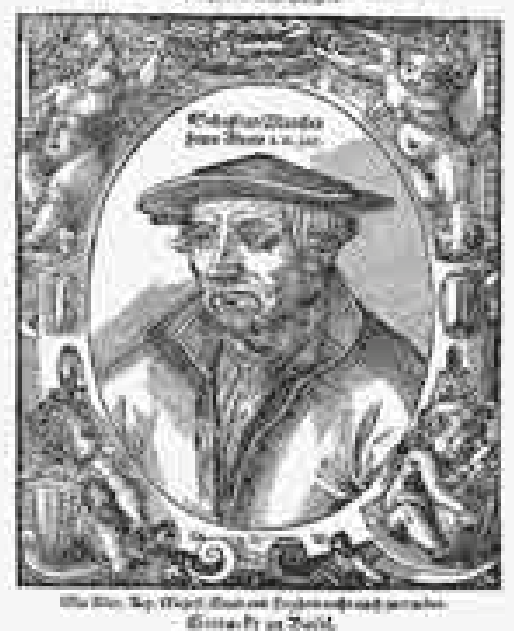

ismertetése véget ért. Talán az akkor már önálló Svájcban sem volt tanácsos leírni, hogy Habsburg Ferdinánd ellenkirályként lépett a magyar trónra

Nem lehetetlen, hogy az említett Honterus-Münster kapcsolatnak is köszönhetően jelent meg már az első kiadásban Nagyszeben (Hermanstatt Hauptsatt) kisméretű $(6,0 \times 5,5 \mathrm{~cm})$ látképe, amely szerepel az 1572-ig megjelent további 11 kiadásban is. A látkép fadúcát többször újravésték: az első, 1544 évi kiadás képét 1546-ban, majd 1550-ben, végül 1567-ben új képek követték. A városkép azonban nem valós ábrázolás, sőt, ugyanez a városkép a könyvben több városnál (például Marseille, Colmar, Pforzheim) is megjelenik. Ennek ellenére újra meg újra vannak olyan vélemények, hogy a kép valós elemekből van összeszerkesztve. (Nagyszeben 1544/1, 56. kép)
Az 1550. évi latin nyelvű kiadásában Brassó (Corona qua Pressovia) képe $(8,0 \times 6,0 \mathrm{~cm})$ is megjelenik, Nagyszeben képéhez hasonlóan képzeletbeli ábrázolással: Brassó képe egy hatalmas szikla tetején lévő vár! Ettől kezdve valamennyi latin, 1552-től kezdve francia- és 1558-tól olasz nyelvű kiadásban is megtalálható, egészen az 1575. évi olasz kiadásig. Az olasz és francia kiadásokban azonban a városnév külön feltüntetése többnyire elmarad, az csak a kép melletti szövegben szerepel. Nem tudjuk mi az oka, de a német nyelvű kiadásokban Brassó képe nem jelent meg. (Brassó 1550/1, 57. kép)

Münster könyvében azonban nemcsak képzeletbeli városképek vannak Már a kezdetektől találunk benne valós látvány képét tükröző, esetenként egészen nagy, akár kétoldalas méretűeket is. Ilyen valós hűségre törekvő első magyar városkép Buda látképe $(17,5 \times 9,0)$ volt, amely az 1550. évi latin nyelvű kiadásban jelent meg, egyszerre a már említett Nándorfehérvár képével. Ettől kezdve ez a Buda látkép minden latin, olasz és francia nyelvű kiadásban (köztük az egyetlen kéthasábos elrendezésű, 1575. évi párizsiban is) szerepelt, viszont a német nyelvû kiadásokban csak 1588-tól jelent meg. A késedelem okát nem ismerjük.

Buda képe nem a város és a vár látképe, hanem csak a budai vár királyi palotájának a képe, amelyet az ismeretlen rajzoló Erhard Schön 1541-ben készített fametszetéről vett át. A képen olvasható feliratok (aula regis, Tonau Danubius, bastei, thermae, Luft garten, Horti amoeni, aula marmorea) Schön képén nem szerepelnek, az azon lévő könig garten itt több megnevezéssel, részletezve látható. Mivel Buda részletes leírása Münster könyvében nem található, a magyarázó feliratok eredete a kép rajzolójának előttünk ismeretlen forrása volt. Közülük csak a fürdő helyének (thermae) bejelölése kétséges, még ha hőforrást jelölne, akkor is. A feliratok segítik az egyébként erőt, hatalmat sugárzó, mutatós kép megértését. A képen nem szerepel Buda neve, viszont a Schön képéről átmásolt magyar címer egyértelműsíti, hogy magyar városról van szó. A különböző nyelvű kiadásokban megjelent Buda látképekből egyet-egyet közlünk. (Buda 1550/1, 58-61. kép)

\section{AnNo Domini 1549}

Az 1548 októberében Pozsonyban tartott országgyűlés határozatot hozott Balassa Menyhért és Basó Mátyás Léva és Murány környéki garázdálkodásának felszámolására. Az 1549 tavaszán indított büntető hadjárat fővezére az ifjabb Nicklas Salm császári generális volt. Elsőként Balassa Menyhért ellen vonultak. Balassa Menyhért várait katonasággal megerősítette, de ő maga Erdélybe 
menekült János Zsigmondhoz. Salm generális hadai először Szitnya várát foglalták el, majd megkezdték Léva ostromát, amit április 22-én adtak fel védői.

Léva ostromáról a Bécsben élő Augustin Hirschvogel készített egy rézkarcot. A metszet címe a képen fent középen címtáblán olvasható: PELEGERUNG DES VESTEN SCHLOS LEIWAY, IM 1549 IAR DE 22 APRIL.S UND IST SOLCHS DURCH HERREN NICLASEN GRAFEN ZU SALMEN GENERAL OBERSTE EROBERT UD EINGENUMEN WORDEN. ETC.

A metszet bal oldalán a palánkkal körbevett Léva mezőváros látható, amely északi végénél van a várkastély, amely a Garam egyik mellékága által táplált tó partján fekszik. A várkastélyt a városban és a városon kívül lévő ágyúsáncokból ostromolják. A kép többi részét sátortáborok és szállítóeszközök rajza tölti ki. Az ágyúsáncokat, tüzérséget, az ellátmányhelyet (Profunant Platz), a spanyol katonák táborát feliratok jelzik, a sátortáboroknál pedig az egyes parancsnokok neve illetve katonaságuk megnevezése szerepel a következők szerint:

- MAGISTER DE KAMPO valójában Bernardo de Aldana tábormester (korabeli magyar elnevezése „Nagykampó”)

- PETHEW HIANISCH HVSSARN Pethő János főpohárnok huszárokkal

- HORBATH BARTHOLOME HVSSARN Horváth(inovich) Bertalan Balassagyarmat kapitánya huszárokkal

- MAXIMILIAN LEISSER OBRISTER ZEIGMISTER Maximilian Leysser ezredes táborszermester

- GENERAL OBERSTER G N V SALM Niklas Graf von Salm főhadparancsnok

- GRAF JVLIVS VON HARDEKH gróf Julius I. zu Hardegg ezredes

- $\quad$ RATH VND SECRETARI KNEISSL Heinrich Wolfgang Kneissl udvari tanácsos

- HERR REINPRECHT V. EBERSTORF Reinprecht Graf zu Tierstein von Ebersdorf főhadparancsnok-helyettes

- HER ERASSM TEVEL Erasmus Teuffel von Gundensdorf győri főkapitány

A metszeten feltüntetett katonai parancsnokok valamennyien ott voltak

Lévánál, annak készítője tehát pontos értesülésekkel rendelkezett.

A metszet összességében megfelel azoknak az elvárásoknak, amelyeket az eseményekről értesülők képes kiegészítésként elvártak. Beleillik a később hasonló célból készült metszetek sorába, azokból sem a tájékoztatás mennyiségi, sem a rajz művészi színvonala tekintetében nem lóg ki. Talán csak növényzetrajza szokatlan és a harcoló katonaság ábrázolásának hiánya. Háborús esemény képéről van szó, ám a metszeten egyetlen katona sem látható! (Léva 1549/1, 62. kép)

Léva elfoglalása után Niklas von Salm csapatai körbezárták Csábrágot, amit június 5-én kerítették kézre. Murány ostromát az ekkorra már hozzájuk csatlakozott Bebek Ferenc csapataival együtt július 5-én kezdték meg, a várostromokban legjártasabb Bernardo de Aldana irányításával. Basó Mátyás a vár rendkívül jó terepadottságoknak is köszönhetően a mintegy tízszeres túlerő ellen negyven napig tudta tartani Murányt, amit végül augusztus 15-én foglaltak el Salm csapatai. Az ostrom vége felé Basó Mátyás kiszökött a várból, de pár nappal később elfogták, testvérével, Mártonnal és 12 katonájával együtt kivégezték.

Murány ostromát is Augustin Hirschvogel örökítette meg. A Murano címú rézkarca már Bartsch jegyzékében (Band 9.192-193. 79.) majd Nagler művészeti lexikonjában (Band VI., 559. 59.) is szerepelt, de azt a szakirodalom tájképként tartotta számon. Első ránézésre a metszeten nem könnyű felismerni, hogy azon a jobboldali hegytetőn egy vár van, bár ebben segít a vár fokán lobogó zászló. Ezzel együtt a kép címe még mindig lehetne akár „Tájkép Murány várával”, vagy hasonló. Ám alaposabb vizsgálat után egyértelmúvé válik, hogy a rajz az ostromlott Murány várát ábrázolja. Ennek felismeréséhez azonban tudni kell, hogy abban a korban az ostromképeken szokás volt a kilőtt ágyúgolyók röppályáát berajzolni. Ilyen röppálya pedig a vár alatti hegynyeregben három helyen is látható. (Murány 1549/1, 63. kép)

A metszettel összefüggésben két megjegyzést teszünk. Az első, hogy Hirschvogel biztosan személyesen járt Muránynál és ott készítette rajzát rézkarcához. Ezt bizonyítja az a 18. század közepén készült, hadmérnöki felmérési lapokhoz csatolt látványrajz, amelyik nézőpontja azonos lehetett Hirschvogelével, a két rajz pedig megdöbbentően azonos látványt nyújt (Claude Rochet rajza, 1740). Ugyanezt nem merjük állítani Léva metszete esetében. A metszeten semmi olyan egyedi jellegzetesség nem fedezhető fel, amelyet egy szóbeli tájékoztatás (és a parancsnokok neveit tartalmazó lista) alapján Hirschvogel ne tudott volna akár Bécsben megrajzolni.

A másik megjegyzésünk a „Murány ostromképe” elnevezésre vonatkozik. Ez bármennyire is pontos megnevezése Hirschvogel munkájának, az mégsem egyike azoknak a 16-17. században tömegesen megjelent ostromképeknek, amelyek az eseményekről szóló nyomtatott tájékoztatások képi kiegészítése céljából készültek. Ez utóbbiakon a hangsúly nem (vagy nemcsak) az esemény helyszínének, hanem magának az eseménynek a bemutatásán (sokszor az egymást követő történések egyidejű feltüntetésével) volt, beleértve azok szereplőinek ábrázolását is. Ezekre a teljesen más megközelítésből készült ostromképekre tökéletes példa magának Hirschvogelnek az előbb ismertetett Léva ostromképe.

Murány képéhez még jellemzésként azt is mondhatjuk: látjuk a metszeten Murány várát, de azt nem látjuk, hogyan néz ki. 


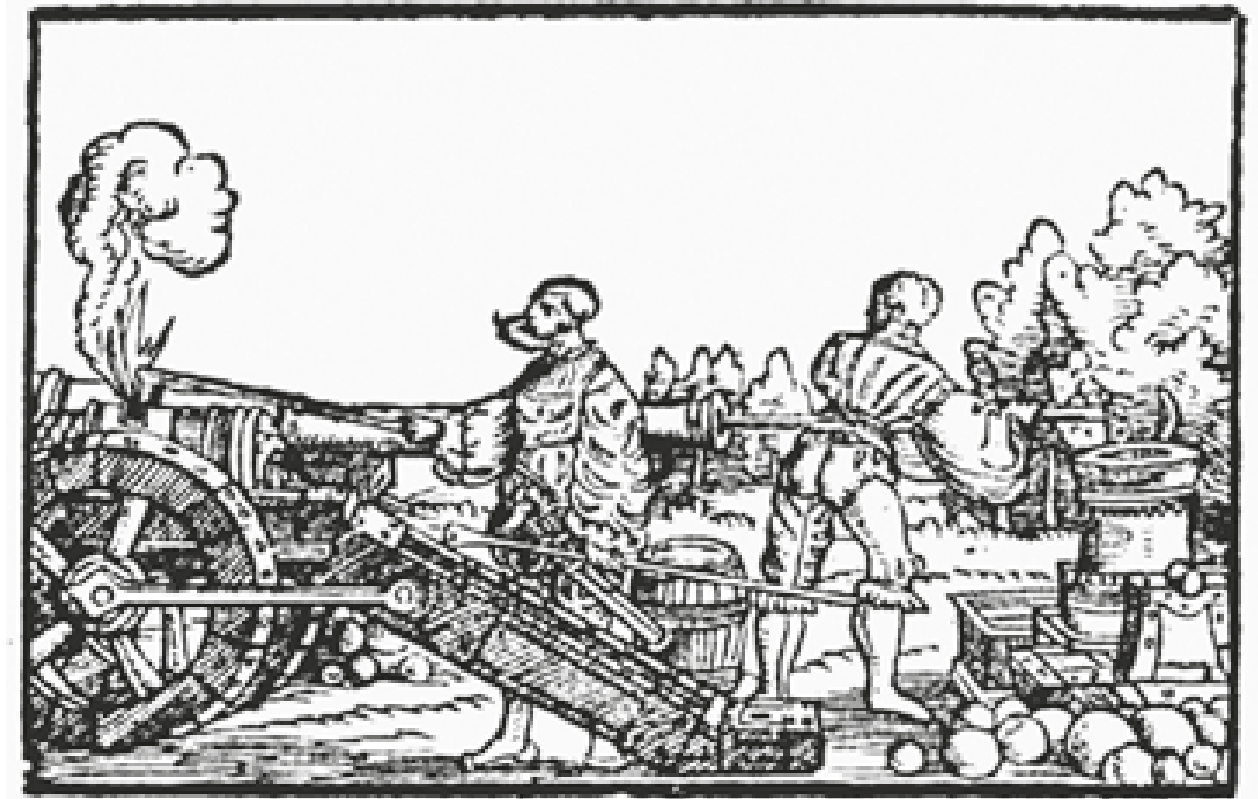

Hirschvogel ostromképeit elnézve megfogalmazódik egy kérdés, amire nem tudunk választ adni. Két metszete egyaránt ostromot ábrázol, miért mégis teljesen eltérő azokon az ostrom bemutatásának képi megfogalmazása? Nem tudjuk a választ, még feltételezést is nehezen találunk. Netán Hirschvogel Murányt önmagának, kedvtelésből rajzolta, vagy meg akart valakit ajándékozni azzal? Amikor arra járt, éppen akkor volt az ostrom, és az csak azért került a képre? Ez nagyon valószínűtlennek túnik, különösen arra gondolva, hogy Léva ostroma pár hónappal korábban volt. Hirschvogel pedig Léváról teljesen más felfogásban készített rajzot.

Az 1549. évi felvidéki hadjárat eseményei nem keltettek érdeklődést Bécstől nyugatra. Nem tudunk nyomtatott híradásokról, ezért további ábrázolásokat még a tudósítások címlapján megjelenő egyszerú fametszetek formájában sem ismerünk.

Hirschvogel 1552-ben térképkészítési felmérések céljából járt Magyarországon. Elképzelhető, hogy hasonló okok miatt már 1549-ben is felkereste a Felvidéket és akkor készítette Murány valamint Léva rajzát.

Hirschvogel munkái előtt magyar helységről rézkarc-rézmetszet technikával csak egy látkép készült, Enea Vico 1542. évi képzelet szülte Buda ábrázolása.

\section{ANNo Domini 1550-1551}

Az igazán érdekes hírek már a 16. században is a furcsa, meghökkentő és váratlan események voltak, amelyekre a kiadók ebben a korban szinte állandó háborús eseményeknél is jobban vártak. Ezek között kitüntetett helyen voltak a torzszülöttek (emberi lény vagy állat), a csodás égi tünemények (üstökösök, halo-jelenség) és a természeti csapások (árvíz, földrengés, tűzvész, sáskajárás stb.). Ilyen Magyarországon történt rendkívüli eseményről számolt be képpel és szöveggel egy Dillingenben, Sebald Mayer kiadásában megjelent röplap. Maga a fametszet az ismertető szöveg nélkül alig lehetne érthető. A történet arról szól, hogy nyáron, Margit nap környékén (ez akkor július 19. volt) a Tisza felett fekvő lévő Szikszó mezővárosában (Marckt Zichsa) hihetetlen mértékben elszaporodtak a kígyók és a gyíkok, akik emberek ezreinek halálát okozták. Arról, hogy mivel vagy miképpen okozták halálukat, nem szól a tudósítás. Mint forrásra hivatkoznak a környéken élő Bebek Ferencre, aki levelében 3000 ember halálát említi és panaszolja, a betegeken semmilyen orvosság nem segít. A röplap azonban nem említ évszámot, időpont megnevezésként mindössze az „elmúlt nyár” szerepel.

A képen három jelenet (közülük kettő eléggé visszataszító) szerepel egyidejűleg, mindháromról említést tesz a beszámoló is. Egy ágyban fekvő halott asszony mellett áll kezében késsel a felcser, az asszony felvágott hasából két kígyó mászik elő, egy másik részleten öt férfi fekszik egymás hegyén-hátán, mindegyikük szájából kígyók és gyíkok bújnak ki. A harmadik jelenet cséplő férfiakat ábrázol (az egyikük cséphadarója pont olyan, mint amilyent száz éve még használtak), akik cséplés közben egy szalmakazalban kígyófészket találtak tele kígyóval és a tulajdonos parancsára a szalmakazlat felgyúitják. A röplap szövege szerint ekkor emberi nyelven megszólalt a legnagyobb kígyó és közölte, őket nem pusztítja el a tűz.

A mesebeli történetnek egy régi, időről időre feléledő népi hiedelem az alapja, ami szerint a nyitott szájjal alvók gyomrába alvás közben kígyók mászhatnak be és ott elszaporodnak. Ez egyébként élettani lehetetlenség, amint azt Magyary-Kossa Gyula (aki a röplap évszám hiánya miatt az eseményt az 1530-as évekre tette) a röplappal kapcsolatban kimutatta. (Kígyóvész Szikszón 1550/2, 64. kép)

A röplap további két változatban is ismert, mindkettőn kiadóként a bécsi Aegidius Adler szerepel. A fametszet a két képen csak első ránézésre azonos, alaposabb szemrevétellel több eltérés figyelhető meg. több részletben különbözik egymástól (pl. az egyiken látható a felkelő Nap, a másikon nem, az egyiken négy, a másikon öt férfi okádja kígyókat). A röplapok szövege azonos, csak a szövegszedés 
más. A legfontosabb különbség azonban, hogy ez utóbbin megjelenik az 1551 évszám. (Kígyóvész Szikszón 1550/3 és 1551/1, 65a, 65b. kép)

$\mathrm{Az}$ évszám nélküli bécsi röplap szöveg- és címszedése a legapróbb részletben is megegyezik a dillingeni röplappal, azonos fadúcról készült a két röplap képe is, de eltér a kiadói jelzés, a bécsi röplapon a Gedruckt zu Wien / durch Egidium Adler szerepel. Minderre nehéz magyarázatot találni azon túl, hogy a dillingeni Sebald Mayer és a bécsi Aegidius Adler kiadók között üzleti kapcsolat lehetett. Feltételezzük, Sebald Mayer a röplapját Aegidius Adler kiadói jelzésével is kinyomtatta és eljuttatta Bécsbe árusításra. Amikor a röplapok elfogytak, Adler egy új fadúcról készített képpel és az eredeti szöveggel a röplapot újra kiadta. Mivel ez már 1551-ben történt, ezért feltüntette az évszámot és a kiadói jelzésben a korábbi „Wien” helyett a helyben használt „Wienn” névformát írta.

A röplap megjelenésének az előzménye is ismert. Ugyanezzel a Szikszó környéki, kígyók és gyíkok okozta rejtélyes betegség történettel több tudósítás is napvilágot látott 1550-ben. Megjelenési hely szinte egyiken sem szerepel, így az App. M. 314. jelzetű tudósításon sem. Hasonlóan a röplapokhoz, a történtek ismertetését követően a kígyók és gyíkok elszaporodását ezek a tudósítások is Isten büntetésének nyilvánítják, ezért az embereket bűnbánatra, megtérésre és vallásos életre szólítják fel. Egy Wormsban megjelent tudósítás a szikszói eseményt kiegészíti azzal, hogy Esslingenben egy fiatal nő hasonló betegségben szenved (erről az esslingeni Anna Ulmerről aztán kiderült, hogy csaló volt, ahogy azt Ráth-Végh István megírta a Magyar kuriózumok című könyvében). Egy másik tudósításhoz Luther Márton rövid írását (Vom jüngsten tage) is csatolták. Ha valakiben mindezek ismeretében sem ötlene fel a Bibliának az a története, amelyben Isten a zsidó népet a pusztai vándorlása során hűtlensége miatt mérges kígyókkal büntetette, akkor csak rá kell tekintenie ez utóbbi tudósítás címlapján lévő képre. Ezen egy asszony térdelve néz fel a Mózes állította póznára tűzött rézkígyóra, a kép alatt pedig a Biblia erre vonatkozó idézete (Numeri XXI.) olvasható. (Kígyóvész Szikszón 1550/1, 66. kép)

A mesés történet aztán egyszerűsítve egy 1564-ben történt esetként szerepel Franzius Farkas Egy jeles vadkert címú híres könyvében (RMK I. 1658) is.

1551 nyarán a Fráter György és I. Ferdinánd között lezárultak a két éve folyó egyezkedések Erdély átadásáról. Júniusban Izabella királynő - Fráter György és a körülmények kényszerére - kiskorú fia nevében I. Ferdinánd javára lemondott az általuk uralt területekről és a választott királyi címről, cserébe az Oppeln-Ratibor hercegséget kapták meg. I. Ferdinánd vállalta, hogy Erdélyt seregeivel megvédi a török szultán várható támadásától, Fráter Györgyöt egyúttal kinevezte erdélyi vajdának és kincstartónak. Izabella és János Zsigmond augusztusban elhagyta Erdélyt. I. Ferdinánd a spanyol Giovanni Battista Castaldo vezetésével zsoldos katonaságot küldött Erdély védelmére, aki Nádasdy Tamás és Báthori András királyi biztosok magyar katonaságával együtt már júniusba bevonultak Erdélybe. Az elpártolás hírére Szulejmán szultán Szokoli Mehmed ruméliai beglerbéget küldte hadakkal Erdély ellen, és utasította a havasalföldi és moldvai vajdákat is Erdély megtámadására.

A törökök a Tiszántúlon több kisebb erősséget (Becskerek, Csanád, Nagylak) elfoglaltak, majd Lippát is átadták védői és polgárai. Szokoli Mehmed hazavonult, Castaldo generális seregei pedig ostromolni kezdték Lippát. Fráter György döntésére november 25-én a reménytelen helyzetbe került török védőket bántatlanul elengedték. Ezekről a harcokról több tudósítás is megjelent, egyikük címlapján egyes vélemények szerint Lippa képzeletbeli képe szerepel. (Lippa 1551/1, 67. kép)

Három héttel Lippa elfoglalása után I. Ferdinánd tudtával és egyetértésével Castaldo zsoldosaival alvinci kastélyában megölette Fráter Györgyöt. A magát buzgó katolikusnak valló Habsburg Ferdinánd a hatalmának növelése érdekébe még az egyházi kiközösítéssel járó bíboros gyilkosságtól sem riadt vissza. III. Gyula pápa 1552 januárjában a gyilkosság valamennyi érintettjét kiközösítéssel sújtotta, de közülük I. Ferdinánd kiközösítését - a királyi hatalom gyakorolhatósága érdekében - ideiglenesen felfüggesztette.

Érdekes módon Fráter György megöléséről (pedig mi rendkívüli esemény, ha nem egy bíboros megölése a királyi egyetértésével?) nem ismerünk egyetlen korabeli híradást se. Az a gyanúnk, hogy a Habsburg udvar cenzúrát rendelt el, amit persze bizonyítani nem tudunk. A hír elterjedését nem volt nehéz megakadályozni. Minden Magyarországról és Erdélyből érkező jelentés, híradás első állomása Bécs, illetve Prága volt. A két városban együtt nem volt egy tucat nyomda, márpedig ha azoknál nem jelent meg a hír nyomtatásban (amit ugyebár nem lehetett nehéz elérni), akkor a hírek nehezebben juthattak tovább. Azt se felejtsük, a Német-római Birodalom császári székében szintén egy Habsburg, V. Károly ült, I. Ferdinánd bátyja, akinek szintén nem volt érdeke a hír széleskörű elterjedése.

Mindez arra is magyarázat lehet, hogy még a tudósítások címlapján megjelenő jelkép értékű ábrázolás sem ismert Fráter György meggyilkolásáról. Az első képet Matthias Merian készítette a gyilkosságáról és az csak a 17. század első felében jelent meg. (Fráter György meggyilkolása, 68. kép) 


\section{$>>>><<<<<$}

I. Ferdinánd az Erdély átvételekor tett ígéretét, nevezetesen, hogy azt megvédi a török támadástól, nem tudta betartani. Az 1552-ben indított török hadjárat során Kara Ahmed másodvezér csapataival először Temesvárt foglalta el, majd Lippát, Lugost, Karánsebest és Aradot. A törökök Temesvár székhellyel megalapították a második vilajetet magyar földön. Közben Stefan Rareș moldvai vajda betört Erdélybe és a Barcaságot valamint a székely vidéket pusztította. Castaldo generális Erdélyben lévő zsoldosai nem a törökök ellen vonultak, hanem kirabolták majd felgyújtották Kolozsvárt és Gyulafehérvárt. A Magyar Királyságban Hadim Ali budai pasa előbb Veszprémet, majd Drégelyt, Szécsényt és több Nógrád megyei várat hódított meg. Az egyesült két török hadsereg szeptember elején elfoglalta Szolnokot, majd Eger ellen vonult. A Német-római Birodalomból I. Ferdinánd megsegítésére Móric szász herceg vezetésével küldött csapatok október elejére Győrhöz érkeztek, de rövid ottani táborozás után harc nélkül visszatértek hazájukba. Eger védőinek hősies védekezését a sokszoros túlerőben lévő törökök nem tudták megtörni, ezért öthetes ostrom után elvonultak. Mindezeknek semmilyen visszhangja nem volt Európában.

III. Gyula pápa négy év elteltével, 1555-ben zárta le Fráter György megölésének egyházi kivizsgálását. I. Ferdinándot és a gyilkosságban résztvevô összes többi személyt felmentette az egyházi kiközösítés alól. A vizsgálat akár a kánonjog megcsúfolásának is mondható, mert annak során semmi mást nem vizsgáltak, csak amit I. Ferdinánd javasolt: elárulta-e Fráter György I. Ferdinándot és megérdemelte-e ezért a halált.

$\mathrm{Az}$ elkövetkezendő pár évben csak Tojgun budai pasa vezetett területszerző hadjáratokat. 1554-ben Salgó és Fülek várát, majd 1555-ben egy Szigetvár elleni támadás előkészítéseként a Somogy megyei Kaposvárt, Babócsát és Koroknát foglalta el.

\section{ANNo Domini 1556}

1556 év elején Szulejmán szultán leváltotta Tojgun pasát, mert nem volt elégedett az előző évi sikereivel és újra Hadim Ali pasát nevezte ki budai beglerbégnek. Szigetvár kapitányának Kerecsényi László távozása után a törökök elleni harcokban már korábban érdemeket szerzett Horváth Márk (más néven Horvát Stancic Markó) lett. Hadim Ali budai pasa Isztambulból háromezer janicsárral indult Magyarországra, seregéhez menetközben ruméliai és belgrádi csapatok is csatlakoztak. Pécs és környékének, Tolna és Somogy megyének török katonasága pedig május közepén Szigetvár közelében, Szentlőrincnél ütött tábort. Eközben a hódoltság északi részén lévő török erők Székesfehérvárnál gyülekeztek, onnan támadták az észak-dunántúli magyar falvakat.

Horváth Márk kinevezése után ismerve a török támadási szándékát minden követ megmozgatott Szigetvár védelmének megerősítésére, de szinte eredmény nélkül. Hadim Ali pasa június 9-én ért Pécsre, majd a következő nap csapataival felszámolva a szentlőrinci tábort Szigetvár alá vonult. Horváth Márknak Szigetváron a fegyvert fogható helyi lakossággal együtt mintegy ezer embere lehetett, szemben a törökök tizenötezerre becsült létszámával (igaz ezeknek talán egyharmada nem volt képzett katona). Szigetvár ostroma 1556. június 10-én vette kezdetét.

Időközben a győri főkapitány Adam Gall von Loosdorf Pápáról érkezett csapatokkal kiegészülve július közepén támadást indított a törökök megszállta területek ellen. Székesfehérvár külvárosát felperzselte, majd a Szabadbattyán környéki falvakat pusztította.

Szigetvár felmentésére Nagykanizsán gyülekeztek I. Ferdinánd seregei, Nádasdy Tamás nádor vezetésével. A haditanács döntése szerint Nádasdy seregével és a hozzá csatlakozott Zrínyi Miklós horvát bánnal és stájer csapatokkal együtt július 18-án kezdte meg az előző évben elvesztett Babócsa ostromát. Ezzel mintegy kényszerítették a Szigetvárt ostromló Ali pasát, hogy az ostromot félbehagyva Babócsa felmentésére induljon.

Szigetváron Horváth Márk várkapitány vezetésével a védők emberfeletti bátorságot tanúsítva minden támadást visszavertek. Nádasdyék számítása bevált, Hadim Ali pasa 41 napi sikertelen ostrom után július 20-án felhagyott Szigetvár ostromával és elvonult Babócsa felmentésére. Július 23-án Babócsa mellett a két sereg véres csatát vívott, ennek során Nádasdy csapatai Babócsát is elfoglalták, majd felrobbantották. Az ütközet utáni haditanácson Zrínyi Miklós és pár magyar főúr további támadást, Ali pasa seregeinek megsemmisítését és a környék további török erősségeinek elfoglalását szorgalmazta. Azonban a többség, köztük Nádasdy Tamás is Ferdinánd főherceg (I. Ferdinánd kisebbik fia) csapatainak megvárása és addig a visszavonulás mellett döntött. Közöttük volt a stájer segélycsapatok vezetője is, akinek a felhatalmazása csak a Babócsáig történő előnyomulásra szólt. A királyi hadak ezután visszavonultak Nagykanizsáig, onnan a magyar csapatok visszatértek állomáshelyükre. A külföldről érkezett katonaság Nagykanizsánál 
várta az új fővezér, Habsburg Ferdinánd fóherceg megérkezését további császári csapatokkal. Ferdinánd főherceg megérkezése vagy egy hónappal elcsúszott, ezalatt a német zsoldosok ellátásukat a környék magyar falvai kirablásából oldották meg. Korabeli források szerint kegyetlenebbül bántak a falvak lakóival, mint a törökök.

Hadim Ali pasa látva a királyi sereg elvonulását, azok üldözése helyett visszatért Szigetvárhoz folytatni annak ostromát. Visszaérkezve meglepetten látta, hogy távollétének egy hete alatt Horváth Márk vezetésével roham ütemben kijavították Szigetvár sérüléseit, köztük egy ötven méter hosszú leomlott várfal szakaszt is. Ali pasa öt napig volt Szigetvárnál, ezalatt a védők több ízben kitörtek és megzavarták az ostromtábor letelepítését. Végül Ali pasa július 31-én hadaival elvonult Pécsre.

Ferdinánd főherceg mintegy hatezer új katonával érkezett, hozzá csatlakozott Nádasdy Tamás és Zrínyi Miklós is csapataival. Úgy döntöttek, hogy Szigetvár környékét tisztítják meg a törököktől. Az elkövetkező mintegy hat hétben a törökökkel több -többnyire azok vereségével végződő - összecsapás volt, visszafoglalták Koroknát majd földig rombolták. Ugyancsak szeptemberben a győri helyőrség és a komáromi sajkások közösen rohanták le Esztergomot, amely őrségének jelentős része a Dunántúlon harcolt Ali pasa seregében. Komáromnál mindannyian (még a lovasok is) gályákra és sajkákra szálltak és éjjel a Dunán ereszkedtek le Esztergomig. Elfoglalták a Rácvárost (a volt királyi várost), kirabolták majd felgyújtották. A vár elfoglalására ágyúk hiányában nem is gondolhattak. Szeptemberben Ferdinánd főherceg csapataival maradandó sikereket nem ért el, az általa vezetett császári-királyi sereg október elején szétoszlott. A Dunántúlon elért legnagyobb siker Szigetvár megtartása volt, köszönhetően Horváth Márk és emberei hősies helytállásának.

Ebben az évben, 1556-ban a Német-rónai birodalomban, de Itáliábanisa törökök elleni küzdelem viszonylag kevés figyelmet kapott. Európa nagy része az V. Károly császár lemondása utáni utódlásra (V. Károly megnevezte utódját öccse, I. Ferdinánd személyében, akit ezen a néven császárrá is választottak) és a császárválasztásra figyelt. Ezért a magyarországi harcokról alig jelentek meg híradások. A Babócsa melletti július 23-i csatáról ismerünk pár beszámolót, címlapukon csatajelenettel (Csata Babócsánál 1556, 69. kép). I. Ferdinándnak az erdélyi adó későbbi befizetését kérő levelére küldött fenyegető szultáni válaszról is megjelent pár beszámoló, ezek címlapján jelképes üzenetként a törökök kegyetlenkedésének a képe tűnik fel. (Török

\section{OBSIDIO ZIGE thienfis An: M.D. LVI. defcripta per Ioan. Sams bucum Tirnauien. Pannonium.}

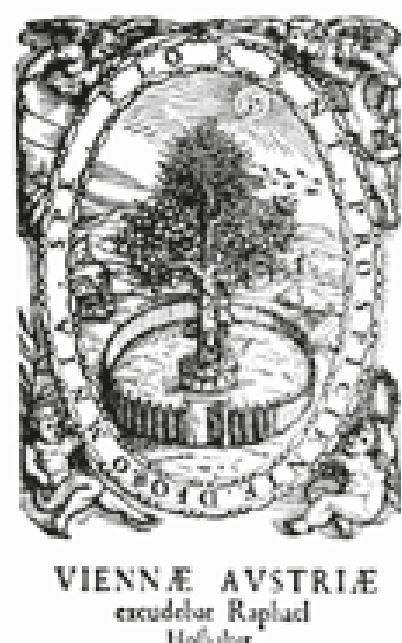
vérengzés 1556, 70. kép)

A haditérképek ugyan nem tartoznak munkánk körébe, de Wolfgang Lazius 1557-ben készített térképével kivételt teszünk. A Bécsben élő humanista tudós, orvos és térképész, I. Ferdinánd történésze fiatal korában a Habsburg csapatok tábori orvosaként többször járt Magyarországon. 1552ben készült el a Lázár diák térképe néven elhíresült, első nyomtatásban megjelent Magyarország térkép átdolgozásával. Ebben a munkájában 27 magyarországi segítőjevolt, ezeknevét a térképén fel is tüntette. A térkép nyomtatásához szükséges tíz fadúcot a bécsi Michael Zimmermann készítette. A térkép a császárrá választott I. Ferdinándnak ajánlva 1556-ban jelent meg. Ezzel egy időben megjelent egy könyve is a Magyar Királyság földrajzi leírásáról (Des Khunigreichs Hungern sampt seinen eingeleibten Landen). Lazius figyelemmel kísérte az 1556. évi török elleni küzdelmeket és azokat Rerum anno 1556 contra Turcas gestarum brevis descriptio címü könyvében meg is örökítette.

Számunkra ezeknél érdekesebb, hogy az év eseményeit egy térképen is bemutatta. Ez a térkép Magyarország térképének északnyugati része, északon és keleten a Duna, délen a Dráva határolt területe, ami nyugaton Szombathely vonaláig terjed, tehát gyakorlatilag a teljes Dunántúlt mutatja. A térképet Ulrich Fuggernek ajánlotta és a hozzá tartozó (egyes példányokra alul ráragasztott) hatalmas lapon Rei contra Turcas gestae anno MDLVI kezdettel az 1556. év eseményeinek részletes leírása olvasható.

A térkép északi részén szaggatott vonal jelzi és felirat közli az Adam Gall von Loosdorf gyốri fókapitány 1556. évi két támadását, júliusban a Székesfehérvár környékének, szeptemberben Esztergom lerohanását. Ugyancsak vonalak jelzik a Győrből és Stájerországból Sárváron keresztül a Nagykanizsa melletti táborba érkező csapatok útvonalát is. Jelöli azt a helyet, 
ahol Ferdinánd főherceg csapatai hajóhidat vertek a Murán. Nagykanizsa mellett egy hatalmas katonai tábor látható. Babócsát körbeveszik a királyi és a török csapatok, a sátortáborok mellett csatajelenet mutatja a július 23-i ütközetet. Látni a török tábort Szentlőrincnél (S. Lorenz), de török tábor van Szigetvártól északra is, nyugatról pedig hatalmas lovassereg érkezik a várhoz. A térkép feltünteti a Buda és Belgrád közötti hadiutat is. (Lazius haditérképe 1556, 71. kép)

Lazius haditérképét ugyan nem másolta a későbbiekben senki, de felismerése, hogy egy hadjárat eseményei térképen is bemutathatók, Szulejmán szultán 1566. évi hadjáratát követően több haditérkép (Matthias Zündt, Hans Liefrinck, Domenico Zenoi és Paolo Forlani munkái) létrejöttében is szerepet játszhatott.

\section{AnNo Domini 1562-1563}

1562-ben megjelent Bécsben a humanista tudós polihisztor Paulus Fabricius 1563. évre szóló naptára Almanach címmel. A népszerű néven kalendáriumoknak nevezett naptárak összeállítása sokféle tartalmuk miatt komoly szellemi feladat volt, ezért alapos iskolázottságot igényelt. Ezt nem csak a naptárrész összeállítása követelte meg (amelyhez matematikai és részben csillagászati ismeretek kellettek), hanem a kalendáriumokban található további egészségügyi és krónika jellegű írások, a prognosztikon megírása, az anekdoták, a versek stb. is.

Fabricius Almanachjának címlapján a címszöveget 18 városkép keretezi. Közülük felül Bécs képe teljes lapszélességü, a többi városkép viszont csak mintegy 2,5x2,5 cm nagyságú. A városok három kivétellel osztrák, azon belül is elsősorban Bécs közeli helységek (Hainburg, Bruck an der Leitha, Krems, Klosterneuburg stb.). A három kivétel három magyar város: Pozsony (Presbvrg), Sopron (Odenbvrg) és Kismarton (Eisenstat). A városképek képzeletbeliek, noha egy kis erőltetéssel Pozsony képén a Várhegy felismerhető. Úgy gondoljuk, ez a fametszetes címlapkeret az Almanachot kiadó Michael Zimmermann munkája. (Kismarton, Pozsony, Sopron 1562/1, 72. kép)

Ugyanezzel a kerettel szintén 1562-ben Zimmermann kiadta Melchior Klayber Diarium című művét is (Kismarton, Pozsony, Sopron 1562/2, 73. kép). A városképekkel díszített címkeret kedvelt lehetett, mert másolókra talált. Bécsben 1579-ben és 1601-ben ezzel került forgalomba naptár, majd 1612-ben Nürnbergben(!) egy Schreibkalender is, természetesen új fadúcról, de azonos sorrendben azonos városok képeivel.

Az idősödő I. Ferdinánd még életében - a Habsburg-ház hatalmának biztosítására - legidősebb fiát, Miksát 1562-ben Prágában cseh, majd Frankfurtba

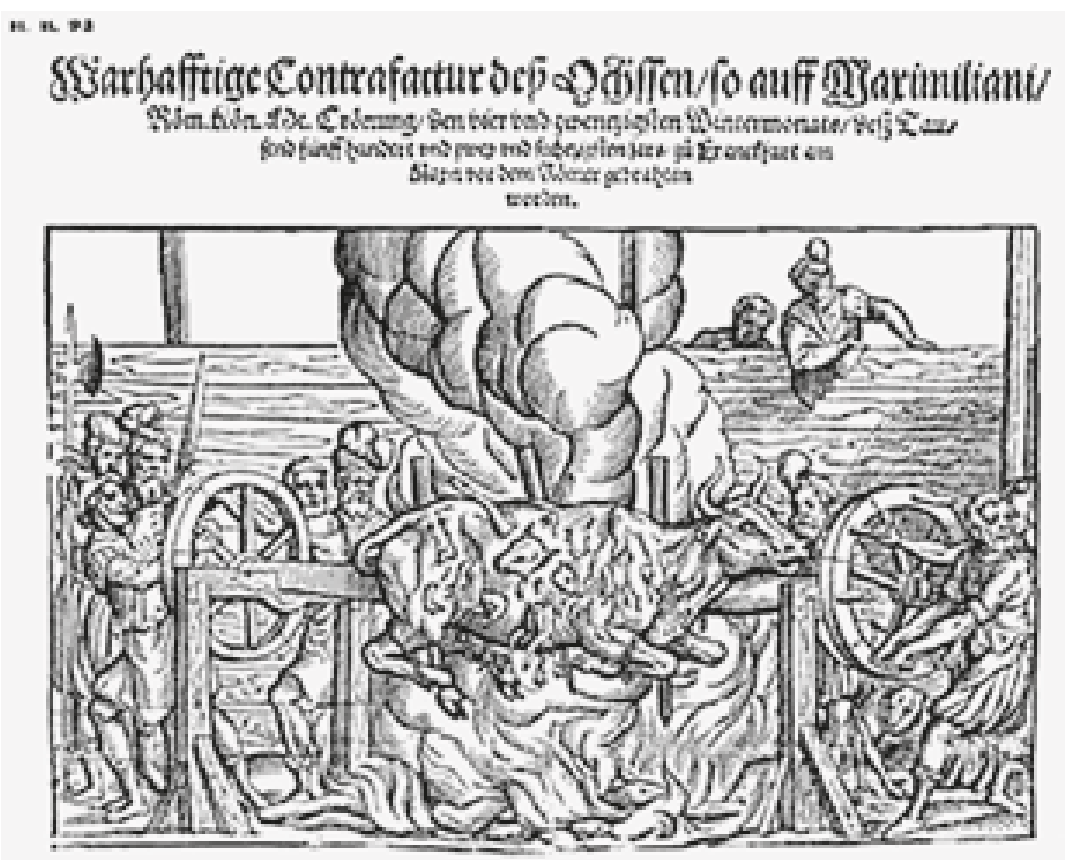

német-római királlyá koronáztatta. I. Ferdinánd királyválasztás nélkül, az 1527 ben tett koronázási esküjét megszegve 1563. szeptember 8-án Miksát magyar királlyá is koronáztatta Pozsonyban.

A koronázás alkalmából készült az a nagyméretű $(63,5 \times 39,5 \mathrm{~cm})$, két dúcról nyomtatott fametszet, amely latin és német nyelvű kísérő szöveggel is ismert. A kísérő szöveg valójában vers, a latin nyelvű változaton három, a német nyelvű változaton kettő. Az elsőn szerepel a szerző, Zsámboky János (Joannes Sambucus) neve is. A német nyelvű vers Zsámboky versének átültetése a kor divatos párrímes versformájába, döntően megtartva annak mondanivalóját. A német nyelvû változaton szerepel, hogy a röplapot Caspar Stainhofer nyomtatta Bécsben. Stainhofer 1566-ban lett nyomdatulajdonos, amikor elvette korábbi mestere, az 1565 nyarán meghalt Michael Zimmermann özvegyét. Stainhofer nyomdászként és kiadóként haláláig, 1576-ig dolgozott Bécsben.

A metszetet újabban (a metszeten lévő jelzés MH olvasatára hivatkozva) egyesek tévesen Martin Hübschmann munkájának tartják. A metszeten azonban nem $\mathrm{MH}$, hanem határozottan felismerhető HM monogram szerepel, ami Nagler szerint (Bd. III.494/ 1251) Hans Mayer fametsző jelzése. Hans Mayer 1565-ben II. Miksa császár szolgálatába állt. 
A metszet egyik változatán sem szerepel a készítés időpontja, így azt csak behatárolni tudjuk. A versben Miksa már császárként szerepel, tehát 1564 második félévénél korábban a metszet ezzel a verssel nem jelenhetett meg. Zsámboky 1564-ben telepedett le Bécsben és tudjuk, hogy 1565 tavaszán Tokaj fametszetes röplapján (lásd később a Tokaj 1565. évi ostromáról készült metszeteknél) dolgozott Michael Zimmemannal, aki 1565. augusztus 15-én meghalt. A Zimmermann-nál alkalmazottként dolgozó Stainhofer az özveggyel kötött házassága révén jutott csak nyomdához, ezért a metszet német nyelvü változata az ő nevével csak ezután, legkorábban valamikor 1566-ban jelenhetett meg. A Habsburg Miksa német-római király 1563. évi bécsi bevonulásáról készített fametszetes könyve - amiben szerepel Michael Zimmermann készítette lap is - 1566. júliusi ajánlással jelent meg. Úgy gondoljuk a röplap Zsámboky latin nyelvű verseivel talán már 1565-ben, Zimmermann halála után, de még özvegye férjhezmenetele előtt megjelent. Zsámboky latin verseinek fordítása németre azonban időigényes volt, ezért azt csak később, már Caspar Stainhofer adta ki. Ez lehet magyarázat arra is, hogy miért nem szerepel a latin nyelvü metszeten nyomdahely. Zsámboky és Stainhofer bizonyára már korábban, a Tokaj fametszet készítése idején megismerhették egymást.

A fametszeten megjelent Zsámboky vers elemzésével és annak német fordításával Gyulai Éva foglalkozott. Véleménye szerint Zsámboky versének német nyelvre átültetése a humanista műveltséggel rendelkező Caspar Stainhofer műve, és az ő munkája a latin nyelvű változat utolsó, harmadik verse is. Zsámboky verse egyébként szinte többet foglalkozik Pozsony ismertetésével és dicsőítésével, mint magával a koronázással.

A metszet címe mindkét kiadáson azonos: WARE CONTERFACTVR DER STADT PRESBVRG, amely a képeken felül középen szószalagon olvasható. Azonosak a nagyszámban található német nyelvú elnevezések illetve magyarázó feliratok is. A képet mintegy kétharmad magasságban kettéosztja a Duna, felette Pozsony város és környezete a koronázásra érkezők táborával, a kép alsó két harmadát pedig a különböző országokból, tartományokból érkezett küldöttségek szálláshelyei töltik ki. (Pozsony 1563/1 és 1566/1, 74, 75. kép)

Pozsony városképe biztosan helyszínen készült rajzok és a városról szerzett ismeretek alapján készült, összességében azt a valósnak tartható látványt nyújtja, amit később a 16. és 17. század folyamán többször is látunk. A városkép jobboldalát a Várhegy uralja a négy saroktornyú várral, felette a Das Schloss felirattal. A városban a Szent Márton templomot (S. Marten), a Klarisszák templomát (S. Clara), a Ferencesek templomát (ezt a korabeli Barfuser /mezítlábas szerzetes/ névvel) és a Városházát (Radhaus) felirat is jelzi. A Várhegy lábánál látni a Vízi-tornyot (Wasser Thurn) és a fegyverraktárt (Arsenal). Ezek mindegyikének az egymáshoz való térbeli elhelyezése megfelel az ismereteknek. A távolban balra feltűnik Dévény és Hainburg, jobbra látnia a győri és a komáromi Duna-ágak szétválását, vagyis a Csallóköz (akkoriban Komáromi szigetnek nevezték) kezdetét.

A nagy eseményre utalnak a Dunán érkező hajók, a lovagi torna kijelölt helye (Turnier platz), az üdvlövésekhez telepített ágyúk, a lacikonyhák. Magára a koronázásra egyedül a Pozsony előtti Duna-szigeten kiépített Királydomb utal, amelyre fellovagolva a megkoronázott király megteszi a négy égtáj felé a jelképes kardvágást (Keiser Schweret). Látni is a dombon a koronát viselő (ez nehezen felismerhető) lovon ülő, kardját felemelő I. Miksa királyt, akit lándzsások gyűrűje vesz körbe.

A Duna innenső partját erdős területek és sátortáborok töltik ki. A kép bal szélén megjelenik Köpcsény (Kittsee) pár házzal. A kép bal alsó sarkánál látható az egymáshoz írt HM készítői jelzés. A képet a táborélet jelenetei teszik élőszerűvé.

\section{AnNo Domini 1565}

1562-ben - köszönhetően Balassa Menyhért átpártolásának János Zsigmondtól I. Ferdinánd oldalára - kiújultak a harcok a királyi Magyarország és az Erdélyi Fejedelemség között. Ezeknek a harcoknak az egyik legfontosabb célja az Alföldről Kassára vezető út tiszai átkelőhelyénél fekvő Tokaj megszerzése volt.

Tokaj az 1530-as évek elejétől Serédy Gáspár, majd halála után utódai birtokában volt. 1556-ban már a reformáció erős támaszának számító jó katona, ám hatalmaskodó Némethi Ferenc volt a várkapitány, akit Serédy Benedek özvegye, Dobó Katalin nevezett ki. A reformáció terjedését szívvel-lélekkel támogató Némethi az 1556 őszén Lengyelországból visszatért és az uralmát visszaállító választott király János Zsigmond oldalára állt. 1562-ben Balassa Menyhért átpártolását követően a királyi hadak megszállták az Erdélyi fejedelemséghez tartozó Szatmárt, Nagybányátés több kisebb várat. Némethi Ferenc - aki időközben folyamatosan erősítette Tokaj várát - ettől kezdve folyamatosan támadta az I. Ferdinánd párti fóurak Tokaj környékén lévő birtokait. Az 1562-63-as harcokat lezáró béketárgyalásokon János Zsigmond bejelentette igényét Tokaj várára is.

1564-ben I. Ferdinánd halála után a harcok kiújultak, előbb Báthory István foglalta vissza Szatmárt és Nagybányát a Balassa családtól, majd ősszel János Zsigmond indított hadjáratot és egészen Kassáig hatolt. Erre válaszul a magyar 
trónt elfoglaló I. Miksa 1565. év elején jelentős sereget gyűjtött össze Kassán, amely vezetésével Lazarus von Schwendit (magyar nevén Schwendi Lázár) bízta meg. Az elzászi származású Schwendi tapasztalt katona volt, korábban jelentős győzelmeket aratott Németalföldön.

A királyi seregekből elsőként a Franz von Poppendorf vezette tüzérség indult meg, majd őket követte Lazarus Schwendi csapataival. Február 4-én érkeztek Tokajhoz, a nagyon kemény téli időben az ostromlók az elfoglalt városban szállásolták el magukat. A következő nap kezdődött a tokaji vár ostroma. Háromnapos folyamatos ágyúzás után a vár Bodrog felőli fala leomlott. Február 8-án próbálkoztak az ostromlók a befagyott folyón keresztül a vár ellen az első rohammal. Mivel Némethi várkapitány az éjszaka folyamán a jeget feltörette, a friss jég beszakadt az ostromlók alatt, a támadás így összeomlott. A kudarcba fulladt roham megismétlésére három nap múlva, február 11-én került sor. A védők ezt a rohamot is visszaverték annak ellenére, hogy annak során Némethi Ferencet egy ráomló kőfal a fején halálosan megsebesítette. A kapitányukat elvesztő védők ezután fegyverszünetet kértek, és február 12-én átadták a teljesen rommá lőtt várat Lazarus Schwendi csapatainak. A négyszáz életben maradt védő (köztük sok sérült) szőnyegekbe tekerve magával vihette várkapitányuk, Némethi Ferenc holttestét is, akit aztán birtokán, Szentjobbon eltemettek.

A tokaji vár és ostromai történetét különböző részletességgel többen feldolgozták, közülük Déthsy Mihályt említjük, aki munkájában közzétette az ostromról két folytatásban megírt, részletes német nyelvú helyszíni beszámolót is. Az már korábban is ismert volt, hogy létezik egy helyszínen készült tusrajz Tokaj ostromáról, amely a beszámoló melléklete lehetett (Wien, Österreichische Staatsarchiv - Haus. Hof. Staats Archiv, Hungarica, Miscellanea f. 427.). Az ismeretlen rajzoló - aki az ostrom során a tüzérséget irányító, majd az 1570-es években Tokaj átépítési terveit véleményező Franz von Poppendorf is lehetett - a várat felülnézetben bemutató rajzán felirattal jelzi azt a helyet, ahol a folyó jege az ostromlók alatt beszakadt és még 3 ágyúállást is. A rajzon szerepel a folyóknál a "Tyssa flu." és a „flu. Wodrockh” név, a város helye a „Tokhay” felirattal van jelölve, a felette lévő magaslatnál a szőlőhegy felirat (Weingandtgepirgen?) nehezen olvasható. Ezek a részletek a helyszín és a történések pontos ismeretére utalnak. (Tokaj rajz, 1565, 76. kép)

A Tokaj elfoglalásáról hírt adó számos tudósítás közül kettőt említünk. Közülük az egyiken a kor többször megjelent ostromképeinek egyike látható (Tokaj 1565/2/b, 82. kép). Michael Zimmermann Bécsben megjelent Zeittung képe azonban rendkívüli figyelemre méltó, mivel a címlapján lévő viszonylag nagyméretű $(12,0 \times 14,5 \mathrm{~cm})$ fametszet egyedinek tűnő várostromot ábrázol. (Tokaj 1565/2/a, 77. kép)

Ha az ostromról készített vázlatrajzot összehasonlítjuk a tudósításon lévő képpel, egyértelmű, hogy az a rajz (vagy annak egy másolata vagy egy hasonló) szolgált előképül Zimmermann fametszetéhez. A rajzon és a fametszeten hasonló a folyók elrendezése és neve, a várkapuhoz vezető híd, a várnak mindkét képen 4 többszögletes sarokbástyája van. Érdemi elérés viszont, hogy a rajz négyszögletes várából a metszeten ötszögletủ lett. Lehet, hogy Zimmermann a hídfőben lévő várkaput kívánta hangsúlyozni. Ennél sokkal jelentősebb azonban, hogy a rajzon a vár közepén lévő négyszögletes épületből a metszeten egy kereknek látszó torony lett. Lehet, hogy valójában nem kerek, csak az épületet övező árok miatt annak látszik.

Zimmermann a rajzon lévő feliratokat „képiesítette”: a Tokaj városnév helyén a várost jelképező templom és pár ház képe jelenik meg, az ágyúsáncok helyén tüzelő ágyúk vannak, a folyó jegének beszakadásánál vízbe esett katonák láthatók. Zimmermann lovasokat, zászlókkal vonuló katonákat is rajzolt, mindezekkel a metszetet igyekezett élettel megtölteni. A kép látványosságának fokozására a vár előterébe, a kép aljára négy tüzelő ágyút, lőporos hordót és ágyúmestert rajzolt kanóctartó-rúddal. A SCHLOSS DOGGAY felirattal (ami a rajzon nem szerepel) pedig egyértelműsítette, mit ábrázol a kép.

Michael Zimmermann-nak (személyéről korábban már volt szó, de őrá még vissza is térünk) ez az egyszerű fametszete a Tokaj ábrázolások ősforrásává vált. Még megjelenésének évéből két másolatát is ismerjük. Nem tudjuk eldönteni, időben melyik készült korábban, csak azt állíthatjuk, hogy az egymástól nagy távolságra lévő két másoló Párizsban és Velencében egymástól függetlenül dolgozott.

A Párizsban megjelent és egyetlen példányban ismert nagyméretű $(25,6 \times 36,0 \mathrm{~cm})$ fametszetet a szakirodalom a kor híres földrajztudósa, a ferences szerzetes Andre Thevet munkájának tartja. A lap Zimmermann fametszetének részleteiben is hűséges, felnagyított másolata, árulkodik erről a templom elhelyezése akárcsak a puskaporos hordó vagy az ágyúállások rajza. A kép alá nyomtatva rövid latin és francia nyelvű ismertetés olvasható Tokaj elfoglalásáról a végén párizsi nyomdanévvel. Apró érdekesség, hogy a zászlók között feltűnik a kétfejű sasos Habsburg lobogó ami Zimmermannál nem szerepel - ez Thevet tájékozottságára vall. Ez az első, francia nyelvterületen megjelent magyar vár (város) ábrázolás. (Tokaj 1565/4, 81. kép) 
Zimmermann fametszetének másik másolója teljesen más stílus és technika követője volt. Domenico Zenoi elismert térkép- és rézmetszet-készítő, nyomdász és kiadó volt Velencében, ahol a Bertelli család, Francesco Camocio és Paolo Forlani mellett meghatározó szerepet játszott az 1560-70-es évek térkép- és metszetkiadásában. A többiekhez hasonlóan térképei és látképei többnyire mások korábbi múveinek átdolgozásai, kiegészítései. Zenoi metszetén $(29,5 \times 40,8 \mathrm{~cm})$ Zimmermann vár ábrázolását kissé balra eldöntve annyi változtatással látjuk, hogy a vár belsejében több az épület. Ezek közül kimagaslik az immár egyértelműen kerek toronyépület, amit vizesárok övez. Gondosan jelöli a folyók torkolatát (confluxus aquae), viszont Zimmermannhoz képest a Tisza továbbfolyását 90 fokkal felfelé elfordítja. Égtájként Nyugatot a lap tetején jelöli, a valóságtól mintegy 45 fokkal eltérve. A legjelentősebb változtatást a kép vár alatti részén hajtja végre: a vár alatt a folyón egy üresen hagyott téglalap jelenik meg (talán feliratot akart ide helyezni?), az alatt helyezi el a várat ostromló ütegeket, és azok alatt a Tisza és Bodrog között (tehát a Bodrogközben!) megjelenik Tokaj városa (Oppidum Toggay) hatalmas templomával és házaival. Nem túlzás azt állítani, hogy Zenoi munkáján az ostromlott vár és a képzeletbeli Tokaj város képe azonos hangsúllyal szerepel. A kép alján a császári címer alatti címtáblán röviden ismerteti Tokajt és az ostromot. Biztosan ismerte Zimmermann tudósításának szövegét is, hiszen nála is a befagyott folyón keresztül rohamozzák az ostromlók a várat, sőt nem csak rajzban, hanem felirattal is jelöli a helyet, ahol a jég az ágyúk és katonák alatt beszakadt. (Tokaj 1565/1, 78. kép)

Domenico Zenoi (további magyar vonatkozású műveiről később még szó lesz) finom karcú és látványos metszete népszerû lehetett, hiszen több kiadását is ismerjük: a változatlanul hagyott lemez megjelent később Donato Bertelli és Francesco Camocio kiadásában és névnélküli „Apresso” kiegészítéssel is. (Tokaj 1565/1 változatai, 79. kép)

Zenoi munkája a későbbi Tokaj metszeteken évtizedekig érezteti hatását, azokon az idővel hatalmassá növő kerek torony mindig megjelenik. Ennek köszönhetően a korábbi helytörténészek igazoltnak érezték egy 14. századi kör alaprajzú lakótorony meglétét, ami köré később kiépült maga a vár. Soós Elemér a tokaji vár hadtörténetéről írt munkájában közölte is a torony metszeteken alapuló rekonstrukciós rajzát.

1565-ben egy negyedik Tokaj metszet (Tokaj 1565/3) is megjelent. Ez egy röplapon lévő fametszet, a röplapnak egyetlen példánya ismert, amely Bécsben az Albertina gyủjteményében található. Ezen Tokaj ostromképe mellett az 1565. évi ostrom német és latin nyelvű nyomtatott ismertetése is szerepel. A bécsi kiadású röplapon nyomdászként a már többször említett Michael Zimmermann szerepel.

Elsőként Majláth Béla adott hírt erről a röplapról, amely szerepelt az 1882-ben Bécsben rendezett könyvkiállítás Hungarica anyagában. Borbély Andor 1933ban állapította meg, hogy annak szövege Zsámboky János műve. A Debreceni Szemlében megjelent ismertetésében azonban csak a röplapon lévő fametszet képét tette közzé a röplap szöveges része nélkül, és mindeddig csak ennek a képnek további másolatai voltak ismertek. Most megszerezve a röplap teljes, a szövegrészt is feltüntető képét, azon a Borbély Andor által közölt címleírás

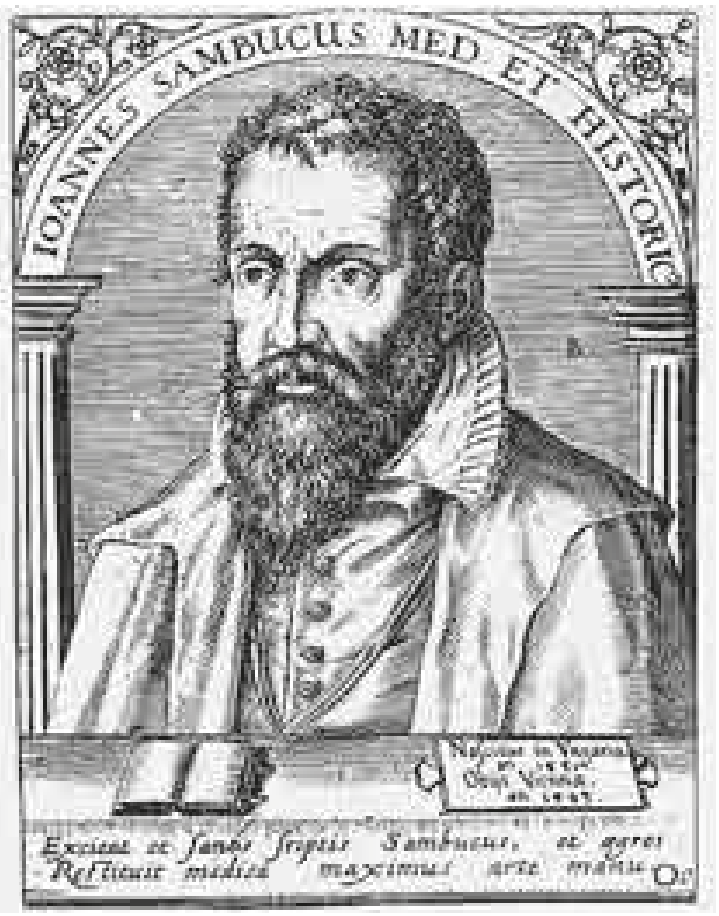
„Auctore Sambucus" részét nem találtuk, mint ahogy Sambucus sajátkezű aláírása se látható egyértelmúen. Ez utóbbi akár az elmúlt évtizedekben végbement fakulás következménye is lehet. A felmerült kétségek eloszlatására indokolt lenne a röplap alapos vizsgálata.

Az Albertinában őrzött egyetlen ismert példány vászonra vont, nagyon rossz állapotú, szöveges része sok helyen hiányos. Borbély Andor szerint a röplapon Zsámboky Jánosnak a nyomtatott szövegbe beszúrt és a képre írt sajátkezü, javítási célzatú megjegyzései szerepelnek. Ezért ezt a röplap javítópéldányának (próbalevonatnak) tartjuk. Szövegjavítások csak a latin nyelvű változatban fordulnak elő, ezért is gondoljuk, hogy az a német szöveg fordítása, amit Zsámboky készített. A német szöveggel részletesen nem foglalkoztunk, de egyes részei megállapíthatóan egyeznek Zimmermann korábban ismertetett tudósításával (Tokaj 1565/2/a,). A képre rávezetett javítások többek között mutatják Balassa Menyhért csapatainak helyét a tiszai rév túlsó oldalán, az ágyúállások napi haladását, a különböző ágyútípusok neveit és ehhez hasonló pontosításokat.

A humanista polihisztor Zsámboky János 1564-ben sok éves európai vándorlás után telepedett le Bécsben, ahol a császári udvar megbecsült 
történészeként élt haláláig. Zsámboky Bécsben történt letelepedésekor Michael Zimmermann már ismert nyomdász volt. A zürichi születésű Michael Zimmerman 1552-ben jutott nyomdához Bécsben, amikor feleségül vette Aegidius Adler nyomdász özvegyét. Nem csak nyomdász volt, hanem festő és jó nevű fametsző (Formschneider) is. Mint írtuk, ő véste és nyomtatta ki 1556-ban Wolfgang Lazius híres Magyarország térképét. Zsámboky térképkészítőként tudhatott Zimmermann térképdúcokat készítőmunkájáról, Zimmermann pedig ismerhette Zsámboky térképészeti munkásságát. A történetíró Zsámboky figyelemmel kísérte szülőhazája háborús eseményeit. Tinódi Lantos Sebestyén költeménye nyomán megírta Eger vár hősi védelmének (Rerum Ad Agriam Anno M.D.LII. Viennae, 1558) és Szigetvár 1556. évi ostromának történetét (Obsidio Zigethiensis, Viennae, 1558). Zsámboky adta ki először teljességében Antonio Bonfini magyar történetírását is.

A röplapon lévő Tokaj kép nem hasonlít az előbbiekben ismertetett Tokaj ábrázolásokhoz. Felülnézetből készült, sajnos, égtáj jelölések nélkül. Felirat jelöli a Tiszát és a Bodrogot, viszont a várból a városba vezető híd helyzetéből arra következtethetünk, hogy a kép a Kis-Bodrogot ábrázolja a folyó fó ágaként és a mai Bodrog az, ami szinte merőleges kanyarral fordul el a Tiszába ömlés felé (ezt a hibát a kor hadmérnökei is gyakran elkövették alaprajzuk készítésénél). Megjegyezzük, a mindennapi élet szempontjából nem volt annak jelentősége, melyik a Bodrog fóága és melyik a mellékága. A rajzon téves a Tisza folyásának megrajzolása is, aminek a vár sarkánál (ahol a Bodrog csatlakozik) mintegy derékszögben megtörve délre (a kép tájolása szerint a jobb felső sarok felé) kellene haladnia. Összességében tehát folyórajza - amely Tokajnál meghatározó pontatlan. Meglepően pontos viszont a képen a híres tokaji rév helye (a kép jobb felső sarkánál), ahol a jégtől megtisztított folyón az átkelő kompot is bemutatja.

A kép az ostrom kezdeti szakaszát mutatja, a császáriak már megszállták a várost és megkezdték a vár ágyúzását. Tokaj városát a kép jobb alsó sarkában rajzolt házak mutatják. Az ágyúütegek a bodrogközi oldalon és a város felöli oldalon állnak, egy részük pedig a város feletti domboldalon. A kép bal alsó sarkában látszik az a hely, ahol a befagyott Bodrog jegére terített szalmán és deszkákon a tüzérség átkelt a Bodrogközbe. A Tisza Rakamaz felőli oldalán mindössze két ágyú van. A képen vonalak jelölik az ágyúlövések, illetve a várból viszonzott lövések röppályáját.

A vár környezetének ábrázolását úgy foglalhatjuk össze, hogy az a vízrajzi ábrázolások tévedései mellett többségében egyezik a tájról és az ostromról szóló ismereteknek.

A vár alaprajzi elrendezése - a markánsan elkülönülő Külső-várral és Belsővárral - megfelel az 1560-as évek vége felé készített, „32” jelzésű alaprajznak, amely másolata több példányban is fennmaradt (pl. Stockholm, Hadilevéltár, Handritade Kartwerk Nr. 23/32). Ezt az általános megállapítást kiegészíthetjük a hely- és hadiismeretekre egyaránt utaló képi részletekkel: a Külső-vár legsebezhetőbb részénél - a hidat védő kaputorony és a sarokbástya között - a magasított várfallal, a kőből épült északkeleti sarokbástya aprólékos kidolgozottságával, a bástyáktól a Belsővár árkáig vezető, a szakaszolt védelmet lehetővé tevő traverz falak megrajzolásával, a védők mozgását szolgáló utak és átjárók jelölésével, a Serédy Gáspár építtette kaputorony feltüntetésével. Ezek alapján úgy gondoljuk, hogy a metszet a külső erődítmény látképét valóságra törekvően közvetíti. A Külső-vár területén bizonyára voltak épületek (szálláshelyek, raktárak, stb.), azonban létezésükről vagy számukról nincsenek korból adatok, a képen öt egyszerű épület látható.

A metszeten a Belső-vár képe ránézésre is hitelesíti az ostromleírás állítását, hogy a védők a Külső-vár elvesztése után a Belső-várba visszavonulva folytatták a védekezést. A Belső-vár valóban védhetőnek látszik, ha nem is az ágyútűz, de gyalogos rohamok ellen. A védőárkon belül közel négyzet alakú kőből rakott magas várfal húzódik, sarkain köríves bástyákkal. A védőfalon belül a falhoz közel, egymással párhuzamosan két épület (mindkettő emeletes) látható, sarkaikon egy-egy négyszögletes toronnyal. Az épületeket a saroktornyoknál falak kötik össze. A nyugati oldalon lévő épület szemmel láthatóan magasabb, a keleti oldali épület város felőli sarkánál lévő torony nem toronysisakos, hanem reneszánsz pártázatos. A Belső-vár hegy felőli oldalán - ahol nagyobb a hely az épületeket összekötő fal és a várfal között - megjelennek a traverz falak. A Belső-várból híd vezet a vasaló alakú bástyához. (Tokaj 1565/3, 80. kép)

A metszeten néhány olyan valós részlet is látható, amelyek nem szerepelnek sem a Zimmermann kiadta tudósításban, sem a hivatalos beszámolóhoz készített rajzon. Zsámbokynak tehát további forrásokkal is kellett rendelkeznie. Nem tudjuk, hogyan jutott ezekhez, de császári történészként a hadmérnöki rajzokhoz is hozzájuthatott. Egyik lehetőségként arra gondolunk, hogy Lazarus Schwendi Tokaj elfoglalása után azonnal rendelkezett a vár helyreállítására, aminek feladatát a frissen kinevezett Jacob Raminger várkapitány kapta. Az év folyamán a helyreállítás költségei között szerepel a várépítő-hadmérnök Octavio Baldigaranak fizette összeg is, aki ezek szerint közreműködött az újjáépítésben. Baldigara munkájához készíthetett rajzokat, írásos feljegyzéseket, amelyek Bécsbe is eljuthattak még 1565 tavaszán. Írásos forrásból egy másik lehetőségről is tudunk: Lazarus Schwendi táborában, majd hadjáratában ott volt Natale Angielini milánói hadmérnök, aki rajzot készített Tokajról és Szatmárról. Ez a Tokaj rajz ma már nem ismert, a Szatmár rajza fennmaradt. 
A korábban ismertetett három metszettől eltérően Zsámboky röplapján nem látni, hogy az ostromlók alatt a jég beszakadt.

Michael Zimmermann 1565. augusztus 15-én meghalt, nyomdája vezetését özvegye vette át. A Tokaj ostromáról megjelent tudósítás és a Zimmermann halála közötti pár hónap egy próbalevonat elkészítésére elegendőnek bizonyult. Nem tudjuk, hogy a Zsámboky javasolta kiegészítésekkel, javításokkal elkészült-e a röplap végleges változata és az forgalomba került-e. Zimmermann fametszői szakértelme a javításoknál biztosan szükséges lett volna. Zsámboky életét apja halála miatti örökségi ügyei is lekötötték. Mindezért úgy gondoljuk, a röplap javított változata nem készült el.

Összegezve véleményünket a Zsámboky-Zimmermann páros röplapján megjelent Tokaj látképről, azt mindenképpen valóságra törekvőnek tartjuk, sok hiteles részlet megrajzolásával. Nézőpontjának megválasztása miatt azonban nem tudott olyan látványos lenni, mint a Johannes Janssonius Urbium Totius Germaniae Superioris könyvében megjelent, Georg Hoefnagel munkájaként ismert Tokaj látkép (Tokaj 1657/1) vagy a Lucas Georg Georg Ssicha rajzai nyomán készült Merian kiadású metszetek (Tokaj 1672/1,1672/2 és 1677/1). Ennek ellenére csak sajnálni lehet, hogy nem vált ismertté és nem lett későbbi ábrázolások előképévé.

Tokaj után Lazarus Schwendi elfoglalta Szatmárt és Nagybányát, majd Erdőd és Kővár is a császáriak kezére került (Szatmár 1565/1, 83. kép). Valójában Tokaj után Schwendi csapatai szinte sehol nem találkoztak ellenállással, a felsorolt erősségek többségét János Zsigmond katonasága sorsára hagyta és visszavonult Nagyváradra. A veszteségek hatására János Zsigmond márciusban megkötötte I. Miksával az úgynevezett Szatmári-egyezményt, amelyben lemondva királyi címéről vállalta a töröktől való elpártolást uralmának megtartása fejében. Nem sokkal később azonban János Zsigmond elbizonytalanodott, hogy I. Miksához pártolása esetén meg tudja-e tartani Erdélyt a törökkel szemben. Ekkor érkezett vissza Isztambulból a korábban követként odaküldött Bekes Gáspár azzal a hírrel, hogy a Porta segítséget ad a császári erők elleni további küzdelmekhez. Ennek ismeretében János Zsigmond Báthory Istvánt küldte Bécsbe azzal az üzenettel, hogy az egyezményt csak akkor tartja érvényesnek, ha visszakapja Tokajt. I. Miksa az üzenetet követően Báthory Istvánt elfogatta és bebörtönözte. A János Zsigmondnak küldött török segélycsapatok megérkezésének hírére május elején Lazarus Schwendi - Tokaj és Szatmár kivételével - feladta a tavasszal elfoglalt helyeket és megerősített táborába húzódott vissza Szatmárnál. Tétlenül nézte, hogy János Zsigmond és a segítségére küldött Hasszán temesvári pasa hathetes ostrom után Erdődöt, majd Nagybányát is visszafoglalta. Mivel a török segélycsapatokat vezető Hasszán temesvári pasa szultáni parancsra fegyverszünetet kötött Lazarus Schwendivel és visszatért Temesvárra. János Zsigmond is kénytelen volt visszavonulni Erdélybe, Lazarus Schwendi viszont a fegyverszünet ellenére ismét elfoglalta Nagybányát.

Miksa császár és király rendkívül sokra értékelte a hadjárat sikereit (ez volt uralkodásának első háborúja), ami szerepet játszhatott abban, hogy a korban jelentősnek nem mondható harcoknak élénk visszhangja volt. A birodalmi városokban tucatjával jelentek meg a hadjáratról szóló tudósítások, amelyek közül pár címlapján megjelent képet bemutatunk. (Lazarus Schwendi hadjárata 1565/1 és 2, 84, 85. kép)

Errôl a hadjáratról egy térkép is készült, amely Natale Angielini hadmérnök-térképész műve. A hadászati célokból készült rajzoknál, térképeknél szokatlanul Miksa császár engedélyezte a térkép sokszorosított formában történő közreadását, feltehetően hírverési céllal. A térképen Natale Angielini a császár engedélyét külön is említi.

Az Angielini név régóta ismert volt a 16. században készült hadmérnöki térképekkel, felmérési rajzokkal és erődítés tervekkel foglalkozók körében. Ismert volt a Nicolo és Natale keresztnév is, ám mindenki természetesnek vette, hogy azonos személy két keresztnéven történő említéséről van szó. Szathmáry Tibor térképtörténész boncolgatta 1993-ban, hogy a nevek mögött azonos vagy két különböző személy van-e, majd ennek a kérdésnek a kutatásait Pálffy Géza foglalta össze és döntötte el kimutatva, hogy Natale és Nicolo testvérek voltak és mindketten császári szolgálatban álltak.

Natale Angielini ott volt Lazarus Schwendi hadjáratában és egy korabeli forrás szerint rajzot készített az elfoglalt Tokajról és Szatmárról is. Tokaj rajza nem ismert, a Szatmár rajz pedig azonos lehet azzal, amit eddig Nicolo Angeilini rajzának tartottak (ÖNB, Wien, Sammlung von Handschriften Nr. 8609 fol. 78). Ekkor készülhetett az Északkelet-Magyarország térképe is, bemutatva rajta Lazarus Schwendi hadseregének vonulását és az elfoglalt helyeket. A térkép azt az állapotot tükrözi, amikor Lazarus Schwendi János Zsigmond Erdélybe történt vissza vonulása után ismét megszállta Nagybányát (1565 szeptemberoktóber). A térképet Bécsben nyomtathatták, az azon lévő monogramot (VTB) nem sikerült megfejtenünk, így a készítő rézmetsző kilétét nem ismerjük. A térkép jobb sarkában egy felragasztott papírlapon olvasható Natale Angelini részletes beszámolója a hadjárat fontosabb történéseiről, a térképen azok helyszíneinek betűjelölése szerinti sorrendben. 
Natale Angielini munkáját térképész szemmel nem feladatunk értékelni, csupán annyit jegyzünk meg, hogy azon a tájolás, a Tisza és a Szamos folyásának ábrázolása meglehetősen egyedinek tűnik. A települések jelölése a kor térképein megszokott jelképes ábrázolások (egyszerú templom, pár ház), de a katonailag jelentősebb helyeknél, mint Huszt, Munkács, Nagybánya, Kővár, Szatmár és Tokaj eltér a szokványos ábrázolástól. Huszt és Munkács esetében felmerül a helyszín ismerete, Nagybánya (Bana, Wagna) egy nagyobb város képét mutatja, Kővár (Chivar) és különösen Szatmár alaprajzi bemutatása (négyszögletes alaprajz a saját nagyméretű rajzán lévő valós ötszögletű alaprajz helyett) végtelenül egyszerű. Ami figyelemreméltó, az Tokajnál a Belső-vár négyzet formájú, emeletes épületként való bemutatása, ami jellegét tekintve megfelel a Zsámboky-Zimmermann Tokaj röplapon lévő Belső-várnak. (Natale Angielini térképe 1565, 86. kép)

Az 1564. július 25-én meghalt I. Ferdinánd temetésére csak egy évvel később, 1565 augusztusában került sor Bécsben. I. Ferdinándot végakarata szerint felesége, Jagelló Anna mellé kellett temetni a prágai Szent Vitus templom kriptájába. Azokban az évszázadokban nem volt szokatlan, hogy uralkodók vagy főemberek halála és temetése között hosszabb idő telt el. Megemlítjük I. Miksa király halála és temetése között is hat hónap telt el. Minél előkelőbb emberről volt szó, annál nagyobb volt a temetésre meghívandók száma. A meghívottak pedig nagy távolságból, esetenként több száz kilométerről, avagy más országból is érkeztek. Az utazások megszervezése ugyan olyan komoly feladat volt, mint a temetésre érkezettek elszállásolásának és ellátásának biztosítása. Mindez a korszak adott fejlettségi színvonalán roppant időigényes volt. Egy uralkodó, különösen egy császár esetében a temetés szervezésének nehézségei sokszorosra nőttek, hiszen egyrészt birodalmának minden országa, tartomány képviselőinek meg kellett jelennie a temetésen, mégpedig nem is akármilyen szinten, másrészt illett meghívni a rokon királyi családokat, a német-római császár esetében a választófejedelmeket és a birodalom többi közjogi méltóságát is. Az utazási és sokszor a politikai, vagy háborús helyzet miatt a meghívottaknak végül jó, ha a fele megjelent.

Az elvégzendő szervezési feladatok és a frissen a császári trónra lépő Miksa halaszhatatlan császári ügyeinek ismeretében a temetést 1565. március közepére tűzték ki Prágába. A közbe jött események (a király betegsége, a magyarországi harcok kiújulása és a Tokaj elfoglalásával kialakult politikai és háborús helyzet) miatt azonban az időpontot halasztani kellett. Megváltoztatták az ünnepélyes temetési szertartás helyszínét is, ez a császári székhely Bécs lett, így I. Miksának nem kellett hosszabb időre távol lennie a napi ügyeket intéző udvari hivataloktól. Az ünnepélyes temetési szertartásra végül 1565. augusztus 6-7-én a bécsi Szent István dómban került sor.

A temetési menet a Hofburgból indult a Szent István templomhoz. Elöl haladtak a birodalmi jelvények hordozói, majd az országok zászlóit vivők, akiket a lóvezetők a teljes testüket csülökig érő fekete lepellel - rajtuk az országok címerével - takart lovakkal kísértek. Őket az egyes országok - köztük a Magyar Királyság felségjelvényeit vivők sora követte, majd az egyházi méltóságok következtek. I. Ferdinánd holttestét főurak (köztük voltak magyarok is) gyászkereveten vitték a vállukon. Utánuk vonult II. Miksa császár a főhercegekkel és a többi családtaggal, majd következett a követek, a főurak és más világi méltóságok hosszú sora.

I. Ferdinánd temetésén a Magyar Királyság zászlaját a Bécsben udvari étekfogóként szolgáló Zrínyi György vitte, a címeres gyászlepellel takart lovat Batthyányi Boldizsár udvari pohárnok vezette és Stephanus Freydenthal troppaui kapitány kísérte (I. Ferdinánd temetése 1566/1, 89. kép). A királyság jelvényeit a kardot, a jogart, az országalmát és a koronát - Dessewffy János udvarmester, Mérey Mihály nádori helytartó, Bánffy László ajtónálló és Zrínyi Miklós tárnokmester vitte (I. Ferdinánd temetése 1566/2, 90. kép). A temetésről 1566ban kiadott emlékkönyv metszetei között (amelyeket a szakirodalom a könyvet kiadó Wolfgang Meyerpeck munkájának tart) ennek a két jelenetnek a képe is szerepel. A két képen szereplő valamennyi magyar foúrról, így Zrínyi Miklósról, és fiáról, Györgyről ez az első ábrázolás.

A Szent István dómban tartott gyászszertartáson a történetíró Forgách Ferenc nagyváradi püspök tartotta a gyászbeszédet. A másnapi szertartások után ugyanez a menet kísérte I. Ferdinánd holttestét a városkapuig, ahol egy hat fekete ló húzta gyászhintóba tették és elvitték Prágába. I. Ferdinánd császárt és királyt 1565. augusztus 21-én a Szent Vitus templomban tartott szertartással helyezték örök nyugalomra felesége, Anna királyné mellé.

\section{Anno Domini 1566}

Szulejmán szultán a császári csapatok újabb bevonulását Nagybányára a megkötött fegyverszünet megsértésének és egyúttal háborús hadüzenetnek tekintette. Ezért elhatározta, hogy 1566-ban személyesen vezet büntető hadjáratot 
II Miksa császár (akinek magyar királyságát az oszmán hatalom János Zsigmond választott király haláláig nem ismerte el) ellen.

Szulejmán szultán 1566. május elsején indult el hatalmas seregével Isztambulból, június végére ért Zimonyhoz. Itt kereste fel őt János Zsigmond 400 fős erdélyi küldöttségével június 29-én. Addigra azonban már több háborús esemény történt Magyarországon. Szulejmán elindulásának hírére Hasszán budai pasa - mintegy érdemszerzésül - június 8-án megkezdte Várpalota ostromát. A védők Thury György várkapitány vezetésével eredményesen védekeztek. Tíz napi ostrom után megérkezett Eckhardt von Salm győri kapitány vezetésével a felmentő sereg, Hasszán pasa ekkor jelentős veszteséggel visszavonult. A királyi katonaság június végén visszafoglalta a töröktől Veszprémet, majd Tatát, Várgesztest és Vitány várát. Szulejmán gyávaságáért augusztus elején kivégeztette Hasszán budai pasát.

Várpalota ostromáról és Veszprém visszafoglalásáról ugyan jelentek meg tudósítások, ám azok címlapján legtöbbször csak a kétfejű sasos császári címer szerepel. A Tata ostromáról megjelent híradáson csak jelképes ostromképet látunk. Várpalota és Veszprém ostromát Nicolaus Höniger örökítette meg könyvében, igaz a szokott, több esemény ábrázolására is felhasznált jelképértékű kis fametszetekkel. (Várpalota és Veszprém 1578/1, 87-88. kép)

A török főseregből kivált Pertev basa másodvezér 30 ezer emberével előbb Borosjenőt és Világos várát foglalta el, majd július 2-án megkezdte Gyula ostromát. Szulejmán 1566. augusztus elején ért a Zrínyi Miklós védte Szigetvárhoz és augusztus 6-án kezdte meg annak ostromát. Gyula és Szigetvár ostromának lefolyása részleteiben is jól ismert, számos korabeli forrását többen is feldolgozták.

II. Miksa császárnak az 1565 decemberében kezdődő augsburgi birodalmi gyűlésen sikerült komoly támogatást szereznie az 1566-ra tervezett törökellenes hadjáratához. A birodalmi seregekhez az itáliai fejedelmek további hat-nyolcezer fős katonai segítséget ígértek. Májustól kezdve a Német-római Birodalomból és az Itáliából folyamatosan érkező csapatok ideiglenesen Magyaróvárnál táboroztak, mivel a gyülekezésre már korábban kijelölt tábor kialakítása Győrnél még nem fejeződött be. A csapatok létszáma júniusban már meghaladta az ötvenezer főt. Időközben az országban tartózkodó császári és magyar seregek a Dunántúlon várak sorát foglalták vissza a töröktől, majd Komáromnál gyülekeztek. Amikor II. Miksa császár értesült Szulejmán szultán hatalmas hadseregének Magyarországra érkezéséről, 1566. június végén többféle megfontolásból úgy döntött, hogy a Magyaróvárnál és máshol várakozó seregek - a Kassánál és a Dráva mentén elhelyezkedők kivételével - mind vonuljanak a győri táborba. A győri táborhely előkészítése azonban ekkor még mindig nem volt kész, ezért a nagyobb csapatok csak augusztus elejétől érkezhettek. Mintegy két hetet vett igénybe, hogy szinte valamennyi kisebb-nagyobb sereg összegyűljön Győrnél. II. Miksa császár augusztus 15-én érkezett meg Győrbe, ahol az összehívott haditanács képtelen volt dönteni a hadjárat további céljairól.

Az 1566. évi hadjárat eseményeiről szinte felmérhetetlenül sok tudósítás jelent meg, elsősorban Gyula és Szigetvár ostromáról, majd azok elvesztéséről, de pár tudósítást Lazarus Schwendi és János Zsigmond hadjáratairól is ismerünk. A tudósítások címlapján megjelenő fametszeteknek azonban - Tokaj kivételével, bár az Michael Zimmermann előző évben már közreadott fametszete újabb kiadása volt - semmi közük nem volt a történések illetve azok helyszínei valóságához. Ennek ellenére közülük is párat bemutatunk, jellemzésül a kor képzeletvilágára és ízlésére.

Miután katonáinak több mint a felét már elvesztette, augusztus közepén Kerecsényi László gyulai várkapitány úgy ítélte meg, további ostromrohamnak a vár már nem tud ellenállni. Az élelmiszer tartalékok vészesen elfogytak (ebben szerepe volt a nagy számban odamenekült helyi lakosságnak), sőt, vízhiány is fellépett. Fegyverszünetet kért Pertev basától, majd megállapodtak vár átadásának feltételeiben. Ezek szerint a várban lévők javaikkal együtt szabadon elvonulhatnak, ehhez a törökök a szükséges szekereket biztosítják és túszokat is adnak. Szeptember 2-án a védők kivonultak, ám nem jutottak messzire, mert a törökök megtámadták őket és többségüket megölték. A zűrzavarban a török túszok megszöktek, Kerecsényit elfogták és Belgrádba szállították ahol hamarosan kivégezték.

Gyula elfoglalásáról összesen 7 metszet jelent meg, közülük 5 a háború eseményeit legjobban figyelemmel kísérő Velencében. Ez az öt, az ostromot felülnézetben bemutató metszet a vár alaprajza tekintetében jelentéktelen eltérések mellett azonos képet mutat és az ostromjelenetekben (katonák, ágyúk, sátrak stb.) is csak rajzi eltérések vannak. Leegyszerúsítve mondhatjuk, ezek a metszetek egymás másolatai, amelyeknél nehezen dönthető el, ha egyáltalán eldönthető ki kit és mikor másolt. A metszetek címei se sok segítséget jelentenek ebben, bár azt egyértelműen eldöntik, hogy utolsóként az egyik Domenico Zenoi metszet készült, amely címében a vár elfoglalásának időpontja (szeptember 3.) szerepel. A másik négy metszet címében Gyula még csak a „hitetlenek” által ostromlott, Erdély határánál lévő várként tűnik fel (Fortezza nel confini di Transilvania assediata da infideli). Mindegyik metszeten látható a korabeli térképeken is megjelenő, amúgy kissé rejtélyes Sarkadi-tó (Lago Sargad vagy Sarcad). 
Figyelemmel az 1566-ban Velencében készült többi metszetre is, úgy gondoljuk, elsőként Domenico Zenoi készítette el metszetét (Gyula (1566)/1, 91. kép), amit Paolo Forlani a maga stílusában hűségesen lemásolt (Gyula 1567/2/a, 95. kép). Forlani metszete 1568-ban jobb alsó sarkában 87 lapszámmal újra megjelent (Gyula 1567/2/b, 96. kép). Zenoi metszetén az ostromlóknál 5 értelmező felirat szerepel, köztük a tüzérség parancsnoka és a lovon ülő táborparancsnok (ez utóbbi kettő Forlani képéről lemaradt).

Nicolo Nelli metszetén az előző alaprajz köszön vissza, ám a vár épületei egyedi sajátosságokat mutatnak eltérve a Zenoi metszet egyhangú, szinte jelképként feltűnő földszintes házaitól. Ez a metszet nyújtottabb Zenoi metszeténél, így a vár előtt több hely van az ostromjelenetek megrajzolására. A képen a Lago Sargad az egyetlen felirat. (Gyula 1566/3, 92. kép)

A Velencében megjelent metszetek sorát záró Zenoi munka - amely címében közli Gyula elfoglalását és megnevezi Perthan (Pertev) basát is - kísértetiesen egyezik Nicolo Nelli metszetével. Még annak gyanúja is felmerülhet, hogy ez a metszet (átjavított címmel) a Nelli metszet lemezével készült. Ez a kép 1569-ben újra megjelent Giulio Ballino híres De disegni delle piu illustri citta könyvében. (Gyula 1567/1, 97. kép)

$\mathrm{Az}$ összes Velencében megjelent Gyula metszetnek van egy közös tulajdonsága, pontosabban fogalmazva, közös hibája: mindegyikük valótlan képet közöl. Déthsy Mihály mutatta ki (A gyulai veduták kérdése, 1960), hogy ezeken a metszeteken az egri vár alaprajza köszön vissza, feltehetően Paolo Mirandola hadmérnöknek az egri várról készített egyik modellrajza nyomán. Mirandola egyébként 1562-ben Gyula várának felmérését is elvégezte. Nem tudjuk, nem tudhatjuk, mi okozta a keveredést.

Déthsy Mihály azt is lehetőnek tartja, hogy a hadmérnöki rajzon szereplő Eger helynevet félreolvasták. Csak az mondható biztosnak, hogy 1566-ban Velencében egy rézmetsző számára elérhető volt egy magyarországi vár tervrajza. Ezt nem tarjuk meglepőnek, mert egyrészt a Velencei Köztársaság a kor egyik legkiterjedtebb kémhálózatát működtette, másrészt a magyarországi várak felmérését, épitését szinte kizárólag Itáliából érkezett hadmérnökök és várépítőmesterek végezték. Azt pedig, hogy egy tervraj rézmetszőhöz kerülése nem egy véletlenszerú, egyszeri eset, azt az 1566-ban Velencében készült további metszetek is igazolják.
Gyula elfoglalásáról Matthias Zündt is készített metszetet Nürnbergben. Déthsy Mihály szerint az ezen látható várrajz „több-kevesebb hasonlóságot mutat” a valósághoz. A képen határozottan elkülönül a két részből álló vár és a terjedelmes város képe. A metszeten a folyónevek (Feketekerecz, Fekyerkerecz) és a Kőrös híd (Körch prück) felirat hiteles adatforrásra utal, a vártól távolabb fekvő Remadahacz település talán az egykori Remeteháza lehet. A címben szerepel Kerecsényi

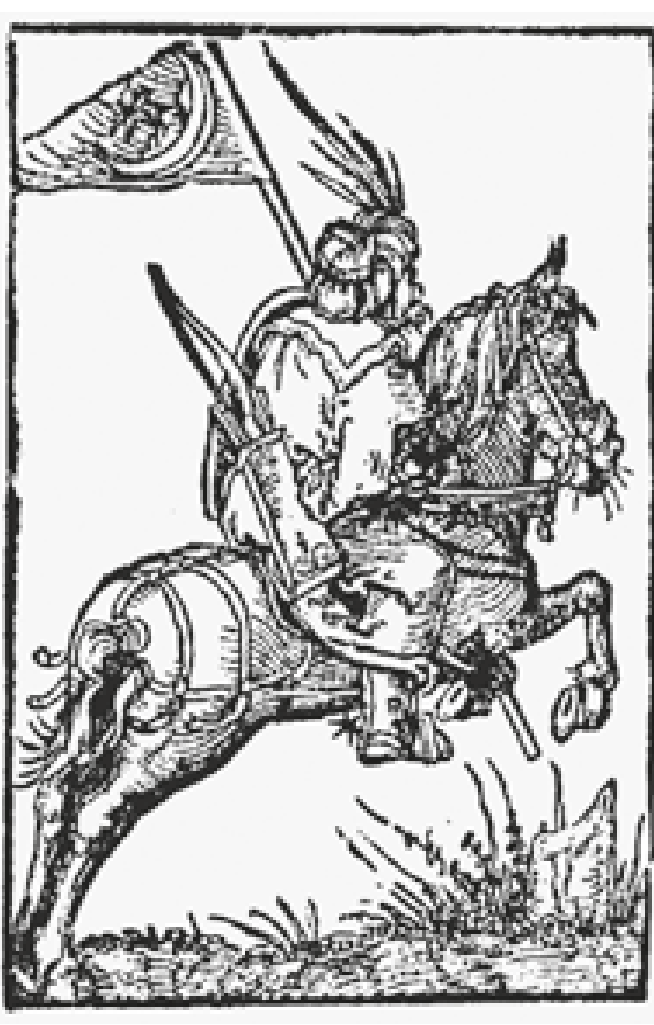
Csáktornyára és a családi sírboltban eltemették.
László várkapitány neve (Kereczthini Laslaw). Matthias Zündt metszete összességében igényes és mutatós, helytörténeti forrásértéke azonban - elsősorban a város látképét tekintve megkérdőjelezhető. (Gyula 1566/2, 93. kép)

Mindeddig ismeretlen volt az a metszet, amely Prágában készült, és amely az érdeminek nem nevezhető eltérésektől (az azonos tartalmú feliratok írásformája és helye, sátortetők díszítése stb.) eltekintve megegyezik Matthias Zündt metszetével. A címfeliratban is csak annyi a különbség, hogy Zündt neve helyett a „zu Prag” készítési hely szerepel. Ennek a két metszetnek az elkészülte nem lehet független egymástól, de az összefüggést tartalmilag nem ismerjük. (Gyula 1566/4, 94. kép)

Szigetvár ostroma szeptember 7-ig tartott, amikor a Belső-várba szorult Zrínyi Miklós felmérve a további védekezés lehetetlenségét, a vár feladása helyett a megmaradt embereivel a Belső-várból kitörve a hősi halált választotta. Szigetvár elfoglalását Szulejmán szultán nem érte meg, pár nappal korábban az ostromtáborban meghalt, de halálát a katonaság előtt eltitkolták. Szokoli Mehmed nagyvezér Zrínyi Miklós levágott fejét Budán keresztül megküldte a győri császári táborba, ahonnan azt díszes kísérettel vitték

Az 1566. évi török sikerek közül Szigetvár elvesztésének volt a legnagyobb visszhangja a keresztény Európában, és ez a megjelent metszetek számában is megmutatkozik. Itáliában 10, német földön 4, Párizsban 2 és Antwerpenben 1, összesen 17 metszet látott napvilágot. Amint látjuk, itt is a Szigetvárhoz legközelebb eső itáliai érdeklődés ( a velencei mellett immár római is) volt a legnagyobb.

Velencében Domenico Zenoi több metszetet is készített Szigetvár ostromáról illetve elfoglalásáról. Elsőnek a Szigetvár 1566/8 azonosítójú (99. kép), majd ezt 
követően a Szigetvár 1567/1 metszet (100. kép) került ki a nyomdából. A két metszet nem csak címében, de néhány feliratában és részletrajzában is különbözik, nem azonos lemezről készült, tehát nem tekinthetjük ezeket próbalevonatnak. A korábbi metszet címében csak azt közli, hogy a képen a magyarországi Ziget vára látható (Ziget fortezza nel paese d'Ongheria), a második már a vár szeptember 14-i elfoglalásáról számol be (Ziget, nel paese d'Ongheria preso / dal campo di turchi, l'anno 1566 alli 14. Stt. / essendo stato lungamente diffeso dal conte di / Esdrino gran capitano onghero. / Dnco Zenoi). (Az Itáliában készült metszetek feliratainak fordítása Könyves Tóth Kálmánnak köszönhető.) Jellegzetessége mindkét metszetnek a jobb felső sarokban lévő sánccal kerített hatalmas sátor, amelynél az első képen a GRAN TURCO felirat jelzi, hogy az a szultán táborhelye. A keleti tájolású metszeteken - amelyeken egyszerre láthatók balról-jobbra sorrendben a Külső-vár, az Óváros és az Újváros védelmében folytatott küzdelmek - feltűnik a Belső-vár nyugati oldalához, pontosabban a Nádasdy bástyához vezető, gyapotból és fából épített töltés, amiről felirat is tájékoztat. Az Óvárosból nyugatra kivezető rövid híd a vár körüli tavat és a várost övező mocsarat elválasztó hosszú, egyenes töltésben folytatódik, amely a kép alján három irányba elágazik.

Apponyi Sándor egy további, az előzőeknél jóval nagyobb méretű Szigetvár metszetről $(41,3 \times 29,2 \mathrm{~cm})$ is feltételezte, hogy az Domenico Zenoi műve (lásd Pierre Gentile: Deux veritables Discours. Paris, 1567.). Habár a rajzstílus hasonlósága feltűnő, meg kell jegyeznünk, hogy Zenoi mindig feltüntette munkáin a nevét, már csak a velencei rézmetszők közti állandó és éles versengés miatt is. Az is elgondolkodtató, hogy Zenoi metszetein a Ziget, ezen a metszeten pedig a Seghet helynév szerepel.

Ez a rendkívül finom rajzú metszet (Szigetvár (1567)/1, 98. kép) hosszú címe (fordítását lásd a mellékletben) több érdekességet is tartalmaz. Egyrészt közli, hogy a metszet Magyarországból most érkezett rajz alapján készült, másrészt hírt ad arról, hogy a várból kicsapó védők foglyul ejtették a janicsár agát. Ez valóban megtörtént, mégpedig augusztus 26-án. Dacára ennek az eseménynek a metszet egy jóval korábbi, valójában az ostrom megkezdésének megfelelő állapotot mutat, amikor a védők készleteket felhalmozva várják a támadást és ennek megfelelően a vár fokán is a védők zászlója lobog. A metszeten nem szerepel a Belső-vár Nádasdy bástyájához vezető töltés sem. A képen csak felirat jelzi a szultán táborhelyét. Az Óváros nyugati hídjának és a hozzá csatlakozó töltésnek a rajza egyezik a Zenoi metszeten láthatóval. A janicsár aga elfogása azonban nem úgy és nem ott történt, ahogy azt a cím, illetve a metszet mutatja: az agát a Külső-várhoz vezető töltésen fogták el a beszámolók szerint, ez a töltés azonban nem szerepel a metszeten.
Paolo Forlani kisméretű sorozatában is szerepel egy Szigetvár ostromát bemutató metszet. A leíró jellegű cím számos információt ad a várról (amit bevehetetlennek nevez), az azt körülvevő mocsárról, a hidakról, az ostromló török 100000 fős hadseregéről. A képen a szokásos négyrészes Szigetvár alaprajz, a vár megrohanása még nem kezdődött meg, de már elkészült az ostromágyúk védelmére összehordott ágyúdomb (monte fatto da turchi) és az Újváros déli várfalának árkán átvezető érthetetlenül kígyózó formában megépített ostromtöltés (trinciera fatta da turchi). Mindezeket a földmunkákat a törökök az ostrom első napjaiban elkészítették. Körsánc nélkül, csak felirattal mutatja meg a szultáni táborhelyet (il gran turcho) a jobb felső saroknál. Eltérően az eddigi metszetektől, ezen a képen az Óvárosnak nincs nyugati kivezető hídja, a töltés nekifut a nyugati városfalnak. A metszeten pár magyarázó felirat is feltűnik, köztük a vár védelmében rendkívül fontos szerepet játszó Pécsi-kapuhoz vezető híd megnevezése. Összességében a metszet közvetlen az ostrom megkezdése utáni, az Újváros augusztus 10-i kiürítése előtti állapotot tükrözi, ezért nem is szerepelhet rajta a Belső-vár nyugati falához épített töltés sem (Szigetvár 1567/2/a, 101. kép). Forlani metszete 1568-ban jobb alsó sarkában 87 lapszámmal újra megjelent. (Szigetvár 1567/2/b, 102. kép)

Paolo Forlaninak van nagyobb méretű Szigetvár metszete $(42,8 \times 29,2 \mathrm{~cm})$ is. A metszeten pontosan az látható, amit a címkeretben lévő hosszú felirat közöl, fordítása szerint: „Minden olvasóhoz / Az itt lévő rajz Sziget(vár) hiteles ábrázolása, mai valóságos állapotában, az átjárókkal amelyek a ki- és bejáratokhoz valamint az egyik területrôl a másikra vezetnek, továbbá azokkal, amelyek a szárazulatról vezetnek be, ezek pedig mind hidak, közülük néhány felvont állapotban, és amely (hely) körbe van véve vízzel és mocsarakkal, amint ezen a rajzon is látszik, és a mocsarak a partok és a vizek tekintetében azért vannak ezen a rajzon így ábrázolva, mert nagyon nagyok és csak így fértek el, de ennek egyébként itt nincs különösebb jelentősége. A tábor ott azon a helyen van, ahol az A.B.C.-vel van jelölve." A Belsőés Külső-várat, az Óvárost és az Újvárost alaprajzban bemutató metszeten csak azok nevei, a háromszor a Paludi (mocsár) felirat, az égtájak és a táborhelyek betűjelölése valamint a mocsarat tápláló vízfolyás elnevezése szerepel. Helyrajza egyébként teljesen megegyezik Forlani korábbi metszetének helyrajzával, a hosszú és egyenes nyugati töltés itt is nekifut az Óváros falának. Úgy gondoljuk, ez a metszet is rögtön azután készült, hogy Szigetvár ostromának híre megérkezett Velencébe. (Szigetvár 1566/6/b, 103. kép)

Forlani követve a Szigetvár ostromáról érkező újabb híreket, előbbi munkáját jelentősen átdolgozta. Ehhez korábbi metszetének lemezét használta 
fel, a címet változatlanul hagyva véste arra a képi és szöveges kiegészítéseket. Az amúgy meglehetősen sivárnak tűnő képre rárajzolta az ostromtábort, az ágyúk védelmét szolgáló földhányást, az Újvároshoz kígyóvonalban épített töltést, az Óvárost és az Újvárost elfoglaltként tüntette fel (az előbbi sarokbástyáin félholdas zászlók lobognak), a Belső- és Külső-várba épületeket rajzolt. A Külső-vár és az Óváros közötti területre, ahol a felszedett híd volt, odarajzolta a törökök gyapottal töltött zsákokból épített feltöltését.

A metszeten a legfontosabbakat Forlani két hosszabb feliratban közli. Az egyik a Belső-vár alatt olvasható: „Amikor a gróf látta, hogy nem képes tovább tartani magát a hitetlenek kemény és kegyetlen támadásaival szemben, összehordatta a kastélyba /Belső-várba/az összes hadifelszerelést és tüzet vettetett erre, majd visszahúzódott Szigetbe /a Külső-várba/ ahonnan hősiesen csatát kezdvén meghalt”. A másik felirat pedig a Külső-vár és az Óváros között van: „Ezt töltötték fel a törökök rőzsével, gyapjúval és földdel, itt tört ki és halt meg a hős és halhatatlan /?hírü?/gróf Zrínyi Miklós".

Ez a két felirat nem csak azt bizonyítja egyértelmúen, hogy ez a metszet Szigetvár elfoglalása után készült, hanem azt is, hogy Forlaninak Zrínyi halála körülményeiről is többé-kevésbé pontos értesülései voltak. De nem mindenben: a lőpor véletlenül robbant fel, Zrínyi kitörése nem a Külső-várból, hanem a Belsővárból történt és Zrínyi nem a töltésen, hanem a Belső-vár kapuja előtt halt meg. (Szigetvár 1566/6/a, 104. kép)

Velencében még egy metszet jelent meg Szigetvár elfoglalásáról. Az „Ordinanza Turchesca alla presa / di ZIGHET in Ongaria / l’Anno 1566" (A törökök hadrendje a Magyarországon lévő Szigetvár elfoglalásánál / 1566. év) címú metszetnek, amelyet Gio. Francisco Camocio készített, a címén kívül semmi köze Szigetvárhoz. A metszeten a kor vándormotívumának is nevezhető török császári hadsereg felvonulási képe látható, amelyet Jost Amman már 1564-ben elkészített és ismert Ferrando Bertelli és Paolo Forlani munkájaként is. Megjegyezzük, ugyanez az ábrázolás megjelent Székesfehérvár 1593. évi ostromképeként is, igaz, ott legalább a vár fölé odavésték a Stulweyssenburg feliratot. (Szigetvár, 1566/7, 105. kép)

Az egyik legismertebb metszetet Szigetvár ostromáról a Rómában dolgozó Antonio Lafreri készítette. Munkája méltán híres, részletes és finom kidolgozása mellett annak látványosságát növeli mérete $(50,9 \times 34,6 \mathrm{~cm})$ is. Lafreri metszete címében nem utal Szigetvár elfoglalására, csak az ostromára (Szigetvár igaz képe, a várkastélyával, az Újvárral, a mocsárral, tóval, folyóval és hidakkal és egyéb nevezetes dolgai feliratokkal megjelölve, a törökök készítette magaslat és az onnan indított roham bemutatásával). Lafreri metszetén semmi olyan képi elem nem szerepel, ami Zenoi és különösen Forlani különböző metszetein ne lenne látható. Korábban úgy véltük, kizárólag Forlani metszeteinek ismerete gyakorolt hatást Lafrerire, ma már ebben nem vagyunk biztosak. Végül is a metszet értékelhető Antonio Lafreri önálló művészi alkotásaként is, amelyet több metszet ismeretéből, saját stílusában készített. Lafreri metszetének lemeze később Giovanni Orlandihoz, majd Henricus van Schoelhöz került és a metszet 1602-ben mindkettőjük kiadásában újra megjelent. (Szigetvár 1566/2, 106. kép)

Rómában még egy nagyméretű és rendkívül ritkán előforduló Szigetvár metszet látott napvilágot, amely Mario Cartaro jelzése szerepel. A Lafreri metszetnél valamennyivel nagyobb lap címe (ZIGHET várának hiteles rajza, ahol most a török (szultán) személyesen táborozik, és látszik néhány támadás, melyekben a keresztények kis veszteséggel, de nagy tisztességükre a törököket szégyenükre nagy veszteséggel visszaverték) arról árulkodik, hogy ez a kép is az ostromlott Szigetvárt mutatja, és még a vár eleste hírének Rómába érkezése előtt készült. A cím végén B. F. (Bartolomeo Faleti?) privilégiuma szerepel. A nem túlrajzolt lapon a körsánccal védett szultáni tábor (igaz, a metszet ellenkező felső sarkában), a körlakú ostromgyűrű és az Újváros déli oldalánál lévő ágyúállások Domenico Zenoi első metszetének ismeretére utalnak. (Szigetvár (1566)/4, 107. kép)

Mario Vaccario metszete jutott el Párizsba André Thevet földrajztudóshoz, aki fametszetét ennek alapján készítette, igaz, tükör másolatban, így ez az egyetlen nyugati tájolású Szigetvár metszet. Thevetnek még emlékezetében élhetett előző évi Tokaj metszete, talán ezért rajzolt erre a képére erdélyi sereget és külön erdélyi táborhelyet is. Egyéb írásos forrásai is lehettek, mert több török csapatot megnevez, köztük a budai basa seregét is (nota bene sem az augusztus elején kivégeztetett budai basa utóda, sem a csapatai nem voltak ott Szigetvár ostrománál). Metszete egyébként sűrűn telerajzolt csapatokkal, szállító eszközökkel, sátrakkal. Thevet hosszú ajánlásában arról ír, hogy Szulejmán szultán elfoglalta Szigetvárt. Sem a szultán halálát, sem Zrínyi Miklós nevét nem említi, viszont reményét fejezi ki, hogy a keresztények visszafoglalják a várat. Thevetnek ez a színezett fametszete is csak egyetlen példányban ismert. (Szigetvár (1566)/3, 108. kép)

Mindeddig nem volt ismert az francia röplap, melyen felül Szigetvár ostromképe, alatta Vray dessein de la ville \& forteresse de Zighet assiegée par le Turc en personne címmel egyhasábos nyomtatott szöveg ismerteti részletesen az ostromot, megemlítve Zrínyi hősiességét. A beszámoló a vár elfoglalásával zárul, amely során valamennyi védőt megölték. Sem a metszeten, sem a nyomtatott 
szövegben semmilyen jelzés vagy utalás nincs a röplap kiadójára vagy a metszet készítőjére. A metszet egyébként Cartaro munkájának kicsinyített, ám hű másolata, amelyen készítője elóképe üres helyeit ágyúkkal, csatajelenettel és sátrakkal töltötte ki, a képre rárajzolva az ismertetésben szereplő mesterséges ágyúdombot (Montaigne artificielle pour baterie) is. Előképéről még az égtájrózsát is átvette, amit az égtájak betújelölésével ki is egészített -de rosszul, így ez a Szigetvár metszet jelölése szerint északi tájolású lett. Összességében mutatós fametszet, a kor divatjának megfelelően ez is utólag színezett. (Szigetvár (1566)/5, 109. kép)

Hans Liefrinck flamand és francia nyelvú ismertetéssel Antwerpenben megjelent röplapján a Szigetvár kép Forlani kisméretű metszetének másolata (Szigetvár (1566)/1, 110. kép). A metszet alatti, két hasábban lévő ismertetés első mondatai is Forlani metszetének címfeliratában lévőket közlik. Az ismertetés azzal a bizakodással zárul, hogy Szigetvár megtartása a biztosíték a török zsarnokság elleni, tehát a vár elfoglalásának híre még nem jutott el Antwerpenbe - de ugyanakkor Forlani metszete igen! Mindez elég hihetetlenül hangzik. Lehet, hogy a röplap később jelent meg 1566. évi dátummal, és Liefrinck nem értesült az elfoglalásról vagy az nem érdekelte. Liefrinck lemásolta Matthias Zündt Magyarországról készített 1566. évi haditérképét is és azt saját nevével kiadta.

Matthias Zündt a már korábban ismertetett Gyula metszete és 1566. évi haditérképe mellett Szigetvár ostromáról is készített metszetet. Képén Szigetvár alaprajzi ábrázolása kisebb-nagyobb eltérésekkel egyezik az abban az évben készült más metszetekével. Ez azt mutatja, hogy abban az időben csak egyetlen Szigetvár felmérési rajz létezett, és annak másolatai jutottak el a német városokba és Itáliába. A szerencsésen megválasztott forma (kissé elnyújtott téglalap) kedvező lehetőséget adott a keleti tájolású képen az észak-dél irányban hosszan elnyúló, négyrészes alaprajz elhelyezésére. A várat övező tavat tápláló patak, az ostromtábor és az ágyúállások elhelyezése, a mesterséges ágyúdomb, a jobb felső sarokban a szultáni sátor (Soliman Zelt) feltüntetése Forlani kisebb metszetére emlékeztetnek, megjegyezve, hogy mindezek a nyomtatásban megjelent tudósításokban is szerepelnek. Zündt az
Újváros alatt feltüntet egy vízimalmot, két őrtornyot (Wacht Thurn) és a nyugati őrtorony mellett egy hatalmas kutat (Brun). A címtábla közli, hogy 1566-ban a török szultán hadai ostromolják Szigetet, amit Zrínyi gróf véd. A vár elfoglalását nem említi (Szigetvár 1566/3,111. kép). A metszetnek létezhet címtábla nélküli változata, ennek csak fényképét ismerjük, adatait nem, lappang. (176. kép)

Zündt metszetével teljesen azonos képet mutat az a német nyelvú metszet, amelynek készítőjét nem ismerjük. A két metszetnekazonos a mérete és acímtáblán nem szerepel a "Nurmberg Mathis zündt” jeltés. A metszeten lévő valamennyi felirat Zündt metszetén is látható, eltérés csak a kisbetűs-nagybetűs írásformában és a feliratok pontos helyében van. Emlékeztetve Zündt Gyula metszetének és annak Prágában készült „ikertestvére” ismertetésére (Gyula 1566/2 és 1566/4), úgy gondoljuk, ez a metszet is Prágában készült. A ki-kit másolt kérdésre itt sem tudunk választ adni. (Szigetvár 1566/5, 112. kép)

Zündt készítette korának egyik legszebb Zrínyi Miklós félalakos mellkép-metszetét, amelyen a háttérben jól felismerhetően megjelenik Szigetvár képe is. A kép alatti szöveg elmondja, hogy az ostrom július 31-től szeptember 7-ig tartott és Zrínyi Miklós a Belső-vár hídján „mint egy keresztény és lovag" végezte életét (sein Leben als Christlich und Ritterlich beschlossen). (Szigetvár 1566/3, 113.kép)

A Szigetvár ostromáról készült metszetek ismertetésében utolsónak hagytuk Matthes Francken Augsburgban készített fametszetét. Ezen szinte minden megtalálható, ami Zündt metszetén szerepel, de teljesen más formában bemutatva. Az alaprajz szabályos négyszögekből van összeállítva, egységesített sarokbástyákkal, semmi közük az egyes részek valódi arányaihoz. Mai elnevezéssel akár egy kubista felfogású alaprajznak is mondható. Ugyanilyen aránytévesztések láthatók a metszet további ábrázolásainál is: az őrtornyoknál, az épületeknél, a kútnál. Mégis, mindezek kiegészítve a viszonylag bőséges feliratokkal a képen ábrázoltakat könnyen érthetővé teszik. Megjegyezzük, ez az egyetlen metszet, amelyen helyesen jelenik meg az Almamelléktől induló, a vár körüli tavat és a mocsarat tápláló Alma patak (ma Almás patak) neve. Honnan tudta a metszet készítője a patak nevét, az talány. (Szigetvár (1566)/2, 114. kép) 
Összefoglalva a Szigetvár elfoglalása alkalmából megjelent metszeteket, hangsúlyoznunk kell, hogy egyetlen metszetkészítő sem járt a helyszínen, vagyis mindegyikük „kapott anyagból” dolgozott: Szigetvár alaprajzból, a helyszínről érkezett írásos vagy szóbeli híradásokból, később a már nyomtatásban megjelent tudósításokból. Ismert, hogy nem csak Zrínyi Miklósnak sikerült egy-egy helyzetjelentést, segítséget kérő levelet kijuttatni az ostromlott Szigetvárból, hanem a szultáni táborban lévő követek, mint a francia követ is folyamatosan küldte jelentéseit Velencén keresztül hazájába. Szigetvár alaprajzával kapcsolatban elmondjuk, ma nem ismerünk Szigetvárról 1566 előtt készült hadmérnöki felmérést vagy alaprajzot. De kellett lennie és azt fel is használták a metszetkészítől. Ennek bizonyítéka, mint már írtuk, hogy az egymástól távol eső Velencében és Nürnbergben időben szinte egyszerre, lényegtelen eltérésekkel azonos alaprajzi elrendezésű Szigetvár metszetek láttak napvilágot. Megjegyezzük, az 1556. évi ostrom során súlyosan megrongált Szigetvár újjáépítését az a Paolo Mirandola hadmérnök végezte (és készíthette az ehhez szükséges felmérési rajzokat), akinek más tervrajzát is felhasználták metszetkészítéshez Velencében (lásd a korábban leírtakat Gyula 1566. évi metszeteinél).

$\mathrm{Az}$ is tudott, hogy a város és a vár környezetéről semmilyen tereprajz nem létezett, tehát a metszeteken ábrázolt terep a szóbeli vagy leírt tájékoztatások képi megfogalmazása és annak megfelelően megbízható. (Zárójelben egy példa: Forlani egyik metszetének hosszú címleírásában szerepel „Il fiume che fa il lago intorno alle forteze e fa il paludi/ a folyó, ami tóvá nő az erőd körül és mocsárrá alakul". A metszeten ennek a közlésnek a képi megfogalmazása vagyis lerajzolása pontosan olyan, amilyennek azt Forlani elképzelte és aminek feltehetően nem sok köze volt a valósághoz.) Ugyanez igaz a metszeteken ábrázolt eseményekre is. Ezért valamennyi Szigetvár metszet legfeljebb másodlagos értékű forrásnak, és nem személyes megfigyeléseken, felméréseken vagy tapasztalaton alapuló hiteles forrásnak számít. Csak az valós belőle, amiről megbízható írásos forrás is van, de az is csak üzenetében, nem képi formájában vagy annak a metszeten lévő helyében. Ez egyaránt igaz a mesterséges ágyúdomb kinézetére és helyére, az őrtornyokra, a kútra, az ostromtáborra, gyakorlatilag a metszet minden részletére.

Az azonos Szigetvár alaprajz használatának cáfolataként nem fogadható el érvként az, hogy az alaprajz összetevőinek (Belső- és Külső-vár, Óváros, Újváros) rajza az egyes metszeteken alakra, egymáshoz viszonyított arányaiban és távolságaiban nem azonos. Ezek az eltérések a „nyersanyagtól” bőven belefértek a metszetkészítők alkotói szabadságába. Ezért. teljesen értelmetlenek az olyan megállapítások, mint „ez a metszet eltérően a másik metszettől helyesen mutatja a Belsö-vár és Külsó-vár közti távolságot" vagy az ehhez hasonlók. Ezeknél a tájékoztatásra és nem a történések hiteles képi megőrzése céljából készült metszetek elemzésénél mindig erőltetettnek hatnak az olyan megközelítések is, mint az ábrázolás „haditáj” minősítése, vagy „a szigetvári hadi táj természeti, épitett és efemer elemeinek csoportosítása". Öncélú és félrevezető egy metszetbe mindenáron „belelátni” azt, amit keresünk, szeretnénk megtalálni, netán tudunk, hanem el kell fogadni azt, amit és ahogyan az mutat.

Gyula és Szigetvár ostroma és elfoglalása idején II. Miksa császár a Német-római Birodalomból és Itáliából érkezett mintegy huszonötezer lovas és nyolcvanezer gyalogos katonájával tétlenül várakozott Győrnél. Gyula elestének híre szeptember 6-án, Szigetváré szeptember 13-án érkezett meg a táborba. A Haditanács nem tudván Szulejmán szultán haláláról, továbbra is a helyben várakozás mellett döntött mindaddig, amíg nem ismerik meg a török hadvezetés további terveit. Ez a várakozás aztán hat hétig tartott, a Haditanács ennyi idő alatt sem tudott döntést hozni, elinduljanak-e a török ellen, és ha igen, merre.

Időközben szeptember 29-én Győr városát egy tűzvész (egyes híresztelések szerint a zsoldos katonák okozták) szinte teljesen elpusztította. Október közepétől a külföldről érkezett segélycsapatok lassan megkezdték a tábor elhagyását. A Haditanács október 21-én döntött a hadjárat befejezéséről, a tábor pedig november elejére kiürült.

A Győrnél gyülekező, majd táborozó csapatok híre Európa-szerte ismertté vált, arról számos híradás jelent meg, ha nem önállóan, akkor az időszerú hírekbe befoglalva. Később ezek közül is bemutatunk néhányat, előbb azonban a Győrről készített metszeteket ismertetjük. Érthető módon jóval kevesebb Győr metszet (változatokkal együtt összesen 7) készült, mint Szigetvárról, és azok mind olasz földön, Velencében és Rómában készültek olyan rézmetszők munkájaként, akik abban a évben a többi magyarországi eseményről is készítettek metszetet.

Elsőként Domenico Zenoi metszeteit ismertetjük. Első metszete feltehetően arra hírre született, hogy Győr lesz a törökök ellen induló birodalmi és itáliai csapatok gyülekező helye. A metszeten Győr város alaprajzát látjuk, hét bástyával, egy várkapuval, a város területén elszórt egyszerű épületekkel, a bal sarokban lévő bástyán egy templom és egy nagyobb ház fallal elválasztva a áros többi részétől. Az alaprajz közepén látható a FORTEZZA DI IAVARINO címfelirat, a város előtt egy lovascsapat császári kétfejú sasos zászlóval. A metszetre már rátekintéssel is megállapítható, hogy azon egy kissé „felöltöztetett” hadmérnöki alaprajz látható. 
Előképe a Győr város védelmi átépítésére készített valamelyik felvételi alaprajz vagy modellrajz lehetett. Ilyenekből több is fennmaradt, köztük Pietro Ferrabosco hadmérnök nevéhez köthetőek is. Van egy jelentős eltérés azonban minden korábban készült hadmérnöki rajztól: Zenoi metszetéről lemaradt a város nyugati kapuja a várfal vizes árkán átvezető híddal. Zenoi jelzése a metszeten jobbra lent egy kőlapon van. (Győr (1566)/3, 115. kép)

Zenoi ezt a metszetét átdolgozta annak a hírnek a megérkezése után, hogy az első csapatok már gyülekeznek Győrnél. Megjegyezzük, hogy ennek a metszetváltozatnak az elfogadott szakmai elnevezése a 2. lemezállapot, az előbbié pedig az 1. lemezállapot, és nem próbanyomat, aminek más a jelentése (elsősorban befejezetlenségre utal). A metszeten a cím kiegészítése utal a táborozásra: „...nei confini dell'Austria, et Ongheria, doue / al presente si troua il campo de Christiani" (Győr vára Ausztria és Magyarország határán, ahol jelenleg a keresztények tábora található). A városban több a ház, köztük két nagyobb terjedelmű, tornyos épületcsoport, egy soha nem volt kerek, kupolás templom és már két sarokbástyán is lobog a császári zászló. A város körül az eddigi lovascsapaton túl balra és a jobb sarokban megjelenik pár lovas és gyalogos katona. (Győr (1566)/1, 116. kép)

Paolo Forlani metszete címében szintén a győri táborozásra utal: FORTEZZA DI IAVARIN / dove si troua hora il campo de l'impator (Győr vára ahol most a császári táborhely van.) Képileg alig különbözik Zenoi első metszetétől, a városban más a házak elhelyezése és száma, a Győr előtti lovascsapat és az elszórtan látható katonák rajza is kissé más. Ezen a metszeten sincs rajta a város nyugati bejárata. Meggyőződésünk, hogy Forlani Zenoi munkáját másolta, kapcsolatáról Zenoival később részletesen is szólunk. Forlani jelzése az „in mezaria de / l'insegna della / Colonna" a város a délre előreugró Császár-bástyáján olvasható. Forlani 1566-ban kapott engedélyt, hogy Velence Merzaria városrészében lévő üzlete elé egy oszlopot (colonna) feltüntető cégért elhelyezzen. Ettől kezdve munkáin neve helyett gyakran az üzlete megnevezése jelenik meg. Ez a metszet 1568-ban újra megjelent jobb sarkában 86 lapszámmal. (Györ 1567/1/a és Győr 1567/1/b, 117, 118. kép)

Zenoi a Győrnél lévő katonai táborról is készített metszetet, amelyen természetesen szintén szerepel Győr városa alaprajzban bemutatva. A rendhagyó módon dél-délnyugati tájolású metszetnek beszédes címe van: „Il campo del Imp. piantato sopra Iavarino, il quale mediante lettere d'Alphabeto si mostrano il numere Cavaleria, et con numeri d'abaco tutta la fanteria" (A Győr fölött letelepített császári tábor, amely az ABC betűivel mutatja a lovasság számát, és abakusz /arab/ számokkal a gyalogságét). A kép alján elhelyezett Győr alaprajzon azonban nem szerepel a fallal elkerített Castellun avagy Püspökvár. Egyébként az egész város lángokban áll, ami egyértelmű utalás a szeptember 29-i tűzvészre - és egyúttal támpont a metszet készítési időpontjának meghatározásához. A metszeten sok az értelmező felirat (Borgho, Isola di Comar, munitione, strade, palludi), és látható az Újvárost nyugatról határoló 1564-ben épült védősánc.

A metszet legnagyobb részét a Dunától a Rábáig saroképítményekkel és ágyúállásokkal erősített védősánc övezte táborhely tölti ki. A táborhely közepén helyezkedik el a „piaza il iperator”, vagyis a császár és kíséretének kijelölt hely. Az egyes csapatok táborai (amelyek mind szigorú geometriai alakzatúak) közötti területeket „Strade”, a táborhelyek és a védősánc közötti területet pedig „piaza la bataglia" felirattal jelöli és bemutatja a tüzérség és a muníció elhelyezés területeit. A metszetet Zenoi azzal kívánta életszerűvé tenni, hogy a kijelölt területeket telezsúfolta sátrakkal, gyalogos és lovas katonákkal, az ágyúdombokra ágyúkat rajzolt, a város jelképértékű házai pedig lángokban állnak. A táborban lévő hadvezérek közül ötöt lóháton ülve ábrázol - köztük a ferrarai herceget - és meg is nevez. A metszeten felül két oszlopban jelmagyarázatként (1-5 és AA-L) jelöléssel) 48500 főből álló hadsereget ismertet. (Győr (1566)/a, 120. kép)

Zenoinak ez a metszete az utóbbi időben érdekes módon nagyon sok kritikát kapott. A kritikát megfogalmazók abból indulnak ki, hogy az 1566-ban készített Győr metszeteknek egyetlen képi forrása Nicolo Angielini 1566-ban készített rajza lehet. Ebből a rajzból az eredeti példány nem maradt fenn, egykori létezéséről csak Georg Hoefnagel Győr metszetén lévő üzenetből tudunk, ami szerint a rajz nem 1566-ban, hanem 1567-ben készült. Több 17. század eleji rajzot, amelyek hasonlítanak Hoefnagel metszetére, Angielini rajza másolatának tartanak. Zenoi kritikát kap azért, mert eltér Angielini rajzától, feltüntet olyanokat, amik Angielininél nem szerepelnek (például a mocsaras terület), de kétségbe vonták a metszet adatai-feliratai megbízhatóságát is. Súlyos elmarasztalást kapott a táborhely közel négyzethálós alakzata, mondván: „azt nyilvánvalóan az antik római castrum ekkor már közismert elrendezése inspirálta".

Zenoi győri metszeteinek előbbiekben ismertetett elmarasztalását azonban felülvizsgálatra kényszeríti egy újonnan felfedezett rajz. A Pázmány Péter Katolikus Egyetem „Vestigia” Kutatócsoportja a Modenában lévő Állami Levéltárban végzett kutatásai során egyebek mellett rábukkant egy katonai tábor tervrajzára. (Archivio di Stato di Modena, Mappario Estense, Militare, n. 129.). A rajzon ugyan évszám nincs, de a Giavarino felirat és a terven szereplő császári sátorhely egyértelműsíti, hogy ez az 1566. évi Győr melletti császári tábor elhelyezési vázrajza. Zenoi 
metszete hűségesen követi ezt a rajzot, nem csak képileg, de felirataiban is: nincs egyetlen felirat a rajzon (köztük a Zenoi metszetén kifogásoltak is), ami ne szerepelne Zenoinál, legtöbbször képben is bemutatva (pl. a tüzérség helyén ágyúk). (Győri tábor tervrajza, 119. kép)

Ez a táborterv rajz nem csak Zenoi megbízható forrásválasztását igazolja, hanem megcáfol állításokat a korai Győr metszetek készítéséről. Így például azt, hogy nem a rejtélyes Angielini rajz volt avagy lehetett az egyetlen forrása minden Győr metszetnek. Ebben eddig is biztosak voltunk, ám csak logikai úton tudtuk véleményünket igazolni: egy 1567-ben készített rajz nem lehetett előképe 1566-ban megjelent metszeteknek. Az a vélemény se tartható tovább, hogy Zenoi táborterv metszetének előképe Mario Cartaro Rómában készült metszete volt, illetve Zenoi metszetét a római castrum elrendezés ismerete ihlette.

Elidőzve kissé a ritkaság számba menő győri tábor tervénél, magától értetődő, hogy egy nagyobb létszámú hadsereg (II. Miksa császár hadai összesen több mint százezer katonával az volt) táborhelyének kialakítása komoly előkészületeket követelt meg. Több mindenről nem szólva csak párat említünk ezek közül: a táborhely területének pontos meghatározását (jelen esetben Győr városától délre-délkeletre eső, a Mosoni-Duna és Rába által határolt viszonylag sík területet), és minden eshetőségre gondolva ki kellet jelölni a tábor védelmét szolgáló védősáncok helyét. Sokféle szempontra figyelemmel (pl. a csapatvezérek rangja, a nemzetiség, a létszám, a fegyvernem, az ágyúk elhelyezése, a puskapor biztonságos tárolása stb.) a táborhelyen belül úgy kellett kijelölni az egyes csapatok elhelyezését, hogy a táboron belüli mozgás is lehetséges legyen. Ezt követően elő kellett készíteni a terepet, alkalmassá téve azt a táborverésre és el kellett készíteni a védősáncokat.

A modenai levéltárban felfedezett győri táborterv rajza ennek az előkészületi folyamatnak a részeként készülhetett. Feltételezzük, hogy a rajz egy példányát minden önálló sereg már Győrbe érkezése előtt megkapta, megkönnyítve ezzel a számukra kijelölt helyen történő táborverést. A Modenában lévő táborterv példány a Győrhöz csapataival augusztus közepén megérkező II. Alfonz d'Este ferrarai herceg (II. Miksa császár sógora) hadmérnökei útján kerülhetett Ferrarába a családi levéltárba.

Maga a táborterv egy végtelenül egyszerű, geometrikus felépítésű vázlatrajz, a megszokott északi helyett dél-délnyugati tájolással. A rajzon a várfalakkal körülvett, bástyákkal megerősített Győr alaprajza vázlatszinten megfelel Pietro Ferrabosco 1564-ben készített felmérési rajzának. A táborhelyet a Dunától a Rábáig saroképítményekkel és ágyúállásokkal erősített védősánc övezi.

Nem tudni pontosan, hogy mikor épült meg Győrnél a tábor körüli védősánc. Adatok vannak arra, hogy júniusban már folyt a táborhely előkészítése és a Győr

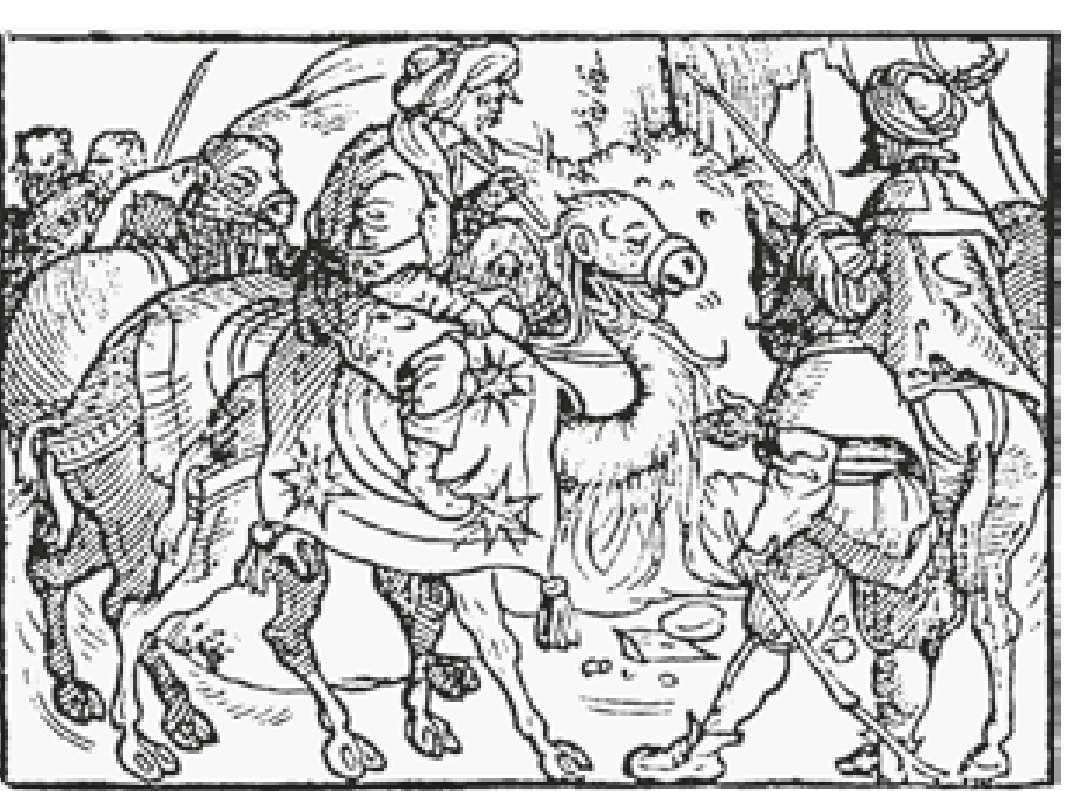
közelében időnként feltűnő kisebb török csapatok miatt a tábor körüli sáncok is épültek már. Az biztos, hogy Szigetvár elestének hírére a tábor addig elkészült védelmét tovább erősítették, tartva a török fősereg Győr felé vonulásától. Szeptember végére a védősáncok a szükséges helyeken mind elkészültek.

Hangsúlyozzuk, hogy az előkerült rajz egy előzetes vázlatterv, s mint ilyen, azon nem is szerepelhet, hogy végül a megérkezett magyar, császári és külföldi csapatok - a császár és kíséretének kijelölt helytől eltekintve - a táboron belül hol és milyen alakzatban helyezkedtek el. Abban biztosak vagyunk, hogy nem a vázrajz szerint tökéletes mértani formában. De abban is biztosak vagyunk, készült egy olyan táborrajz is, amelyen szerepelt az egyes seregek helyének tényleges elhelyezkedése - talán pont erre a rajzra rávezetve - hiszen arra a hadsereg vezetésének szüksége volt. Talán egy ilyen „nevesített” rajz egyszer még elő is kerül. Azok a 17. század eleji, az elveszett Angielini rajz későbbi másolatainak tartott rajzok, amelyek - akár csak részben is - feltüntetik az egyes seregek térbeli elhelyezkedését, egy ilyen véglegesített táborterv-rajz ismeretében is készülhettek.

Rövid idővel ezután Zenoi egy újabb metszetet készített a győri táborról, ennek okát a metszet címében közli: „Il campo del Imp. piantato sopra Iavarino, con i nomi assi(?) Principi e signori et(?) il numere dele genti tratto da una coppia autenthica et? da me con ogni diligenza intagliato In Venetia l'anno 1566". (A Győr 
fölött letelepített császári tábor, a segítő(?) hercegek és nagyurak neveivel és az emberek [vagyis a katonák] számával amelyeket egy hiteles másolatból vettem és teljes szorgalommal lemezbe véstem Velencében, az 1566. évben). Vagyis Zenoi a táborban lévő seregekről, azok vezéreiről a korábbiaknál megbízhatóbb és részletesebb adatokhoz jutott, ezért szükségesnek tartotta "teljes szorgalommal” egy új lemez elkészítését. Feltehetően Zenoi forrása egy, a győri táborból érkezett beszámoló másolata volt.

A metszet tükrözi az újabb adatokat: azon lóháton már 18 hadvezér szerepel nevével együtt. Közöttük mindössze egy a magyar, Báthori András országbíró (il Battori). A metszeten felül elhelyezett felsorolás szerint a hadsereg létszáma 51200ra emelkedett. Zenoi a cím alatt tájékoztatást ad a Drávánál Károly főherceg, illetve az északkeleti Magyarországon Lazarus Schwendi vezette seregekről is. Az új metszet a staffázsokban követi elődjét, bár azok elhelyezése és rajza eltérő, és a feliratokban is vannak változások (kis betûs - nagy betús írásforma, elmarad a Danubio felirat stb.) A metszet bal felső sarkában egy korábban ott szereplő hosszabb felirat eltávolításának nyomai láthatók, feltehetően Zenoi munka közben megváltoztatta a címfeliratot. (Győr 1567/2, 121. kép)

1566-ban még egy metszet készült Győr és a körülötte táborozó keresztény seregek bemutatására. Ezt Mario Cartaro készítette Rómában, címe „IAVARINO in ongaria et trinciere doue al presente si ritrova lo Imperatore aloggiato con lo esercito". A metszet koncepciójában eltér Zenoi metszetétől, hiszen a Győr nagyobb térségét feltüntető térképen a város alaprajza és az azt ölelő tábor képe szinte elvész. A város és a tábor képe azonban azonos elemeket is tartalmaz Zenoi metszetével, különösen a tábort körülvevő védősánc és a tábor belső geometrikusnak ható elrendezése tekintetében. Győr térségének ábrázolásához Rómában találhatott olasz kartográfusok által készített térképeket. Nem kívánunk foglalkozni azzal, hogy Cartaro metszete Zenoi munkájának ismeretét tükrözi (nem lehetetlen), avagy Cartaro is hozzájutott a győri táborterv egy példányához (talán egy véglegesített csapat elhelyezési rajzhoz is), amire bizonyára több lehetősége is volt. Ezek közül megemlítjük azokat a győri táborról Rómába érkezett jelentéseket, amelyeket a Cartaro metszetén is feltűnő Delfini Zakariás pápai nuncius - aki 1565-től győri püspök is volt - küldött. (Győr 1566/1,122. kép)

Mindeközben az ország keleti felében kevesebb volt a háborús esemény. A nyár elején Lazarus Schwendi a Felső-Magyarországi királyi csapatokkal János Zsigmond támadására várt. Időközben katonái megszállták az Izsákai András által átadott Hajdú-Bihar megyei Zsáka mocsárvárát. Július végén indult meg János Zsigmond támadása. Előbb Bajom várát, aztán Zsákát foglalt vissza, majd Tokaj ellen vonult, hidat veretett a Tiszán és megkezdte Tokaj ostromát. Az erdélyiek megsegítésére rendelt tatár csapatok addigra már felégették Tokaj városát, majd tovább pusztították a környéket. Rövidesen megérkeztek Tokajhoz a Pertev basa küldte török segéderők is. Jakob Raminger várkapitány vezetésével a védők azonban sikeresen visszaverték az ostromlókat.

Zsáka elfoglalásáról mindössze egy metszet jelent meg. A jelzés nélküli munnkát a szakirodalom Domenico Zenoi múvének tulajdonítja, de ennek oka ismeretlen. Zsáka elfoglalásának szinte nem volt hírértéke az év eddig ismertetett eseményei mellett, de az mégis eljutott elég pontos értesülésekkel együtt Velencébe. Ez feltehetően János Zsigmond udvartartásában lévő számos olasz udvaronc egyikének köszönhető.

A „Saaca” nevet viselő metszeten egy náddal sűrún benőtt területen vizesárokkal körülvett, két oldalról csak palánkkal védett szerény erősség képe látható, amelyet kétfelől ostromtábor és tüzelő ágyúk kerítenek. A kép jobb szélén és alul pár egyszerú ház a községet mutatja. A kép címe részletes tájékoztatást ad arról, hogy a várat 1566. szeptember 30-án a Király (il Re, vagyis János Zsigmond) csapatai elfoglalták. A minden valószínűség szerint képzelet szülte képen (amelyet a címben Kis-Velencének is neveznek) egy valós jelenet mégis van. Rövid ostrom után a várat védő német zsoldosok szabad elvonulás fejében fel akarták adni a várat, 
amit Bay András várkapitány nem engedett. Erre a zsoldosok elfogták a kapitányt és üzenetet küldtek az ostromlóknak, átadják nekik kapitányukat, ha ők szabadon távozhatnak. A megegyezés létrejött, a zsoldosok a megkötözött Bay Andrást betették egy csónakba és átvitték az ostromtáborba. A metszeten ez a jelenet is látható. Az elfoglalás időpontja vitatható, a legtöbb forrás ennél korábbra teszi, bár a pontos ideje ismeretlen. A metszet szerepel egy 1567-ben megjelent városképgyüjteményben, majd 1569-ben Giulio Ballino híres De disegni delle piu illustri citta könyvében. (Zsáka 1567/1, 123. kép)

Tokaj 1566. évi őszi ostroma az év többi eseményéhez képest kevés figyelmet kapott. Érdekességként említhető, hogy az eseményről kiadott kevés tudósítás egyikén ismét megjelent Zimmermann korábbi fametszete, ezúttal 1566 évszámmal (Tokaj 1565/2/c, 124. kép). További metszetek csak Velencében készültek, és azok mind Domenico Zenoi előző évi metszetének másolatai, sőt, többségük az ő műve.

Zenoi egyik metszetén a Tokaj várát három oldalról is ostromágyúk lövik. A kép jobb oldalán a király táborhelye (Allogi de sua Maesta) tábora, másik oldalán az erdélyi seregek és az ostromtábor vezetôjének (Allogi del marescaleo dil Campo) tábora. Zenoi ezeken a Tokaj metszetein János Zsigmondot következetesen II. János választott magyar királynak nevezi „Re Ioanne secondo, eletto d'Ongheria” (Tokaj (1566)/1, 126. kép). Ennek a metszetnek ismert egy félkész állapotban készített levonata is, amelyen baloldalt felül az ostromlók és táboruk helye még üres. (Tokaj (1566)/2, 125. kép)

Zenoi másik Tokaj metszete sokkal finomabb rajzú, a csapatok mellett tábori életképekkel. A két kép között (amint arra a metszet címe is utal) a döntő különbség, hogy baloldalon az erdélyi seregek helyén Perthán (helyesen Pertev) basa vezetésével török és tatár csapatok táboroznak. A jobb oldali királyi tábort két oldalról olasz csapatok sátrai veszik körül (ők lehettek a velenceiek hírforrásai), az erdélyi csapatok tábora a címtábla mellé került. Biztos, hogy ez a metszet később készült az előzőnél, a török segédcsapatok megérkezése után. Maga Pertev basa nem volt ott Tokajnál. (Tokaj 1567/1, 127. kép)

Még egy Tokaj metszetet ismerünk, amely Zenoi korábbi metszetének másolata. Ez a metszet szövegírása alapján Paolo Forlani műve lehet. A metszet befejezetlenségét sugallja, hogy a folyóneveknek csak az üresen hagyott helye látható, ahol maguk a nevek nem szerepelnek. A címből hiányzik az esemény évszáma és a metszet készítőjének neve. (Tokaj 1567/2, 128. kép)

János Zsigmond pár napi ostrom után értesülve Szulejmán szultán haláláról, október 4-én felhagyott az ostrommal és a Szigetvárról hazavonuló,

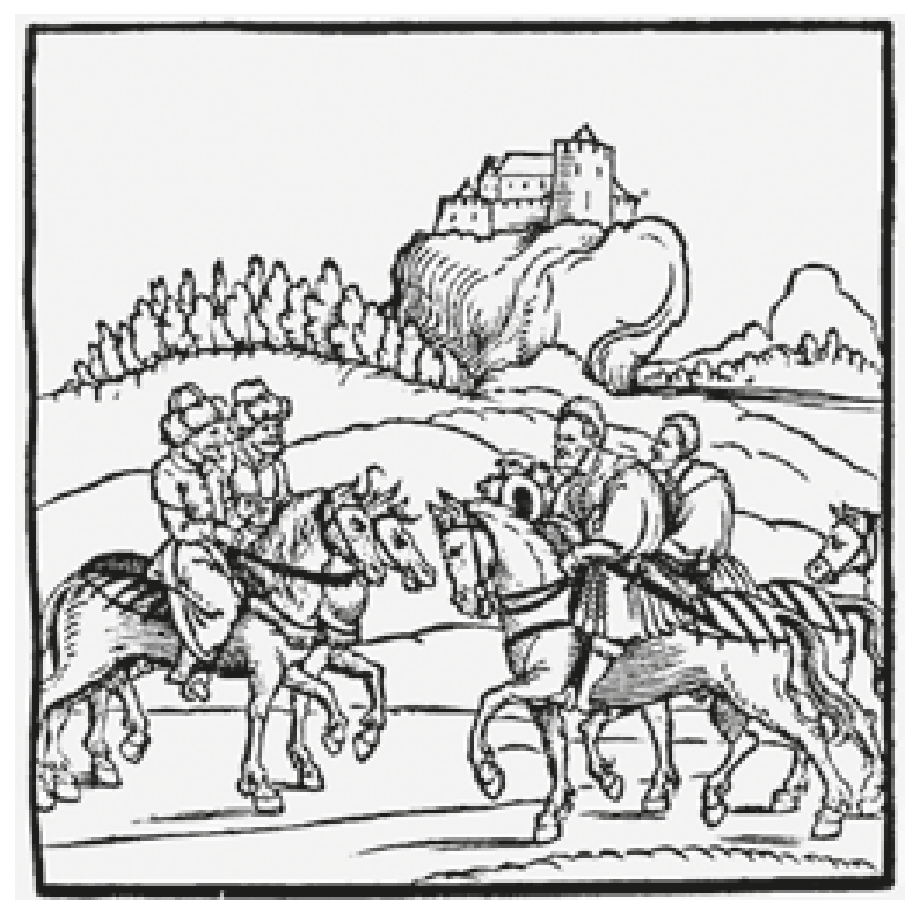

az országot végig égető-rabló tatár csapatok ellen vonult. Debrecen közelében összecsapott a tatár sereggel és szétverte azt, ezzel több ezer rabságba hurcolt magyar foglyot is kiszabadított.

$\mathrm{Az}$ 1566. esztendőben megjelent egy olyan metszet is, amelynek létrejötte nem kötődött az év háborús eseményeihez. Zsámboki János Emblemata könyvében az Oláh Miklós esztergomi érseket dicsőítő verséhez mellékelt képen Esztergom látképe tűnik fel. Az Esztergom látképeit feldolgozó Lepold Antal a képet valósnak tartja, amely a Duna Párkány felőli oldaláról, északnyugat nézetből készült. Véleménye szerint a látkép hibája, hogy a Víziváros és a Vár a Duna felett azonos magasságban, összeolvadva jelenik meg. Nekünk kétségeink vannak Lepold megállapításával, úgy hisszük, a kép képzeletszülte. A metszet Zsámboki könyvének további antwerpeni kiadásaiban is megjelent. (Esztergom 1566/1, 129. kép)

Amint már említettük, Szulejmán szultán utolsó, 1566-ban Magyarországra vezetett hadjáratáról több tucat tudósítás jelent meg. A hírek forrása a Győrnél táborozó birodalmi hadsereg Bécsbe, az Udvari Haditanácshoz küldött jelentései lehettek. Ebből a több tucatból az 1566. év eseményeinek lezárásaként kettőt mutatunk be, mindkettő Zrínyi Miklós hősiességéhez kapcsolódik. Ezek a Szigetvár 
elestét követő években jelentek meg és mindkettôjük címlapján a megszokott sematikus képektől eltérő ábrázolás van. Előbb az ostromnak Nürnbergben 1567ben kiadott naponkénti beszámolóját említjük, amely szerzője a tudósítás szerint Zrínyi életben maradt titkára (feltehetően ez Crenko Ferenccel azonos), majd a Bázelben 1568-ban megjelent, Zrínyi hősiességéről szóló ének/verset említjük. Ez utóbbin lévő kép egyesek szerint Zrínyi Miklós végső kitörését mutatja. Ezt a véleményüket arra alapozzák, hogy a kitörő harcosok lovon ülő vezérének süvegdísze a Zrínyi címerben lévő kitárt sasszárnyakra emlékeztet. Ezt az indoklást nem tartjuk meggyőzőnek. (Zrínyi - Szigetvár 1 és 2, 135, 136. kép)

\section{Metszetkészítők Velencében, Rómában, Nürnbergben}

Az 1565-66 év során készült metszeteket számba véve láthatjuk, hogy Domenico Zenoi és Paolo Forlani készítette azok több mint felét, összesen 26 metszetet. Az eseményekről a szintén velencei Nicolo Nelli, Giovanni Francisco Camocio, Lodovico Pozzoserato és Ferrando Bertelli is készített metszetet. Ezért látjuk szükségesnek, hogy Zenoi és Forlani munkásságáról és általánosságban a velencei metszetkészítőkről és metszetkiadókról bővebben is szóljunk.

Velence a 16. század közepén a könyv- és térkép, metszet kiadásban nemcsak Itáliában, de világviszonylatban is kiemelkedő szerepet töltött be. Első jelentős térképészei Giovanni Andrea Vavassore, majd Giacomo Gastaldi nyomán (egyedül az ő műhelyéből legalább 104 önálló lap került ki!) a század második felében számos további térkép- és metszetkiadó (akik gyakran maguk rajzolták és metszették is azokat) működött. Közülük csak a jelentőseket említjük: a Bertelli család (Ferrando, Donato és Oratio), Giovanni Francesco Camocio, Bolognini Zaltieri, Nicolo Nelli. Ebbe a körbe tartozott Domenico Zenoi és a Veronából származó Paolo Forlani is. Tulajdonképpen ezek a kiadók uralták a teljes térkép-és metszetpiacot (a metszetek között a látképek, akkori szóhasználat szerint veduták mellett arcképek, művészrajzok, mitológiai és allegorikus jelenetek, tudományos rajzok stb. is szerepeltek). A velencei térképkiadás erősen különbözött a Rómában Antonio Salamanca, Antonio Lafreri és Claudio Duchetti nevével fémjelzett, szintén jelentős térképészeti központtól, amely elsősorban az olasz föld térképészetére összpontosított. Velencében (valószínűleg az egész akkori világra kiterjedő kereskedelmi és ahhoz kapcsolódó hajózási érdekeltség miatt) a térképkészítés Itália mellett a világ minden részénekábrázolására kiterjedtés nemcsak földrészek, egyes országok, de szigetek és fontosabb kikötők térképei is nagy számban jelentek meg. Önmagában az Adriai-tenger és a Földközi-tengeri szigetek, illetve azok kikötőiről készült térképek, metszetek száma is több százra tehető. Mivel egyre nőtt az igény a közvéleményt foglalkoztató események képes ábrázolására is, a meglévő térképekre vagy a térképszerű (vagy városok esetén alaprajzos, később madártávlatból és perspektívából készült) rajzokra kerültek rá a csapatok, hadihajók, harcoló katonák, túzvészek, csodás jelenségek képei, a metszet címe pedig egyúttal megnevezte a helyet és több esetben részletesen ismertette magát az eseményt is. Velencében mindezek elképzelhetetlen mennyiségben jelentek meg az egymással rivalizáló kiadóknál. A megjelentek között azonban kevés az eredeti mú, a legtöbb térkép, metszet másoktól átvett rajzok másolata vagy azok összedolgozása volt. A kiadók (és a nekik dolgozó több tucat, köztük jó pár csak monogramjáról vagy még úgy sem ismert rézmetsző) többsége igénytelen munkát végzett, az egymással való versenyzés szülte gyorsaság is a minőség és az igényesség rovására ment. Sok a befejezetlen állapotúnak tűnő megjelent mű, a tartalmi pontatlanságokról nem is beszélve. Az így készült metszetek nyomólemezeit később rendszeresen adták-vették, csereberélték, kivakarva a lemezről a korábbi készítő (tulajdonos vagy kiadó) nevét, helyére újat véstek. Mindezek következtében még a jelzésekkel ellátott metszetek esetében is nehéz sokszor eldönteni, ki kit másolt, ki kinek a rajzát „fejlesztette tovább”.

A térkép és látkép metszetek mindig szóló laponként, egymástól eltérő méretben jelentek meg. Az 1560-as évek közepe felé fogalmazódott meg az ötlet - valószínűleg „vásárlói” igényeknek köszönhetően -, hogy a metszetlapok könyvbe kötve is megjelentethetők és árusíthatók. Ez a gondolat valósult meg az úgynevezett Lafreri atlaszokban, amelyekbe különböző szerzők különböző méretú térképeit és metszeteit találjuk egybekötve. Ezek nehézkesen kezelhető voltából következett az egységes és lekicsinyített méretú metszetek készítésének és könyvbe foglalásának ötlete, amely valóra váltói 1567-ben Zenoi és Forlani voltak Velencében, őket követte 1568-ban Ferrando Bertelli.

Domenico Zenoi életrajzi adatait szinte nem is ismerjük. A ThiemeBecker lexikon és Nagler alig ír róla, csak az 1560 és 1580 közötti működését említi, megjegyezve, hogy inkább metsző volt, mint festő és művészi kiadót is múködtetett. Rendkívül sokféle metszetet készített, allegorikus jeleneteket, arcképeket (köztük II. Szelim szultánét), vallásos metszeteket, térképeket, városképeket és eseményeket egyaránt. 1566-ban folyamodott privilégiumért a már elkészült, illetve jövőben készülő metszeteinek másolások elleni védelme érdekében. Ezt csak feltételesen kapta meg, mert időről-időre összeütközésbe 
került a hatóságokkal erkölcstelennek minősített versek és metszetek kiadása miatt. Zenoi együttmúködött más kiadókkal is, ennek bizonyítékának tekinthető, hogy a hatóságok erkölcstelen kiadványainak egy részét Camocio raktáraiban találták meg. Üzleti kapcsolatai nemcsak Velencében voltak, de Rómában is, Francesco Salamancával.

Zenoi - noha munkái művészi színvonala nem kiemelkedő - Velencében az igényesebb rézmetszők közé tartozott. Metszetei többségét nevével vagy annak rövidített formájával (keresztnevét rövidítve írja) jelzi, gyakran feltüntetve annak készítési évszámát, később a megszerzett privilégiumot is. A metszeteken lévő címek és feliratok, égtájjelölések betúi könnyen olvashatóak, címfeliratait általában címtáblán (amely váltakozva egyszerú vagy díszített) helyezi el. Metszetei aprólékosan kidolgozottak, rajzait finom vonalvezetés jellemzi. Jelenetábrázolásai azonban általában sematikusak: sátrak, vonuló csapattestek, ritkábban egy-két lovaskatona, apró, egy-két vonallal megrajzolt katonák. Épületrajzai is egyszerűek. Eseményeket ábrázoló metszetei mindig felülnézetben készültek, alaprajzot tükröző képek, amelyek térhatása (ha egyáltalán van) minimális. Magyar vonatkozású munkái közül egyedül Eger metszete nevezhető igazi látképnek, azonban mint látni fogjuk a valóság tekintetében pont ez a kép a leggyengébb. Zenoi munkásságának feldolgozása még nem történt meg.

Paolo Forlani /Veronese/ életéről ugyanolyan keveset tudunk, mint Zenoiéról. Veronából települt át Velencébe, nevét gyakran Paolo Forlani Veronese formában írja. Első ismert munkája, egy Németország-térkép 1560-ból származik. Kiadói tevékenységéről is tudunk, azonban térképei, egyéb metszetei többsége más kiadóknál, elsősorban Giovanni Franceso Camocionál és a Bertellieknél jelentek meg az 1560-as évek első felében. 1570-71-ben a római Claudio Duchettinek dolgozott, majd pár év szünettel munkássága 1574-ig követhető nyomon. Eltérően a sokféle metszetet készítő Zenoitól, Forlani elsősorban térképeket készített, amelyek szinte kivétel nélkül mások munkáinak másolatai, vagy azok egybeolvasztása. 1566-ban üzletet nyitott Velence Merzaria kerületében, ahol engedélyt kapott egy oszlopot (colonna) feltüntető cégér használatára. Ettől kezdve metszetein gyakran feltűnik azonosításként a „Merzaria all'insegna della Colonna” jelzés, időnként a „Colonna” felirat egy oszlop rajzával helyettesítve.

David Woodward 1990-ben Paolo Forlani 144 lapját ismertette, ezeknek azonban több mint fele jelzés nélküli és azokat csak a stílusjegyek alapján sorolta Forlani munkái közé. Munkásságának pontos feltérképezését nehezíti, hogy az elkészült térképek, metszetek lemezeinek „vándorlása” Velencében volt a leggyakoribb. Lemezek készültek jelzés nélkül (és ezekről készültek levonatok), majd ezekre később véstek elsősorban kiadói jelzéseket. A jelzéssel készült lemezek eladása után ezeket vagy kivakarták és helyére más jelzés került, az új kiadó vagy az új tulajdonos jelzése. Számtalan esetben előfordult, hogy az új tulajdonos a lemezt kissé átjavíttatta. Mindezek miatt a metszetek létező lemezállapotainak száma szinte felmérhetetlen. Forlani kisméretű városképes metszeteit senki nem dolgozta még fel, így ez a munkássága ismeretlen. Egyes vélemények szerint matematikával is foglalkozott, ennek bizonyítékának tekintik egy nyolclapos asztronómiai metszetsorozatát.

Forlani metszői munkásságának színvonala elmarad Zenoiétól, metszeteinek többsége elnagyoltnak tûnik. Gyakori foglalkoztatásának egyik oka lehetett, hogy azon kevés rézmetsző közé tartozott (Zenoihoz hasonlóan), aki teljesen elsajátította a szövegírás rézbemetszését is. Munkái sajátos betúkaraktereiről is felismerhetôk, amelyek közül különösen az alul szinte teljesen zárt "g” betű egyedi. Térképeire szívesen rajzolt égtájrózsákat is. Térképein a korban megszokottnál jóval terjengősebb ajánlások találhatók, amiből egyes kutatók arra következtetnek, hogy anyagi nehézségek miatt jobban rászorult a bőkezú támogatókra.

Régi vita zajlik arról, hogy Zenoi és Forlani másolta-e egymás metszeteit. Erre az okot az szolgáltatja, hogy egyes kisméretü Tokaj, Győr, Gyula és Szigetvár metszeteik feltűnő hasonlóságot mutatnak. Tokaj esetében nem vitatható, hogy az 1566-ban megjelent és Forlaninak tulajdonított Tokaj metszet Zenoi 1565-ben megjelent nagyméretű Tokaj képe nyomán készült. Nem ennyire egyértelmű a másolás kérdése a további három látkép esetében. Mivel a jelek szerint ugyanazok a képi és egyéb forrásaik voltak, ideértve az eseményekről érkezett beszámolókat is, metszeteikre - saját stílusukban - megegyező dolgokat rajzoltak, ami egyfajta magyarázat is lehet a hasonlóságra. Mi mégis úgy gondoljuk, Forlani volt az, aki másolhatta Zenoi metszeteit de Zenoi soha nem másolta Forlani munkáit (maradva csak a magyar tárgyú metszeteiknél).

Álláspontunk igazolására megemlítjük, hogy Győr és Szigetvár esetében Zenoinak két-két metszete is van, ezek közül az egyik az események korábbi (Győr esetében a táborozás, Szigetvárnál az ostrom) időpontját mutatja, mint Forlani metszete. Egy metszetet lemásolni, majd azt rajzi megoldásokkal korábbi történéseknek megfelelő időpontra átalakítani már csak üzleti szempontból is ésszerútlen lenne. Még ennél is ésszerútlenebb ezek után egy második metszetet készíteni a későbbi történések bemutatására. Ne feledjük, Zenoi és Forlani nem 


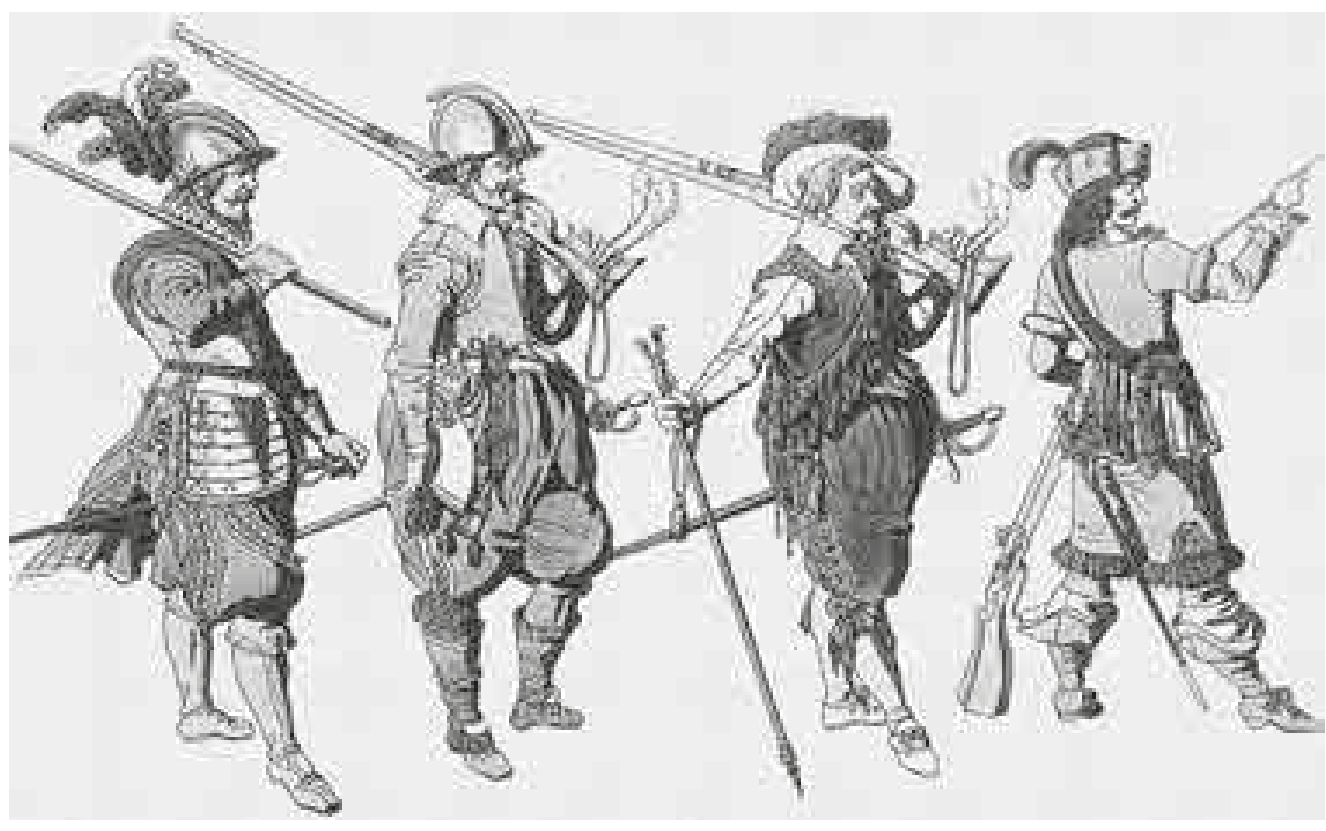

csak metszetkészítők, hanem kiadók is voltak és a piacról éltek. Az ilyen jellegü, tájékoztatást szolgáló termékekből pedig mindig a legfrissebb a kelendő.

A Zenoi mellett szóló másik érvünk még ennél is bizonyítóbb jellegú. Alberto Ganado kutatásaiból (Alberto Ganado: The Forlani-Zenoi town books of 1567. In: Florilegicum Cartographicum, Leipzig 1993.) ismert, hogy Domenico Zenoi 1566-ban 15 évre szóló privilégiumot kért a velencei Signoriától hivatkozva arra, hogy az „...védelmet jelent számára azokkal a rosszindulatú emberekkel szemben, akik semmi mást nem tesznek, mint szomszédjaikat sértik, rászokva metszeteik újravésésére...". Nem említi ugyan kérelmében Forlanit, de az előbbi példák alapján akár rá is gondolhatott. Zenoi 1566. december 5-én kapta meg a privilégiumot, de azzal a feltétellel, hogy munkáit időről-időre ellenőrzés alá kell bocsátania. Zenoi biztosan nem kért volna „hatósági védelmet a másolók ellen”, ha azzal egy időben ôt is lehetett volna másolással vádolni.

Domenico Zenoi munkásságának még egy magyar vonatkozása van: szándéka volt a Magyarország várait, városait bemutató, erre alkalmas méretben készített metszeteket könyv formájában kiadni és ezt a tervét - igaz, máig sem tisztázott körülmények között csak töredékesen- valóra is váltotta.

Úgy gondoljuk Zenoi a privilégium kérelmezésekor már erre a tervezett könyvére is gondolhatott és metszetei későbbi változatait is ehhez a könyvhöz készítette. Könyve végül a metszet-címlapon (amely egyes vélemények szerint nem is címlap, csak önálló „dedikációs” lap) lévő ajánlás végén szereplő dátum szerint 1567. április 4-én jelent meg. A címlapon lévő Ajánlásból idézzük:

„... elhatároztam, hogy Nagyságod neve alatt hozom nyilvánosságra ezt a Magyarország főbb erôdítményeit tartalmazó könyvet, úgy ítéltem meg, jó lesz, ha ebben a kényelmes formában illesztem ide ezeknek a tartományoknak teljességét, amelyet mind ez ideig más ki nem metszett. Velencéből, 1567. április 4-én. Nagyságod alázatos szolgája Domenicus Zenoi. Cum privilegio". (Az Ajánlás teljes szövegének fordítását a mellékletek között közöljük.)

Az ajánlásból több dolog egyértelmúvé válik: Zenoi Magyarországot metszetekben és térképekben bemutató könyvet adott ki, amely a korábban megszokott nagyméretű lapok helyett könnyebben kezelhető kisméretú lapokból (“... ebben a kényelmes formában ...") állt. Zenoi különösen büszke volt arra, hogy metszeteit könnyen kezelhető, a korábbiaknál kisebb méretben készítette, amit az 1566. évi hadjárat alkalmából közreadott AusztriaMagyarország térképén fel is tüntet: „... soha még nem nyomtatták ezt a térképet ilyen kicsi formában...." Ez a térképe egyébként akkora, mint a kisméretű Tokaj vagy Szigetvár metszete. Az Ajánlásból az is kiderül, hogy Zenoi könyvét a későbbiekben további lapokkal tervezte bővíteni.

A könyvről tudjuk, hogy megjelent, azonban eredeti teljességében nem maradt fenn. Csak olyan példányokat ismerünk, amelyek valamilyen későbbi időpontban közös kötésbe kerültek más hasonló tartalmú könyvek metszeteivel. Az Országos Széchenyi Könyvtár példányában Zenoi könyvének címlapja mellett szerepel Forlani könyvének címlapja is, akárcsak a Hellwig gyűjtemény példányában. Mindkét könyvben csak Zenoi és Forlani metszetei találhatók, azonban más számban és nem azonosak. Ezekből Zenoi könyvének eredeti tartalma nem határozható meg. Úgy gondoljuk, hogy a korábbiakban ismertetett Tokaj, Gyula, Győr, Szigetvár és Zsáka metszet mellett szerepelhetett a könyvben Zenoi Bécs metszete (amely címe Vienna cittá principal d'Ongheria és privilégium jelzés, még 1566-ból!), az 1567-ben készített Eger metszete és Magyarország térképe, de talán Konstantinápoly látképe is.

Az előzőekben szóba került Forlani könyv szintén 1567-ben jelent meg. Címe Il primo libro della citta et fortezze principale del mondo (A világ főbb városainak és várainak első könyve) arra utal, hogy Forlani nem egyetlen ország metszeteit akarta közzétenni, hanem egy az egész világot felölelő összeállítást. A címlapon a cím alatt hosszú ajánlás olvasható (ennek fordítását is közöljük a 
Mellékletekben), amelyben Forlani a művét I. kötetnek nevezi, tehát ő is a mú folytatását tervezte. Ebből a könyvből sem maradt fenn eredeti példány, három későbbi kötésben ismert példányában különböző számú Forlani és Zenoi metszet szerepel, többnyire azok, amelyek a Zenoi címlapú kötetekben is megtalálhatók.

Mindezek azt sejtetik, sem Zenoi, sem Forlani könyve nem készült el az eredeti elképzelésnek megfelelően és a kilátásba helyezett folytatások sem születtek meg. Úgy gondoljuk, ebben szerepe lehetett annak, hogy értesültek a Bertelli család tervéről az 1568-ban megjelenő Civitatum aliquot insigniorum / Disegni di alcune piu illustri citta et fortezze del mondo... címủ metszetes könyv előkészületeiről. A több nemzedéken átnyúló könyv- és metszetkiadó családdal egyikük se versenyezhetett. Nem zárjuk ki annak lehetőségét sem, hogy az addig elkészített metszeteiket Zenoi és Forlani nem külön-külön adta ki valamikor 1567-ben könyv formájában, hanem közösen, mindkettőjük címlapjával. Forlani magyar metszeteinek lemezei aztán Ferrando Bertellihez kerültek, megjelent könyvében szerepelnek is. Zenoi lemezeit pedig Bolognino Zaltierinek adta át, aki azokat 1569-ben Guilio Ballino De' Disegni Delle piu illustri cittá del mondo címü könyvében jelentette meg, hátoldalukon földrajz és történelmi ismertetéssel Ballino 50 metszetes műve három évvel megelőzte a hasonló elgondolás szerint szerkesztett monumentális Braun-Hogenberg mű első kötetét! Forlani lemezeiről később is készültek levonatok, Zenoi lemezeinek azonban a Ballino könyv megjelenés után - Eger kivételével nyoma veszett.

1567-ben feltehetően a könyvük kiadására készülve Zenoi és Forlani egyaránt készített még magyar vonatkozású metszetet. Zenoi Eger képe teljesen légből kapott képet mutat: egy kúpszerú hegy oldalába rajzolt körfallal kerített város(?) közepén egy hatalmas kör alakú torony tetején császári zászló lobog. Nem tudjuk, miért esett a választás Egerre, az 1552. évi ostromnak és a Dobó István vezette védők hősies ellenállásának nem volt híre külföldön, Zenoi a címben nem is említi. Egert a címben Magyarország nagy jelentőségű várának nevezi, de a vár felett a hegytetőnél lévő felirattal rögtön rámutat a gyenge pontjára: Questo monte e alquanto superiore alla fortezza, ma percio non li fa alcun nocumento (Ez a hegy jelentősen a vár fölé magasodik, azonban ez (a várra) nem jelent semmiféle veszélyt). Zenoi tévedett, jelentett veszélyt, amint a későbbi ostrom bizonyította. (Eger 1567/1, 130. kép)

Már a következő évben megjelent Zenoi Eger metszetének másolata Ferrando Bertelli említett könyvében. A valamivel kisebb metszeten a címben az 1568 évszám és a jobb sarokban Lodovico Pozzoserrato jelzése ( $L P$ ) szerepel (Eger 1568/1,131. kép). Ennek jelzés nélküli, szintén 1568. évszámmal megjelent változata is ismert (Eger 1568/2,132. kép). Zenoi eredeti lemezét később az 1596.

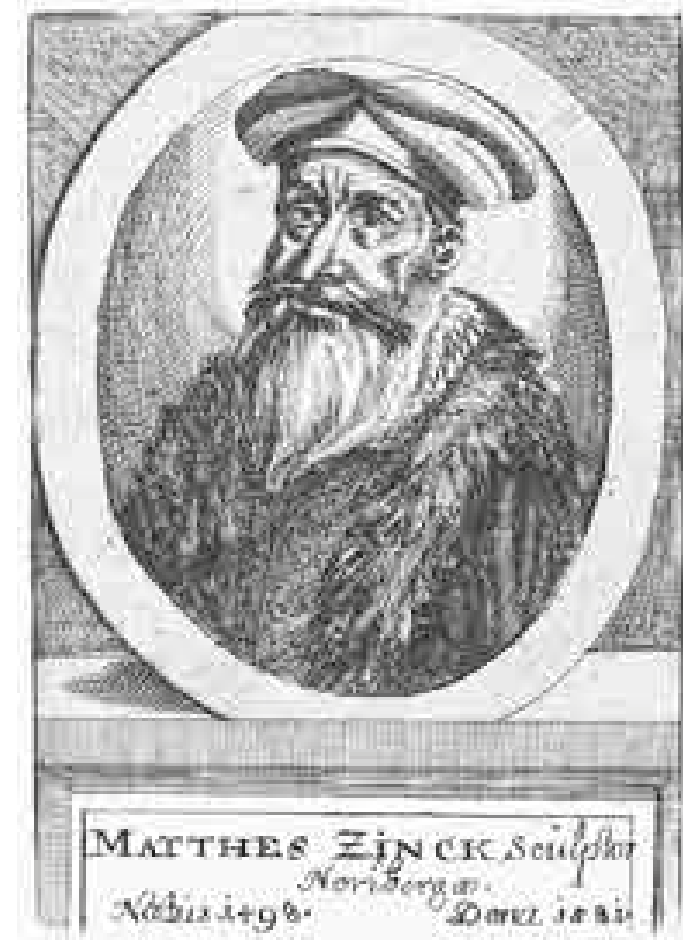
évi ostrom ábrázolásához is felhasználták.

Forlani 1567-ben Komáromról készített egy alaprajzi metszetet. Komárom az előző évben a magyar és a Felvidéken telelő császári seregek részleges gyülekező helye volt, így ábrázolása köthető az 1566. év eseményeihez. Címében leírja, hogy Komárom a Duna feltöltötte szigeten fekszik, ám a metszeten a sziget nem ismerhető fel. A két Duna-ág összefolyásában lévő területre ékelődik be egy elnyújtott háromszögletű (felülnézetben vasaló alakú) vár, előtte egyszerű falakkal-palánkkal(?) kerített négyszögletű város, jelkép értékű elszórt, kissé bizarr épületcsoportokkal, pár katonával. Nem egy figyelemfelkeltő alkotás. (Komárom 1567/1, 133. kép)

Ennek a Komárom metszetnek az alig kisebb másolata Forlani jelzése helyén Bertelli kiadó jelzésével (ferando bertelli Excudebat) 1568-ban megjelent Bertelli könyvében. (Komárom 1568/1, 134. kép)

$\mathrm{Az}$ 1566. év eseményeiről valamennyi Velencében és Rómában készült metszet címének és fontosabb feliratainak, valamint Domenico Zenoi könyve Ajánlásának szövegét Könyves Tóth Kálmán fordításában a Mellékletekben közöljük.

Az 1566. évi eseményekről készített metszeteknek és azok létrejöttét meghatározó körülmények ismertetését Matthias Zündt (?1572) munkásságával zárjuk. A Velencében múködő rézmetszők mellett egyetlen németföldi mesterként ő készített több metszetet is a Magyar Királyság területén történtekről. Matthias Zündt /Zyndt/ Nürnbergben született ötvös, rézmetsző, rajzoló. Wenzel Jamnitzer múhelyében tanult, 1556-ban kapott polgárjogot, 1559ben Jamnitzer Prágába küldte tanulni, 1560-ban tette le a mestervizsgát. Ötvös munkái mellett készített metszeteket, mintegy 70 múve ismert, arcképek, bibliai történetek, allegorikus képek, látképek, csatajelenetek, köztük Gotha ostroma 
1567-ben, az 1571. évi török ellenes harcok Máltánál. Térképeket is metszett, köztük két Magyarország térképet: a már említett 1566. évi haditérképet majd 1567-ben Wolfgang Lazius munkája nyomán egy nagyméretű Magyarország térképet. Ezen szintén jelöli a jelentősebb háborús eseményeket (mint Buda és Esztergom elfoglalás, Tokaj 1565. évi ostroma stb.). Ezt a térképét később Prágában kisebb javításokkal Jacobus Pross (Bross) kétszer is kiadta. Zündt egyik híres műve a négy lemezről készült Grodnó látkép (1568), amelyen a lengyelek az érkező török és orosz követséget ünnepélyesen fogadják. Portré-metszetét Panzer készítette, ám azon Zündt halálának évszáma (1581) téves.

II. Miksa császár már 1567 nyarán követeket küldött a Portához békekötési ajánlattal. Hosszas alkudozás után 1568 februárjában megkötötték a meghosszabbítható, 8 évre szóló fegyverszünetet (békét) Drinápolyban, amely az Erdélyi Fejedelemségre is kiterjedt. II. Miksa császár a béke fejében évente 30000 arany „tiszteletteljes ajándék” fizetését vállalta a mindenkori török szultánnak.

\section{A háborús békeévek első fele (1569-1580)}

A Drinápolyban kötött békét (a muzulmán hittételek miatt hivatalosan csak fegyverszünet) követő években az egykori Magyar Királyság területén viszonylagos nyugalom volt. A törökök megszállta városok és a királyi végvárak katonaságának portyázásai, a másik fél fennhatósága alatti területek kifosztása, az ezeket követô összecsapások, bosszúhadjáratoktörténéseinagyon ritkánérkeztekmegérdeklődést keltő hírként Nyugat-Európába. Ennek is köszönhető, hogy a háborúskodást követő években elsősorban könyvekben jelentek meg az egykori fővárost, Budát illetve a Magyarországon korábban történteket bemutató metszetek. Ugyanakkor ezekben az évtizedekben a rendkívüli eseményekről (tűzvész, égi jelenség stb.) tudósító képes tudósítások (röplapok) száma is növekedett.

\section{Civitates Orbis Terrarum 1572}

Georg Braun (1541-1622) kanonok és Franz Hogenberg (1535-1590) festő és rézmetsző közös vállalkozásaként jelent meg 1572-ben Kölnben Civitates Orbis Terrarum címmel a világ városait képekben és rövid ismertető leírásokban bemutató, nagyfólió méretű mű I. kötete. A kiadókat Abraham Ortelius - a kor egységesített méretű térképeit Atlasz névvel könyv formájában először kiadó térképész - ösztönözte saját munkája példáján művük elkészítésére. Ortelius elképzelése szerint az ő Atlasza és a vele azonos méretű Braun-Hogenberg mű kötetei együtt mutatták volna be térképeken és látképeken keresztül az akkor ismert teljes világot. Braunék 59 városképet tartalmazó I. kötetét 1617-ig további 5 kötet követte, mindegyik más címmel, egy kivétellel 60-60 városképpel. Franz Hogenberg halála után helyébe idővel fia (vagy unokaöccse?), Abraham Hogenberg (15781653) lépett. A teljes 6 kötetes Braun-Hogenberg müben - amelyet a szakirodalom Civitates Orbis Terrarum címen (ez valójában csak az I. kötet címe) tart számon összesen 363 látkép jelent meg. Minden közzétett városképhez - a képi információ kiegészítéseként - a hely történetének szöveges ismertetése tartozott, amelyet a látkép hátoldalára nyomtattak, mindig egyhasábos szedéssel és lapszámozással. Az olvasó így egyszerre kapott szöveges és képi ismertetést az ábrázolt városról.

A velencei metszetkészítők ismertetésénél foglalkoztunk már Giulio Ballino művével, amely a Braun-Hogenberg múvel azonos célzattal készült. Ez a mű azonban nem volt, nem is lehetett a Braun-Hogenberg mű vetélytársa. Ballino csak Velencében készített metszeteket tudott felhasználni, könyvében a metszetek jóval kisebbek voltak a Braun-Hogenberg könyv metszeteinél, legtöbbjük alaprajz volt és nem látványkép. A Braun-Hogenberg mű nyomtatás után színezett lapokkal is forgalomba került, ami a nagyméretű látképek látványosságát tovább fokozta. Ballino könyvének további kötetei nem is jelentek meg.

Georg Braun és Franz Hogenberg a hatalmas mű elkészítésénél osztozott a feladatokon. Braun tervezte és szerkesztette az egyes köteteket és rá hárult a megjelent városképekhez tartozó ismertető szövegek megírása vagy véglegesítése. Hogenberg a metszetek nyomtatásához szükséges lemezeket véste és intézte a nyomdai ügyeket. Franz Hogenberg halála után Simon van den Neuwel (latinosan Simon Novellanus) készítette az V. és VI. kötet látképeihez szükséges lemezeket.

A Braun-Hogenberg kiadó páros csak olyan városok látképeit jelentette meg, amelyeket másoktól sikerült közzétételre megszerezniük. Ők maguk természetesen sem anyagi, sem biztonsági megfontolásokból nem vállalhatták azt, hogy a helyszínekre küldjenek múvészeket látképek rajzolására. A látképek beszerzését mindkettenintézték. Braun kanonokelsősorban a kor tudósaival tartottkapcsolatain, Hogenberg pedig a más városokban működő könyv- és metszetkiadókon keresztül. A mű további köteteinek megjelenése érdekében már az I. kötet előszavában maguk kérik az olvasókat arra, juttassanak el addig még nem szereplő városokról rajzokat, elsősorban azokból az országokból, ahonnan még nem kaptak egyetlen látképet sem. Egyúttal felsorolják, hogy eddig kiktől érkeztek már látképek, közöttük említve Georg Hoefnagelt, mint „antwerpeni kereskedőt és múkedvelőt” akinek a későbbi kötetekben közel két tucat magyar városképet köszönhetünk. 
A mű rendkívüli népszerűségét mutatja, hogy közel 50 kiadását ismerjük, az eredeti latin mellett francia és német fordításban is. Egyes köteteket külön is újra kiadtak, néha az eredeti megjelenési évszámmal, néha évszám nélkül. A hat kötetben összesen 23 magyar látkép jelent meg, de ezek Buda és Pozsony kivételével a most tárgyalt korszak után láttak napvilágot.

A Civitates Orbis Terrarum 59 városképe között szerepelt Buda látképe (Rózsa 1999/2) is, kiadásonként változó 41 vagy 42 lapszámmal, hátoldalán egyhasábos ismertető szöveggel, Bécs látképével közös lapon, alul. A metszet lemeze még a könyvkészítés kezdetekor megsérülhetett, mert valamennyi ismert példány bal alsó sarkánál pótlás látható. A korai példányokon a sarok pótlásánál a keretcsatlakozás megtört, a pótolt lemezsarkon csak pár ferde vonalból álló vésés van. A későbbi példányokon a keretcsatlakozást kijavították, és a pótlást egy utólag odavésett bokorral kívánták leplezni. Mindkét változatból ismertek olyan példányok, amelyeken Bécs és Buda látképe között a „Cum privilegio” felirat szerepel. Ennek okát nem ismerjük, de létezésükből arra lehet következtetni, hogy ez a metszetlap önállóan is forgalomba került.

A metszet címe a képen felül elhelyezett címtáblán olvasható: „BVDA, vulgo Ofen prima et regia Vngarici regni civitas, ad Danubium sita: Quam Ptolemaus Curtam, vel, ut aliis persuasum est, Salmum nominat. Fran: Ire:" (Buda, közönségesen Ofen, a Magyar Királyság első és királyi városa, a Duna partján fekszik, és amely Ptolemaios szerint Curta-nak, avagy mint mások véleménye, Salmusnak neveznek. Fran/ciscus/ Ire/neus/). A cím valójában az ókori Buda leírásának idézete Franciscus Ireneus Germaniae Exegesis című művéből.

Mivel Buda 1541 óta török kézen volt, szóba se jöhetett arról a helyszínen rajzot készíteni. A megjelent Buda metszet rajzolója ezért látképéhez Erhard Schön Buda 1541. évi ostromáról készített fametszetét használta előképként, valójában kicsinyítve lemásolta azt. Ennek során elhagyott a Schön metszetét szinte zsúfolttá tevő minden ostrom jelenetet és a Gellért hegytől délre lévő ostromtábor képét, amely az öt dúcról nyomtatott metszet jobboldali két dúcát teljesen kitöltötte. Átvette viszont a Schön látképén „münchs garten” névvel (Szerzetesek kertje) szereplő kert képét, de magyarázó felirat nélkül. Sajnos a városkép felett lévő feliratokat (templomok nevei) se vette át. A képen mindössze két felirat látható, a Danubius Flus és a királyi palota felett az Aula Regis, ezek viszont Schön metszetén nincsenek. A déli várfok és a Szent Gellért hegy közti nyílásban elmosódottan látható Pest, a háttérbe tornyosuló hegyek a látkép térhatását szolgálják.
A kép közepén az előtérben európai öltözetű, kardos férfi katona beszélget két nővel, ami az egész kép békés hangulatát növeli. Az ismeretlen rajzoló és a szintén ismeretlen rézmetsző (aki feltehetően Franz Hogenberg volt vagy valaki az ő múhelyéből) Buda mutatós látképét készítette el. (Buda 1572/1, 170. kép)

\section{Sebastian Münster: Cosmographia (1574-től)}

A már korábban ismertetett Sebastian Münster Cosmographia könyve 1574ben jelentősen átdolgozva jelent meg. A korábbi kiadásokban a Magyar Királyság történetének ismertetése befejeződött II. Lajos király halálával. Ez most kiegészült, de furcsa módon az 1526 és 1565 közötti eseményeket nem a Magyar Királyság történeténél, hanem Szulejmán szultán uralkodásánál ismerteti. Magyarország ismertetésénél a Mohács melletti csatavesztést rögtön Tokaj 1565. évi ostroma, azt pedig Szulejmán 1566. évi hadjárata, pontosabban Gyula és Szigetvár ostroma követi. A könyvben megjelenik Tokaj és Gyula fametszetes képe is Domenico Zenoi kisméretű Tokaj 1567/1 (127. kép) és egyik Gyula metszetének másolataként. Az 1572-ben még szereplő Nagyszeben fantázia városkép viszont kimaradt a múből és a további kiadásokban sem jelent meg. Ugyanez a Tokaj és Gyula metszet látható az 1578. évi kiadásban, amely az 1574. évi szinte változatlan újra nyomása. (Tokaj 1574/1, 141. kép és Gyula 1574/1, 143. kép)

Baselben két további mű is megjelent 1578-ban, mely a magyar illetve az oszmán történelemmel foglalkozik. Elsőként Alfons Ulloa munkáját említjük. A Beschreibung Des Letsten Vngerischen Zugs... (Basel, Sebastian Heinric-petri 1578) című múben négy metszet jelent meg az 1565-1566. évi harcokról: Tokaj, Gyula, Szigetvár és Győr, ez utóbbi az 1566. évi császári tábor képével. Ezek a fametszetek is Domenico Zenoi (szinte biztosan a Giulio Ballino könyvében megjelent) munkáinak másolatai, közülük Gyula és Szigetvár metszetén megjelenik készítőjének, Gregorius Sickingernek a jelzése (G S vésővel). Ezek a metszetek a könyvben $90^{\circ}$-kal elfogatva szerepelnek. (Tokaj, Gyula, Szigetvár, Győr 1578/1, 137-140. kép)

A másik mü Nicolaus Höniger: Erster und Ander Theil der Türckischen Historien (Basel, S. Heinripetri, 1578.) című könyve. Ebben is szerepel az Ulloa könyvben is megjelent Tokaj (kétszer), Gyula, Szigetvár képe, még pedig azonos fadúcról nyomva. Új képként megjelenik Georg Sickinger jelzésével Zsáka (ez is Zenoi műve és egyetlen megjelenése korábban a Ballino könyvben volt), és Münster művének nem német nyelvű kiadásaiban korábban már megjelent Buda fametszet (ez is kétszer). A könyvben megjelent Várpalota és Veszprém 
ábrázolásról már korábban szóltunk. A könyvnek létezik egy 1596-ban megjelent második kiadása is. (Tokaj és Gyula 1578/2, 142. és 144. kép)

Sebastian Münster könyvének 1588. évi németnyelvű kiadásában Tokaj és Gyula látképe az új fadúcokról készült és első ízben megjelent a velük azonos nagyságú Győr, Szigetvár és Zsáka metszet. Mint láttuk, mind az öt kép fadúca 1578-ban készült Ulloa, Alfons és Höniger, Nicolaus múveihez. Ebben semmi meglepő nincsen, hiszen mindhárom műnek Sebastian Henricpetri volt a kiadója. (Győr 1588/1 146. kép, Szigetvár 1588/1 145. kép és Zsáka 1588/1 147. kép)

Ebben a kiadásban szerepel először Münster könyvében az erdélyi Vöröstorony (Der Rotthurn) kicsiny, képzeletbeli képe, amely később csak kétszer, 1592-ben és 1598-ban látott még napvilágot. Buda látképe is szerepel, amely korábban a németnyelvű kiadásokban nem jelent meg (Vöröstorony 1588/1, 148. kép)

Buda, Győr, Gyula, Szigetvár, Tokaj és Zsáka azonos dúcról készült képe (változó oldalszámmal) Sebatian Münster művének 1628-ig megjelent minden további kiadásában szerepel.

Az előzőekben ismertetett három szerző (Sebastian Münster, Alfons Ulloa és Nicolaus Höniger) könyveiben megjelent magyar vonatkozású metszetek adatait részletesen lásd a Mellékletben.

$>>>><<<<<$

Amint már korábban írtuk, hivatalosan béke volt, de a törökök megszállta városok és a királyi végvárak katonaságának portyázásai, a másik fél fennhatósága alatti területek kifosztása, az ezeket követő összecsapások szinte folyamatosak voltak. Ezek azonban nagyon ritkán keltették fel más országokban a kiadók figyelmét. Az igazi érdeklődés már abban a korban is a rendkívüli események iránt volt (ismerős történet a postásról, aki megharapta a kutyát...). A katasztrófák (tűzvészek, robbanások, árvizek, földrengések), a csodás természeti jelenségek (üstökös, égi tünemények), a torzszülöttek, a hátborzongató kivégzések viszont mindig felkeltették a figyelmet. Ilyen események pedig a magyar földön is történtek, pár képes röplap megjelenését ilyen (igaz vagy nem igaz) eseménynek köszönhetünk.

\section{ANNo Domini 1576}

Temesváron 1576 februárjában ezernégyszáz mázsa lőpor robbant fel, ami romba döntötte a várost. A Nürnbergben megjelent röplap címe közli, hogy a Magyarországon lévő Temesvár most a törökök birtokában van. A röplap szövege ismerteti, hogy a város az erdélyi hegyeknél, a Temes folyó partján fekszik, a lőporraktárt pedig egy keresztény fogoly gyúitotta fel. A nyomtatott szöveg többi része azonban nem magával az eseménnyel, hanem az ilyen eseményekből általánosságban levonható erkölcsi-vallási tanulságokkal foglalkozik.

Magán a fametszeten a város felismerhetetlen, legnagyobb részt takarja a robbanás képe, amelyben emberek, lovak, törmelékek szállnak fel az ég felé. A Temes tele van menekülő csónakokkal, a folyó parton török katonák és jajveszékelő asszonyok tárják karjaikat az ég felé. (Temesvár 1576/1,150. kép)

Az eseményt nem csak ez a röplap örökítette meg. Prágában Michael Peterle kiadásában az esemény leírása verses formában jelent meg (Ein erschrecklich Newes Liedt aus Ungern, von der Stadt Temesuar... ). A vers szerint a budai pasa 11 hajón ezernégyszáz mázsa lőport küldött Temesvárra, hogy a temesvári beglerbég jutassa el segítségként az erdélyi vajda Lengyelországban szított lázadásához. Ám isteni csoda folytán a városban tűz ütött ki és a lázadóknak szánt lôpor felrobbant. A város romba dőlt, a Temes folyó kiöntött és tengerré változtatta a környéket. Egy másik tudósítás a címlapján a vízzel elöntött Temesvár képzeletbeli képével jelent meg. Ez a tudósítás kissé másképpen írja le a történteket, ugyanis a lőpor véletlenül robbant fel, nincs szó keresztény fogolyról, de a város itt is porig rombolódottés a kiáradt Temes szintén elöntötte a környéket. Az igazság kedvéért megjegyezzük, a Temes folyó nem érinti Temesvárt, azonban a 19. század előtt a Temesköz rendezetlen és ezért kiismerhetetlen vízrajza miatt a Temesvárt érintő Bega folyót Kis-Temesnek is hívták, Temesvárt pedig mint a Temes folyó mellett fekvő várost elfogadottan emlegették. Azonban akár Bega, akár Temes volt a folyó neve, Temesvár a török korban vízi úton hajóval nem volt megközelíthető. (Temesvár 1576/2, 151. kép)

Ehhez a történethez annyit hozzáfüzünk, hogy Báthory István erdélyi fejedelem I. Miksa királlyal 1571-ben kötött titkos egyezsége alapján elfogadta, hogy fejedelem helyett erdélyi vajdának nevezzék. Ezt az egyezséget csak az I. Miksa király támogatta Bekes Gáspár féle támadás után mondta fel 1575-ben. Még annak az évnek a végén a lengyel trónért folyó küzdelemben Báthory István végkép ellenséges viszonyba került a trónra szintén pályázó I. Miksa királlyal. A török szultán Báthoryt támogatta Miksával szemben. Vagyis nem zárható ki, hogy a budai pasa támogatta az „erdélyi vajdát” lengyelországi harcaiban, mint ahogy ezek érthetővé teszik a tudósítások erdélyi vajda ellenes hangvételét is Azt azért megjegyezzük, abban a korban ezernégyszáz mázsa, vagyis 140 tonna lőpor eljuttatása ilyen távolságra vízen vagy szárazföldön egyaránt nehezen elhihető. 


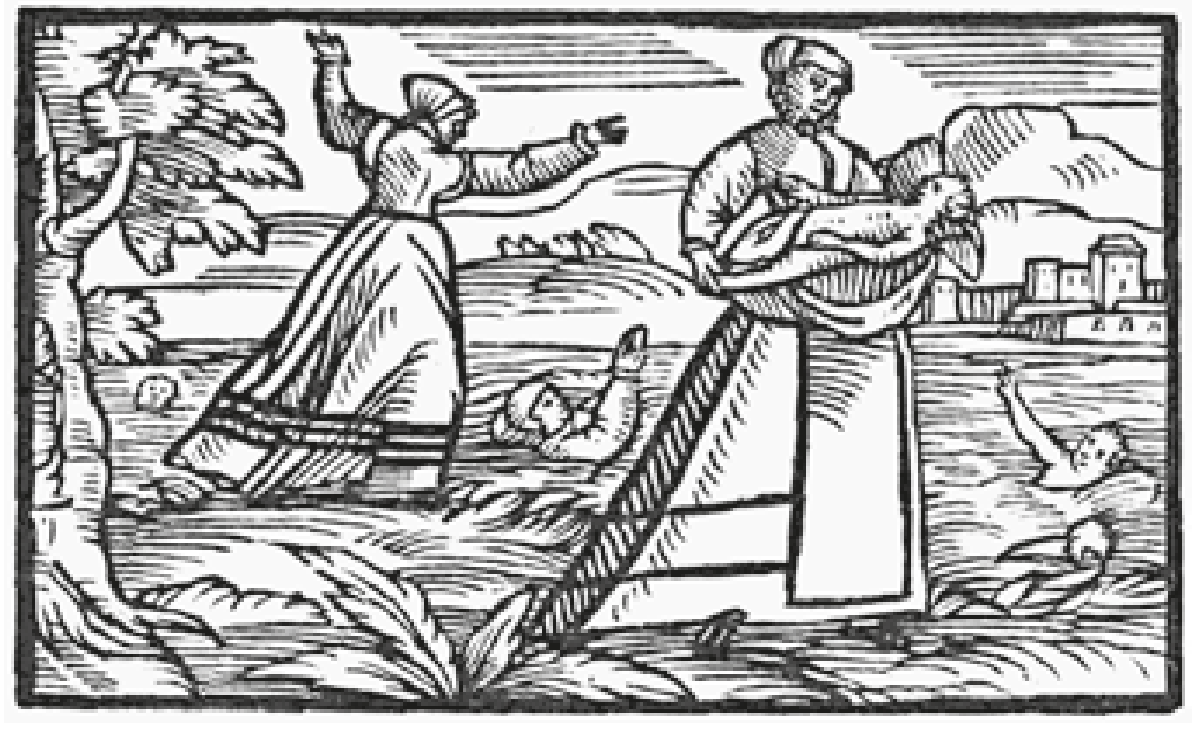

Ugyanebben az évben egy ugyancsak Nürnbergben megjelent röplap Jost Amman metszetével egy Vácnál történt eseményről tudósít. 1576 nyárutóján a budai pasa, Szokoli Musztafa mulatságot rendezett katonáinak Vác mellett. Erre látványosságként oda vitette oroszlánjait is. A mulatságnak a legnagyobb látványossága az lett volna a célba lövés után, hogy az Eger környékén elfogott és ki nem váltott tíz magyar rabot az oroszlánok elé vetik. Elsőként közülük a legfiatalabbat egy oszlophoz kötözték, az oroszlánok gondozója pedig egy felhergelt oroszlánt ráuszított. Mindenki azt várta, az oroszlán széttépi a szerencsétlen fiatalembert, ám meglepő fordulat történt: az oroszlán lerángatta a kikötött fogoly két csizmáját, majd mintegy szelídített angol dog elkezdett a fogollyal játszani. Az oroszlánt gondozója egyfolytában ösztökélte a fogoly ellen, ám az oroszlán egy idő után megunta az unszolást, nekiugrott gondozójának és őt marcangolta szét. A megdöbbent törökök kérték a pasától az ifjú fogoly megöletését, ám a pasa azt felelte, ha a vadállat megkímélte annak életét, ő nem lesz kegyetlenebb a vadállatnál. A röplapot, illetve az azon szerepló történet egy másik változatát Tragor Ignác is említi Váci érdekességek című művében, de annak megtörténtében ő sem foglal állást.

Jost Amman metszetén már az a jelenet látszik, ahol a csizmák a földön hevernek az oszlophoz kötözött fogoly előtt és az oroszlán neki ugrik az idomítójának. A többi fogoly hátrakötözött kézzel várja az őrök között a sorsát.
A háttérben feltűnő város lenne Vác, amit a szövegben latin nevén (Vacia) is említenek. (Vác 1576/1, 149. kép)

A röplapnak egy szétvágott példányáról is tudunk. Szövege egy papírlapra felragasztva a Herzog August Bibliothek Hungarica gyújteményében, Jost Amman rézkarca pedig Herzog Anton Ulrich Múzeumban található.

\section{AnNo Domini 1577}

Az Alföldről és Erdélyből a Kassán keresztül Krakkóba vezető út mentén fekvő Szikszó tehetős mezőváros volt, vásártartási joggal. Nagyméretű gótikus temploma a 15. században épült, a 16. században a városnak már iskolája is volt. Lakosai korán a reformáció hívei lettek, és idővel Szikszó annak egyik szellemi központjává is vált. A mezőváros 1564-től adót fizetett a budai pasának, ennek ellenére portyázó török csapatok gyakran megsarcolták.

1577. november 10-én országos vásár volt Szikszón. Ennek kifosztására indult Ferhát bég, Fülek várának parancsnoka csapataival Szikszóra. Délelőtt, a vasárnapi istentisztelet idején ért csapataival Szikszóhoz, ahol a megtámadott lakosság egy része a fallal kerített templomba szorulva védekezett. A templomot a törökök nem tudták elfoglalni, de kirabolva a vásározókat és a várost, mintegy ezer rabul ejtett emberrel és hatalmas zsákmánnyal elvonultak. A rajtaütés hírére azonban Szendrő várából Rákóczy Zsigmond a hozzá Kassáról csatlakozó Prépostváry Bálint és Geszti Ferenc katonáival másnap este Vadna környékén utolérte és szétverte Ferhát bég csapatait és kiszabadította a foglyokat.

Szikszó megtámadásáról az idősebb Georg Mack adott ki egy fametszetes röplapot Nürnbergben. A kéthasábos szöveg felett lévő kép közepét egy fallal körülvett templom uralja, amelyet török katonák támadnak és látni a falon belül a védekezőket. A szöveg végén az eredeti kiadói jelzésből (Zu Nürnberg bey Georg Mack Illuministen beym Sonnenbad) csak a „Sonnenbad” maradt meg, Nürnberg egyik városrészének, a Judengasse környéke már feledésbe merült neve, ahol az idősebb Georg Mack műhelye volt. Georg Mack egyébként fametszetes röplapjain önmagát következetesen mint Illuministen-t, vagyis mint színezőt tüntette fel.

A képen a templom előtt török lovasok fogják közre a láthatóan megrémült lakosságot. A háttérben látni ahogyan a megrakott szekerekkel elvonuló törökök és a szemből érkező magyar csapatok összecsapnak. A kéthasábos ismertetés pontosan felsorolja az eseményeket (honnan érkeztek törökök, mennyi volt a török és magyar veszteség, hány zászló volt a zsákmány, kik estek el a török főemberek közül stb.) 
vagyis Nürnbergbe elég sok hír eljuthatott az eseményről. Az ismertetés azzal a zárul, hogy a keresztény seregek győzelmének dicséretére az égen egy üstökös jelent meg. Erről az 1577 novemberében megjelent üstökösről az idősebb Georg Mack maga is készített fametszetes röplapot. (Szikszó 1577/1, 152. kép)

Megjegyezzük erről a szikszói török támadásról egy akkor készült mutatós színes rajzot is ismerünk, amely Zürichben a Wickiana gyűjtemény 1577. évi kötetében van beragasztva.

Szikszó megtámadását az előző évben trónra lépett Rudolf császár és király a nyolc évre meghosszabbított Drinápolyi-béke (fegyverszünet) megsértésének nyilvánította és felfüggesztette a békeszerződésében szereplő évi harmincezer arany „ajándék” fizetését. III. Murád szultán hadjárat indításával fenyegetőző válaszára a császári udvar visszakozott és továbbra is fizette az éves ajándékot.

\section{Anno Domini 1578}

Budán 1578-ban hatalmas tűzvész pusztított. A tüzet a királyi palota közelében lévő lőporraktárba becsapó villám okozta Pünkösd vasárnapján, május 19-én a délelőtti vihar alatt. A borzalmas erejű robbanás nyomán keletkezett tűz a szeles időben gyorsan átterjedt a polgárvárosra is. Rengeteg ház leégett, egyes források szerint a tűzvészben kétezer ember vesztette életét. A robbanás ereje a bástyán lévő ágyúkat a Dunába röpítette és romba döntötte a Csonka-tornyot.

A tűzvészről két röplapot is ismerünk, mindkettő Nürnbergben jelent meg. A Leonhard Heussler röplapján lévő fametszetről a Braun-Hogenberg mű 1572-ben megjelent Buda látképének egyszerűsített változata köszön vissza. A kép rajzolója nem a tűzvészre, hanem a lőporrobbanásra összpontosított: a királyi palota felett látjuk a hatalmas robbanás képét levegőbe repült ágyúkkal, tornyokkal, törmelékkel, lángnyelvekkel. A tűz még nem terjedt át a városra. A kép baloldalán menekülő emberek, a várpalota körül halottak, romok hevernek. A kép alatt baloldalt a történések leírása, jobboldalt Intés a keresztény olvasókhoz. (Buda 1578/1, 170. kép)

A másik röplap körül rengeteg a bizonytalanság, pedig több változatban is ismert. Az egyik változaton (Rózsa 1999/295) a fametszet felett a címe: Newe zeyttung auss Hungeren von Ofen vnnd Pesst. A képen egy folyó egyik partján az OFEN felirat alatt egy dombon lévő vár, a másik part síkságán PEST név alatt egy város képzeletszülte képe tűnik fel. Ugyanakkor a valóságnak megfelelően a kettő között a nevenincs folyón egy hajóhíd vezet keresztül. A képen nyoma sincs robbanásnak, hanem a felhőkből hull csodás tűzeső (a rajz és a színezés alapján akár véreső is lehet), amely beborítja a folyó partján álló Budát és Pestet. A középen kettévágott kép (közepén keskeny csíknyi hiánnyal) és alatta a kéthasábos röplap szöveg (felül pár sor hiánnyal) egy papírlapra van felragasztva. A szöveg végén legalul a kiadó olvasható: Zu Nurmberg, bey Georg Macken, Illuministen beym Sonnenbad. Az egyetlen példányban ismert röplapot a Fővárosi Szabó Ervin Könyvtár Budapest gyűjteménye őrzi.

A röplap szövege meglepetést okoz, ugyanis abban egyetlen szó sem esik Budárólés az ottani tűzvészről. Az ismertetés - kiindulva a szerző meggyőződéséből - szerint a rendkívüli természeti jelenségek (tűz- vagy véreső, égi jelenségek, mint üstökös vagy halo-jelenség) Istennek az emberiség bűnbánatra, megtérésre történő figyelmeztetése, a rendkívüli katasztrófák, sáskajárás, háborúk, járványok pedig büntetés az istentelen életért. Ennek megfelelően a 13. századtól kezdve felsorolja mindezeket (már amiről tudomása volt), a végén pedig az 1577 novemberében megjelent üstökös hasonló jelentését taglalja. Tehát lényegében sem a kép címe, sem a röplap szövege nem utal arra, mit látunk a képen: robbanás okozta tüzet, tűzesőt, netán véresőt, és amit látunk, az mikor történt. (Buda 1578/2/a, 154. kép)

A bizonytalanság megszüntetését nem segítette, hogy Klinda Mária könyvtáros már évtizedekkel ezelőtt ismertette, hogy a röplap szövege eredetileg az idősebb Georg Mack 1577 év végén Nürnbergben kiadott, az akkor feltűnt üstököst bemutató röplapján (lásd korábban Szikszónál írtakat) jelent meg, azt arról vágták le és ragasztották tévedésből a tűzeső (véreső?) verte Budát és Pestet mutató kép alá.

A képnek ismert egy változata (másik fadúcról készült, az előtér rajzában van markáns eltérés) amelynek a címe szerencsére többet mond: Newe zeyttung auss Hungeren von Ofen vnnd Pesst/geschechen im 1578. Jar. Tehát annyi már biztos, hogy az ábrázolt esemény 1578-ban történt. Sajnos, ennek a röplapnak is hiányzik a szövege, így csak feltételezhetjük, hogy a fametszet és röplap az 1578-ban Budán történt robbanás és az azt követő tűzvész alkalmából készült. A német városokban a Budán történtekről megjelent tudósítások többsége „mennyből esett tűzről” (das Fewer vom Himmel herabgefalle) számol be. (Buda 1578/2/b, 155. kép)

A tűzvészben a babonás törökök Allah büntetését látták. A még 1566-ban Szigetvárnál budai pasává kinevezett Szokoli Musztafa (Szulejmán szultán és utódja II. Szelim szultán sikeres nagyvezérének, Szokoli Mehmednek unokaöccse) 
megbuktatására ellenségei-állítólag-ezta hiedelmetis felhasználták. Nem tudjuk, igaz-e ez a hír, az viszont tény, III. Murád szultán parancsára Szokoli Musztafa pasát 1578 őszén megfojtották. 1579 év elején egy Nürnbergben megjelent tudósítás képet is közölt erről és ismertette, hogy Szokoli Musztafával egy időben megkapta a szultáni selyemzsinórt a szigetvári Mili bég, a füleki Hasszán bég és a szolnoki Ophiron bég. (Musztafa pasa megfojtása 1579/1 és 1579/2, 156, 157. kép)

Ezek a „selyemzsinóros” kivégzési képek a korban igazi vándorképek voltak. A 16. században alig jelent meg az Oszmán Birodalommal vagy a törökökkel és szultánjaikkal általánosságban foglalkozó olyan mű, amelyben ennek a sajátosan török, selyemzsinórral való kivégzésnek a képe ne jelent volna meg.

\section{ANno Domini 1579}

A 16-17. században tömegével megjelent csodás vagy annak tartott eseményeket, katasztrófákat leíró vagy bemutató szöveges és képes tudósítások sorába tartozik az a röplap is, amely az 1579. március 9-én Kassa és környékén feltűnt három (!) üstökösről megkésve, 1580-ban verses formában adott hírt.

Ez a röplap nem maradt fen a maga teljességében, hanem szétvagdosva, külön-külön a röplap címsorai, a fametszet, a kép alatti négyhasábos hosszú

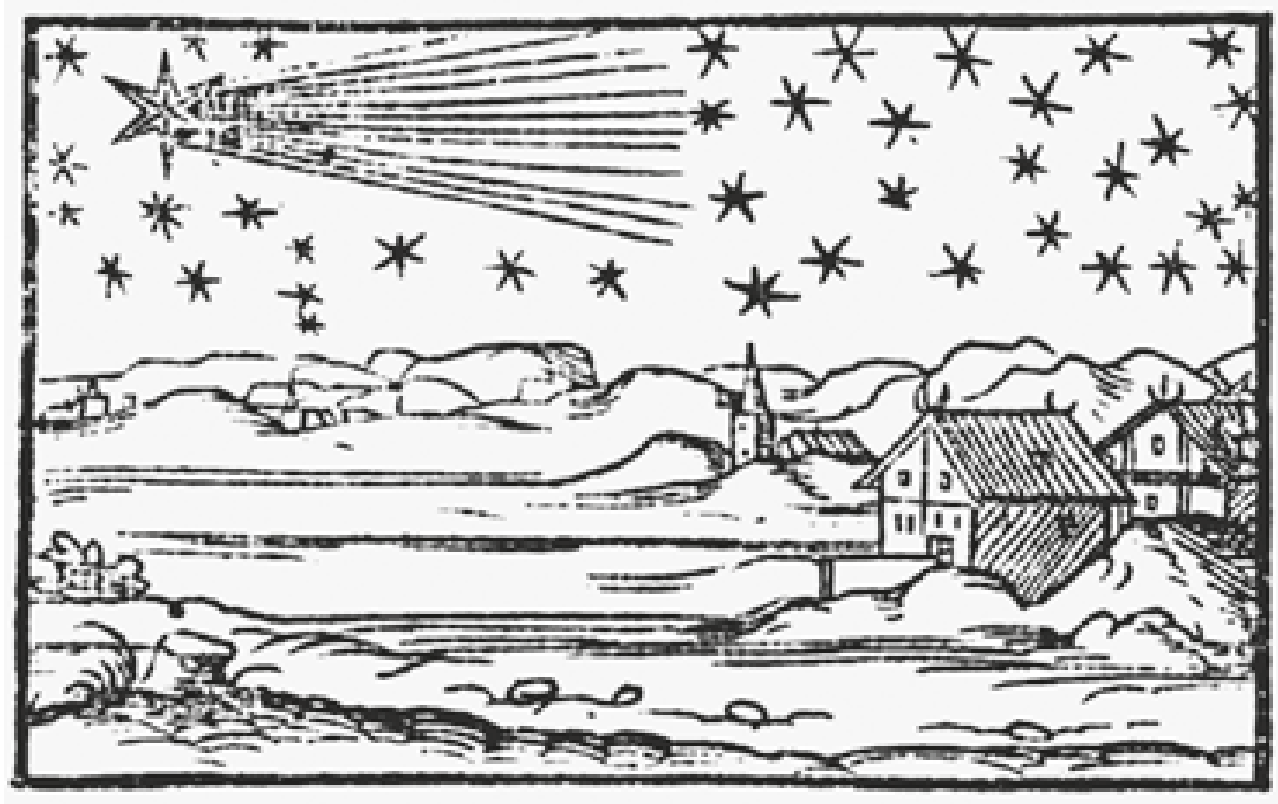

verses szöveg és a röplap kiadójának neve, városa. Ezeket aztán valaki gondosan elrendezve (a kép felett a röplap címsorai, másik két lapon két-két hasáb szöveg és a végén a kiadói jelzés) három lapra felragasztotta és így maradt fenn az utókornak. A röplapon legalul a Gedruckt bey Anthony Corthois im Frankfurt am Main, im Jar 1580. olvasható. A vers - szerzőjét nem ismerjük - az elején röviden leírja a három üstökös nyújtotta látványt (feltehetően halo-jelenség lehetett), majd a kor égi tüneményekhez fűződő morális és vallási meggyőződéseit fejti ki.

A képen Kassa látképe - nem meglepő módon - képzeletbeli. A kép jobb sarkában két török áll, az egyikük felmutat az égre, ahol a három üstökös csóvája lándzsát, kardot és félholdas török zászlót formáz, köztük lovas csapatok csapnak össze. (Kassa 1580/1, 158,159. kép)

\section{A háborús békeévek második része (1580-1592)}

Hiába hosszabbították azonban meg a Drinápolyi békét, a két fél, a török helyőrségek és a királyi végvárak közti hadakozás nem szűnt meg. Igaz, ez nem hadjáratokban vagy várostromok formájában történt, inkább rajtaütésszerü, váratlan támadásokban, amelyek célja a minél könnyebb zsákmányszerzés volt. Így érthető, hogy a vásárok, vagy a tavaszi legelőre kihajtott állatok, netán a katonai utánpótlás szállítások voltak a kedvelt célpontok, az ellenséges területen fekvo", védekezésre képtelen falvak kirablása mellett. Ezeknek a híre szinte el se jutott Bécsen túlra. A következőkben említünk ezekből pár példát.

Az egri, szatmári és pár kisebb erősség katonaságából toborzott pár ezer fôs csapat - köztük ott volt fiatal egri hadnagyként Balassi Bálint is - közösen támadt rá 1580. április 21-én a Hatvanban tartott török vásárra. A vásárt a városon kívüli mezőn tartották, viszonylag gyenge katonai őrség felügyeletével. A végvári katonaság támadásának hírére a város helyőrsége ugyan kivonult, de rövid összecsapás után felmérve a támadók túlerejét, visszavonult a város falai mögé. A portyázók jelentős zsákmánnyal tértek vissza Egerbe, ahol a prédát (köztük török nőket és török tiszteket is) kótyavetyére bocsátották.

1585. augusztus 24-én ecsedi Báthori István támadta meg a törökök Turán rendezett vásárát és keveredett csatába a szolnoki béggel. 1586 nyarán egyszerre indult portyára Komáromból Pálffy Miklós komáromi kapitány Székesfehérvár irányába és Izsák bég Székesfehérvárról Szőny felé. Összetalálkozásukból Pálffy Miklós került ki győztesen. 1586 őszén Hasszán szigetvári bég katonáival végigrabolta a Muraköz keleti részét és biztonságban hazavonult, a környék végvárainak riasztott katonasága nem tudta utolérni. 


\section{ANno Domini 1587}

Az 1587-es év magyar-török összecsapásokban ennél is gazdagabb volt. Februárban Nádasdy Ferenc az „erős fekete bég” pápai és várpalotai csapatokkal kiegészülve meglepetésszerűen megrohanta a Somogy megyei Koppány erősségét, annak parancsnokát, Redseb béget 600 emberével(?) elfogta, az erődöt pedig lerombolta majd felgyújtotta. Júliusban azonban Nádasdy Ferenc, immár Pálffy Miklóssal együtt Hamzsabégnél jelentős veszteséget szenvedett: a törökök legelő ménesét hajtották el, ám Szinán pasa lovasaival utolérte őket és több száz katonájukat levágva visszaszerezte a lovakat.

$\mathrm{Az}$ 1587. év legjelentősebb összecsapása a Zala megyei Kacorlaknál történt. A Szigetvárra frissen kinevezett, magyar származásúként ismert Seszuvar (Sehszühvár, magyar nevén Sasvár) bég Mohamed pécsi bég, az új koppányi bég, Hasszán bég valamint a pozsegai és diakovári helyőrségek katonáiból mintegy nyolcezer (más források szerint ötezer) fős sereget szervezett a Muraköz kifosztására. Zrínyi György kanizsai kapitány erről értesülve Nádasdy Ferenctől, Batthyányi Boldizsártól, a varasdi főkapitányságtól és Kaproncáról kért segítséget, végül mintegy 3000 katonát gyüjtött össze.

Seszuvar bég csapatai tizenhét falut kiraboltak és feldúltak, több száz foglyot ejtettek, majd Kanizsát északról megkerülve akartak hazajutni. A sok zsákmány és a gyalog hajtott rabok miatt azonban csak lassan tudtak haladni. Zrínyi György és társai csapataikkal a Zala megyei Szentbalázs és Kacorlak közti mocsaras területnél lesben állva várták a mit sem sejtő törököket és augusztus 9-én az odaérkezőket váratlanul lerohanták. A győzelem és a zsákmány hatalmas volt, nem is beszélve a több száz fogoly kiszabadításáról. Mintegy 2500 török esett el, egy részük a menekülés közben fulladt a mocsarakba, többüket bujkálás közben a környékbeli falvak lakói verték agyon. A törökök egy része belefulladt a mocsarakba. Seszuvar bég - akinek ez a vereség tönkretette további katonai pályafutását - ötnapi bujkálás után jutott el a segesdi török erődbe. Más forrás szerint a törökök vesztesége mintegy ezer halott és hatszáz sebesült volt, míg Zrínyiék mindössze 11 embert vesztettek A törökök közül 1523 került fogságba, köztük Mohamed pécsi bég s Hasszán koppányi bég és több aga. A zsákmányban volt 19 zászló és 1100 ló is. Zrínyi György ünnepélyes Te Deum keretében a zsákmányolt zászlókat a nagykanizsai ferences templomban bemutatta és oltárra helyezte.

Az eseményekről Erhard Pöckhl, Zrínyi György titkára írt beszámolót, ami eljutott Johannes Manlius nyomdászhoz, aki azt még 1587-ben Monyorókeréken (ma Eberau, Burgenland) kiadta. Ez volt az első magyar földön megjelent

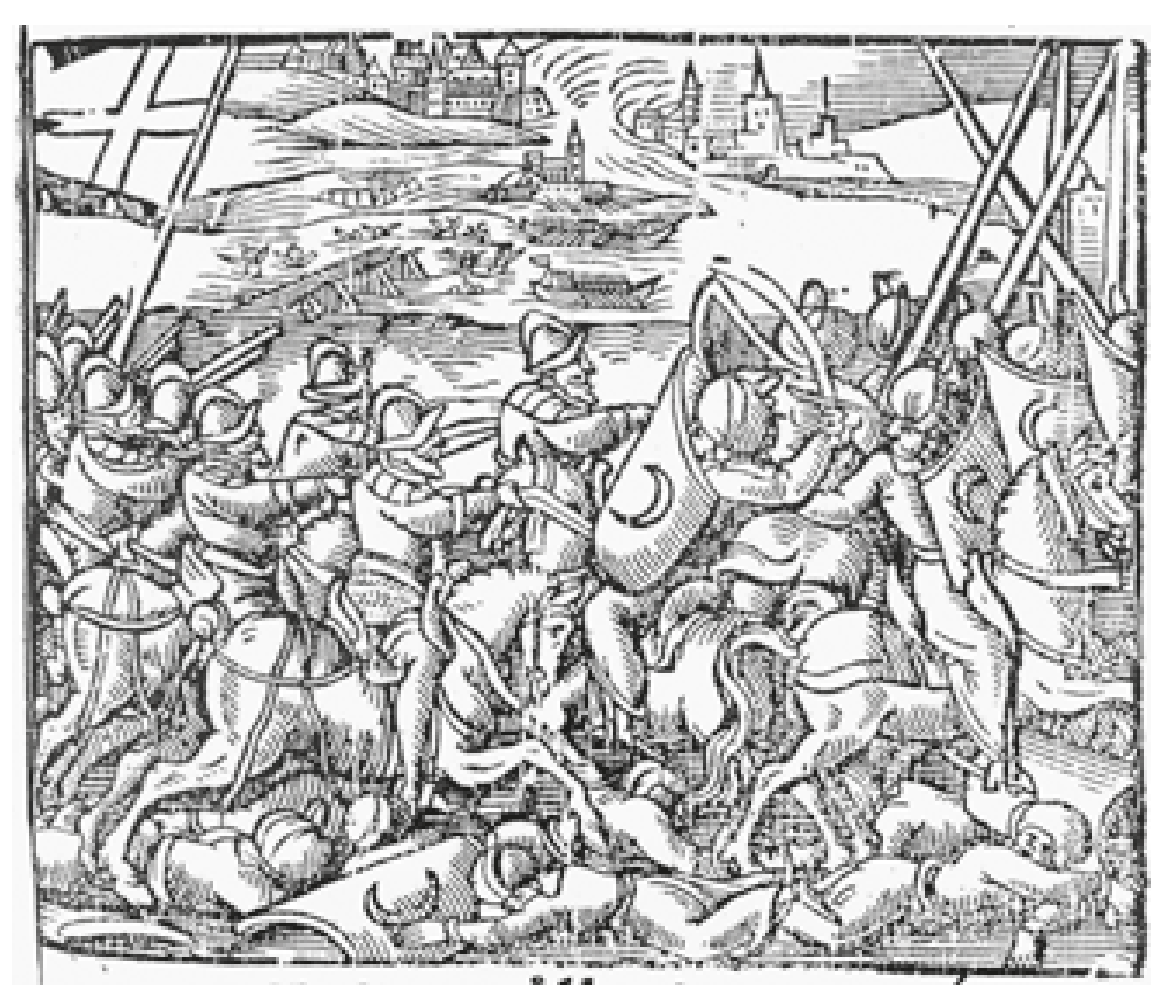

haditudósítás. Érdekes módon a tudósítás címében a csata színhelyeként a Kacorlak északi szomszédságában lévő Sarkan Zigethe (Sárkánysziget) neve szerepel. Erhard Pöckhl tudósítása aztán eljutott Grazba, majd onnan tovább a német városokba, ahol több kiadásban is megjelent. A beszámolót német és latin nyelven verses formában is közzétették. Az eseményről megjelent tudósítások némelyikének címlapján lévő fametszet a rabokat hajtó török katonákat vagy a csatajelenetet mutatja. (Kacorlaki csata 1. és 2, 162, 163. kép)

Az idősebb Hans Rogel augsburgi kiadó fametszetes röplapján a beszámoló német nyelvű verses változatát adta közre. Rogelnek több röplapja is megjelent beszámolva a kor érdekesebb eseményeiről (üstökös járás, a lepantói csata stb.), egyik lapján Zrínyi Miklóst, a szigetvári hős képét tette közzé.

A kép alatt a röplap ötsoros címe (Newe zeitung auß Ungern, auch warhaffte und eygentliche abcontrafactur: welcher massen der Saswar Bascha von Siget...) magának történteknek is a rövid leírása. Alatta olvasható az öt hasábban elrendezett vers a kor kedvelt párrímes formájában. A vers után következik a jelmagyarázat, majd legvégül a kiadói jelzés (Zu Augspurg bey Hans Rogel formschneyder). 


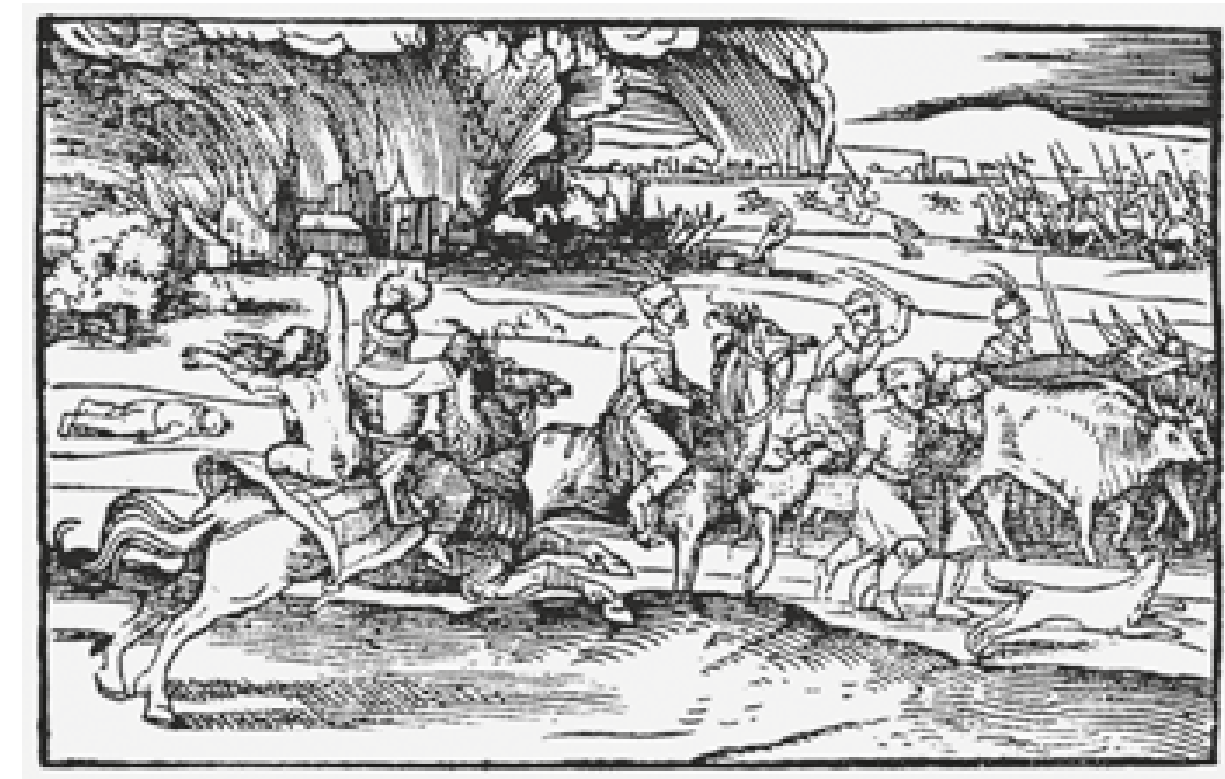

A röplap csatát bemutató fametszete nehezen áttekinthető. A kép közepén azt látjuk, ahogy a magyar lovasok beszorítják a törököket a mocsárba. A képen betűjelölések mutatják a jelképesen ábrázolt Szigetvárt, Kanizsát, Kacorlakot (Kazarlach) és az utóbbi közelében fekvő Kilimánt (Kieimansigeth), valamint az egyes csapatok vezéreit. A mocsarat körbevevő erdőkben mindenhol elszórva magyar és török lovasok. Jelzés mutat (M) egy kis lovas csoportot, amely a győzelem hírével belovagol Kanizsára. A fametszet a maga müfajában - fogalmazzunk finoman - nem egy kiemelkedő alkotás. (Kacorlaki csata 3, 160,161. kép)

\section{ANNo Domini 1588-1592}

Szikszó mezőváros az 1580-as évek közepétől nem fizette meg az éves adóját a budai pasának. Ezekben az években a templomot erősséggé alakították, a várost pedig árokkal és sövénykerítéssel építették körbe. 1588-ban Frenk Juszuf budai pasa az „engedetlen, adót nem fizető szikszóiak” megbüntetésére hadjáratot szervezett és szeptember végére tízezernél több katonát rendelt a hozzátartozó várakból a Fülek melletti gyülekező táborba. A török támadás hírére Szikszó és környékének lakossága elmenekült. A török sereg Egert északról megkerülve, Rimaszécsen keresztül október 8-án délelőtt ért Szikszóhoz, ahol az ott maradt lakosok a megerősített templomba vették be magukat. A törökök a város kirablása és felgyújtása után Alsóvadász felé vonultak és ott tábort vertek, amit a rablott holmiktól zsúfolt szekerekkel vettek körül.

A török támadás hírére Rákóczi Zsigmond egri fókapitány szervezte meg az ellentámadást és a környező várakból összesen kétezer lovast és mintegy ötszáz gyalogos katonát gyüjtött össze. A magyar csapatok október 8-án estére érkeztek Szikszóhoz és azonnal támadást intézek a török tábor ellen. A korabeli híradások szerint a csatateret az égő város világította meg. A több órás küzdelmet végül az döntötte el, hogy egy lovascsapat elfoglalta a törökök ágyúit és azt ellenük fordította. A csatatéren mintegy kétezer török valamint ötszáz magyar és német katona maradt holtan. A győztesek zsákmánya hatalmas volt, közte négy ágyú, zászlók, előkelő török foglyok.

Természetesen a hír először tudósítások formájában terjedt, ezekből kettőt mutatunk be. (Szikszó 1588/4 és 1588/5, 167, 168. kép)

A Szikszó melletti ütközetről három metszetet is ismerünk, közülük kettő (egy rézmetszet és egy fametszet) röplapon jelent meg. A három kép azonos a csata hadrendjének bemutatásban, ám erősen különböző stílusuk miatt teljesen más képet mutatnak.

Az önálló lapként forgalomba került metszetet a szakirodalom Franz Hogenberg műhelyében készültnek tartja, bár a későbbi Geschichtsblätter sorozatban nem szerepel. A kép alján jobbra Erlo (Eger), balra Sendere (Szendrő) várának jelképes ábrázolása utal arra, honnan érkeztek a magyar királyi csapatok. A kép alatti vers Sámsonhoz hasonlítja a keresztényeket, az ütközetet pedig Dávid és Góliát harcának nevezi.

A kép közepén áll a magyar csapatok derékhada: középen a huszárok, tőlük jobbra a vörös és sárga, balra a fehér és fekete lovas-puskások (archibusierek, ezeket a kabátjuk színe alapján különböztették meg). Őket három oldalról török csapatok veszik körül, a negyedik oldalról pedig négy ágyú tüzel rájuk. A kép előterében lovasok nyargalnak az ágyúk felé, közöttük herr Ragozy Sigmund oberster zu Erla és Humani Varau (? Homonnay Drugeth). A képen a törökök mögött megrakott szekerek hada állomásozik, leghátul egy lángokban álló hatalmas város (die stat SIXA) képe. (Szikszó 1588/1, 164. kép)

A Prágában Michel Peterle kiadásában megjelent röplap képén ugyanez van előadva. A mozgalmas metszetet Andreas Andresen nyomán a szakirodalom (nem tudni miért) Wolfgang Meyerpeck munkájának tartja. Itt is lángokban áll a távolban Szikszó, ezúttal a bal sarokban. A szekerek hosszú sorban a török 
csapatok mögött vonulnak a háttérben. Az előző metszettel azonos hadrendben felsorakozott királyi csapatokat itt is körbeveszi az ellenség, de egy részük már menekül, a magyar lovasok pedig már az ágyúk elfoglalásáért harcolnak. A kép alján megjelenik Alsóvadász jelképes rajza. A kép alatt az egyhasábos röplapszöveg részletes tájékoztatást ad a török csapatok és a magyar csapatok felvonulásáról, létszámáról, parancsnokaikról, a csatáról és a veszteségek adatairól. Az ismertetés után következik a képen lévő betűjelölések jelmagyarázata. Ez a legkorábbi olyan röplap (a magyar vonatkozású események között), amelyen nem fametszet, hanem rézmetszet szerepel. (Szikszó 1588/2, 165. kép)

A másik röplapon fametszet van és Nürnbergben jelent meg. Úgy tűnik, rajzolója mindkét előbb említett metszetet ismerte, mert mindkettőről visszaköszönnek részletek: Hogenberg metszetéről a hadrend felállás és a háttérben az égő Szikszó képe, Meyerpeck munkájáról az előtér a szőlőhegyekkel és Alsóvadásszal. A képen több magyarázó felirat van (merről érkeztek a magyar csapatok, hol volt Rákóczi támadása stb.). A kép alatti egyhasábos szöveg itt is alapos tájékoztatást ad az eseményekről. (Szikszó 1588/3, 166. kép)

A Braun-Hogenberg mú IV. kötete Liber quartus Vrbium praecipuarum totius mundi címmel 1588-ban jelent meg, benne 44 oldalszámmal Pozsony látképe. A metszet hátoldalán egyhasábos szövegben a város történetének ismertetése szerepel (a későbbi kiadásokban ez a szöveg az újabb történésekkel bővült, egészen II. Ferdinánd 1618-ban történt koronázásáig).

A metszet címe a jobb felső sarokban lévő címtáblán olvasható: POSONIUVM vel Pisonium ut Lazius Hungariae urbs (Posonium vagy Pisonium Laziusnál mint Magyarország városa). A képen felül középen a város német neve „Pressburg” jelenik meg. A déli nézetből készült látképnek sem a rajzolóját, sem a rézmetszőjét nem ismerjük, bár metszőként Franz Hogenbergre vagy Simon Novellanusra gondolhatunk megalapozottan, mivel mindketten készítettek lemezeket Georg Braun kanonok híres múvéhez.

Meggyőződésünk, hogy az ismeretlen rajzolónak látképéhez helyszínen készült vázlatok is rendelkezésére álltak. A kép hegy-vízrajza hozzávetőlegesen megegyezika valósággal, méga Várhegy alakja is elfogadható. A négy saroktornyos vár kiépítettsége összhangban van a Pietro Ferrabosco vezetésével 1556-ban befejezettátépítésről ismert forrásokkal. A városképet uraló jellegzetes épületek (Szent Márton templom, Klarisszák temploma, Ferences templom, Városháza tornya) egymáshoz viszonyított térbeli elhelyezése is megfelelő. A képen több olyan épület vagy épület csoport van, amely már az 1563-ban készített délkeleti nézőpontú fametszeten is látható. A vízimalom, a komp mind valós ábrázolás, persze pontos helyük ma már nem ismert. Összhatásában igényes látkép. (Pozsony 1588/1, 171. kép)

Győr város erődítményének alaprajza 1589-ben jelent meg Daniel Specklin Architektura von Vestungen című várépítészetről kiadott könyvében. Az elzászi származású Specklin fiatal korában 1555-56-ban dolgozott a komáromi vár átépítésén. Könyvében több magyar vár kiépítettségéről is ír, ám csak Győr alaprajzát tette közzé.

A metszeten látható alaprajz készítésének időpontja nem ismert. A szabályos utcahálózat utalhat az 1566-os túzvész után tervezett helyreállítási javaslatra. Több részlete Ferrabosco alaprajzával mutat azonosságot. Az alaprajzon nem szerepel a Dunai-kapu és nem jelennek meg a Püspökvár épületei sem. (Györ 1589/1, 169. kép)

Daniel Specklin hagyatéka és tervrajz gyűjteménye - köztük ennek a Győr alaprajznak egy változata - ma is megvan, azt Kisari Balla György dolgozta fel és tette közzé Karlsruhei térképek a török háborúk korából című könyvében.

A kor híres orientalista tudósa, Johannes Löwenklau (Johann Lewenklaw, Leunclavius) Neue Chronika türkischer Nation címú könyvében egyetlen kép, Buda metszete jelent meg (Rózsa 1999/101) jelent meg. Löwenklau tagja volt a Heinrich von Lichtenstein vezette császári követségnek, amely 1584-ben a Drinápolyban kötött fegyverszünet újabb meghosszabbítása miatt ment Isztambulba. Bécsből hajóval utaztak, közben megálltak pár napra Budán. Amikor Frenk Juszuf budai pasa meglátogatására mentek, útközben találkoztak azzal a furcsa menettel, amelyet a metszet megörökít.

A kép megjelent a könyv 1590. évi és 1595. évi kiadásában is. Az első kiadásban lévő metszeten a felvonulást mutató kép felett az olvasó tájékoztatásra szóló szöveg elmondja, hogy ennek a "török látványosság”-nak (Türckische Spectaculs) képét a 118-119. oldal közé kötik (vagyis ott szerepel az esemény leírása). Loewenklau részletesen ismerteti a menetet, kezdve az elöl haladó három cigányzenésszel és három félmeztelen lándzsással. Ez a szöveg a második kiadásban megjelent metszeten nem szerepel.

A menetnél érdekesebb számunkra a kép (amelyen minden felirat olasz nyelvü) hátterében megjelenő, a Duna keleti oldaláról megrajzolt Buda látkép. Rögtön szembetűnik, hogy a rajzoló alapvető hibát követett el: a képen Buda várának az északi végében van a király vár és attól még északabbra a Szent Gellért-hegy, amelynek neve a képen tévesen Montagna di. S. Biasio, vagyis Szent Balázs-hegy. Ugyancsak téves a Mária Magdolna templom neve, a S. Martha 


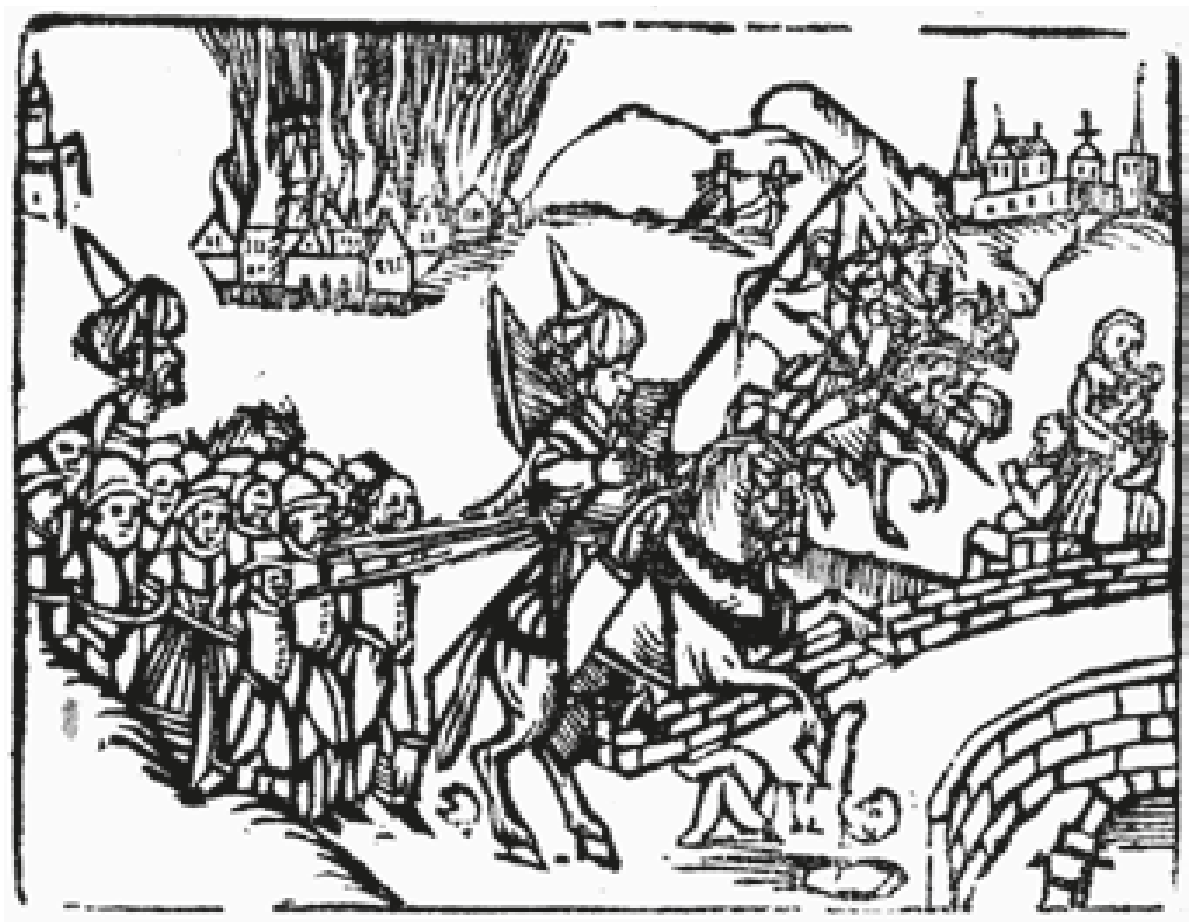

Chiesa de Christian, viszont a keresztények temploma megnevezés jó. A mai Mátyás templomnál a Quondam Nostra Donna adeso meszit de Thurchi (egykor Miasszonyunk most törökök mecsete) és a királyi palota feletti felirat (Il Castello Regale Buda Ofen) helyes.

A képen a valóságnak csupán Buda és Pest a Duna szemben lévő oldalain való ábrázolása és Buda megnevezett három legfontosabb épületének egymáshoz viszonyított térbeli elhelyezése felel meg. Helyismeretre utal a palota nagy kerek déli bástyájának rajza és a Gellért hegy lábánál feltüntetett fürdők látképe. A látkép többi része, ideértve az épületrajzokat is képzeletbeli. Nem tudjuk, ki volt a rajzoló. Arra gondolunk, hogy a küldöttségben lehetett valaki, akinek volt egy kezdetleges rajzkészsége (bár a felvonulók rajza kiforrott kézre vallanak) és tudott olaszul is. Löwenklau talán érzelmi vagy hitelességi okok miatt ragaszkodhatott ahhoz, hogy ez a helyszínen készült rajz jelenjen meg a könyvében (talán maga volt a rajzoló?). Érdekes módon ezt az egyébként nem színvonalas metszetet később Georg Hoefnagel felhasználta keleti nézetű Buda látképéhez. (Buda 1590/1, 172. kép)

Wolfgang Halbmaister röplapja egy szörnyszülöttről ad hírt 1590. június 14-i időponttal. A röplapot W. L. Strauss tette közzé a német fametszetes nyomtatványokról kiadott munkájában, az esemény helyszíneként Győr városát megnevezve. A Walter Strauss ismertette példány sajnos nyomdai selejtnek tekinthető. Címe csak részben olvasható, a verses röplapszöveg nagyobb fele festékkel fedett, a többi része is nehezen kibetűzhető. A címben az „Ungern” szó a mondaton belüli helye alapján mindenképpen helymegjelölésként szerepel. Sajnos, az előtte lévő helységnév olvashatatlan.

A képen egy képzeletbeli városkép látható minden felirat nélkül. A várostól jobbra egy hatalmas kőhíd, a folyón nehezen felismerhetően úszik egy teknőben egy gyermek. A város előtt férfiak csoportja vesz körül egy teknőben fekvő torzszülöttet. (Györ 1590/1, 173. kép)

A kép és az olvasható szövegfoszlányok alapján azt feltételezzük, hogy a szörnyszülöttet egy Georg Burgenzan(?) nevű katona és háziasszonyok találták, amint teknőben úszott a folyón. A szörnyszülöttet eltemették, feltehetően Győrben (zu Rab). Győri szörnyszülöttről egyéb irodalmi említést nem ismerünk.

A röplap őrzési helyeként W. L. Strauss csak várost nevezett meg (Bratislava), közintézményt nem. Pozsonyi kutatásaink sorén meggyőződtünk arról, hogy a röplapról a pozsonyi közgyűjteményekben nem tudnak. Helyi szakértők szerint a röplapot W. L. Strauss valamelyik híresebb pozsonyi magángyűjteményből (talán Rudolf Fila festőművész gyűjteménye) ismerhette. Abban bizakodunk, hogy ez a mostani nagyon szegényes ismertetés és a röplap képének közzététele segíthet a Strauss által leírt példány megtalálásában vagy netán egy másik példány megismerésében.

Lucas Mayer röplapján 1591-ben a pozsonyi vár képzeletszülte rajza is megjelenik. A röplap egy Pozsonyban történt esetről számol be, amely történet a középkor óta újra meg újra felbukkanó zsidóság elleni vérvád-történetek egyike (a megszentelt ostya meggyalázása).

A „vérvád” történet szerint egy művelt Leó nevü zsidó Wormsban áttért a katolikus hitre, majd megismerkedett egy Petrus Rodamus nevű szerzetessel, aki betegként ápolta majd kertészként befogadta a kolostorába. Leó ellopott három megszentelt ostyát és elment Pozsonyba, ahol egy zsidónál szállt meg és eldicsekedett az ostyákkal. Leó elutazott Nikolsburgba, távolléte alatt házigazdája pár másik zsidóval az egyik ostyát kettévágta, mire abból vér fröccsent ki. A házba, ahol ez történt, abban a pillanatban belecsapott egy villám és az porig égett a benne lévő zsidókkal, köztük a házigazda feleségével és két gyermekével együtt. A házból csak hárman tudtak kimenekülni, a megszentelt 
ostyák azonban a tűzben sértetlenek maradtak. A városkapitány a tűzesetet kivizsgáltatta. Ennek során az életben maradt zsidók egyike kínvallatás után elmondta a történteket. A városkapitány mind a három zsidót tortúrára és karóba húzásra ítélte.

A röplap fametszete a történet ismerete nélkül szinte értelmezhetetlen. A kép hátterében középen egy vázlatos várkép, attól balra három karóba húzott ember látható. A kép jobb oldalán egy ház áll lángokban (ez lehet az a ház amelybe az ostya meggyalázása után belecsapott a villám), bejáratában egy nő két gyerekkel. A kép baloldalán a templom és az előtte álló szerzetes egy férfival (aki lehet a Leó nevű zsidó) feltehetően az a kolostor, ahonnan három ostyát ellopták. (Pozsony 1591/1, 174. kép)

A röplappal összefüggésben egyetértően idézzük következőket: „A mohácsi vész után Mária királynő kiűzi Pozsonyból a zsidókat. Ettől kezdve majdnem két évszázadon át Pozsonyban zsidókról sehol nincsen szó, csak 1591ben Németországban jelent meg egy képes röplap, melyben gonosz gyúlölettel P.-i zsidók által elkövetett ostyagyalázást koholtak, de ennek sem P.-i, sem más magyar, sem ausztriai forrásokban sehol nyoma sincsen”. (Magyar Zsidó Lexikon, Budapest, 1929. Szerk. Újvári Péter 718. oldal).

A teljesség miatt közöljük, hogy a pozsonyi vérvád történet egy 1591ben megjelent bécsi tudósításban is szerepel, szóról-szóra egyezően a röplap leírásával. Ez feltehetően a lexikon szerkesztésekor még nem volt ismert. Nem tudjuk, hogy a röplap megjelenésének köszönhető a tudósítás, vagy a tudósítás megismerése késztette Lucas Mayert röplapja kiadására, de ez talán érdektelen is.

$\mathrm{Az}$ igazán hitelesnek tekinthető forrásokban (mint Pozsony város bőségesen fennmaradt iratai) ennek a történetnek nyoma sincs. Egyébként nem ez volt az első ilyen jellegű „vérvád” történet a Magyar Királyságban. Bonfini történetírásában az 1494. évi nagyszombati vérvád eljárást ismerteti, a Bazinban 1529 Pünkösdjekor máglyára küldött harminc zsidóról pedig több korabeli tudósítás (köztük egy bécsi) is beszámolt.

Lucas Mayernek egy másik röplapja 1592-ben jelent meg, az ezen lévő Buda látképet Rózsa György katalógusában a „nem hiteles” képek (Rózsa 1999/298) közé sorolta. Az eseményekről bécsi forrásból beszámoló híradás az 1592. év első felének török támadásait foglalja össze, kezdve a horvátországi Bihács és Petrinja elfoglalásával a szigetvári törökök dunántúli dúlásán át a budai pasa Eger környéki portyázásáig. A szinte az egész országra kiterjedő harcokat a röplap fametszete érzékletesen mutatja be: a kép egyik sarkában Buda, ellentétes sarkában Bihács látképe van, a kettő közti teljes területet pedig harci jelenetek töltik ki. (Buda 1592/1, 175. kép)

$$
>>>><<<<<
$$

A korszak eseményeit inkább kevesebb, mint több megbízhatósággal bemutató metszetek ismertetését egy olyan metszettel zárjuk, amely nem kötődik egyetlen adott eseményhez, vagy helyhez sem, ezért valójában nem is tartozna munkánk körébe. Viszont a metszeten jelképesen látható mindaz a tragédia, ami a 16. században magyar földön történt. Ahogyan a magunk szabta határokat átlépve már kivételt tettünk Wolfgang Lazius és Natale Angielini haditérképével, ezzel a metszettel is kivételt teszünk.

Ez a metszet nem ismeretlen a magyar történelem tárgyi emlékeivel is foglalkozó történészek és művészettörténészek előtt, képe többek között már a Domanovszky Sándor szerkesztette híres Magyar müvelődéstörténetben is szerepelt, Galavics Géza pedig részletesen is foglalkozott vele a Kössünk kardot az pogány ellen című könyvében. Megjegyezzük, a metszet hátoldalán Zrínyi Mikós ismeretlen nyughelyének sírverse olvasható.

A metszetet Hungária vértanúsága névvel is elfogadott említeni, mi is így teszünk. A Martin Schrott Wappenbuch-jában 1581-ben megjelent fametszetet készítő Johann Nel egyetlen képben próbálta bemutatni a Magyar Királyságnak a 16. század évtizedeiben egyre tragikusabbá vált helyzetét, annak okát és felcsillantani a reményt az ország sorsának jobbra fordulására. A Magyar Királyság helyzetét a koronás, ám megkötözött és megcsonkított Hungária alakja jelképezi, a két oldalán álló török katonák pedig, akik Hungária karjait levágták a kétségbeejtő helyzet magyarázatát. A jobb jövő lehetőségét a Hungária kiszabadítására a képen balról Germániából (vagyis a Német-római Birodalomból) érkező katonák jelentik. A kép érthetőségét latin nyelvű feliratok segítik. Hungária alakja felett a felirat Krisztus segítségét kéri, az érkező katonák felett pedig az olvasható, hogy a törökök már nem sokáig kegyetlenkedhetnek, mert Germánia megbünteti őket. A Münchenben, majd később Augsburgban dolgozó Johann Nel (jelzése IN a képen középen alul) műve kétségtelenül jó szándékú, a Magyar Királyság iránt együtt érző megértést sugárzó, és a helyzet megszüntetésre az egyetlen lehetséges megoldást is felvázolja. Ám mint tudjuk, 


\section{HungáRIA VÉRTANÚSÁGA}

sem az eltelt, sem az elkövetkezendő évtizedek még sokáig nem valósították meg a Magyar Királyság birodalmi segítséggel történő helyreállítását. Igaz, a tragikus állapot létrejöttében, vagyis a törökök egyre terjeszkedő hódításában szerepe volt az ország megosztottságának és a Habsburg uralkodók közismert vezetői alkalmatlanságának is. Összességében a metszet azt is sugallja, hogy a 16. század végén Európa szerte kialakulhatott az a vélemény, hogy a Magyar Királyság megvédése (ami közvetett érdeke volt a közeli nyugati országoknak) csak összefogással érhető el.

A metszeten azonban Hungária helyzetének jelképes bemutatása mellett van még egy képcsoport, amely az utolsó száz év Hungária megmentéséért életüket is feláldozóknak állít emléket. A kép jobb alsó sarkában azt a jelenetet látjuk, ahogyan II. Lajos lovával belesüllyed a mocsárba, felette sorakozik Mátyás király, I. Ulászló király, Bakity Pál, Hunyadi János, gróf Zrínyi Miklós és Thúry György páncélba öltöztetett holtteste azzal a közös megnevezéssel, hogy a hazát fegyverrel és vérükkel védelmezve mindannyian életüket is feláldozták. ((Hungária vértanúsága 1581, 8. oldal)

Ez a „hősi képsor” egy üzenetnek is tekinthető mindenkinek, megjelenésekor és a mai korban egyaránt: a magyarok mindent megtettek hazájukért, ami tőlük elvárható volt. Ha kellett, életüket is adták. És nem csak a kép mutatja heten, hanem sokkal többen. És nem csak abban a korban, hanem évszázadokon át, azóta is.

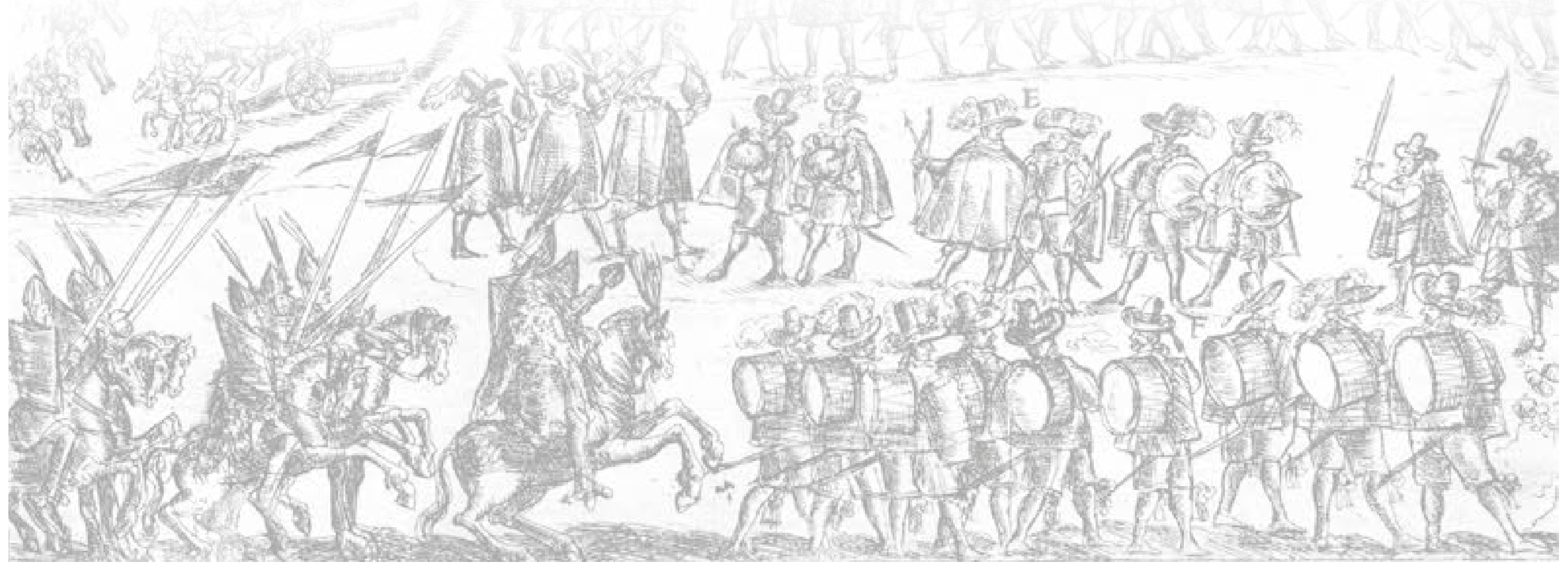




\section{ÖSSZEFOGLALÁS}

Nem biztos, hogy szerencsés egy ilyen jellegű munka összefoglalóját számok felsorolásával kezdeni, bár mostanában többenis kedvelika statisztika jellegűadatokat. De ezt kell tennünk, mert másképpen nem tudunk rendezett formában mennyiségi áttekintést adni a munkánkban összegyűjtött és csoportosított metszetekről.

A 16. század magyar történelmének eseményeiről és azok helyszíneiről munkánkban közölt metszeteket a maguk számszerűségében nem is egyszerű bemutatni. Ennek több oka is van, elsőként említjük, hogy a metszeteket többféle megfontolásból és többféleképpen is csoportosítanunk kellett. Az is nehézséget jelent, hogy metszetek különböző nyelveken kiadott változatait (ha vannak) ebben a munkánkban önálló műnek tekintettük (lásd az Ehrenpforte latin és német, vagy Sebastian Münster könyveinek több nyelven történt megjelentetését). A kiinduló csoportosításnál a metszeteket a Magyar Történelmi Képcsarnok metszetnyilvántartásával egyezően két fő csoportba, nevezetesen „események” és „helyszínek” metszetek közé soroltuk. Az egyes metszetek csoportbesorolását a Mellékletek között található Katalógus tartalmazza.

Természetesen tudjuk, hogy minden eseményhez tartozik helyszín, így első hallásra ez a csoportosítás természetellenesnek tűnhet. Ha nagyon szigorún vesszük a fogalmakat, akkor a Braun-Hogenberg múben megjelent Buda és Pozsony látkép, valamint Michael Zimmermann városképes címlapja kivételével minden metszetet az események csoportba kellene sorolnunk. Ezért is hangsúlyozzuk, ez a csoportosítás munkánknak csupán formai részét érinti, csak technikai szerepe van, amely az anyag rendezhetőségét és kezelhetőségét segíti. A csoportba sorolásnak az egyes metszetek ismertetésénél nincs semmilyen jelentősége.

Az eseményeket bemutató metszeteken azonban sok esetben meg sem jelenik az esemény helyszíne. Erre példának a Bécsben tartott Habsurg Jagelló kettős eljegyzés metszeteit hozzuk fel. Az 1515-ben történt ünnepélyes eseményről hírt adó metszetek többségén még jelképértékűen sem jelenik meg Bécs ábrázolása. Ezért ezeket az „eseményképek” csoportba soroltuk. De ugyanez a helyzet a Fráter György meggyilkolását vagy Szokoli Musztafa budai pasa megfojtását mutató metszeteknél: a helyszínt tudjuk, de az nincs a képen. A törökök pusztítását-öldöklését mutató, adott helyhez nem kötődő metszetek is az események csoportjába kerültek.

Ezek ellentétjei a jelentősebb várostromokról született metszetek (Szigetvár, Tokaj, Gyula stb.), amelyeknél a vár vagy a város képe fontosabb lehet, mint az ostromjelenetek gyakran légből kapott (persze, a városkép is lehet az) ábrázolása. Nem akarunk hosszan foglalkozni azzal, hogy több metszet esetében nem is egyszerű eldönteni, hogy melyik csoportba kerüljön. Buda 1526-ban történt török megszállásáról hírt adó francia tudósítás címlapján egy várkastély van Ofen felirattal, ezt nem lehet eseményképnek tekinteni. Ugyanakkor Erhard Schön Buda 1541. évi ostromáról készített fametszete ostromkép, vagyis esemény, de már Rózsa György is „helyszínként” Budapest látképei közé sorolta. A besorolásnál egyébként kötöttségnek tekintettük a már korábban létrehozott, a kezdetektől 1800-ig tartó időszakot felölelő magyar várak, városok falvak metszet-adattárunkkal való átjárhatóságot, és ami a 16. századi metszetek közül abban már helyszínként szerepelt, annak besorolását nem változtattuk meg. Ugyanígy jártunk el Rózsa György Budapest látképeinek feldolgozásával, minden általa nem hitelesnek minősített ábrázolással is foglakoztunk és azokat a Buda „helyszínhez” soroltuk.

Összességében 16 esemény 46 metszete (közük két térkép) került az „Események” csoportjába és 28 település 129 metszete (köztük 23 Buda metszet) a „Helyszínek” csoportjába. A 28 helyszín közül 12 a történelmi Magyar Királyság azon területein fekszik, amelyek ma más államokhoz tartoznak. Nem soroltuk be egyik csoportba sem munkánk utolsó, a Hungária vértanúsága elnevezésű metszetet és a két helyszínen készült, metszet előképként is felhasználható rajzot.

A mindösszesen 176 metszet közül 54 alkalmi nyomtatvány címlapján, 21 pedig röplapon jelent meg, a többi vagy könyvben, vagy önálló metszetlapként került forgalomba.

Munkánk bevezetésében már általánosságban szóltunk az eseményekről tudósító nyomtatványokról és azok címlapján esetenként megjelenő kis fametszetekről. Ezeknek a tudósításoknak a társadalmi jelentőségéről és szerepéről, valamint a tudósítások és az események iránti érdeklődés kölcsönhatásairól tanulmányok, könyvek szinte felmérhetetlen sora jelent meg. Mindezekkel nem foglalkozunk, csak annyit állapítunk meg, hogy a 16. századi Európa társadalmi-gazdasági fejlődésével párhuzamosan a különböző címeken és különböző múfajban (próza, vers, szerkesztett hír vagy egyéni beszámoló) megjelent tudósítások mennyisége a század folyamán sokszorosára nőtt. Az is megfigyelhető, hogy a Német-római Birodalom, illetve a Habsburgok uralta további területeken megjelent politikai tartalmú (nemzetközi ügyek, háborúk, 
békekötések stb.) tudósításokban a Habsburg hatalom jó hírét romboló hírek nem jelentek meg, ami valamilyen birodalmi és városi cenzúra múködésére utal.

A tudósítások tartalmi megbízhatósága mindig a tudósítás forrásától függött. Nem egy esetben tudjuk, hogy egy másik városban megjelent tudósítás szövegét jelentették meg szóról szóra, nagy ritkán célozva arra, hogy az utánközlés. A kiadóktól már akkor sem állt távol a szenzációközlésre való törekvés, ami a tárgyilagosság rovására is mehetett, sőt időnként soha meg nem történt, elsősorban nevelő jellegú históriák jelentek meg. A kiadók különös figyelmet fordítottak a rendkívüli, avagy csodás vagy annak tartott természeti jelenségek iránt, amelyek az égi tüneményektől kezdve a természeti csapásokon (földrengés, árvíz, sáskajárás stb.) vagy balesteken (robbanás, túzvész stb.) át a torzszülöttekig terjedt.

A tudósítások nyelve pár Németalföldön megjelent francia és Prágában megjelent cseh nyelvú tudósítás kivételével német volt. Francia nyelvterületen nagyon kevés tudósítás látott napvilágot a Magyar Királyság történéseiről és amiket kiadtak, azokban nem szerepelt kép. Az olasz nyelvterületen megjelent (tudomásunk szerint rendkívül kevés számú) tudósítással munkánkban nem foglalkoztunk.

A megjelent tudósítások tömkelegéből természetesen minket a Magyar Királyságban történt eseményekkel foglalkozók érdekeltek. Munkánkhoz segítséget jelentett, hogy ezekről több jegyzék - adott esetben más összeállítások részeként - is ismert. Azonban a világhálón hihetetlen mennyiségben közzétett könyvtári gyűjtemények anyagában még ma is található a szakirodalomban eddig le nem írt tudósítás, vagy egy leírtnak eddig nem ismert változata. Tovább szúkítve a kört ezek közül is csak azokkal a tudósításokkal foglalkoztunk, amelyek címlapján a tudósításban közölt eseményhez kapcsolódó képet láthatunk.

Ezek a képek - nagyságukkal alkalmazkodva a tudósítások méretéhez - ritkán haladták meg a 10×10 centimétert. Ez a méretbeli korlátozás a kiadók számára előnyösnek számított (egy kisméretű fametszet gyorsabban és feltehetően olcsóbban elkészíthető volt), ugyanakkor hatással volt elsősorban a kép tartalmára (mi fért el egy ilyen kicsi méretű képen), de annak művészi színvonalára is. Egyébként megfigyelhető, hogy a 16. század elején a címlapokon még több a múvészi igényességgel készült fametszet, sőt közöttük elismert múvészek alkotásai is megjelennek (sajnos, magyar vonatkozású tudósításon nem). A későbbi évtizedekben azonban már ezek a fametszetek is a tömegtermelés színvonalát tükrözik. Az megszokott gyakorlat volt, hogy egy-egy csatajelenet vagy várostrom fadúcát többször is felhasználták, akár ugyanabban az évben másik esemény tudósításához. Tudunk arra is példát, hogy ugyanaz a fametszet jelent meg 1514-ben és 1532-ben kiadott beszámoló címlapját (VD 16 V 2594 és VD16 S 2759) vagy ami szinte hihetetlen, Buda 1526-ban megjelent kis fantázia képe 1598-ban Győr képeként jelent meg újra!

Az 1514-ben meghirdetett keresztes hadjárat-amely a magyar történelembe Dózsa György nevéhez kötődve írta be a nevét - volt az első olyan magyarországi esemény, amelynek híradásai címlapján kép jelent meg. A több helyen is kiadott tudósításokon egy keresztes vitéz látható, kezében a keresztesek (képzeletbeli) zászlajával. A keresztes vitéz képe legalább három változatban ismert, azok kifejezetten igényes munkák. Egy tudósítás címlapján megjelent Dózsa György tüzes trónon ülő képe is, amint egyik embere kiharap egy darabot a vállából. Ez a kép kissé módosítva 1519-ben ismét napvilágot látott. (1-5. kép).

Az 1515-ben Bécsben tartott Habsburg-Jagelló szerződés megkötése joggal váltott ki érdeklődést és Johannes Cuspinianus császári történész is gondoskodott arról, hogy annak híre menjen. A tudósítások fametszetei közül említjük azt a maga középkori merevségével együtt is kedves hangulatot árasztó képet, amelyen Anna és Mária királykisasszonyok és a gyermek II. Lajos látható (9. kép). Nándorfehérvár elfoglalásáról nem jelent meg híradás, ám annak elvesztésére utalva a következő évben a török veszélyre történő figyelem felhívás jelent meg, verses formában. Az igényes kivitelű kiadvány címlapján a törökök magyarországi fosztogatást bemutató kép szintén a színvonalasabb fametszetek közé tartozik (21. kép). A mohácsi csatavesztésről nagyszámú tudósítás jelent meg, címlapjukon általában csatajelenettel, ezek között van kezdetleges rajzú és látványos is. A csata után a feldúlt falvakban történt kegyetlenkedéseket tükrözi az a gyermekgyilkosságokat mutató fametszet, amelyet feltehetően a Heródes elrendelte betlehemi kisdedek megölése ihletett és a következő évek egyik vándorképévé vált (35. kép). I. Ferdinánd koronázásának híradásai közül a németalföldi tudósítások képei érdekesek, ezek közül kettő (egy hajóval történő megérkezés és egy kápolna oltára előtti jelenet) értelmezése elgondolkodtató kérdéseket vet fel (38, 39. kép).

Buda látképe az 1526-ban történt rövid török megszállása majd 1541-ben elfoglalása hírére kiadott tudósítások címlapján csak képzeletbeli ábrázolások formájában köszön vissza, és ezt mondhatjuk Kőszeg 1532-ben és Esztergom 1543-ban történt ostromáról is.

Először 1550-ben jelentek meg tudósítások a Szikszónál történt csodás betegségről, a kígyójárványról, amelyeket a rendkívüli mértékben elszaporodott kígyók és gyíkok okoztak. Ezek egyike mindezt Isten büntetésének nyilvánítja és az embereket az istenes életre való visszatérésre szólítja fel. Mondanivalóját 
jelképesen a címlapkép is megerősíti. A kép egy ószövetségi történetet idéz, amelyben Isten a pusztában vándorló zsidó népet zúgolódásáért mérges kígyók rájuk bocsátásával büntette, amely ellen védelmet csak a Mózes által csináltatott, póznára tűzött rézkígyóra tekintés jelentett. A fametszet Mózest, a póznán a rézkígyót és egy attól segítséget remélő nőt ábrázol. Igazi beszéló kép. (66. kép). Az 1551. évben Erdélyért folytatott küzdelem emlékét őrizte meg Lippa ostromának tudósításon megjelent képzeletbeli képe. (67. kép)

Az 1556. évi dunántúli harcoknak nem volt jelentős külföldi visszhangja, a pár tudósításon megjelent kép között igazán érdekest nem találtunk. Más a helyzet az 1565. évi, de különösen a Szulejmán szultán vezette 1566. évi hadjárat esetében. 1565 telén-tavaszán Lazarus Schwendi felvidéki főkapitány Tokaj elfoglalása után sorra hódította vissza az erőtlen János Zsigmondtól az előző években elfoglalt helyeket, köztük Szatmárt és Nagybányát. A magyar trónt frissen elfoglalt I. Miksa fontosnak tartotta a sikerek széles körú megismertetését, és ennek köszönhető, hogy a katonailag nem igazán jelentős hadjáratról több tudósítás is megjelent. Ezek egyikén feltűnik Szatmár ostromának képzeletbeli látványa (83. kép), ilyet eddig nem ismertünk. Ám ennél sokkal jelentősebb az a Tokaj elfoglalásáról szóló tudósítás, amelyet a kor jó nevű fametszője, a nyomdát is üzemeltető Michael Zimmermann adott ki Bécsben. Ennek címlapján Tokajnak egy valóságra törekvő ábrázolása látható, amelynek előképét, egy helyszínen készült felmérési rajzot is ismerni véljük. (77. kép)

$\mathrm{Az}$ 1566. évi hadjáratról ötvennél több tudósítást tartunk számon képekkel, ám ezek között igazán érdekeset nem találtunk, nagyon sok köztük a többször is megjelent fametszet. A sok lehetôség közül végül azt a két tudósítást választottuk, amelyek kifejezetten Zrínyi Miklós hősiességének hirdetésére jelentek meg. (135, 136. kép)

A Drinápolyban 1568-ban megkötött, majd meghosszabbított fegyverszünet évtizedeiben nem volt ugyan teljes fegyvernyugvás, de olyan mértékű harci események se nagyon, amelyek felkeltették volna a külföld figyelmét: Ami kevés tudósítás megjelent, azok közül több rendkívüli eseményekkel foglalkozott. Ilyen volt Temesváron a lőporkészlet felrobbanása, ennek egy képzeletbeli városképet köszönhetünk (151. kép), vagy Szokoli Musztafa budai pasa és négy további török főtiszt kivégzése. Ez utóbbi, a selyemzsinór-jelenetnek is nevezett, megfojtással történő kivégzési kép szintén vándorkép volt a 16. században: nem csak tudósításokon szerepelt, hanem az oszmán birodalommal foglalkozó könyvekben is megtalálható. (156. kép)
Az 1587-ben Kacorlak melletti ütközet híre annak is köszönhetően terjedt el, hogy Erhard Pöckhl, Zrínyi György titkára részletes beszámolót írt róla. Írása először Monyorókeréken jelent meg és az volt az első magyar nyomdában készült tudósítás. A Kacorlaknál vívott ütközetről kiadott tudósítások egyikén lévő képet, amelyen a törökök a rabokat hajtják, akár a török pusztítás eseményei közé is sorolhattuk volna. (162. kép)

Válogatásunk utolsó két tudósítása Rákóczi Zsigmond egri fókapitány csapatainak 1588 őszén Szikszó melletti győzelméről ad hírt. Ezek egyikén bájosan egyszerű ostromkép jelent meg, ami a csata fordulópontját, a török ágyúállások elfoglalását(?) mutatja. (168. kép)

A közzétett címlapképeket több mint száz közül válogattuk, igyekezve azokból a jellemzők mellett az egyedi jellegúeket is bemutatni. Esetükben nem beszélhetünk értékes művészi munkáról (bár akad közük ilyen is), de a legtöbbjük nem is múvészi szándékból született. Kevés köztük az olyan, ahol szorosabb kapcsolatot találunk a tudósítás tartalma és a kép között. Talán ilyen az 1577-ben megjelent beszámoló, amely leírja, hogy a lőporrobbanás után a Temes elöntötte Temesvárt és tengerré változtatta a teljes környéket. A képen a várost víz veszi körül, amelyen vitorlás hajókat látunk. (151. kép) Tokaj címlapképén lehet látni a tudósításban leírt eseményt, amikor az ostromlók alatt beszakadt a befagyott folyó. (77. kép) De ezek a ritka kivételek. A tudósítás kiadója elővehette egy ahhoz megfelelőnek tartott korábban közzétett kép még használható fadúcát (ha volt), vagy megrendelt egy csataképet, ostromképet, aminek elkészítéséhez vagy odaadta a szöveget vagy nem, a többi a rajzoló-fametszőn múlott.

Ezeknek az összegyüjtött címlapképeknek az igazi értéke az ismertetett eseményekre való képi utalás, ezért van helyük a magyar történelem képi emlékei között.

Mint említettük, a munkánkban feldolgozott metszetek közül 21 jelent meg röplapon, ezek egyharmada eddig nem volt ismert a magyar szakirodalomban. A röplapok szinte mindig színezetten kerültek forgalomban, sajnos fekete-fehér fényképük nem adja vissza látványosságukat. Meg kell említenünk, hogy még szakmai berkekben is vita van a röplap pontos fogalmi meghatározása terén. Vannak, akik a röplapok közé sorolandónak tartanak minden olyan metszetlapot, amelyen a kép alatt nyomtatott szöveg van, legyen az a metszetlap címe (amely leíró cím esetében akár több soros is lehet), vagy a jelmagyarázat. Vannak, akik röplapnak tekintik Erhard Schön Buda ostroma fametszetét az aljára ragasztott Hans Sachs verssel, ezzel mi nem értünk egyet. A Bambergben felfedezett, 1526-ban készült Mohácsi-csata metszetet az irodalomban említik egylapos nyomtatványként, röplapként és metszetlapként is, mi ez utóbbit fogadjuk el. 
A feldolgozott kor röplapjainak többsége egyéb forrásokból is jól ismert eseményekről (koronázás Pozsonyban, Tokaj, Szigetvár ostroma, csaták Szikszónál stb.) ad hosszabb-rövideb írásos és képi tájékoztatást. Van azonban pár olyan röplap, amelyen az ismertetett esemény kapcsán kétségek merülnek fel, hogy azok a közöltek szerint történtek-e vagy egyáltalán megtörténtek-e. Ezek mindegyike olyan jellegű eseményről tudósít, amely csodás jelenségnek vagy természeti katasztrófának tekinthető és mint ilyen a kiadók kedvenc témái, vagyis jól eladható termékei voltak (és még ma is: tempora mutantur, sed nos non mutantur). Közülük néhány a magyar szakirodalom előtt eddig ismeretlen volt.

Elsőként a Budán 1578-ban Pünkösd vasárnap történt lőpor robbanás történetét említjük, amelyről több röplapot ismerünk. A Nürnbergben Leonhard Heussler kiadásában megjelent röplapon Buda látképe - amennyire a robbanás képétől felismerhető - a Braun-Hogenberg műben megjelent Buda látkép egyszerűsített másolata. A röplap alatti szöveg egy keresztényi intést is tartalmaz, amelyben az olvasót emlékezteti a földi élet mulandóságára. (153. kép)

A Fővárosi Szabó Ervin Könyvtár gyűjteményében lévő másik röplap Buda képzeletbeli látképével az alá ragasztott szöveg jelzése (Zu Nurmberg, bey Georg Macken, Illuministen beym Sonnenbad) szerint szintén Nürnbergben készült. A röplapszövegben szó sincs azonban a Budán történtekről, azt Georg Mack egy korábbi röplapjáról vágták le és ragasztották a lángoló Buda kép alá. Mivel a kép feletti röplap sem az eseményt, sem annak időpontját nem nevezi meg, a kép maga pedig nem robbanást, hanem felhőkből alázúduló tűzesőt mutat, bizonytalanság volt, hogy a kép egyáltalán mikor és minek a bemutatására készült. Mostani kutatásaink során megtaláltuk ennek a röplapmetszetnek egy olyan változatát, amelyen a kép feletti cím tartalmazza az 1578 évszámot is. Sajnos az ehhez a képhez tartozó röplapszöveg is elveszett. $(154,155$. kép)

A Temesváron történt lőporrobbanásról egy szintén Nürnbergben megjelent röplap számol be. Itt a robbanás története az érdekes, amelyről a röplap mellett több tudósítás is beszámolt, de különböző történettel. Van ahol a lőport egy keresztény fogoly robbantotta fel, van ahol villámcsapás okozta robbanást. A legtöbb tudósítás szerint a lőport a budai pasa küldte az erdélyi vajdának (Báthory Istvánnak) lengyelországi harcaihoz. Egy másik tudósítás arról ír, hogy az ezernégyszáz mázsa lőpor a Temes folyón hajóval érkezett Temesvárra. Abban mindegyik beszámoló megegyezik, hogy a robbanás után a Temes elárasztotta a környéket és a történtek Isten büntetése az emberiség bűneiért. Temesvár helytörténetében ez az esemény más forrásból nem ismert.
Egy további röplapon megjelent történetről annak egyedisége miatt szólunk. Ez a három változatban ismert röplap arról ad hírt, hogy Szikszó környékén mérhetetlenül elszaporodtak a kígyók és a gyíkok, amik valami betegséget okoznak, amibe Bebek Ferenc levele szerint már háromezer embernél több is meghalt, a betegekből és a holttestekből kígyók másznak elő. Ennek a történetnek hiteles forrásokban nem találtuk a nyomát, az előadott formában az nem is történhetett meg. Talán Szikszó környékén elszaporodtak a keresztes viperák (ma is vannak arrafele) és a megszokottnál sokkal több halálos kígyómarás történt. A röplap előzményeiről korábban már írtunk. (64, 65a és b. kép)

Kétségeink vannak Jost Amman röplapjának (a budai pasa Vác mellett mulatságot szervezett katonáinak, ahol az oroszlánja nem a póznához kötözött keresztény ifjút, hanem saját idomárját tépte szét), és a Kassánál feltűnt csodás égi jelenségről megjelent röplap igazság tartalmával. Ez utóbbi kötelességének érzi az embereket figyelmeztetni bűneik megbánására, a mindennapi vallásos életvitelre. Egy további röplap szerinti, Pozsonyban 1591-ben lejátszódó zsidó vérvád történettel nincsenek kétségeink, tudjuk, hogy az kitalált, időről-időre ismételten felbukkanó történet új környezetbe helyezve. A győri szörnyszülöttről szóló röplap állapota miatt valójában értékelhetetlen, hiszen olvashatatlansága miatt maga a közzétett történet sem ismert. A röplapon megadott pontos időponthoz (1590. június 14.) Magyarországon szörnyszülött születése nem köthető. (149, 158, 173, 174. képek)

Ezek az előbbi röplapok inkább jellemzőek a kor emberének érdeklődési körére, illetve a vallásos élet mindennapokra kiterjedő általános elfogadottságára, mint a 16. század magyar történelmére. Igazságtartalmuktól függetlenül annak idején így is hozzájárultak a Magyar Királyságról szóló ismeretek bővítéséhez (ne boncoljuk, milyen irányba) és az arról külföldön kialakuló képhez. Mondhatnánk, színesítik a 16. századi magyar kultúrtörténetet.

A munkánkban feldolgozott többi metszet vagy szóló lapokon, vagy könyvekben jelent meg. A metszetek készítői között kevés a múvészettörténelemben jelentős alkotóként számon tartott művész. Két Hans Springinklee, egy Hans Sebald Beham, három Erhard Schön, egy Virgil Solis, két Augustin Hirschvogel és talán egy Jost Amman mű tartozik ebbe a körbe. Ha arra gondolunk, hogy tévedés lenne a magyar történelem értékmérőjének tekinteni, hány metszetet készítettek „nagy nevek” a magyar eseményekről vagy városokról, akkor ez nem baj. De úgy tartjuk, jobb lenne, ha több neves művész magyar vonatkozású alkotására lehetnénk büszkék.

Az önálló metszetek (vagyis nem a címlapokon vagy röplapokon lévők) közel egy negyede könyvben jelent meg, többségük szövegközti képként. Közülük 
a legtöbb Baselben Henricus Petrus és fia Sebastian Henric Petri kiadásában, szinte kizárólag Sebastian Münster, Alphons Uloa valamint Nicolaus Höniger műveiben látott napvilágot és mind szövegközti fametszet. A Velencében készült metszetek közül több is megjelent könyvekben (ezekkel a könyvekkel munkánkban részletesebben is foglalkoztunk), ezek mind rézmetszetek. A Velencében, de elsősorban a Rómában megjelent metszetek felbukkannak a kor egyedi összeállításaiban, az úgynevezett Lafreri-atlaszokban is.

A rézmetszők többségét név szerint ismerjük, szinte mind a 16. század második felében alkottak. Közülük a nürnbergi Matthias Zündt, a több helyen dolgozó Wolfgang Meyerpeck, a velencei Domenico Zenoi és Paolo Forlani Veronese, a római Enea Vico, Antonio Lafreri és Mario Cartaro saját korukban az ismertebb és elismertebb rézmetszők közé tartoztak. A metszetkiadókban és rézmetszőkben bővelkedő Németalföld annak ellenére sem tanúsított érdeklődést a Magyar Királyság eseményei iránt, hogy szintén Habsburg uralom alatt volt. Igaz, az osztrák és spanyol Habsburg ág kapcsolata V. Károly császár uralma után már nem volt zavartalan. Az Európa szerte érdeklődést kiváltó 1565. és 1566. évi magyar földön történt eseményekről még Franciaországban is több metszet (André Thevet két műve mellett egy ismeretlen rajzoló röplapja Szigetvár ostromáról) jelent meg, mint Németalföldön (Hans Liefrinck Szigetvár metszetlapja).

A felkutatott és ismertetett metszeteknek pontosan egyharmada, 58 mú az előbb említett két év eseményeiről készült. Figyelemreméltó, de érthető is, hogy ezeknek több mint fele, 32 metszet az oszmán hatalommal közvetlenül határos és annak mindenkori fenyegetettségében élő Velencében jelent meg.

A metszetek között alig egy tucat van, ami mostani kutatómunkánk során vált ismertté, közülük néhányat megemlítünk. Közöttük van Augustin Hirschvogelnek az Apponyi metszet-gyüjteményben lévő Léva ostromát mutató rézkarca és a szintén általa jelzett Murány ostromkép sem szerepelt a nyilvántartott magyar esemény metszetek között. (62, 63. kép) Michael Zmmermann bécsi fametsző és nyomdász 1562-ben készített címlap-kerete, amelyet kisméretű városképekből (köztük Kismarton, Pozsony és Sopron képe) állított össze eddig is ismert volt, de rábukkantunk ennek a címlap-keretnek egy másik, szintén 1562-ben megjelent kiadására is. (73. kép) Említenünk kell egy 1566. évi Gyula ostromképet amely rajzát tekintve ikertestvére Matthias Zündt Gyula metszetének. A két metszet csak a feliratok írásformájában tér el, és címfeliratában is csak annyi a különbség, hogy a most felfedezett metszeten a „zu Prag” kiadási hely jelzése van Matthias Zündt neve helyett. Már eddig is ismert volt egy Szigetvár „ikermetszet”, hasonlóan egy névtelen metsző és szintén Matthias Zündt műveként. Ez a névtelen metsző egész biztosan azonos a „zu Prag” jelzésű metszet készítőjével és az is biztos, hogy ezeknek a metszeteknek a létrejötte között szoros összefüggés van. Ennél többet (ki kit másolt?) azonban nem tudunk, mert nem találtunk ebben a korban Prágában működő rézmetszőt. $(95,112$. kép)

Eltérve a magunk felállított határoktól, munkánkban két haditérképpel (Wolfgang Lazius 1566 és Natale Angielini 1565) is foglalkoztunk és azok képét közöljük. (71, 86. kép) Ugyancsak közéteszünk két kézi rajzot is, amelyek metszetelőképek lehettek. Ezek ismertetésénél kifejtettük, miért tartjuk indokoltnak a velük való foglalkozást. Müfajánál fogva nem illik munkánkba az utolsóként ismertetett Hungária vértanúsága metszet sem, de közlését munkánkban részletesen indokoltuk.

Nem térünk ki az elől a kérdés elől, amelyet a metszetekkel ismerkedők tesznek fel legtöbbször: mennyire hiteles a metszeten látható kép vagy ábrázolás? A válasz előtt, mint kiindulási pontokat, két dolgot kell leszögezni. Az első, hogy az olyan fokú és fajta hitelesség, amit a fényképek nyújtanak a ma éló ember számára (és ezért azt a korábbi korok képeitől is elvárja), az a 16-17. században készített metszeteken nem létezik, de nem is létezhetne. Ez elsősorban a látkép metszetekre vonatkozik és a helytörténészek egyik legnagyobb gondja, akik a metszetekből az elmúlt korok városképeit szeretnék megismerni, avagy helyreállítani.

A másik kiindulási pont, hogy az eseményábrázolások tekintetében a látvány hitelessége nem, csak a tartalom hitelessége értelmezhető és értékelhető. Egy csatakép soha nem a csata alatt készült, hanem utólag, a legritkább esetben személyes élmény vagy emlék, hanem szinte mindig képzelet alapján. Ez nem csak a csataképekre igaz, hanem bármilyen és bármelyik korban történt eseményről készült metszetre, lehet az akár temetési menet vagy eljegyzési kép. A metszet nyújtotta kép attól még nem hiteles, ha azon az esemény tényleges szereplői megjelennek (lásd Hans Spriginklee Habsburg-Jagelló eljegyzési metszetét). Egy esemény képéről csak a tárgyi hitelesség dönthető el. Ha azon olyan valaki vagy valami is szerepel, ami nem felel meg a történelmi ismereteknek vagy az adott kornak, akkor a kép hamis. Maradva az eljegyzési képnél, hamis lenne Springlinklee metszete, ha azon szerepelne az akkor Kasztíliában nevelkedő gyermek Ferdinánd fóherceg, vagy Zsigmond lengyel király nem kardot, hanem cilindert viselne.

Más megítélés alá tartoznak a helységeket bemutató látképek, amelyek két fajtáját szokták megkülönböztetni. Az ostromképeken általában látható az ostromlott vár vagy város képe, de az feltűnhet más jellegű esemény hátterében is. Ezeket másodlagos városképnek szokták nevezni. Vannak olyan metszetek, 
amelyeknek kizárólagosan a város bemutatása a célja (ilyenek a Braun-Hogenberg mű metszetei), ezeket nevezzük látkép metszeteknek. Mindkét esetben csak annak van értelme, ha azt vizsgáljuk, hogy a rajz készítője törekedett-e arra, hogy rajza a városról a valóságot tükrözze (két templom helyett ne rajzoljon hármat, a két templom tömege arányaiban és térbeli elhelyezésében feleljen meg a valóságnak stb.) Ezek és az ehhez hasonló képi elemek legtöbbje más forrásokból ismert lehet, tehát a valóságra törekvés viszonylag könnyen ellenőrizhető. Vigyázat: ha egy városképen minden máshonnan is ismert képi elem megtalálható, attól a városkép még nem mondható hitelesnek. A metszet ismert képi elemeken túlmenő részeit nem lehet ellenőrizni (a kisebb részletek nagy távlatból amúgy nem is láthatóak). Ezért a kép hitelessége helyett többen a város- vagy várképeknél inkább a látvány hitelességéről beszélnek, ami más, mint a fénykép nyújtotta hitelesség. Magunk részérről szívesebben beszélünk látképek esetében a valósághüségről, amibe a tartalmi és képi megfelelőség is beleértendő.

Egy városkép vagy látkép valósághủ ábrázolása elképzelhetetlen helyszínen készített rajzvázlatok (vagy ilyenek alapján készült korábbi kép) felhasználása nélkül. Ezek elkészítéséhez idő és biztos körülmények kellettek, amik háborús időkben a hadseregben szolgáló, jó rajzkészségű hadmérnököknek vagy az ostromsereghez csatlakozott vándor rajzolóknak adatott meg. Ha a törökök ostromoltak egy magyar kézen lévő várat, ott helyszíni rajzok készítésének a lehetősége fel se merült. Egy török kézen lévő vár lerajzolása békeidőben pedig életveszélyes kísérlet lett volna: kémkedés miatt a rajzoló akár életével is fizethetett, ha a törökök elkapták. Ezek miatt érthető, hogy a munkánkban szereplő 28 helyszín közül csak néhánynál van értelme ezt a „hiteles-valósághü" kérdést felvetni.

Szerencsére az egykori főváros, Buda ezek közé tartozik. Az 1541-es ostrom idején egy ismeretlen rajzoló (kilétéről lásd az Erhard Schön Buda metszeténél leírtakat) a helyszínen nagyon pontos rajzokat készített, aminek köszönhetően Erhard Schön nagyméretű fametszete biztonsággal állítható valósághű - bár nem hibátlan - látképnek. Ez a minősítés megilleti Schön metszetének a BraunHogenberg műben megjelent hüséges másolatát, illetve részben az abból kimásolt budai várpalota Sebastian Münster múvében megjelent származékát. Csak sajnálni lehet, hogy a 16. században született további 20 Buda ábrázolás mind képzeletbeli. A Murány várát nagy messzeségből bemutató Hirschvogel metszet pontosan azt a látványt nyújtja, mint egy kétszáz évvel később készített rajz, valósághűsége nem kérdőjelezhető meg. Hasonló a helyzet a Buda helyébe lépő másik fővárossal,
Pozsonnyal is. Az I. Miksa koronázása alkalmából megjelent röplapon lévő Pozsony látkép tereprajza és a város fontosabb épületei megfelelnek az ismereteknek. A kép összhatásában valóságérzetet ébreszt, és ez érződik az ebből a képből is merítő ismeretlen rajzoló metszetén, ami a Braun-Hogenberg mủben jelent meg.

Másféle megítélést igényelnek azok az 1566. évi hadjáratot követően megjelent metszetek, amelyek egy-egy város vagy vár alaprajzát mutatják (Győr, Gyula, Komárom, Szigetvár). Ezeknek a helyeknek a korban készült hadmérnöki alaprajzai több levéltárban vagy más közgyúiteményben is fennmaradtak. Az összehasonlítás alapján az mondható, hogy a metszeteken látható alaprajzok nagy vonalakban megegyeznek a fennmaradt rajzokkal (Gyula a kivétel, amelyhez tévedésből Eger alaprajzát használták fel). Itt a vizsgálódást érdemes befejezni. Egyrészt az alaprajzba berajzolt épületek kinézetéről szinte semmiféle adatot nem ismerni. Másrészt az ostrom időben egymást követő eseményeinek a metszeten egy időben történő ábrázolása a kép teljességének értékelését lehetetlenné teszi. Az, hogy ezekből mi került rá a képre, és hova, az a rendelkezésre álló helytől épp annyira függött, mint a rézmetsző ismereteitől, netán ízlésétől. Annyi mondható csak, hogy a képen több, vagy kevesebb, netán meg nem történt esemény is szerepel.

Tokaj ábrázolásának története megint egészen más. A szakirodalom szerint Zsámboky János és Michael Zimmermann közös vállalkozása az a röplap, amelynek csak egy javító példánya maradt fenn. Ez a röplap ebben az állapotában Tokaj képével és a javítási rájegyzésekkel a valóságra törekvés mintaképe is lehetne. Kár, hogy a röplap Tokaj képével javított formában nem jelent meg. (80. kép)

$\mathrm{Az}$ összes többi metszet, amely a helyszínek, vagyis a látképek közé lett sorolva, sajnálatosan képzeletbeli ábrázolás, néha véletlenszerű valós képi elemekkel. Emlékeztetőnek, múlt felidézőnek jók, talán még tetszetősök és szemgyönyörködtetők is, de egyetlen történelmi forrásértékük a létezésük.

A bevezetésben írtunk az ilyen jellegú munkák teljességre törekvő anyaggyűjtésérőll. Amit most átadunk, biztosan nem teljes és nem hisszük, hogy minden, ma még bárhol is létező metszetet össze tudtunk gyüjteni. Az alkalmi nyomtatványok címlapján megjelenő képek esetében ez nem is volt célunk, de azért sajnálni fogjuk, ha ezek közül felbukkan majd olyan, amit szívesen betettünk volna a munkánkba. Úgy hisszük, hogy nem ismert további röplapok felbukkanása valószínúbb, mint önálló metszetlapoké, vagy könyvben megjelent metszetek előkerülése. A közgyűjtemények anyagának hihetetlen mértékben növekvő megismerhetősége a világhálón azonban még sok meglepetést tartogathat. 
MELLÉKLETEK 
A Mellékletekben az ismertetett metszetek adatait tartalmazó Katalógus, a könyv használhatóságát segítő segédletek, mutatók és az Egyesített irodalomjegyzék szerepel.

A metszeteket a kezelhetőség érdekébe helyszínek és események szerint két csoportba soroltuk. Természetesen ez a csoportba sorolás minden esetben egyedi megfontolások alapján történt, hiszen nincs esemény helyszín nélkül, de készülhetett helyszínábrázolás, vagyis egy városkép csupán a látvány kedvéért esemény nélkül (igaz, a 16. században erre alig volt példa). A korszakra jellemzó várostromok többsége a helyszínek csoportba, a csatametszetek és a beltéri események (pl. Habsburg-Jagelló eljegyzés, Fráter György megölése) az események csoportba került.

A Katalógusban ABC sorrendben előbb a helyszínek csoportjába tartozó metszetek adatai szerepelnek, majd ezt követik az időrendbe sorolt események képei. A metszetek adatai közül elsősorban azok szerepelnek, amelyek a közölt képről ránézéssel nem állapíthatók meg (méret, megjelenési hely, készítő stb.). A metszetek elnevezésére a már ismertetett metszetazonosítót (helynév vagy eseménynév, év, sorszám) használjuk, majd megadjuk a méretet, a készítőjét (ha ismert), annak jelzését, esetenként a kép címét vagy más fontosnak tartott adatot. A metszet technikáját csak a fametszeteknél tüntetjük fel, rézmetszet-rézkarc esetében nem. Utolsó adatként az azonosító képszámot adjuk meg, amellyel a metszet a képtáblákon szerepel. A korábbi metszet-katalógusunk I-V. kötetében még nem szerepelö és a magyar metszet-szakirodalomban sem ismertetett metszeteket a Katalógusban *-gal jelöljük. A Katalógus néhány fennmaradt helyszíni felvételi rajz adataival zárul.
A Katalógust két összeállítás követi. Az első az 1566. évi hadjáratról Itáliában megjelent metszetek cím- és egyéb feliratainak fordításai, a másik Sebastian Münster Cosmographia múvének különböző kiadásaiban megjelent magyar vonatkozású metszetek leltára. Ezek után szerepel a Művészek, metszetkiadók jegyzéke, majd a sort az Egyesített irodalomjegyzék zárja. Ebben szerepelnek mindazok a tudósítások (lehetőleg megadva VD 16 azonosítójukat), amelyek címlapját közöljük. Ezt követik azok a könyvek, amelyekben az ismertetett metszetek megjelentek, majd a felhasznált irodalom jegyzéke.

A felsorolt metszetek pár kivétellel mind megtalálhatók magyarország köz- és magángyűjteményekben. Ha a metszet olyan tudósításban vagy könyvben jelent meg, amely megvan az Apponyi Hungarica gyüjteményben, akkor annak lelőhelyeként az Apponyi azonosítót megadjuk, egyéb esetben nem. A mindig több példányban készült röplapoknál, vagy önálló metszetlapoknál lelőhelyeként sem a külföldi, sem a hazai magángyűjteményeket (a szerző gyűjteménye kivételével) nevesíteni nem áll módunkban, ezért lelőhelyként elsősorban a magyarországi közgyűjteményeket adtuk meg. Lelőhelyként ugyanakkor feltüntettünk néhány korábbi, azóta szétszóródott híres magángyưjteményt (pl. gróf Pálffy József gyűjteménye /Szomolány/, Szántai gyűjtemény /Párizs/, Gróf László gyűjteménye /Oxford/) is, ha fényképfelvételük fennmaradt. A nagyon ritkán előforduló metszetek esetében lelőhelyként külföldi közgyűjteményeket is megnevezünk, ha azok magyar közgyűjteményben nem találhatók vagy a magángyűjteményt ahol őrzik nem nevezhettük meg, netán egyetlen ismert példányról van szó.

\section{Rövidítések:}

App. H. Országos Széchényi Könyvtár, Apponyi Hungarica gyüjtemény

App. M. Országos Széchényi Könyvtár, Apponyi Metszetgyüjtemény

BNF Bibliothèque nationale de France, Paris

BTM_Budapest Történeti Múzeum, Budapest

FSZEK Fővárosi Szabó Ervin Könyvtár, Budapest

HAB Herzog August Bibliothek, Wolfenbüttel

MNM Magyar Nemzeti Múzeum, Budapest

Németh S. Katalin Németh S. Katalin: Ungarische Drucke und Hungarica 1480-1720. Katalog der Herzog August Bibliothek, Wolfenbüttel

o. k. oldalak között

OSZK Országos Széchényi Könyvtár, Budapest

Röpl. Hubay Ilona: Röplapok, újságlapok, röpiratok 1480-1718. Bp., 1948.

Strauss Strauss, Walter L.: The German Single-Leaf Woodcut 1550-1600. A Pictorial Catalogue I-III. New York, Abaris Books Inc., 1975.

Szalai Szalai Béla: Magyar várak, városok, falvak metszeteken, 1515-1800. I-V., Budapest, /Múzeum Antikvárium/, $2006-2018$.

TKcs Magyar Nemzeti Múzeum, Történelmi Képcsarnok, Budapest 


\section{KATALÓGUS}

\section{HELYSZÍNEK}

\section{Brassó}

Brassó 1550/1* Szövegközti fametszet, hátoldalán szöveg, méret 8,0x6,0 $\mathrm{cm}$. Ismeretlen metsző műve. Képzeletbeli ábrázolás. Megjelent Münster, Sebastian: Cosmographiae universalis Basel, Heinrich Petri, 1550. 919. oldal. A metszet további megjelenéseit lásd a Mellékletek között Sebastian Münster Cosmographia könyvének fametszetes magyar városképei címmel. (57. kép)

\section{Buda}

1. Buda 1526/1 Fametszet tudósítás címlapján, méret kb. 10,6×11,9 cm. Ismeretlen metsző műve, képzeletbeli ábrázolás. A kép felett „Ofen” felirat. Megjelent: SEnsuyuêt les faictz du chien in/saciable du sang chrestien, ql se/ nöme Lempereur de Turquie. [...] Nouuellemēt translate Dallemãt/en francoys. [Kolofon:] Finis. L’an. M. D. XXVI. a címlapon. OSZK, App. H. 1656. Rózsa 1999/286 (30. kép)

2. Buda 1526/2 Fametszet tudósítás címlapján, méret kb. 8,0×9,5cm. Ismeretlen metsző műve. A képen a háttérben egy égő város képe, előtte két szekér katonákkal. A tudósítás Buda és Pest kirablásáról, felgyújtásáról és a környék elpusztításáról szól. Megjelent: Hernach volget des Bluthundts der sich nennet eyn Türckischen Kayser [...] an vnnsern der Hungerischen Landtschafften gantz vnmenschlich getriben hat/vnd noch teglichs thut. [Nürnberg: Jobst Gutknecht 1526], a címlapon. VD16 B 5796 OSZK, Röplap 66. Rózsa Ø (31. kép)

3. Buda 1526/3 Fametszet tudósítás címlapján, méret kb. 10,6×11,9 cm. Ismeretlen metsző műve. A fametszet korábbi szerzők szerint a mohácsi vereség után magára hagyott Budára behatoló törökök utcai kegyetlenkedését ábrázolja. Megjelent: Hernach volgt des Bluthundts, der sych nennedt ein Türckischer Keiser [...] auff den 8. Tag Augusti [...] Mitbrüdern der Vngrischen Lantschaften gantz unmenschlich triben hat, vnd noch teglich tut. [Augsburg], [Steiner], 1526. a címlapon. VD16 B 5794. A tudósítás utolsó oldalán egy másik tudósítás címlapján is megjelent fametszet (Török vérengzés 1526), amelyen török katonák kisgyermekeket vágnak ketté. A metszet újra megjelent a Vier warhafftige Missiue : eyne der frawen Jsabella Künigin vn[d] nachgelassne Wittib in Vngern [...] Auß dem Latein inns Teütsch gebracht [Augsburg] [Steiner], 1542. tudósítás címlapjának hátoldalán. VD16 V 1055 Rózsa 1999/287. (34. kép)

4. Buda 1532/1 Méret 34,5x27,0 cm, a kép alatti szöveg 20,5×8,5 cm. Agostino Veneziano (Agostino de Musi Veneziano) rézmetszete, jelzése 1532/A. V. a kép jobb alsó sarkában, a kiadó Antonio Salamanca jelzése (Ant. Sal. exc.) felett. Címe nincs, a kép alatti szövegtáblán az 1532. évi török hadjárat rövid ismertetése. A térképszerű ábrázoláson a Duna ausztriai és felsőmagyarországi szakasza, jobb szélen Buda jelképes ábrázolása, a kép többi részét a török és a császári katonaság tábora tölti ki. OSZK, App. M. 554 Rózsa 1999/288 (43. kép)

5. Buda 1536/1 Szövegközti fametszet, hátoldalán szöveg, mérete 4,7x4,7 cm. Ismeretlen metsző műve, képzeletbeli ábrázolás. Címe, felirata nincs. Megjelent Münster, Sebastian: MAPPA EVROPAE, Eygentlich /fürgebildet, aussgelegt vnd beschriebenn. Frankfurt am Main, Christian Egenolph, 1536. Eiii levél, a Császár fürdő képzeletbeli képe mellett, balra. Rózsa 1999/289 (44. kép)

6. Buda 1536/2 Szövegközti fametszet, hátoldalán szöveg, mérete 4,7x4,7 $\mathrm{cm}$. Ismeretlen metsző műve, képzeletbeli ábrázolás. Címe, felirata nincs. Megjelent Münster, Sebastian: MAPPA EVROPAE, Eygentlich /fürgebildet, aussgelegt vnd beschriebenn. Frankfurt am Main, Christian Egenolph, 1536. Eiii levél, Buda képzeletbeli képe mellett, jobbra. Rózsa 1999/290 (45. kép)

7. Buda 1541/1 Fametszet, méret 142,9x44,5 cm. Öt fadúcról nyomva. Erhard Schön múve, amely Hans Sachsnak Buda 1541. évi ostromáról írt versévek közös lapon jelent meg. Címe a kép felett „Ein ware Contrafactur oder verzeychnus der Königlichen Stat Ofen in Vngern jr belegerung sampt dem vnglückhafftigen Scharmuetzel des pluturstigen Tuercken mit dem Konigklichen heerleger im September des 1541. jars." Buda nyugati nézetű látképe, sok valós részlettel, több azonosító felirattal. A kép alatt 15 hasábos verses szöveg „Schaw an ein war Contrafactur ... Das wünscht vns vs Nürnberg H. S.” a végén impresszum: „Steffan Homer zu Nûrenberg.” Egyetlen ismert példány Albertina Museum, Wien. A 20. században az eredeti fadúcokról utánnyomatok készültek. Rózsa 1999/1 (46. kép)

8. Buda 1541/2 Fametszet tudósítás címlapján, méret kb. 11,0x 8,5 cm. Ismeretlen metsző műve, Buda jelképértékű ábrázolása a háttérben egy dombtetőn. Megjelent: Warhafftige Anzeygu[n]g wie es im Leger vor Ofen 
ergangen ist. [Nürnberg], [Andreae, Hieronymus], 1541. a címlapon. VD16 W 195 OSZK, App. H. 1717 Rózsa 1999/293 (49. kép)

9. Buda 1541/3 Fametszet tudósítás címlapján, méret kb. 11,0x13,0 cm. Ismeretlen metsző műve, Buda jelképértékű ábrázolása a csatajelenet hátterében. Megjelent: Warhafftige Anzeygu[n]g wie es im Leger vor Ofen ergangen ist. [Augsburg], [Steiner], 1541. a címlapon. VD16 W 191 Rózsa Ø (50. kép)

10. Buda 1541/4 Fametszet tudósítás címlapján, méret kb. 9,0x6,0 cm. Ismeretlen metsző műve, csatajelenet az ostromló Roggendorf és Budához érkező török seregei között(?). A tudósítás utolsó oldalán szintén egy csatajelent fametszete van. Megjelent: Warhafftige Anzeigung wie es im Leger vor Ofen ergangen ist. [Augsburg], [Steiner],1541. a címlapon. VD16 W 192 Rózsa Ø (51. kép)

11. Buda 1542/1 Fametszet, méret 101,0x36,3 cm. Négy fadúcról nyomva, Virgil Solis műve, Pest 1542. évi ostromát ábrázolja. Buda valósnak tűnő keleti nézetű képe. Az egykor gróf Pálffy János pozsonyi gyűjteményében lévő példány (fényképe az MTKcs gyűjteményében) ma lappang. Másik hiányos, bal szélső fadúc nélküli példánya Nürnberg, Germanisches Nationalmuseum Graphische Sammlung Inv. Nr. HB 262 Kapsel 1340. Rózsa 1999/378 (47. kép)

12. Buda 1542/2 Méret 40,5×29,0 cm. Vico Enea műve, jelzése „E. V. 1542” a kép jobb alsó részén. Címe nincs. Buda keleti nézetű látképe pár valós részlettel, olasz feliratokkal. OSZK, App. M. 25. Rózsa 1999/100 (53. kép)

13. Buda 1550/1 Szövegközti fametszet, hátoldalán szöveg, méret 17,7x9,0 cm. Ismeretlen metsző műve, a királyi palota másolata Erhard Schön metszetéről. Megjelent Münster, Sebastian: Cosmographiae uniuersalis Lib. VI. Basel, Henricum Petri, 1550. 868. oldal és Höniger, Nicolaus: Erster und Ander Theil der Türckischen Historien. Basel, Sebastian Heinric-petri, 1578. 10 oldal. A metszet további megjelenéseit lásd a Mellékletek között Sebastian Münster Cosmographia könyvének fametszetes magyar városképei címmel. Rózsa 1999/38 (58-61. kép)

14. Buda 1572/1 Bécs látképével közös lapon, méret 47,8x31,2 cm (az egész metszet), Buda képe 47,8x15,0 cm. Ismeretlen rézmetsző műve. Címe fent a képben szószalagon: „BVDA, vulgo Ofen, prima \&regia/ Vngarici regni ciuitas, ad Danubium/sita: quam Ptolemaeus Curtam, vei, vt alijs / persuasum est, Salmum nominat. Fran: Jre." Megjelent Braun, G. - Hogenberg, F.: Civitates orbis terrarum. Liber primus. Köln, 1572. 41. lap. A metszet megjelent a mű későbbi kiadásaiban is, egyes példányokon a két látkép között „cum privilegio” felirattal. Rózsa 1999/2 (170. kép)

15. Buda 1578/1 Fametszet röplapon, méret 28,5x17,1 cm (a metszet). Ismeretlen metsző műve. A lángokban álló város képe a Braun--Hogenberg könyvben megjelent Buda látkép származéka. A röplap címe két sorban a kép felett „Kurtze und warhafftige Historia/ deß/ was sich am verschinen Pfingstmontag/ den 19. des Monats May/ dises 78. Jars/ zu Ofen in Vngern zugetragen/mit einer Christlichen eriñerung." A kép alatt szöveg két hasábban, a bal oldali az esemény leírása, a jobb oldali hasáb erkölcsi intés a keresztény olvasóhoz. A röplap végén „Gedruckt zu Nürnberg durch Leonhard Heussler” impresszum. Zürich Zentralbibliothek Graphische Sammlung (GSM) PAS II 15/31. Rózsa 1999/3 (153. kép)

16. Buda 1578/2/a Fametszet röplapon, méret 24,5x16,5 cm (a metszet). Ismeretlen metsző műve. Képzeletbeli városkép, OFEN és PEST feliratokkal, tűzesővel. A röplap címe a kép felett „Newe zeyttung auss Hungeren von Ofen vnnd Pesst.” Az egyetlen ismert példányon a kép alatti röplapszöveg a „Zu Nurmberg, bey Georg Macken, Illuministen beym Sonnenbad" impresszummal nem az eredeti, hanem egy másik röplaphoz tartozik. FSZEK Budapest Gyűjtemény Bp 0941/370. A példányról 2006-ban fakszimile kiadás készült. A röplap az 1578 Pünkösdkor történt lőporrobbanás alkalmából jelenhetett meg. Rózsa 1999/295 (154. kép)

17. Buda 1578/2/b Fametszet, méret $24,2 \times 18,7$ cm. Ismeretlen metsző műve. Az előzővel azonos képzeletbeli városkép, OFEN és PEST feliratokkal, tűzesővel. A kép felett „Newe zeytung auß Hungeren von Ofen vnd Pesst/ geschehen im 1578. Jar" felirat. Az egyetlen ismert példánya - amely bizonyára egy röplapról lett levágva - Zürichben a Johann Jakob Wick gyűjteményben. Egyes vélemények szerint Valentin Schönig (Augsburg) műve. Zürich Zentralbibliothek Graphische Sammlung (GSM) PAS II 15/29. A röplap az 1578 Pünkösdkor történt lőporrobbanás alkalmából jelenhetett meg. Rózsa 1999/295 változat (155. kép)

18. Buda 1581/1 Szövegközti fametszet, hátoldalán szöveg, méret 14,3×11,0 cm. Ismeretlen metsző műve. Címe nincs. Képzeletbeli városkép Buda 1526. évi török kirablásáról szóló szöveg illusztrálásához. Megjelent Pantaleone, Henricus: Militaris ordinis Johannitorum, Rhodiorum aut Melitensium [...] ad praesentem usque 1581 annum historia nova, libris 12 comprehensa Basileae, [Guarin], 1581. 204. o. Rózsa 1999/296 (32. kép)

19. Buda 1581/2 Szövegközti fametszet, hátoldalán szöveg, méret 14,2x10,3 $\mathrm{cm}$. Ismeretlen metsző műve. Címe nincs. Képzeletbeli városkép, illusztráció Buda 1541. évi török elfoglalásának leírásához. Megjelent Pantaleone, Henricus: Militaris ordinis Johannitorum, Rhodiorum aut Melitensium [...] ad praesentem usque 1581 annum historia nova, libris 12 comprehensa Basileae, [Guarin], 1581. 286. o. Rózsa 1999/297 (33. kép)

20. Buda 1590/1 Fametszet, méret $26,5 \times 15,0 \mathrm{~cm}$. Ismeretlen metsző műve. A képen egy török zenés felvonulás, a háttérben Buda kezdetleges keleti nézetű 
látképe. A metszet felett három sorban a kép könyvön belüli elhelyezésének (a könyvkötő számára?) leírása. Megjelent Löwenklau, Johannes: Neuwe Chronica türckischer Nation von Türcken selbs beschrieben, volgendts gemehrt, unnd in vier Bücher abgetheilt; alles jetzo durch Hansen Lewenklaw von Amelbeurn. Franckfurt am Mayn, Andres Wechels seligen Erben, 1590. Theil III. 118-119. A könyv 1595. évi kiadásában a metszet feletti háromsoros leírás elmarad. Rózsa 1999/101 (172. kép)

21. Buda 1592/1 Fametszet röplapon, méret 34,9x27,2 cm (a metszet). Lucas Mayer műve. A kép bal felső sarkában Buda képzeletbeli képe, a jobb felső sarokban egy város, felette WIHITSH felirat. A képet harci jelenetek és török fosztogatások képei töltik ki. A röplap címe két sorban a kép felett: Erschröckliche Newe Zeitung geschriben auss Wien den 19 Junij dises 92 Jars. Wie der ürcken vil Christen Blut vergossen hat A kép alatt szöveg három hasábban, végén impresszum: Nürnberg bey Lucas Mayer Form/schneider zuerfragen. Rózsa 1999/298. (175. kép)

Eger

1. Eger 1567/1 Méret 27,5×19,5 cm. Zenoi, Domenico műve, jelzése „Dnco Zenoi” a cím alatt, a kartusban. Címe „AGRIA fortezz .... l'anno 1567” a jobb felső sarokban kartuson, négy sorban. Megjelent Forlani, Paolo Veronese: Il primo libro delle citta. Venetia, 1567. (28) lap OSZK, App. H. 3069. A metszet hátoldala mindkét felén Eger leírásával és „35” lapjelzéssel megjelent Ballino, Giulio: De disegni delle piu illustri citta et fortezze. Venetia, 1569. 35. lap OSZK, App. H. 428. (130. kép)

2. Eger 1568/1/a Méret 26,1x18,2 cm. Pozzoserrato, Ludovico műve, jelzése „L.P.” a jobb alsó sarokban, nagyon kicsi táblán. Címe „AGRIA fortezza ... l’anno 1568” a jobb felső sarokban kartuson, négy sorban. „1567. évi metszetének másolata kisebb méretben és átjavított évszámmal Megjelent Bertelli, Ferrando: Civitates aliquot insigniorum et locorum. Venetia, 1568. MNM TKcs T.3854 (131. kép)

3. Eger 1568/1/b. Az előző metszet, de az „L.P." jelzést eltávolították, csak a helye ismerhető fel. Szalai gyűjtemény (132. kép)

\section{Esztergom}

1. Esztergom 1543/1/b Fametszet tudósítás címlapján, méret kb. 7,5x10,0 $\mathrm{cm}$. Ismeretlen metsző műve. Képzeletbeli ábrázolás. Megjelent: Gründliche vnd warhafftige Anzaygung wie das Königlich Schloß Gran in Hungern von den
Türcken belegert beschossen vnd eingenommen ist. [Nürnberg], [Vom Berg; Neuber] 1543. a címlapon. Németh S. Katalin H717. VD16 G 3528 (54. kép)

2. Esztergom 1543/1/c Fametszet tudósítás címlapján, méret kb. 11,0x13,0 cm. Ismeretlen metsző műve. Képzeletbeli ábrázolás. Megjelent: Gründliche unnd warhafftige Anzeygung, wie das königlich Schloss Gran, in Hungern von den Türcken belegert, beschossen, und erbermiglich von den Jtalianern dem Türcken uber geben. [S.l.], [1543] a címlapon. Németh SK Hungarica H 718. (55. kép)

3. Esztergom 1566/1 Szövegközti fametszet, hátoldalán szöveg, méret 5,4x5,4 $\mathrm{cm}$. Ismeretlen metsző műve. Az előtérben lovaskocsi, lovas, építkezés. A kép alatt Oláh Miklós esztergomi érseket dicsőítő vers. Megjelent Sambucus, Joannes: Emblemata et aliquot nummi antiqui operis. Antwerpen, 1566. 240. oldal OSZK, App. H. 397) A könyv későbbi kiadásaiban a kép a 238. oldalon található. (129. kép)

\section{Győr}

1. Győr 1566/1 Méret 52,8x38,8 cm. Cartaro (Kartaro), Mario műve, jelzése „15 MVK (egymásra írva) 66” a címtáblán legalul, a lépték alatt. Címe „IAVARINO in ongaria et trinciere doue al present ... con lo esercito" a bal alsó sarokban címtáblán, három sorban. British Museum Maps C.7.e.1 (122. kép)

2. Győr (1566)/1 Méret 19,7x14,6 cm. Zenoi, Domenico műve, jelzése „Domenico Zenoi” a kép jobb alsó sarkában egy kövön. Címe „FORTEZZA DI IAVARINO/nei confini dell'Austria ... il campo del Christiani” a várudvaron, három sorban. MNM TKcs T.3860 (116. kép)

3. Győr (1566)/2 Méret 20,1x17,3 cm. Zenoi, Domenico műve, jelzése „Dnco Zenoi” a képen baloldalt felül, a cím alatt. Címe „Il Campo del Imp. pientato sopra Iavarino ... tutta la fanteriaa kép bal felső sarkában, öt sorban, nagyon apró betűkkel. (Bibliothéque nationale de France Cabinet des Estampes, Paris P165434 (120. kép)

4. Győr (1566)/3 Méret 19,7×14,6 cm. Zenoi, Domenico műve, jelzése „Domenico Zenoi” a kép jobb alsó sarkában egy kövön. Címe „FORTEZZA DI IAVARINO” a várudvaron. Jelzése „Domenico Zenoi” a kép jobb alsó sarkában egy kövön. A képen az (1566)/1 alatti metszetnél jóval kevesebb épület és katona. Hadtörténeti Intézet Térképtár H. III.b 78. (115. kép)

5. Győr 1567/1/a Méret 18,0x14,0 cm. Forlani, Paolo Veronese műve, jelzése „In mezaria de l'insegna della Colonna” a lefelé néző bástyán. Címe „FORTEZZA DI IAVARIN / doue si trova hora il campo de l'impator" a várudvaron, két sorban. Megjelent Forlani, Paolo Veronese: Il primo libro delle citta. Venetia, 1567. 
OSZK, App. H. 3070. A metszet újra megjelent Bertelli, Ferrando: Civitates aliquot insigniorum. Velence, 1568. Bachmann 901. (117. kép)

6. Győr 1567/1/b Az előző metszet újra megjelent a jobb alsó sarokban „86” lapjelzéssel (Camocio, G.F.): Isole famose porte, fortezze. Venetia, (1571)/ című könyvben 86. lapon. OSZK, App. H. 612/koll.2. (118. kép)

7. Győr 1567/2 Méret 20,5x14,9 cm. Zenoi, Domenico műve, jelzése „Domenico Zenoi” a kép bal oldalán, a négysoros leírás alatt. Címe „Il Cápo del Imp. sopra Iavarino con ... in Venetia l'anno 1566" a bal felső sarokban, négy sorban, nagyon apró betűkkel. Megjelent Forlani, Paolo Veronese: Il primo libro delle citta. Venetia, 1567. (23) lap OSZK, App. H. 3069. (121. kép)

8. Győr 1578/1 Szövegközti fametszet, hátoldalán szöveg, mérete 15,5x12,0 cm. Ismeretlen metsző műve."Abcontrafactur der Keyserlichen Maiestat Lager" a kép rövidebbik oldala felett, a képhez képest 90 fokkal elforgatva. Megjelent Ulloa, Alfons: Beschreibung des letsten Ungerischen Zugs. Basel / Henrichpetri/, 1578. lxxiij (73) oldal (140. kép)

9. Győr 1578/2 Szövegközti fametszet, hátoldalán szöveg, mérete 15,5x12,0 cm. Ismeretlen metsző műve. Nicolaus Höniger Ander Theil des Türckischen Historien Basel, 1596 a ccxxxij (232) oldalon és később Münster, Sebastian: Cosmographiae Universalis. Basel, 1578. 966. oldal. A metszet további megjelenéseit lásd a Mellékletek között Sebastian Münster Cosmographia könyvének fametszetes magyar városképei címmel. (146. kép)

10. Győr 1589/1 Méret 19,3x15,0 cm. Ismeretlen metsző rézmetszete, alaprajz. „BB” jelzés az alaprajz közepén. Megjelent Specklin, Daniel: Architektura von Vestungen. Strassburg, 1589. 17--18 lapok között. OSZK, Ant. 899 (169. kép)

11. Győr 1590/1* Fametszet röplapon, 25,0x14,0 cm a metszet, 26,7x36,7 cm az egész lap. Wolfgang Halbmaister műve. A képen a háttérben egy képzeletbeli városkép, attól jobbra egy hatalmas kőhíd, a folyó partján állókkal. A város előtt férfiak csoportja vesz körül egy teknőben fekvő gyermeket. A röplap szövegének nagyobbik része festékhiba miatt nem olvasható. Címe öt sorban a kép felett, második fele olvashatatlan: Warhafftige Contrafactur und Beschreibung eine erschröklichen Missgeburdt und Wunder Welches im diesen jetz fest werten Neuntzigsten jahr den vierzehenden Tag Juni [...]. A röplap alján Wolfgang Halbmaister /Wien/ impresszuma. Strauss 1550-1600 Vol. III. (173. kép)

\section{Gyula}

1. Gyula 1566/2 Méret 32,2x22,0 cm. Zündt, Matthias műve, jelzése „Nürnberg Mathis Zündt” az ismertető szöveg végén. Címe „GYULA” a képen fent kissé balra, külön keretben. A kép bal alsó sarkában, keretben Gyula 1566 évi elestének leírása öt sorban. OSZK, App. M. 30 (93. kép)

2. Gyula 1566/3 Méret 21,3x13,4 cm. Nelli, Nicolo műve, jelzése „Nicolo Nelli 1566” a címkeret jobb alsó sarkában. Címe „GIVLA / Fortezza in Ongheria nel confini di Trans / silvania assediata da insideli” a jobb felső sarokban, külön keretben, három sorban. OSZK, App. M. 29 (92. kép)

3. Gyula 1566/4* Méret 32,4x22,4 cm. Ismeretlen rézmetsző műve, amely jelzése (zu Prag) szerint Prágában készült. Címe „GYULA” a képen fent kissé balra, külön keretben. A kép bal alsó sarkában, keretben Gyula 1566 évi elestének leírása öt sorban, végén „zu Prag” helymegjelöléssel. Mathias Zündt Gyula 1566/2 metszetével zonos képet mutat. Ugyanennek az ismeretlen metszőnek van egy Szigetvár metszete is, amely képe megegyezik Matthias Zündt Szigetvár metszetével. Dillingen, Studienbibliothek Lafreri Atlas - X 123\#Nr.69a. A metszetnek a Germanisches Nationalmuseum-ban lévő példányát (Inventarnr. HB229) Matthias Zündt műveként tartják nyilván. (94. kép)

4. Gyula (1566)/1 Méret 18,0x13,5 cm. Zenoi, Domenico műve, jelzése „Domenico Zenoi” a címkeret jobb alsó sarkában. Címe „GIVLA Fortezza nel confin di Transsilvania ... l'anno 1566" a jobb felső sarokban külön keretben, három sorban. MNM TKcs T.5605 (91. kép)

5. Gyula 1567/1 Méret 21,3x13,4 cm. Zenoi, Domenico műve, jelzése „Dnco Zenoi 1566” a címkeret jobb alsó sarkában. Címe „GIVLA / Fortezza in Ongheria ... de Perthan bassa di Signor Turcho" a jobbfelső sarokban külön keretben, négy sorban. Megjelent Forlani, Paolo Veronese: Il primo libro delle citta. Venetia, 1567. (30) lap. OSZK, App. H. 3069 A metszet hátoldalán Gyula 21 soros leírásával és „38” lapjelzéssel újra megjelent Ballino, Giulio: De disegni delle piu illustri citta et fortezze. Venetia, 1569. 38. lap (OSZK, App. H. 428 (13) lap. (97. kép)

6. Gyula 1567/2/a Méret 17,7x13,7 cm. Forlani, Paolo Veronese múve, jelzése „Paolo Forlani Veronese ... della Colonna” a címkeret alatt három sorban. Címe „Vero disegno di Giula ... l'anno MDLXVI” a jobb felső sarokban külön keretben, négy sorban. Megjelent Forlani, Paolo Veronese: Il primo libro delle citta. Venetia, 1567. (15) lap OSZK, App. H. 3070 A metszet újra megjelent Bertelli, Ferrando: Civitates aliquot insigniorum. Velence, 1568. műben. (95. kép)

7. /b. A metszet újra megjelemt jobb alsó sarkában „87” lapjelzéssel a (Camocio, G.F.): Isole famose porte, fortezze. Venetia, (1571). című könyvben 87. lapként OSZK, App. H. 612/koll.2. (96. kép)

8. Gyula 1574/1 Szövegközti fametszet, hátoldalán szöveg, mérete 15,3×12,3 cm. Ismeretlen metsző műve. Megjelent Münster, Sebastian: Cosmographiae Universalis. Basel, 1574. 1192. oldal. A metszet újra megjelent a könyv 1578. évi kiadásában is. (143. kép) 
9. Gyula 1578/1 Szövegközti fametszet, hátoldalán szöveg, mérete 15,4×12,4 $\mathrm{cm}$. Gregorius Sickinger fametszete, jelzése „G+S” a képen baloldalt alul. Megjelent Ulloa, Alfons: Beschreibung des letsten Ungerischen Zugs. Basel / Henrichpetri/, 1578. xciij (93) oldal. (138. kép)

10. Gyula 1578/2 Szövegközti fametszet, hátoldalán szöveg, mérete 15,4x12,4 cm. Gregorius Sickinger fametszete, jelzése „G+S” a képen baloldalt alul. Höniger, Nicolaus: Ander Theil der Türckischen Historien. Basel, 1578. cxciiij (194) oldal és Münster, Sebastian: Cosmographiae Universalis. Basel, 1588 és A metszet további megjelenéseit lásd a Mellékletek között Sebastian Münster Cosmographia könyvének fametszetes magyar városképei címmel. (144. kép)

\section{Kassa}

Kassa 1580/1* Fametszet röplapon, méret 23,5x17,5 cm (a metszet). Ismeretlen metsző műve. A képen egy képzeletbeli városkép, előtte a bal sarokban két török katona, egyikük az égre mutatat, ahol három üstökös látszik. Közülük a jobb oldali lándzsában, a középső egy örök zászlóban, a baloldali egy kardban végződik. Mögöttük az égbolton egy csatajelent jelenik meg, a felhőkből vércseppek potyognak. A röplap címe a röplapról levágva és a kép fölé ragasztva: „Eigentliche und warhaffrige beschreibung der dreyen erschreckliche Commeten welche zu Cascha in Ungern ... verfast und aussgelegt /etc.” A kép alatt a verses szöveg négy hasábban, a röplap alján impresszum: „Gedruckt bey Anhony Corthois zu Frankfurt am Main / Im Jahr 1580. Zürich Zentralbibliothek - EBI04 [Sammlung von Nachrichten zur Zeitgeschichte aus den Jahren 1560-87 Johann Jakob Wick] Band 1580 Page 107r-109r (158-159. kép)

\section{Kismarton}

1. Kismarton 1562/1 Fametszet, részletkép címlapmetszeten, mérete kb 2,7x2,7, az egész címlap 16,0x21,0 cm. Ismeretlen metsző műve, képzeletbeli ábrázolás. Címe „EISENSTAT” a részletképen felül. (10) Sematikus városkép. A címlapot 18 város látképe keretezi, Kismarton képe jobb oldalon felülről harmadik kép, Baden és Bruck an der Leith között. Megjelent Fabricius, Paul Almanach [...] auff das Jahr M.D.L.X.III. Wien /Zimmermann, Michael/, 1562 címlapján. Michael Zimmermann városképes címlap-keretét később többször is felhasználták különböző kalendáriumokhoz (pl. Bartholomeus Reisacker: Schreibkalender, 1575, Schreib Kalender Wien, 1601) Bécsben, sőt Nürnbergben is (Newer und Alter Schreibkalender, Nürnberg 1612), néha a városképek sorrendje felcserélve, és a városnevek írásmódja is változott. (72. kép)
2. Kismarton $1562 / 2^{*}$ Fametszet, részletkép címlapmetszeten, méret $\mathrm{kb}$. 2,7x2,7 cm (az egész címlap 16,0x21,0). Címe „EISENSTAt” a részletképen felül. Sematikus városkép. A címlapot 18 város látképe keretezi, Kismarton képe a jobb szélen, Baden és Bruck am der Leita képe között. Megjelent: Diarivm Cvm Ivdicio Astrologico. Per Magistrum Klayberum à Weyssenhorn [...] Ad Annum Christi Salvatoris nostri. M.D.LXIII. Viennae Austriae, Michael Zimmerman, [1562] címlapján. A címkeret további megjelenéseiről lásd a Kismarton 1562/1 metszetnél leírtakat. (73. kép)

\section{Komárom}

1. Komárom 1567/1 Méret 26,6×17,6 cm. Forlani, Paolo Veronese műve, jelzése „Alla libraria della Colonna” a cím alatt a címkeretben. Címe „Il vero disegno del sito e della fortezza di Comar ... parte del' Ungaria in Venetia l'Anno 1567" a bal felső sarokban külön keretben, három sorban. Megjelent Forlani, Paolo Veronese: Il primo libro delle citta. Venetia, 1567. (25) lap. OSZK, App. H. 3069 A metszet újra megjelent Ballino, Giulio: De disegni delle piu illustri citta et fortezze. Venetia, 1569. 37. lap. (133. kép)

. Komárom 1568/1 Méret 25,2×17,2 cm. Bertelli, Ferrando műve, jelzése „Ferando bertelli excudebat” a cím alatt a címkeretben. Címe „Il vero disegno del sito e della fortezza di Comar ... parte del' Ungaria” a bal felső sarokban külön keretben, három sorban. Megjelent Bertelli, Ferrando: Civitatis aliquot insigniorum. Venetia, 1568. MNM TKcs T.3883 (134. kép)

\section{Kőszeg}

Kőszeg (1532)/1 Méret 111,9x30,5 cm. Erhard Schön fametszete. Címe „Ein Klag zu Gott vber die grausamliche manigfaltigen wütery deß Blutdürstigen Türcken vmb gnedige Hilff” a kép felett. A várkép felett „Güns” felirat. A metszetkép Hans Sachsnak a kőszegi ostromról irt dicsőítő versével közös lapon jelent meg, azonban ilyen példány ma már nem ismert. (12) British Museum MS/PM/OBJ. No. C.B. I. 439-3. 49-10-31-255.(42. kép)

2. Kőszeg 1532/2* Fametszet tudósítás címlapján, méret kb. 6,0x6,0 cm. Ismeretlen metsző műve. Képzeletbeli várkép. Megjelent: Des Turckischen keysers veruaerlicke beleg, der stadt è̄ slot Guns genomt, è̄ des seluen na twaelf verlorē stormen aftoceh[!], bi dē edelē ridder Niclaes Jurischitz [...] aen Ferdinandus roomsche coninc wt der voorghenoemde stadt Guns. Amsterdam, Pietersz Doen, 1532 a címlapon. (40. kép) 
3. Kőszeg 1532/3 Fametszet tudósítás címlapján, méret kb. 12,0x8,0 cm. Ismeretlen metsző műve. A képen egy küldönc térden állva nyújt át egy levelet egy török méltóságnak. Megjelent: Des Türcken erschrökenliche Belegerung der Stat vnd Schloß Günß [...] Ritter Niclaus Jurischitz Hauptman daselbs/ Römischer Künig. Mayestat auß Günß/ warhafftiglich zůgeschrieben. [S.l.], 1532. a címlapon. VD16 ZV 29162 (41. kép)

\section{Léva}

Léva 1549/1* Méret 47,7x27,3 cm. Hirschvogel, Augustin műve, jelzése „15A†HF49” a metszeten balra, alul. Címe „PELEGERUNG DES VESTEN SCHLOS LEIWAY, IM 1549 IAR DE 22 APRIL.S UND IST SOLCHS DURCH HERREN NICLASEN GRAFEN ZU SALMEN GENERAL OBERSTE EROBERT UD EINGENUMEN WORDEN. ETC.i" a képen fent középen, három sorban. Az ostromképen egyetlen katona sem látható. OSZK, App. M. 358. (62. kép)

\section{Lippa}

Lippa 1551/1* Fametszet tudósítás címlapján, méret kb. 8,5×10,0 cm. Ismeretlen metsző műve. Képzeletbeli ábrázolás. Megjelent: Newe Zeitung Von der Turkischen Kriegsrustung, so itzigen Winter in Ungern gebracht, etc. Leipzig, Georg Hangsohen, 1551. a címlapon. (67. kép)

\section{Murány}

Murány 1549/1 Méret 28,0x17,3 cm. Hirschvogel, Augustin műve. Címe „MVRANO” a képen jobbra fent, a vár felett. A bal oldali hegynyeregben ostromtábor. A képen alul, kissé jobbra „1549” évszám. Az ostromjelenet nehezen ismerhető fel, a metszet összességében inkább tájkép jellegű. Jane S. Peters (ed.): The Illustrated Bartsch 18 Formerly Volume 9 (Part 1) German Masters of the Sixteenth Century. New York, OPAL Publishing Corporation, 1982, 95-363. képpel. A metszet egy példánya Albertina Museum, Wien, Inv. DG1930/2163 (63. kép)

\section{Nagyszeben}

Nagyszeben 1544/1 Szövegközti fametszet, hátoldalán szöveg, méret 6,0x5,5 cm. Ismeretlen metsző műve. Képzeletbeli ábrázolás. Megjelent: Münster, Sebastian: Cosmographey oder Beschreibung aller Länder. Basel,
Heinrich Petri, 1544. 554. oldal. A metszet további megjelenéseit lásd a Mellékletek között Sebastian Münster Cosmographia könyvének fametszetes magyar városképei címmel. (56. kép)

\section{Nándorfehérvár /Belgrád/}

1. Nándorfehérvár 1521/1 Fametszet, méret 39,7x20,9 cm. Hans Sebald Beham műve. Címe nincs. A képen fent középen áthúzott kézírással „Pozson” felirat. A kép jobb oldalán hegytetőn vár, a hegyoldalon a várig felkúszó erős város képe. A kép előterében a folyón csónakok török katonákkal. Budapest, MNM TKcs T.39 (2 példány) Bubics 82/30 (képpel). (14. kép)

3. Nándorfehérvár 1522/1* Fametszet, méret 39,0x28,1 cm. Hans Sebald Beham műve. A képen fent, a képmezőbe nyomtatva 19 sorban a város és az ostrom leírása, a végén „Gedruckt zu Nürnberg durch Wolffgang Resch formschneider. 1522." jelzés. Olim Szántai gyűjtemény, Párizs. Egy másik példánya Wien, Albertina Museum Inv. D/I/21/58 (15. kép)

4. Nándorfehérvár 1522/2* Fametszet, méret 37,0x26,8 cm. Hans Sebald Beham műve. A látkép bal széléről mintegy másfék $\mathrm{cm}$ lemaradt, kisebb lapon egyébként azonos az előzővel. Azonos a lapra nyomtatott ismertető szöveg is, de más szedéssel 15 sorban, a végén „Gedruckt zu Nürnberg durch Jost Denecker. 1522.” jelzés. Egy példánya Sammlung Universitätsbibliothek Heidelberg, Inv. nr. EBD 019 (16. kép)

5. Nándorfehérvár 1550/1 Szövegközti fametszet, hátoldalán szöveg, méret kb. 15,0x12,0 cm. Jakob Clausenő műve, jelzése egymásra írt I és G ligatúra a folyóra nyíló városkapunál. Hans Sebald Beham metszetének másolata. Megjelent Münster, Sebastian: Cosmographiae universalis. Basel, Heinrich Petri, 1550. 869. oldal. A metszet további megjelenéseit lásd a Mellékletek között Sebastian Münster Cosmográfiájának fametszetes magyar városképei címmel. (17-20. kép)

\section{Pozsony}

1. Pozsony 1562/1/ Fametszet, részletkép címlapmetszeten, mérete kb. 2,7x2,7, az egész címlap 16,0x21,0 cm. Ismeretlen metsző műve, képzeletbeli ábrázolás. Címe „PRESBVRG” a részletképen felül. A címlapot 18 város látképe keretezi, Pozsony képe alul, Judenburg és Sopron képe között. Megjelent Fabricius, Paul Almanach [...] auff das Jahr M.D.L.X.III. Wien /Zimmermann, Michael/, 1562. Michael Zimmermann városképes címlap-keretét később többször is felhasználták különböző kalendáriumokhoz (pl. Bartholomeus Reisacker: Schreibkalender, 1575, Schreib Kalender Wien, 1601) Bécsben, sőt Nürnbergben 
is (Newer und Alter Schreibkalender, Nürnberg 1612), néha a városképek sorrendje felcserélve, és a városnevek írásmódja is változott. (72. kép)

2. Pozsony 1562/2* Fametszet, részletkép címlapmetszeten, méret kb. 2,7x2,7 cm (az egész címlap 16,0x21,0) Címe „PRESBVRG” a részletképen felül. Sematikus városkép. A címlapot 18 város látképe keretezi, Pozsony képe alul, Judenburg és Sopron képe között. Megjelent: Diarivm Cvm Ivdicio Astrologico. Per Magistrum Klayberum à Weyssenhorn [...] Ad Annum Christi Salvatoris nostri. M.D.LXIII. Viennae Austriae, Michael Zimmerman, [1562] címlapján. A címkeret további megjelenéseiről lásd a Pozsony 1562/1 metszetnél leírtakat. (73. kép)

3. Pozsony 1563/1 Fametszet röplapon, méret 63,6x40,0 cm. Mayer /Mayr/, Hans műve, jelzése „HM” (egymásra írva) jelzés a bal saroknál a sátortól balra, a bokor alatt. Címe „WARE CONTERFACTVR DER STADT PRESBVRG” a képen fent középen, szószalagon. A röplap címe a kép felett két sorban Warhafftige Contrafactur und Beschreibung Krönung Maximiliani des Andern/Römischen Kaysers/ so geschehen in Bressburg in Ungern M.D.LXIIJ. DNE 8. Septemb. A metszet alján „An den Leser. Kurzer Begriff der ganzen Krönung." felirat, a metszet alatt a koronázási események verses leírása négy hasábban, a végén négyhasábos leírása olvasható, a végén Caspar Stainhofer bécsi impresszumával. Szántai gyűjtemény és MG Ba, C7196 (75. kép)

4. Pozsony 1566/1 Fametszet röplapon, méret 63,6x40,0 cm. Mayer /Mayr/, Hans műve, jelzése „HM” (egymásra írva) jelzés a bal saroknál a sátortól balra, a bokor alatt. Címe „WARE CONTERFACTVR DER STADT PRESBVRG” a képen fent középen, szószalagon. A röplap címe a kép felett két sorban „CORONATIO MAXIMILIANI II. FACTA POSO // NII VIII. SEPT. MDLXIII.CVM LOCI, COMITATVS, PICTVRA ETC.” felirat két sorban. A kép alatt „SAMBVCVS AD LECTOREM" kezdettel (Zsámboky János alias Johannes Sambucus) verse négy hasábbban. A röplap egy példánya fennmaradt bekötve a (Steinhofer, Caspar) Gründliche und Kurtze Beschreibung des alten und jungen Zuges von Frankfurt bis Wien 1566. könyvben. München, SB Rar.250.20 (74. kép)

5. Pozsony 1588/1 Méret 48,6x29,5 cm. Ismeretlen művész rézmetszete. Címe „POSONIVM uel / Pissonium vt Lazius Hungariae vrbs” a kép jobb felső sarkában táblán, két sorban. A képen fent középen «Pressburg» felirat. Megjelent Braun, G. - Hogenberg, F. Civitates orbis terrarum. Köln, IV. kötet 44. lap OSZK, App. M. 63. (171. kép)

6. Pozsony 1591/1* Fametszet röplapon, méret $28,0 \times 17,5 \mathrm{~cm}$ a kép, 29,0x38,5 cm az egész lap. Lucas Mayer műve. A képen jobbra egy égő ház, a háttérben vár, három karóba húzott ember, templom. Az előtérben egy asztal körül álló férfiak. Címe három sorban a kép felett Ein erschröckliche
Newe Zeitung, so sich im 1591. Jar zu Preß=burgk in Ungern zu getragen/ wie daselbst etliche Juden[...] Christen zu einer warnung. A röplap alján Lucas Mayer (Nürnberg) impresszuma. Olim Pálffy gyűjteény, Szomolány. Strauss 1550-1600 II/703. (174. kép)

\section{Sopron}

1. Sopron 1562/1 Fametszet, részletkép címlapmetszeten, mérete kb. 2,7x2,7, az egész címlap 16,0x21,0 cm. Ismeretlen metsző műve, képzeletbeli ábrázolás. Címe „ODENBVRG” a részletképen felül. A címlapot 18 város látképe keretezi, Sopron képe a jobb alsó sarokban, Pozsony és Hainburg között. Megjelent Fabricius, Paul Almanach [...] auff das Jahr M.D.L.X.III. Wien /Zimmermann, Michael/, 1562. Michael Zimmermann városképes címlapkeretét később többször is felhasználták különböző kalendáriumokhoz (pl. Bartholomeus Reisacker: Schreibkalender, 1575, Schreib Kalender Wien, 1601) Bécsben, sőt Nürnbergben is (Newer und Alter Schreibkalender, Nürnberg 1612), néha a városképek sorrendje felcserélve, és a városnevek írásmódja is változott. (72. kép)

2. Sopron $1562 / 2 *$ részletkép címlapon, méret kb. 2,7x2,7 cm (az egész címlap $16,0 \times 21,0 \mathrm{~cm}$ ) Címe „ODENBVRG” a részletképen felül. A címlapot 18 város látképe keretezi, Sopron képe a jobb alsó sarokban, Pozsony és Hainburg képe között. Megjelent: Diarivm Cvm Ivdicio Astrologico. Per Magistrum Klayberum à Weyssenhorn [...] Ad Annum Christi Salvatoris nostri. M.D.LXIII. Viennae Austriae, Michael Zimmerman, [1562] címlapján. A címkeret további megjelenéseiről lásd a Pozsony 1562/1 metszetnél leírtakat. (73. kép)

\section{Szatmár}

Szatmár 1565/1* Fametszet tudósítás címlapján, méret kb. kb. 9,0x6,5 cm. Ismeretlen metsző műve. Képzeletbeli ábrázolás. Megjelent: Ein new Lied, vo. d'Kais. Maj Obristen Lasarus von. Schwendj wz er vor Sackmar den 27. May diss 65. jars [...] heben an. [S.l.], 1565. VD 16 N 1281 a címlapon. (83. kép)

\section{Székesfehérvár}

Székesfehérvár 1515/1 Fametszet emléklapon, méret 15,3×24,6 cm /a kép feletti szótekerccsel/, az egész lap 68,0x49,9 cm. Hans Springlinklee műve, részletkép a több művész által készített Miksa császár tetteit dicsőítő lapon (Ehrenpforte des Kaiser Maximilian I.) a jobb oldali kapuíven a felső 
sorban, középen. A részletképen felül szótekercsen Székesfehérvár 1490ben történt elfoglalásának leírása. A kép előterében a bevonuló csapatok, a háttérben fallal, bástyákkal körbevett város. Az emléklap megjelent latin és német nyelvű feliratokkal is. Első kiadása 1517, a második 1526, a harmadik 1559. Székesfehérvár Szent István király Múzeum 80.43 .1 (12-13. kép)

\section{Szigetvár}

1. Szigetvár 1566/2 Méret 50,9x34,6 cm. Lafreri, Antonio műve, jelzése „Ant. Lafrerij Formis Romae. MD.LXVI” a címtáblán alul. Címe „Il Vero ritratto de Zigeth con il suo Castello ... datogli da essi” a bal felső sarokban díszes táblán, öt sorban. A metszet 1602-ben Giovanni Orlandi és Henricus van Schoel kiadásában is megjelent. OSZK, App. M. 20 (106. kép)

2. Szigetvár 1566/3 Méret 32,5x22,7 cm. Zündt, Matthias műve, jelzése „Nurmberg, Mathis zündt” az ostromleírás végén. Címe „ZYGETH” a képen fent középen, külön keretben. A bal alsó sarokban táblán 4 sorban az ostrom leírása. OSZK, App. M. 28 (111. kép) [? címtábla nélküli változat? 176. kép]

3. Szigetvár 1566/4 Részletkép arcképen, méret 19,0x28,5 cm (az egész metszet, a részlet mérete nem meghatározható).Zündt, Matthias műve, jelzése «zu Nurmberg aus gangeb bei Matias Zindten» az ostromleírás végén. Zrínyi Miklós haditrófeákkal díszített, ovális mellképének baloldali hátterében. A mellkép alatt 10 sorban az ostrom leírása. OSZK, App. M. 26 (113. kép)

4. Szigetvár 1566/5 Méret 30,6x21,3 cm. Ismeretlen rézmetsző múve. Címe „ZIGETH” a képen fent középen, külön keretben. A bal alsó sarokban 5 sorban az 1566 évi ostrom leírása külön keretben. Az 1566/3 alatti Matthias Zündt metszettel azonos kép. Zrínyi Miklós Múzeum, Szigetvár 66.6.1 (112. kép)

5. Szigetvár 1566/6/a Méret 42,8×29,2 cm. Forlani, Paolo Veronese műve, jelzése „In Venetia l’Anno MDCLXVI Merzaria al segno della Colonna” jelzés a címtáblán alul. Címe „Alli Lettori / Il vero disegno de sito pianta di Ziget ...” a bal felső sarokban táblán, nyolc sorban. Zrínyi Miklós Múzeum, Szigetvár 70.5.2 (104. kép)

6. Szigetvár $1566 / 6 / b$. Az előző metszet korábbi lemezállapotáról készült példány az ostromló csapatok és azok magyarázó feliratai nélkül. David Woodward 61.01. Biblioteca Marucelliana, Firenze, Stampe vol. 423 Atlante Lafrery cc. 163v-164r (103. kép)

7. Szigetvár 1566/7 méret 25,7x17,2 cm. Camocio, Giovanni Francesco műve, jelzése „In Vinezia appresse Gio. Franco Camocio” a címtáblán alul. Címe „Ordinanza Thurchesca alla presa / di ZIGHET in Ongaria / l’anno 1566” a képen fent középen, címtáblán. A metszet egy példánya bekötve a Teatro della piu moderne. Venetia /Temini, G./, 1625. OSZK, App. H. 3262 könyvben található. Minden valószínúség szerint azonban nem ez a metszet első megjelenésének időpontja, amely Camocio müködési idejére /1569-1571/ tehető. (105. kép)

8. Szigetvár 1566/8 Méret 19,9x14,5 cm. Zenoi, Domenico műve, jelzése „Dnco Zenoi „a címkeret jobb alsó sarkában. Címe „Ziget fortezza nel paese Ongheria" a bal felső sarokban külön keretben, egy sorban. Szalai gyűjtemény (99. kép)

9. Szigetvár (1566)/1 Méret 20,3×13,3 (a kép alatti szöveggel 20,3x23,9) cm. Liefrinck, Hans müve, jelzése „Geprint Thantwerpen by Hans Liefrinck” a bal oldali leírás alatt. Címe nincs, a kép alatt két hasábban, flamandul és franciául az 1566. évi ostrom leírása. Bibliothéque nationale de France, Cabinet des Estampes, Paris P165457 (110. kép)

10. Szigetvár (1566)/2 Fametszet, méret 39,0x30,0 cm. Ismeretlen metsző munkája. Címe a kép felett két sorban Warhaftige Contrafactur und verzeychnuss des gewaltigen Schloss Zigeth ... des Türcken. Kép alatt Gedruckt zu Augsburg, bey Mattheus Franck (12) British Museum 1870d.2 Walter L. Strauss The German single-leaf woodcut 1550-1600 Vol. I. 203 (114. kép)

11. Szigetvár (1566)/3 Fametszet röplapon, méret 59,5x41,7 (az egész röplap 43,0x60,7) cm. Thevet, Andre műve. Címe „LE VRAZ POVTRAICT DES FORTS DE SEGHET ASSIEGE PAR LES TURCS MDLXVI” a kép felett. A kép jobb oldalán alul „THEVET AU LECTEVR” felirat alatt történelmi leírás 10 sorban, alatta Mathurin Breuille impresszuma. Royal Geographical Society London, Library Vol. 262H5. (108. kép)

12. Szigetvár (1566)/4 Méret 51,2x39,4 cm Cartaro, Mario műve, jelzése „MKV” (egymásra írva) monogram a metszet bal alsó sarkában. Címe „IL VERO DISEGNO DELLA / Fortezza di ZIGHET doue hora (...) honor' di Christiani Con priuilegio Roma. / B.F.” a kép bal alsó sarkában, 8 sorban. A „B.F.” kiadói jelzés mögött valószínúleg a Rómában működő Bartolomeo Faleti rejlik. (7) Newberry Library, Chicago Novacco 2F 095 (107. kép)

13. Szigetvár (1566)/5* Fametszet röplapon, méret $24,7 \times 18,5$, az egész lap $38,0 x 27,0 \mathrm{~cm}$. Ismeretlen múvész alkotása. Címe nincs. A bal felső sarokban csapatokkal köralakban körülvett szultáni sátor. A kép alatt „Vray dessein de la ville \& forteresse de Zighet assiegée par le Turc en personne” címmel az esemény ismertetése. Paris, BNdeF, Dép. Arsenal, GR FOL-146 (76) (109. kép)

14. Szigetvár 1567/1 Méret 19,9x14,5 cm. Zenoi, Domenico műve, jelzése „Dnco Zenoi „a címkeret jobb alsó sarkában. Címe „Ziget fortezza ... l’anno 1566 ... dal Conte Esdrino gran capitano onghero” a bal felső sarokban külön keretben, négy sorban. Megjelent Forlani, Paolo Veronese: Il primo libro delle 
citta. Venetia, 1567. (26) lap OSZK, App. H. 3069 A metszet újra megjelent (hátoldalán Szigetvár leírása 33 sorban és „40” lapjelzés) a Ballino, Giulio: De disegni delle piu illustri citta et fortezze. Venetia, 1569. 40. lap. OSZK, App. H. 428 (99. kép)

15. Szigetvár 1567/2/a Méret $18,3 \times 13,5 \mathrm{~cm}$. Forlani, Paolo Veronese műve, jelzése „in Ven. merzaria alla II.” a címfelirat végén. Címe „ZIGET fortezza innespugnabile ... 100000 Turchi l'anno MDLXVI." a bal felső sarokban külön keretben, hét sorban. Megjelent Forlani, Paolo Veronese: Il primo libro delle citta. Venetia, 1567. (17) lap OSZK, App. H. 3070. A metszet újra megjelent Bertelli, Ferrando: Civitates aliquot insigniorum. Velence, 1568. müben. (101. kép)

16. Szigetvár 1567/2//b. Az előző metszet megjelent a jobb alsó sarkában „88” lapjelzéssel a (Camocio, G.F.): Isole famose porte, fortezze. Venetia, (1571). címü könyvben 88. lapként, OSZK, App. H. 612/koll.2. (102. kép)

17. Szigetvár (1567)/1 Méret 41,3(átlag)x29,2 cm. Jelzetlen, egyes vélemények szerint Zenoi, Domenico műve. Címe „Disegno de Seghet venuto novamente..." a bal felső sarokban lévő díszes táblán, hat sorban. A képen több felirat, a tó közepén fekvő belső-vár felett „Seghet”, a jobb alsó sarokban lépték. Megjelent Gentil, Pierre: Deux veritables Discours. Paris, 1567. (a könyv végén) OSZK, App. H. 419. Apponyi Sándor a metszetet Domenico Zenoi munkájának tulajdonította, és nem tartotta azt a könyvhöz eredetileg tartozó metszetnek (francia nyelvű könyv mellett olasz nyelvü metszet!). (98. kép)

18. Szigetvár 1578/1 Szövegközti fametszet, hátoldalán szöveg méret 15,2x12,2 cm. Gregorius Sickinger fametszete, jelzése „G S”, alatta véső, alul középen. Címe „Abcontrafactur der Gewaltigen Vestung Sigeth” a kép rövidebbik oldala felett, a képhez képest 90 fokkal elforgatva. Megjelent Ulloa, Alfons: Beschreibung des letsten Ungerischen Zugs. Basel / Henrichpetri/, 1578. lxxvij (77) oldal. (139. kép)

19. Szigetvár 1578/2 Szövegközti fametszet, hátoldalán szöveg, méret 15,2x12,2 cm. Gregorius Sickinger fametszete, jelzése „G S”, alatta véső, alul középen. Höniger, Nicolaus: Ander Theil der Türckischen Historien. Basel /Henrichpetri/, 1578. cciiij (204) oldal és később Münster, Sebastian: Cosmographiae Universalis. Basel, 1578. 1187. oldal és. A metszet tovább megjelenéseit lásd a Mellékletek között Sebastian Münster Cosmographia könyvének fametszetes magyar városképei címmel. (145. kép)

\section{Szikszó}

1. Szikszó 1577/1 Fametszet röplapon, méret kb. 25,0x21,0 cm, az egész lap 29,0x39,0 cm. Georg Mack d. E. műve. A röplap címe: Zeitung aus Ungern ... Türcken zu Sixo beschen am tag Markt. A kép alatt kéthasábos leírás, legalul impresszum „Zu Nürnberg, bey Georg Macken Illuministen beym Sonnen Bad". Zürich Zentralbibliothek (PAS II 15 14) (13) (14) Strauss II/649. (152. kép)

2. Szikszó $\mathbf{1 5 8 8 / 1}$ Méret $30,5 \times 20,0 \mathrm{~cm}$ a kép alatti szöveg nélkül. Franz Hogenberg(?) műve. Címe: „Kurtze und wafftige entwerffung des grawsammen Infals der Türcken ins Hungerlandt [...] worden sindt" a képen felül, végigfutó keskeny keretben. A kép alatt az esemény leírása verses formában, 5 hasábban, a végén „Mense Octobris Ao. 1588.” Szalai gyűjtemény. A metszet a Hogenberg metszetek gyűjteményes kiadásában / Geschichtsblatter/ nem jelent meg. (164. kép)

3. Szikszó 1588/2* Röplapon, méret 35,9x25,6 cm, az egész lap 40,2×57,8 $\mathrm{cm}$. Meyerpeck, Wolfgang műve. A képen balra fent egy lángokban álló helység képe, jelölése „A: Syxo”. A képet harci jelenet tölti ki. Jobbra lent egy település, jelölése „P: Wadas” feltehetően a Szikszóval szomszédos Alsóvadász. A röplap címe: „Warhafter Kurttzer Bericht wie es sich in der Schlacht so im ober Krais Hungern [...] vor Sixo gehalten] Geschehen den 8. tag Octobris Anno 1588." Legalul jobbra impresszum: Gedruckt zu Prag in der kleinern Stat bey Michael Peterle an der Schlossstiegen. (12) Szalai gyűjtemény; Drugulin 774. A metszeten a Drugulin által említett Meyerpeck jelzés nem szerepel. (165. kép)

4. Szikszó 1588/3* Fametszet röplapon, méret 29,2×17,6 cm, az egész lap $29,4 \times 38,4$ cm. A röplap címe a kép felett „Zeitung oder Bericht ... Schlacht so das teutsch und Ungarisch Kriegs/volck in Oberhungern [...] den 8. tag Octobris des jetzogen 1.5.88. Jars.” négy sorban. A kép alatt egy hasábos röplap szöveg, alatta impresszum: „Gedruckt zu Nürnberg bey Georg Lang Formschneider in der Judengassen”. Walter L. Strauss: The German singleleaf woodcut 1550-1600 Vol. II. 578. Egy példánya Universitätsbibliothek Erlangen-Nürnberg H62/Einblattdruck A.III.7. H60/AC 84127 H713. Gyulai Éva: A pácini kastély Urak és szolgák a kora újkori északkelet-magyarországi kastélyokban 2014. (166. kép)

5. 1588 Szikszó $\mathbf{1 5 8 8 / 4}$ Fametszet tudósítás címlapján, méret kb. 10,0x8,0 $\mathrm{cm}$. Ismeretlen metsző műve. Csatajelenet előterében egy álló páncélos katona, a háttérben egy égő vár. Megjelent: Newe Zeittung aus Vngern. Kurtzer bericht der bey dem Marckt Sixo in Ober Hungern/von den Deutschen vnd Vngerischen Kriegsvolck [...] Den 8. Octobris/Anno 158 8. Gehaltenen Schlacht. M.D.LXXXVIII. Praga, Valda, Burian, 1588. a címlapon. VD16 XL 103 (157. kép)

6. Szikszó 1588/5 Fametszet tudósítás címlapján, méret kb. 11,50x8,0 cm. Ismeretlen metsző műve. A képen jobbra egy égő templom, balra bástya, 
előtte ágyúállás. Megjelent: Tuerckische Niderlag vnd Newe Zeyttung. Ein kurtzer Bericht/ wie es sich auff der gehaltenen Schlacht/ so das Deut=sche vnd Hungerische Kriegßvolck/ in ObernVngern [...] Vor Sigeet gehalten/ begeben vnd zugetragen hat. Geschehen den 8. Octobris/Anno 1588. Coburg, [Kröner, Valentin], 1588. VD16 ZV 23860 (168. kép)

\section{Temesvár}

1. Temesvár 1576/1 Fametszet röplapon, méret 31,5x19,8, az egész lap $31,5 \times 40,3 \mathrm{~cm}$. A kép hátterében egy égő város képe, robbanási jelenettel. $\mathrm{A}$ kép felett a röplap címe három sorban Warhafftige und erschreckliche New Zeitung aus Ungern von der Stadt Temeswar / zu jetziger Zeit Türckisch... A kép alatt az esemény leírása egyhasábos szövegben, legalul Leonhard Blümel nürnbergi impresszuma. Zürich Zentralbibliothek (PAS II. 13:3). Strauss 1550-1600 I/122 (150. kép)

2. Temesvár 1576/2* Fametszet tudósítás címlapján, méret kb. 8,0x6,5 cm. Ismeretlen metsző műve. Képzeletbeli ábrázolás. Megjelent Warhafftige grausa=me vnd erschreckliche newe zeitung aus/ Vngern/ wie die Stadt Temesuar/ zu jetziger zeit [...] zu ach=ten ist.[S.l.], 1576. címlapom. VD16 ZV 23866 (151. kép)

\section{Tokaj}

1. Tokaj 1565/1/a Méret 29,5x40,8 cm. Domenico Zenoi műve, jelzése „,,Domenico Zenoi f” a címtábla jobb alsó sarkában. Címe: „TOCQKAY over DOGGEY fortezza ... l'anno 1565 per Lazaro Sansvendi ... da guerra" a kép közepén alul, díszes táblán, öt sorban. A metszet újra megjelent /b. a cím alatt „Apresso Gio. Francesco Camatio” /OSZK, App. M.23/, majd /c. „Apresso Donato Bertelli” /MNM TKcs T.969/ végül /d.* csak „Apresso” név nélkül / Róma, Biblioteca Apostolica Vaticana/ kiadói jelzéssel. Bifolco Tavola 522. (78. és 79. kép)

2. Tokaj 1565/2/a Fametszet tudósítás címlapján, méret kb. 12,5×14,0 cm. Michael Zimmermann műve. Megjelent: Zeittung von der Rö. Khay. Mt. Etc. Khriegssvolckh in Zips. Wien, Michael Zimmermann, (1565) a címlapon. Németh S. Katalin H2331. (77. kép)

3. Tokaj 1565/2/b* Fametszet tudósítás címlapján, méret kb. 8,0x8,0 cm. Ismeretlen metsző műve, képzeletbeli ábrázolás. Megjelent: Zweyerley Newe Zeittungen. Welcher Gestalt das Schloss Daggay in Vngern durch jetzigen Grosmechtigẽ Keysers Maximiliani Kriegsvolck dem Tuercken Christliches
Namen Erbfeind widerumb dieses 65. Jhars abgewonnen vnd eroebert. [S.l.], 1565. címlapján. VD16 W 1747. OSZK, Hubay 243. (82. kép)

4. Tokaj 1565/2/c* Fametszet tudósítás címlapján, méret kb. 12,5×14,0 cm Ismeretlen metsző műve. Michael Zimmermann fametszetével azonos kép, a kép alatt 1566 évszámmal. Megjelent: Ein Schön New Lied, darinn gemeldt wirdt, was diß 1566. Jar ist außgericht worden, Von dem Herrn Lazarus von Schwende [...] Jm thon wie man singt vom Künig Ludwig auß Vngern, [et]c., [Augsburg, Franck], 1566 [VD16 S 3619]. (124. kép)

5. Tokaj 1565/3 Fametszet röplapon, méret 40,0x61,0, az egész röplap 61,0x61,0 cm. Zsámboky János és Michael Zimmermann műve. A röplap címe és a vár elfoglalásának leírása a kép mellett jobbra. A röplap címe: Situs et vera positio arcis Tokay ... anno MDLXV. febr. XI. expugnata et capta est. Warhafte Conterfactur des Schlosses Toggey in Hungern in 1565 Jahr Belegert und den 11 febr. erobert worden. Wien, Michael Zimmermann 1565. Wien, Albertina Museum DG1962/1188. Borbély Andor: Adatok Tokaj vára helytörténetéhez (In: Debreceni Szemle 1933.) (80. kép)

6. Tokaj 1565/4 Fametszet röplapon, méret 24,6x35,0, az egész röplap 25,6x36,0 cm. Thevet, Andre műve. Címe: „Le vray pourtraict du Chasteau de Thokay." a kép felett. A röplap szövege a kép alatt latinul 4 sorban és franciául 5 sorban az 1565. februári ostrom leírásával. A leírás alatt impresszum: „A Paris, par Iehan de Gourmont, Rue S. Iehan de Latran, pres le College de Cambray”. Royal Geographical Society, London, Library Vol. 262H5. (81. kép)

7. Tokaj (1566)/1 Méret 19,9x14,5 cm. Zenoi, Domenico műve, jelzése „Dnco Zenoi” a címkeret jobb alsó sarkában. Címe „Tochai, fortezza nel confini di Tran/silvania, et Ongheria ... del Re Ioanne secudo ... l'anno 1566." a jobb felső sarokban külön keretben, öt sorban. A várat mindhárom irányból az erdélyi seregek veszik körül. Szalai gyűjtemény (126. kép)

8. Tokaj (1566)/2 Méret 19,9x14,5 cm. Zenoi, Domenico műve, jelzése „Dmco Zenoi” kézírással a címkeret jobb alsó sarkában. Címe „Tochai fortezza nel confini di Transilvania et Ongheria ... Perthan Bassa ... Turcho l'anno MDLXVI" kézírással a jobb felső sarokban külön keretben, négy sorban. Próbanyomat, a kép bal felső oldala üres. Stúdió Antikvárium Katalógus 2012. (125. kép)

9. Tokaj 1567/1 Méret 20,0x14,5 cm. Zenoi, Domenico műve, jelzése „Dmco Zenoi” a címkeretben, a cím alatt. Címe „Tochai fortezza nel confini di Transilvania et Ongheria ... Perthan Bassa ... Turcho l'anno 1566" a jobb felső sarokban külön keretben, öt sorban. Megjelent Forlani, Paolo Veronese: Il primo libro delle citta. Venetia, 1567. (29) lap (OSZK, App. H. 3069. A metszet újra megjelent Ballino, Giulio: De disegni delle piu illustri citta et fortezze. Venetia, 1569. könyv 39. lapján, hátoldalán Tokaj leírása 21 sorban. (127. kép) 
10. Tokaj 1567/2 Méret 18,0×13,5 cm. Forlani, Paolo Veronese műve. Címe „Toquay fortezza nel confini d'Ongaria verso Transilvania si veramente come ogi di si trova” a jobb felső sarokban külön keretben, három sorban. Megjelent Forlani, Paolo Veronese: Il primo libro delle citta. Venetia, 1567. (16) lap OSZK, App. H. 3070. A metszet újra megjelent Bertelli, Ferrando: Civitates aliquot insigniorum. /Velence, 1568/ című könyvben is. A metszet megtalálható egyes XVI. századi olasz úgynevezett Lafreri kompozit atlaszokban is. (128. kép)

11. Tokaj 1574/1 Szövegközti fametszet, hátoldalán szöveg, méret 15,1x12,0 cm. Ismeretlen metsző műve. Megjelent Münster, Sebastian: Cosmographiae Universalis. Basel, 1574. 1191. oldal (12) ÖNB Bildarchiv Fid.C.B.116-050. A metszet megjelent a mű 1578. évi kiadásában is. (141. kép)

12. Tokaj 1578/1 Szövegközti fametszet, hátoldalán szöveg, méret 15,1x12,0 cm. metsző műve. Címe „Abcontrafactur der Vestung Tokay” a kép rövidebbik oldala felett, a képhez képest 90 fokkal elforgatva. Megjelent Ulloa, Alfons Beschreibung des letsten Ungerischen Zugs. Basel /Henrichpetri/, 1578. cxij (112) oldal. (137. kép)

13. Tokaj 1578/2 Szövegközti fametszet, hátoldalán szöveg, méret 15,1x12,0 cm. Ismeretlen metsző műve. Megjelent Höniger, Nicolaus Ander Theil der Türckischen Historien... Basel /Henrichpetri/, 1578. clxxxvj (186) oldalon felül és Münster, Sebastian Cosmographiae Universalis. Basel, 1588. A metszet további megjelenéseit lásd a Mellékletek között Sebastian Münster Cosmographia könyvének fametszetes magyar városképei címmel. (142. kép)

\section{Vác}

Vác 1576/1* röplapon, méret 28,7x21,5 cm (a rézkarc) Jost, Amman műve. A röplap címe két sorban a röplapon felül: „Warhaftige Historia die sich vnlangst zu Wotzen/in Ungern mit einem gefangen/Christen vnnd Löwen zugetragen hatt.”, alatta: „Zu Nürnberg by Jost Amman Reisser.” Zürich Zentralbibliothek PAS II 13/16. A röplap egy példánya kettévágva: a röplapszöveg üres lapra felragasztva a Herzog August Bibliothek Hungarica gyűjteményében (Németh S Katalin H2220), a kép pedig a Herzog Anton Ulrich Museum, Braunschweig metszetgyűjteményében Inv. JAmman WB 3.19 (149. kép)

\section{Várpalota}

Várpalota 1578/1 Szövegközti fametszet, hátoldalán szöveg, méret 8,1x7,8 $\mathrm{cm}$. Ismeretlen metsző műve. Képzeletbeli ábrázolás. Megjelent Höniger, Nicolaus Ander Theil der Türckischen Historien. Basel /Henrichpetri/, 1578. cxcij (192) oldal (87-88. kép)

\section{Veszprém}

Veszprém 1578/1/a Szövegközti fametszet, hátoldalán szöveg, méret 7,9x7,8 cm. Ismeretlen metsző műve. Képzeletbeli ábrázolás. Megjelent Höniger, Nicolaus Ander Theil der Türckischen Historien. Basel /Henrichpetri/, 1578. cxciij (193) oldal. A mű 1596. évi kiadásban a kép a ccvj (206) oldalon jelent meg, (87-88. kép)

\section{Vöröstorony}

Vöröstorony 1588/1* Szövegközti fametszet, hátoldalán szöveg, méret $7,0 \times 5,0 \mathrm{~cm}$. Ismeretlen metsző műve. Képzeletbeli ábrázolás. Megjelent Münster, Sebastian Cosmographey oder Beschreibung aller Länder. Basel, Heinrich Petri, 1588. 1225. oldal. A metszet további megjelenéseit lásd a Mellékletek között Sebastian Münster Cosmográfiájának fametszetes magyar városképei címmel. (148. kép)

\section{Zsáka}

1. Zsáka 1567/1 Méret 27,2x20,2 cm. Zenoi, Domenico (?) mûve. A jobb alsó sarokban külön keretben 12 soros leírás és jelmagyarázat. Megjelent Forlani, Paolo Veronese: Il primo libro delle citta. Venetia, 1567. (24) lap. A metszet újra megjelent Ballino, Giulio: De disegni delle piu illustri citta et fortezze. / Venetia, 1569. App. H.428/ címú könyvének (41) lapjaként (123. kép)

2. Zsáka 1578/1 Szövegközti fametszet, hátoldalán szöveg, méret 15,5x12,4 cm. Gregorius Sickinger fametszete, jelzése „G S”, alatta véső, alul balra. Höniger, Nicolaus Ander Theil der Türckischen Historien. Basel, 1578. ccxj (211) oldal és később Münster, Sebastian Cosmographiae Universalis. Basel, 1578. 1188. A metszet további megjelenéseit lásd a Mellékletek között Sebastian Münster Cosmographia könyvének fametszetes magyar városképei címmel. (147. kép)

\section{ESEMÉNYEK}

\section{Dózsa György-féle parasztháború 1514}

1. Keresztes katona 1514/1 Fametszet tudósítás címlapján, méret kb. 10,0x10,4 $\mathrm{cm}$. Ismeretlen metsző műve. A keresztes katona hétköznapinak tűnő öltözetben, sapkával. Megjelent: Ain groß wunderzaichen das da geschehen ist durch das Creütz, das ain Cardinal hat außgeben, in dem gantzen Hungerischen lannd wider die Thürckhen. [München], | [Schobser], [1514] a címlapon. VD 16 G 3477 (1. kép) 
2. Keresztes katona 1514/2 Fametszet tudósítás címlapján, méret kb. 10,0x13,5,0 cm. Ismeretlen metsző műve. A keresztes katonán hatalmas tollas fejfedő, az óriási zászló az egész hátteret kitölti. Megjelent: Ein groß wunderzaichen das do geschehen ist durch das Creütz, das ein Cardinal hat außgeben, in dem gantzen Hungerischen lannd wider die Thürckhen. Leipzig, Martin Landsberg, 1514. a címlapon. Németh SK Hungarica H707 (2. kép)

3. Keresztes katona 1514/3 Fametszet tudósítás címlapján, méret kb. 9,5×13,0 cm. Ismeretlen metsző műve. A képen a keresztes katona mellpáncélban, karddal. Megjelent: Ain groß wunderzaychen das do geschehen ist durch das Creütz, das ain Cardinal hat außgeben in dem gantzen Vngerischen Landt wider die Turcken. [Nürnberg], [Stuchs], [1514]. a címlapon. VD16 G 3479 (3. kép)

4. Dózsa György kivégzése 1514/1 Fametszet tudósítás címlapján, méret kb. 10,5x12,0 cm. Ismeretlen metsző műve. A képen Dózsa György koronával a fején trónszéken ül, egy ember a vállába harap, előtte muzsikusok. Megjelent: Die auffrur so geschehen ist im Vn=gerlandt/ mit den Creützern/ Vnnd auch darbey wie man der Creützer Haubtman hat gefangen vnnd getödt. Nürnberg, Huber Wolfgang, 1514. a címlapon. Németh, S.K. Hungarica H 64. VD16 A 4072 (4. kép)

5. Dózsa György kivégzése 1519/1 Fametszet tudósítás címlapján, méret kb. 11,7x11,7 cm. Ismeretlen metsző műve. A képen a trónszéken ül Dózsa György fejére fogókkal lángoló koronát tesznek, egy ember a vállába harap előtte muzsikusok. Megjelent Taurinus, Stephanus Olomucensis Stephani Taurini Stauromachia, id est cruciatorum servile bellum. Viennae Pannoniae [Wien], Joannes Singrenius, 1519. a címlapon. (címlap hátoldalán Madonna kép) OSZK, App. H. 137 VD16 T 247 (5. kép)

\section{Habsburg-Jagelló szerződés 1515}

1. Habsburg-Jagelló szerződés 1515/1 Fametszet tudósítás címlapján, méret kb. 10,0x10,0 cm. Ismeretlen metsző műve. A képen középen a kétfejű sas a császári koronával, körötte a pólyás magyar, a cseh, a lengyel és a Jagelló címer. Megjelent Cuspinianus, Johannes: Congressus ac celeberrimi conuentus Caesaris Max. et trium regum Hungariae, Boemiae, et Poloniae. In Vienna Panoniae, mense Iulio. Anno 1515 facti, breuis ac uerissima descriptio. [Wien], [Singriener], 1515. a címlapon. VD 16 C 6482 (6. kép)

2. Habsburg-Jagelló szerződés 1515/2 Fametszet tudósítás címlapján, méret kb. 11,0x8,0 cm. Ismeretlen metsző műve. A képen a trónon ülő Miksa császárnak nyújtanak át térden állva egy írást. Megjelent: Die verainigung Kaiserlicher Ma. mit Künig von Vngern, Polan, Böhern etc., Auch wie vn[d] wa sye zu samen komen sein [...] vn[d] wie sye zu Wien einzogen seind mit mer verlauffung etc. vnd handlung alles hierinnen clerlich begriffen. [Augsburg], [Oeglin], [1515] a címlapon. VD16 V 626 (7. kép)

3. Habsburg-Jagelló szerződés 1515/3 Fametszet tudósítás címlapján, méret kb. 12,5x9,5 cm. Ismeretlen metsző műve. eljegyzés A képen két koronás lovas (II. Ulászló magyar és I. Zsigmond lengyel király) köszönti egymást egy város (Bécs?) előtt. Megjelent: Keiserlicher Maie=stat ynreitung zů Wien.mit dem Künig von Vngern/vnd Künig von Polen/mit sampt den Küniginen [...] als hernach stat. Straßburg, Hupfuff, Matthias, 1515. a címlapon. VD16 N 1082 (8. kép)

4. Habsburg-Jagelló szerződés 1515/4 Fametszet, méret kb.9,0x7,5 cm. Ismeretlen metsző műve. A képen két fiatal nő áll, feléjük egy fiú lovagol egy kisméretű lovon. Megjelent: Keiserlicher Maie=stat ynreitung zů Wien. mit dem Künig von Vngern/ vnd Künig von Polen/ mit sampt den Küniginen [...] als hernach stat. Straßburg, Hupfuff, Matthias, 1515. utolsó oldalon. VD16 N 1082 (9. kép)

5. Habsburg-Jagelló szerződés 1515/5 Fametszet emléklapon, méret 15,3×24,6 cm /a kép feletti szótekerccsel/, az egész lap 295×357 cm. Hans Springlinklee műve, részletkép a több művész által készített Miksa császár tetteit dicsőítő lapon (Ehrenpforte des Kaiser Maximilian I.) a jobb oldali kapuíven az alsó sorban középen. A részletképen felül szótekercsen az esemény ismertetése. A képen Miksa császár előtt a unokája, Mária és Lajos, Ulászló király középen Lajossal és Annával, jobbra Zsigmond lengyel király. Az emléklap megjelent latin és német nyelvű feliratokkal is. Első kiadás éve 1517, a másodiké 1526, a harmadiké 1559. Egyes részletképek külön is megjelentek. (10-11. kép)

\section{Lajos és Mária királyné 1523}

II. Lajos és Mária 1523 Fametszet címlapon, méret kb. 11,5x11,5 cm. Ismeretlen metsző műve. A képen egy koronás férfi és egy koronás nő áll, a férfi lába alatt egy török katona, egy angyal fegyvereket nyújt a férfi felé. Megjelent Grünbeck, Joseph: Doctor Joseph Gruenpeck von Burckhausen entlicher beschluss [...] aufrüstung der Türcken. An Künig Ludwigen/ vnd frawen Mariam Künigin zů Hungern vnd Beham. [S.l.], [1523] a címlapon. (csatajelenet záró képek) VD 16 G 3629 Hubay 50. (22. kép)

\section{Mohácsi csata 1526}

1. Mohácsi csata 1 Fametszet, méret 37,5x28,2 cm, az egész lap. Ismeretlen fametsző műve, ismeretlen nyomdában jelent meg. Címe a kép felett Des Türckischen Keysers Solymon schlacht / So mit dem Künig von Hungern gethan, 
Anno rc. XXVI. A képen felül gyalogosok, alul lovasok csatája, cseh zászlók alatt. Staatsbibliothek Bamberg, Sammlung Helleriana. Seláf Levente-Tóvizi Ágnes: Ismeretlen illusztrált röplap a mohácsi csatáról. (29. kép)

2. Mohácsi csata 2 Fametszet tudósítás címlapján, méret kb. 9,0×13,0 cm Ismeretlen metsző műve. A képen lgyalogos katonák csatája, jobbra fiatal harcos, királyi koronával. Megjelent: Ein newer Bergreyen, von Künig Ludwig auss Ungern Jm thon, Frölich so will ich singen Ein ander new Lied, auss der Römer History gezogen Jn Frauwen Eeren thon./ [Hans Sachs] [Strassburg], [Jakob Frölich], [um 1550] VD16 ZV 28094 (23. kép)

3. Mohácsi csata 3 Fametszet tudósítás címlapján, méret kb. 9,0x7,0 cm Ismeretlen metsző műve. A képen sisakos lovas katonák összecsapása. Megjelent: New zeytung. Die Schlacht des Turckischen Keysers mit Ludouico etwan König zu Vn=gern geschehen am tag Johannis entheuptung .1526. [...] Jtem des Türcken feyndtsbrieff/König Ludouico zugesandt vor der schlacht. [...] New zeytung vom Babst zu Rome am.xxvij. tag Septembris geschehen. Leipzig, Stöckel, Jakob, 1526. VD16 ZV 11475 (24. kép)

4. Mohácsi csata 4 Fametszet tudósítás címlapján, méret kb. 11,5x8,0 cm. Ismeretlen metsző műve. A képen harci jelenet, középen egy katona egy bunkóval fejbe ver egy összeeső másik katonát. Megjelent: Hernach volgt des Blutthundts, der sich nennet ein Türgkischen keyser, gethaten [...] auff den xxviij. tag Augusti [...] der Vngerischen landschafften, gantz vn=menschlich triben hat, vnd noch täglichs thut. (Zu Basel durch Adam Petri. M. D. XXVI.) a címlapon. VD 16 B 5795 OSZK, App. H. 189. Hubay 66b (25. kép)

5. Mohácsi csata 5 Fametszet tudósítás címlapján, méret kb. 10,5x7,5 cm Ismeretlen metsző műve. A képen lovascsata, balra keresztények, jobbra törökök, középen török zászló. törökök. Megjelent: New zeytung. Die Schlacht des Turckischen Keysers mit Ludouico etwan König zu Vngern geschehen am tag Johannis entheuptung M.D.XXVI 1526. [...] getzeyten aus Polen. New zeytung vom Babst zu Rome am.xxvij. tag Septembris geschehen. M. D. XXVI. Leipzig, Stöckel, Jakob, 1526. a címlapon. OSZK, App. H. 190 (26. kép)

6. Mohácsi csata 6 Fametszet tudósítás címlapján, méret kb. 9,0×7,0 cm Ismeretlen metsző műve. A képen lovasok összecsapása, balra törökök skorpiós zászlóval. Megjelent: New erbarmliche tzydũge vã der groisser schlacht/ so der Tuircksch Keyser/ mnit dem Konynck vã Vngern [...] Jtem die Offenbarũg Broder Rẽyhartzs/ Des//gelichen Methosius wie der Turck/vur Coellen sal erschlagen werden. [Köln, Arnd von Aich, 1526], a címlapon. VD16 N 2129. Hubay 63e. (27. kép)

7. Mohácsi csata 7 Fametszet címlapon, mérete kb. 12,0x14,0 cm. Ismeretlen metsző műve. A képen lándzsás katonák csatája, hatalmas zászlókkal, egyes vélemények szerint Hans Schäufelein metszetének másolata. Megjelent
Sporer, Merten: Eyn new lied von der schlacht die der Vngerisch Künig vnd der Türck mit einander ge=than haben. Jm speten thon. Nürnberg, Hans Hergot, 1526. Hans Schäufelein fametszete. VD 16 S 8363 (28. kép)

\section{Ferdinánd koronázása 1527}

1. I. Ferdinánd koronázása 1 Magyarországon 1527/2 Fametszet tudósítás címlapján, méret kb. 10,0x11,50 cm. Ismeretlen metsző műve. A képen kis lovascsapat, az első lovas fején koronás sisak van. Megjelent: Künig Ferdinande[n] zu Hungern vnnd Beheim, Ertzhertzogen zu Osterreich [et] c. Einreytten vnd Krönung zu Stulweyssenburg in Hungern. [S.l.], 1527. a címlapon. OSZK, Hubay 78 (36. kép)

2. I. Ferdinánd koronázása 2 Fametszet tudósítás címlapján, méret kb 10,5x12,0 cm. Ismeretlen metsző műve. A képen a koronázási menet részlete(?) a muzsikusokkal, zászlókkal. Megjelent: La triumphante entree et couronnement de Fernant De la Royalle maiesté de Honguerie [...] Stoel Wittenburch le dernier iour Doctobre, Anno. M.CCCCC et XXVII. Anvers, Guillaume Vorsterman, 1527. a címlapon. OSZK, App. H. 196 (37. kép)

3. I. Ferdinánd koronázása 3 Fametszet tudósítás címlapján, méret kb. 10,0x8,5 cm. Ismeretlen metsző műve. A képen egy hajó köt ki egy városnál. Megjelent: La triumphante entree et couronnement de Fernant, de la royale maieste de Hon=guerie [...] Stoel Wittenburch le dernier iour Doctobre, anno domini mil cinq cens vingt sept. [S.l.], [1527] a címlapon. (38. kép)

4, I. Ferdinánd koronázása 4 Fametszet, méret kb. 8,5×14,0 cm. Ismeretlen metsző műve. A képen egy koronás személy templomi öltözetben térdel egy oltár előtt. Megjelent: La triumphante entree et couronnement de Fernant, de la royale maieste de Hon=guerie [...] Stoel Wittenburch le dernier iour Doctobre, anno domini mil cinq cens vingt sept. [S.l.], [1527] az utolsó oldalon. (39. kép)

\section{Buda, foglyok kivégzése 1541}

Buda, foglyok kivégzése 1541 Fametszet, méret 37,2x27,0 cm. Erhard Schön műve. Címe nincs. Eredetileg Hans Sachs Ein tyrannische that des Türcken, [...] die künigin ins ellend verschickt im 1541. jar." című versével együtt (?) jelent meg. A képen a Szulejmán szultánnak 1541. augusztus 27-én átadott fogságba esett császári katonák kivégzése látható. Kunstsammlungen der Veste Coburg, Inv.-No. VI,457,116 Röttinger 252. Kelényi B. Ottó 1932/19. (48. kép)

\section{Kígyóvész Szikszón}

1. Kígyóvész Szikszón 1550/1 Fametszet, méret kb. 7,5x6,5cm. Ismeretlen metsző műve. A képen egy nő térdel és feltekint a Mózes állította rézkígyóra. 
Megjelent: Eyne Warhafftige/ erschreckliche/ vnd vnerho̊rte newe zeittung/ so im lande zu Vngern/von Ottergezichte vnd Eidexen/ diesen Sommer sich zugetra=gen hat. [S.l.], 1550. a címlapon. VD16 ZV 26609 (66. kép)

3. Kígyóvész Szikszón 1550/2 Fametszet röplapon, méret 23,5x14,7 cm (a metszet). Ismeretlen fametsző műve. A képen felkelő Nap, a földön fekvő férfiakból és egy ágyon fekvő női holttestből kígyók és gyíkok másznak elő. A röplap címe három sorban a kép felett „Warhafftige/ erschrockliche/ Newe zeytung/ so im Land zu Hungern/ von Nattergezüchte vnnd Eydexen/ disen Sommer sich zügetragen hat." A kép alatt egy hasábos szöveg. A röplap végén „Gedruckt zu Dillingen/ durch Sebaldum Mayer” impresszum. Walter L. Strauss: The German single-leaf woodcut 1550-1600 Vol. II. 728. (65a. kép)

4. Kígyóvész Szikszón 1550/3 Fametszet röplapon, méret 23,5x14,7 cm (a metszet). Ismeretlen fametsző műve. A képen felkelő Nap, a földön fekvő férfiakból és egy ágyon fekvő női holttestből kígyók és gyíkok másznak elő. A röplap címe három sorban a kép felett „Warhafftige/ erschrockliche/ Newe zeytung/ so im Land zu Hungern/ von Nattergezüchte vnnd Eydexen/ disen Sommer sich zügetragen hat." A kép alatt egy hasábos szöveg. A röplap végén „Gedruckt zu Wien/ durch Egidium Adler” impresszum. Zürich Zentral Bibliothek Graphische Sammlung (GSM) PAS II 12/30. (65a. kép)

5. Kígyóvész Szikszón 1551/1 Fametszet röplapon, méret 22,8x14,0 cm (a metszet). Ismeretlen fametsző műve. A képen a földön fekvő férfiakból és egy ágyon fekvő női holttestből kígyókés gyíkok másznak elő. A röplap címe három sorban a kép felett „Warhafftige/ erschrockliche neüwe zyttung/so im land zu Hungern/von nattern gezüchte vnd eydexen/ diser sommer sich zuogetragen hat. 1551” A kép alatt egy hasábos szöveg. A röplap végén „Gedruckt zu Wienn/ durch Egidium Adler" impresszum. Zürich Zentralbibliothek Graphische Sammlung (GSM) PAS II 2/20 (65b. kép)

\section{Fráter György meggyilkolása 1551}

Fráter György meggyilkolása Szövegközti rézmetszet, hátoldalán nyomtatott szöveg, méret 15,3x11,3 cm. Matthäus Merian vagy műhelyének rézmetszete. A képen egy idős, barátruhás férfit szúr le hátulról egy katona, egy másik pisztolyból tüzel rá. Két álló katona figyeli a jelenetet. Megjelent Gottfried, Joh. Ludwig Historische Chronick oder Beschreibung der merckwürdigsten Geschichte. Frankfurt am Main, Matheus Merian, 1630. 812. o. MNM TKcs 11605. (68. kép)

\section{6 év eseményei}

1. Csata Babócsánál 1556 Fametszet tudósítás címlapján, méret kb. 10,0x8,0 $\mathrm{cm}$. Ismeretlen metsző műve. A képen lovasok csatája, háttérben hegytetőn egy vár. Megjelent: NEwe Zeytungen ausz Hungern/ wie abermals die vnsern durch mithülffe Grotlicher gnaden/dem Blůthunde der gantzen Christenkait/in etlichen Scharmützeln [...] den drey vn zwentzigsten tag des Hewmonds/dises Jars M.D.Lvj. Jtem Ein erschrrocklich Wunderzaichen von zwayen Erdbidmen [...] Constantinopel im diesem M. D. LVI. Jar. [S.l.], (Gedruckt durch Valentin Geyszler|), [Nürnberg 1556]. a címlapon. VD 16 N 1100 (69. kép)

2. Wolfgang Lazius haditérképe 1556 Méret 44,0x34,3 cm. Michael Zimmermann fametszete. Wolfgang Lazius Magyarország térképének Dunántúl részlete, az 1556. év eseményeinek feltüntetésével. A térkép aljára ragasztható lapon megjelent az 1556. év eseményeinek leírása is Bécsben Joannis Oporini kiadásában. A térkép újra megjelent Adam Henripetri 1577. éviajánlásával az Adam Henricpetri: General-Historien der aller namhafftigsten unnd fürnembsten Geschichten. Basel, 1577. 90-91. oldal között. (71. kép)

\section{Ferdinánd temetése 1565}

1. I. Ferdinánd temetése 1566/1 Fametszet, méret kb. 43×32 cm (lapméret) Wolgang Meyerpeck műve. A képen az országzászló és az ország címer felvonultatása a temetési menetben. Megjelent Hannewald, Bartholomaeus Parentalia Divo Ferdinando Caesari Avgvsto patri patriae etc. a Maximiliano imperatore etc., Ferdinando et Carolo serenissimis Archiducibus Austriae Fratribus singulari pietate persoluta. Viennae, Anno Domini M.D.LXV. VIII. Idus Augusti. Augusta Vindelicorum, W. Meyerpeck, 1566. VD 16 H 53020. tábla (89. kép)

2. I. Ferdinánd temetése 1566/2 Fametszet, méret kb. 43×32 cm (lapméret) Wolgang Meyerpeck műve. A képen a koronázási klenódiumok (kard, jogar, országalma, korona) felvonultatása a temetési menetben. Megjelent Hannewald, Bartholomaeus Parentalia Divo Ferdinando Caesari Avgvsto patri patriae etc. a Maximiliano imperatore etc., Ferdinando et Carolo serenissimis Archiducibus Austriae Fratribus singulari pietate persoluta. Viennae, Anno Domini M.D.LXV. VIII. Idus Augusti. Augusta Vindelicorum, W. Meyerpeck, 1566. VD 16 H 530 25. tábla (90. kép)

\section{Lazarus Schwendi hadjárata 1565}

1. Lazarus Schwendi hadjárata 1565/1 Fametszet tudósítás címlapján, méret $\mathrm{kb}$. 8,0x6,0 cm. Ismeretlen metsző műve. A képen páncélos lovasok csapata, az első lovas szokatlan mellvérttel. Megjelent: Warhafftige Gründtliche beschreibung, Was der Rom. Kay. May. Vnsers aller genedigsten, Herrn General, vnd Feldhauptman inn Zips, Herren Lazarum vonn Schwendi [...] fürgenommen sey worden. München, Adam Berg, 1565. a címlapon. VD16 W 303 (84. kép) 
2. Lazarus Schwendi hadjárata 1565/2 Fametszet tudósítás címlapján, méret kb. 10,0x8,0 cm. Ismeretlen metsző műve. A képen lovasok csatája, háttérben hegytetőn egy vár. Megjelent: Zeyttung von der Rö. Kay. Mt. [et]c. Kriegsvolck in Zips, vnnd was dasselb ein zeit herumb gegen Jrer Mt. [et]c. widerwertige auszgericht. 1565. [S.l.], 1565. a címlapon. VD16 Z 289 (85. kép)

3. Natale Angielini térképe 1565 Térkép, rézmetszet, méret $71 \times 36 \mathrm{~cm}$. Natale Angelini hadmérnök műve. Magyarország északkeleti részének térképe, feltüntetve rajta Lazarus Schwendi kassai főkapitány 1565 tavaszi hadjáratának útvonala és eseményei. A térkép címe: Loca in Ungaria recepta ab invictiss. Imp. Max. II = Die Orter so neulich in Ungern eingenomen sein . A térkép jobb sarkára ragasztott nyomtatott szövegben Natale Angielini Wahrhafftige beschreibung der Orter so Herr Lazaro von Schwenda kezdetü beszámolója a hadjáratról. OSZK, App. M. 131 (86. kép)

\section{Zrínyi Miklós - Szigetvár}

1. Zrínyi Miklós-Szigetvár 1 Fametszet tudósítás címlapján, méret kb. 10,5x7,0 cm. Ismeretlen metsző műve. A képen egy lovascsapat érkezik egy várhoz, zászlójukon a sugárzó Nap, ugyan ez Nap látható a csapat vezérének lótakaróján is Megjelent: Ein verzaichnus von des Thewren Heldens, des Grauen von Serin[...] Befestigung zu Siget, im Jar M.D.LXVI. von seiner G. Secretario beschrieben [...] erledigt worden ist. Nürnberg, [Neuber], 1567. a címlapon. (135. kép)

2. Zrínyi Miklós-Szigetvár 2 Fametszet tudósítás címlapján, méret kb. 10,0x7,5 cm. Ismeretlen metsző műve. A kép közepén katonák tömegével körbevett lovas, süvegén egy agancs forma süvegdísszel, mögötte zászló, épület. Megjelent: Ein hüpsch new Lied / Von dem Graffen, Thewren Ritter und Helden Graff Niclaus von Serin / Wie er so Ritterlich in Ungern [...] den Türcken und sein hauffen etc./ Im thon: Wie man das Lied von Olmitz singt. Basel, Samuel Apiarius, 1568. a címlapon. (136. kép)

\section{Szokoli Musztafa budai pasa megfojtása 1578}

1. Szokoli Musztafa budai pasa megfojtása 1 Fametszet tudósítás címlapján, méret kb. 11,0x8,0 cm. Ismeretlen metsző műve. A képen egy földön fekvő, díszruhás török megfojtása létható. Megjelent: Deßœ Türckischen Keysers ernstliche Straff : [...] Mustapha Bassa zu Ofen vnd noch an andern dreyen Beegen [...] vom leben zum todt gebracht. Nürnberg, Heußler, 1579. a címlapon (hátoldalán a bégek megfojtása jelenet) VD16 T 2256 (156. kép)
2. Szokoli Musztafa budai pasa megfojtása 2 Fametszet tudósítás címlapján, méret kb. 7,0x5,0 cm. Ismeretlen metsző műve. A képen egy térdelő, díszruhás török megfojtása létható. Megjelent: Dess Trurckischen Keysers ernst=liche Straff. Warhaffte [...] andern dreyen Beegen/ [...] Zephan, dess Trurckischen Keysers obrister Stal=meister [...] die vier gemelten Herren [...] vom leben zum todt gebracht. M.D.LXXIX. Nürnberg, Leonhardt Heussler, 1579. a címlapon. VD16 T 2257 (157. kép)

\section{Kacorlaki csata 1587}

1. Kacorlaki csata 1587/1 Fametszet tudósítás címlapján, méret kb. 11,0x8,0 $\mathrm{cm}$. Ismeretlen metsző múve. A fametszeten török katonák hajtanak rabszíjra füzött foglyokat, a háttérben égő falu. Megjelent: Newe Zeitung auß Ungern, auch gründtlicher und warhaffter Bericht, welcher massen der Saswar Bascha von Siget sambt andern dreyen Beegen den 9. Augustii dises 1587. Jars über die Fünff tausendt starck herauß gefallen [...] geschrieben. Nürnberg, Leonhard Haussler, 1587. a címlapon. VD16 P 3820 (162. kép)

2. Kacorlaki csata $\mathbf{1 5 8 7 / 2}$ Fametszet tudósítás címlapján, méret kb. 9,0x7,0 cm. Ismeretlen metsző múve. Csatakép keresztény és török katonákkal, a háttérben egy vár. Megjelent: VICTORIA, Oder Zeyttungen/ so die Christen denn XXj.Augusti/ Anno 87. Jnn Vngern bey Katzerlach/glück=/lich mit Gottes hilff dem Türcken aberhalten/ Dergleichen bey Manns gedencken nie er=hrort oder geschehen ist. Anno Domini M.D.LXXXVII. Augsburg Josias Wrorli, 1587. a címlapon. VD16 V 1194 (163. kép)

3. Kacorlaki csata $\mathbf{1 5 8 7 / 3}$ Fametszet röplapon, méret $38,0 \times 27,5 \mathrm{~cm}$ (a metszet). Ismeretlen fametsző műve. Címe nincs, a térképszerű táj közepén csatajelenet, a képen A-O jelölések. A röplap címe hat sorban a kép alatt, kezdete Newe Zeitung auß Vngern/ auch warhaffte vnd eygentliche Abcontrafactur. Az öt hasábban elrendezett szöveg verses formában iserteti a történteket, a vers végén az A-O jelmagyarázattal. A röplap alján Hans Rogel (Augsburg) impresszuma. A röplapszöveg a röplapról levágva és üres lapra felragasztva Zürich Zentralbibliothek Graphische Sammlung (GSM) PAS II 24/12 (160-161. kép)

\section{Törökök fosztogatása, vérengzése}

1. Török fosztogatás 1522 Fametszet tudósítás címlapján, méret kb. 11,3×11,0 $\mathrm{cm}$. Ismeretlen metsző műve. A képen török lovasok hajtanak megkötözött kezű férfiakat, gyermekes nőket és háziállatokat. Megjelent: Ain Ermahnung wider die Türcken, vnd wie sy die Christen durchechtend im Land Ungern, / Im Jar MDXXII. 
[Augsburg], [Silvan Otmar]. 1522. a címlapon. Hubay 39. VD16 E 3794 (21. kép)

2. Török vérengzés 1526 Fametszet tudósítás címlapján, méret kb. 11,3×13,0 $\mathrm{cm}$. Ismeretlen metsző műve. A képen három török katona kardjával három kisgyermeket öl meg. Megjelent: Hernach volgt des Bluthunds der sich nennet eyn Türckischẽ Keyser [...] an vnsern mitbrüdern der Vngrischen landtschafften [...] gantz vnd noch teglichs thüt. Nürnberg, Hergot, Hans, 1526. a címlapon. VD16 ZV 2106. A metszet újra megjelent Hernach volgt des Bluthundts, der sych nennedt ein Türckischer Keiser [...]noch teglich tut. [Augsburg], [Steiner], 1526. tudósítás utolsó oldalán. VD16 B 5794 (35. kép)

3. Törökök vérengzés 1542 Fametszet tudósítás címlapján, méret kb. 10,0x10,0 $\mathrm{cm}$. Ismeretlen metsző műve. A képen törökök gyilkolnak nőket, gyermekeket. Megjelent: HJe nach volgend Vier neuwe klägliche/vnd zů Got rüffende Ge=sang [...] des Christenlichen blüts/ den Türgken. Augsburg, Heinrich Steiner, 1542. (kottával, záró képpel) a címlapon. VD16 V 1027 (52. kép)

4. Török vérengzés 1556 Fametszet tudósítás címlapján, méret kb. 11,5x8,0 $\mathrm{cm}$. Ismeretlen metsző műve. A képen egy török lovas egy halott csecsemő lándzsára tűzött holttestével. Megjelent: Newe Zeittung. Des Türckischen Keisers Absagbrieff, so er newlich dem Römischen Könige Ferdinando, bey seinem Legaten zugesand. Uns armen Christen erschrecklich und sehr erbermlich zu hören. [Wittenberg] [Seitz], 1556. a címlapon. VD16 N 757 (70. kép)

\section{Hungária vértanúsága}

Hungária vértanúsága 1581. Méret 28,5x20,4 cm. Johann Nel fametszete, jelzése $I N$ a képen lent, középen. A képen a megkötözött és megcsonkított Hungária, mellette két török harcos, balról érkező csapatok, jobbra magyar hősök holttestei. Megjelent Schrott, Martin Wappenbuch des Heiligen Römischen Reichs, vnd allgemainer Christenheit in Europa. München, Adam Berg, 1581. OSZK, App. H. 487. 13-14 (175. kép)

\section{Rajzok}

Tokaj, 1565 Wien, Österreichische Staatsarchiv - Haus. Hof. Staats Archiv, Hungarica, Miscellanea f. 427. (76. kép)

Győr, táborterv, 1566 Archivio di Stato di Modena, Mappario Estense, Militare, n. 129. (119. kép)

Szikszó 1588 Claudius a Roussel kassai főkapitány az 1588. évi ütközetről rajzot küldött Ferdinánd és Mátyás főhercegnek, illetve a Haditanácsnak. Jelzete: Wien, Österreichisches Staatsarchiv, Kriegsarchiv, Protokolle des Wiener Hofkriegrates, Exp. Bd. 182. fol.272., Bd. 183. fol. 79

Murány Claude Rochet hadmérnök rajza 1740. Hadtörténeti Intézet és Múzeum Hadtörténeti Térképtár G I h 3445;

\section{Az 1566. évi hadjáratról Itáliában megjelent metszetek feliratainak fordítása}

\section{Domenico Zenoi munkái}

1. Eger 1567/1 „AGRIA, fortezza nel paese di / Ongheria nel modo che al pre / sente si troua, la quale é di gran: / de importanza. l'anno 1567 / Dnco Zenoi" (Eger igen nagy jelentőségű magyarországi vár ahogyan az ma találtatik az 1567. évben. Dnco Zenoi.) A metszeten lévő felirat: „Questo monte e alquanto superiore alla fortezza, ma percio non li fa alcun nocumento" (Ez a hegy jelentősen a vár fölé magasodik, azonban ez (a várra) nem jelent semmiféle veszélyt) $27,5 \times 19,5 \mathrm{~cm}$

2. Győr (1566)/3 „FORTEZZA DI IAVARINO.” (Győr vára.) Jelezve jobb oldalt alul „Domenico Zenoi”. 19,7x14,6cm

3. Győr (1566)/1 „FORTEZZA DI IAVARINO / nei confini dell'Austria, et Ongheria, doue / al presente si troua il campo de Christiani” (Győr vára Ausztria és Magyarország határán, ahol jelenleg a keresztények tábora található.) Jelezve jobb oldalt alul „Domenico Zenoi”. 19,7x14,6cm

4. Győr (1566)/2 „Il campo del Imp. Piantato sopra / Iauarino, il quale mediante lettere / d'Alphabeto si mostrano il numero / dela Caualeria, et con numeri / d'abaco tutta la fanteria / Dnco Zenoi" (A császár Győr felett felvert táborának rajza, a lovas csapatok száma az ABC betűivel, a gyalogságé pedig számokkal jelölve a számtáblán. Dnco Zenoi.) 20,1x17,3cm

5. Győr 1567/2 „Il Campo del Imp. Sopra Iauarino con i nomi de .......(stai?) / Principe e signori, el il numere dele genti tratto da / una coppia autenthica, et da me con ogni diligenza / intagliato. In Venetia l'anno 1566. / Domenico / Zenoi/" (A császár tábora Győr felett, a hercegek és nagyurak neveivel, amelyet az eredeti dokumentum másolatában szereplő létszámok szerint nagy gondossággal véstem ide. Velencében, az 1566. évben. Domenico / Zenoi.) 20,5x14,9cm

6. Gyula (1566)/1 „GIVLA, Fortezza nie confini dell Tran / silvania, et Ongheria nel mod che' al presente / si troua Assediata da infideli l'anno 1566 / misura di passa / Domenico Zenoi" (Gyula vára Magyarország és Erdély határán, ahogyan azt jelenleg, az 1566. évben a hitetlenek ostromolják. /Lépték/ Domenico Zenoi.) $18,0 \times 13,5 \mathrm{~cm}$

7. Gyula 1567/1 „GIVLA Fortezza in Ongheria nei confini Tran / silvania, presa alli 3. settembrio da Perthan Bassa / di Signor Turcho / misur di passa / Dnco Zenoi 1566" (Gyula vára Magyarországon, Erdély határán, amelyet Perthan basa török nagyúr szeptember 3-án elfoglalt /Lépték/ Dnco Zenoi 1566.) $21,3 \times 13,4 \mathrm{~cm}$ 
8. Szigetvár 1566/81 „Ziget, nel paese d’Ongheria / Dnco Zenoi” (Szigetvár vára Magyarországon, Dnco Zenoi).

9. Szigetvár 1567/1 „Ziget, nel paese d'Ongheria preso / dal campo di turchi l'anno 1566 alli 14. Stt. / essendo stato lungamente diffeso dal conte di / Esdrinogran capitano onghero. / Dnco Zenoi" (Szigetvárvára Magyarországon, elfoglalva a török tábor által 1566 szeptember 14-én, miután hosszasan védelmezte Zrínyi gróf magyar főkapitány. Dnco Zenoi.) 19,9x14,5cm

10. Tokaj (1566)/1 „Tochai, fortezza nei confini di Trans: / silvania, et Ongheria come al p(rese)nte / si troua assediato dal campo del Re / Ioanne secundo, elletto d’Ongheria / l’anno 1566. / Dnco Zenoi." (Tokaj vára Erdély és Magyarország határán, ahogyan azt most az 1566. évben II. János választott magyar király tábora ostromolja. Dnco Zenoi.) 19,9x14,5cm

11. Tokaj 1567/1 „Tochai, fortezza nei confini di Transsilva /nia, et Ongheria, Assediato dal campo / elletto d'ongheria /del Re / et da Perthan Bassa, del Signor Turcho / l'anno 1566 / Domco Zenoi" (Tokaj vára Erdély és Magyarország határán, (amelyet) az 1566. évben II. János választott magyar király és Perthan basa török vezér tábora ostromolt. Domco Zenoi.) $20,0 \times 14,5 \mathrm{~cm}$

12. Tokaj 1567/2 „Tochai, fortezza nei confini di Trans: / silvania, et Ongheria, come al p(rese)nte / si troua assediato dal campo del Re / Ioanne secodo, elletto d'Ongheria / l'anno MDCLXVI. / Dnco Zenoi." (Tokaj vára Erdély és Magyarország határán, ahogyan azt II. János választott magyar király tábora ostromolja most az 1566. évben. Dnco Zenoi.) 19,9x14,5cm

13. Zsáka 1567/1 „Dissegno del Castello di Saaca in / Ongaria il quale spendendo il noine / qualo al governo di piccola Vine / gia, ma ueramente essendo ricetto d' / ladri; sii per comademeto del'Re cin: / to da assedio, et abbattuto l'Anno 1566 / a' 30 di Settebre, doue i Tedeschi, ha / uendo sopra il muro portato Andrea / Boy, lor Capitano, co piedi, e con le / mani legate, e poscia al Re datolo / percioche arreitrsi non haueua volun / te chiedeuauo humilemete perdono. / A Castel di Saaca / B Campo del Re / C Argere de Tedeschi." ( A Magyarországon lévő Zsáka várának rajza, ...... mintegy kicsi Velence, de mostanában latrok martaléka, ezért a király parancsára ostrom alá fogták és 1566. szeptember 30-án elfoglalták, ahol a németek Bay Andrást mert nem akarta magát megadni, felvitték a várfalra és kezét-lábát megkötözve átadták a királynak, és ezzel (a cselekedetükkel) akartak bocsánatot nyerni. A. Zsáka vára B. a Király tábora C. a németek szállása) 27,2×20,2cm

14. Szigetvár (1567)/1 (Zenoi?) „Disegno d. ${ }^{a}$ Sighet uenuto nouamente di ongaria / Nel qual si uede come uien batuta e da qual banda./ Vedesi ancora la batalia doue fu preso il gran basa / Capitan di ianiceri da una imboscata fata da cristiani / Fata con tute le sue strade perli fiumare e paludi con / Iusta misura cosa che ne li altri fin ora non si ritrova." (Sziget(vár)
Magyarországról újonnan érkezett rajza, amelyen látszik, hogyan és mekkora sereggel ostromolták, még az a csata is látszik, ahol a keresztények csapdát állítva elfogták a janicsárok nagy basáját, (és) ezt biztonságban azon az úton hajtották végre, amely a vízen és mocsáron pontosan vezettek (építettek). Ilyesmire mindeddig másutt nem volt példa.)

$41,3 \times 29,2 \mathrm{~cm}$

\section{Paolo Forlani munkái}

1. Győr1567/1/a „FORTEZZA DI IAVARIN / dove si troua hora il campo de l'impator” és alul a bástyán „in mezaria de / l'insegna della / Colonna” (Győr vára ahol most a császári táborhely van.) 18,0x14,0cm

2. Győr1567/1/b Ugyanaz, de a jobb alsó sarokban „86” lapjelzés.

3. Gyula 1567/2/a "Vero disegno di Giula, si / come e ueramente situate / ogi con L'assedio D’infide / li. l'anno M.D.LXVI. / misura di passa” és „Paolo Forlani Veronese intalgli: / atore i. ven. All'insegne della / Colonna” (Gyula várának igaz rajzolatja, ahogy azt most 1566-ban a hitetlenek ostromolják. /lépték/ A veronai Paolo Forlani rézmetsző Velencében az Oszlop cégérnél) $17,7 \times 13,7 \mathrm{~cm}$

4. Gyula 1567/2/b Ugyanaz, de a jobb alsó sarokban „87”, lapjelzés.

5. Komárom 1567/1 „Jl vero disegno del sito' e della fortezza di / Comar ' terra parta sopra un 'isola fatta dal / Danubio fiume nella parte del Vngaria / In Venetia l’anno 1567. Alla libraria della Colonna” (Komárom vára és környékének igaz rajzolatja Magyarországon, a Duna alkotta sziget feltöltésén. Velencében 1567. A Colonna /az Oszlophoz/ könyvesboltban.) 26,6x17,6cm

6. Szigetvár 1567/2/a „ZIGET, fortezza innespugnabile, si come ogi / di é ueramente situata, con li ponti per l'intrata / et uscita si della terra come d'una fortezza á l'al / tr quali ponti sou levatori, e cinto d'acqua et / paludi come nel presente disegno si uede: et / hora assediata dal gran Turco con 100000 Tur: / chi l'anno M.D.LXVI. In. Ven. Merzaria alla I" (A bevehetetlen Szigetvár vára ahogyan az ma a valóságban elhelyezkedik, vízzel és mocsárral körülvéve, a környező szárazföldhöz ki- és bejárást szolgáló hidakkal, amelyek közül egyesek felnyithatók, valamint egy további erődítménnyel, amint ezek a rajzon láthatók, most az 1566. évben a török szultán (Nagyság) és 100000 török által ostromolva. Velencében, Merzaria, az Oszlophoz /cégérnél/.) $18,3 \times 13,5 \mathrm{~cm}$

7. Szigetvár 1567/2/b Ugyanaz, de a jobb alsó sarokban „88” lapjelzés.

8. Tokaj 1567/2 „Toquay fortezza ne'i confini / d'Ongaria, uerso Transilvania / si ueramente come ogi di si troua" (Tokaj Magyarország Erdély felőli határán, ahogy az ma a valóságban találtatik.) 18,0x13,5cm 
Szigetvár 1566/6/a „Alli Lettori / Jl uero disegno del sito pianta di ziget, si ueramente come ogi di è situata. / con li passi come sta per l'intrata, et uscita, si da l'una piazza, a l'altra. / come anco de la terra, quali passi, tutti son ponti, che alcuni che si leuano. / jntorno è circonta d'acqua è paludi come nel presente disegno si uede, però / li paludi si e inquesta forma quanto alle riue de lacqua, per che son asai gra[n]de / et non si piglia in disegno, per non esser piu che tanto d'importantia. jl ca[m]po / sie da quela parte doue è signato .A.B.C. / Jn Venetia l'Anno M D L X V I Merzaria al segno della Colonna."

(Minden olvasóhoz / Az itt lévő rajz Sziget(vár) hiteles ábrázolása, mai valóságos állapotában, az átjárókkal amelyek a ki- és bejáratokhoz valamint az egyik területről a másikra vezetnek, továbbá azokkal, amelyek a szárazulatró vezetnek be, ezek pedig mind hidak, amelyek közül néhány felemelhető, és amely (hely) körbe van véve vízzel és mocsarakkal, amint ezen a rajzon is látszik, és a mocsarak a partok és a vizek tekintetében azért vannak ezen a rajzon így ábrázolva, mert nagyon nagyok és csak így fértek el, de ennek egyébként itt nincs különösebb jelentősége. A tábor ott azon a helyen van, ahol az A.B.C.-vel van jelölve. / Velencében, 1566-ban, Merzaria, az Oszlopnál /cégérnél/)

Szigetvár 1566/6/b A címtáblán lévő cím azonos az előzővel.

Az Óváros bejárata alatt Questa e intrada et viali cinque qiesi (Ez a bejárat és út Pécsnek).

A Külsővár és Óváros közötti felirat (részben olvashatatlan): Qui fu atterrato da turchi con legnani (legnoni?) cotoni e terra; da li dete l'asalto doue fu morto il ualoroso et immortal (?) conte nicolo d'Sedrin n...stre(?) che uiste(?) fu destrutione di turchi. (Itt töltötték fel a törökök rőzsével, gyapjúval és földdel, itt tört ki, ahol meg (is) halt a hős és halhatatlan (?) Zerinvári Miklós gróf a törökök által (?).

A Belsô-vár alatti felirat: „Quando il conte vede piu non potersi tenere / da li aspri e crudeli assalti d'infideli in chi(-) odo tutta l'altegliaria e dette il fuoco alla / monitione nel castello e si ritiro in ziget / d'ove ualorosamente combattendo mori." (Amikor a gróf látta, hogy nem képes tovább tartani magát a hitetlenek kemény és kegyetlen támadásaival szemben, összehordatta a kastélyba (Belső-várba) az összes hadifelszerelést és tüzet vettetett erre, majd visszahúzódott Szigetbe (Külső-várba), ahonnan hősiesen csatát kezdvén meghalt.) Tooley IM III, [540], 42,8x29,2cm

\section{Zenoi - Forlani másolatok és további velencei rézmetszők múvei}

1. Eger 1568/1/ a (Ludovico Pozzoserrato) „AGRIA, fortezza nel paese di / Ongheria nel modo che al pre /sente si troua, la quale é di gran: / de importanza. l'anno 1568” „L.P." a jobb alsó sarokban. ((Eger igen nagy jelentőségű magyarországi vár ahogyan az ma találtatik az 1568. évben.) 26,1x18,2cm
2. Eger 1568/1/b Ugyanaz a cím, de a jobb sarokban az „LP” jelzés kivakarva.

3. Gyula 1566/3 (Nicolo Nelli) „GIVLA Fortezza in Ongaria nei confini Tran / silvania assediata de infideli / misura di passa/ Nicolo Nelli F. 1566” (Gyula vára Magyarországon, Erdély határánál, a hitetlenektől ostromolva. /lépték/ „Nicolo Nelli F. 1566.) 21,3x13,4cm

4. Komárom 1568/1 (Ferando Bertelli) „Jl vero disegno del sito' e della fortezza di / Comar ' terra parta sopra un 'isola fatta dal / Danubio fiume nella parte del Vngaria / ferando bertelli Excudebat" (Komárom vára és környékének igaz rajzolatja Magyarországon, a Duna alkotta sziget feltöltésén. Kiadta Ferando Bertelli.) 25,2x17,2cm

5. Szigetvár 1566/7 (G.F. Camocio) „Ordinanza Turchesca alla presa / d ZIGHET in Ongaria / l'Anno 1566 / in Vinegia apresse Gio. Fran.co Camocio" (A törökök hadrendje a Magyarországon lévő Szigetvár elfoglalásánál / 1566. év / Velencében, Gio. Franciso Camocio) 25,7x17,2cm

6. Változat 1. (Ferando Bertelli?) „ESERCITO TVRCHESCO” (A török hadsereg) 26,0x17,5cm. Feliratok nélküli korábbi lemez állapot.

7. Változat 2. (Paolo Forlani) „AL S. ALBERTO LAVEZZOLA / Paolo Forlani Veronese / Con questa bellissma et ordinatissima ordinanza suole il gran sig.or Turco presentaria alla batteria et all'assalto di quelche fortezza... Di Venetia, a XXVI. D’Ottobre. M.D.LXVI. Merzaria all'insegna della Colonna" (Ebben az igen szép és igen rendezett hadrendben és az ágyúkkal szokott a török nagyúr (szultán) megjelenni néhány vár ostrománál ... Velencében, 1566. október 26-án, Merzariában, az Oszlophoz) 25,6x17,7cm Tükörkép!

\section{Rómában megjelent metszetek}

1. Szigetvár 1566/2 (Antonio Lafreri) „Jl vero ritratto di Zighet, con Jl suo Castello, / fortezza nuova, Paludi, Lago fiume et ponte et / altre cose Notabili per lettere annotate, con / monstra del monte fatto da Turchi, et / con l'asalto datogli da essi. / Ant. Lafrerij Formis Romae M.D.LXVI." (Szigetvár igaz képe, a várkastélyával, az Újvárral, a mocsárral, tóval, folyóval és hidakkal és egyéb nevezetes dolgai betűkkel (feliratokkal) megjelölve, a törökök készítette hegy és az onnan indított roham bemutatásával. Ant. Lafreri f., Róma, 1566). Később megjelent Henricus van Schoel és Giovanni Orlando jelzésével is. Tooley IM III, [544, 545], 50,9x34,6cm

2. Győr 1566/1 „IAVARINO in ongaria / trinclere dove al presente si trova / lo Jmperatore allogiato con lo esercito / Misura/ 15MVK66" (Győr Magyarországon, és a sáncok, ahol jelenleg a császár hadseregével tartózkodik /lépték/ 1566 Mario Cartaro monogramja) Tooley IM III, [461], 52,8x38,8cm

3. Szigetvár (1566)/4 „IL VERO DISEGNO DELLA / Fortezza di ZIGHET doue hora si / ritroua il turcho accampato in persona, / et datoli alcuni assalti 
nelli quali li Turchi / con gra' danno et uergogna loro sono / stati rebutati et co[n] poca perdita et grand' / honor' di Christiani Con priuilegio Roma. / B.F / [scale] MK [monogram] (SZIGET várának hiteles rajza, ahol most a török (szultán) személyesen táborozik, és látszik néhány támadás, melyekben a keresztények kis veszteséggel, de nagy tisztességükre a törököket szégyenükre nagy veszteséggel visszaverték. Róma. Privilégiummal B.F (Bartolomeo Faleti?) /lépték/ és MKV (Mario Cartaro monogram) Tooley IM III, [546], 51,2x39,4cm

\section{Domenico Zenoi könyvének címlapja}

Clarissimo Signore IERONYMO

Lippomani, Eletto meritissimo Amba-

ssiator Al Serenissimo Arciduca Carlo

Hauendo deliberato di mandar in luce questo libro delle principali fortezze d'Ongheria, sotto il nome di V. M. ho giudicato esser bene di mettervi l'universale di quelle provintie in questa comoda forma, non sin' sino a qui da altri inta-gliata, à fine ch'essa possi discorrervi sopra secondo che moltoen sapra fare per esser stata in molte parti di questi paesi . Et mi rendo certo che V. M. aceterà con grato animo questo libro infirme con quelle particolari fortezze, che mandero giongendo alla giornata con tutto ch'io conosca chiaramente ch'ella * per le rare sue conditioni che le *meriterebbe fossero donate le città istesse più tosto che i disegni. Poi che non solo per la nobiltà d'il sangue, et per i lunghi studij delle lettere, ma ancora per la molta pratica che à del Mondo, et del governo di stato, et per tant'altre sue belle grandi merita di governare come fa gia tanto tempo, che quanto prima le fu concesso per l'ettà sua d'esser creato Meritissimo savio à gt ordini, mostrò in quel carico tal ualor et prudenza che è stata fata continuatamente tant'al-tre volte dapoi contra il voler suo. Nel qual grado essendo hora tutta uia è stata eletta honoratamente Ambasciatore al Serenissimo Arciduca Carlo frate-llo di sua Maestà Cesarea. Vero et manifesto testimonio delle sue rare qualità, delle quali essa sarà inalzata à quei maggiori honori che sono dati da questa illustrissima Republica, et senza piu dire in sua bona gratia mi raccomando.

Dí Venezía il dí 4. Aprile, l’anno M.D.L.X.VII. di Vostra Mag.tia Humil Servitore

Domenico Zenoi Cum Privilegio

Az igen híres-neves Lippomani

JEROMOS úrnak, nagyérdemű Tanácsosnak, a főméltóságú Károly főherceg melletti (nagy)követnek

Miután elhatároztam, hogy Nagyságod (Vostra Maggiorantia) neve alatt hozom nyilvánosságra ezt a Magyarország főbb erődítményeit tartalmazó könyvet, úgy ítéltem meg, jó lesz, ha ebben a kényelmes formában ideillesztem ezeknek a tartományoknak teljességét (térképét? várakat mindenünnen?), amelyet mindezideig más nem készített el (ki nem metszett). Abból a célból teszem ezt, hogy könnyebben társaloghasson róluk. Ezt ugyanis könnyen megteheti majd, hiszen sok helyütt járt ezeken a vidékeken. És biztos vagyok benne, hogy hálás lélekkel fogadja majd Nagyságod ezt a könyvet együtt azokkal a válogatott erődítményekkel, amelyeket naponta füzök (majd) hozzá. Nagyon is világos számomra, hogy Ön, az ön nem mindennapi helyzetében, sokkal inkább megérdemelné magukat a városokat, mint ezeket a rajzokat, és persze nem csak vére nemes volta és könyvekből való hosszadalmas tanulmányai, hanem a Világról és az állam kormányzásáról gyűjtött sok gyakorlati ismerete alapján, és, amit már annyi ideje végez, magában a kormányzásban szerzett érdemei miatt is. Hiszen tudjuk, hogy jóval előbb, mint kora engedte volna, nagyérdemű Tanácsossá kreálták, hogy rendjeleket visel, s hogy íly minőségében mekkora erélyről és okosságról tett bizonyságot. És teszi ezt azóta, állandóan, annyi alkalommal, akár akarata ellenére is. És ezen méltóságát hordozván most pedig megtisztelően kiválasztották, hogy követ legyen Ő Császári Fensége testvérénél, a főméltóságú Károly főhercegnél. Mindez valóságos és nyilvánvaló bizonyítéka az Ön különleges képességeinek, amelyek révén felemelték eme nagyon illusztris Állam magas tisztségeire. Egyebekről nem is szólva ajánlom magam jó kegyelmébe Velencéből, 1567. április 4-én

Nagyságod (di Vostra Maggiorantia) alázatos szolgája

Zenoi Domokos (Könyves Tóth Kálmán fordításai)

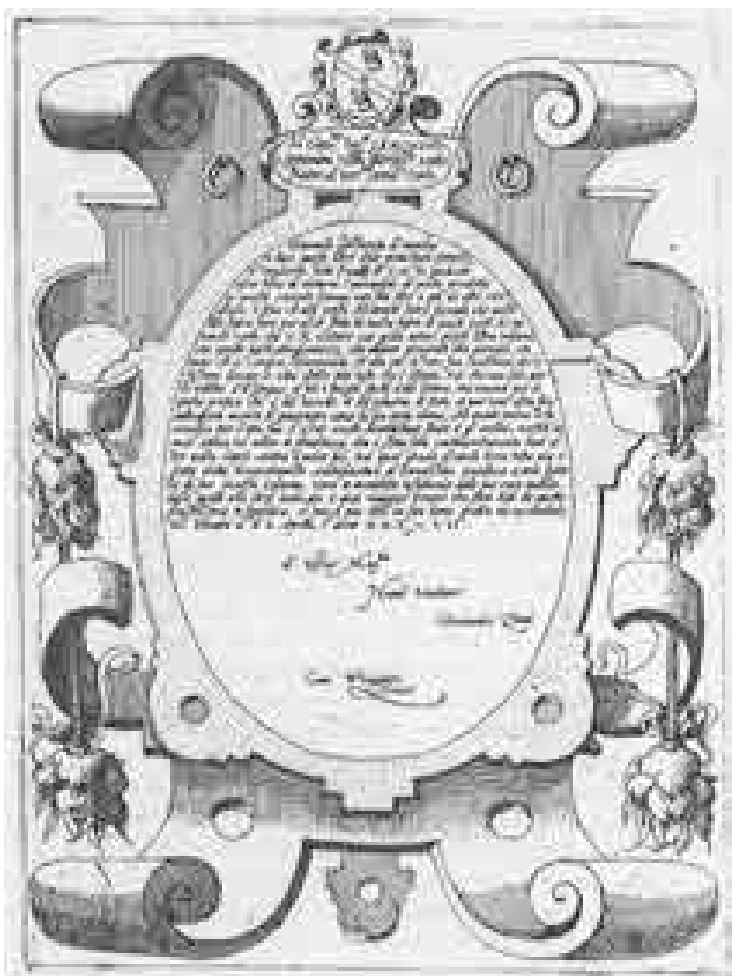




\section{Sebastian Münster Cosmographia könyvének fametszetes magyar városképei}

Sebastian Münster Cosmographia című műve egyre bővülő tartalommal 1544 és 1628 között német, latin, olasz, francia és cseh nyelven összesen 36 kiadást ért meg. A múben - az egyetlen 1554. évi cseh nyelvű kiadás kivételével - a kezdetektől fogva szerepelt térképekkel Magyarország és Erdély ismertetése valamint több szövegközti kisméretű kép, mint a magyar címer, Mátyás király és Attila hun fejedelem portréja, életképek stb.

Erdélynek a kezdetektől történő részletes ismertetése, térképe feltehetően Johann Honterus és Sebastian Münster közötti kapcsolatnak köszönhető. Úgy gondoljuk, ezért jelent meg már az első (német nyelvű kiadásban Nagyszeben (Hermanstatt Hauptsatt) kisméretű, képzeletbeli látképe, majd az 1572-ig a további 11 német nyelvű kiadásban is. A látkép fadúcát többször újravésték: az első, 1544. évi kiadás képét 1546-ban, majd 1550-ben, végül 1567-ben új képek követték, de mindegyikük maradt képzeletbeli ábrázolás. A későbbiekben további két erdélyi hely, Brassó és Vöröstorony képe is megjelent. A kisméretű Brassó $(8,0 \times 6,0)$, Nagyszeben $(6,0 \times 5,5)$ és Vöröstorony $(7,0 \times 5,0)$ képzeletbeli látképe más helységek, helyek képeként is szerepel a műben.

Nagyobb méretü magyar városképek az 1540-es évek kiadásaiban nem szerepeltek. Az első ilyen valóságra törekvő nagyobb látkép (17,5×9,0 cm) Budáé, amely megjelent az 1550. évi első, majd minden további latin nyelvű kiadásban (1552,1554,1559 és 1572). Ez a Buda metszet 1552-től kezdve a francia nyelvü, 1558-tól az olasz nyelvű, majd 1588-tól a német nyelvű kiadásokban is megtalálható.

Budával egyszerre jelent meg először Nándorfehérvár (ma Belgrád) látképe, amely Hans Sebald Beham metszetének másolata. A metszeten lévő I és C ligatúra Jakob Clausen jelzése. Ez a metszet 1550-től a Cosmográfia - az 1575. évi francia nyelvű kivételével - összes kiadásában megjelent.

Ugyancsak szerepel Brassó (Corona qua Pressovia) képe 1550-től kezdve valamennyi latin, 1552-től kezdve francia és 1558-tól olasz-nyelvű kiadásban. Az olasz és francia kiadásokban azonban a városnév külön feltüntetése többnyire elmarad, az csak a kép melletti szövegben szerepel. Hasonlóan Nagyszeben látképéhez, ez a kisméretű szövegközti kép is képzeletbeli.

Az 1574 évi németnyelvű kiadásban először jelenik meg Tokaj és Gyula (kb. 15,5x12,5) látképe, majd azonos fadúcról készült metszetük szerepel az 1578. évi kiadásban is. Az 1588. évi németnyelvű kiadásban a már új fadúcokról készült Tokaj és Gyula látképe mellett első ízben jelenik meg a velük azonos nagyságú Győr, Szigetvár és Zsáka metszet és ugyancsak először szerepel Vöröstorony (Der Rotthurn) kicsiny, képzeletbeli képe.
A Cosmographia 1588. évi kiadásától kezdve Gyula, Szigetvár és Zsáka metszetén G. S. vésnökjelzés (Gregorius Sickinger) szerepel, és Tokaj metszete is új fadúcról készült. Ezek a fadúcok Győr metszetének fadúcával együtt 1578-ban készültek Ulloa, Alfons és Höniger, Nicolaus múveihez (lásd lejjebb).

Buda látképének előképe Erhard Schön 1541-ben készített fametszete volt. A Győr, Gyula, Szigetvár, Tokaj és Zsáka ábrázolások előképei Domenico Zenoi metszetei, amelyek Giulio Ballino: De disegni delle piu illustri citta et fortezze... (Venezia, 1569) című művében jelentek meg.

A továbbiakban három összeállítást közlünk. Előre bocsátjuk, az ismert kiadások közül párat (az 1558 és 1615 évi német, az 1558-1571 közötti olasz, az 1560 és 1565 évi francia kiadást) nem tudtuk átnézni, így azok adatai egyik összeállításunkban sem szerepelnek.

Elsőként felsoroljuk a Münster Cosmographia különböző kiadásait, ismertetve azokat a kiadásokat is, amelyeket nem tudtunk átnézni.

A második összeállításban felsoroljuk ABC sorrendben (és azon belül a megjelenés időrendjében) a megjelent városképeket. Minden képnél megadjuk az oldalszámot (római oldalszám esetén arab számjegyekkel is), a kiadás nyelvét és a megjelenés évét, Az oldalszámok egyébként a latin, olasz és francia nyelvû kiadásokban mindig arab számokkal, a német nyelvű kiadásokban az utolsó évek (1614-1628) kivételével pedig római számmal szerepelnek.

Mivel a Münster mű magyar metszetei (azonos fadúcról) Bázelben további két műben is megjelentek (Ulloa Alfons: Beschreibung Des Letsten Vngerischen Zugs... Basel, S. Heinripetri 1578 és Nicolaus Höniger: Erster und Ander Theil der Türckischen Historien Basel, S. Heinripetri 1578 és 1596.), ezért azokat is szerepeltetjük az egyes helyeknél.

Az eddig felsorolt művekben a metszetek közül Nándorfehérvár 16, Buda 14, Győr 6, Gyula 9, Szigetvár 8, Tokaj 11 és Zsáka 7, az erdélyi helyek közül Brassó 5, Nagyszeben 6, Vöröstorony 3 különböző oldalszámmal ismert.

A harmadik összeállításban felsoroljuk a különböző nyelveken megjelent kiadásokat, ismertetve, melyik kiadásban mely képek jelentek meg. Itt ismertetjük Alfons Ulloa és Nicolaus Höniger munkáiban megjelent képeket is.

\section{Münster Cosmographia kiadások}

\section{Német nyelvű kiadások:}

Cosmographia 1544, 1545, 1546, 1548 (Heinrich Petri, Basel); Cosmographei 1550, 1553, 1556, 1558, 1561 (Heinrich Petri, Basel); Cosmograhey (Heinrich Petri, Basel) 1564, 1567, 1569, 1572 (Sebastian Heinric-Petri, Basel), 1574 [Ruland], 1578 (Sebastian Heinric-Petri, Basel), 1588, 1592, 1598, 1614; Cosmographia (Sebastian Heinric-Petri, Basel) 1615, 1628. 


\section{Latin nyelvü kiadások}

Cosmographia Universalis 1550, 1552, 1554, 1559, 1572 (Heinrich Petri, Basel)

\section{Francia nyelvü kiadások:}

Cosmographie Universelle 1552, 1556, 1560, 1565, 1568 (Heinrich Petri, Basel), 1575 (Nicolas Chesneau és Michel Somnius, Paris, kéthasábos szöveggel).

\section{Cseh nyelvü kiadás:}

Kozmografia Czeska 1554 (Jan Kosorrsky, Praga, illusztráció nélkül)

\section{Olasz nyelvü kiadások}

Cosmographia Universale 1558 (Heinrich Petri, Basel), 1575 (Arnold Birkmann, Cologne), 1558-1571 (Thomasini, Venezia)

\section{Magyar városmetszetek a Cosmographiákban}

Brassó 919 (1550, 1552, 1554, 1559 latin)

Brassó 1072 (1572 latin)

Brassó 991 (1558, 1575 olasz)

Brassó ???? (1558-71 Venezia olasz)

Brassó 1140 (1552, 1556 francia)

Brassó 1103 (1568 francia)

Brassó ???? (1560, 1565 francia)

Buda 868 oldal (latin 1550,1552, 1554, 1559)

Buda 1019 oldal (latin 1572)

Buda 930 oldal (olasz 1558)

Buda ??? (1558-71 Venezia olasz)

Buda 930 oldal (olasz 1575)

Buda 1075 oldal (francia 1552)

Buda 1075 oldal (francia 1556)

Buda ??? (1560, 1565 francia)

Buda 1037 oldal (francia 1568)

Buda 1745-1746 oldal (francia, 1575, kéthasábos)

Buda mclxxx (1180) oldal (1588 német)

Buda mclxxxiii (1183) oldal (1592 német)

Buda mccxvi (1216) oldal (1598 német)

Buda 1365 oldal (1614 német)

Buda 1377 oldal (1628 német)
Buda x (10) oldal (Höniger 1578. I. Theil)

Buda xciii (93) oldal (Höniger 1578. I. Theil)

Buda x (10) oldal (Höniger 1596. II. Theil)

Győr dccccxlvi (946) oldal (1588 német)

Győr dccccxlvi (946) oldal (1592 német)

Győr dcccclxvi (966) oldal (1598 német)

Győr 1139 oldal (1614 német)

Győr 1113 oldal (1628 német)

Györ lxxiii (73) oldal elforgatott kép (Ulloa 1578)

Györ ccxxxii (232) oldal (Höniger 1596)

Gyula mcxcii (1192) oldal (1574 német)

Gyula mcxcii (1192) oldal (1578 német)

Gyula mclxxxvi (1186) oldal (1588 német)

Gyula mclxxxviii (1188) oldal (1592 német)

Gyula mccxxiii (1223) oldal (1598 német)

Gyula 1371 oldal (1614 német)

Gyula 1385 oldal (1628 német)

Gyula xciij (93) oldal elforgatott kép (Ulloa 1578)

Gyula cxciiij (194) oldal (Höniger, 1578)

Gyula ccvii (207) (Höniger 1596)

\section{Nándorfehérvár /Griechische Weissenburg, Belgrád/}

Nándorfehérvár 869 oldal (latin 1550,1552, 1554, 1559)

Nándorfehérvár 1020 oldal (latin 1572)

Nándorfehérvár 931 oldal (olasz 1558)

Nándorfehérvár ??? (1558-71 Venezia olasz)

Nándorfehérvár 931 oldal (olasz 1575)

Nándorfehérvár 1077 oldal (francia 1552)

Nándorfehérvár 1077 oldal (francia 1556)

Nándorfehérvár ??? (1560, 1565 francia)

Nándorfehérvár 1039 oldal (francia 1568)

Nándorfehérvár dccccxcix (999) oldal (latin 1550, 1553, 1556)

Nándorfehérvár ??? (1558 német)

Nándorfehérvár mccxxxix (1239) oldal (német 1561, 1564)

Nándorfehérvár mccxxxii (1231) oldal (német 1567, 1569, 1572)

Nándorfehérvár mclxxxix (1189) oldal (német 1574, 1578)

Nándorfehérvár mclxxxiii (1183) oldal (német 1588) 
Nándorfehérvár mclxxxv (1185) oldal (német 1592)

Nándorfehérvár mccxx (1220) oldal (német 1598)

Nándorfehérvár 1368 oldal (német 1614)

Nándorfehérvár 1382 oldal (német 1628)

Nándorfehérvár iii (3) oldal, ccxxxcii (232) oldal (Höniger, 1578)

Nándorfehérvár cclxxxvii (287) oldal (Höniger 1596)

Nagyszeben dlij (552) oldal (1544 német)

Nagyszeben $d c l v$ (655) oldal (1545, 1546, 1548 német)

Nagyszeben mxxxix (1039) oldal (1550, 1553, 1556 német) Nagyszeben ??? (1558 német)

Nagyszeben mcclxxix (1279) oldal (1561, 1564 német)

Nagyszeben mcclxxi (1271) oldal (1567, 1569, 1572 német)

Szigetvár mclxxxvii (1187) oldal (1588 német)

Szigetvár mclxxxix (1189) oldal (1592 német)

Szigetvár mccxxiv (1224) oldal (1598 német)

Szigetvár 1372 oldal (1614 német)

Szigetvár 1386 oldal (1628 német)

Szigetvár lxxvij (77) oldal elforgatott kép (Ulloa, 1578)

Szigetvár cciiij (204) oldal (Höniger, 1578)

Szigetvár clxvii (167) oldal (Höniger 1596) városnév nélkül

Szigetvár ccxvi (216) oldal (Höniger 1596)

Tokaj mcxci (1191) oldal (1574 német)

Tokaj mcxci (1191) oldal (1578 német)

Tokaj mclxxxv (1185) oldal (1588 német)

Tokaj mclxxxvii (1187) oldal (1592 német)

Tokaj mccxxii (1222) oldal (1598 német)

Tokaj 1370 oldal (1614 német)

Tokaj 1384 oldal (1628 német)

Tokaj cxij (112) oldal elforgatott kép (Ulloa 1578)

Tokaj clxxxvj (186) oldal felül (Höniger 1578)

Tokaj ccxviii (218) oldal (Höniger 1578)

Tokaj cc (200) oldal (Höniger 1596)

Tokaj ccxxxiiii (234) oldal (Höniger 1596)

Zsáka mclxxxviii (1188) oldal (1588 német)

Zsáka mcxc (1190) oldal (1592 német)
Zsáka mccxxv (1225) oldal (1598 német)

Zsáka 1373 oldal (1614 német)

Zsáka 1387 oldal (1628 német)

Zsáka ccxj (211) oldal (Höniger 1578)

Zsáka ccxxii (222) oldal (Höniger 1596)

Vöröstorony mccxxv (1225) (1588 német)

Vöröstorony mccxxvii (1227) (1592 német)

Vöröstorony mcclxii (1262) (1598 német)

\section{Az egyes kiadásokban szereplő magyar városképek}

(a városkép után az oldal száma, ahol a kép szerepel)

Német nyelvü kiadások Cosmographey /Cosmographia/Oder beschreibung Aller Länder...

1544 (német nyelvü) Nagyszeben $\operatorname{dlij}(552)$

1545 (német nyelvü) Nagyszeben $d c l v$ (665)

1546 (német nyelvü) Nagyszeben $\operatorname{dclv}(665)$

1548 (német nyelvü) Nagyszeben dclv (665)

1550 (német nyelvű) Nándorfehérvár dccccxcix (999), Nagyszeben mxxxix (1039) 1553 (német nyelvü) Nándorfehérvár dccccxcix (999), Nagyszeben mxxxix (1039)

1556 (német nyelvü) Nándorfehérvár dccccxcix (999), Nagyszeben mxxxix (1039) 1558 (német nyelvü) ?? (nem láttuk)

1561 (német nyelvű) Nándorfehérvár mccxxxix (1239), Nagyszeben mcclxxix (1279) 1564 (német nyelvű) Nándorfehérvár mccxxxix (1239), Nagyszeben mcclxxix (1279) 1567 (német nyelvű) Nándorfehérvár mccxxxii (1231), Nagyszeben mcclxxi (1271) új kép

1569 (német nyelvű) Nándorfehérvár mccxxxii (1231), Nagyszeben mcclxxi (1271) 1572 (német nyelvű) Nándorfehérvár mccxxxii (1231), Nagyszeben mcclxxi (1271) 1574 (német nyelvű) Nándorfehérvár mclxxxix (1189), Tokaj mcxci (1191), Gyula mcxcii (1192)

1578 (német nyelvű) Nándorfehérvár mclxxxix (1189), Tokaj mcxci (1191) Gyula mcxcii (1192)

1588 (német nyelvű) Győr dccccxlvi (946), Buda mclxxx (1180), Nándorfehérvár mclxxxiii (1183), Tokaj mclxxxv (1185), Gyula mclxxxvi (1186), Szigetvár mclxxxvii (1187), Zsáka mclxxxviii (1188), Vöröstorony mccxxv (1225)

1592 (német nyelvü) Győr dccccxlvi (946), Buda mclxxxiii (1183), Nándorfehérvár mclxxxv (1185), Tokaj mclxxxvii (1187), Gyula mclxxxviii (1188), Szigetvár mclxxxix (1189), Zsáka mcxc (1190), Vöröstorony mccxxvii (1227) 
1598 (német nyelvű) Győr dcccclxvi (966), Buda mccxvi (1216), Nándorfehérvár mccxx (1220), Tokaj mccxxii (1222), Gyula mccxxii (1223), Szigetvár mccxxiv (1224), Zsáka mccxxv (1225), Vöröstorony mcclxii (1262)

1614 (német nyelvű) Győr 1139, Buda 1365, Nándorfehérvár 1368, Tokaj 1370, Gyula 1371, Szigetvár 1372, Zsáka 1373.

1615 (német nyelvü) ?? (nem láttuk)

1628 (német nyelvű) Győr 1113, Buda 1377, Nándorfehérvár 1382, Tokaj 1384, Gyula 1385, Szigetvár 1386, Zsáka 1387.

Latin nyelvú kiadások Cosmographiae uniuersalis Lib[ri] VI.

1550 (latin nyelvű) Buda 868, Nándorfehérvár 869, Brassó 919.

1552 (latin nyelvű) Buda 868, Nándorfehérvár 869, Brassó 919.

1554 (latin nyelvű) Buda 868, Nándorfehérvár 869, Brassó 919.

1559 (latin nyelvű) Buda 868, Nándorfehérvár 869, Brassó 919.

1572 (latin nyelvű) Buda 1019, Nándorfehérvár 1020, Brassó 1072.

Olasz nyelvú kiadások Sei Libri Della Cosmografia Vniuersale

1558 (olasz nyelvű, Basel) Buda 930, Nándorfehérvár 931, Brassó 991. 1558-71 (olasz, Venezia) ?? (nem láttuk)

1575 (olasz nyelvű, Köln) Buda 930, Nándorfehérvár 931, Brassó 991.

Francia nyelvú kiadások La cosmographie universelle de tout le monde 1552 (francia nyelvű) Buda 1075, Nándorfehérvár 1077, Brassó 1140. 1556 (francia nyelvű) Buda 1075, Nándorfehérvár 1077, Brassó 1140. 1560 (francia nyelvü) ?? (nem láttuk)
1565 (francia nyelvü) ?? (nem láttuk)

1568 (francia nyelvű) Buda 1037, Nándorfehérvár 1039, Brassó 1103.

1575 (francia nyelvű, Paris) Buda 1745-1746 (kéthasábos szövegű kiadás)

Ulloa Alfons: Beschreibung Des Letsten Vngerischen Zugs... (Basel, Sebastian Heinric-petri 1578)

Győr lxxiii (73) oldal, Szigetvár lxxvij (77) oldal, Gyula xciij (93) oldal, Tokaj cxij (112) oldal. Valamennyi kép 90 fokkal kép elforgatva

Höniger, Nicolaus: Erster und Ander Theil der Türckischen Historien... (Basel, Sebastian Heinric-petri, 1578).

Erster Theil Nándorfehérvár ccxxxii (232)

Ander Theil Nándorfehérvár iii (3) oldal, Buda x (10) oldal, Buda xciii (93) oldal, Tokaj clxxxvj (186) oldal Gyula cxciiij (194) oldal, Szigetvár cciiij (204) oldal, Tokaj ccxviii (218) oldal. A könyvben szerepel még Várpalota cxcij (192) oldal és Veszprém cxciij (193) oldal kisméretü képzeletbeli képe.

Höniger, Nicolaus: Erster und Ander Theil der Türckischen Historien... (Basel, Sebastian Heinric-petri, 1596).

Erster Theil Nándorfehérvár cclxxxvii (287) oldal

Ander Theil Buda x (10) oldal, Szigetvár /városnév nélkül/ clxvii (167) oldal, Tokaj cc (200) oldal, Gyula ccvii (207) oldal, Szigetvár ccxvi (216) oldal, Győr ccxxxii (232) oldal, Tokaj ccxxxiiii (234) oldal.

Sebastian Münster munkájának tartalmi ismertetésére lásd: FAZEKAS Borbála: Sebastian Münster Cosmographiája, különös tekintettel Magyarországra. In: Historia Nostra II. évf. 1. szám Eger, Lyceum Kiadó, 2017 47-72.Múvészek,

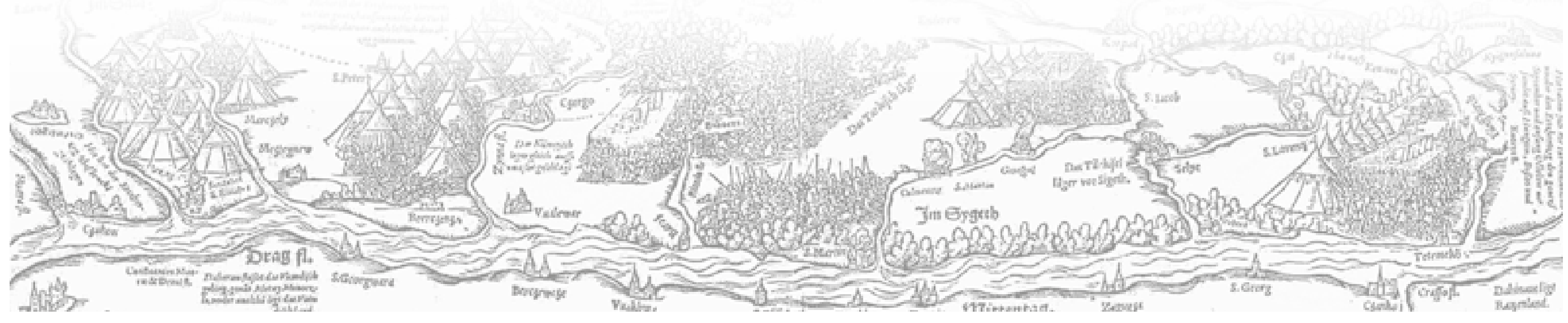




\section{M Ú VÉSZE K, M E TSZET KI A D Ó K}

(a metszetazonosító a Katalógusra, a képszám a Képtáblákra utal)

Adler, Aegidius Kígyóvész Szikszón 1550/3 és 1551/1 (65a, 65b. kép)

Amman, Jost Vác 1576/1 (149. kép)

Angielini, Natale Hadjárat térkép 1565 (86. kép)

Beham, Hans Sebald Nándorfehérvár 1521/1 (14. kép)

Bertelli, Donato Tokaj 1565/1/c (79. kép)

Bertelli, Ferrando Eger 156/1/a (131. kép), Győr 1567/1/a (117. kép), Gyula 1567/2/a (95. kép), Komárom 1568/1 (134. kép), Szigetvár 1567/2/a (101. kép), Tokaj 1567/2 (128. kép)

Blümel, Leonhard /Nürnberg/ Temesvár 1576/1 (150. kép)

Camocio, Giovanni Francesco Győr 1567/1/b (118. kép), Gyula 1567/2/b (96. kép), Szigetvár 1566/7 (15. kép), Szigetvár 1567/2/b (102. kép), Tokaj 1565/1/c (79. kép)

Cartaro (Kartaro), Mario Győr 1566/1 (122. kép), Szigetvár (1566)/4 (107. kép) Clausen, Jakob Nándorfehérvár 1550/1 (17-20. kép)

Corthois, Anthony /Frankfurt/ Kassa 1580/1 (159. kép)

Denecker, Jost Nándorfehérvár 1522/2 (16. kép)

Forlani, Paolo Veronese Győr 1567/1/a-b (117, 118. kép), Gyula 1567/2/a-b (95, 96. kép), Komárom 1567/1 (133. kép), Szigetvár 1566/6/a-b (103, 104. kép), Szigetvár 1567/2/a-b 101, 102. kép), Tokaj 1567/2 (128. kép)

Franck, Mattheus /Augsburg/Szigetvár (1566)/2 (114. kép)

Halbmaister, Wolfgang /Wien/ Győr 1590/1, (173. kép)

Heussler, Leonhard /Nürnberg/Buda 1578/1 (153. kép)

Hirschvogel, Augustin Léva 1549/ (62. kép), Murány 1549/1 (63. kép)

Hogenberg, Franz Buda 1572/1 (170. kép), Pozsony 1588/1 (171. kép), Szikszó

1599/1 (164. kép)

Lafreri, Antonio Szigetvár 1566/2 (106. kép)

Lang, Georg /Nürnberg/Szikszó 1588/3 (166. kép)

Lazius, Wolfgang Haditérkép 1556 (71. kép)

Liefrinck, Hans Szigetvár (1566)/1 (110. kép)

Mack (Macken), Georg /Nürnberg, Sonnenbad/Buda 1578/2/a (154. kép), Szikszó 1577/1 (152. kép)

Mayer /Mayr/, Hans Pozsony 1563/1 és 1566/1 (74, 75. kép)

Mayer, Lucas /Nürnberg/ Pozsony 1591/1 (174. kép), Buda 1592/1 (175. kép)

Mayer, Sebald /Dillingen/ Kígyóvész Szikszón 1550/2 (64. kép)
Merian, Mattheus Fráter György meggyilkolása (68. kép)

Meyerpeck, Wolfgang Szikszó 1588/2 (165. kép)

Musi , Agostino de Veneziano Buda 1532/1 (43. kép)

Nel, Johann Hungária vértanúsága (175. kép)

Nelli, Nicolo Gyula 1566/3 (92. kép)

Orlandi, Giovanni Szigetvár 1566/2 (106. kép)

Pozzoserrato, Ludovico Eger 1568/1/a (131. kép)

Resch, Wolfgang /Nürnberg/ Nándorfehérvár 1522/1 (15. kép)

Rogel, Hans /Augsburg/Kacorlaki csata 1587/3 (160, 161. kép)

Salamanca, Antonio Buda 1532/1 (43. kép)

Schäufelein, Hans Mohácsi csata 7 (28. kép)

Schoel, Henricus van Szigetvár 1566/2 (106. kép)

Schön, Erhard Köszeg 1532/1 (42. kép), Buda 1541 (46. kép), Buda, foglyok kivégzése (48. kép)

Schönig, Valentin /Augsburg/ Buda 1578/2/b (155. kép)

Sickinger, Gregorius Gyula 1579/1 (138. kép), Gyula 1578/2 (144. kép), Szigetvár 1578/1 (139. kép), Szigetvár 1578/2 (145. kép), Tokaj 1578/1 (137. kép), Tokaj 1578/2 (142. kép), Zsáka 1578/1 (147. kép)

Solis, Virgil Pest ostroma 1542 (47. kép)

Springinklee, Hans Habsburg-Jagelló szerződés 1515 (10,11. kép), Székesfehérvár $1515(12,13$. kép)

Thevet, Andre Szigetvár (1566)/3 (108. kép), Tokaj 1565/4 (81. kép)

Vico, Enea Buda 1542/2 (53. kép)

Zenoi, Domenico Eger 1567/1 (130. kép), Győr (1566)/1 (116. kép), Győr (1566)/2 (120. kép), Győr (1566)/3 (115. kép), Győr 1567/2 (121. kép), Gyula (1566)/1 (91. kép), Gyula 1567/1 (97. kép), Szigetvár 1566/8 (99. kép), Szigetvár 1567/1 (100. kép), Tokaj 1565/1 (78. kép), Tokaj (1566)/1 (126. kép), Tokaj (1566)/2 (125. kép), Tokaj 1567/1 (127. kép), Zsáka 1567/1 (123. kép)

Zimmermann, Michael Kismarton, Pozsony, Sopron 1562/1-2 (72, 73. kép), Tokaj 1565/2/a (77. kép), Tokaj 1565/3 (80. kép)

Zündt, Matthias Gyula 1566/2 (94. kép), Szigetvár 1566/3 (111. kép), Szigetvár 1566/4 (113. kép)

„zu Prag” jelzés Gyula 1566/4 (95. kép), Szigetvár 1566/5 (112. kép) 


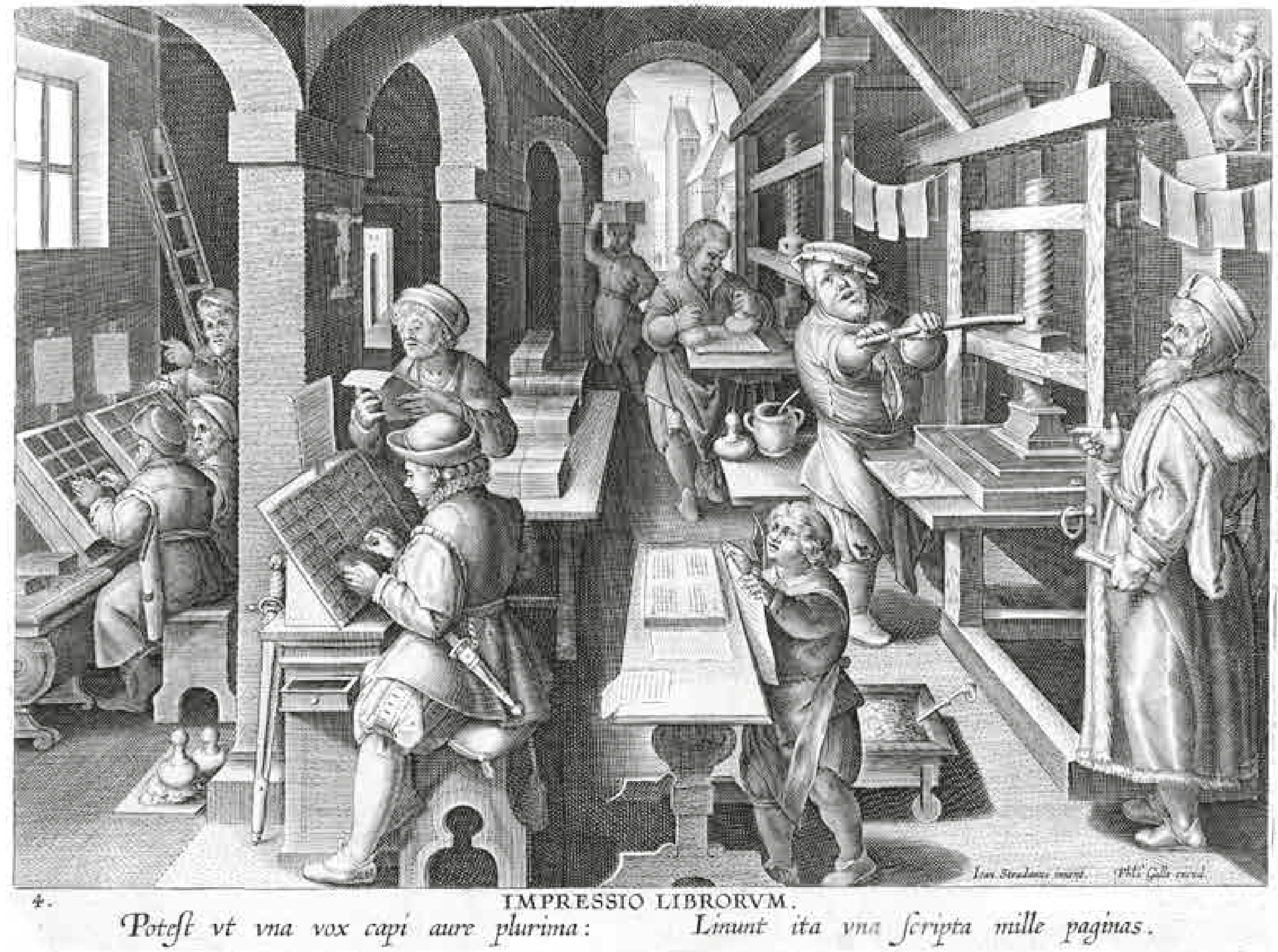




\section{EGYESÍTET T IRODALOMJEGYZÉK}

A 16. század magyar eseményei metszeteit tartalmazó korabeki alkalmi kiadványok és könyvek, felhasznált irodalom

\section{Alkalmi nyomtatványok}

- $\quad$ Ain Ermahnung wider die Türcken, vnd wie sy die Christen durchechtend im Land Ungern, [Augsburg], [Silvan Otmar]. 1522. Hubay 39. VD16 E 3794 (Török fosztogatás 1522, 21. kép)

- $\quad$ Ain groß $\beta$ wunderzaichen das da geschehen ist durch das Creütz, das ain Cardinal hat außgeben, in dem gantzen Hungerischen lannd wider die Thürckhen. [München], [Schobser], [1514]. VD 16 G 3477 (Keresztes katona 1, 1. kép)

- Ain groß wunderzaichen das do geschechen ist durch das Creütz, das ain Cardinal außgeben, inn dem gantzen Hungerischen Lannd wider die Turcken. [S.l.], [Augspurg, Erhard Öglin 1514]. VD16 G 3474 (keresztes katona képe)

- Ain groß wunderzaychen das do geschehen ist durch das Creütz, das ain Cardinal hat außgeben in dem gantzen Vngerischen Landt wider die Turcken, [Nürnberg], [Stuchs], [1514]. VD16 G 3479 (Keresztes katona 3, 3. kép)

- Cuspinianus. Johannes: Congressus ac celeberrimi conuentus Caesaris Max. et trium regum Hungariae, Boemiae, et Poloniae. In Vienna Panoniae, mense Iulio. Anno 1515 facti, breuis ac uerissima descriptio. [Wien], [Singriener], 1515. VD 16 C 6482 (Habsburg-Jagelló szerződés 1515/1, 6. kép)

- Cuspinianus. Johannes: Der namhaftigen Kay. Ma. und dreyer Kunigen zu Hungarn, Beham und Poln zamenkumung und versamlung so zu Wienn in dem Heymonat nach Christi gepurd MDXV iar geschehen: ain kurtze und warhafte erzelung und erklarung. [Wien], [Singriener], 1515. VD 16 C 6484 Németh S Katalin H2304. (címlapon öt címer)

- Des Turckschen keysers veruaerlicke beleg, der stadt ē̄ slot Guns genomt, eñ des seluen na twaelf verlorē stormen aftoceh[!], bi dē edelē ridder Niclaes Jurischitz [...] gescreuen warachtelijckē aen Ferdinandus roomsche coninc wt der voorghenoemde stadt Guns. Amsterdam, Doen Pietersz, 1532. (Köszeg 1532/2, 40. kép)

- Des Türcken erschrökenliche Belegerung der Stat vnd Schloß Günß/Vnnd desselbigen nach zwölff verlorn Stürmen abzug/durch den Theuren Ritter Niclaus Jurischitz Hauptman daselbs/Römischer Künig. Mayestat außGünß/warhafftiglich zůgeschrieben. [S.l.], 1532. VD16 ZV 29162 (Köszeg 1532/3, 41. kép)
- Dess Turckischen Keysers ernst=liche Straff. Warhaffte Beschreibung/ dess grossen ernstlichen Zorns vnd Execution/so Amurathes der Trurckische Keyser/ newlicher zeyt an dem Bassa zu Ofen/vnd noch an andern dreyen Beegen [...] Jbraim Zephan, dess Trurckischen Keysers obrister Stal=meister [...] die vier gemelten Herren [...] vom leben zum todt gebracht. M.D.LXXIX. Nürnberg, Leonhardt Heussler, 1579. VD16 T 2257 (Musztafa budai pasa megfojtása 1579/2, 157. kép)

- Deßœ Türckischen Keysers ernstliche Straff: Warhaffte Beschreibung deß grossen ernstlichen Zorns vnd Execution so Amurathes der Türckische Keyser newlicher zeyt an dem Mustapha Bassa zu Ofen vnd noch an andern dreyen Beegen [...] vom leben zum todt gebracht. Nürnberg, Heußler, 1579. VD16 T 2256 (címlap hátoldalán bégek megfojtása jelenet) (Musztafa budai pasa megfojtása 1579/1, 156. kép)

- Die auffrur so geschehen ist im Vn=gerlandt/ mit den Creützern/Vnnd auch darbey wie man der Creützer Haubtman hat gefangen vnnd getödt. Nürnberg, Wolfgang Huber, 1514. Németh S. Katalin H64. VD16 A 4072 (Dózsa György kivégzése 1514/1, 4. kép)

- Die verainigung Kaiserlicher Ma. mit Künig von Vngern, Polan, Böhern etc., Auch wie vn[d] wa sye zu samen komen seind, vnd ainander enpfangen hond Auch waß sich begeb[e]n hat, vn[d] waß herschaft vnd volck dabey gewesen $v n[d]$ wie sye zu Wien einzogen seind mit mer verlauffung etc. vnd handlung alles hierinnen clerlich begriffen, [Augsburg], [Oeglin], [1515]. VD16 V 626 (Habsburg-Jagelló szerződés 1515/2, 7. kép)

- $\quad$ Ein erschrecklich Newes Liedt aus Ungern, von der Stadt Temesuar ( jetziger zeit Türckisch) wie die von Tausent und vier hundert Centner Pulvera ist zu grund gangen. Im Thon Kompt her zu mir/spricht Gottes Sohn. Gemacht im M.D.L.XXVI. Jar/den XXVII. Mai. Erstliche Gedruckt zu Prag bey Michel Peterle [1576]. (Temesvári lőporrobbanás versben)

- $\quad$ Ein groß wunderzaichen das do geschehen ist durch das Creütz, das ein Cardinal hat außgeben, in dem gantzen Hungerischen lannd wider die Thürckhen. Leipzig, Martin Landsberg, 1514. Németh S Katalin H707. VD 16 G 3476 (Keresztes katona 2 2. kép) 
- $\quad$ Ein hüpsch new Lied / Von dem Graffen, Thewren Ritter und Helden Graff Niclaus von Serin / Wie er so Ritterlich in Ungern gestritten und Manlich gefochten hat wider den Erbfeindt der Christenheit, den Türcken und sein hauffen etc./ Im thon: Wie man das Lied von Olmitz singt. Basel, Samuel Apiarius, 1568. (ZrínyiSzigetvár 2, 136. kép)

- $\quad$ Ein new Lied, vo. d Kais. Maj./ Obristen Lasarus von. Schwendj wz er vor Sackmar den 27. May diss 65. jars mit dem Türcken in einem Scharmitz gehandelt, werdet jr kurzlich hören, im Thon zu singen. Was wöllen wir aber heben an. [S.l.], 1565. VD 16 N 1281 (Szatmár 1565/1, 83. kép)

- $\quad$ Ein newer Bergreyen, von Künig Ludwig auss Ungern Jm thon, Frölich so will ich singen Ein ander new Lied, auss der Römer History gezogen Jn Frauwen Eeren thon./ [Hans Sachs] [Strassburg], [Jakob Frölich], [um 1550] VD16 ZV 28094VD16 B 5790 (Mohácsi csata 1526/2, 23. kép)

- Ein verzaichnus von des Thewren Heldens, des Grauen von Serin, außgestanden not / in derselben Befestigung zu Siget, im Jar M.D.LXVI. von seiner G. Secretario beschrieben, welcher von den Türcken gefangen gewesen, vnd newlicher zeit wider erledigt worden ist. Nürnberg, [Neuber], 1567. (Zrínyi-Szigetvár 1, 135. kép)

- $\quad$ Ein Warhafftige erschroeckliche vnd vnerhoerte newe zeittung so sich im Land zu Vngern von Ottergezicht vñ Eidexen disen Sommer zugetragen hat Welcher von gleichfoermigkeit wegen das Exempel der Junckfrawen zu Eßlingen auch hieher gesetzet ist worden. Worms, Gregor Hofmann, 1550. VD 16 ZV 17196 (Kígyóvész Szikszón és Esslingenben)

- Eine Warhafftige Und Erschreckliche newe Zeitung, so sich im lauffenden 1591. Jahr zu Preßburgk in Ungern zugetragen: Wie daselbst etliche Juden zwey Consecrirte Ostien uberkom[m]en, damit einen schendlichen Mißbrauch und Gotteslesterung geübt. Wien, Nassinger, 1591. VD16 ZV 20458 (Pozsony, szentelt ostya gyalázás története)

- Eine Warhafftige, Erschreckliche, vnd unerhorte newe zeittung, so im Lande zu Ungern von Ottergezichte vnd Eidexen, diesen Sommer sich zugetragen hatt: Numeri am XXI. Gott der HERR sandte fewrige Schlangen vnter das Volck, die bissen das Volck, das ein gros volck in Israel starb, etc. Anno M.D.L. [S.I.], 1550. VD16 ZV 26609 (Kígyóvész Szikszón 1550/1, 66. kép)

- $\quad$ Einœ Schön New Lied, darinn gemeldt wirdt, was diß 1566. Jar ist außgericht worden, Von dem Herrn Lazarus von Schwende vnd dem Thewren Helden Grafen von Serin, Was für Stett vnd Schlösser sie eingenomen vnd was für abbruch sie dem Türcken gethan haben: Jm thon wie man singt vom Künig Ludwig auß Vngern, [et]c. [Augsburg], [Franck], 1566. VD16 S 3619 (Tokaj $1565 / 2 / c, 124$. kép)
- Fabricius, Paul: Almanach durch Doctorem Paulum Fabricium, Röm. Kay. May. Mathematicum Calcuriert unnd gestellert auff das Jahr M.D.L.X.III. Mit Röm. Kay. May. etc. Gnad und Privilegien. Gedruckt zu Wien in Österreich Michael Zimmermann [1562]. (Kismarton, Pozsony, Sopron 1562/1, 72. kép)

- GRÜNBECK, Joseph: Doctor Joseph Gruenpeck von Burckhausen entlicher beschluss/vber die kunfftigen zůsamenfrugung der planeten jm Visch/Warnung ge=gen den vnfellen/so darauss jm. xxiiij. xxv. xxvj. erwach=sen sollen/vorauss wider die aufrüstung der Türcken. An Künig Ludwigen/ vnd frawen Mariam Künigin zů Hungern vnd Beham. [s.l. 1523]. (csatajelenet záró képek) VD 16 G 3629 Hubay 50. (II. Lajos és Mária 1523, 22. kép)

- Gründliche und warhafftige Anzaygung, wie das künigklich Schloß Gran, inn Ungern von den Türcken belegert und eingenommen ist. [Augsburg], [Steiner], 1543. Németh S. Katalin H716. VD16 G 3527 (Esztergom 1543/1/a nincs kép)

- Gründliche unnd warhafftige Anzeygung, wie das königlich Schloss Gran, in Hungern von den Türcken belegert, beschossen, und erbermiglich von den Jtalianern dem Türcken uber geben. [S.l.], [1543]. Németh S. Katalin H718. (Esztergom 1543/1/c, 55. kép)

- Gründliche vnd warhafftige Anzaygung wie das Königlich Schloß Gran in Hungern von den Türcken belegert beschossen vnd eingenommen. [Nürnberg], [Vom Berg; Neuber], 1543. Németh S. Katalin H717. VD16 G 3528 (Esztergom $1543 / 1 / b, 54$. kép)

- Hernach volget des Bluthundts der sich nennet eyn Türckischen Kayser/ gethaten/ so er vň die seinen/ nach eroberung der schlacht/ auff den. xxviij. tag Augusti negst=uergangen geschehen/ an vnnsern mitbrru=dern der Hungerischen Landtschafften gantz vnmenschlich getriben hat/ vnd noch teglichs thut. [S.l.] Nürnberg, Jobst Gutknecht, 1526]. VD16 B 5796 OSZK, Röplap 66. (Buda 1526/2, 31. kép)

- Hernach volgt des Bluthundts der sich nennet eyn Türckischen Keyser, gethaten, so er vnd die seynen, nach eroberung der schlacht, auff den. xxviii. tag Augusti nechstvergangen geschehen, an vnsern mitbrüdern der Vngrische[n] lantschafften gantz vnmenschlich getribe[n] hat, vnd noch teglichs thut. [Nürnberg], [Hergot], 1526. VD16 B 5790 (csatakép)

- Hernach volgt des Bluthunds der sich nennet eyn Türckischẽ Keyser/gethaten/ so er vnd die seynen/ nach eroberung der schlacht/ auff den. xxviij. tag Augusti nechstuergangen/ geschehen/ an vnsern mitbrüdern der Vngrischen landtschafften gantz vnmen=schlich getryben hat/ vnd noch teglichs thüt. Nürnberg, Hans Hergot, 1526. VD16 ZV 2106 (Török vérengzés 1526, 35. kép)

- Hernach volgt des Bluthundts, der sych nennedt ein Türckischer Keiser, Gethaten, so er und die Seinen nach Eroberung der Schlacht, auff den 8. Tag 
Augusti nechst vergangen geschehen, an unsern Mitbrüdern der Vngrischen Lantschaften gantz unmenschlich triben hat, vnd noch teglich tut. [Augsburg], [Steiner], 1526. (végén török vérengzés 1526 képe) VD16 B 5794 Rózsa 1999/287. (Buda 1526/3, 34. kép)

- Hernach volgt des Blutthundts, der sich nennet ein Türgkischen keyser, gethaten, so er vnnd die seinen, nach eroberung der schlacht, auff den xxviij. tag Augusti nechstvergangen geschehen, an vnsern mitbrüdern der Vngerischen landschafften, gantz vn=menschlich triben hat, vnd noch täglichs thut. [S.I.] (Zu Basel durch Adam Petri. M. D. XXVI.), 1526. OSZK, App. H. 189 Hubay 66b (Mohácsi csata 4, 25. kép)

- HJe nach volgend Vier neuwe klägliche/ vnd zů Got rüffende Ge=sang Oder Lieder/wider den blütdurstigen Erbfeind vnd verderber des Christenlichen blüts/ den Türgken/ ye=tzunder inn diser gefährlichen zeyt/ nützlich zů Lesen vnd zů singen/Gemayner Christenhayt zů Ermanung. Augsburg, Heinrich Steiner, 1542. (kottával, záróképpel) VD16 V 1027 (Török vérengzés 1542, 52. kép)

- Keiserlicher Maie=statynreitung zů Wien.mit dem Künig von Vngern/vnd Künig von Polen/ mit sampt den Küniginen/ vast kostlich in guldinen wägen vñ vil ander getzierdẽ / als hernach stat. Straßburg, Matthias Hupfuff, 1515. címlap és záró kép. VD16 N 1082 (Habsburg-Jagelló szerződés 1515/3 és 4, 8-9. kép)

- Klayber, Melchior: Diarivm Cvm Ivdicio Astrologico. Per Magistrum Klayberum à Weyssenhorn, in Archigymnasio Viennensi professorem Mathematum ordinarium Ad Annum Christi Salvatoris nostri. M.D.LXIII. Viennae Austriae, Excudebat Michael Zimmermann, [1562]. (Kismarton, Pozsony, Sopron 1562/2, 73. kép)

- Künig Ferdinande[n] zu Hungern vnnd Beheim, Ertzhertzogen zu Osterreich [et] c. Einreytten vnd Krönung zu Stulweyssenburg in Hungern. [S.l.], 1527. Hubay 78 (I. Ferdinánd koronázása 1, 36. kép)

- La triumphante entree et couronnement de Fernant De la Royalle maiesté de Honguerie et de Bohéme faicte a Stoel Wittenburch le dernier iour Doctobre, Anno. M.CCCCC et XXVII. Anvers, Guillaume Vorsterman, 1527. App. H. 196 (I. Ferdinánd koronázása 2, 37. kép)

- La triumphante entree et couronnement de Fernant, de la royale maieste de Hon=guerie et de Boheme, faicte a Stoel Wittenburch le dernier iour Doctobre, anno domini mil cinq cens vingt sept. [S.l.], [1527]. (címlap és utolsó oldal záróképe) (I. Ferdinánd koronázása 3 és 4, 38-39. kép)

- New erbarmliche tzydũge vã der groisser schlacht/so der Tuircksch Keyser/mit dem Konynck vã Vngern vñ Behem/ yp den xxviij. dach des Augst/ gedã y hait. Jn wilcher \#[der] Koe//Inynck/ vñ vyl groisser Herren synt erschlagen wordẽ [...]
Ouch van der erschrecklicher handelũg/so de Turckẽ yn dẽl gewõnen Steden vñ Flecken/ mit wijff vñ kynder geoeffdt [...] Jtem die Offenbarũg Broder Rẽyhartzs/ Des//gelichen Methosius wie der Turck/vur Coellen sal erschlagen werden. [Köln, - $\quad$ Arnd von Aich, 1526]. VD16 N 2129. Hubay 63e. (Mohácsi csata 6, 27. kép) New zeytung. Die Schlacht des Turckischen Keysers mit Ludouico etwan König zu Vn=gern geschehen am tag Johannis entheuptung 1526. Jtem des Türcken feyndtsbrieff/ König Ludouico zugesandt vor der schlacht./ Jtem eyn kleglicher Sendbrieff so die Vngern dem König jn Polen zugeschickt/ nach der schlacht. Jtem etzlich naw getzeyten aus Polen. New zeytung vom Babst zu Rome am.xxvij. tag Septembris geschehen. 1526. Leipzig, Jakob Stöckel, 1526. VD16 ZV 11475 (Mohácsi csata 1526/3, 24. kép)

- $\quad$ New zeytung. Die Schlacht des Turckischen Keysers mit Ludouico etwan König zu Vngern geschehen am tag Johannis entheuptung M.D.XXVI. Jtem des Türcken feyndtsbrieff/ König Ludouico zugesandt vor der schlacht./ Jtem eyn kleglicher Sendbrieff so die Vngern dem König yn Polen zugeschickt/ nach der schlacht. Jtem etzlich naw getzeyten aus Polen. New zeytung vom Babst zu Rome am.xxvij. tag Septembris geschehen. M. D. XXVI. Leipzig, Jakob Stöckel, 1526. OSZK, App. H. 190 (Mohácsi csata 5, 26. kép)

- $\quad$ Newe Zeittung aus Vngern. Kurtzer bericht der bey dem Marckt Sixo in Ober Hungern/von/ den Deutschen vnd Vngerischen Kriegsvolck zu Roß bey 1700. vnd der Türcken so anfangs wie die gefangenen selbs bekandt 8000. hernach gar 11000. starck worden/ vnd sich/ den Obern Kreiß Vngern zuuerheeren vorsamlet/Den 8. Octobris/Anno 158 8. Gehaltenen Schlacht. M.D.LXXXVIII. Praga, Valda \& Burian, 1588. VD16 XL 103 (Szikszó 1588/4, 167. kép)

- Newe zeittung Wie die Schlachtzu Vngern mit dem Tücrkischen Keyser ergangen: Hatt einer vonn Wien so dabey gewest: herauff jen Dringen Geschriben. M.D.XXVI. [S.l.] [Würzburg: Balthasar Müller], 1526. VD16 B 5796 Hubay 68. (török lovas katona)

- Newe Zeittung. Des Türckischen Keisers Absagbrieff, so er newlich dem Römischen Könige Ferdinando, bey seinem Legaten zugesand. Uns armen Christen erschrecklich und sehr erbermlich zu hören. [Wittenberg] [Seitz], 1556. VD16 N 757 (Török vérengzés 1556, 70. kép)

- Newe Zeitung aus Vngern. Kurtzer Bericht/ der bey dem Marckt Sixo/ in Obern Hun=gern/ von dem Deutschen vnd Vngerischen Kriegss=volck zu Ross/ bey 1700. vnd der Trurcken/ so an=fangs [...] 8000/ hernach gar 11000. starck worden/ vnd sich/ den Obern Krayss Vngern zuuerheren versamlet/ den 8. Octobris/ Anno 1588/ gehaltenen Schlacht. [S.l.], [1588]. VD16 ZV 11468 (Szikszó képzeletbeli képe) 
- $\quad$ Newe Zeitung auß Ungern, auch gründtlicher und warhaffter Bericht, welcher massen der Saswar Bascha von Siget sambt andern dreyen Beegen den 9. Augustii dises 1587. Jars über die Fünff tausendt starck herauß gefallen [...] geschrieben. Nürnberg, Leonhard Haussler, 1587. VD16 P 3820 (Kacorlaki csata 1587/1, 162. kép)

- $\quad$ Newe Zeitung Von der Turkischen Kriegsrustung, so itzigen Winter in Ungern gebracht, etc. Leipzig, Georg Hangsohen, 1551. (Lippa 1551/1, 67. kép)

- NEwe Zeytungen ausz Hungern/ wie abermals die vnsern durch mithülffe Grotlicher gnaden/ dem Blůthunde der gantzen Christenkait/ in etlichen Scharmützeln [...] den drey vn zwentzigsten tag des Hewmonds/ dises Jars M.D.Lvj. Jtem Ein erschrrocklich Wunderzaichen von zwayen Erdbidmen [...] Constantinopel im diesem M. D. LVI. Jar. [S.l.], (Gedruckt durch Valentin Geyszler|), [Nürnberg 1556]. VD 16 N 1100 (Csata Babócsánál 1556, 69. kép)

- SEnsuyuêt les faictz du chien in/saciable du sang chrestien, ql se/nöme Lempereur de Turquie. [...] Nouuellemēt translate Dallemãt/en francoys. [Kolofon] Finis. L'an. M. D. XXVI. OSZK, App. H. 1656. (Buda 1526/1, 30. kép)

- SPORER, Merten: Eyn new lied von der schlacht die der Vngerisch Künivnd der Türck mit einander ge=than haben. Jm speten thon. Nürnberg, Hans Hergot,1526. VD 16 S 8363 (Mohácsi csata 7, 28. kép)

- Taurinus, Stephanus Olomucensis: Stephani Taurini Stauromachia, id est cruciatorum servile bellum Viennae Pannoniae [Wien], Joannes Singrenius, 1519. OSZK, App. H. 137 VD16 T 247 (címlap hátoldalán Madonna kép) (Dózsa György kivégzése 1519/1, 5. kép)

- Tuerckische Niderlag vnd Newe Zeyttung. Ein kurtzer Bericht/ wie es sich auff der gehaltenen Schlacht/ so das Deut=sche vnd Hungerische Kriegßvolck/ in ObernVngern [...] Vor Sigeet gehalten/begeben vnd zugetragen hat. Geschehen den 8. Octobris/ Anno 1588. Coburg, [Valentin Kröner], 1588. VD16 ZV 23860 (Szikszó 1588/5, 168. kép)

- VICTORIA, Oder Zeyttungen/ so die Christen denn XXj. Augusti/ Anno 87. Jnn Vngern bey Katzerlach/glück=lich mit Gottes hilff dem Türcken aberhalten/ Dergleichen bey Manns gedencken nie er=hrort oder geschehen ist. Anno Domini M.D.LXXXVII. Augsburg, Josias Wrorli, 1587. VD16 V 1194 (Kacorlaki csata 1587/2,163. kép)

- Vier warhafftige Missiue: eyne der frawen Jsabella Künigin vn[d] nachgelassne Wittib in Vngern, wie vntreülich der Türck vnd die jren mit jr vmbgangen [...] Auß dem Latein inns Teütsch gebracht. [Augsburg], [Steiner], 1542. VD16 V 1055 Rózsa 1999/287 (a címlap hátoldalán Buda 1526/3, 34. kép)

- Warhafft Anzeygen Küniglicher Mayestet zu Hungern und Beheim etc. Hörzug von Wyen auß inn Hungern biß auff ein halb Meyl under Ofen und gen
Stulweyssenburg etc., [Augsburg, Steiner], 1527. App. H. 198 Hubay 84. VD16 W 747 (azonos az I. Ferdinánd koronázása 1 képpel)

- Warhafftige Anzeigung wie es im Leger vor Ofen ergangen ist. [Augsburg], [Steiner],1541. VD16 W 192 (végén csatajelenet) (Buda 1541/4, 51. kép)

- Warhafftige Anzeygu[n]g wie es im Leger vor Ofen ergangen ist. [Augsburg], [Steiner], 1541. VD16 W 191 Rózsa Ø (Buda 1541/3, 50. kép)

- Warhafftige Anzeygu[n]g wie es im Leger vor Ofen ergangen ist. [Nürnberg], [Hieronymus Andreae], 1541. VD16 W 195 Rózsa 1999/293 (Buda 1541/2, 49. kép)

- Warhafftige grausa=me vnd erschreckliche newe zeitung aus Vngern/ wie die Stadt Temesuar/ zu jetziger zeit Türckisch/ durch sonderliche schickung Gottes/in einem Augenblick gantz vnd gar verderbt/vmb=kert/zersprengt vñ versenckt ist/ auch wo die Stadt vnd Schlos gestanden/ jetzt lauter wasser/vnd nun mehr einem grossen See gleich zu ach=ten ist. [S.I.], 1576. VD16 ZV 23866 (Temesvár 1576/2, 151. kép)

- Warhafftige Gründtliche beschreibung, Was der Rom. Kay. May. Vnsers aller genedigsten, Herrn General, vnd Feldhauptman inn Zips, Herren Lazarum vonn Schwendi, nach Eroberung der Vestin Tockai, vnd etliche mehr Schlösser, Ferrers wider Jre Rebellen vnd widerspennige gehandelt vnd fürgenommen sey worden. München, Adam Berg, 1565. VD16 W 303 (Schwendi hadjárata 1565/1, 84. kép)

- Zeittung von der Rö. Khay. Mt etc. Khriegßvolc kh in Zips vnd was dasselb ain zeit herumb gegen Jrer Mt. etc. widerwertige außgericht. Wien, Zimmermann, 1565. VD16 Z 292 Németh S. Katalin H2331. (Tokaj 1565/2/a, 77. kép)

- Zeyttung von der Rö. Kay. Mt. [et]c. Kriegsvolck in Zips, vnnd was dasselb ein zeit herumb gegen Jrer Mt. [et]c. widerwertige auszgericht. 1565. [S.I.], 1565. VD16 Z 289 (Schwendi hadjárata 1565/2, 85. kép)

- Z Zweyerley Newe Zeittungen. Welcher Gestalt das Schloss Daggay in Vngern durch jetzigen Grosmechtigẽ Keysers Maximiliani Kriegsvolck dem Tuercken Christliches Namen Erbfeind widerumb dieses 65. Jhars abgewonnen vnd eroebert. [S.I.], 1565. VD16 W 1747. OSZK, Hubay 243. (Tokaj 1565/2/b, 82. kép)

- Zweyerley Newe Zeittungen. Welcher Gestalt das Schloss Daggay, In Vngern, durch jetzigen Grosmechtige[n] Keysers Maximiliani Kriegsvolck, dem Türcken Christkiches namen Erbfeind. widerumb dieses 65. Jhars abgewonnen vnd eröbert Jtem/ Ein Ritterlicher Kampff vñ Tur=nier/ zweyer Helden/ als einem Türckischen Hauptman/vnd einemVngerischen jungen Kriegsman. [S.l.], 1565. OSZK, App. H. 392. Hubay Röplap 244. (Tokaj ostromkép ágyúállással) 


\section{Könyvek metszetekkel}

BALlino, Giulio: De disegni delle piu illustri citta et fortezze. Venetia, /Bolognino Zaltieri/, 1569. OSZK, App. H. 428

BerTELLI, Ferando: Civitatis aliquot insigniorum. Venetia, 1568.

Braun, G. - HogenBerg, F. Civitates orbis terrarum. Köln, Bd. I. 1572, Bd. IV. 1588

[CAmocio,G. F.]: Isole famose porte, fortezze. Venetia, (1571)

ForLANI, Paolo Veronese: Il primo libro delle citta. Venetia, 1567. OSZK, App. H. 3069 GentIL, Pierre: Deux veritables Discours. Paris, /lacques du Puys/, 1567. OSZK, App. H. 419 GoTTFRIED, Johann Ludwig: Historische Chronick, Oder Beschreibung Der Merckwürdigsten Geschichte, So sich von Anfang der Welt bis auf das Jahr Christi 1631. Frankfurt am Main, /Matheus Merian/, 1631.

Hannewald, Bartholomaeus: Parentalia Divo Ferdinando Caesari Avgvsto patri patriae etc. a Maximiliano imperatore etc., Ferdinando et Carolo serenissimis Archiducibus Austriae Fratribus singulari pietate persoluta Viennae, Anno Domini M.D.LXV. VIII. Idus Augusti. Augusta Vindelicorum, W. Meyerpeck, 1566. VD 16 H 530 HönIGER, Nicolaus: Ander Theil der Türckischen Historien. Basel, 1578., 1596. OSZK, Ant. 947

LöWENKLAU, Johannes: Neuwe Chronica türckischer Nation von Türcken selbs beschrieben, volgendts gemehrt, unnd in vier Bücher abgetheilt. Franckfurt am Mayn, /Andres Wechels seligen Erben/, 1590.

MÜNSTER, Sebastian: MAPPA EVROPAE, Eygentlich /fürgebildet, aussgelegt vnd beschriebenn. Frankfurt am Main, /Christian Egenolph/, 1536.

MüNSTER, Sebastian: Cosmographey oder Beschreibung aller Länder. Basel, Heinrich Petri, 1544.

PANTALEONE, Henricus: Militaris ordinis Johannitorum, Rhodiorum aut Melitensium [...] ad praesentem usque 1581 annum historia nova, libris 12 comprehensa Basileae, [Guarin], 1581.

SAmBuCus, Joannes: Emblemata et aliquot nummi antiqui operis. Antwerpen, 1566. OSZK, App. H. 397

SchrotT, Martin: Wappenbuch des Heiligen Römischen Reichs, vnd allgemainer Christenheit in Europa, insonderheit des Teutschen Keyserthumbs [...] Welches dann die Haiden vnd Türcken jämmerlich zerrissen, vnd mit der Christen höchsten nachtheil vnd schaden, heutiges tags inhendig haben. München, /Adam Berg/, 1581. OSZK, App. H. 487

SPECKLIN, Daniel: Architektura von Vestungen. Strassburg, /Jobin, Bernhardt/,1589. [STEINHOFER, Caspar]: Gründliche und Kurtze Beschreibung des alten und jungen Zuges von Frankfurt bis Wien 1566. [S.l.], (1566).

UlLoA, Alfons: Beschreibung des letsten Ungerischen Zugs. Basel /Henrichpetri/, 1578. OSZK, App. H. 472

\section{Felhasznált irodalom}

Alchin, Andrew: Bvda, Ofen, Pesto, Buda, Pest. The earliest views of Budapest Budapest legkorábbi látképei. [Szombathely], Yellow Design Kft., 2019.

ANDRESEn, Andreas: Der Der deutsche Peintre-Graveur oder die deutschen Maler als Kupferstecher, I-V. Bd., Leipzig, /Weigel, Rudolf/, 1864-1878.

BACHMANN, Fridrich: Die alten Städtebilder. Leipzig, /Hiersemann, Karl/, 1939. BARTSCH, Adam von: Le peintre graveur. Wien, 1808 Band 9.192-193. 79. (Murány) [PETERS, Jane S. (ed.)]: The Illustrated Bartsch 18 Formerly Vol. 9 (Part 1) German Masters of the Sixteenth Century. New York, /OPAL Publishing Corporation/, 1982, 95-363. képpel (Murány)

BIFolco, Stefano-RonCA, Fabrizio: Cartografia e topografia italiana del XVI secolo, catalogo ragionato delle opere a stampa. Vol. I-III. Rome, /Edizioni Antiquarius/, 2018.

BoRBÉLY Andor: Adatok Tokaj vára helytörténetéhez. In: Debreceni Szemle VII. évf. 172 sz. /1933. október/ 384-391

BoRBÉLY Andor: Zyndt Mátyás nagy haditérképe hazánkról. In: Hadtörténeti Közlemények 35. évf. 1. szám (1934). 197-202

BuBICs Zsigmond: Magyarországi várak és városoknak a magyar nemzeti múzeum könyvtárában létező fa- és rézmetszetei, Budapest,1880.

CENnERnÉ WilhelmB Gizella: Magyarország történetének képeskönyve. Budapest, Képzőművészeti Alap Kiadó,1962.

Cennerné Wilhelmb Gizella: Zsáka vára In: Bihari Múzeum Évkönyve (Berettyóújfalu, 1986) 4-5. sz. 173-180

DÉTSHY Mihály: A Tokaji vár története. In: Tokaj várostörténeti tanulmányok II. kötet - Separatum Tokaj, 1995.

DÉTshy Mihály: A gyulai veduták kérdése. In: A Gyulai Erkel Ferenc Múzeum Kiadványai 18. kötet. Gyula, Erkel Ferenc Múzeum 1960. 3-15

DRUGULIN Wilhelm Eduard: Historischer Bilderatlas II. Theil. Leipzig, /Leipziger Kunst-Comptoir/, 1863

EKLER Péter: „Newe Zeitung auß Ungern...” Verses tudósítás idõsebb Hans Rogel augsburgi műhelyéből Zrínyi György kacorlaki győzelméről (1587). In: LYMBUS Magyarság tudományi Forrásközlemények 2007. 5-18

FARKAS Gábor Farkas: II. Lajos rejtélyes halála I. In: Magyar Könyvszemle, 2000 443-463

FAZEKAS Borbála: Sebastian Münster Cosmographiája, különös tekintettel Magyarországra. In: Historia Nostra II. évf. 1. szám Eger, Lyceum Kiadó, 2017 47-72 GALAvics Géza: Kössünk kardot az pogány ellen. Török háborúk és Képzőmúvészet. Budapest, Képzőművészeti Kiadó, 1986. 
GANADO, Alberto: The Forlani-Zenoi town books of 1567. In: Florilegicum cartographicum Leipzig 1993.

Gerevich Tibor-Genthon István: A magyar történelem képeskönyve. Budapest, Királyi Magyar Egyetemi Nyomda, 1935.

GöDöLle Mátyás: Buda és Pest 1541/42. évi ostromainak ábrázolásai. In: Tanulmányok Budapest múltjából42. kötet (2017.) 165-196

Gyulai Éva: Von Sachen gros, von Angsicht klein - Zsámboky János verse Pozsonyról a Habsburg Miksa koronázásáról készült metszeten, 1563/1566. In: Publicationes Universitatis Miskolcinensis, Sectio Philosophica Tom. XVII., Fasc. 1. (2012), 125-151 GYULAI Éva: A pácini kastély Urak és szolgák a kora újkori északkelet-magyarországi kastélyokban. In: Történelem és Muzeológia - Miskolci Internetes Folyóirat 1. (2014)/1. 156-188

HollsteIn, F. W. H.: German Engravings, Etchings and Woodcuts. XLVII, XLVIII (2000) \& L. (2001). Vol. (151-152 Philipp Hermann)

JANCSó ÁRPÁD: A Bega, a Bánság elkényeztetett folyója. Temesvár, 2007.

KELÉNYI B. Ottó Erhard Schön magyar vonatkozású metszetei különös tekintettel Buda 1541. évi ábrázolására. In: Fővárosi Könyvtár évkönyve, II. szám Budapest, 1932.

KISARI BALLA György: Karlsruhei térképek a török háborúk korából. Budapest, 2000. LEPOLD Antal: Esztergom régi látképei. Szent István Akadémia Értekezései, III. kötet, 5. szám. Budapest, 1944.

MagYary-Kossa Gyula: Magyar orvosi emlékek. Budapest, Magyar Orvosi Kiadó, 1929. II. kötet 103-111

NAGLER, G. K.: Neues allgemeines Künstler-Lexicon. Leipzig 1835-1852. Band VI., 559. 59. (Schloss Muran in Ungarn)

OPPL, Ferdinand - KRAUSE, Heike - SONnLECHNER, Christoph: Wien als Festungstadt in 16. Jahrhundert. Zum Kartographischen Werk der Mailänder Familie Angielini. Vienna, /Böhlau Verlag/, 2017.

Pálffy Géza: Magyar címerek, zászlók és felségjelvények a Habsburgok dinasztikushatalmi reprezentációjában a 16. században. In: Történelmi Szemle XLVII. évf. 2005. 1-2. sz. 241-275

PÁLffy Géza: A haditérképészet kezdetei a Habsburg Monarchiában. Budapest, Archívum-Magyar Országos Levéltár, 2011. XII. tábla

PAPP Júlia: Siegmund von Herberstein kiadványainak magyar vonatkozású illusztrációi In: Magyar Könyvszemle (137) 2021/1. 1-38

PAPP Júlia: A szigetvári hadi táj képzőmüvészeti ábrázolása a 16-17. században. In: Turbék. Szulejmán szultán zarándokvárosa. Szerk. PAP Norbert BTK - PTE, Budapest, Pécs, 2020. 451-534

PAPP Júlia: Egy 15. század végi illusztráció „újrahasznosítása” a mohácsi csatáról tudósító német hírlevelekben. In: Magyar Könyvszemle 135. évf. 3. szám (2019)
PAUlER Gyula: Buda ostroma Roggendorf, bevétele Szoliman által 1541. Pest, 1860. RÁTH-VÉGH István: Magyar kuriózumok Budpest, Pán Kiadó, 1989.115-122

RózSA György: Budapest régi látképei 1493-1800. Budapest, Akadémiai Kiadó, 1963. II. kiadás, Budapest, Új Művészeti Kiadó, 1999.

RöTtInger, Heinrich: Neue Mitteilungen über Virgil Solis. In: Zeitschrift für Bücherfreunde, Neue Folge 16 (1924), 77-85

RöTTINGER, Heinrich: Erhard Schön und Niklas Stör, der pseudo-Schön. Zwei Untersuchungen zur Geschichte des alten Nürnberger Holzschnittes. (Studien zur deutschen Kunstgeschichte, 229.) Strassburg, 1925.

SACHS, Hans: Der unglückhafftig scharmützel deß Türcken vor Ofen. OSZK, Röplap/192

SELÁf Levente-Tóvizi Ágnes Ismeretlen illusztrált röplap a mohácsi csatáról. Magyar Könyvszemle 130. évf. 2. sz. (2014) 261-271

STRAuSS, Walter L.: The German Single-Leaf Woodcut 1550-1600. A Pictorial Catalogue I-III. New York, /Abaris Books Inc./, 1975.

SzABó András: Az 1588-as szikszói csata és propagandája. In: Hadtörténelmi Közlemények 1999/4. 851-860

SzAKÁLY Ferenc: Egy zsoldosvezér emlékiratai a XVI. század közepén vívott magyarországi háborúkról. In: Bernardo de Aldana magyarországi hadjárata [15481552]. Közreadja, ford. ScHolz László. Bp. 1986. (Bibliotheca Historica) 5-56 SzALAI Béla: Tokaj vár metszetes könyve [Tokaj], Árvay és Tsa, 2004.

SzALAi Béla: Magyar várak, városok, falvak metszeteken, 1515-1800. I-V., Budapest, Múzeum Antikvárium, 2006-2018.

Szalai Béla: The representation of the Hungarian Towns in Domenico Zenoi's and Paolo Forlani's Cartographic Work - Prikazi ugarskih gradova u kartografskim djelima Domenica Zenoija i Paolo Forlanija In: Kartografija i Informacie XVIII. Br. Zagreb 2012/Vol. 11. 5-37

SzALAi Béla: Buda várának első hiteles, keleti nézetü, eddig ismeretlen látképe 1542ből. In: Magyar Grafika 2015 3. sz. 58-61

SzALAI Béla: Az 1566. évi gyôri táborterv rajza és Győr metszetek a modenai Állami levéltárban. In: Vestigia 3. Italianista tanulmányok a magyar humanizmus és a tizenöt éves háború idejéről Szerkesztők: Domokos György, W. Somogyi Judit, Szovák Márton. Vestigia Kutatócsoport, Budapest, 2020.183-96

SzALAI Béla: Régi dolgok mai szemmel -könyvekről, metszetekről, érmekről, zászlókról. Budapest, Múzeum Antikvárium, 2020. 18-40

SzALAi Béla: Augustin Hirschvogel metszetei az 1549. évi hadjáratról. In: Magyar Könyvszemle (137) 2021/1.

SzATHMÁRY Tibor: Nicolaus Angielus Magyarország térképe. In: Cartographica Hungarica Térképtörténeti Magzin 3. szám Budapest, Akadémiai nyomda, 1993. 2-13 
TimAnN, Ursula: Untersuchungen zu Nürnberger Holzschnitt und Briefmalerei in der ersten Hälfte des 16. Jahrhundert: mit besonderer Berücksichtigung von Hans Guldenmund und Niclas Meldeman. Münster in Westfalen, LIT, 1993. 143-147

TinóDi LANTos Sebestyén: Szitnya, Léva, Csábrág és Murány várának megvétele. 1549 TRAGOR IGNÁc: Váci érdekességek Váci könyvek 9. (Vác, 1923) I. Könyv: Általános rész 96-97 VÉGH András: Buda város középkori helyrajza I. Budapest, 2006.

Végh András: Buda I. kötet, 1686-ig. (Magyar Várostörténeti Atlasz 4.) Budapest, 2015
VELEnCzei Katalin: A székesfehérvári Püspöki Könyvtár 16. századi nyomtatványairól. In: Fata libelli - a nyolcvanéves Borsa Gedeon köszöntésére írták barátai és tanítványai. Szerk. P. Vásárhelyi Judit Bp., 2003. 125-139

Woodward, David: The Maps and Prints of Paolo Forlani. Chicago, Newberry Library, 1990.

ZAVADOVA, Katharina: Verny a pravy obraz slovenskych miest. Bratislava /Tatran/, 1974. Zenoi, Domenico: Il primo libro delle citta. Venetia, 1567. OSZK, App. H. 3070

\section{O. A. M. D. G.}

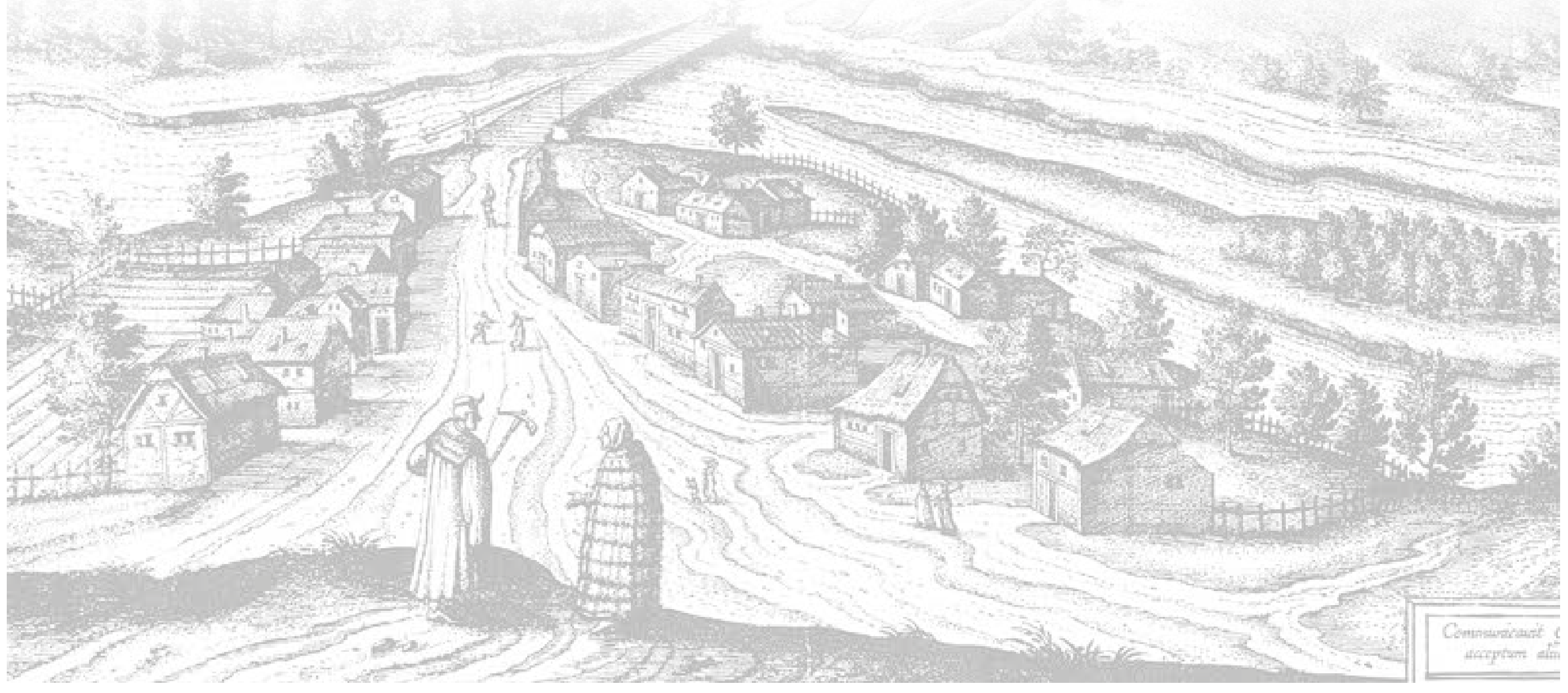


KÉPTÁBLÁK 


\section{KÉ P J E G Y Z É K}

1556 év eseményei 69. 71. kép

Brassó 57. kép

Buda 30-34, 43--47, 49-51, 53, 58--61, 153-155, 170, 172, 175. kép

Buda, foglyok kivégzése 1541 48. kép

Dózsa György-féle parasztháború 1514 1-5. kép

Eger 130-132. kép

Esztergom 54. 55, 129. kép

Fráter György meggyilkolása 1551 68. kép

Győr 115-118, 120-122, 140, 146, 169, 173. kép

Gyula 91-97, 138, 143, 144. kép

Habsburg-Jagelló szerződés 1515 6-11. kép

Hungária vértanúsága 6. oldal

I. Ferdinánd koronázása 1527 36-39. kép

I. Ferdinánd temetése 1565 89, 90. lép

II. Lajos és Mária királyné 1523 22. kép

Kacorlaki csata 1587 159-162. kép

Kassa 158, 159. kép

Kígyóvész Szikszón 1550-5164, 65a, 65b, 66. kép

Kismarton 72, 73. kép

Komárom 133, 134. kép

Kőszeg 40-42. kép

Lazarus Schwendi hadjárata 1565 84-86. kép

\section{Léva 62. kép}

Lippa 67. kép

Mohácsi csata 1526 23-29. kép

Murány 63. kép

Musztafa pasa megfojtása 1578 156, 157. kép

Nagyszeben 56. kép

Nándorfehérvár /Belgrád/ 14-20. kép

Pozsony 72-75, 174. kép

Sopron 72, 73. kép

Szatmár 83. kép

Székesfehérvár 12, 13. kép

Szigetvár 98-114, 139, 145, 176. kép

Szikszó 152, 164-168. kép

Temesvár 150, 151. kép

Tokaj 76--82, 124--128, 137, 141, 142. kép

Török fosztogatás, vérengzés 21,35 , 52, 70. kép

Vác 149. kép

Várpalota 87--88. kép

Veszprém 87-88. kép

Vöröstorony 148. kép

Zrínyi Miklós - Szigetvár 135, 136. kép

Zsáka 123, 147. kép 


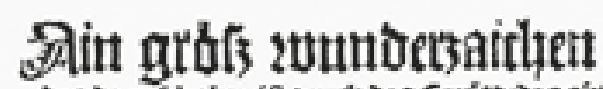

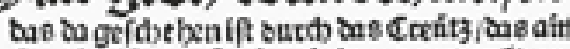

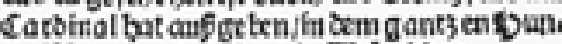
Gedifbenlauns witer bie Djürdiben.

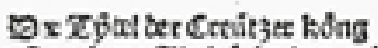

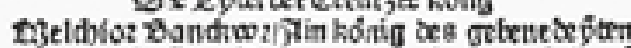

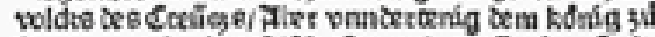

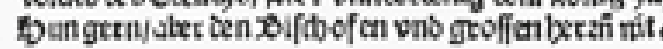

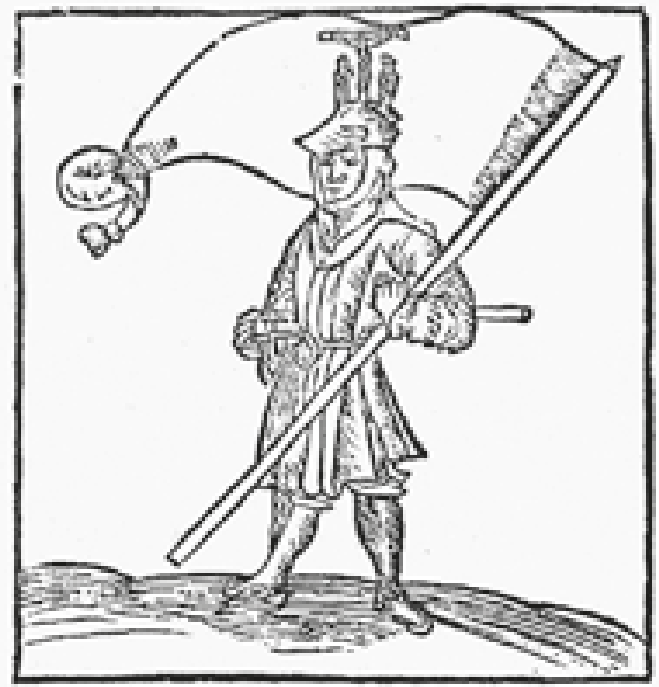

1. kép Keresztes katona 1514/1

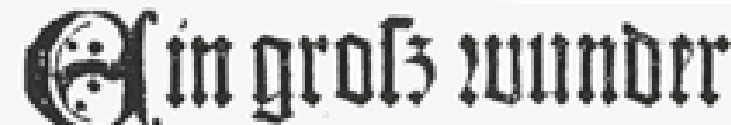

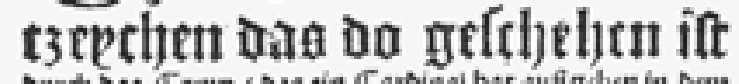

Dusch bas Creary oas tin Caroinal bat aufigaben in bens

gengen Dagea fbea Ranbe wiber bit Zíncten.

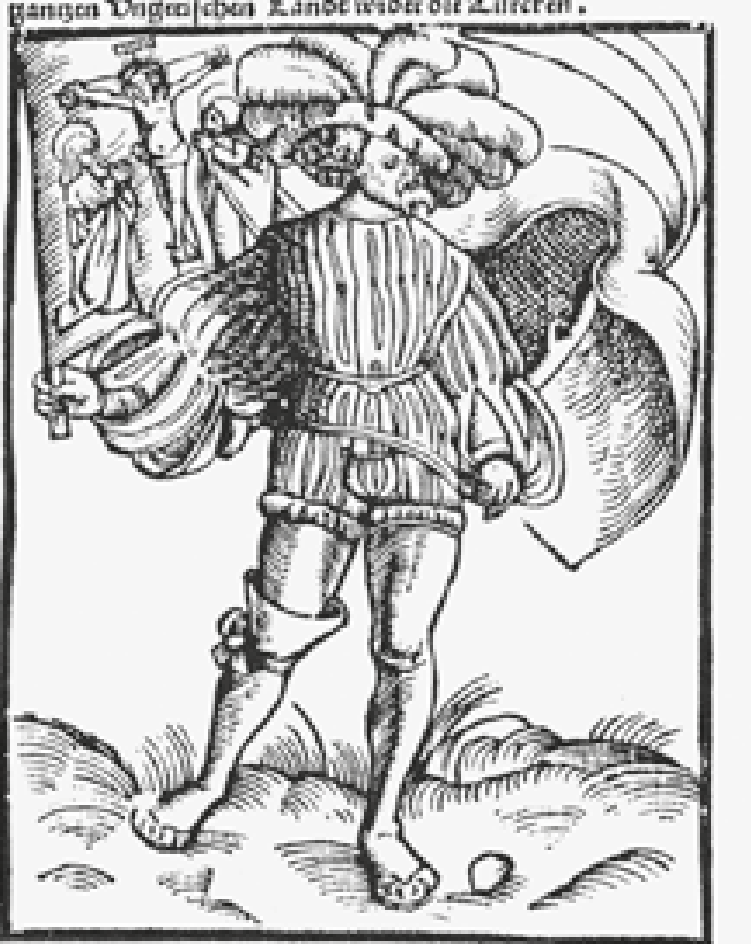

2. kép Keresztes katona 1514/2
Eingrof wutoertsaycben oas oo ge

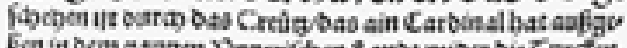

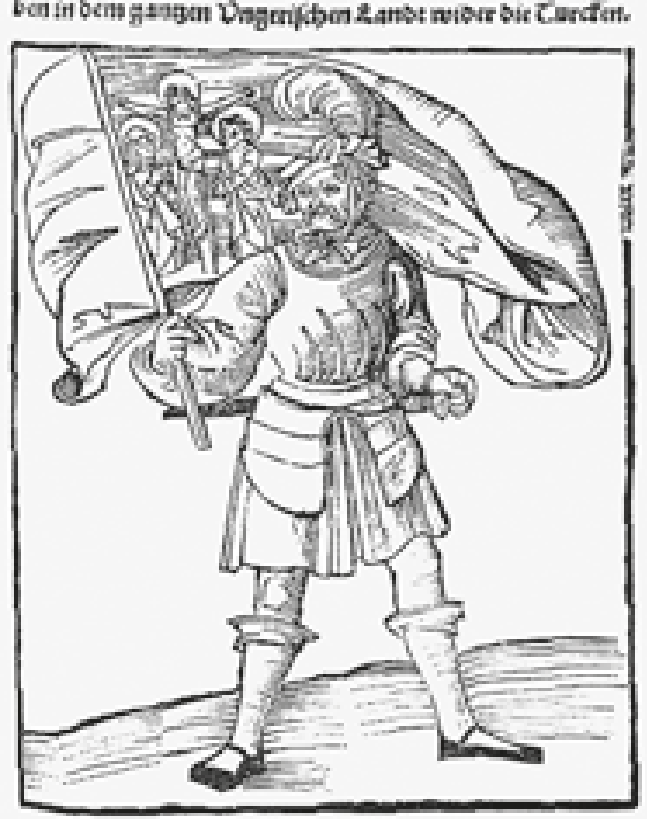

3. kép Keresztes katona 1514/3 


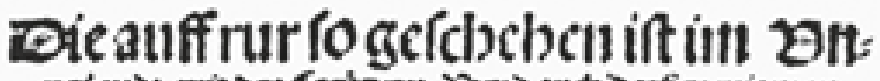

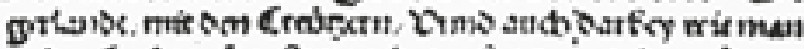

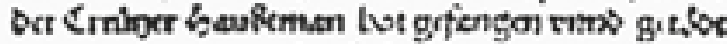

3eckel Jorg.

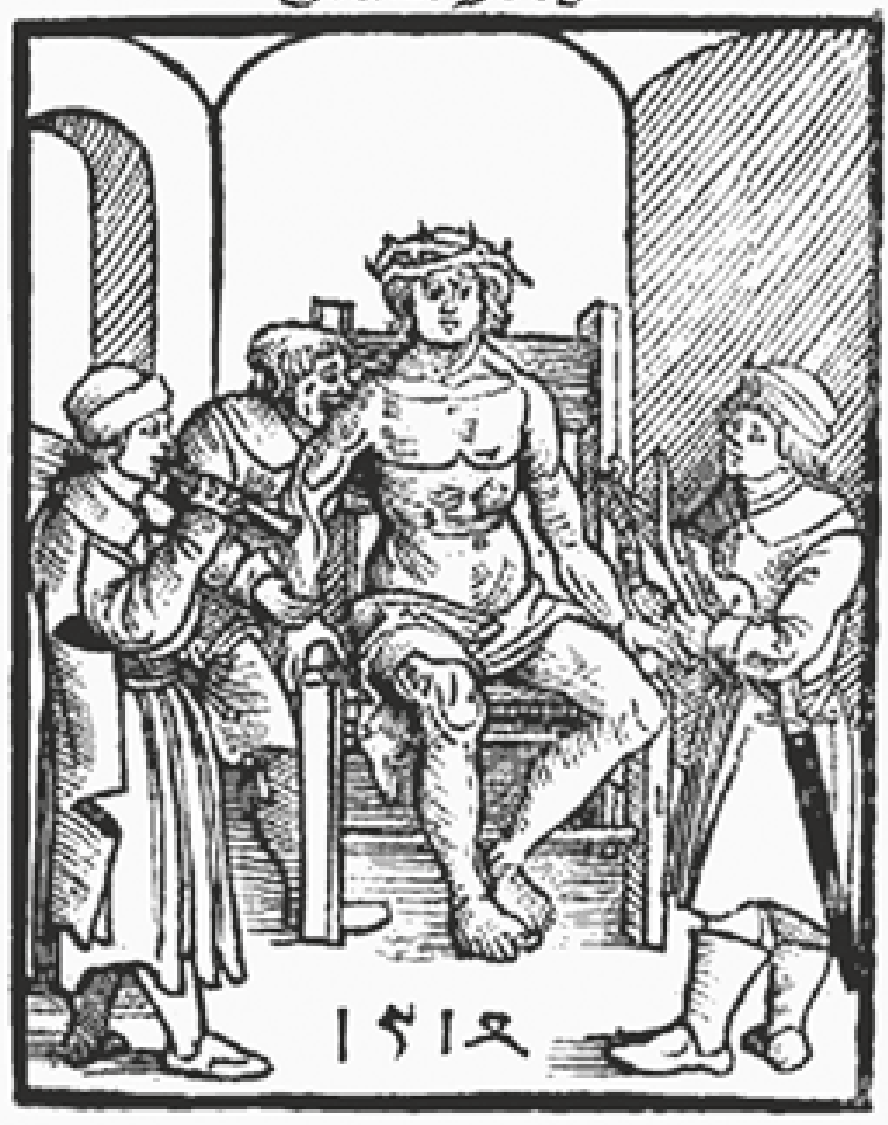

$$
\text { for germ anyter. }
$$

STEPHANI TAVRINI OLOMIVCEN.STAV romachiarid eft Cruciatos: Seruile Bellum.Cd'anno ab orbe redépto poft fefąrmillefimú quartodecimo \& Fan noniá/\&Collimitaneas puincias ualde miferabiliter des populanerat. In Quinquibros fummatim digeftí.

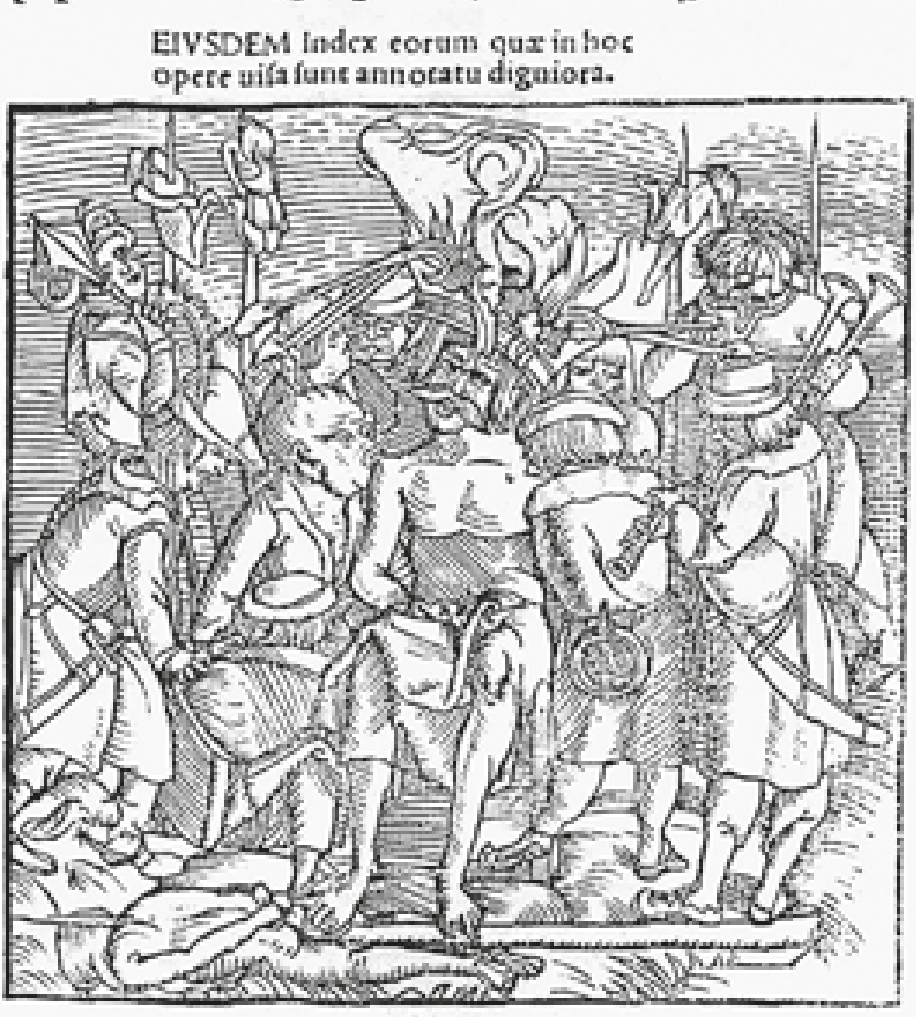

Georgins Zckst 
CONGRESSVS AC CELEBERRIMT CONVEN TVS CAESARIS MAX.ET TRIVM REGVM HVNGARIAE,BOEMIAE,ET POLONIAE. In VIENia Panonix, menfe IVLIO. Anno M. D. XV. fati breuis ac uerifsi ma defcriptio.

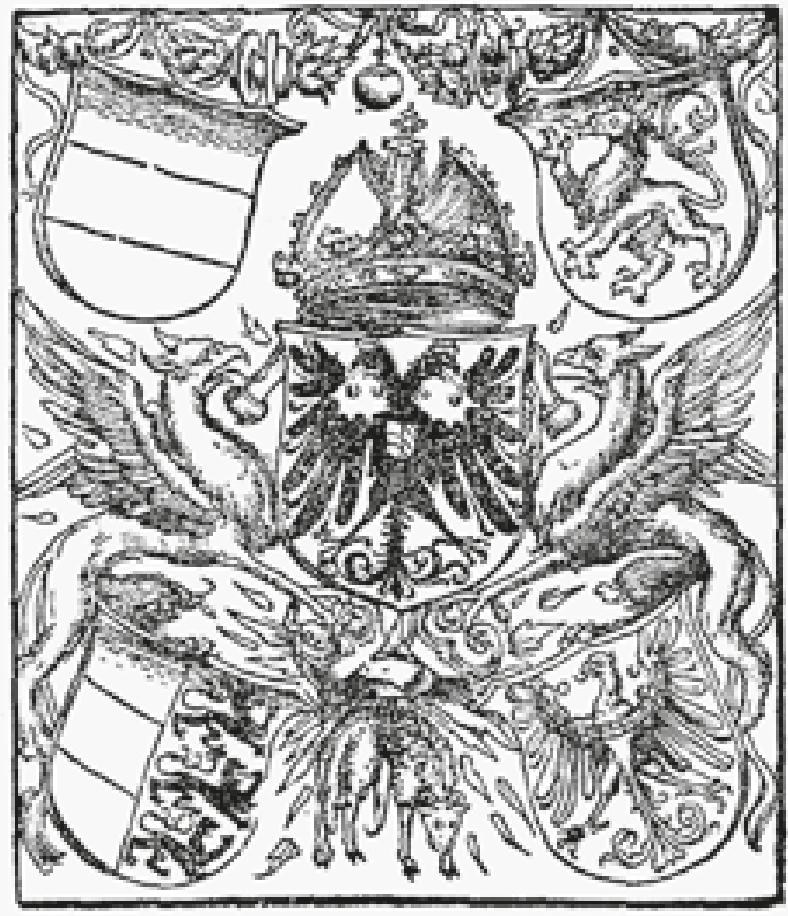

Die verainigung likaferlicber DSa.

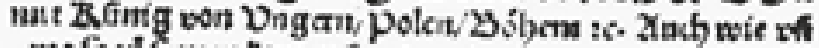

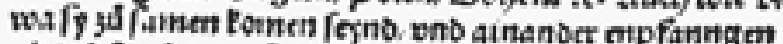

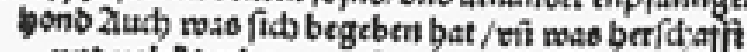
vono vold oarbey gewd en vinno wie fy sá wien einjegent feino mittmer valurffunng tc. vnobanolung alles bierinnen Nerlich begrifien.

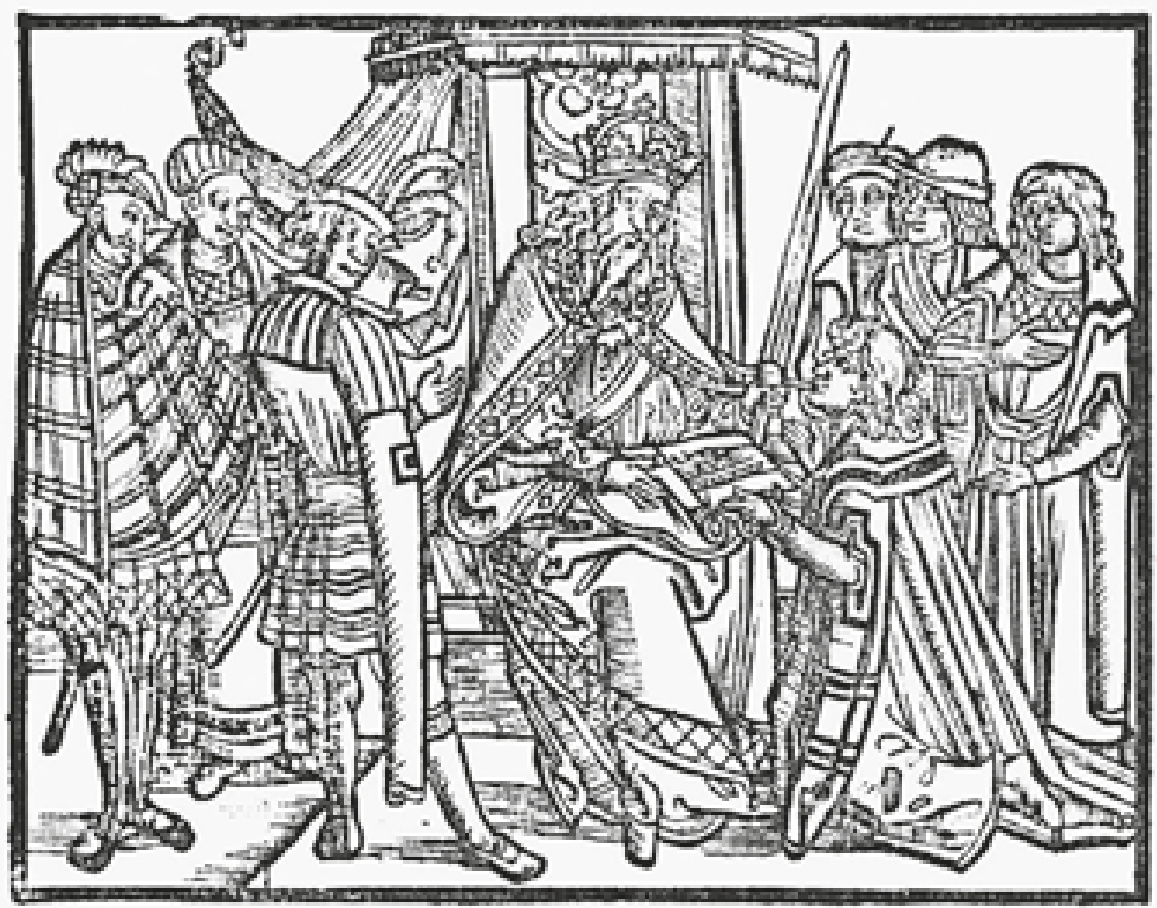




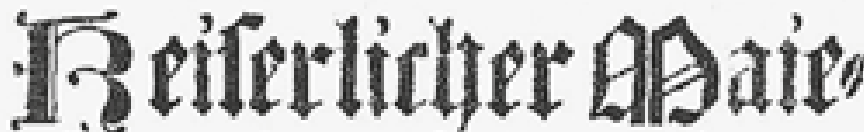

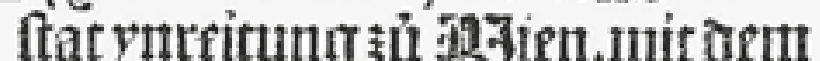
Tkúnig von Yngen / vis Tünig von pslan/mit

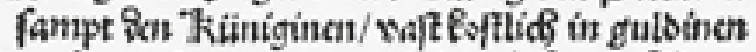
wiggen wĩ vilander gesicrod/ale kcrinadffat.

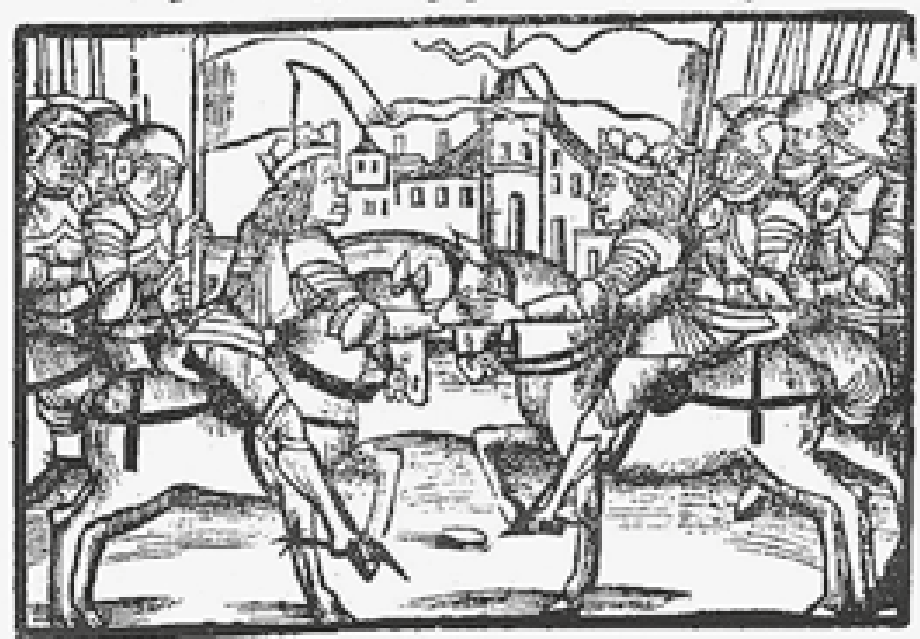

Tact muitag far "kevferlice (Wayeftat rat geffaltés

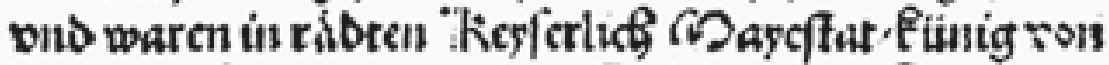

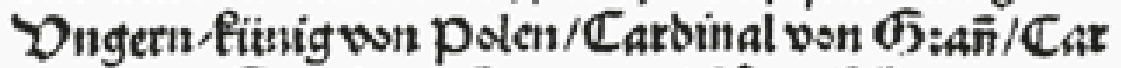
Dinalvon 65urgt/ ein fer: von $2386 \mathrm{cmi}$ țon genaus

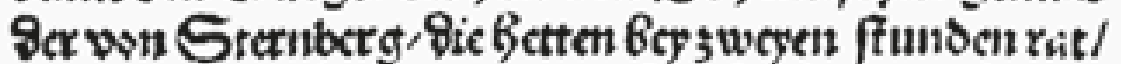
Darimen was fun/t uyentande \&añ vie frocn per fort.

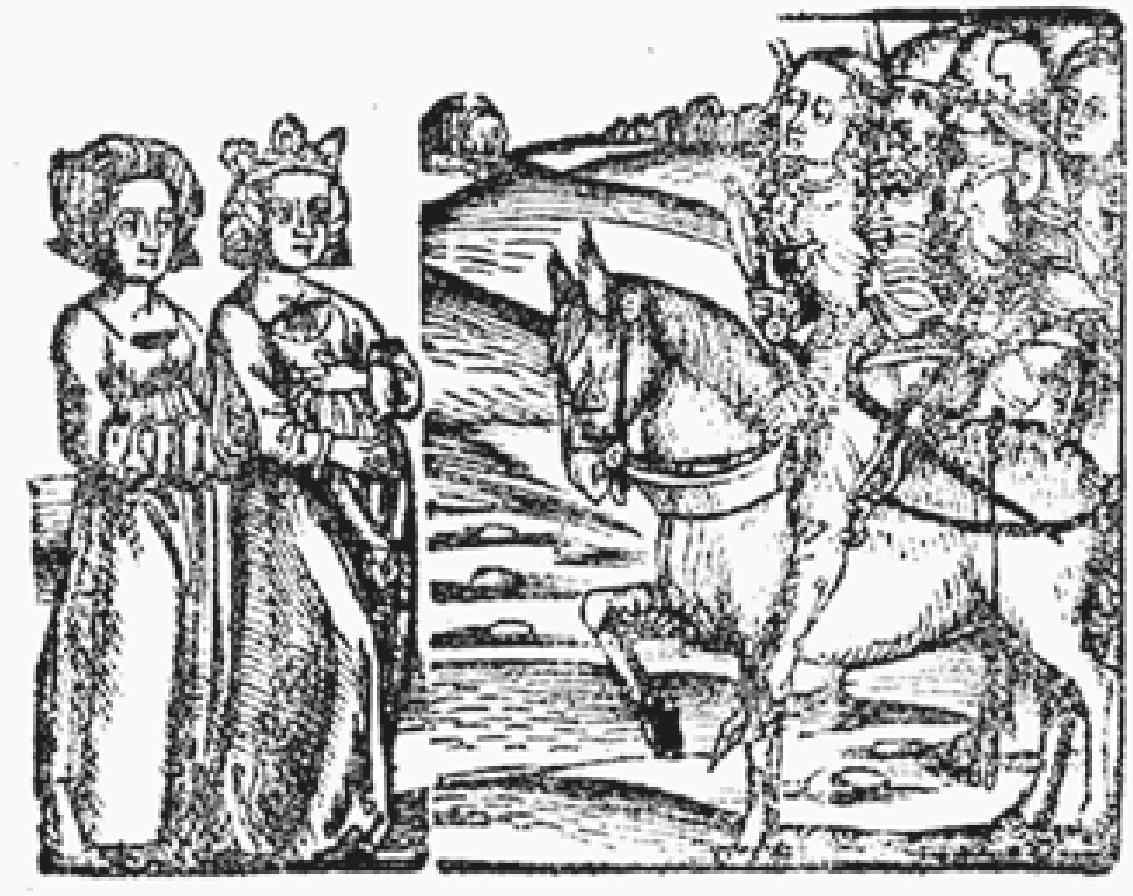




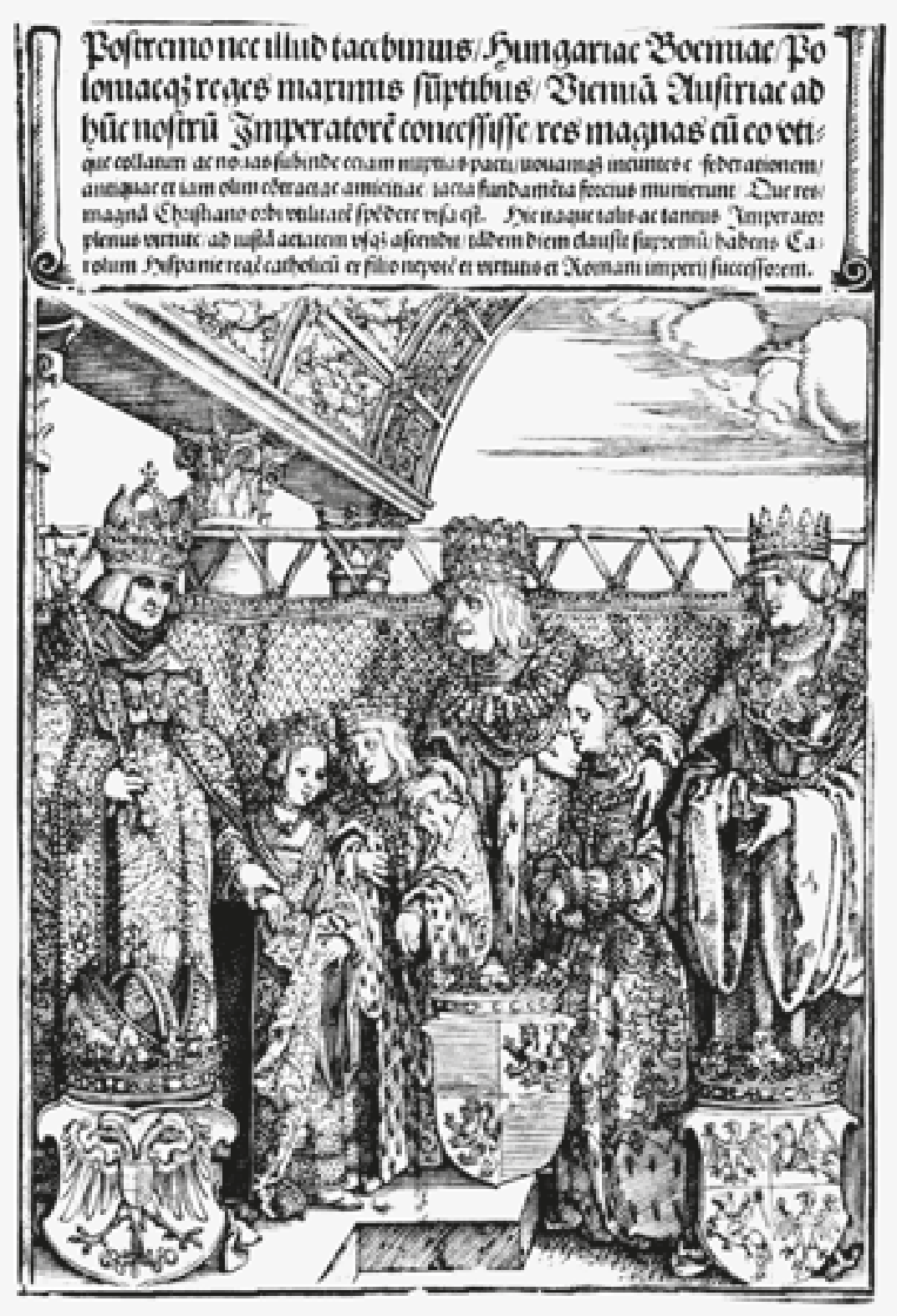

10. kép Habsburg-Jagelló szerződés 1515/5 (latin)

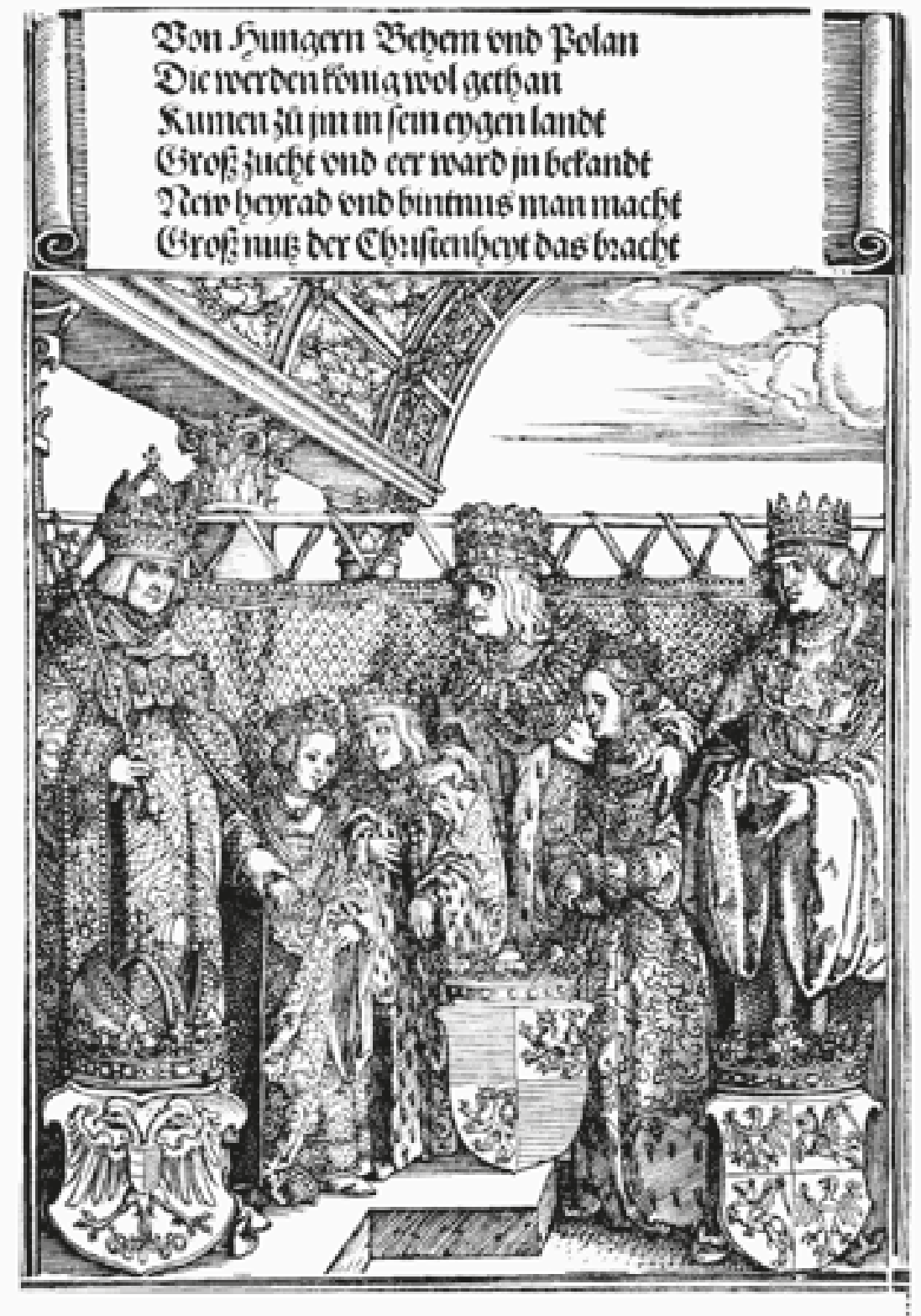

11. kép Habsburg-Jagelló szerződés 1515/5 (német) 


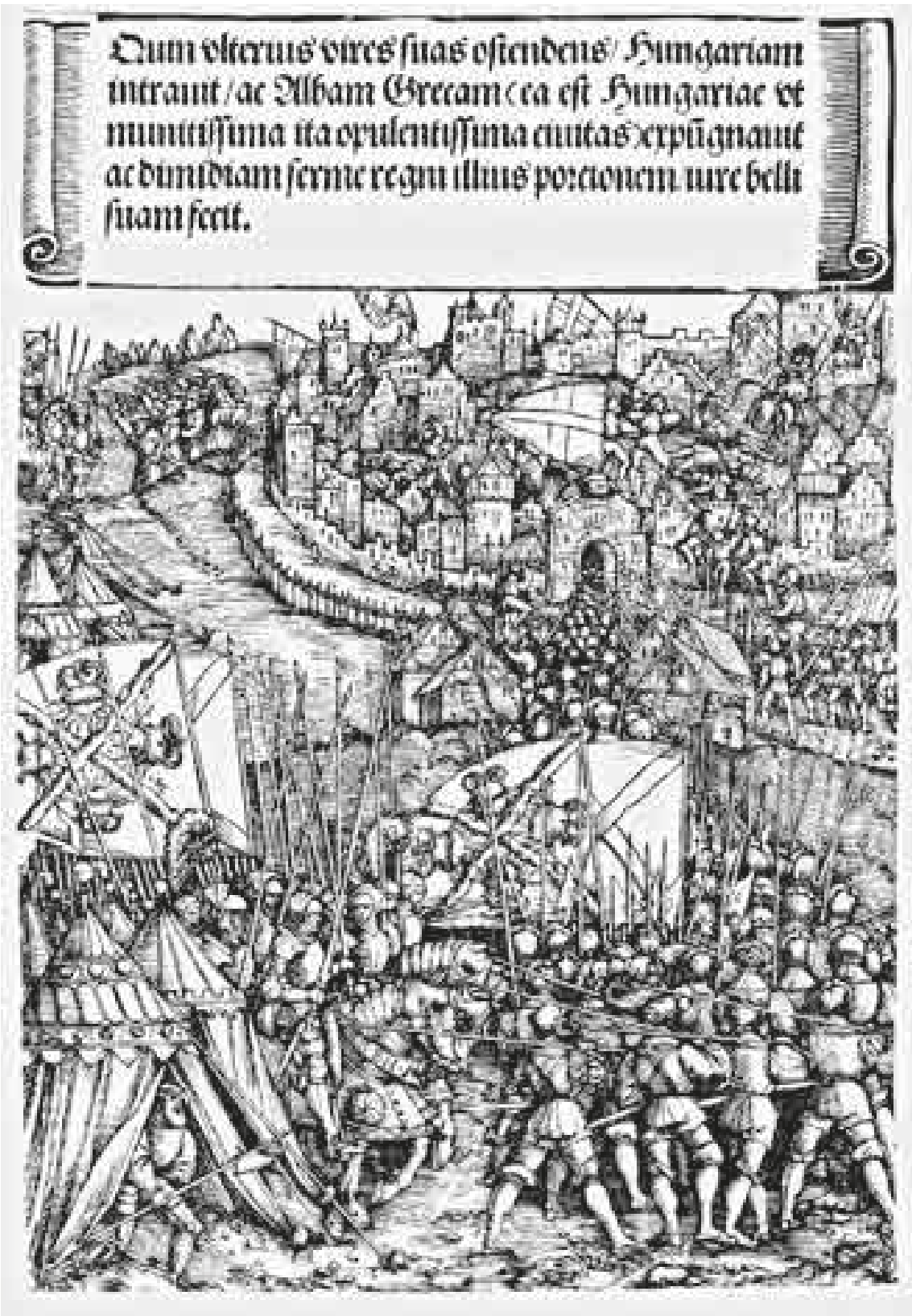

12. kép Székesfehérvár 1515/1 (latin)

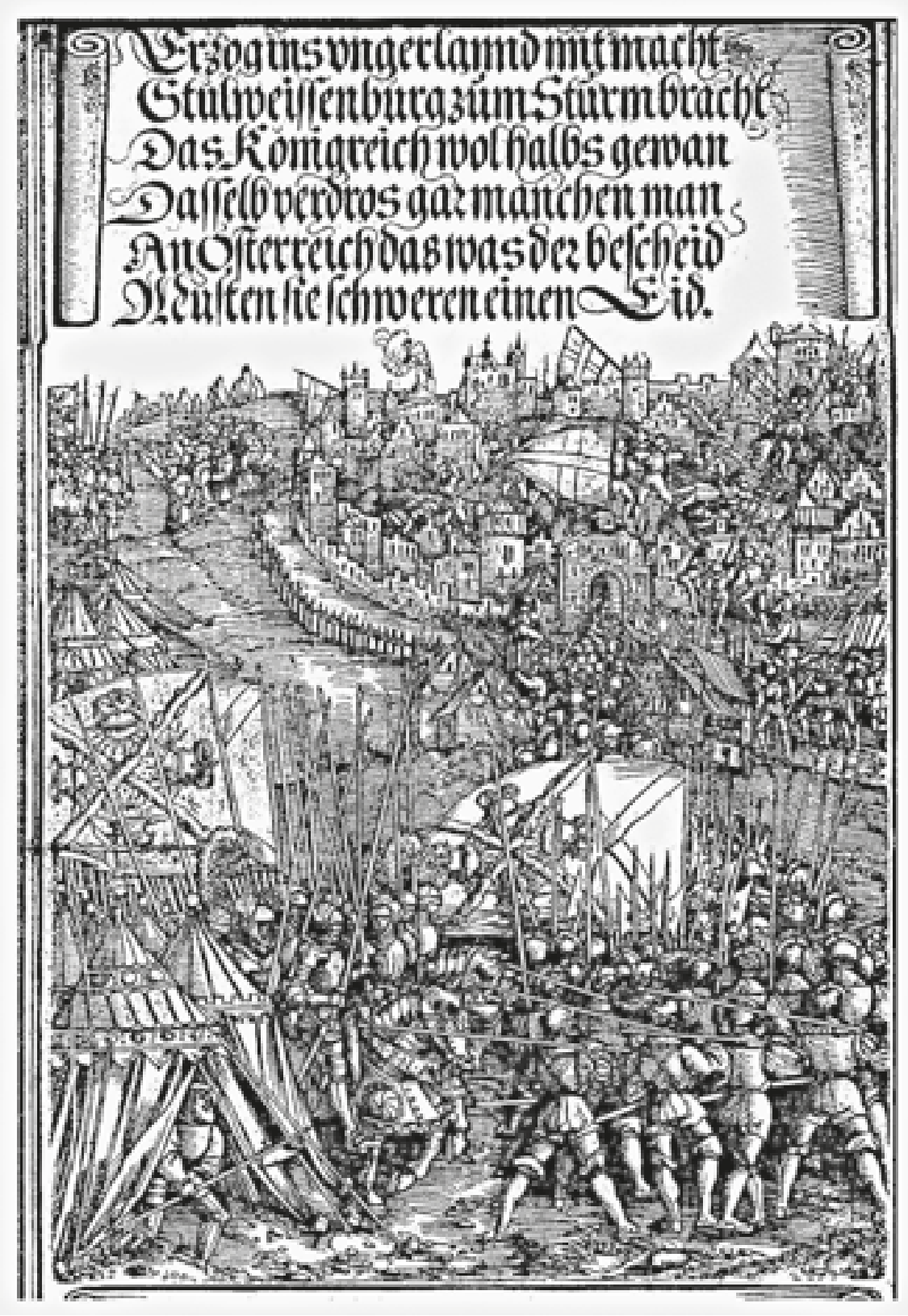

13. kép Székesfehérvár 1515/1 (német) 


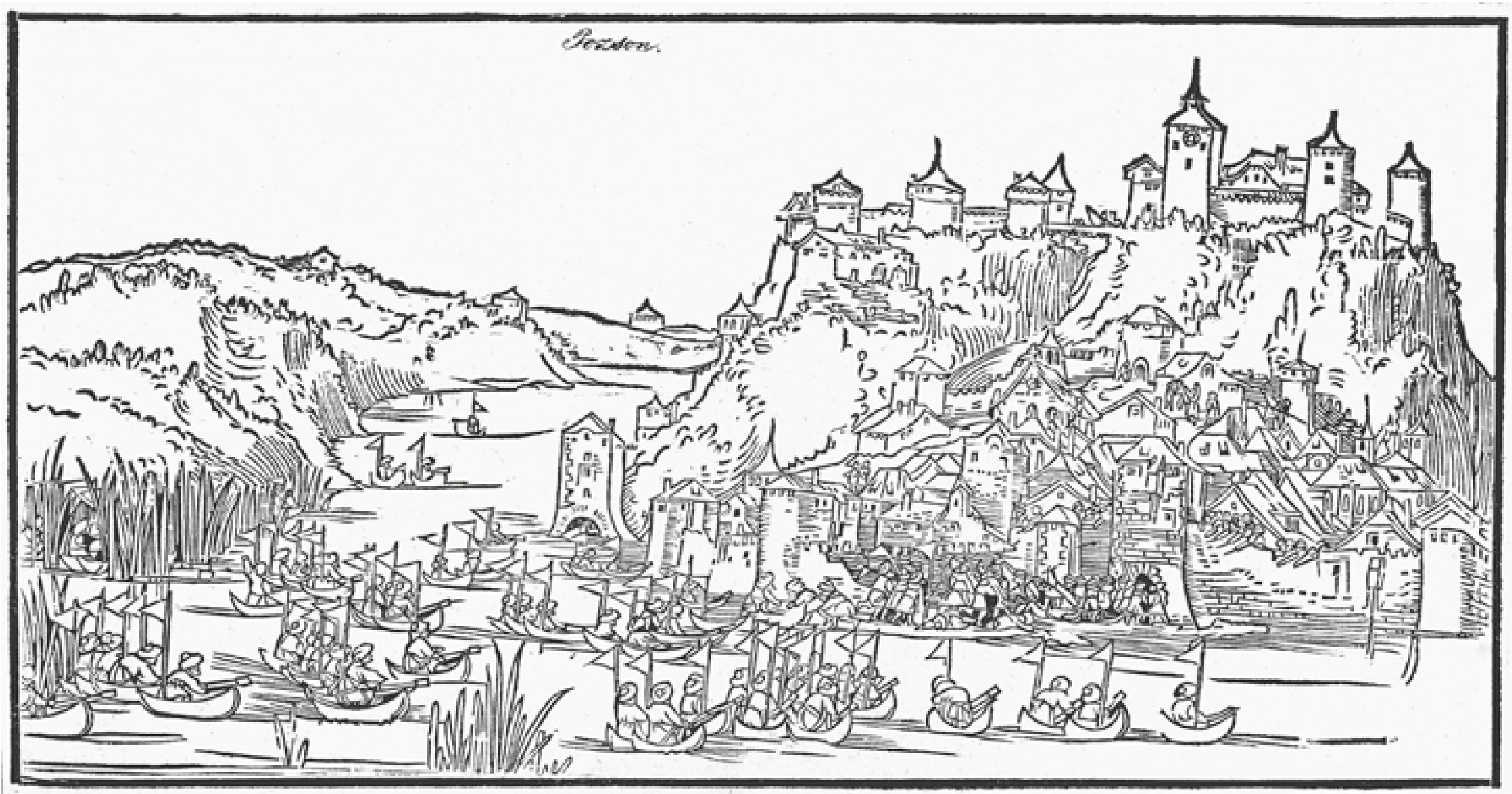




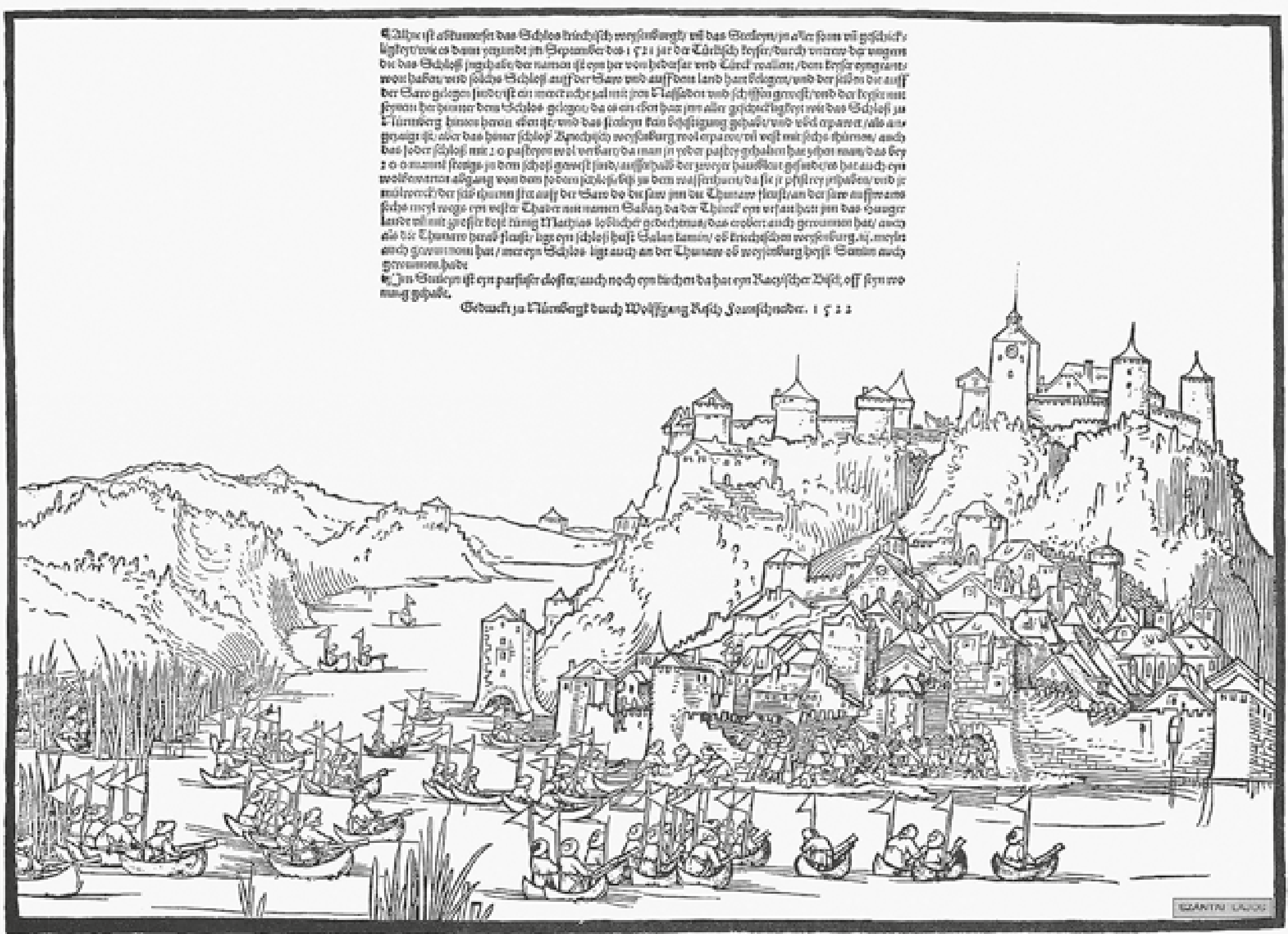

15. kép Nándorfehérvár 1522/1 


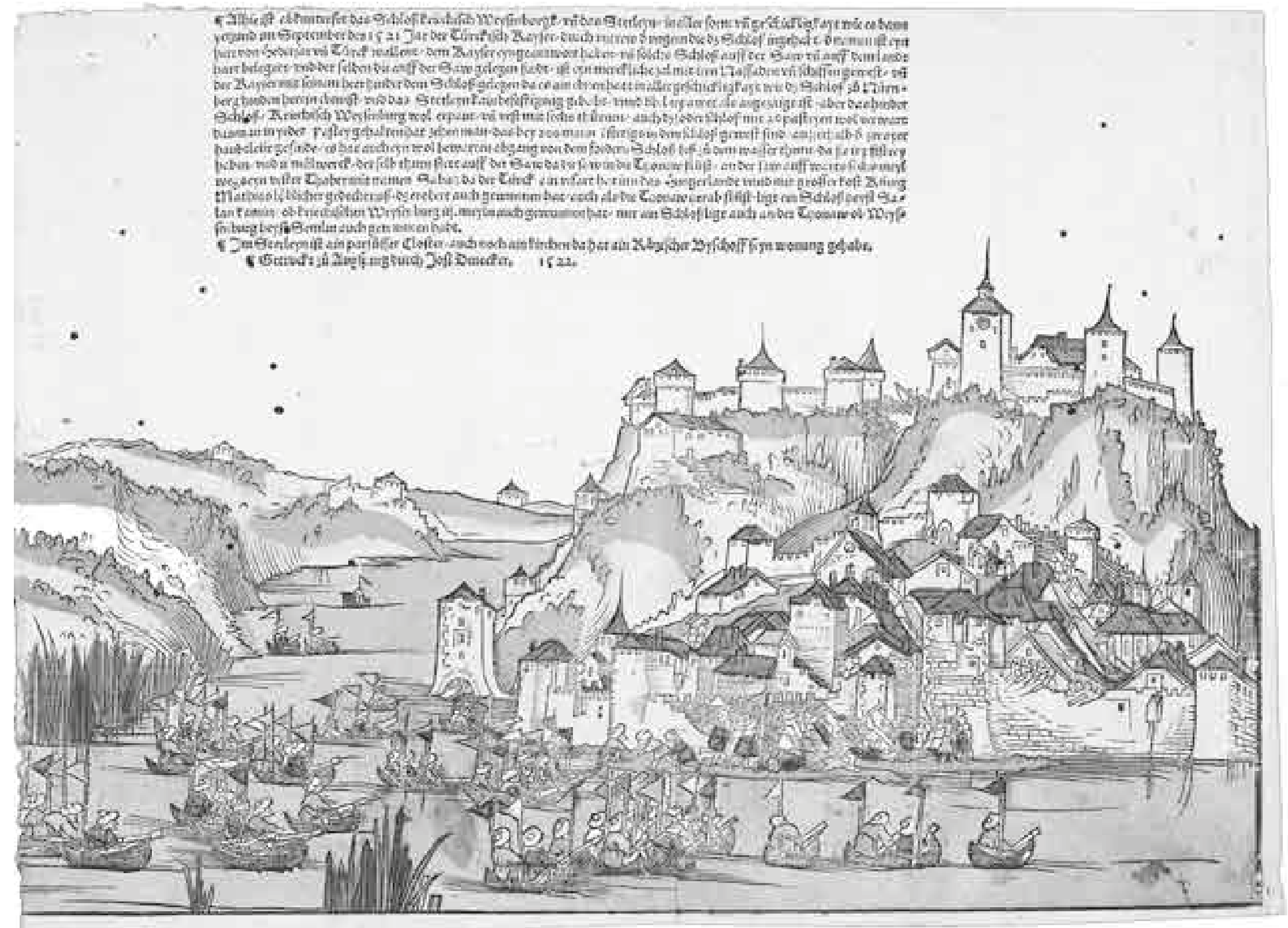

16. kép Nándorfehérvár 1522/2 
Liber IIII.

869

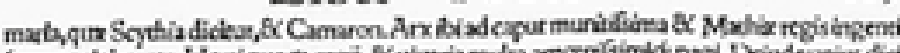

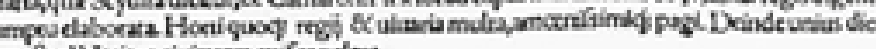
(cegent.

\section{Peuce,Syrmium.}

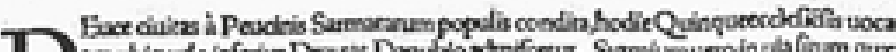

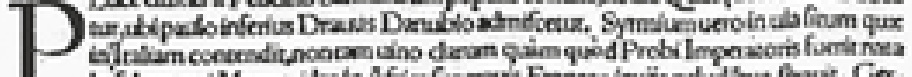

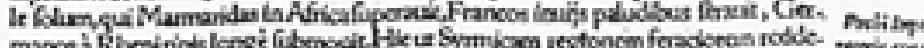

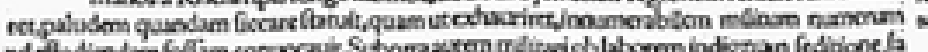

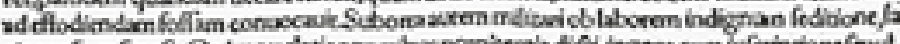

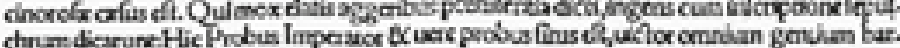
chrnm diarune Hic Probus Impera

\section{ALBA GRAECA QVAE \& Belgradum \&'Taurunum \& fecun-} dum allos Tonuinimon.

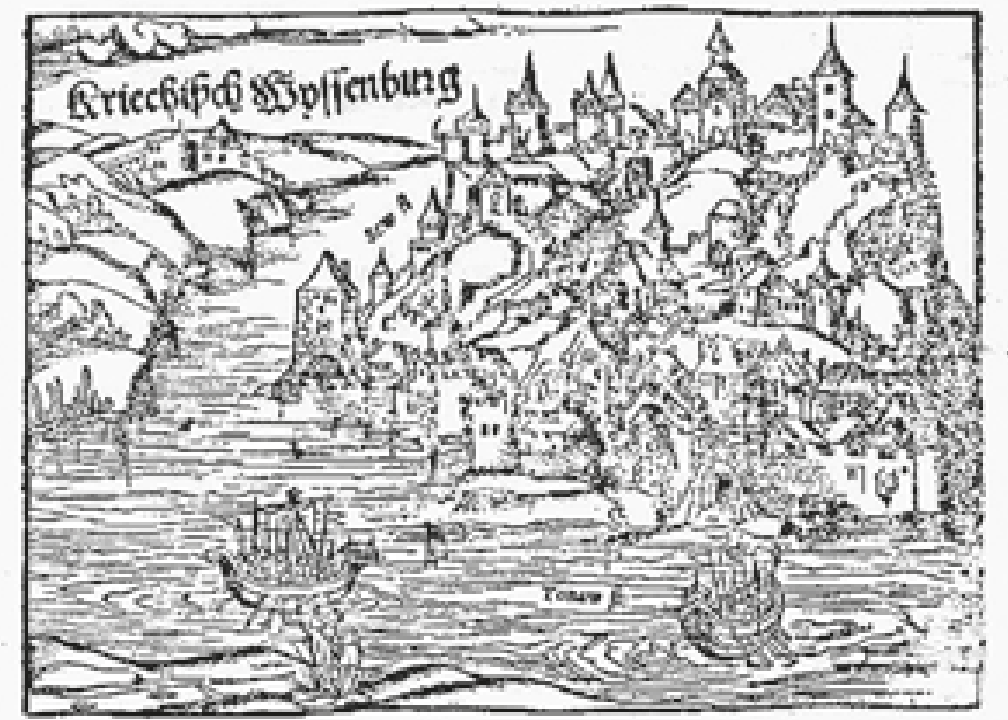

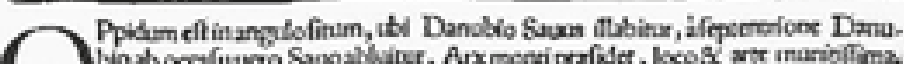

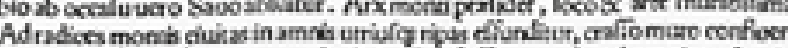

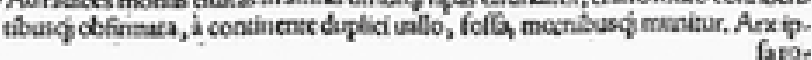

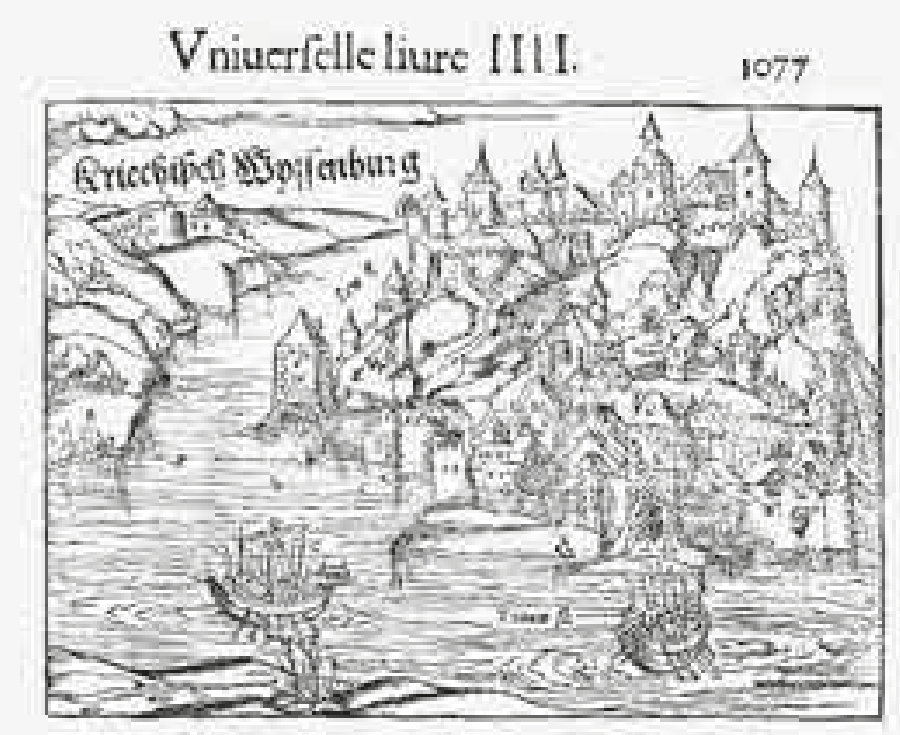

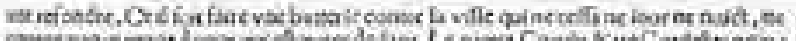
Fthodo

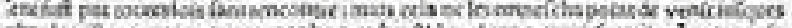

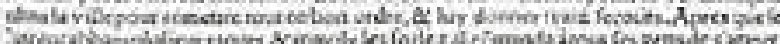

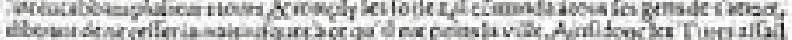

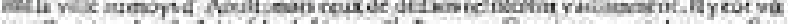

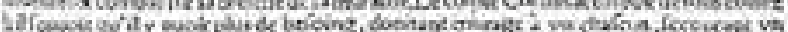

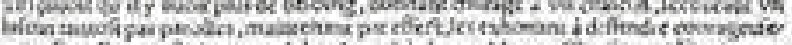

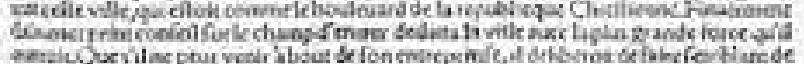

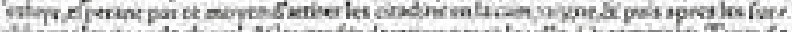

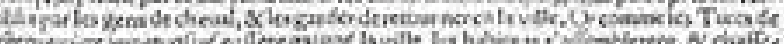

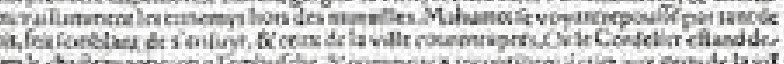

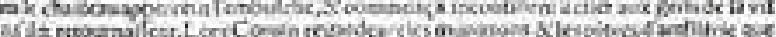

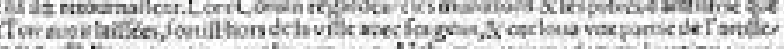

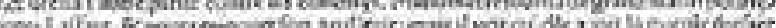

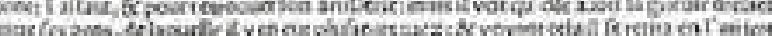

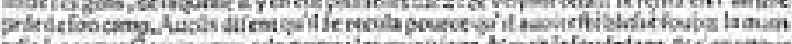

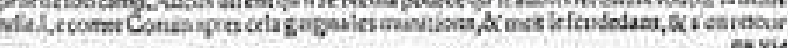




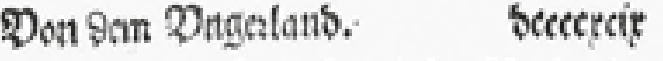

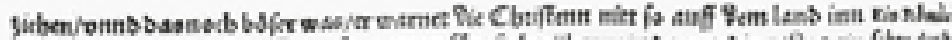

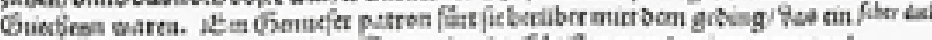

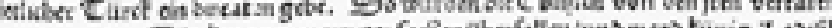

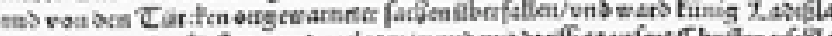

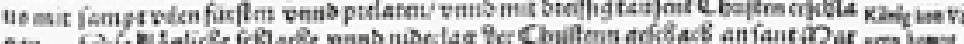

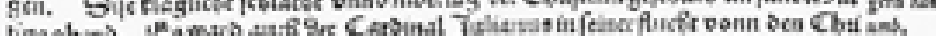

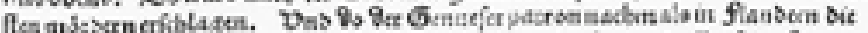

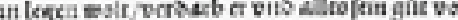

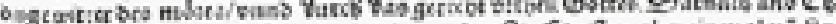
(a)

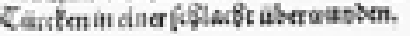

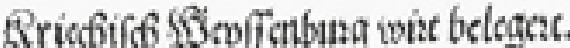

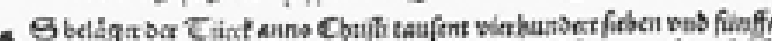

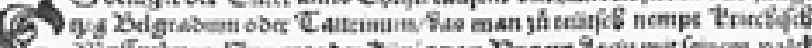

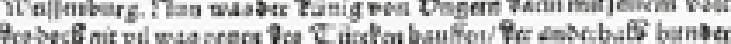

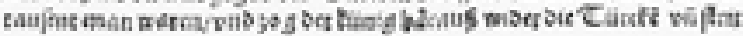

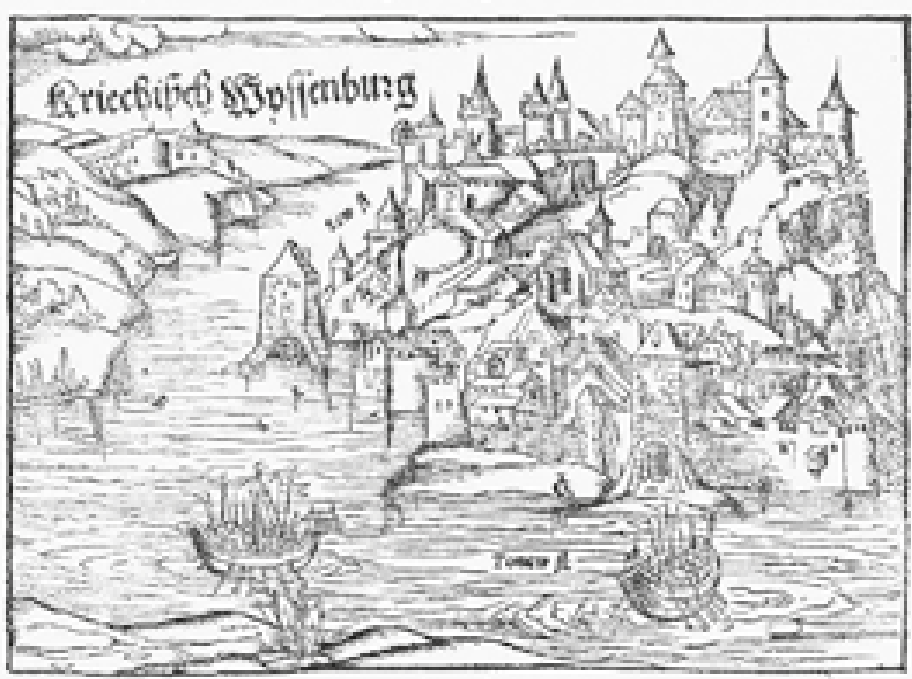

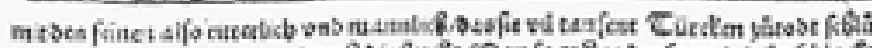

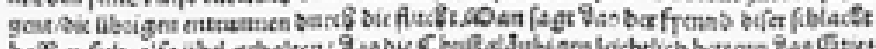

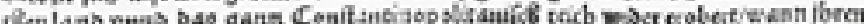

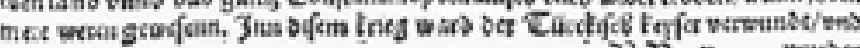

$$
\text { Vै }
$$

Lib. HIII.

$93 i$

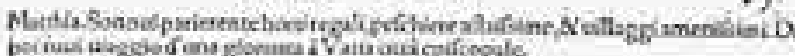
mart, ibaia

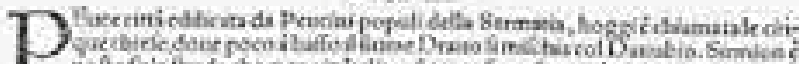

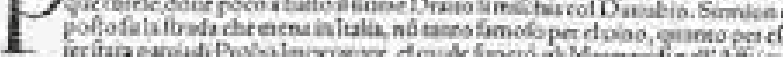

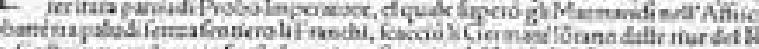

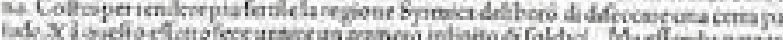
Qdatich rint

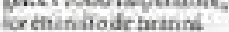

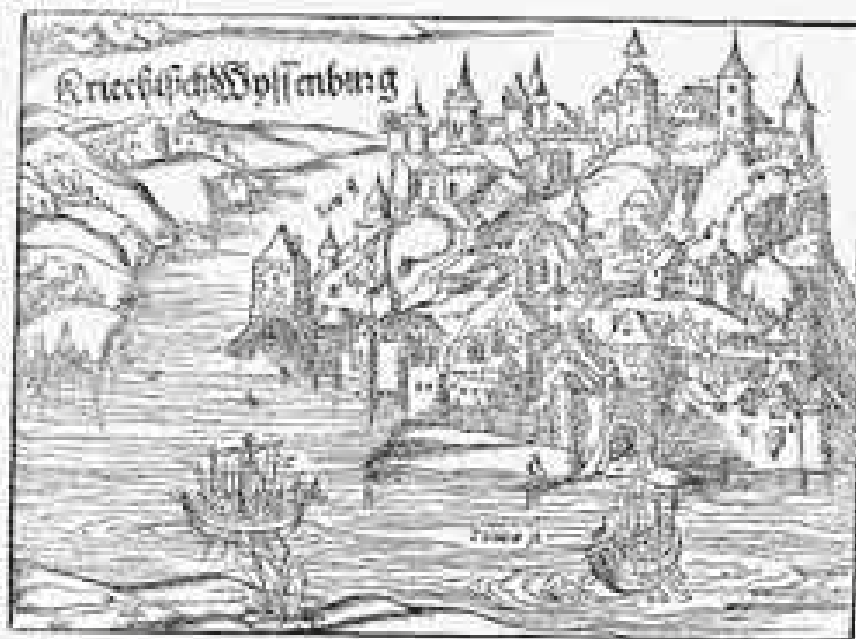

Alba Greca, la quale fi adimanda criandio

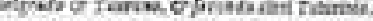

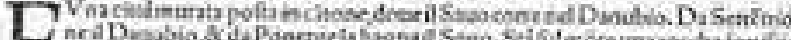

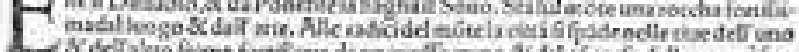

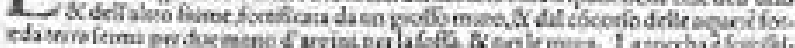

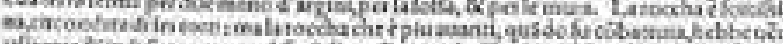

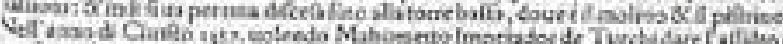

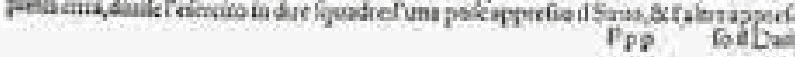




\section{恧in Ermanung tvioet

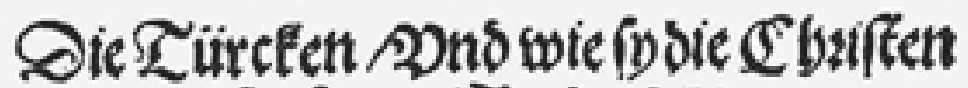 surdsedtent.\$mlant\$ngetn.}

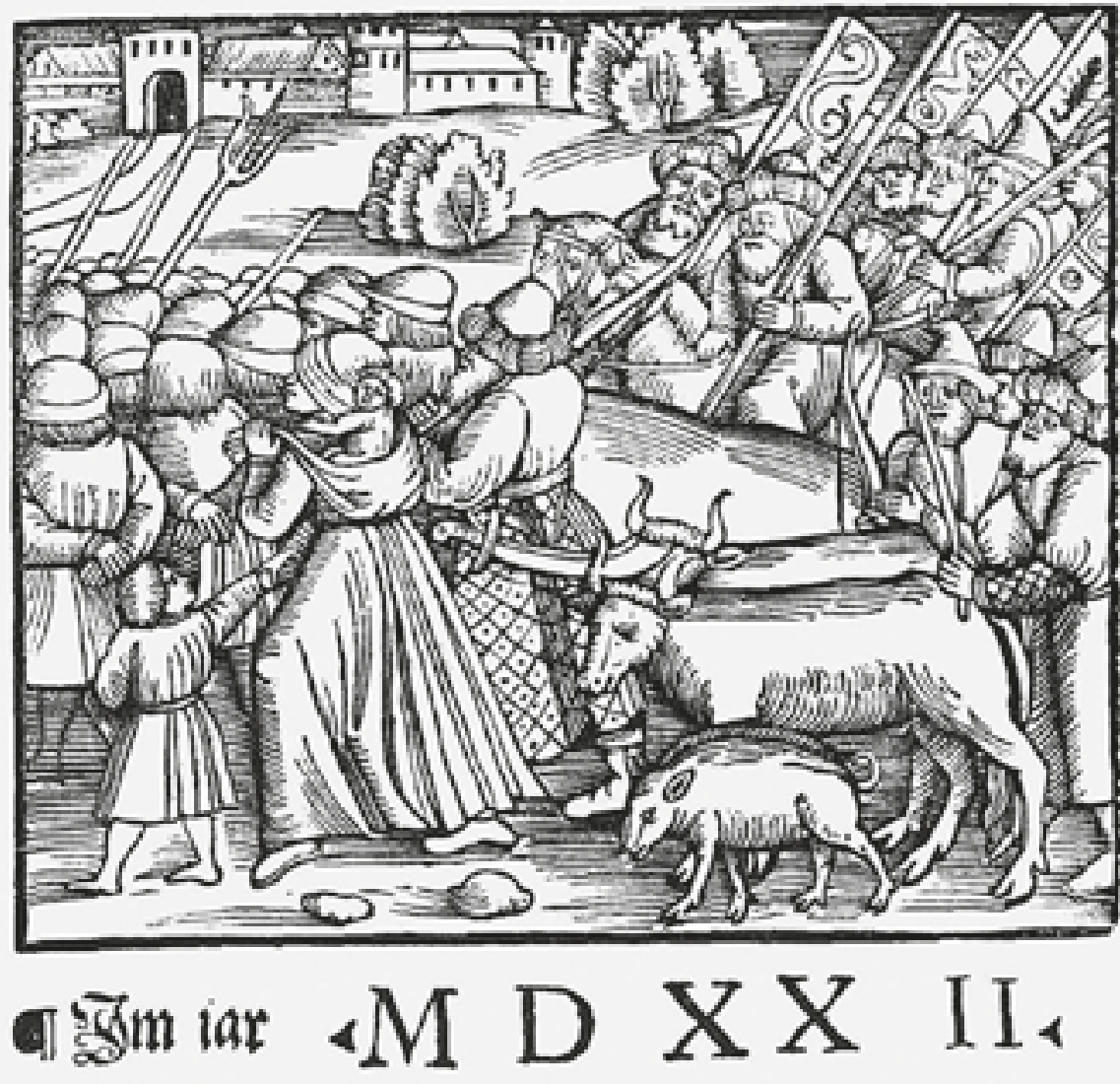

Docto? 3orcpl) Brucnpeck von

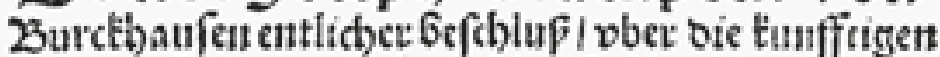

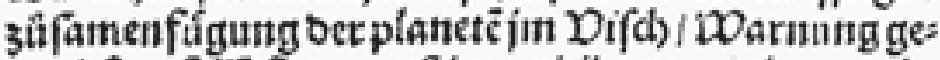

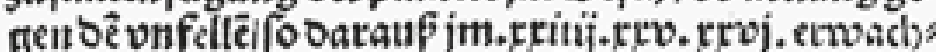

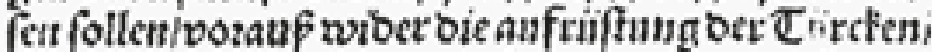

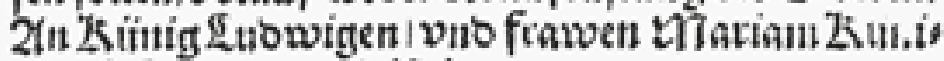
gin zů ঢuntgetu vib becham.

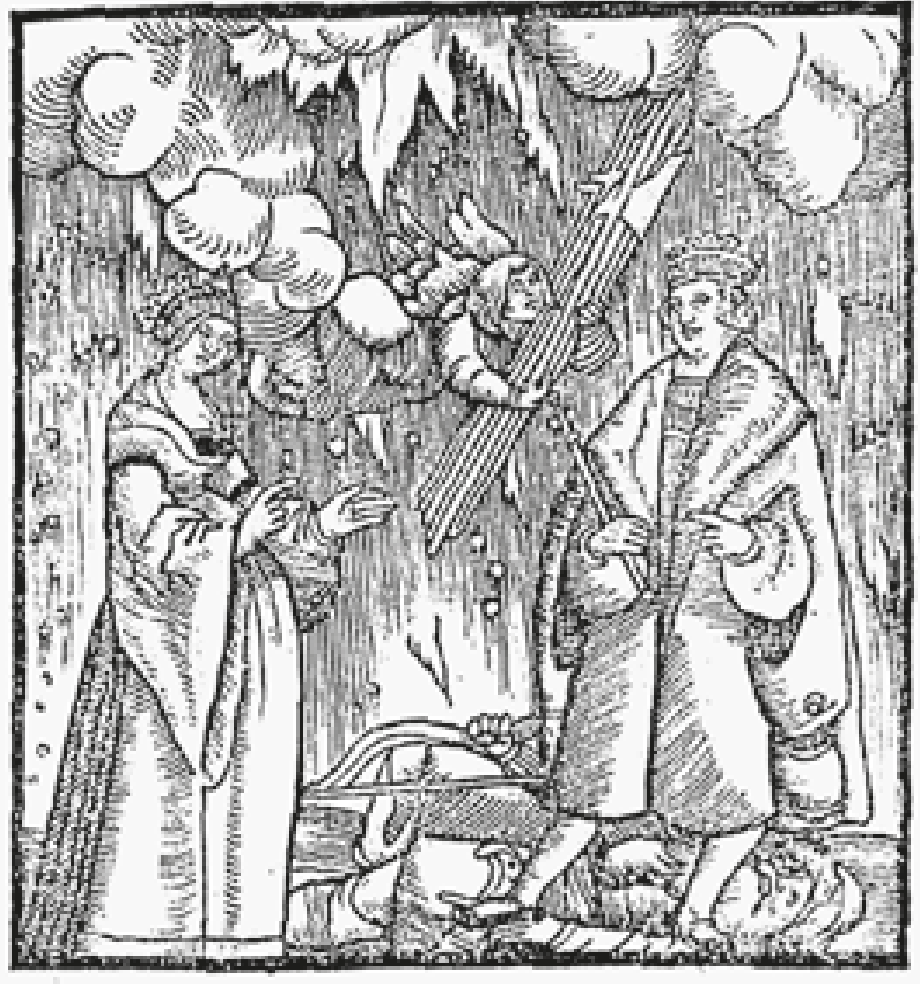




\section{KE in newer 2 ergreyen /} von titinig Lubwig auf ons gern. Jmetbon/ Jrólub) fo will id) finger.

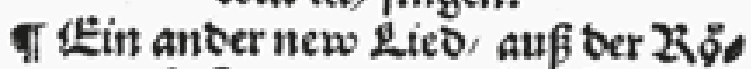
mer biftory gezogen, In fraus swen Keren thon.

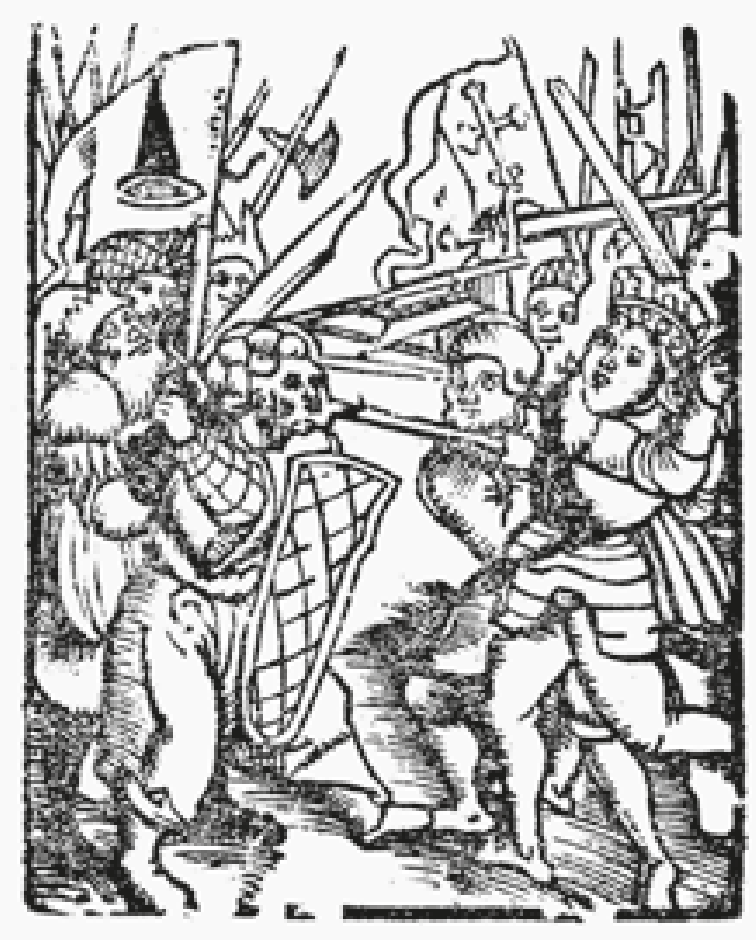

\section{Petw 3tuttum} This Sthlathe Des בurtkiftlen Zicsfers mit Lubouice erwan Zoónigy su bne gern gefebeben am tag Iobanmic eirbeuptang of 5 \& 6 .

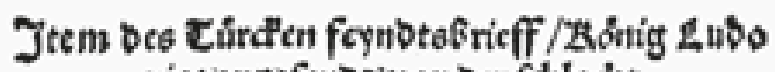
uiro $3 u g e$ (andor'vor ocr (d)lad)t.

Jtem eyn tleglider Sens6rieff fo Die Dngetn Dem Zsónig in polen sugefobiaft / nacb oct fdoladyt.

Jtems eblid) naw gerseyteri aus polen.

Pew 3etumy yom 19abt 3u thome

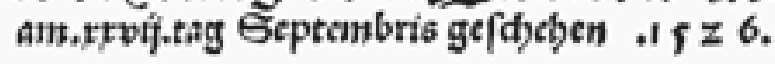

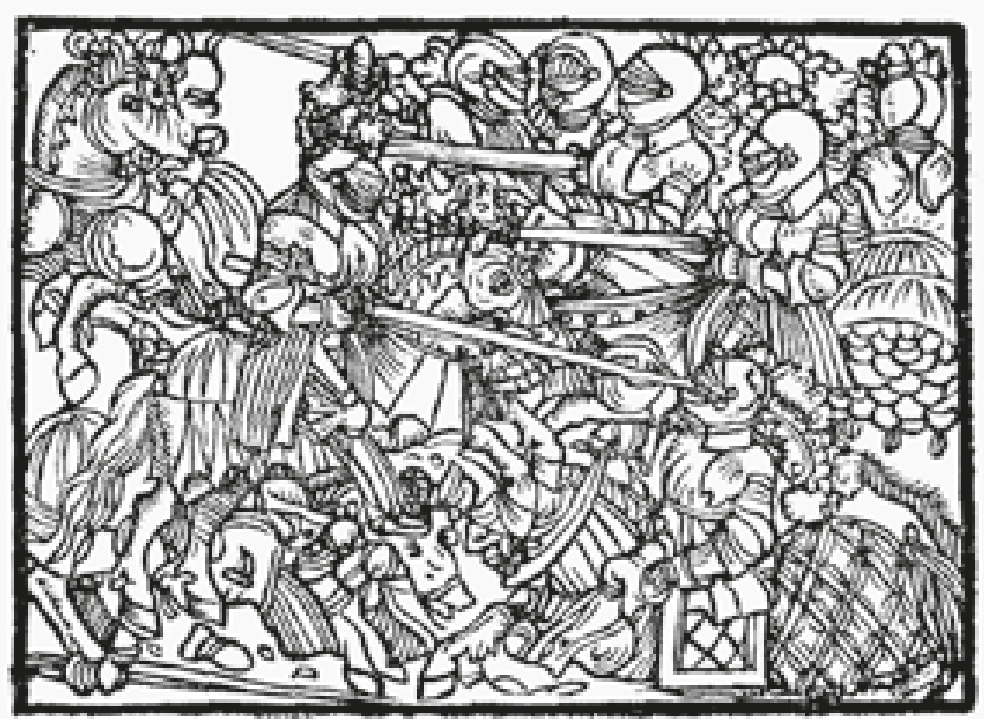




\section{Bbrthach volgt ors Solittbundts der fich nenner

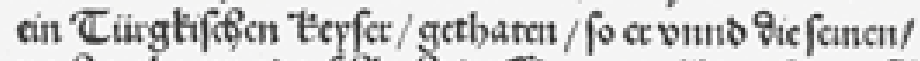

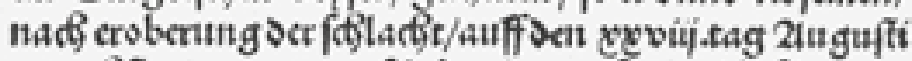 nect) t vergangen gefeheben/ant vnfen mirbtủbert ier Wngerifchen lansfobaffien/ganiz vis men'cblicb triben bat/pitonocts tågliợe thür.}

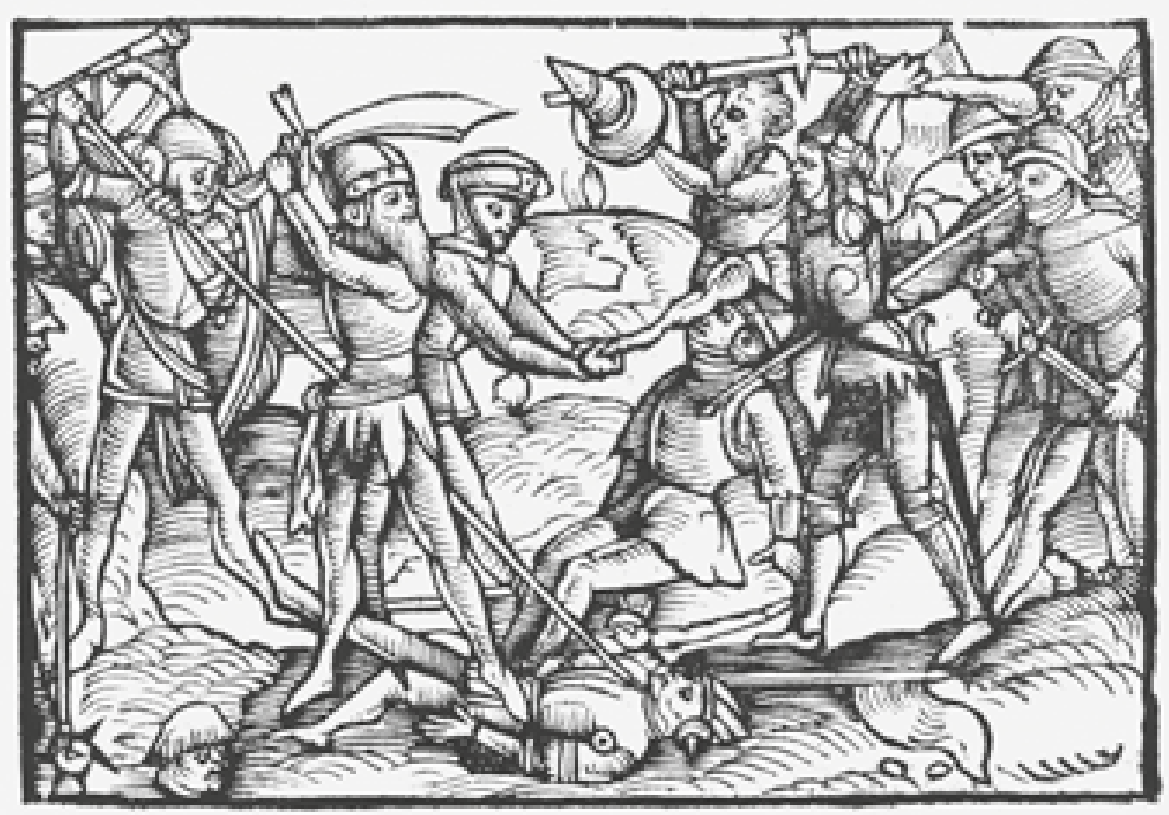

\section{Pewzeytung.}

3e Gcblacbt oes Turckifcbenn Keyfers mit 2 Loouico ctwan kónig zu Dungern gefabeben am tagjobantis cutbeuptung

$$
\text { 2D. D. krví. }
$$

Jtem oev Iúrcken feynotsbrieff/ Kỏnig 2 Loouico 3ugefanot nor ocr fablacbe.

Jem eyn Eleglicber Senobrieff fo oie Dngem ocur Kònigyn 'polcu zugefcbicte/ nacbocr fablacbt.

Jem et3lich naw get3eytten aus "Polen.

Mewzeyttung vom Babit zu kome am. krvij. Septembris ge[cbeben. ID. D. $\mathrm{krvi}$.

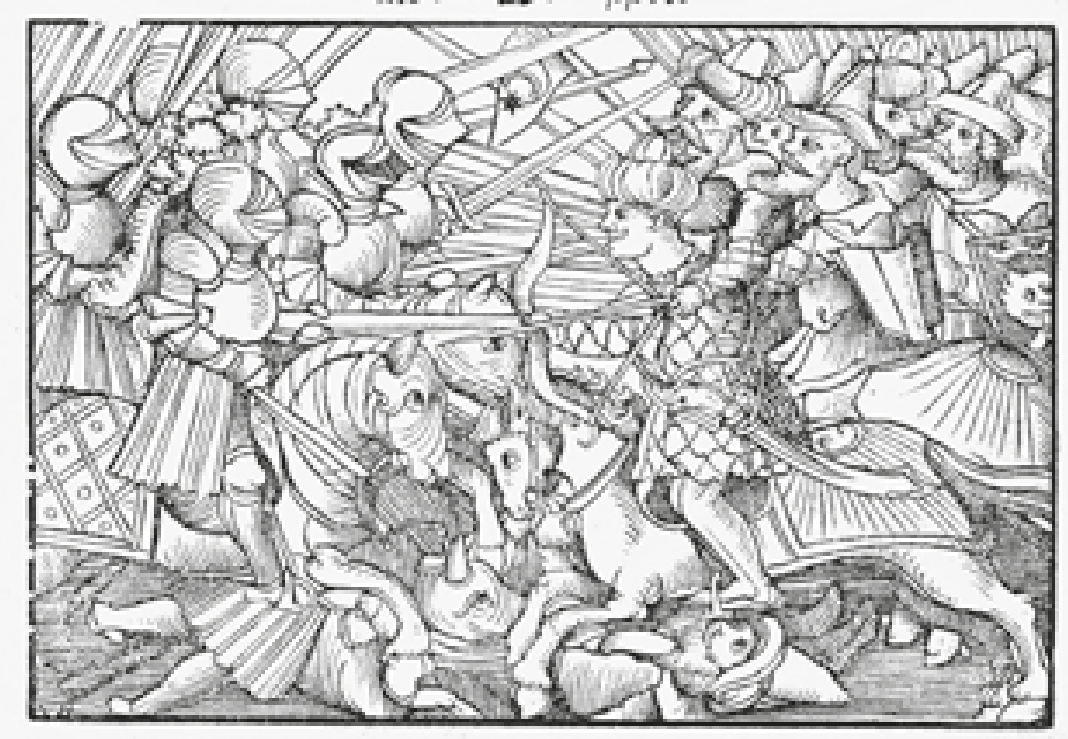




\section{1.} Em erbarmlicile tapouีige vã

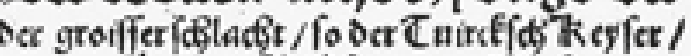

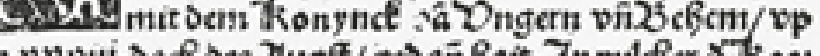

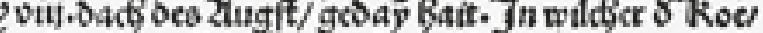

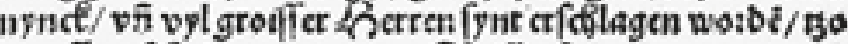
groiffem [daben/gemeyncr $\mathbb{C}$ bstfenketit.

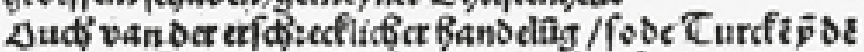

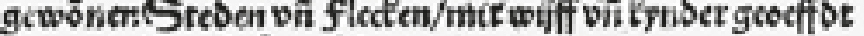
Batuen/erBarntlidß 50 Rö:ct.

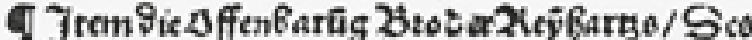
gelifen (DetBofus/wieder Curcf/vur Collen fal af oflagen werben.

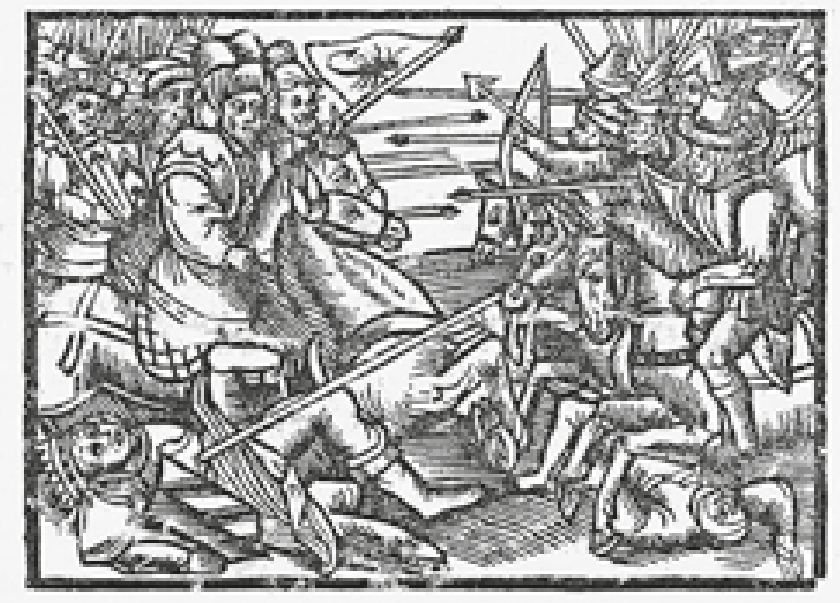

\section{Evinew liedron ocr} (a)lad) oic Der Ongerifa) Ziumg vno oer Cinct int cinsmoer ges thanbaben. Jm Spcent tbon.

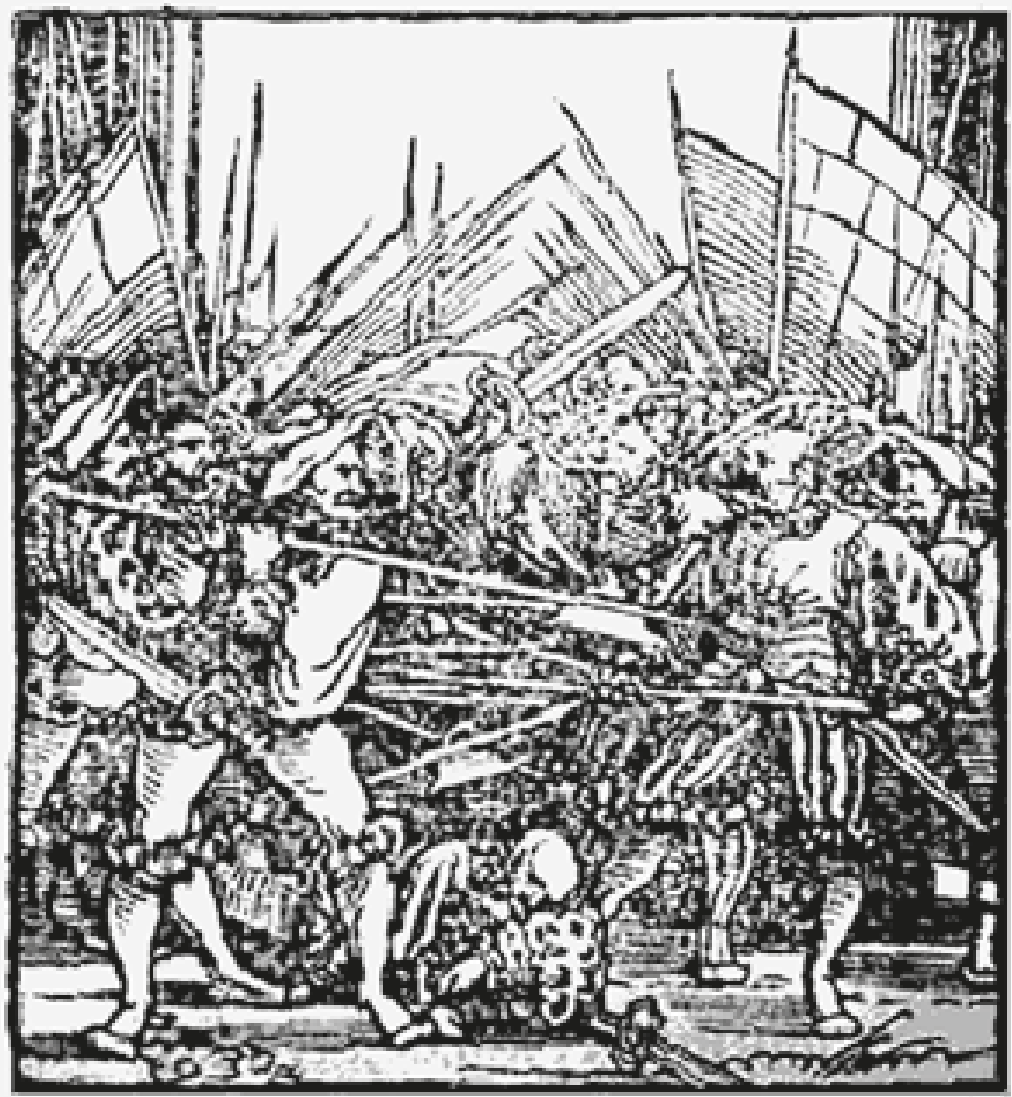




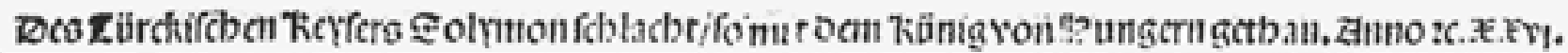

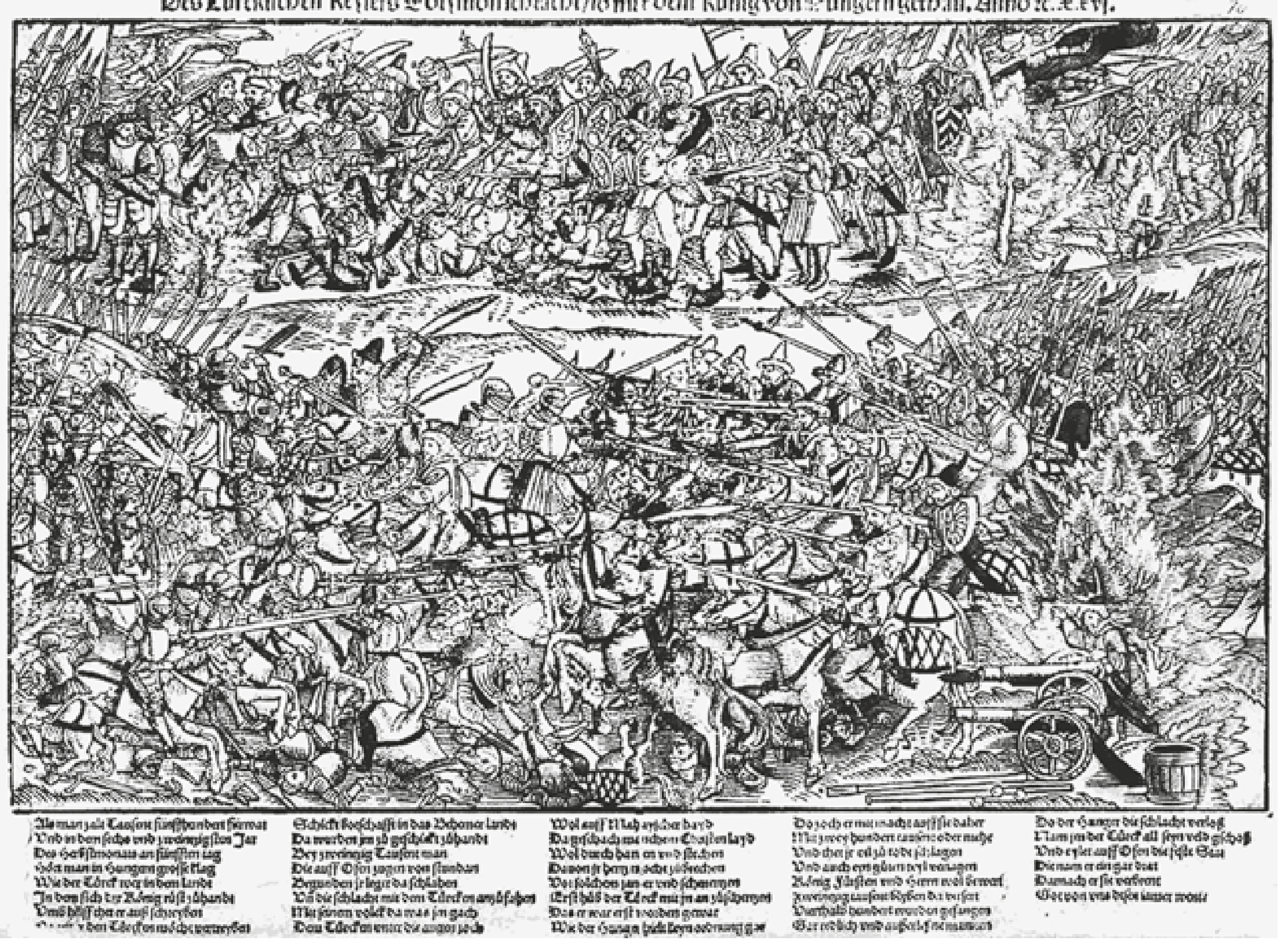

29. kép Mohácsi csata 1526/1 


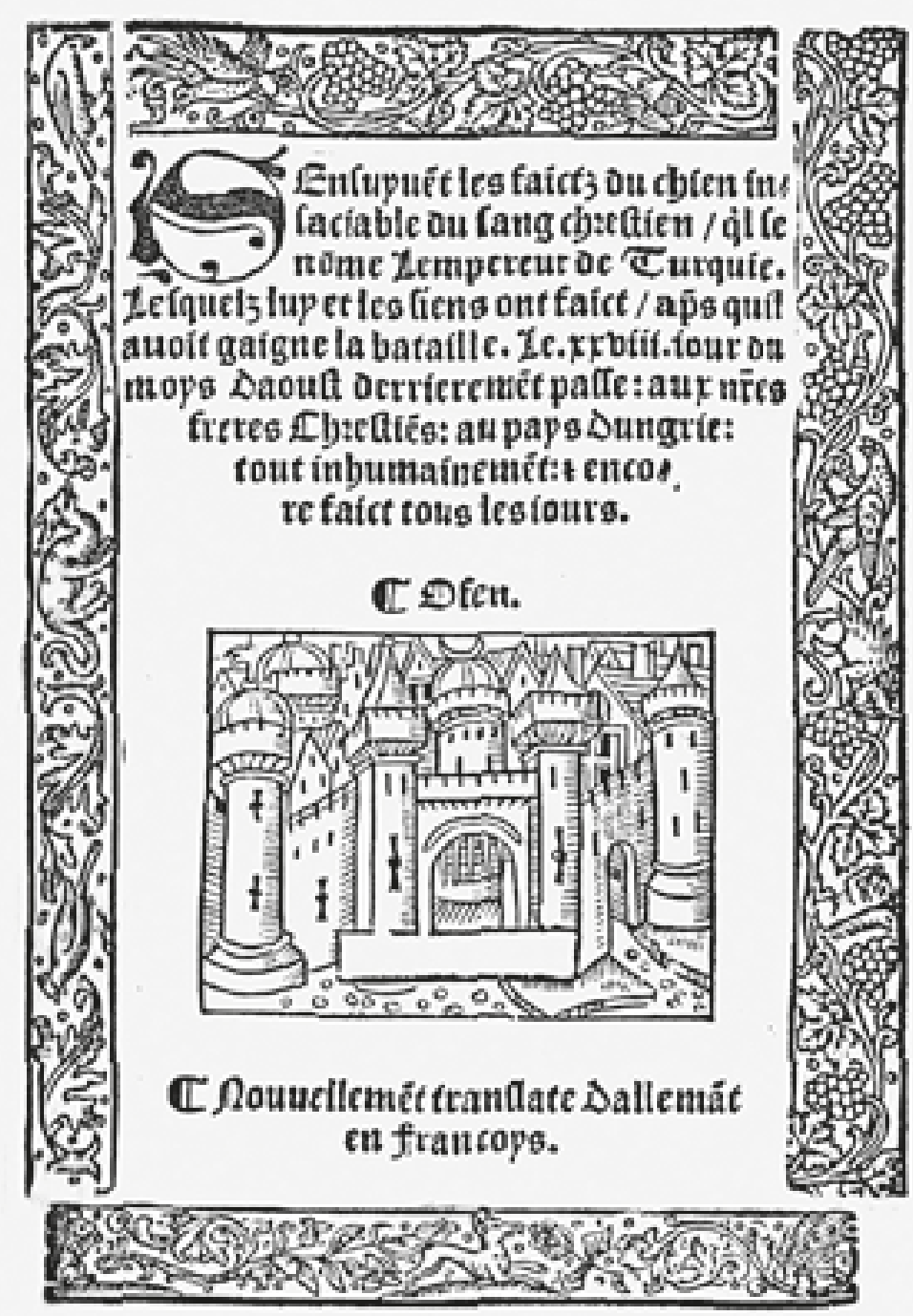

30. kép Buda 1526/1

\section{Bernacbvolget oes Blutbunots oer} ficb nennet eqn Türckifcben TRapfer gethaten//o er wĩ oie feinen/ nach eroberung oer fblacht/atuff Dent. rnviij. tag 2lugtufti inegfts vergalngen gef cheben/an vonr/ern mit6rts oect ber bungerifonen Santot/chaffen gants vumenf(h)lid) getribet bat/ vito noch teglichetbut.

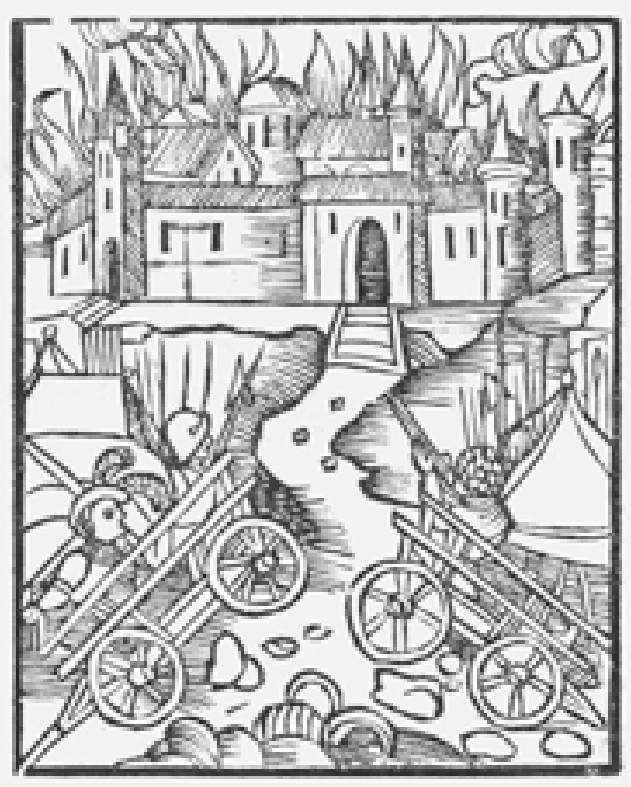


304

DE ORD. IOANNITARVM

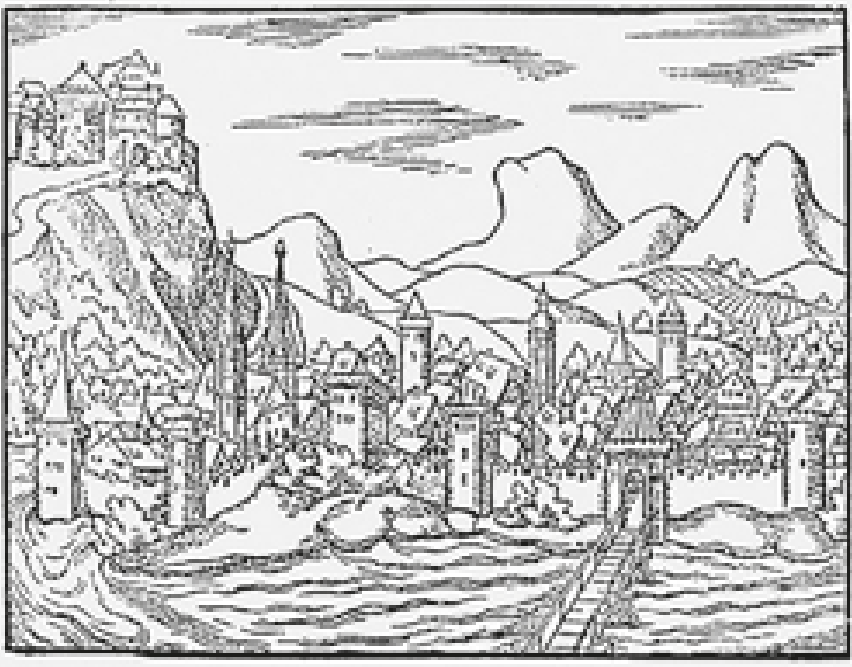

1316
Tanatas

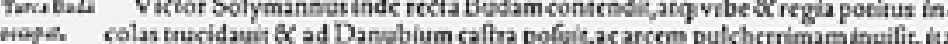

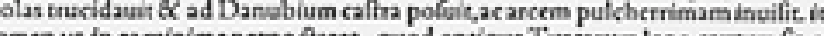

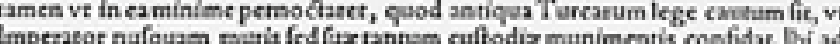

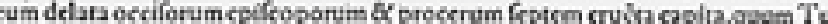

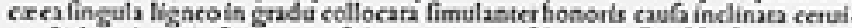

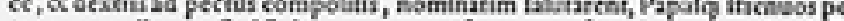

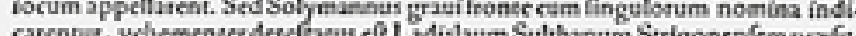

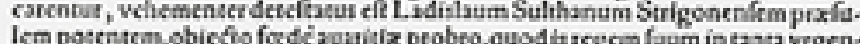

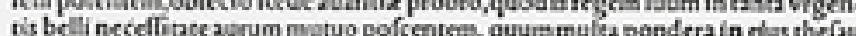

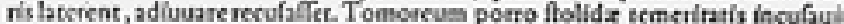

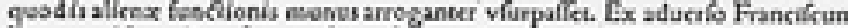

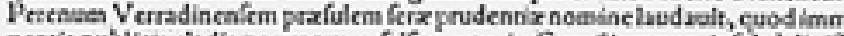

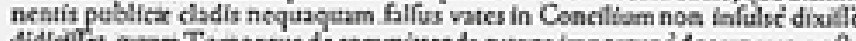

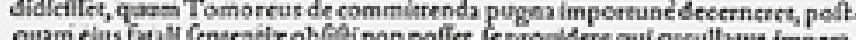

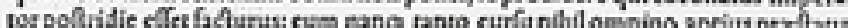

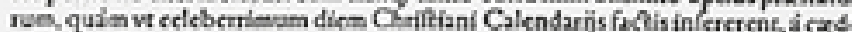
migina minto

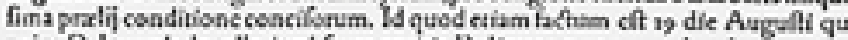

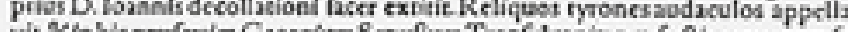

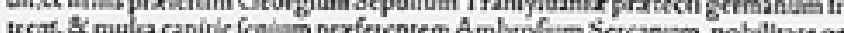
therisoperitus sid

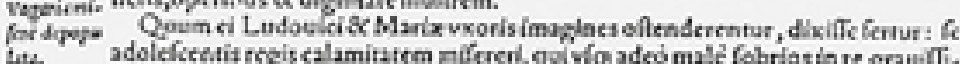
macon.
RERVM MEMORABILIVM, STRENVISSIMI ORDINIS IOANNITARVM, RHODIOR VM, AVT MELITENSIVM EQVITVM, TERRA MA

\section{Liber decimus.}

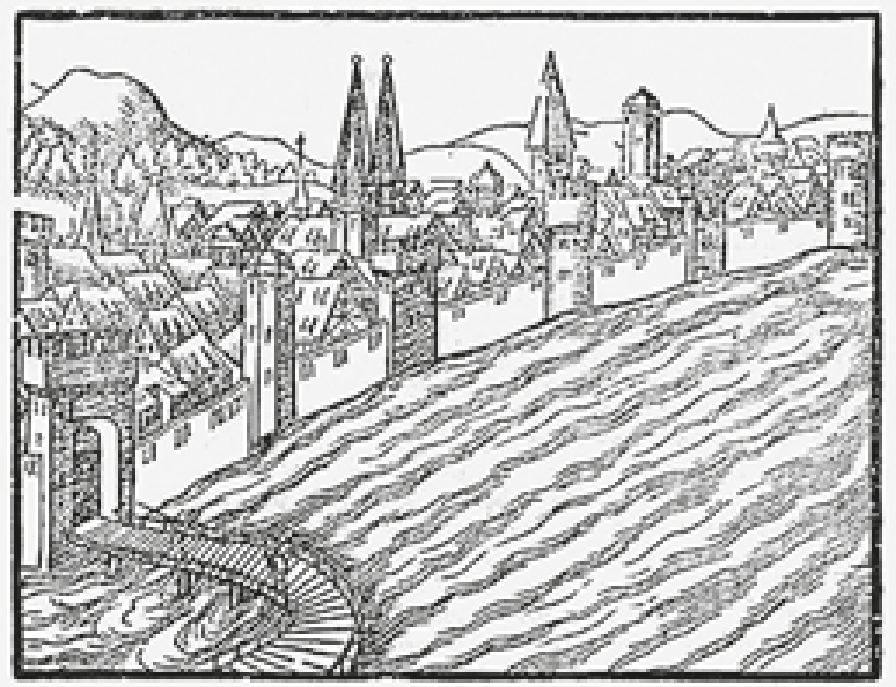

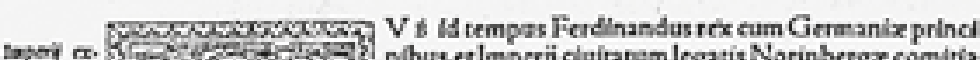

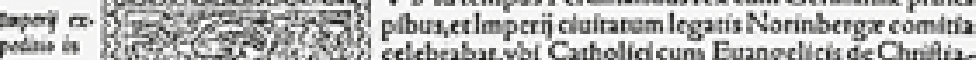

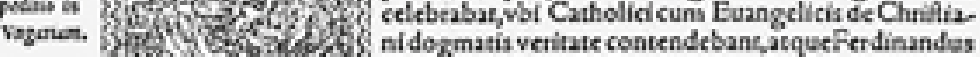

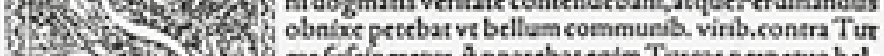

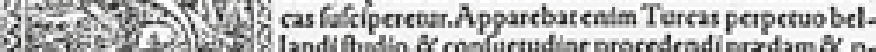

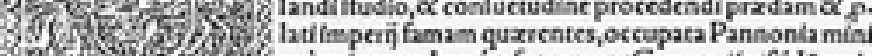

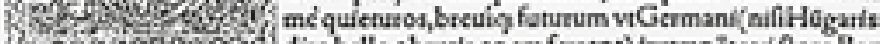

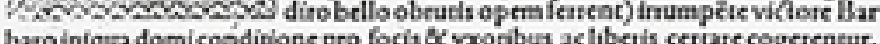
baro iniqua domiconditione pro locis $\alpha$ vronbus deliberis certate cogerentur. lagrelis

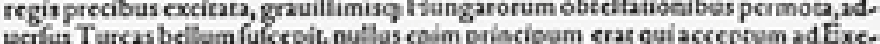
chium \&Budam dedecus nobili aufu farciendum, Eudamg̨ue omnino tepeten 


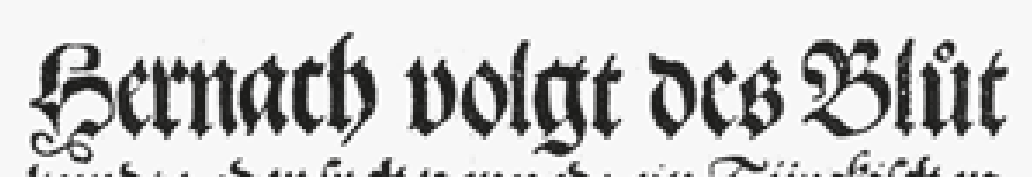
bundto / Ser inds nented cin Sirctitiden

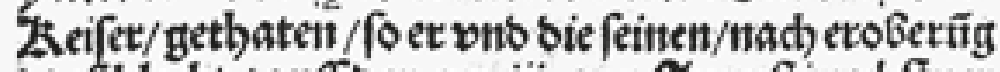

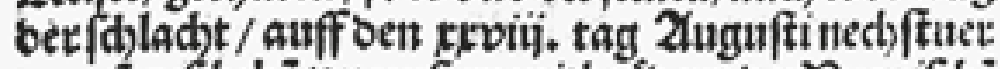

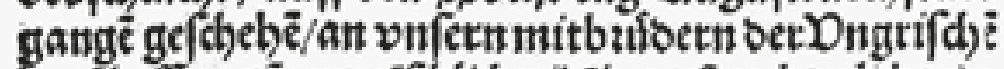

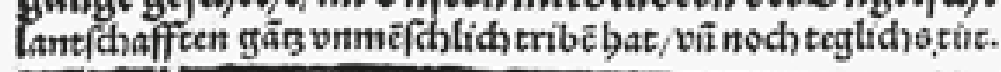

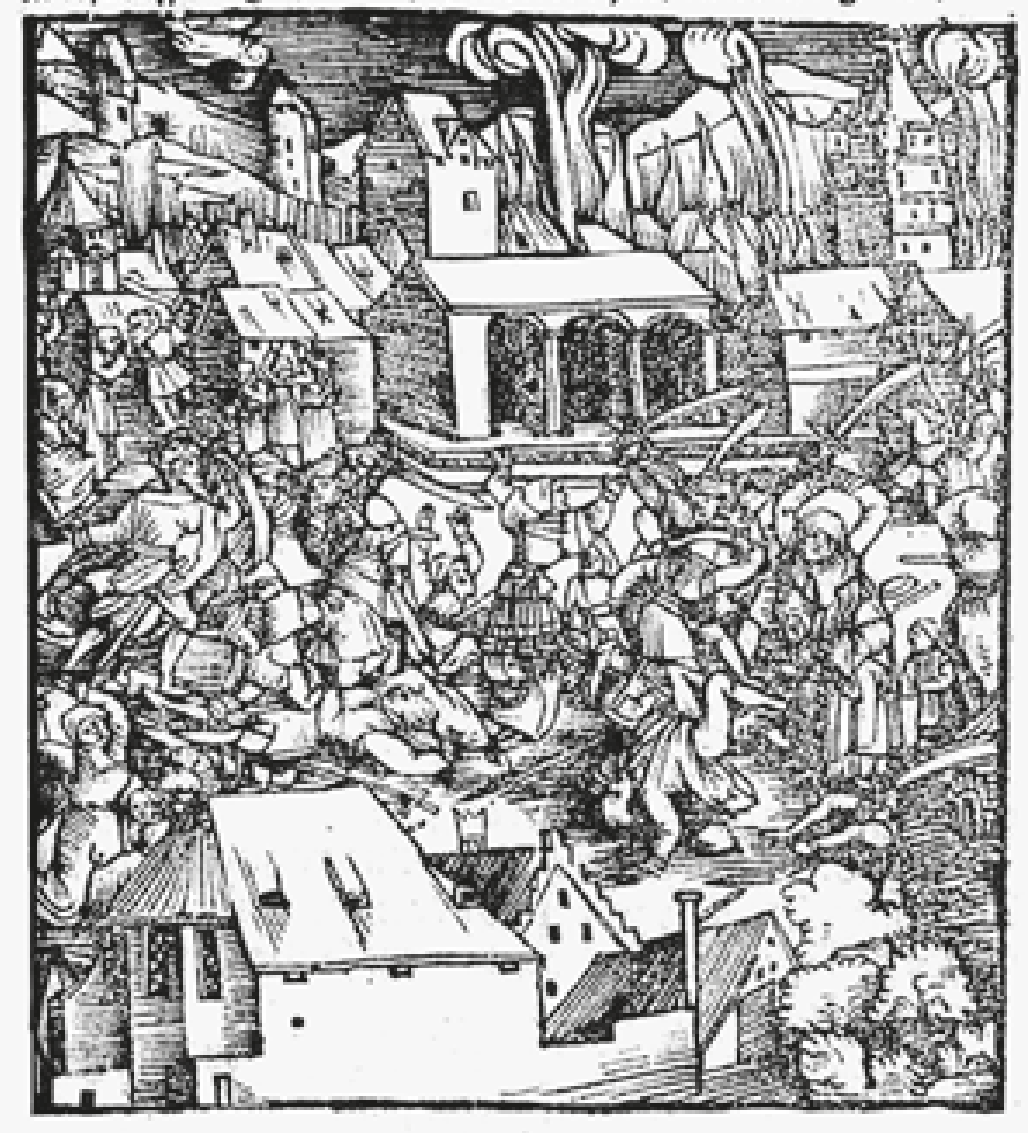

\section{Daruacb volgt oes Bluotbunots}

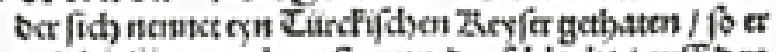
vito bie (ainat nad) crobaung oer foblad) / auff ocn

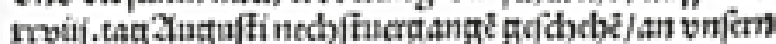

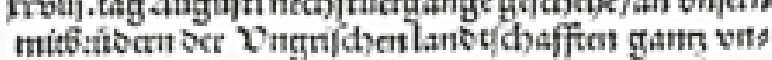

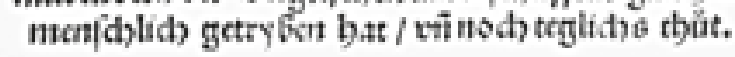

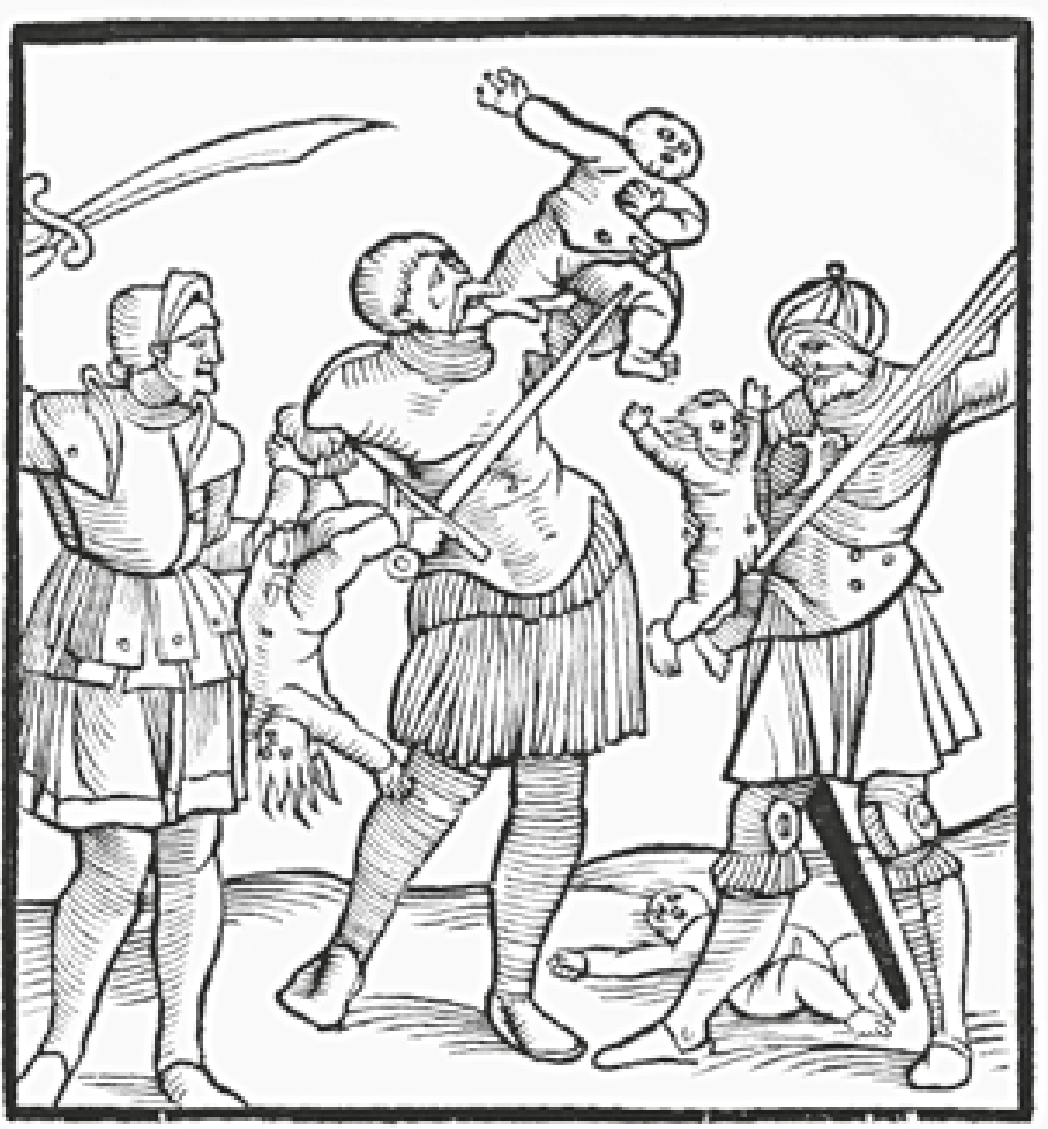




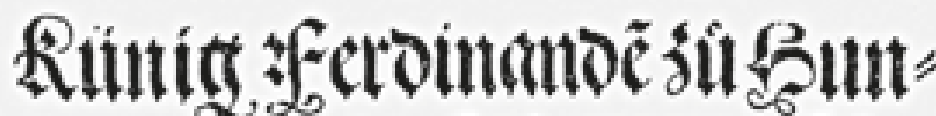
gernvind 2 Selocin. Ertzbertyogen ju O fter

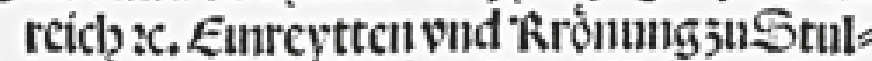

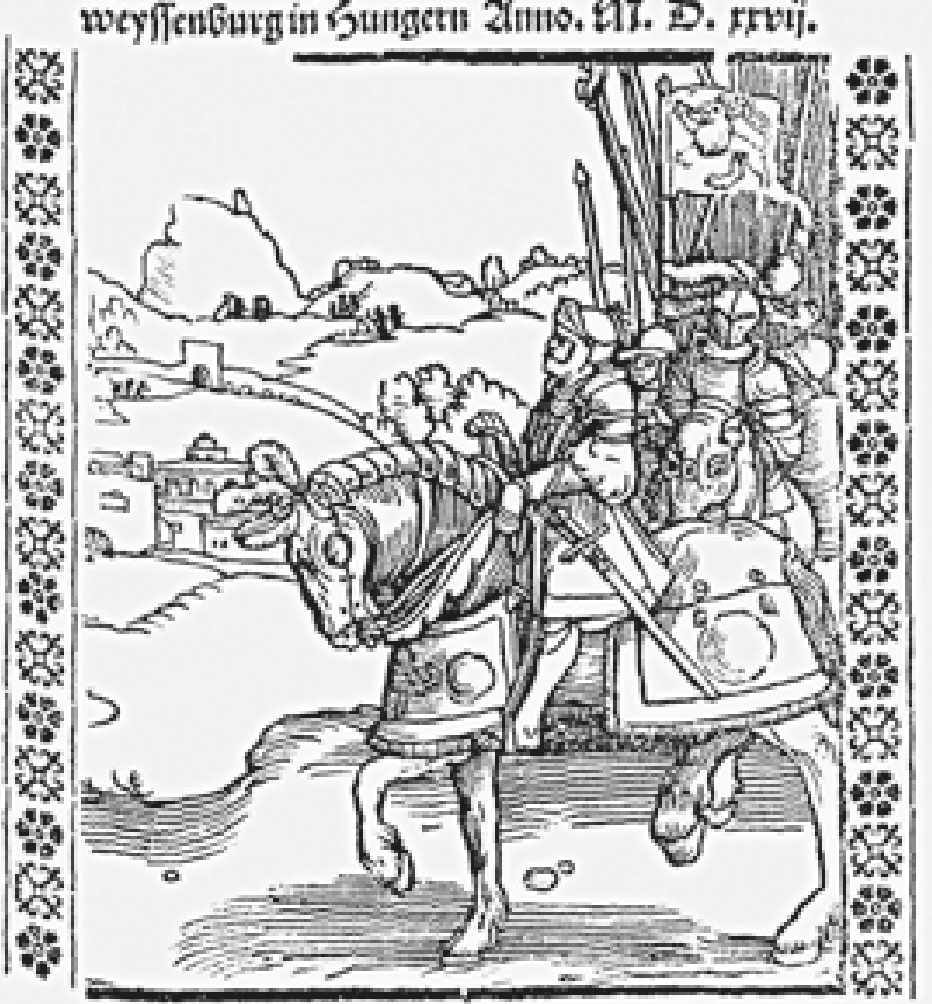

\section{Zattumulyantedntteet tou rounement de ffernant

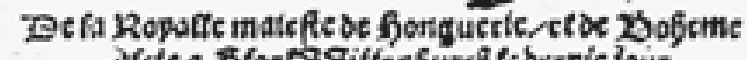

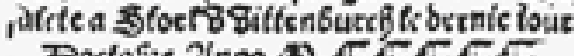

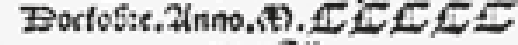 et ye 8id.}

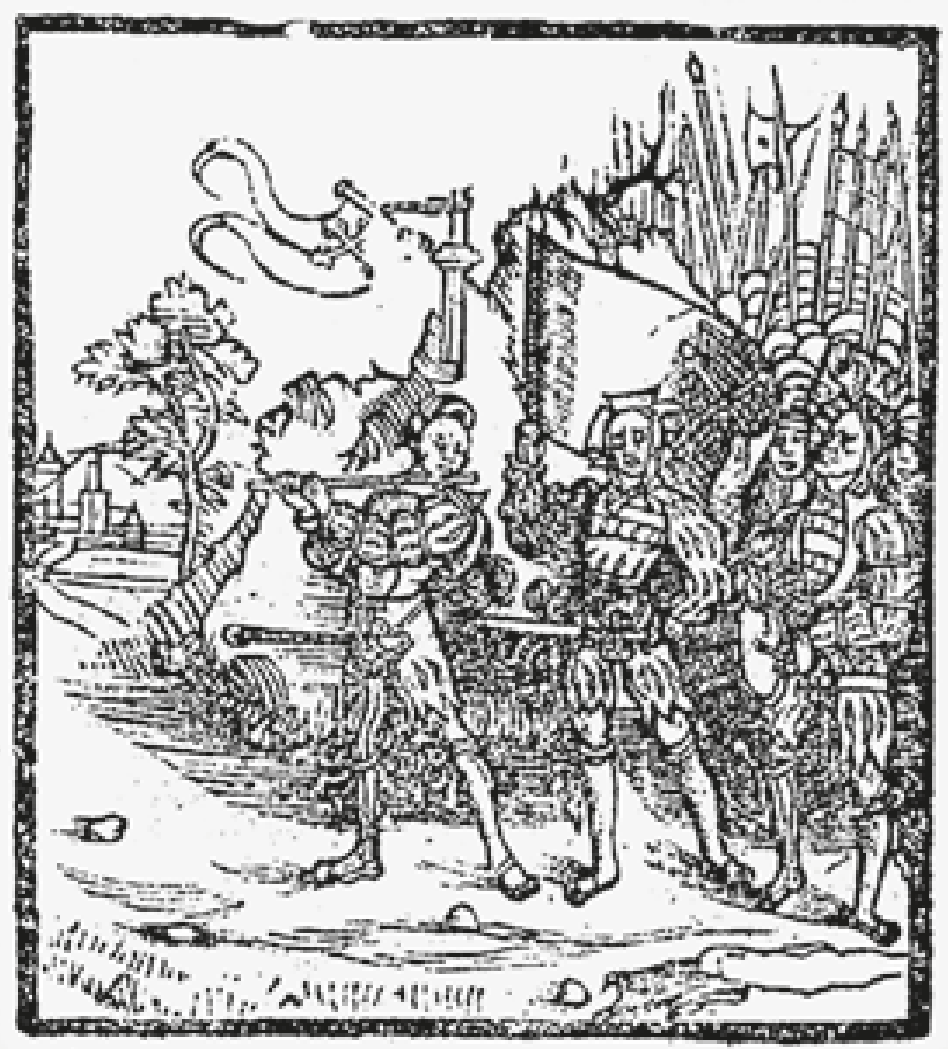

0. 


\section{CI $\mathfrak{a}$ triumphante enttee $\mathfrak{a t}$}

coutornement oe ferthantl be fa topafe matefte de fyons guetieiet oe Bofeme/ faictea Stoel bbitte?

Gutef fe oetnier iout Dorto6ze.

Antro Domini mil

cint?

certe Exingt

fept.

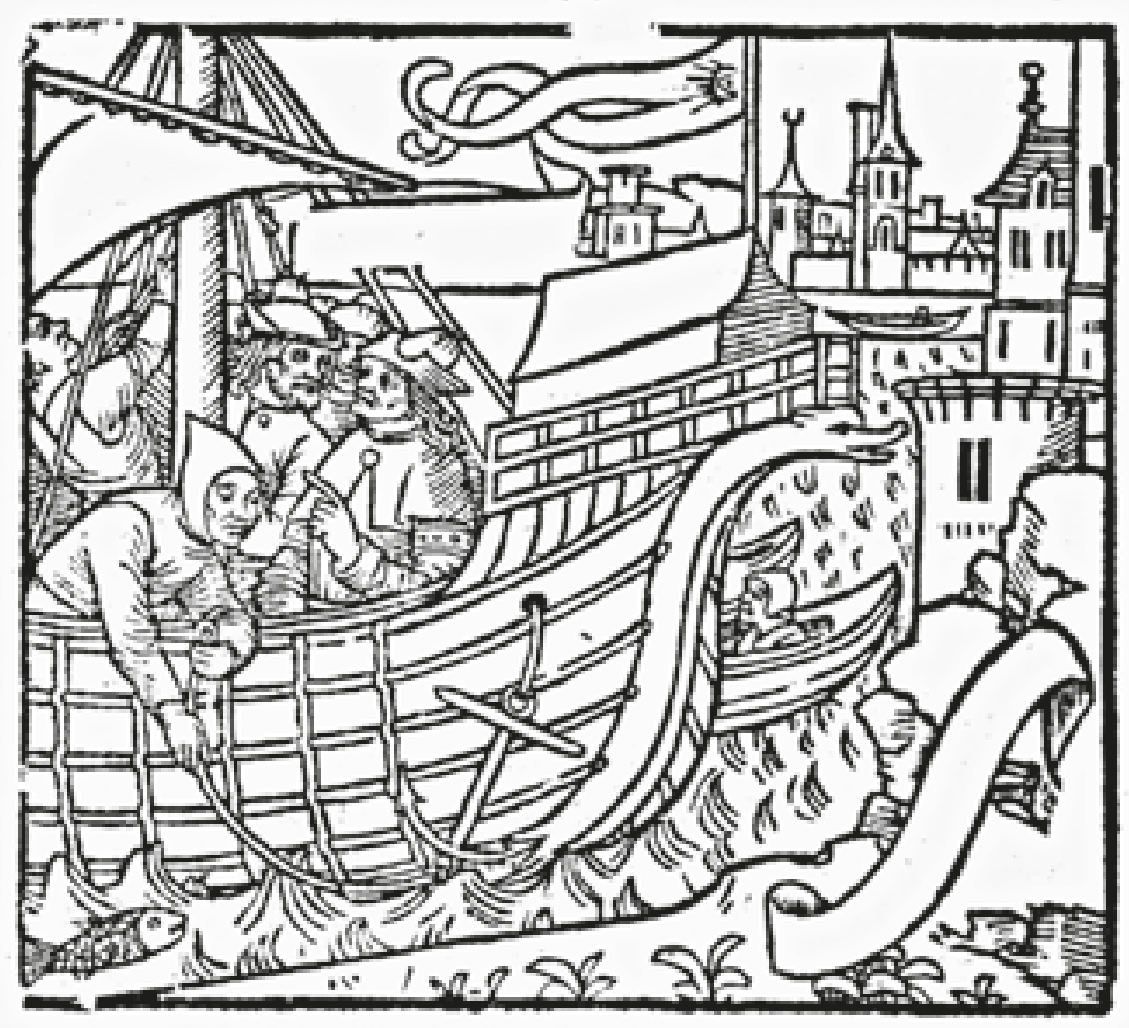

38. kép I. Ferdinánd koronázása 1527/3

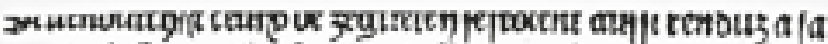
maiefte tomfe ef fauoient cflau pout feut top/et qiuf:

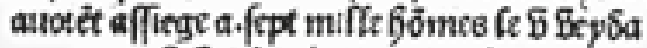
conte Gefian de żose ensemp ò top

fut bing baut chafteau ch $S e$, nenbuted'erpetane fe gai gnet: a le troluye a fa maiefte topufte.

\section{f3八刀马.}

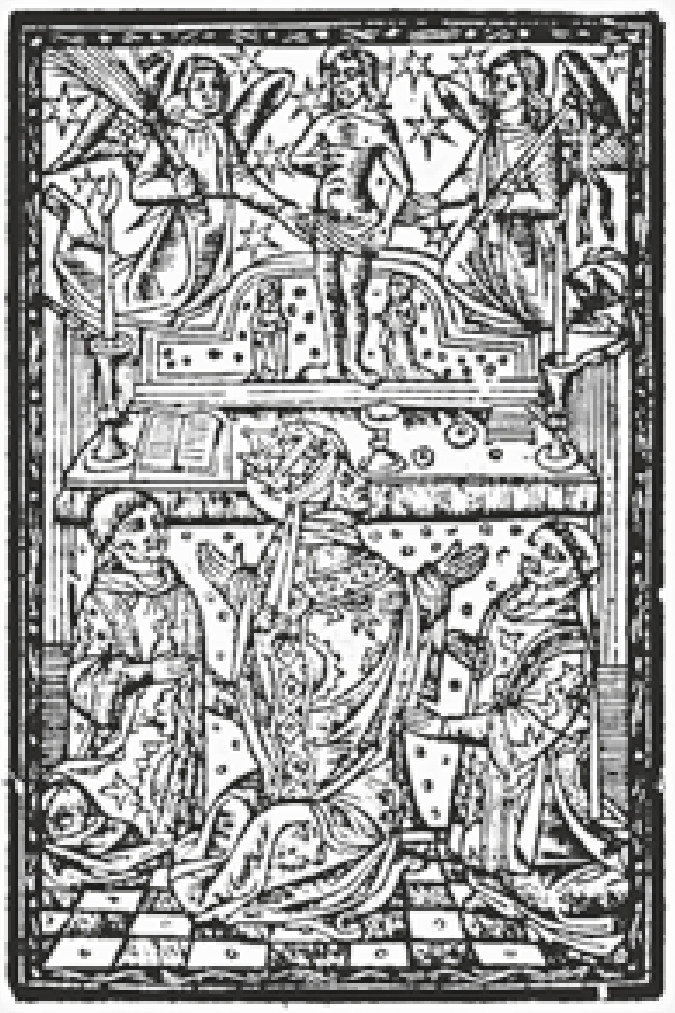

39. kép I. Ferdinánd koronázása 1527/4 

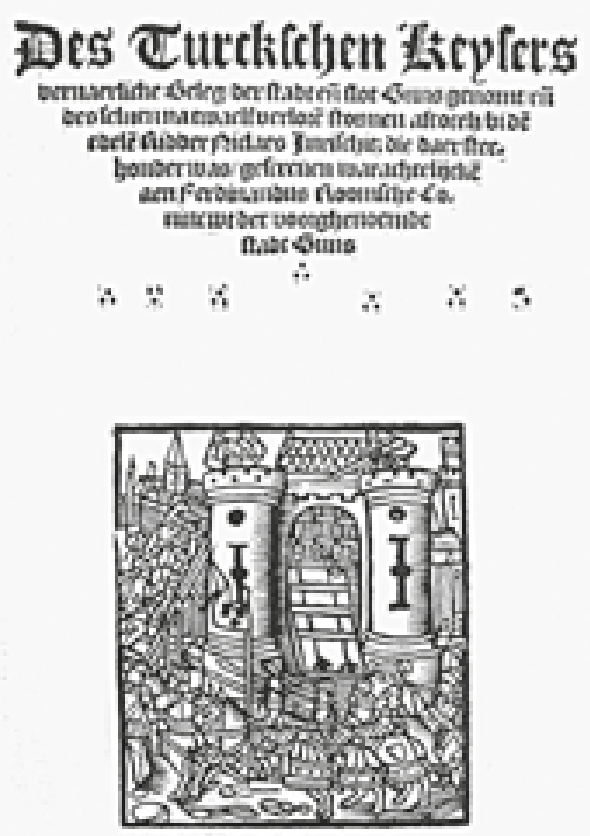

40. kép Kőszeg 1532/2
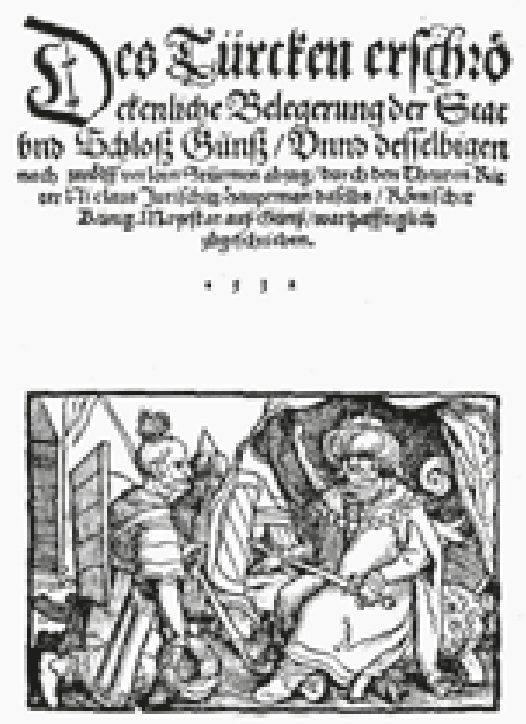

41. kép Köszeg 1532/3

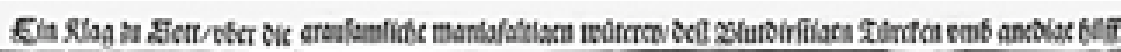

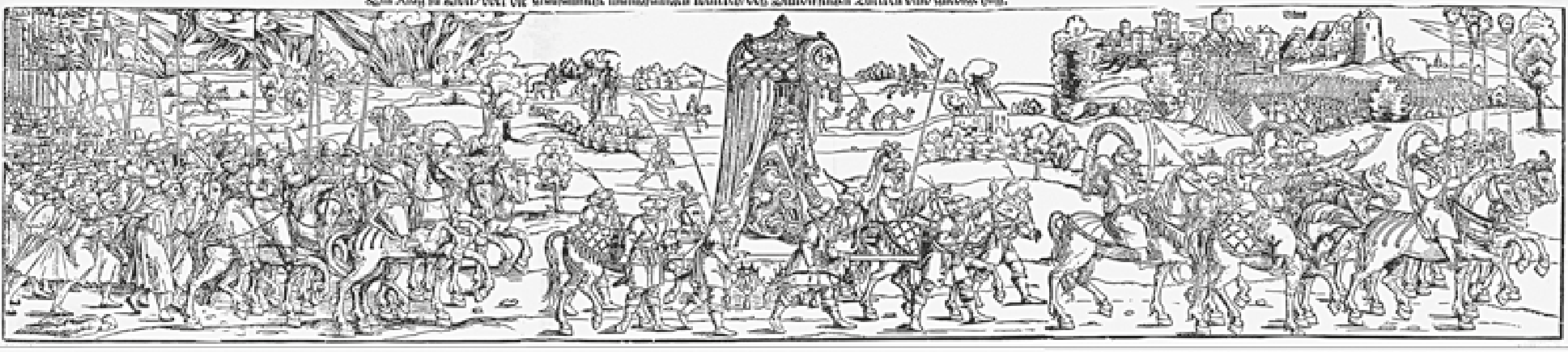




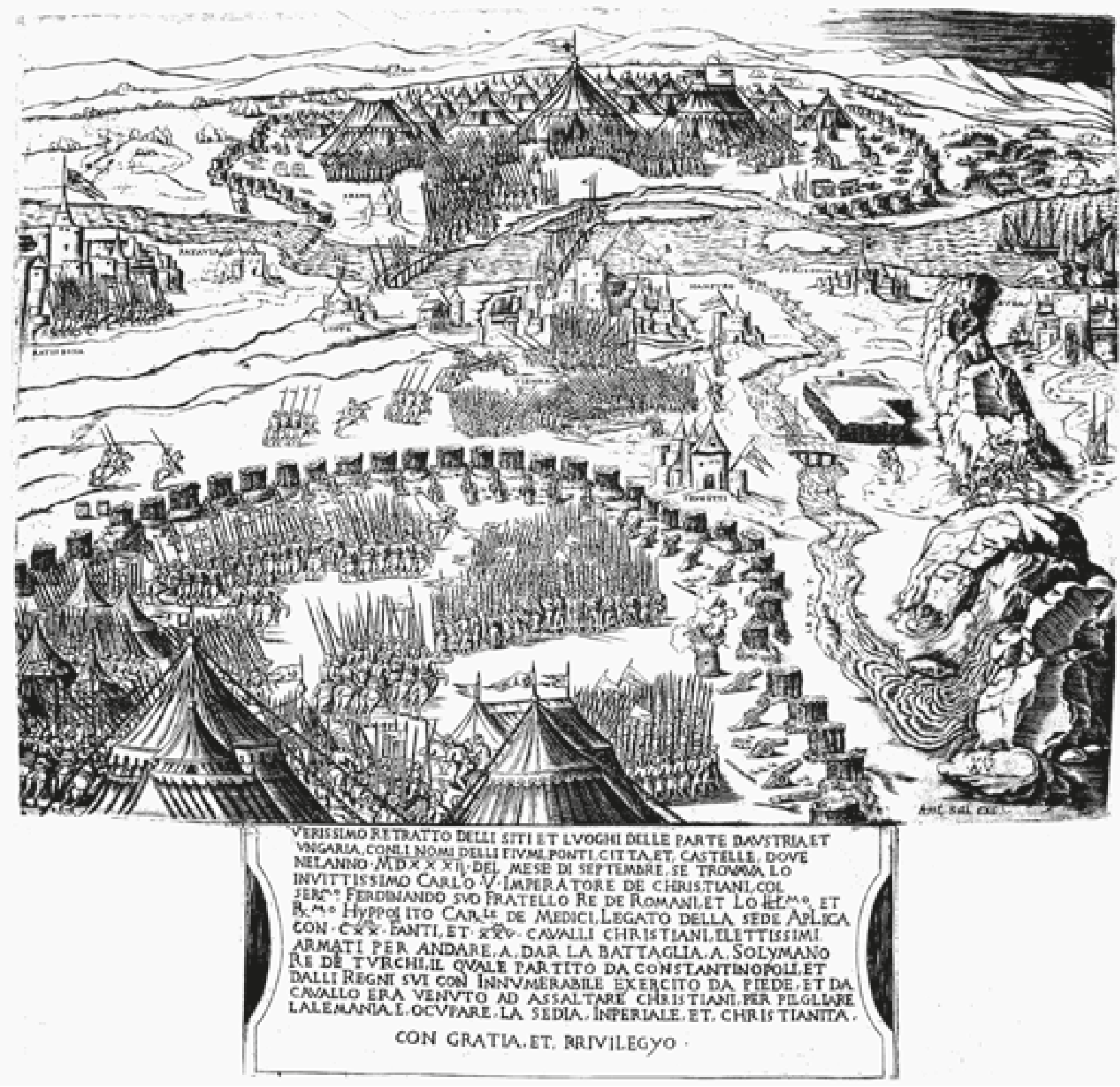




\section{Şungaria/sab ift Butgerlant.}

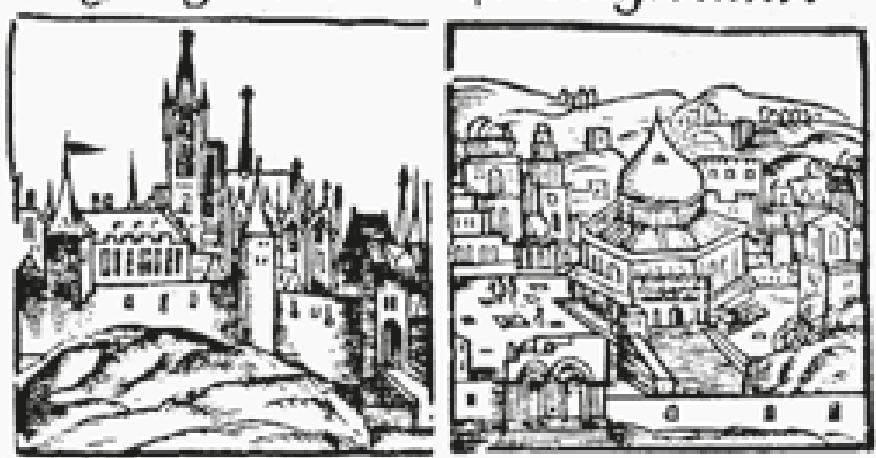

D Vngaria/funft dae niber ober vnber pantonia genannt.

Daben ou buni etwa Pamen/vno nads in bungern nente.

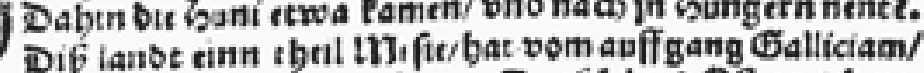

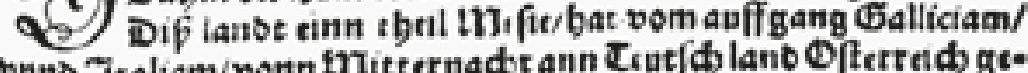

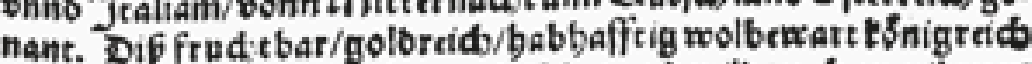
nant. Dif frud t

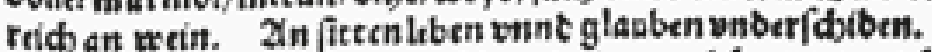

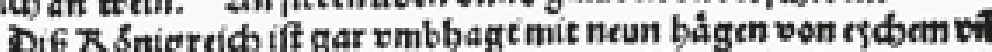
aller ley hartem bolg/einn bag bat jweinBig fotit in ber baryte vnnb aller ley bartem bols/eint oas angerlanto/barnad in sweingig meilen/aber einer ringe

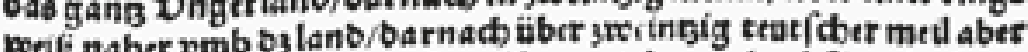
cinc/fo vil am ring vno anf ang tleyner/aber an ber ţóbe vinobteç eincr/fo vil am ring vno anter/ venno io fout an bif auff oen neunoen.

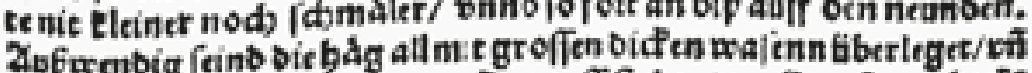

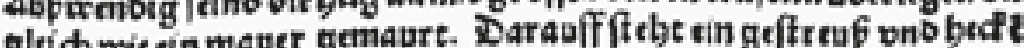

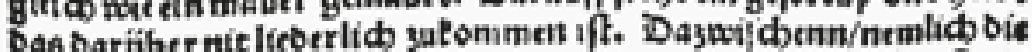

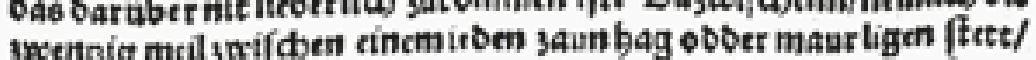
merde/ osiffer/ flede'enn/ etwa zettett venno jer/trawoet/etwa /o nas benb an einanber/Das mann cin men/doenn von einer betberg su $D e r$ anbern bơren mag.

Diebarpftate dif labibs ift Ofen gmant: 


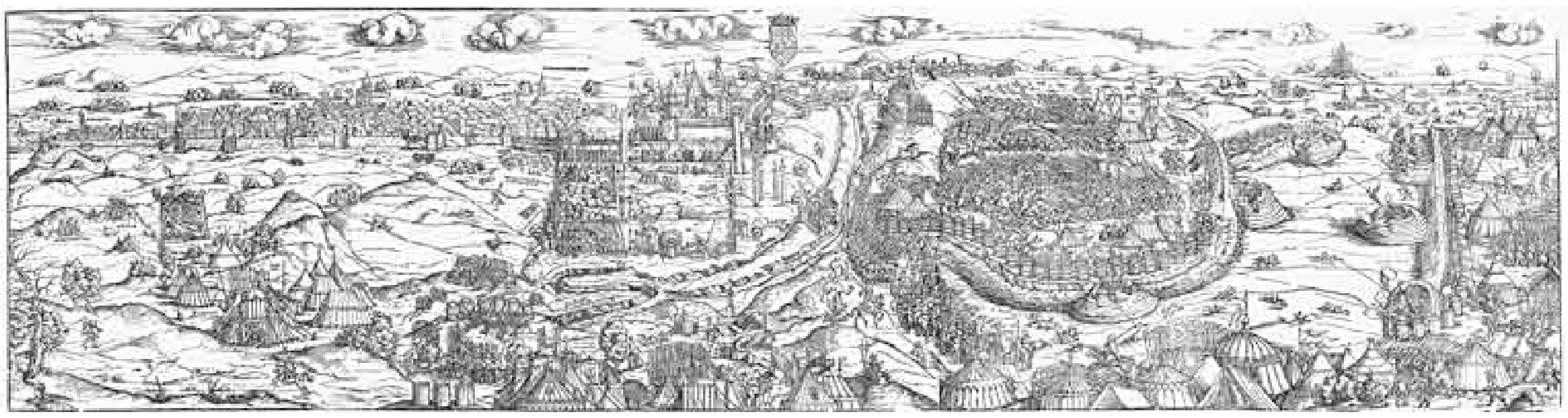

46. kép Erhard Schön Buda 1541/1

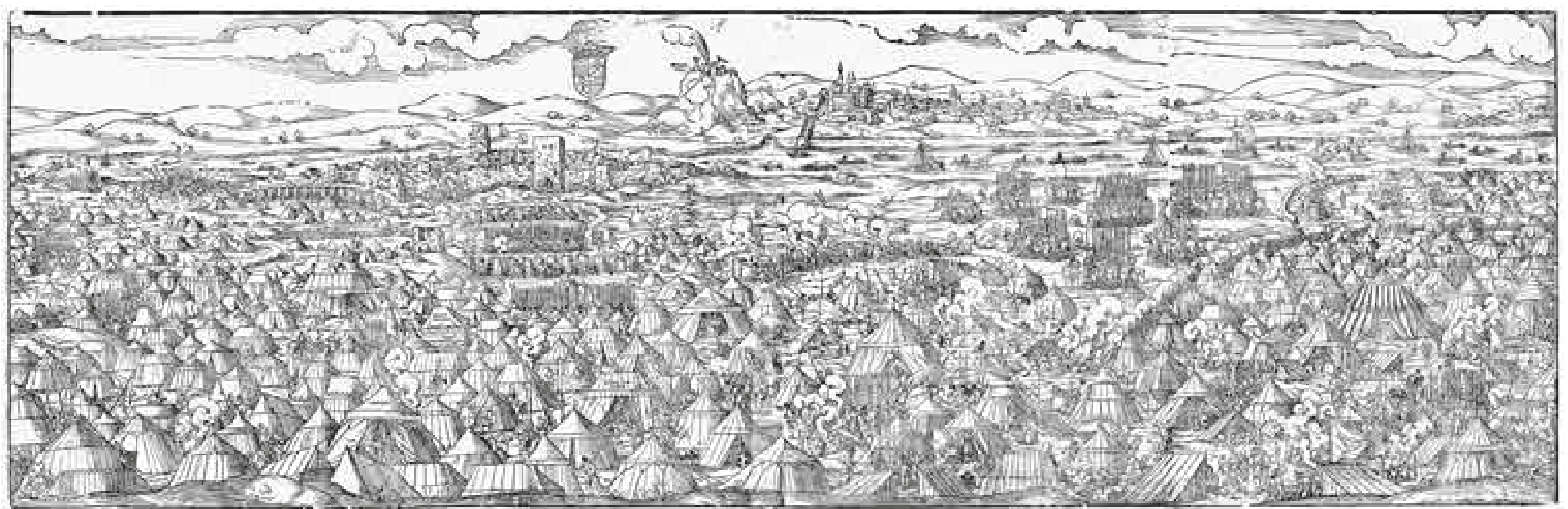




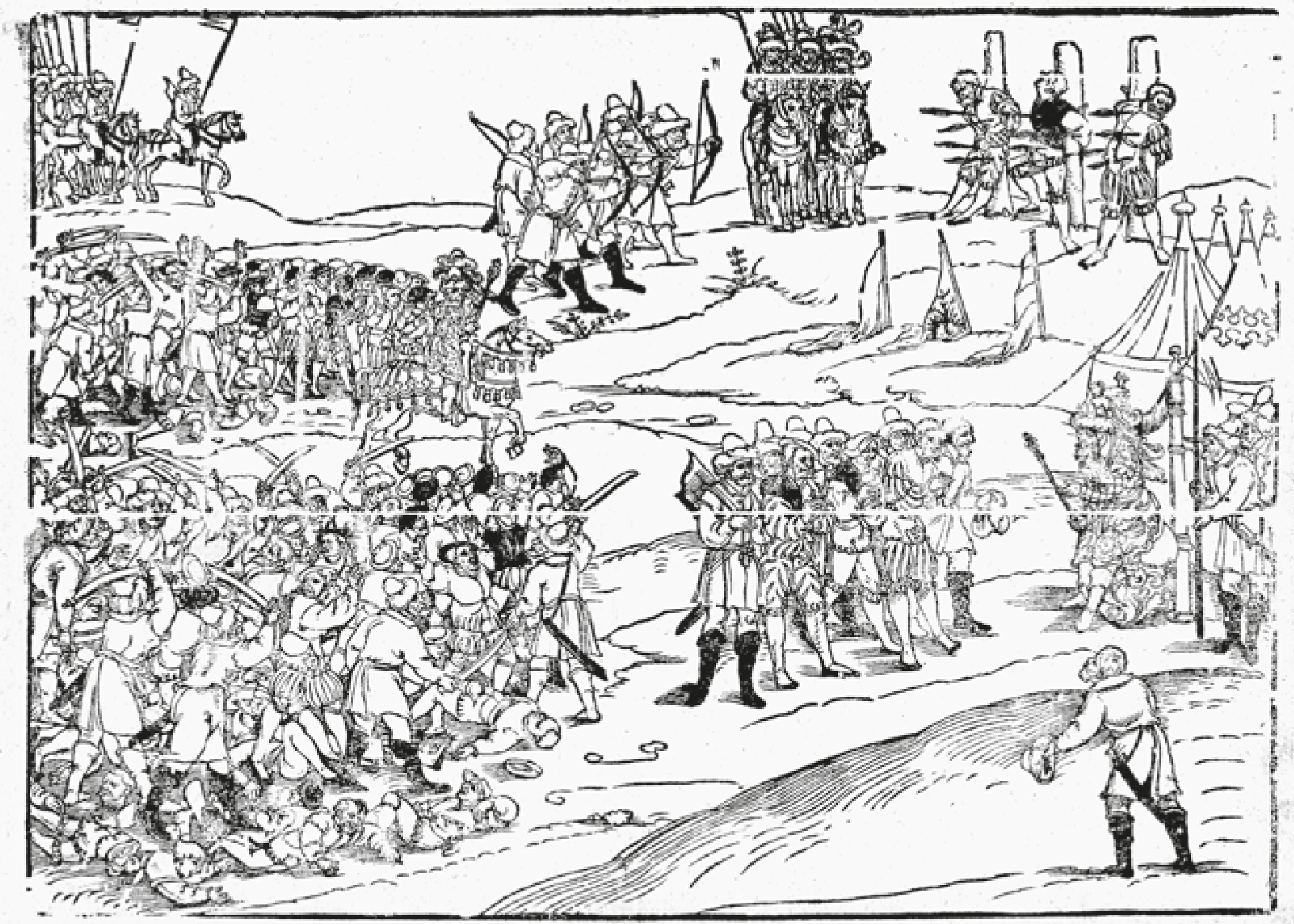




\section{Bargaffitige Onterngūg} ivie es im seger vol Spen ergangen ift.

.1541 .

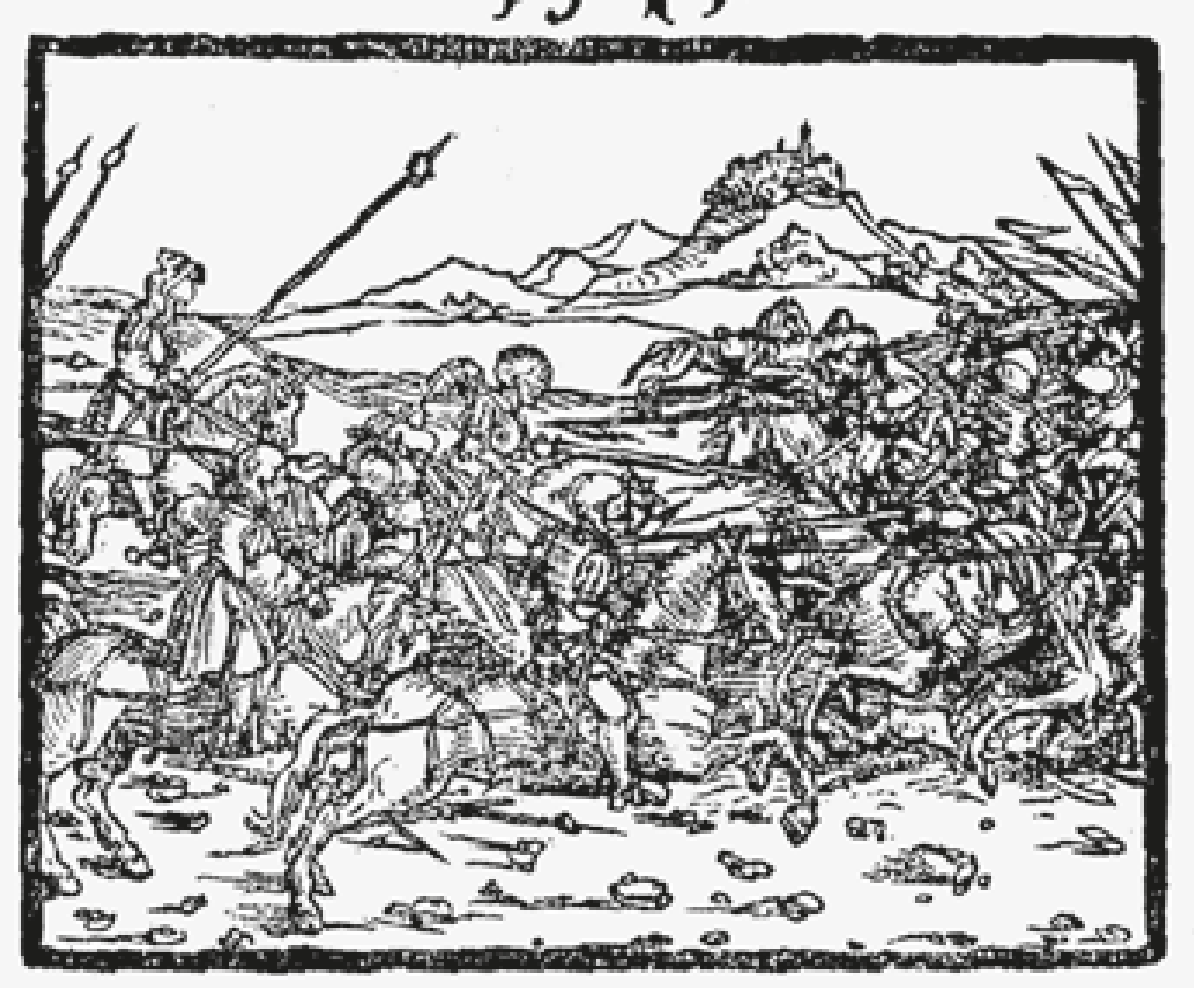

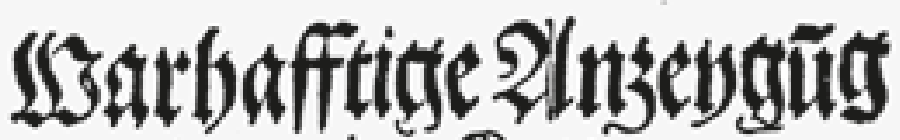 wie es im Retter do: ofentertgangenift. \\ I 541}

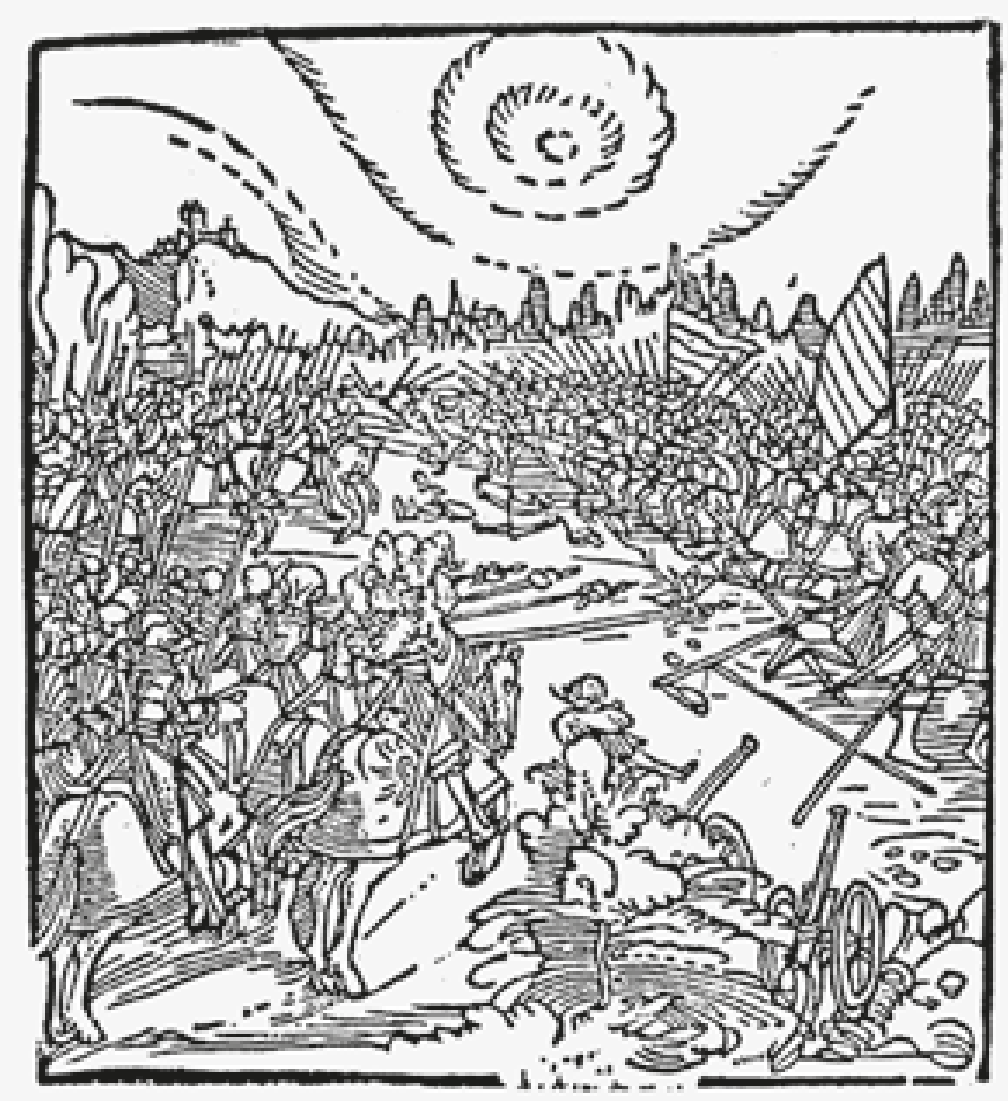

50. kép Buda 1541/2 


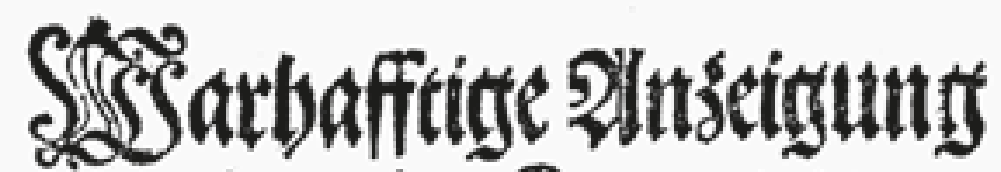 wie es int erget vo: ofentergangenift.}

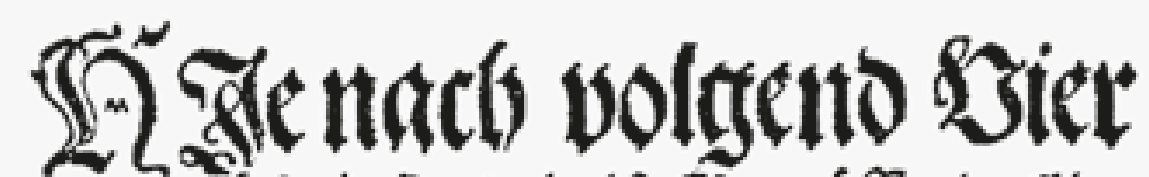

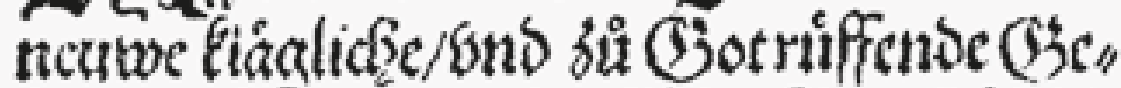

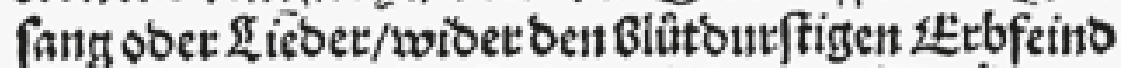
vno verderber Des Cbsiffenlicben biüte/ Den Tüirgten/yet

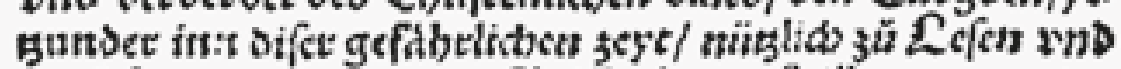
zi̊ fingen/ Eemayner Clsziftenbayt 3ü Lrmanung/

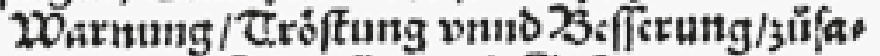
men Geoucte smm 2nuggangen.

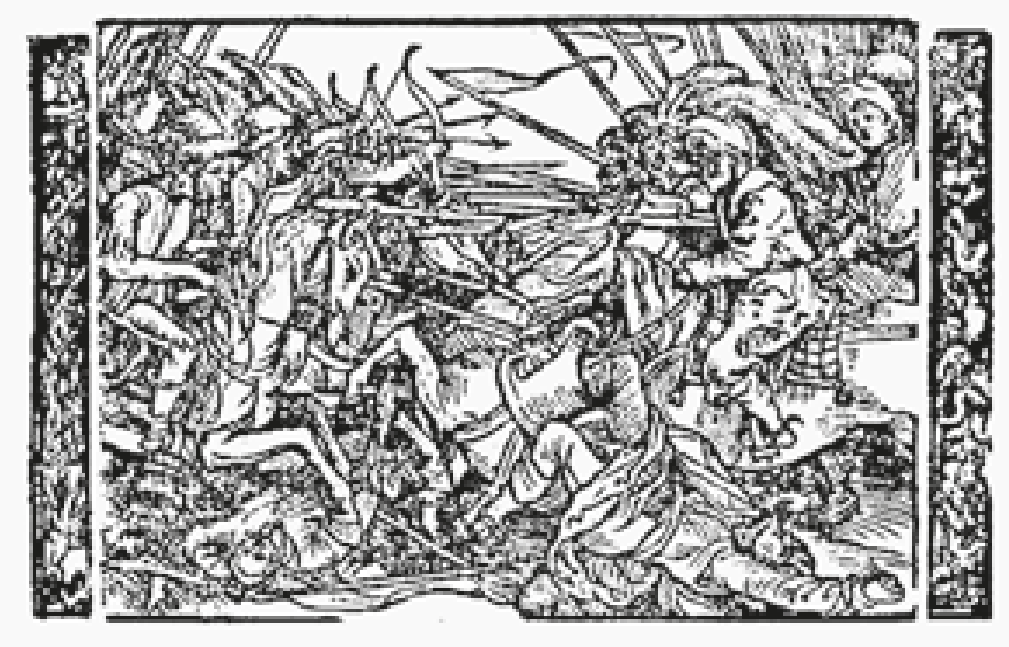

\section{D. XLI.}

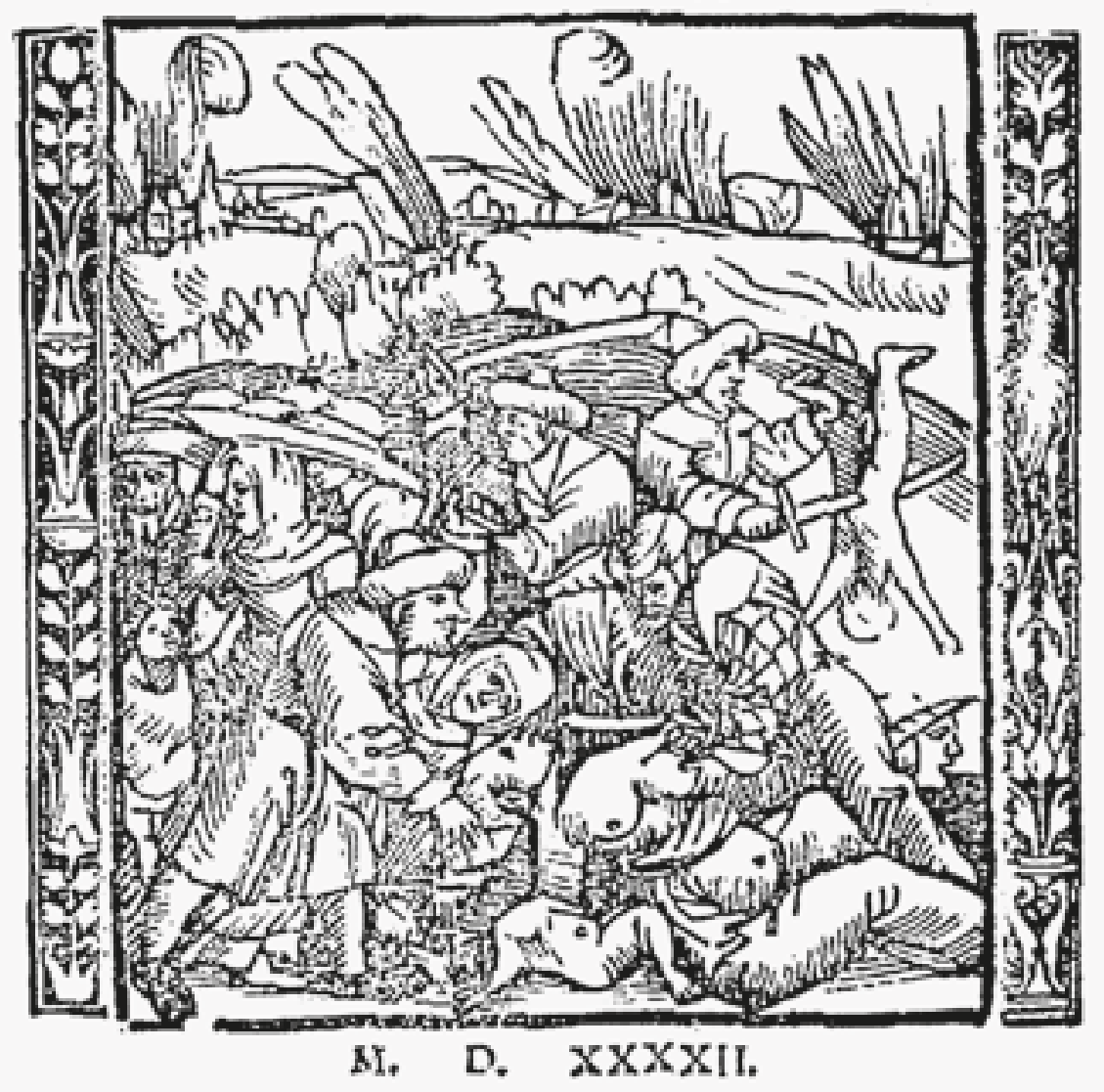




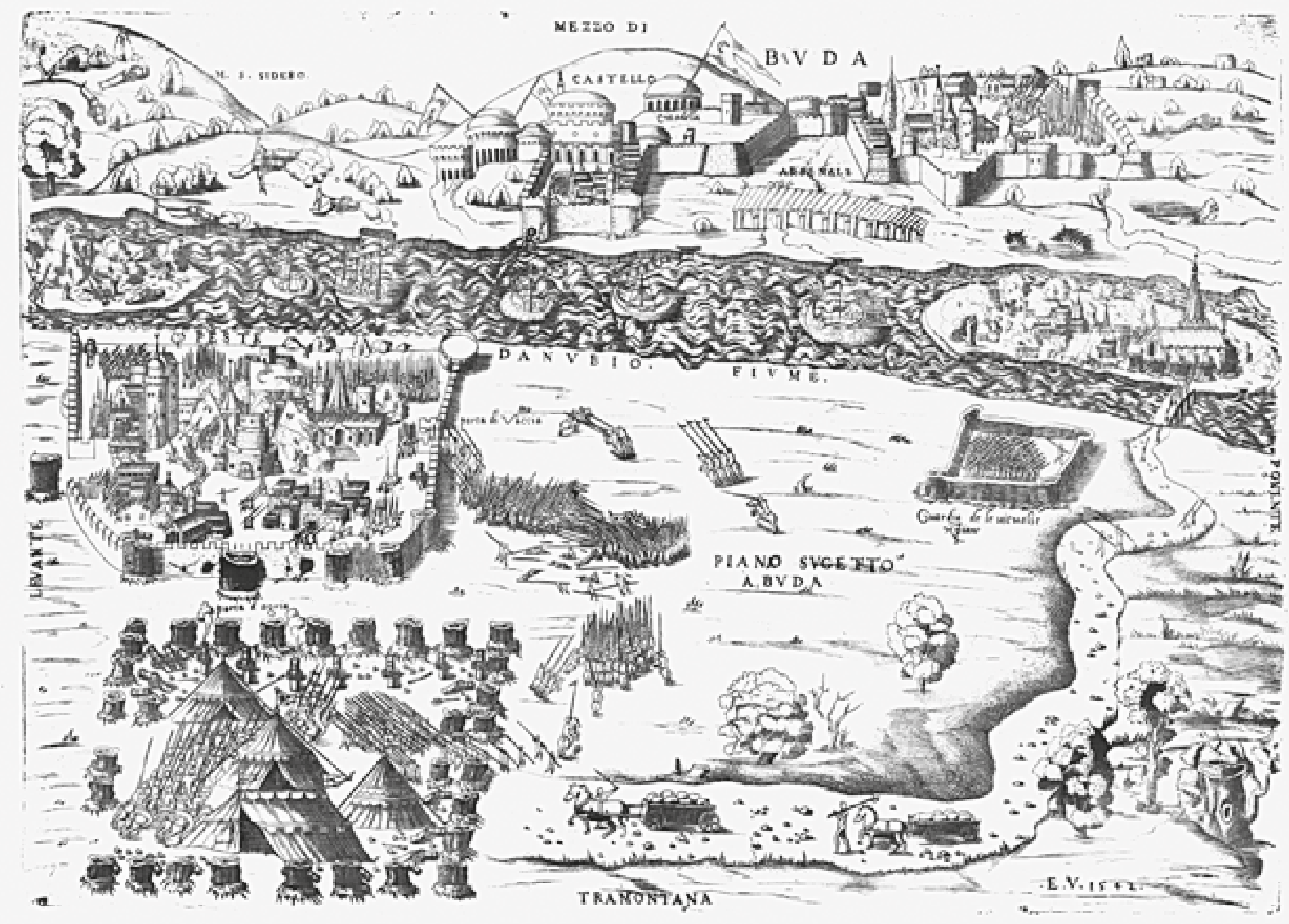




\section{Stiumblitfecendomarthaff}

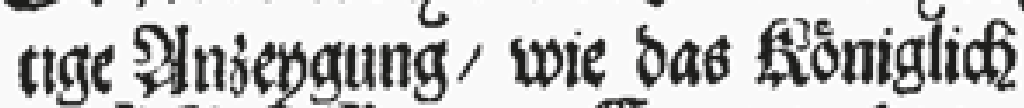
Scilof Sran / m Sungern/bon ben Circten belegert/6ersolfen/ ons engenomen iff.

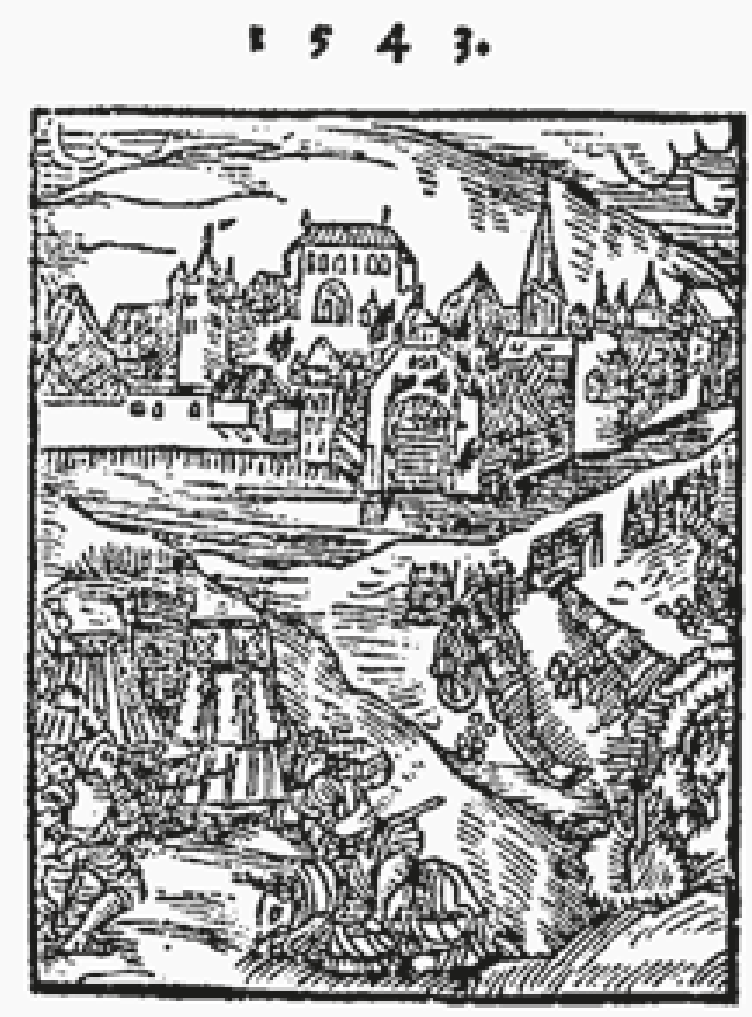

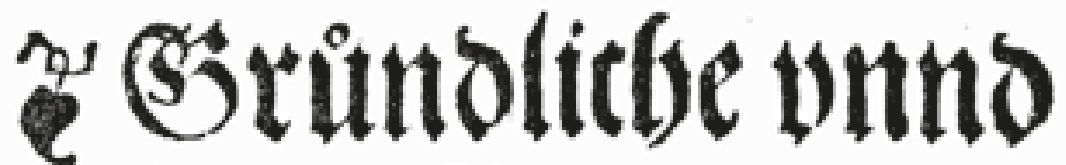
warbafftige Anzeygung / wie

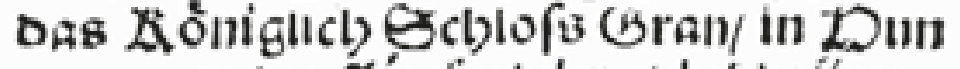

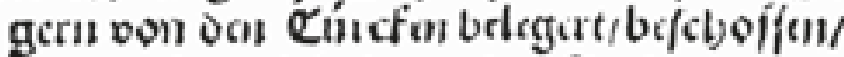
vito abamiglich von oan Jtaliancrn oail círction vbar gaban.

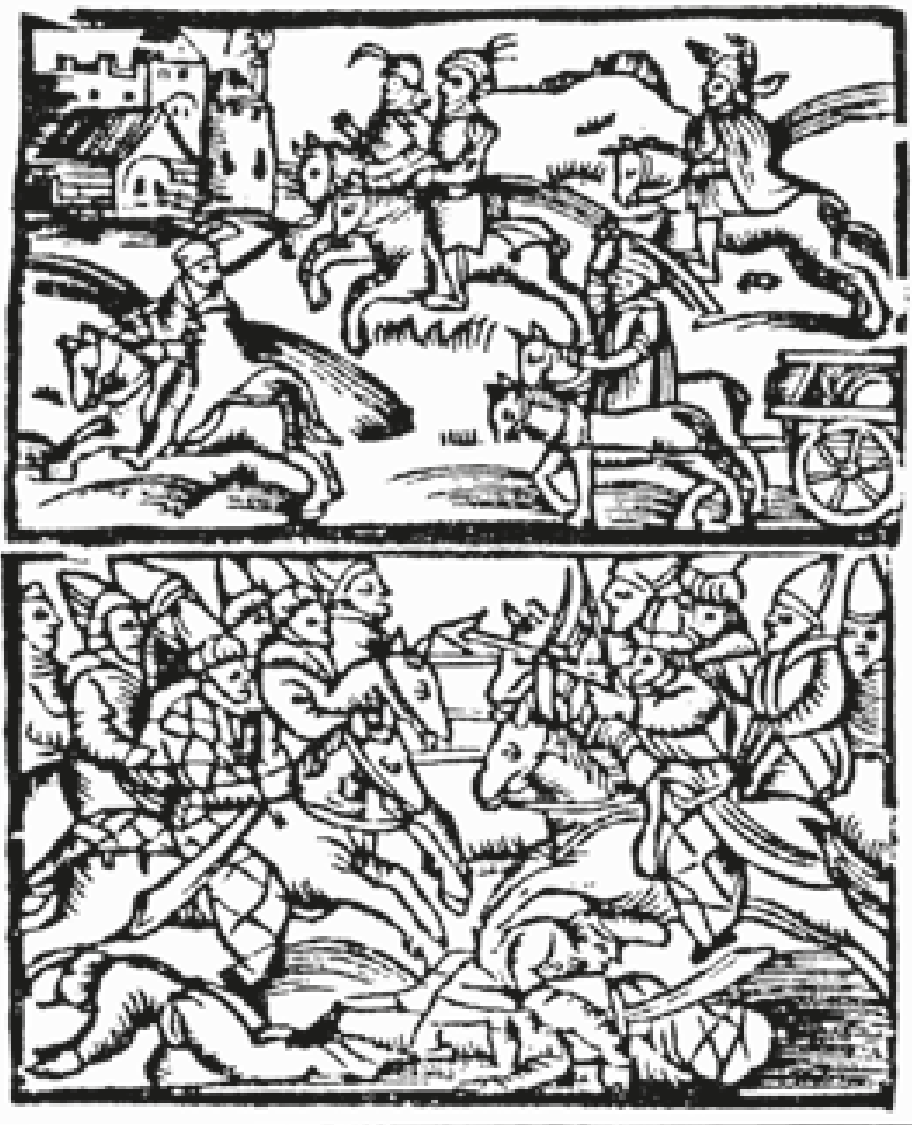


Von sen Gicbenbiirgent.

Sclo

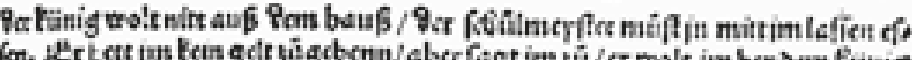

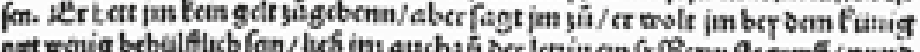

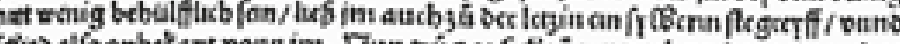

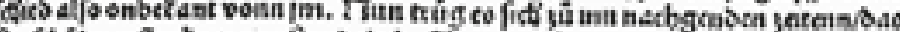

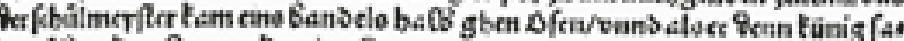

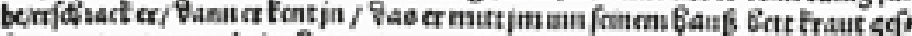

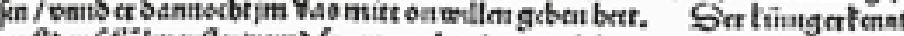

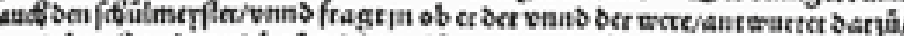

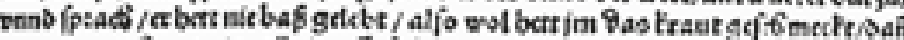

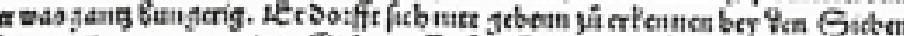

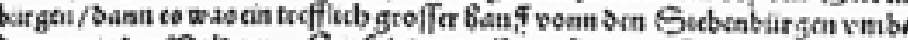

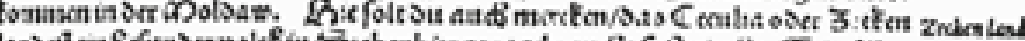

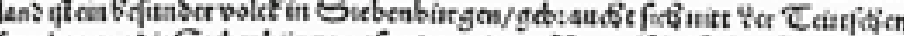

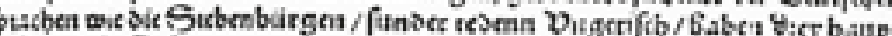

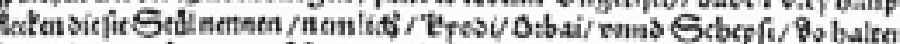

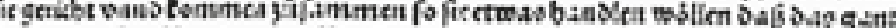

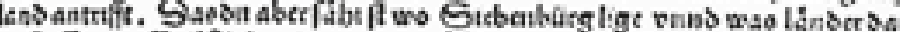

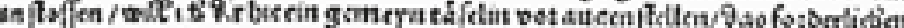

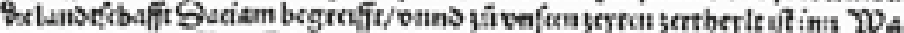

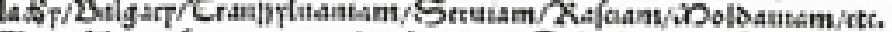

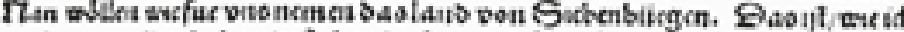

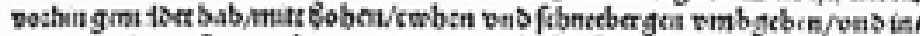

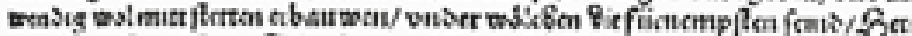

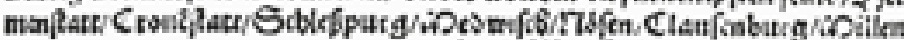

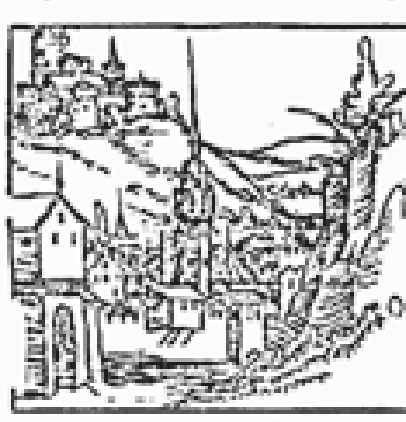

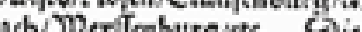

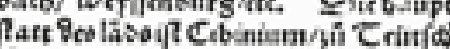

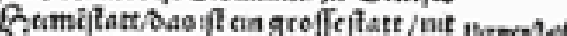

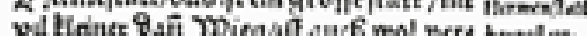

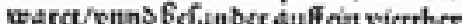

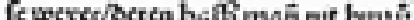

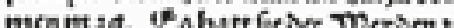

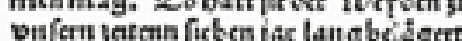

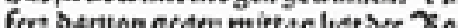
tharnein fard f flofoiun iem gobirs

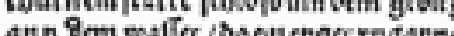

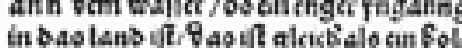

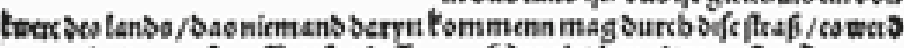

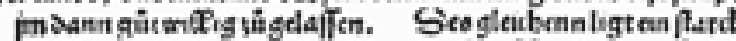

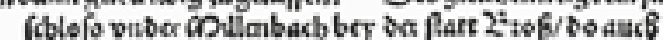

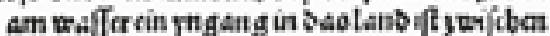
Den boben fobsectbergen.

33 if Ctonerflats
107

DE TRANSS Y LVANIA

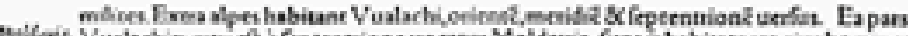

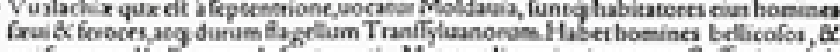

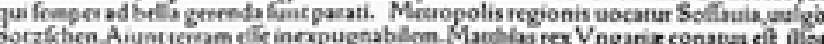

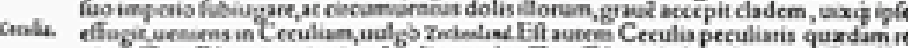

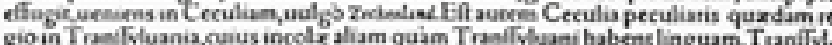

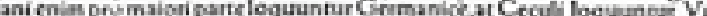

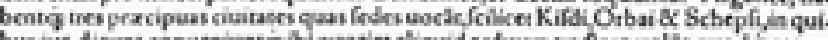
concenoper

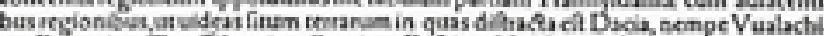

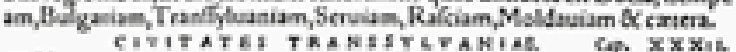

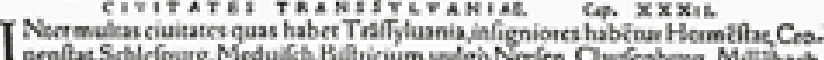

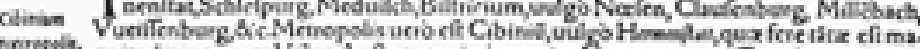

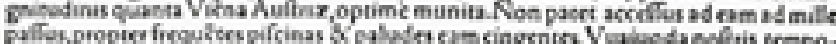

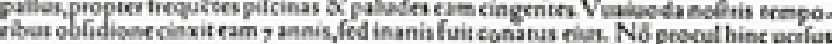

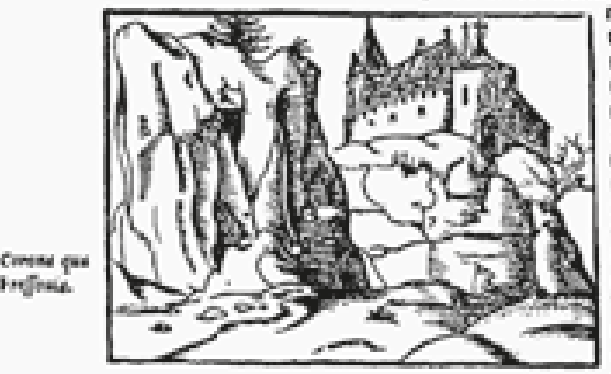

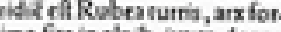

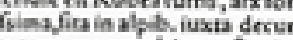

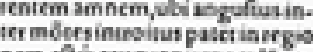
ocmellä́ceupropugnaculas to. insters, ut is illo pante nemos

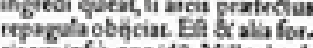
og arxinfta eppida Mallenbad

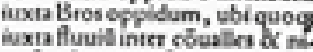
Yodan'pes iter effquod ducit in

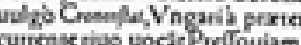

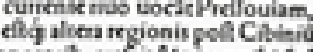

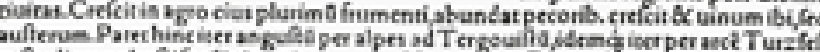

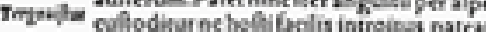

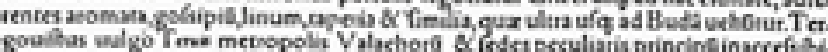

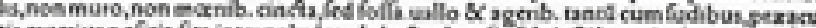

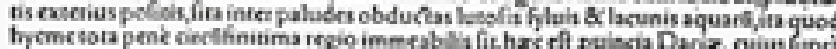

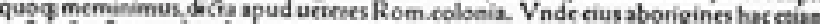

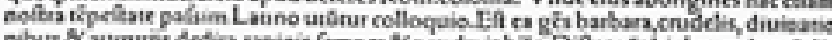

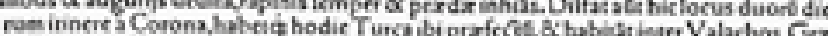

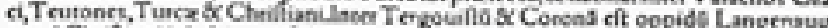

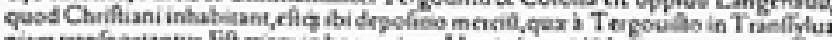

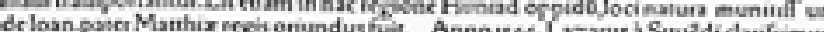

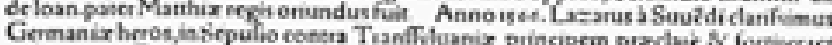

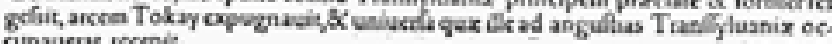
eupaders, toctpe. 
868 DeVngaria

BV DA, uulgo Ofen, prima \& regia

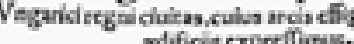

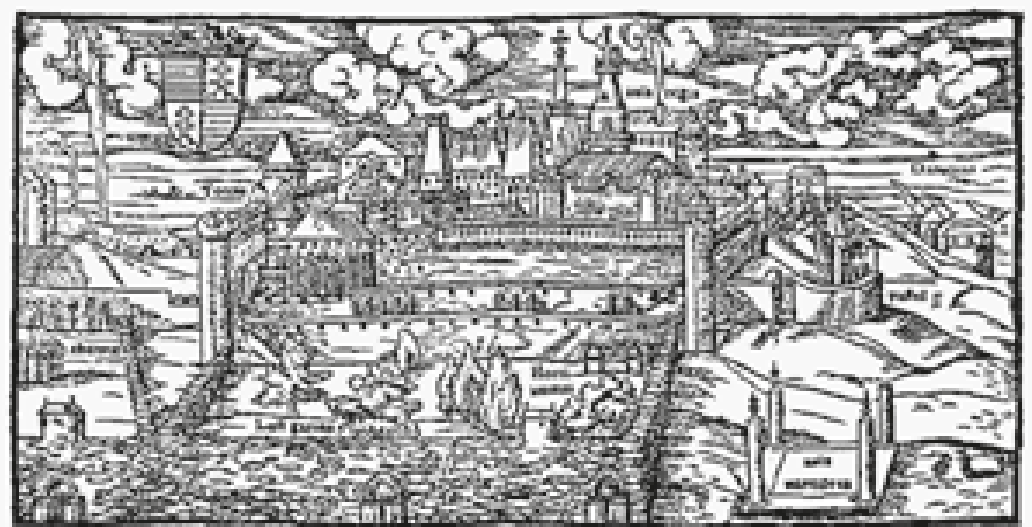

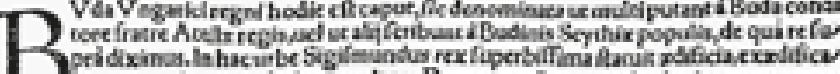

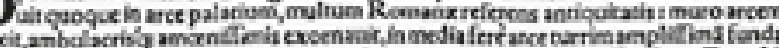

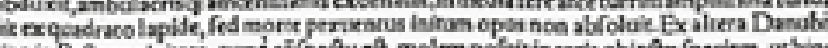

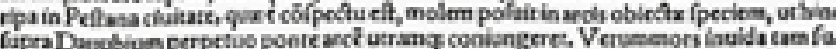

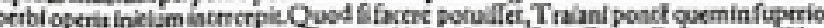
is M.

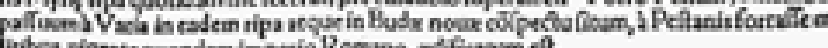

Agria,Caffiouia.

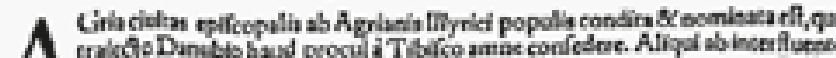

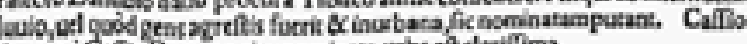

\section{Pifonium,Nitria, Camaron.}

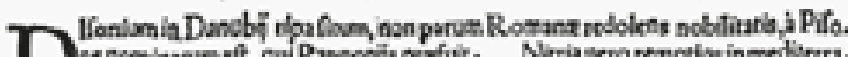
Oén

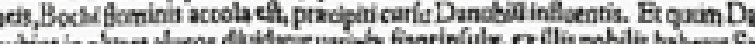

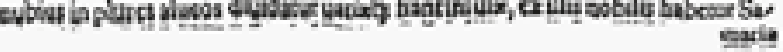

930 Dell' Vngaria

Budachiamata uolgarmente Ofen,laprima \&

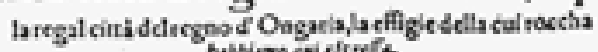

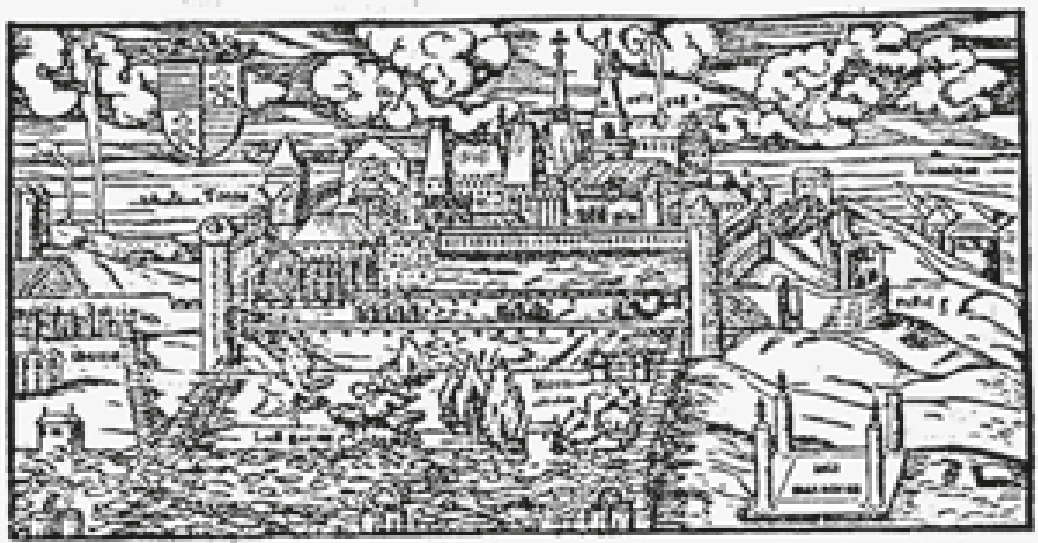

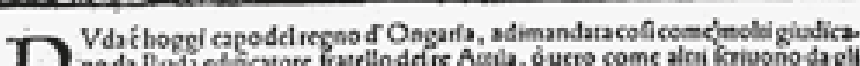

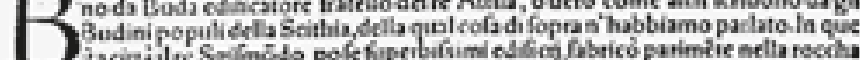

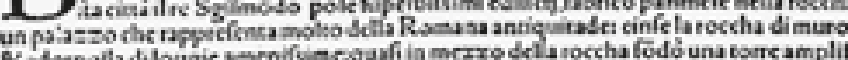

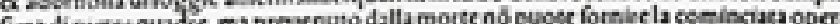

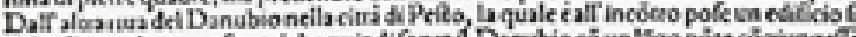

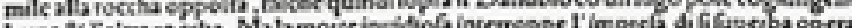

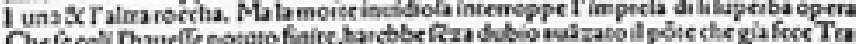
Cher

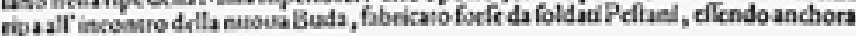
in piedir imperio kemano.

$$
\text { Agiacefintia. }
$$

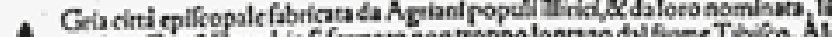

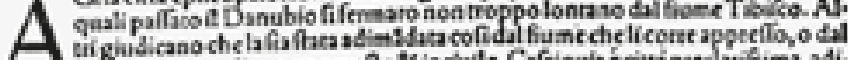

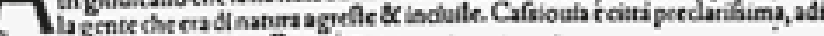
mandatada Cafilio cirtadino Romateo.

Ironia z poffa alla ripa del Danubiola qualerapprefenna non poso drila Rema

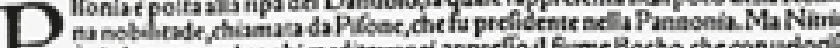

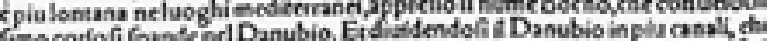

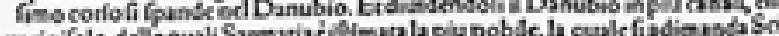

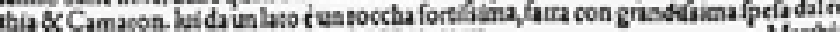


Vniuerelle, Liure IIII.

BVDE, APPSLLES VVLGAIREMENT OFEN, QVI EST LA

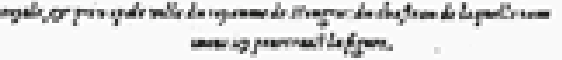

1746

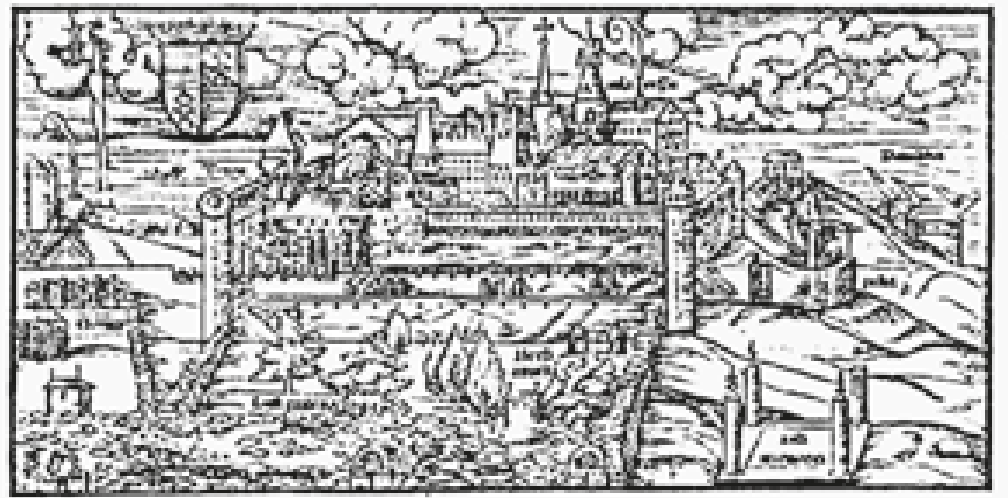

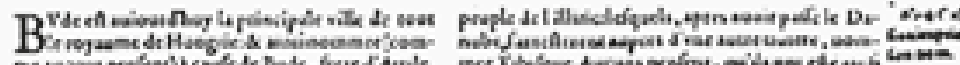

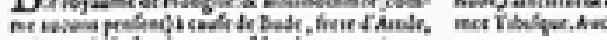

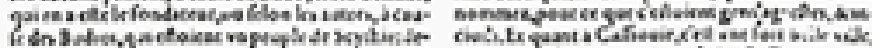

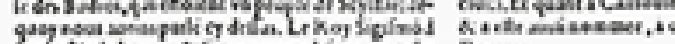

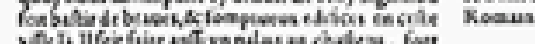

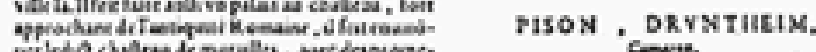

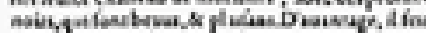

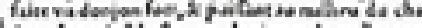

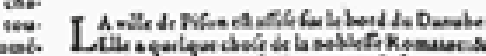

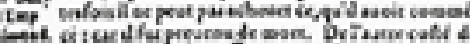

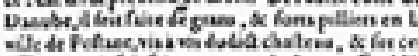

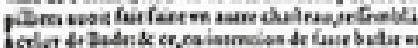

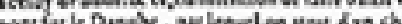

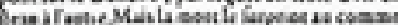

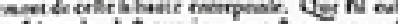

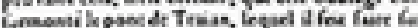

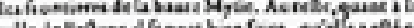

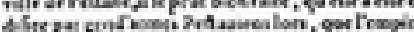

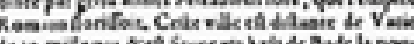

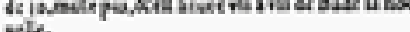
AGRIA CASSIOVIE.

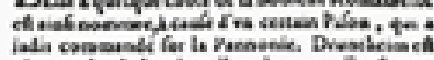

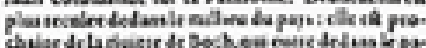

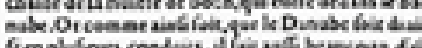

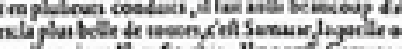

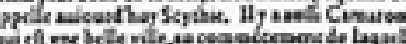

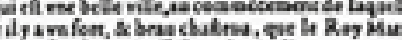

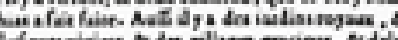

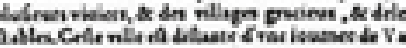

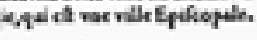

PLYCE, LT SYkMIL.

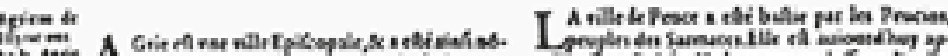

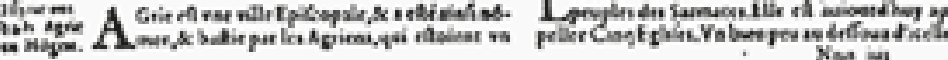

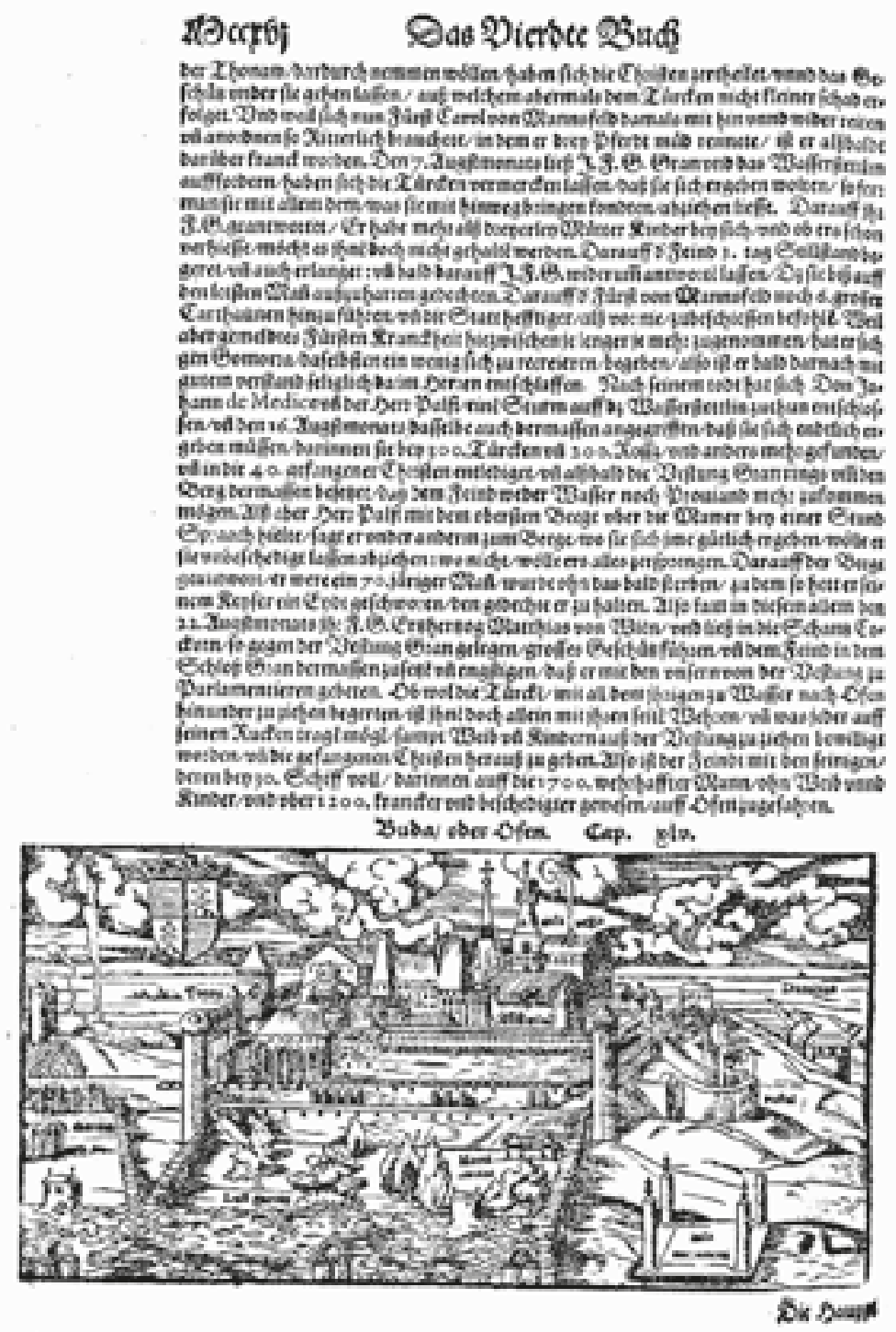




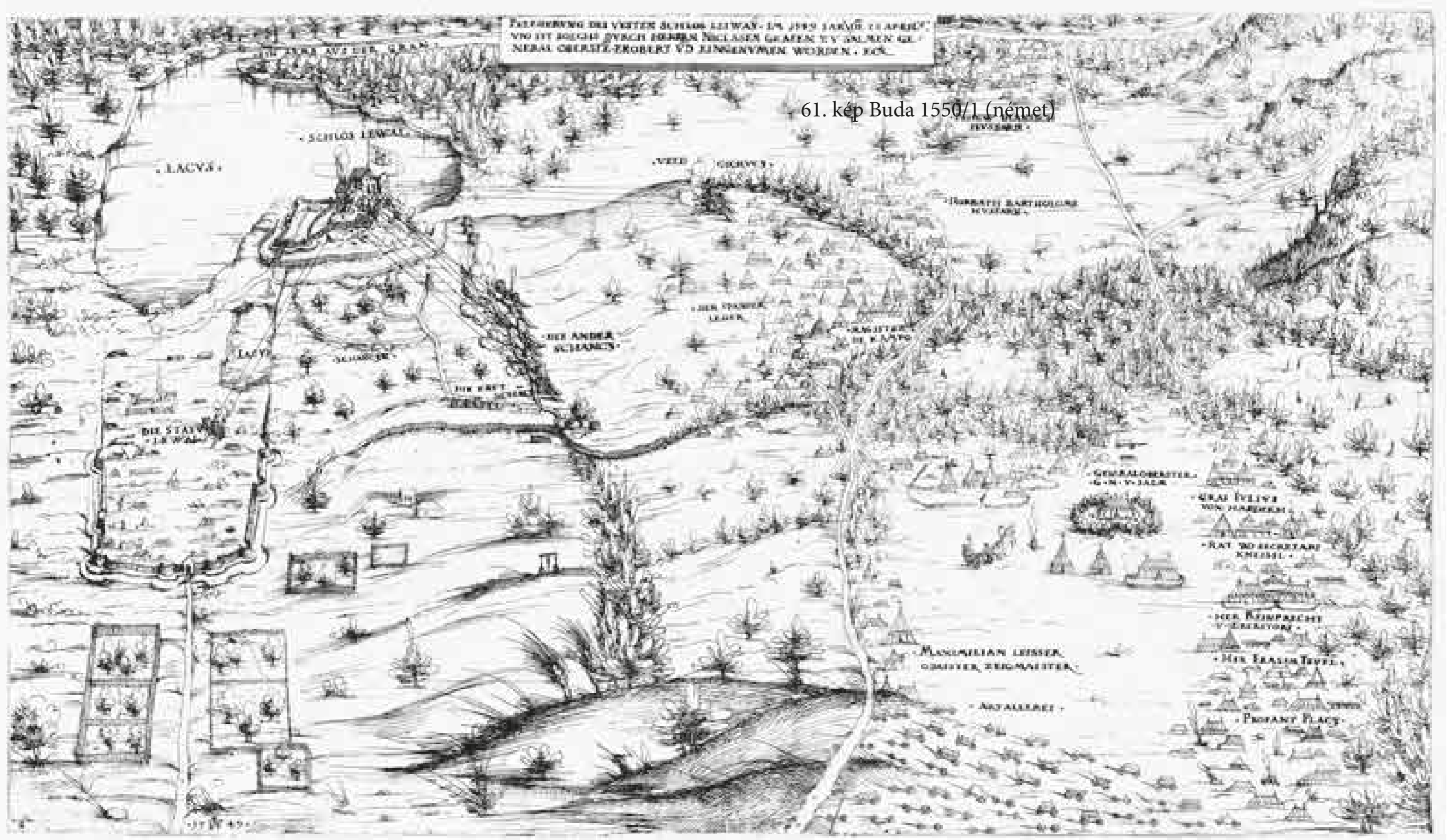

62. kép Léva 1549/1 


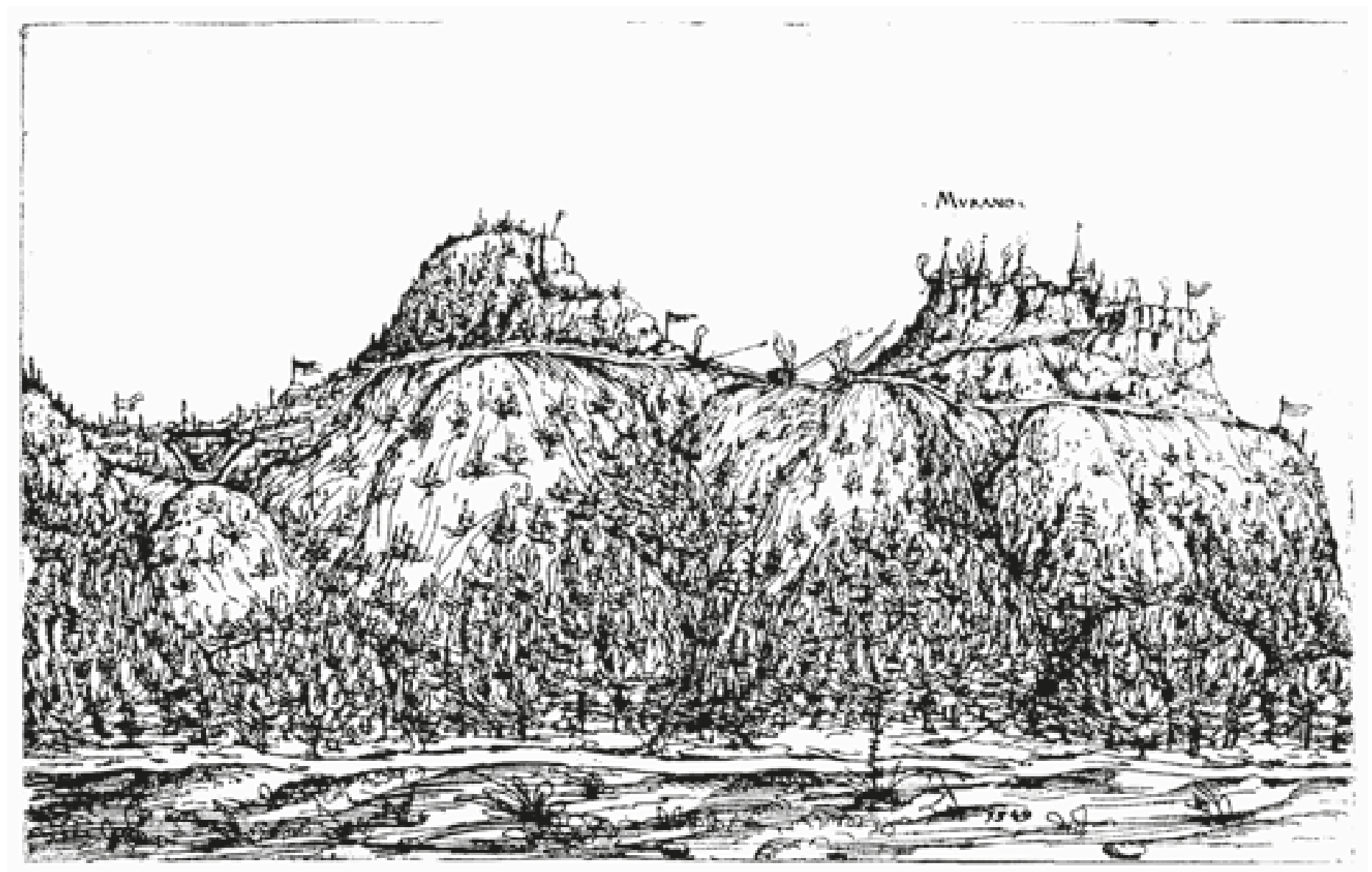




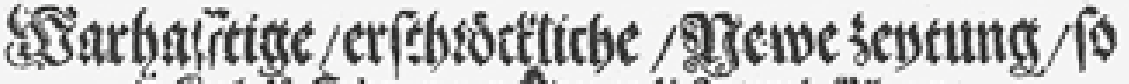

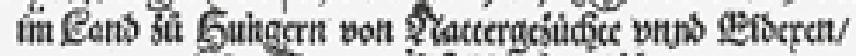

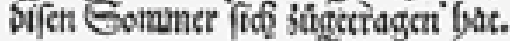

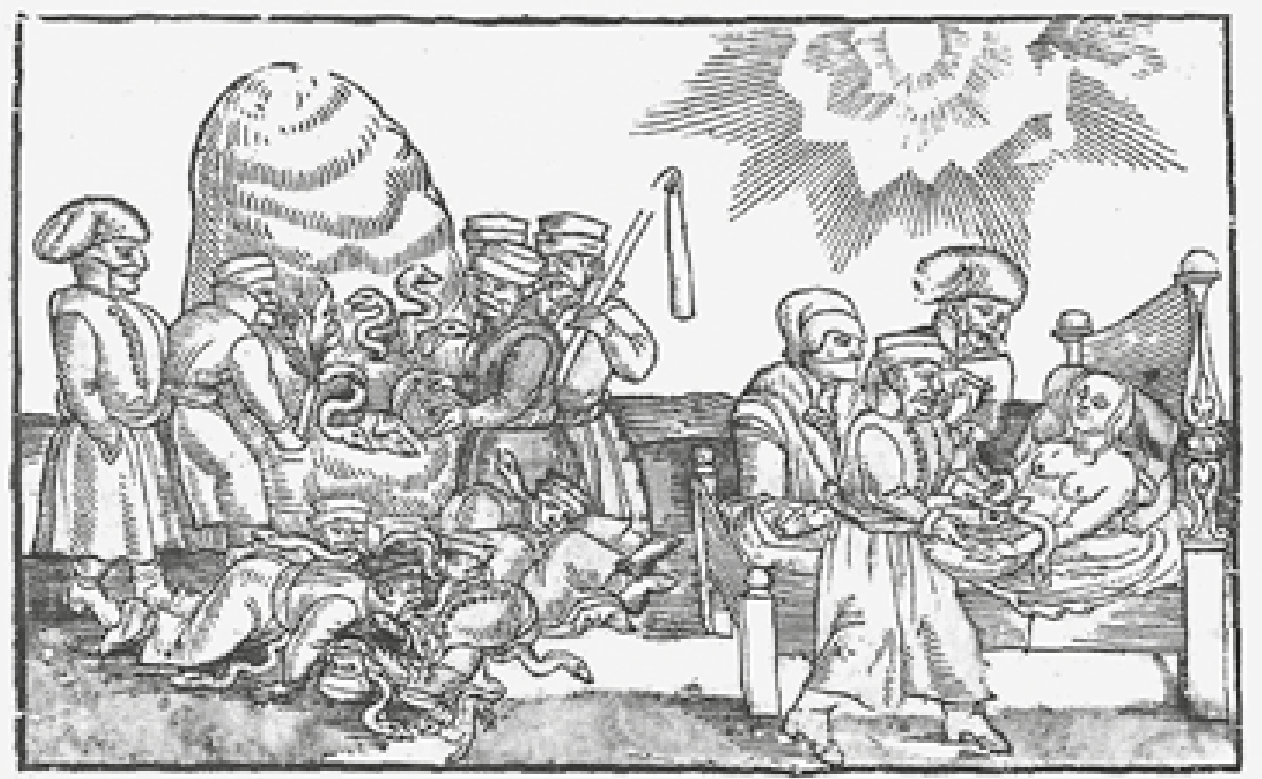

E

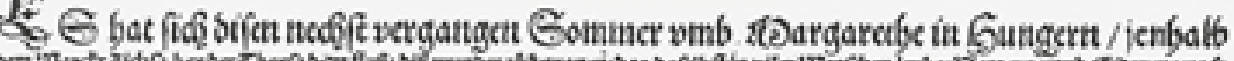

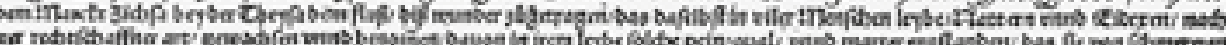

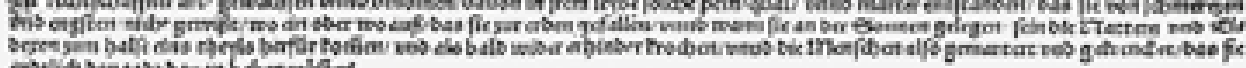

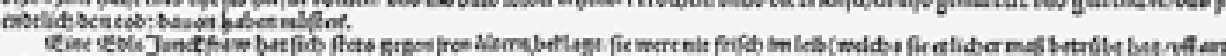

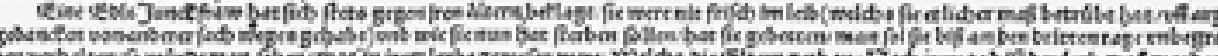

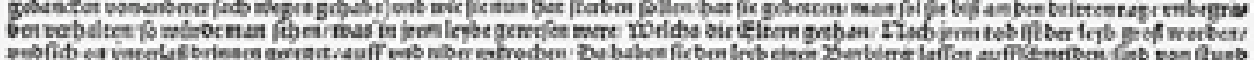

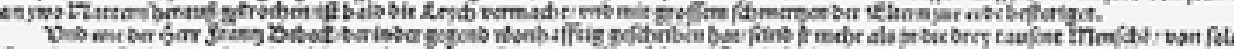

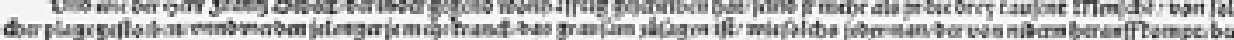

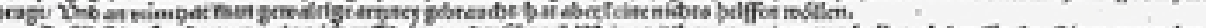

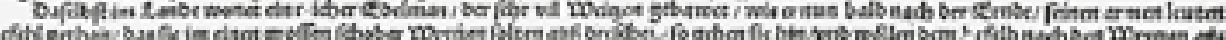

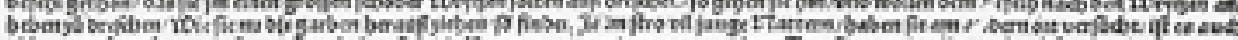

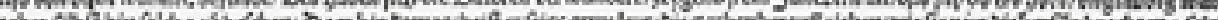
schet Ge

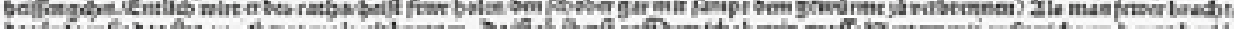

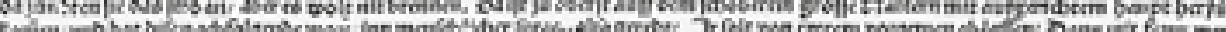

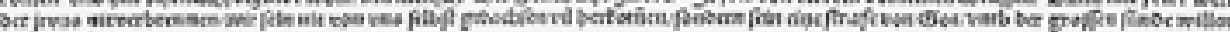

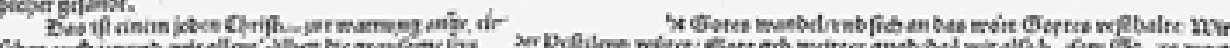

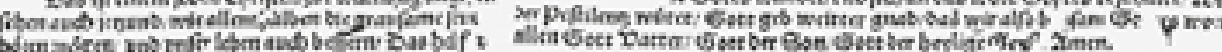

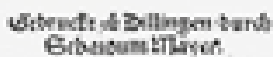




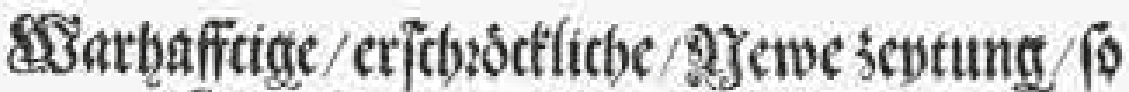

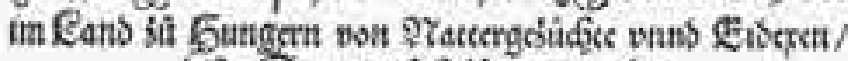
bitar Eormuner fis sügetragen bat.

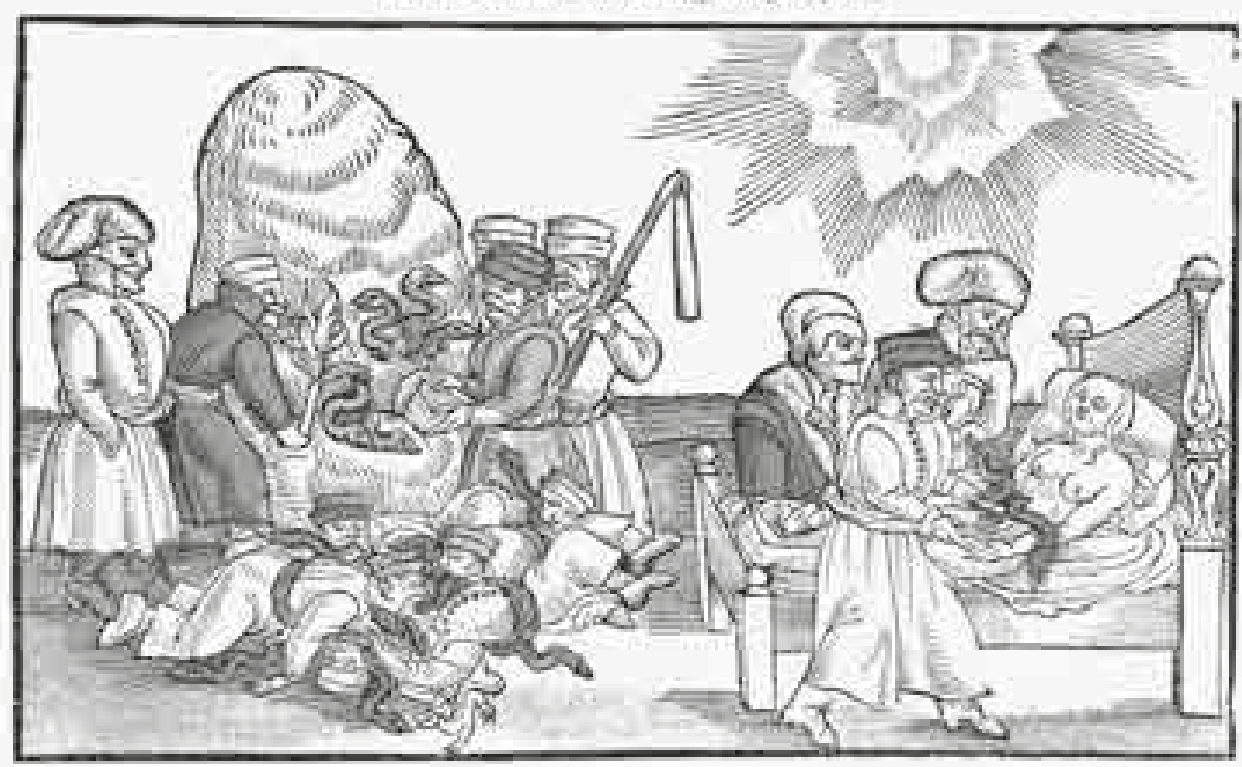

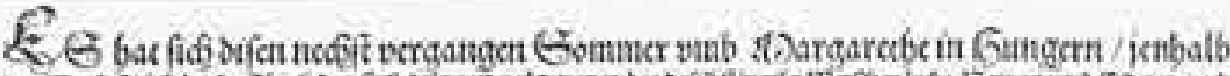

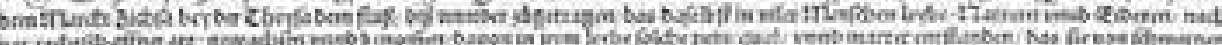

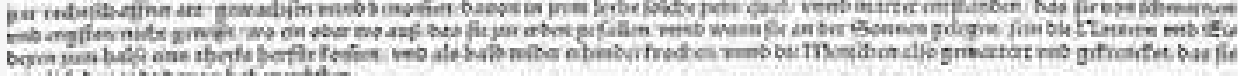

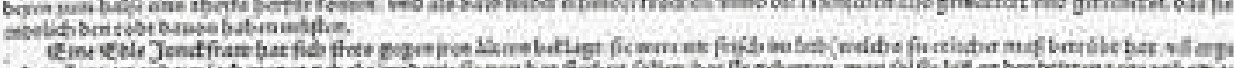
mertester

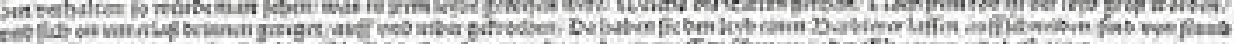
esmo:

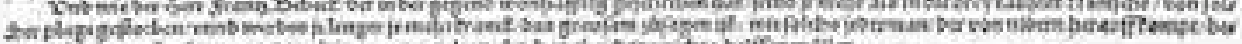

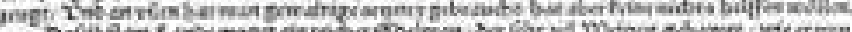

Cor

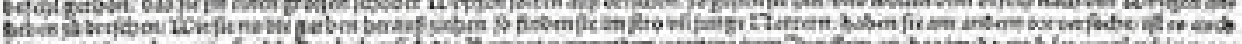

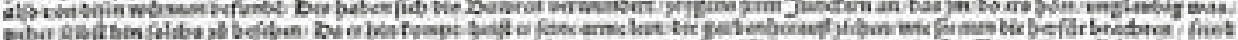

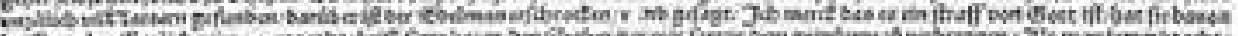
bolfing - e-

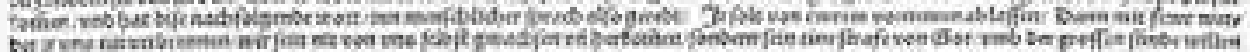

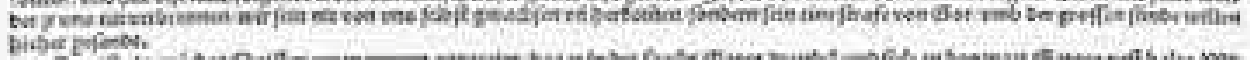

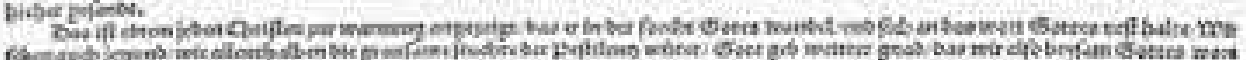

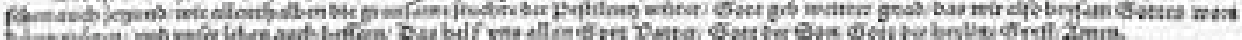

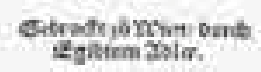




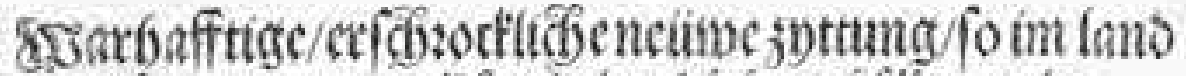

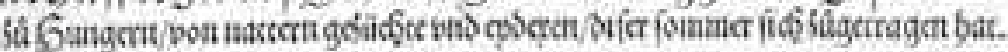

1551

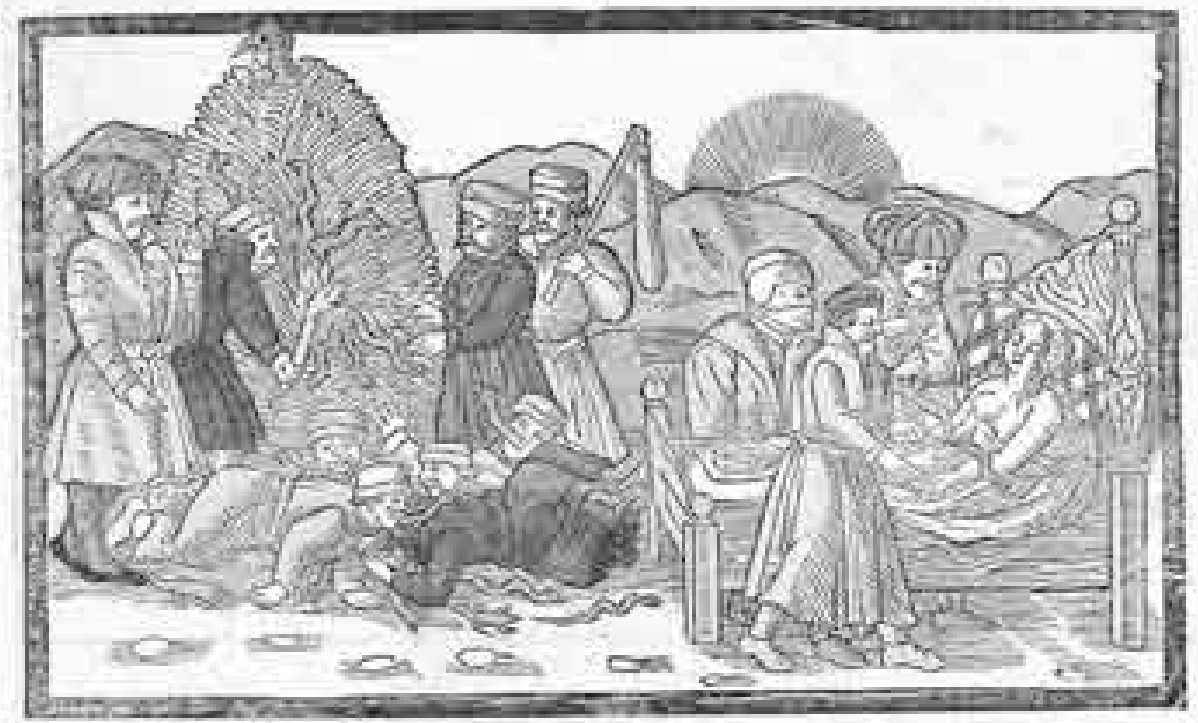

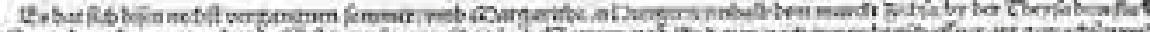

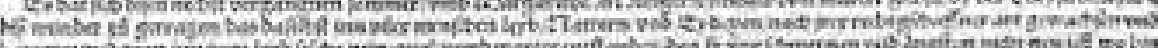

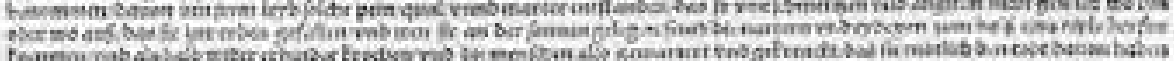
injiten

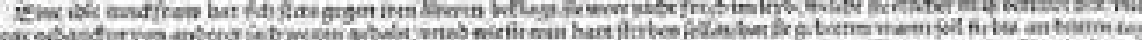

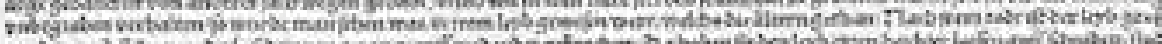

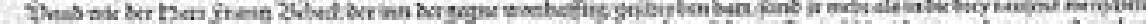
(1)

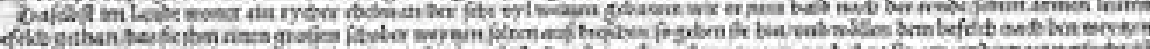
cont s.

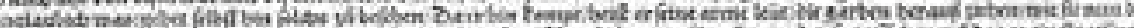
oriar

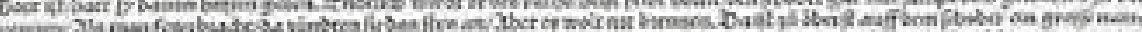

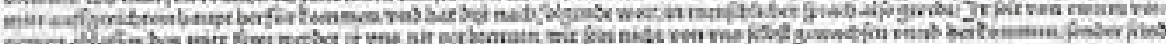

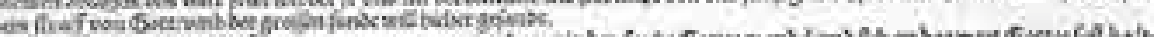

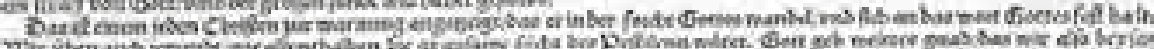

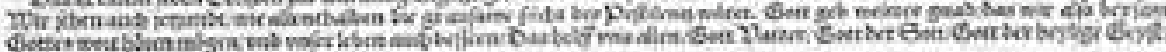

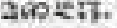

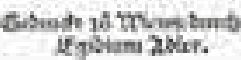




\section{Evmessatfaffitite!}

erfcbrecklicbe/ onownerbòrte

newe 3 eittung/fo im lanbe 3 L Dngcrn/von

Dttergejichte ono fEioexen / Diefen

Eommer ficb jugetra:

genbat.

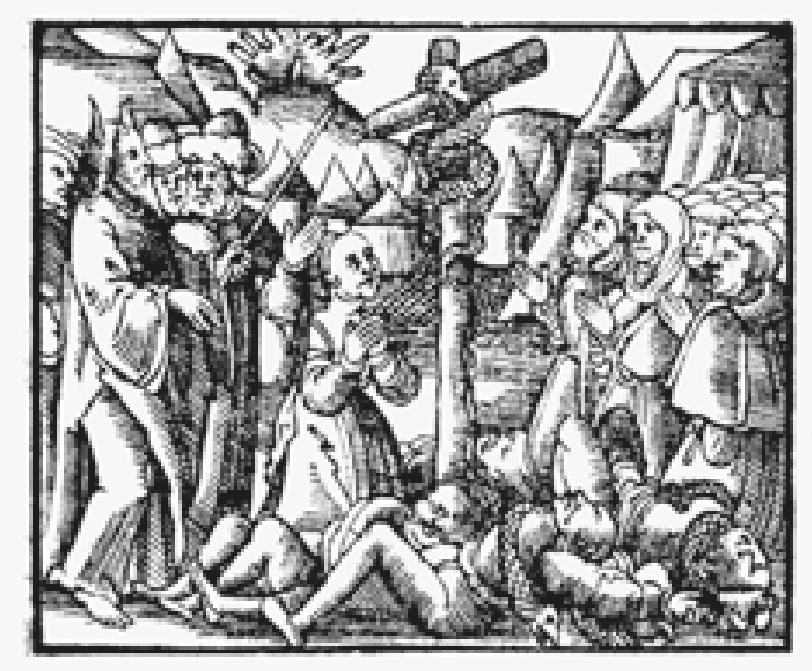

numeri am XXI.

Gott oer $D$ Q $X X$ fante ferorige Ecblangen viter oas volct / bie biffen oas volct / Oas ein gros voldt in Jiracl ftarb/rc.

Anno M. D. L. 


\section{Mewe 3eitunte oer curckifcben "Rriegsru" ftung/ fo jusigen wointer in Dngern ges brador/wiejbranfenglidsen begegs net/vHD allentbalbent fid) 34 getragen bat / Flaub? wirsig bieber ges fitriebert.}
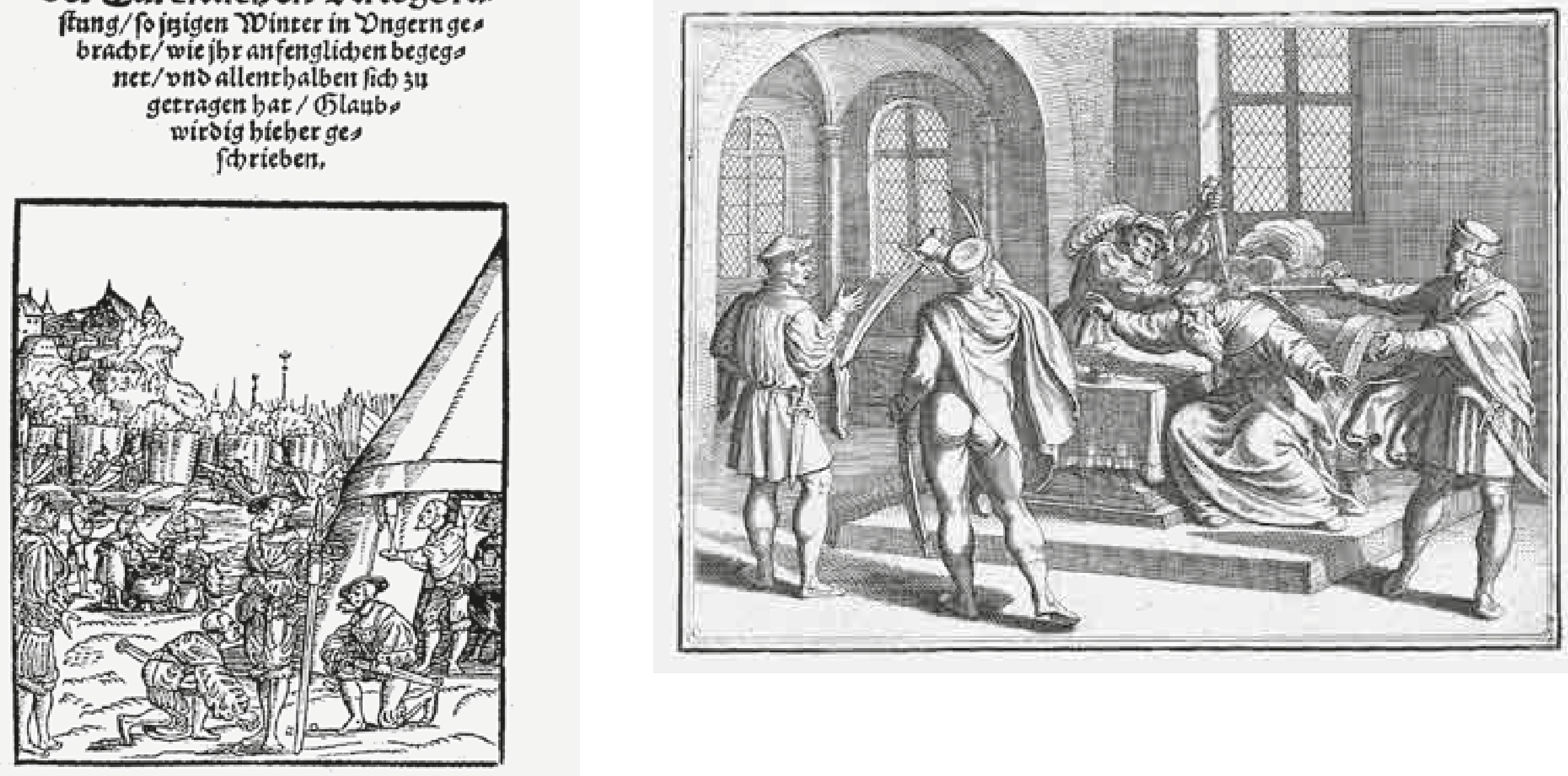


\section{SPCSive 3ctutumgen auf?}

bungern-wie abermals de bnjera durt? mutbi.ffe Gótliaber gnaben/ ocm 23lütbunoe ocr gangen Ebriftentait in etliden $G$ darmisgeln obgejigt/ ond aud vict Cürglifte Sabnen Daruon gebzadr baben/ roeldes gefdecben ift ocn becs on jworngigften tag

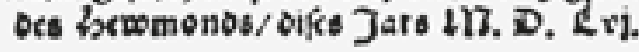

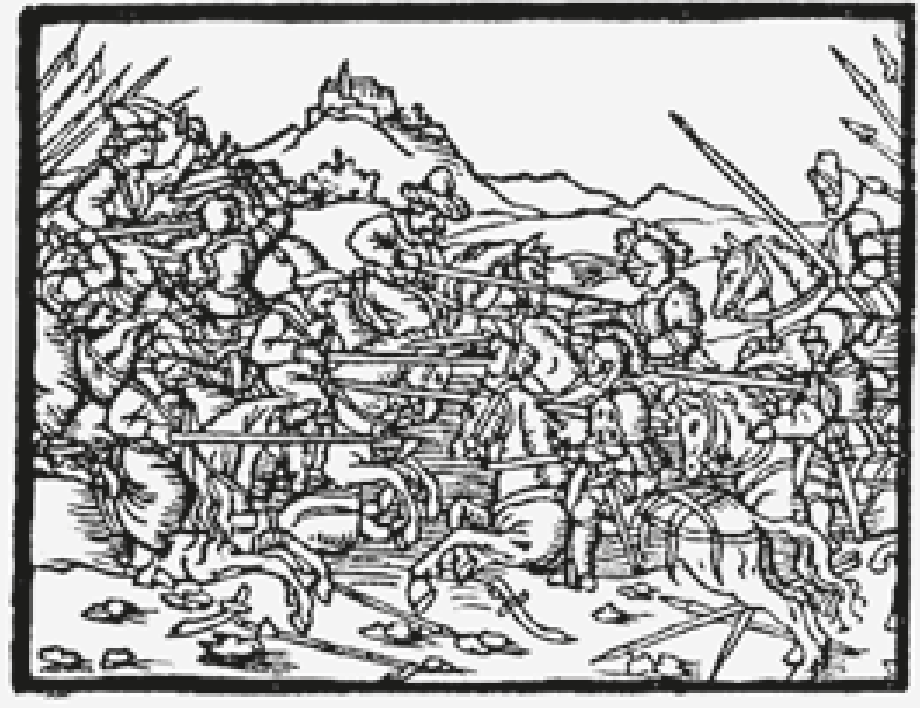

gremvon znoarcn tEtrbiomen/melche auth gcfdes ben feino ză kioffanta vnno Confantio nopel in orfem kT. D. $\mathbb{E} v j$. Jar.
Acroç̌citung.

\section{Deb Tlircfilfoch}

Reilers $\mathfrak{A}$ blagbrieff / fo crnct:

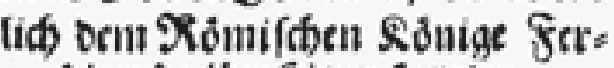
binanbo / bey feintem Legaten jugefand.

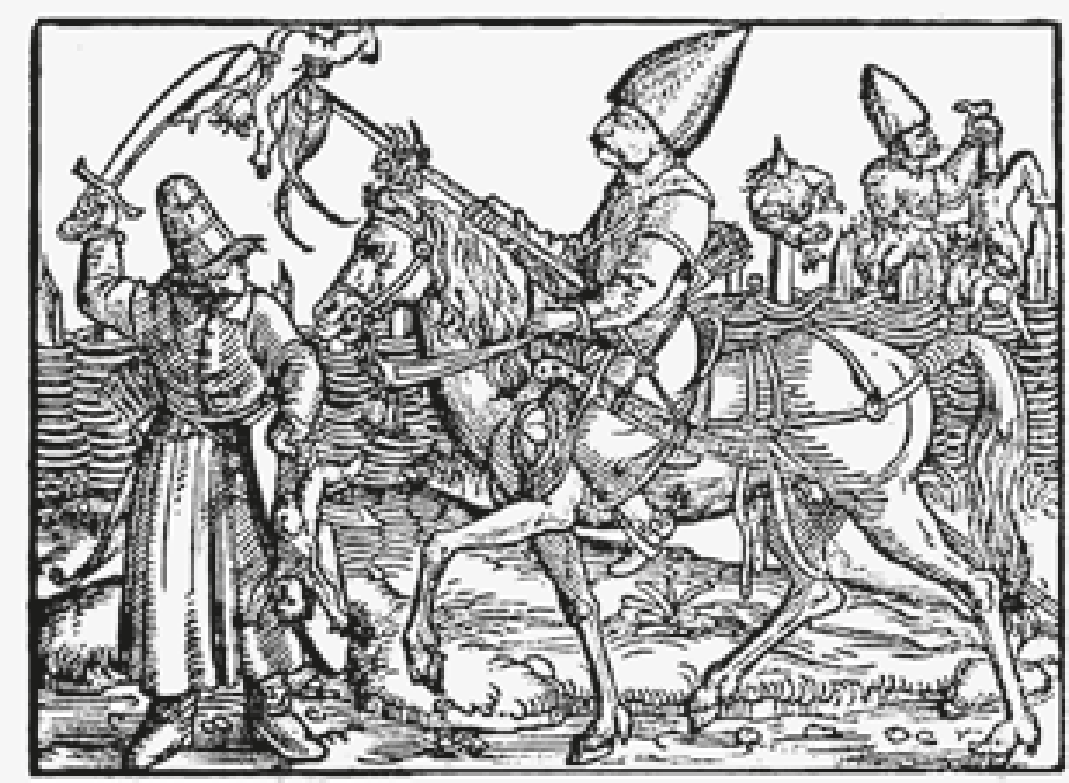

Bus armen Strtiften erforectlid) unb pepr erbermlido su bóren. 1556. 


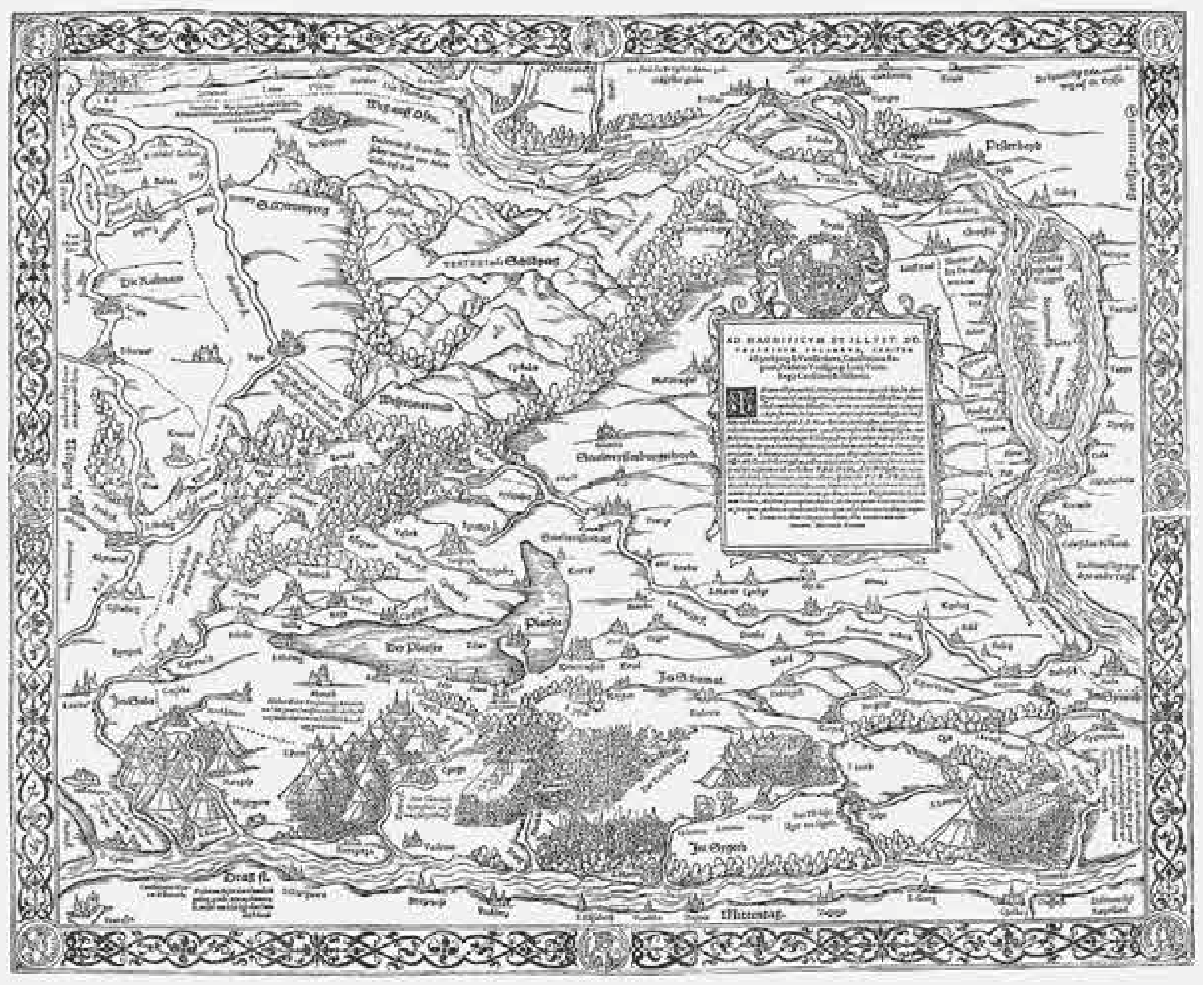




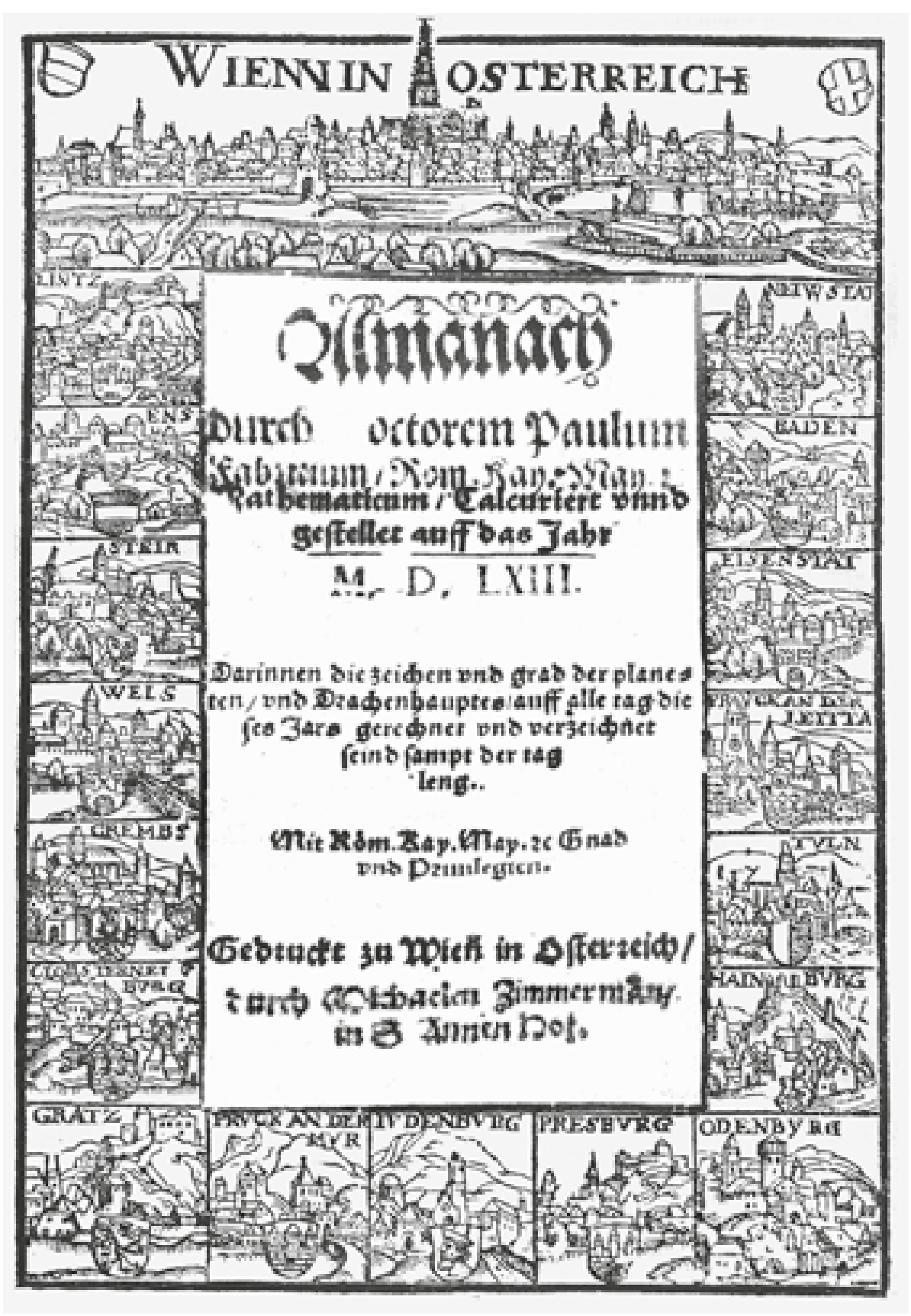

72. kép Kismarton, Pozsony és Sopron 1562/1

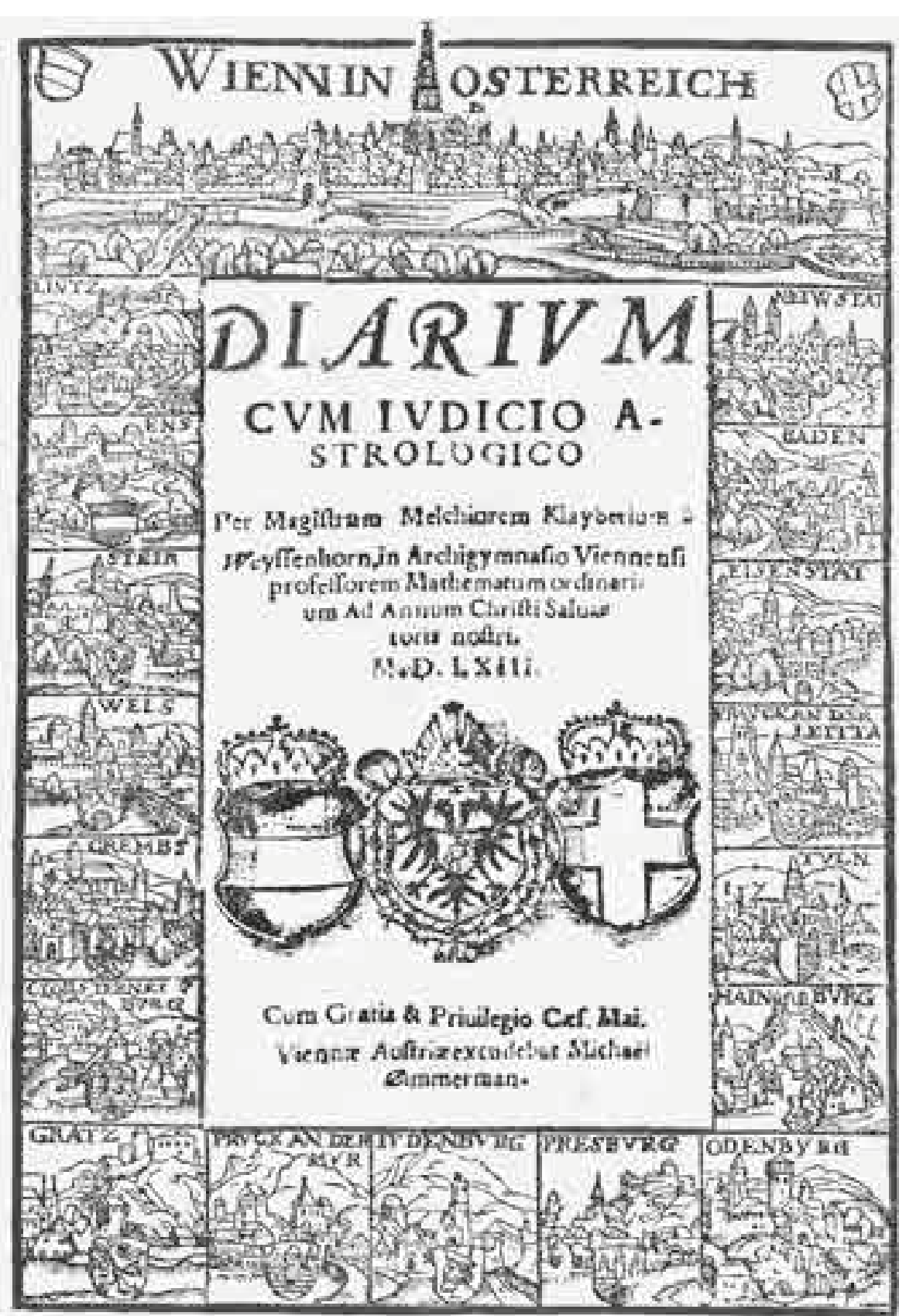

73. kép Kismarton, Pozsony és Sopron 1562/2 


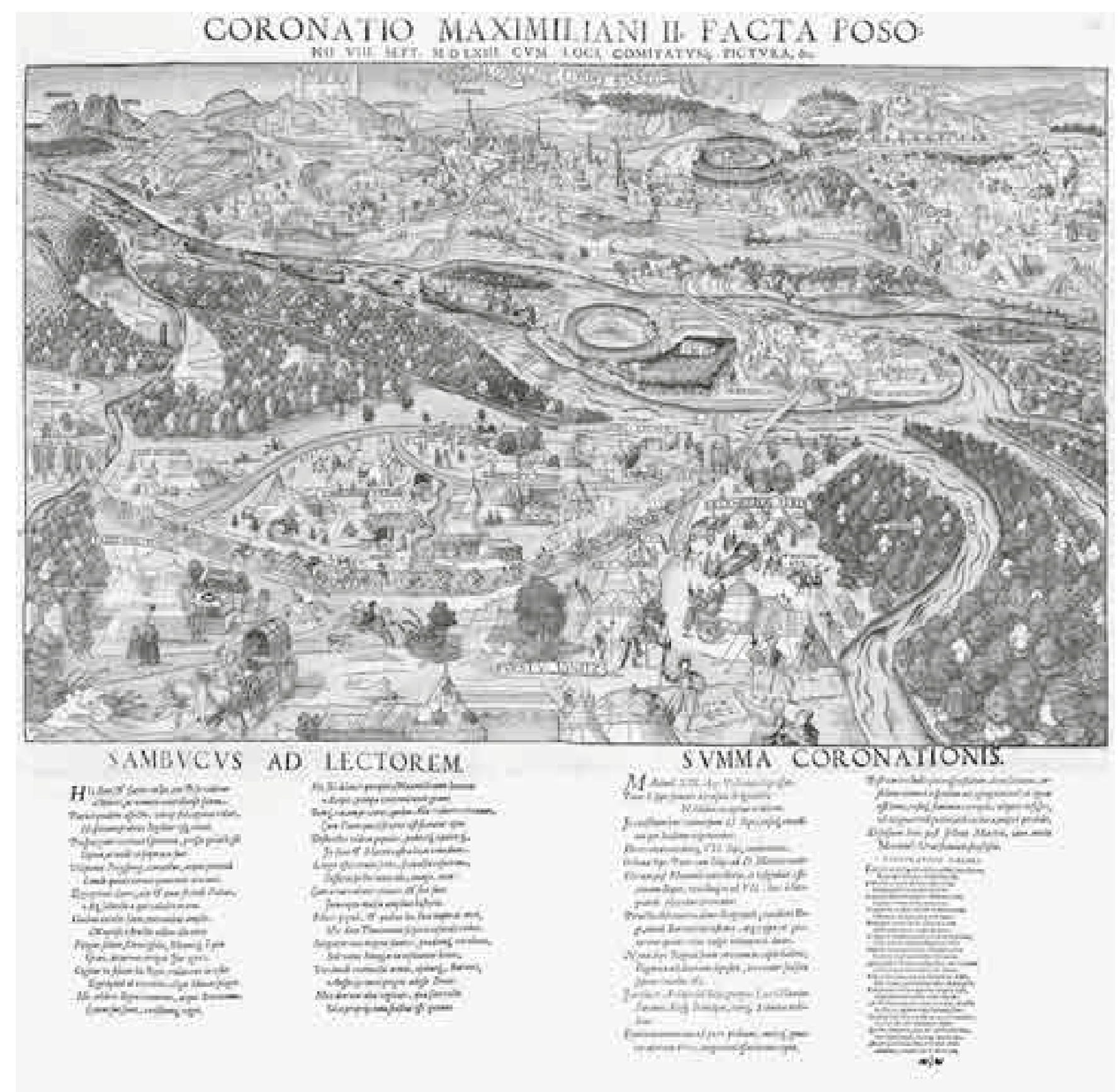



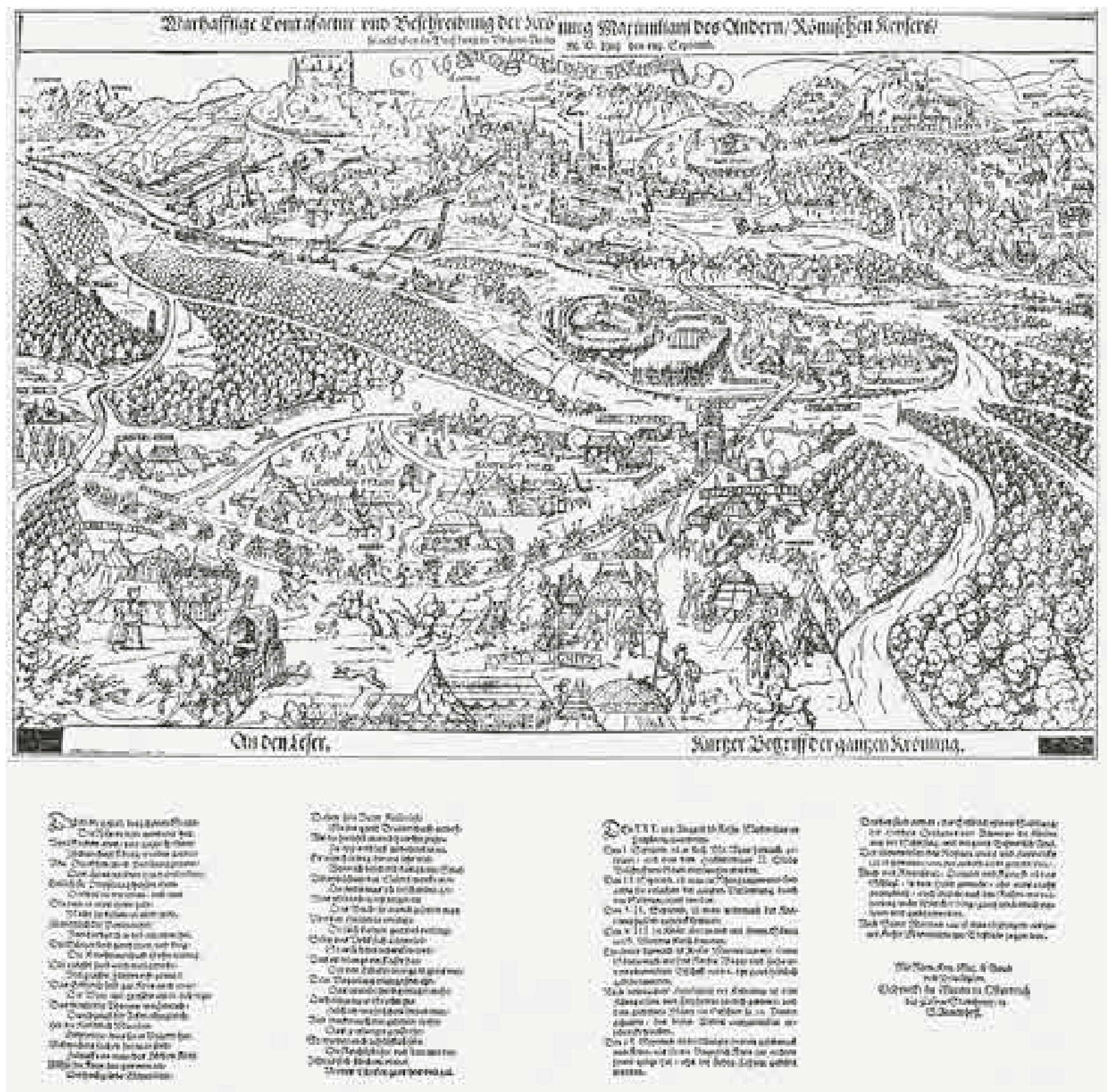


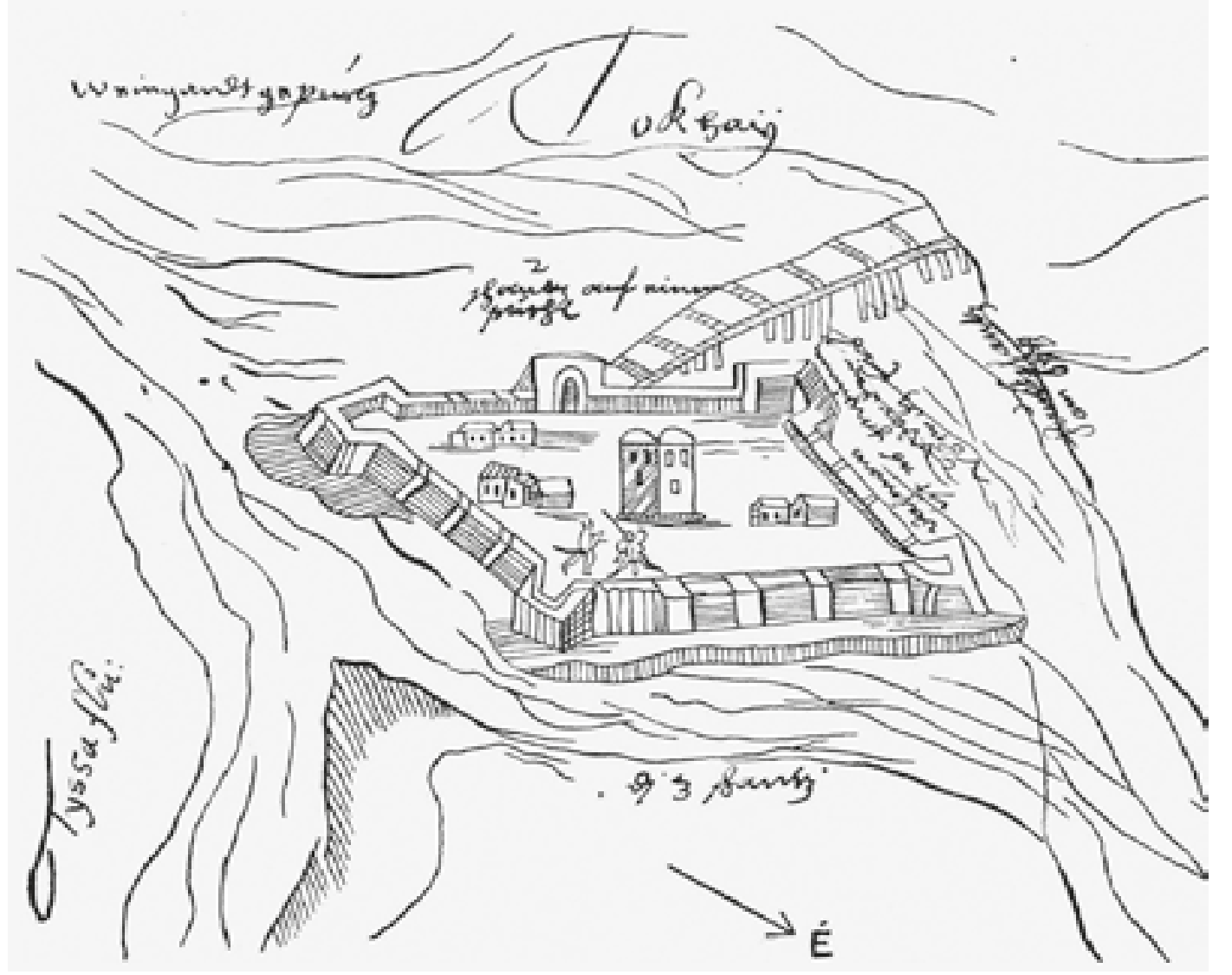

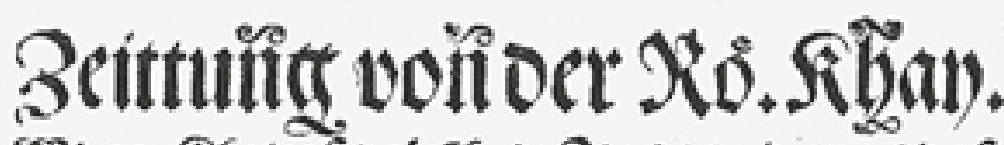

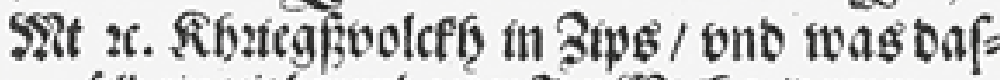
ferb ain zeit herumb gegen Jrer S2it. 亿. fvidertivertoc aufactiot.

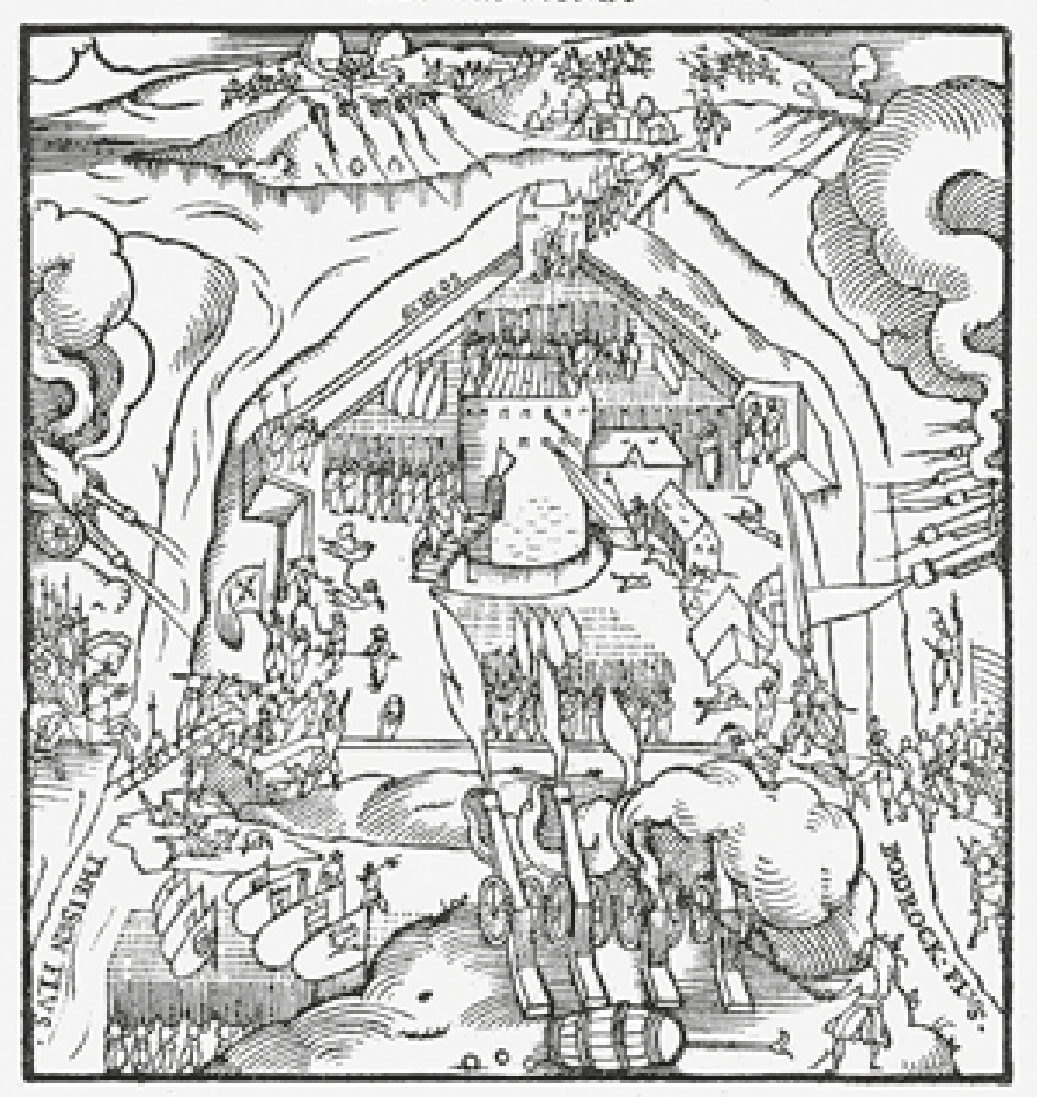




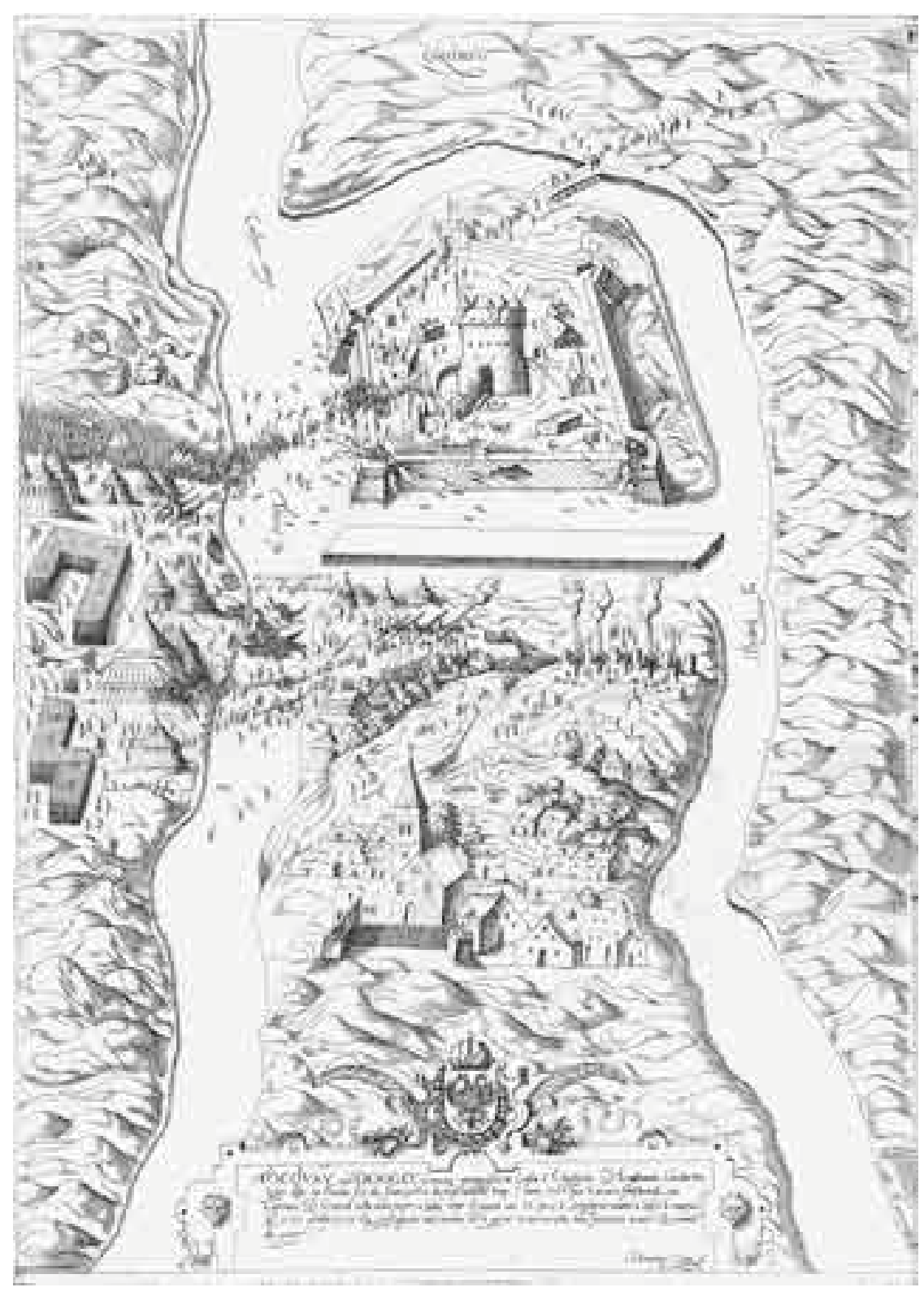

78. kép Tokaj 1565/1/a
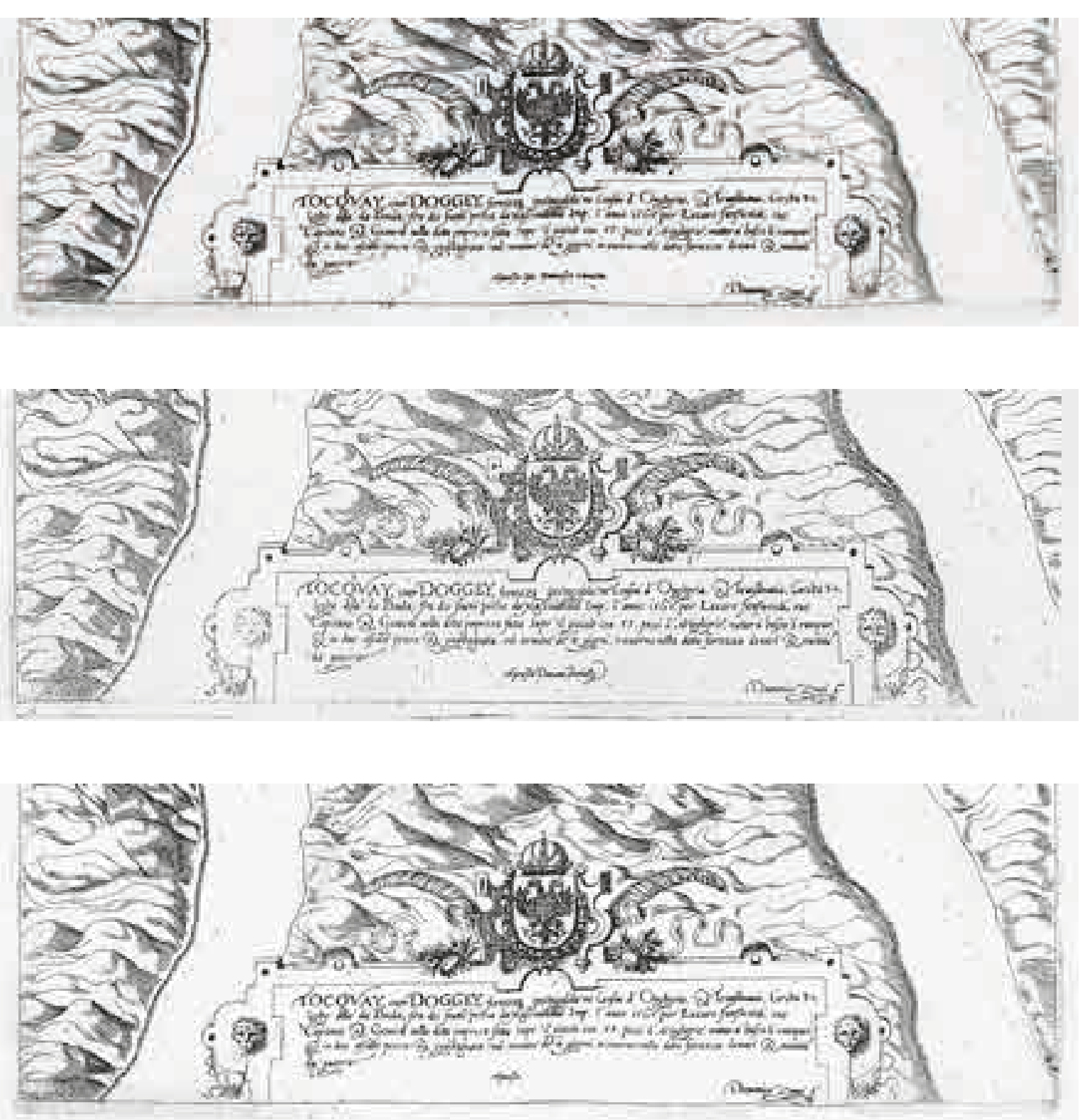

79. kép Tokaj 1565/1/b, c, d kiadói változatok 


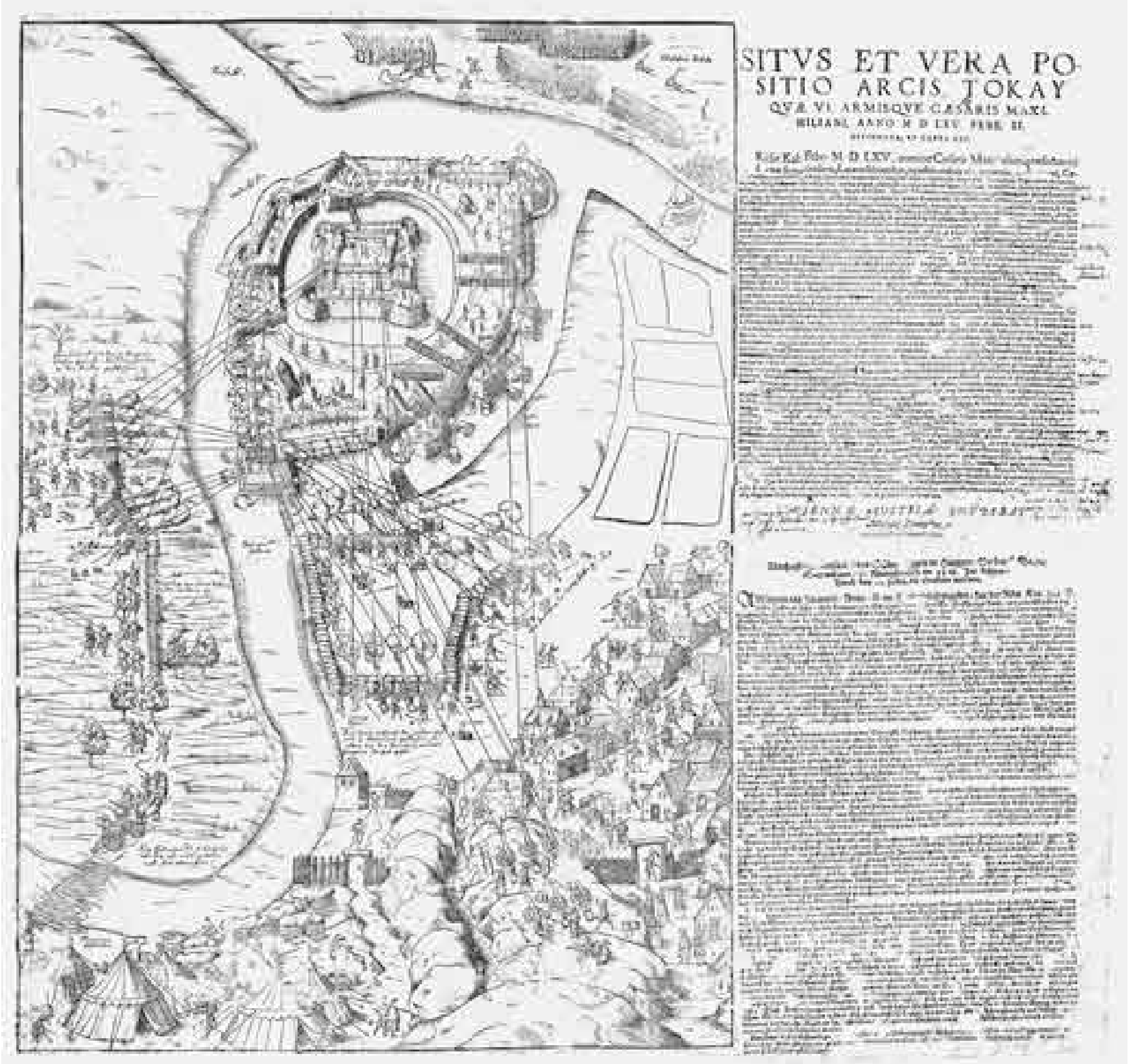


5. Le vray pourtraic du Chafteau de Thokay.

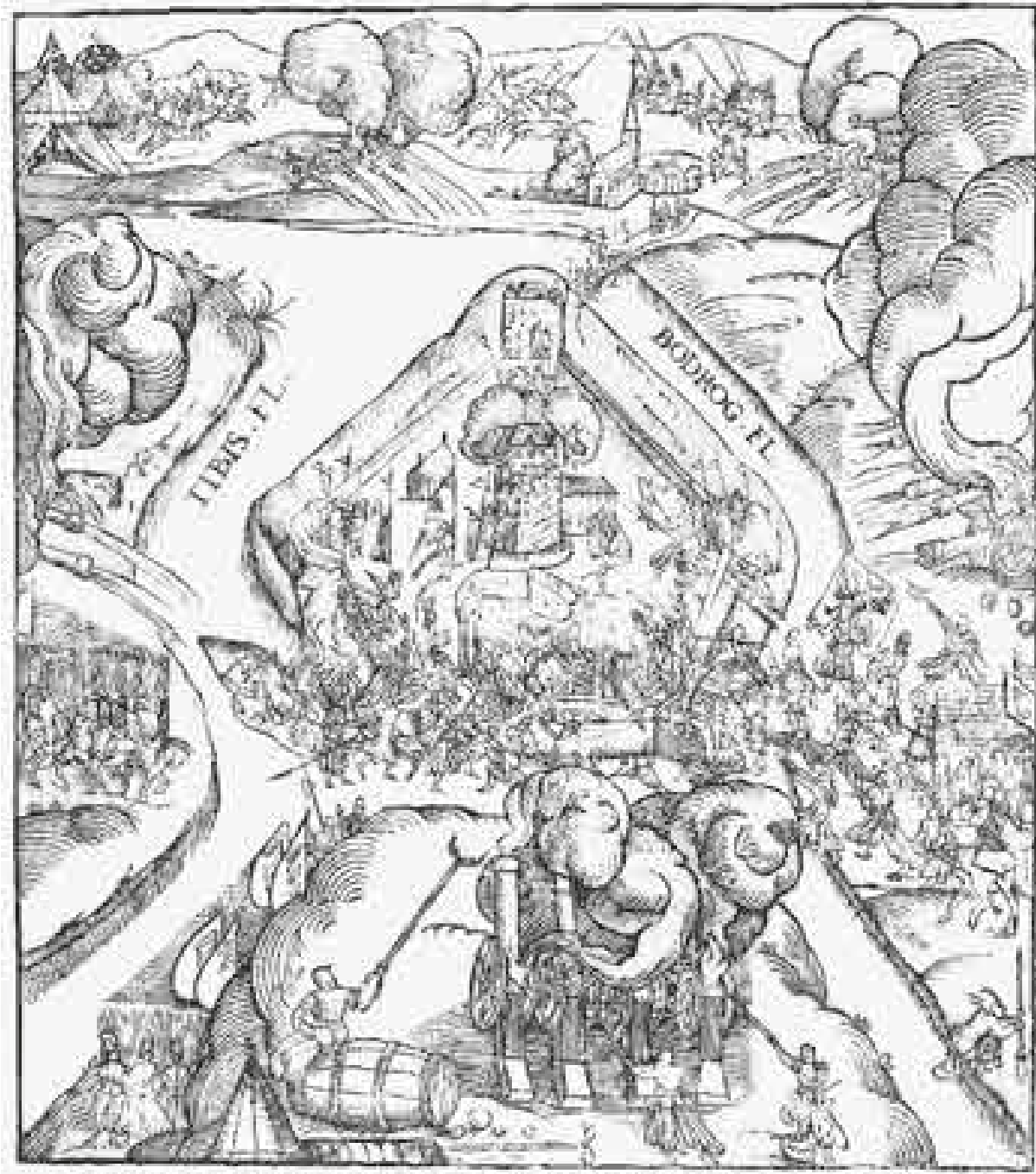

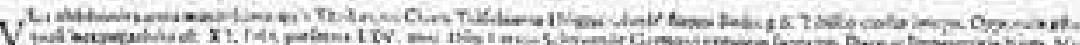

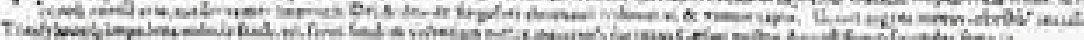

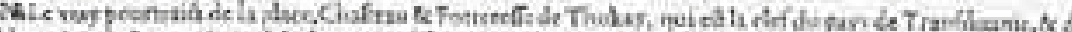

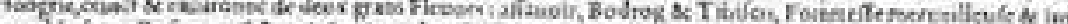

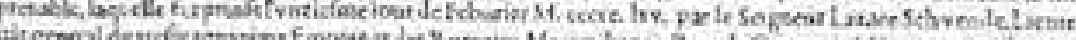
ith $A$ P d

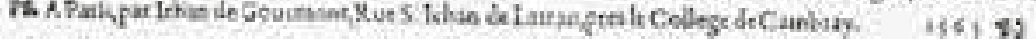


3̧weyerlen Rerve 3etttungen.

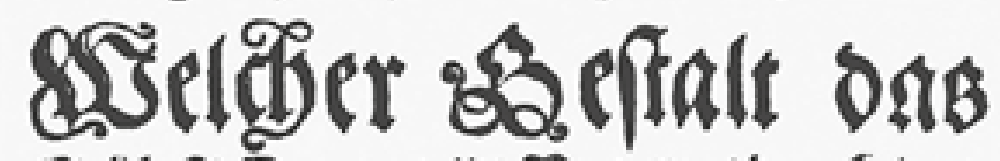

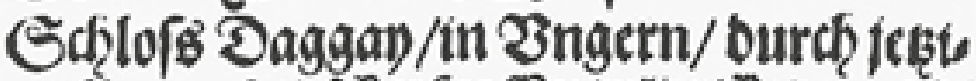
gen Grosmedt tige Reyfers Daximitiant R riegsvold / bem Earcten/ Cbriftides t7amene serbfetno/miderumb biefes

61. 3bare abgetmonnen vno ersbert.

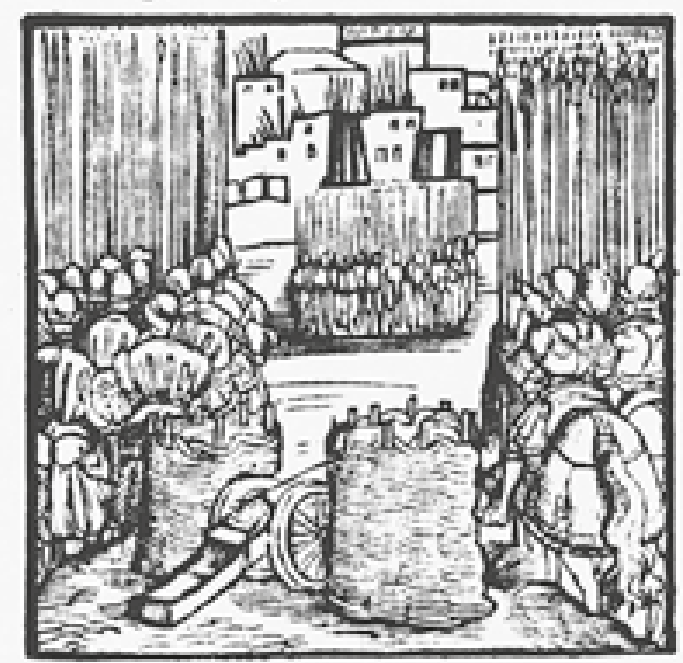

צtem / Ein গitterlicher Rampff vif Iut, nier/zneper Beloen/als einem Eurcfifden Rauptman/nndeiuem Dnqeniben jungen Briegsman/ Bte jres Gilanbens balben/vmb \& cib ens \&eben/auff Sffentidem plata/bey Eaborada in Dngern/

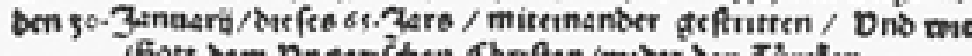
Gott oem Dngerifoen Cbnften/wriocr oxn Eürelen orn Bisg verliegen/eti.

\section{Ëin new Lied / $/$ õ} 8 Rairerliffen Zleateftet DB ziffert Rafarus vö Gad)wertoi wo et vor Gactmat bert 27 . QDay

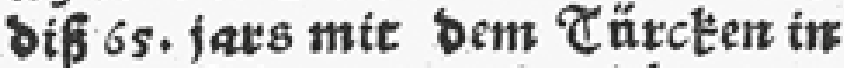
einem Gdarmits gebandlet/wev Den fr Eurtslicb bózent. jm Thort si̊ firtgert, $\mathfrak{D O}_{\mathfrak{a}}$ wóller wit aber bebert att.

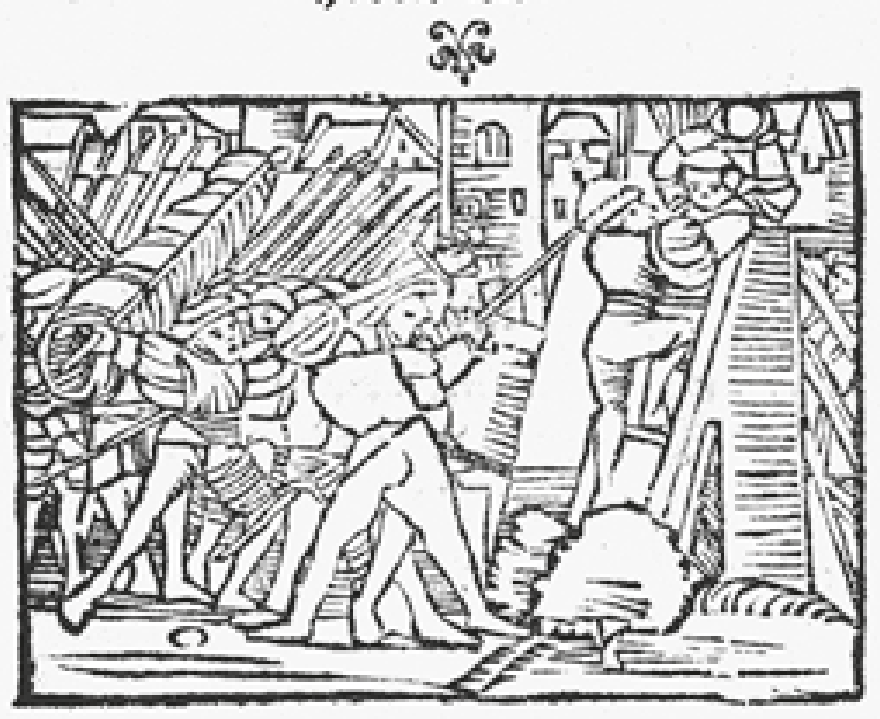

$M \cdot D \cdot L$ X V. 


\section{Tatbaffitge Grtmotli=}

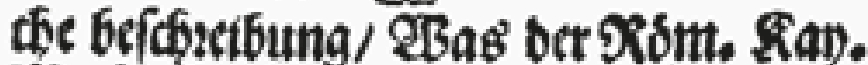

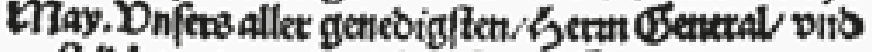

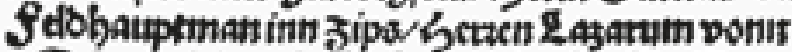

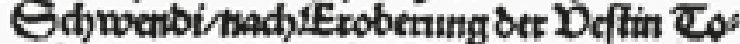

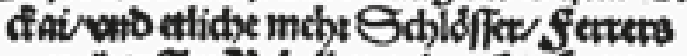

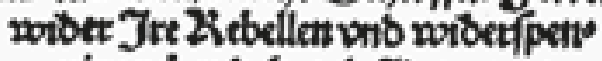

nigegehanoelt volo firrgettom menfoy wostoet.

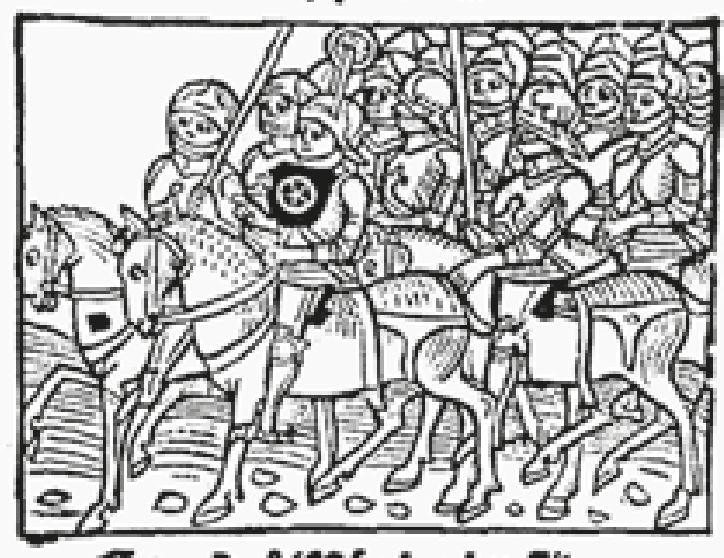

Betrudt 3 åmintudyenbey 2toan berg.

Anno, M.D.LXV.

\section{Zevttunty won der 2 So.}

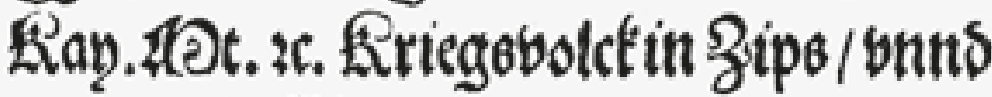
wa 6 daffelb ein zeet berumb gegen Jrex s0c.2c. wotberwer tige autgigertifit.

$$
1565 .
$$

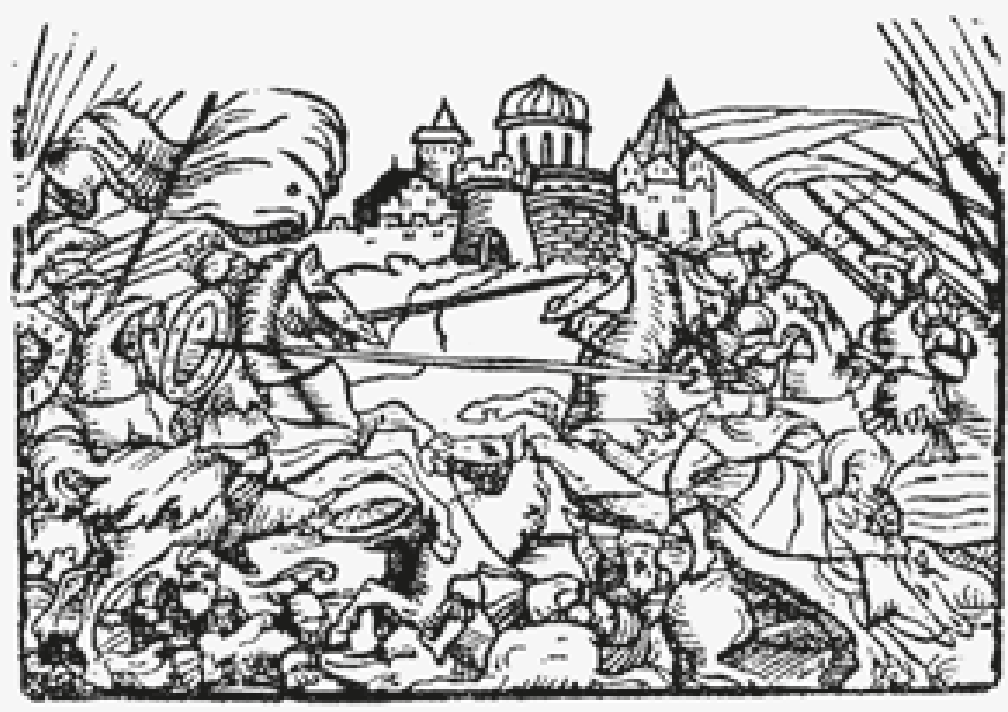




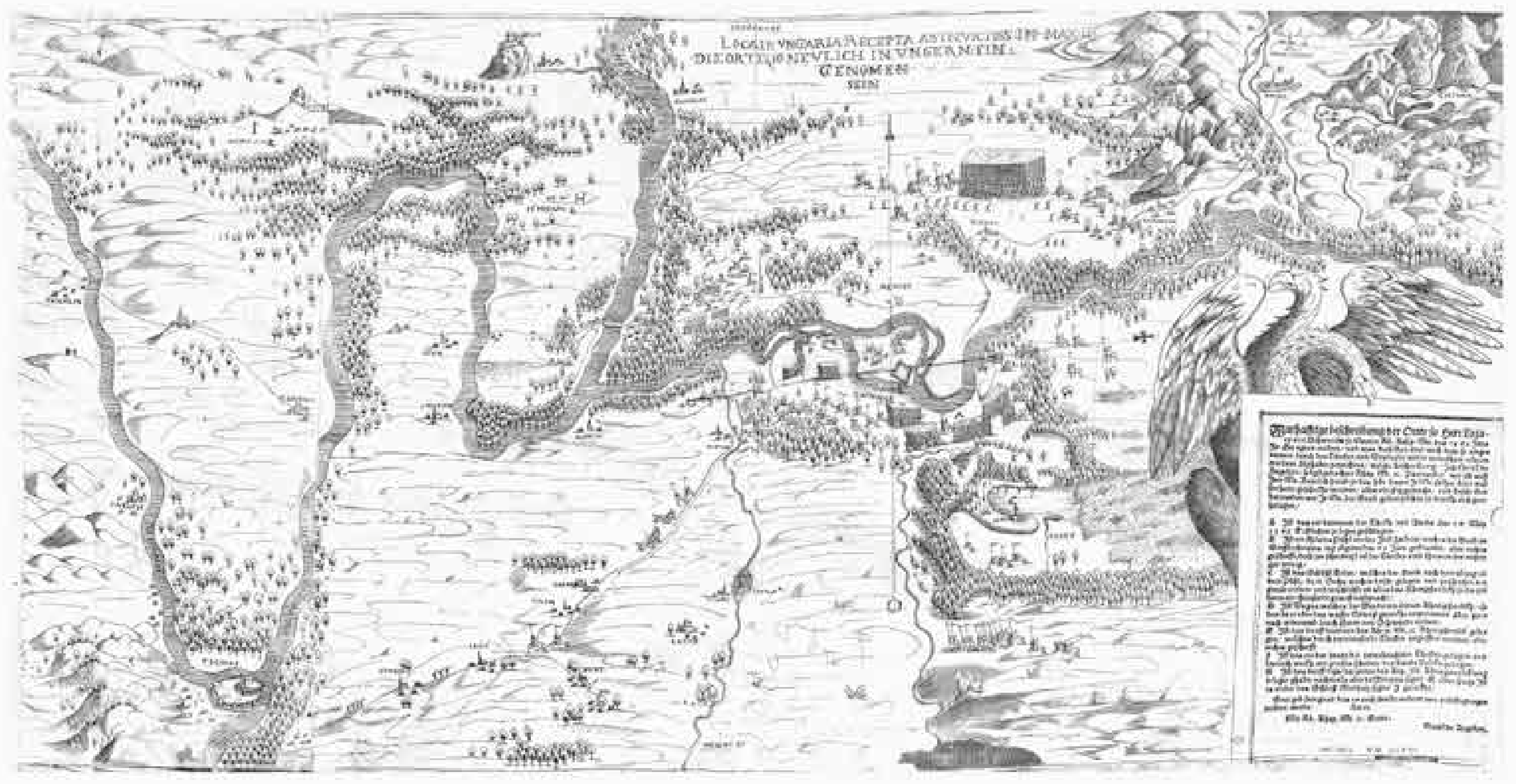




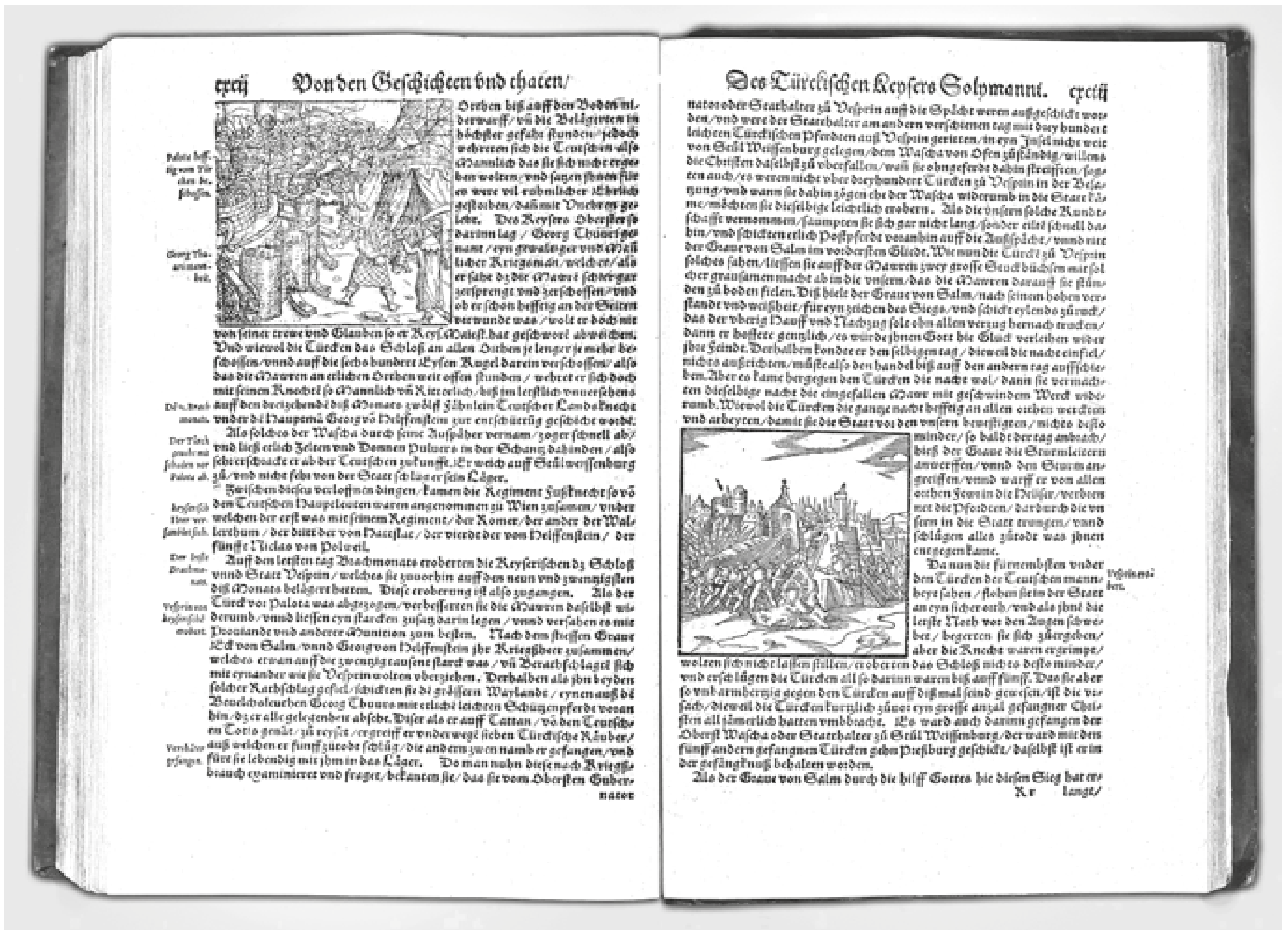




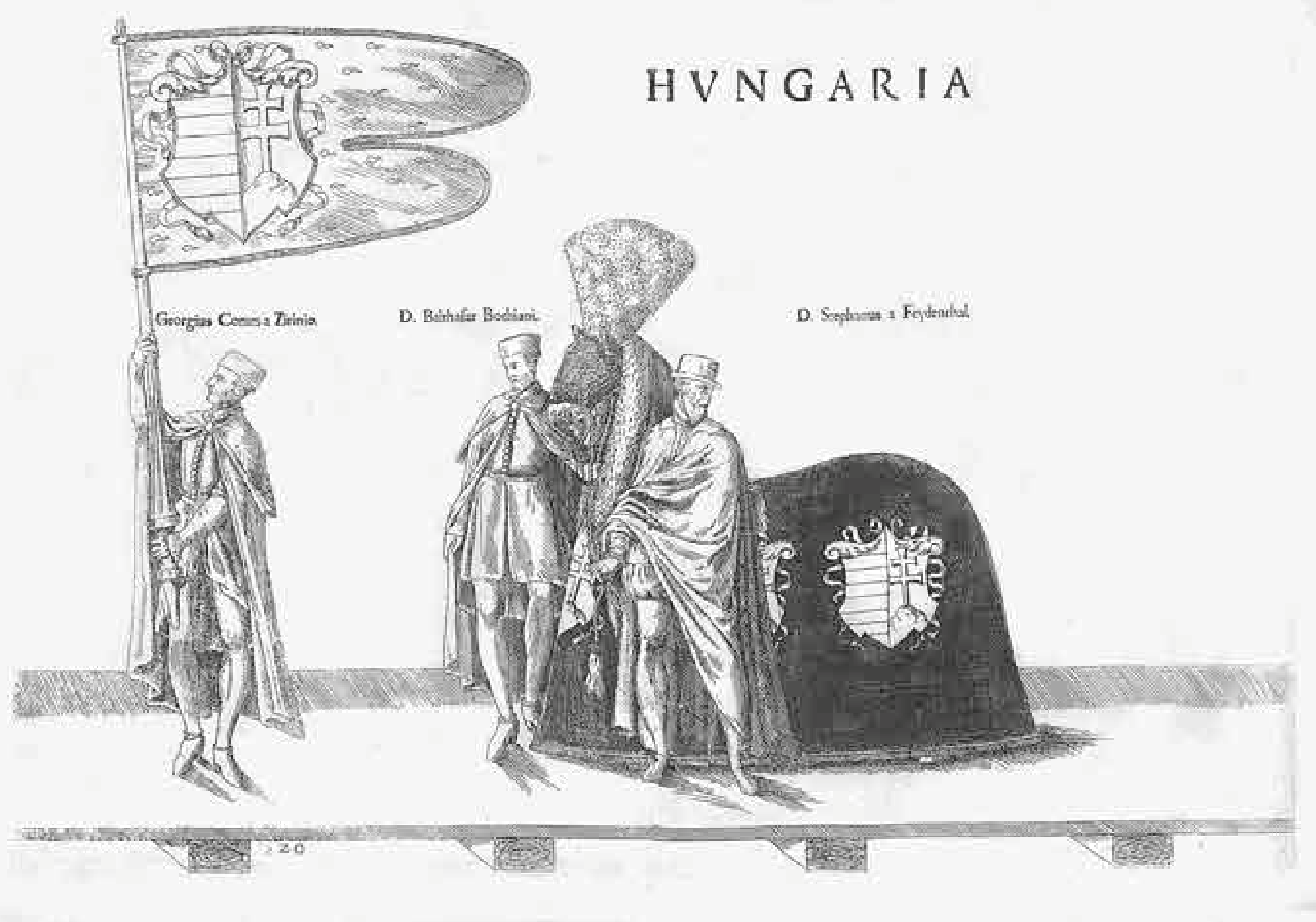




\section{REGNI HVNGARIAE CLINODIA.}

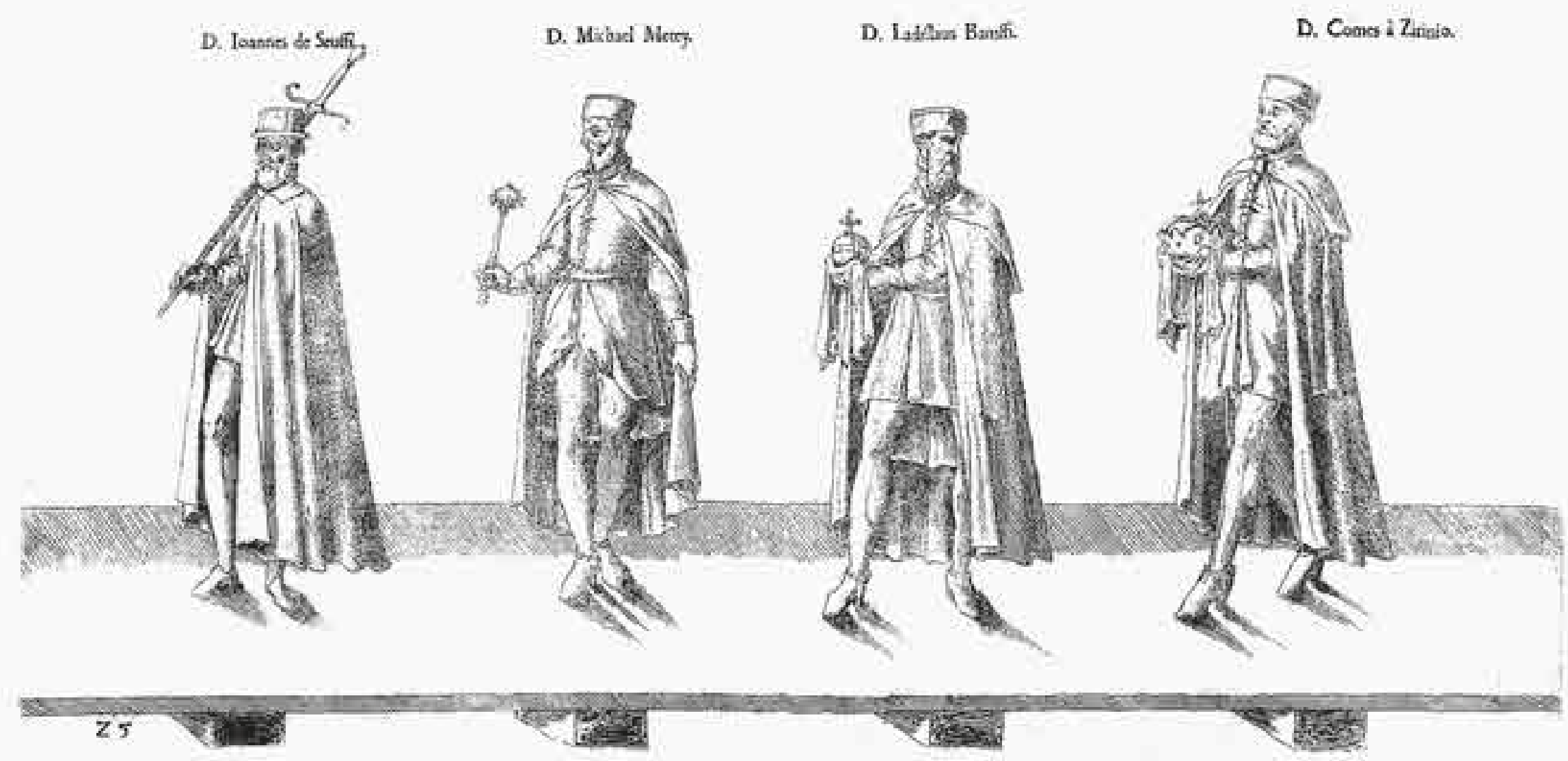




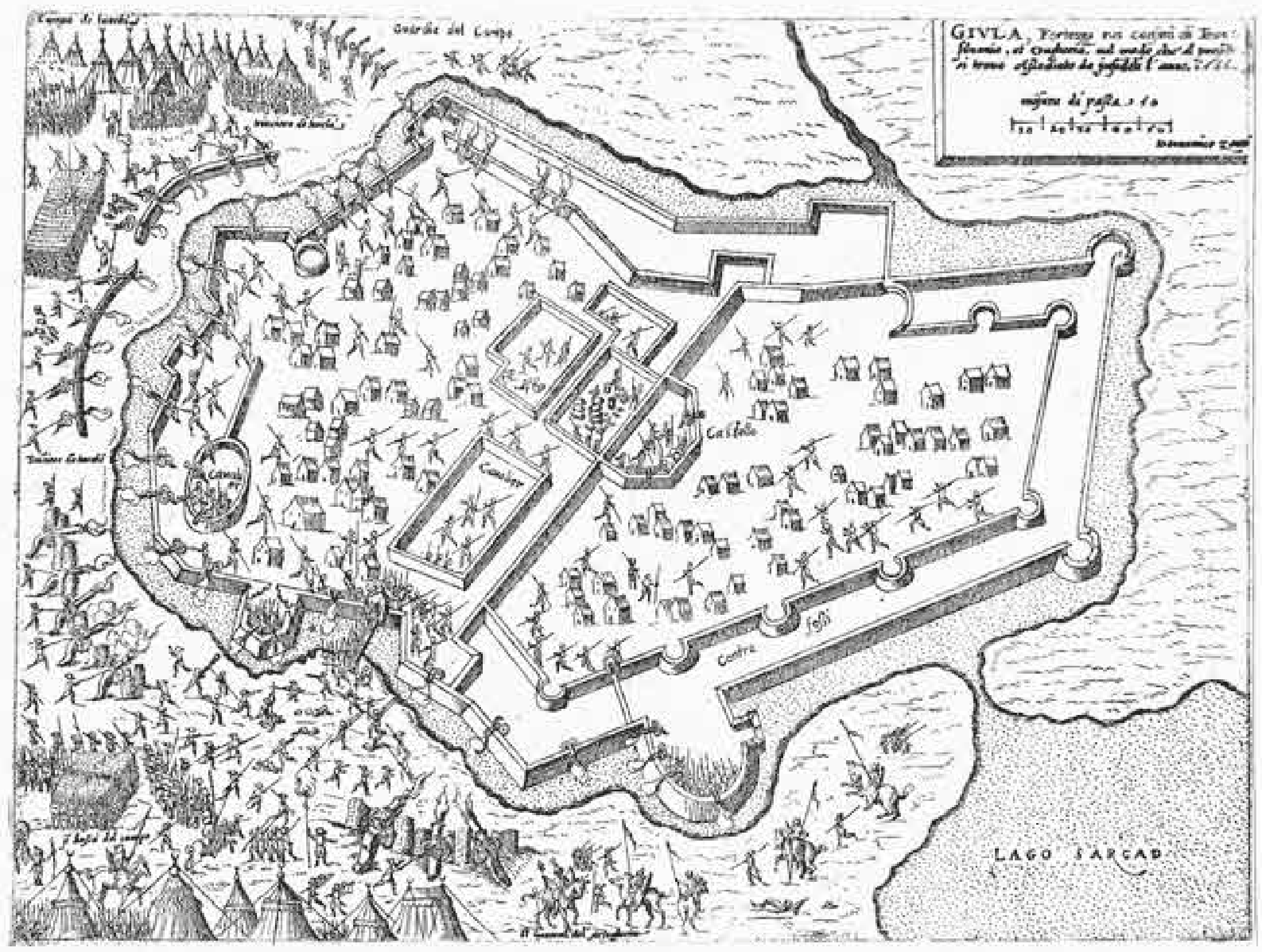




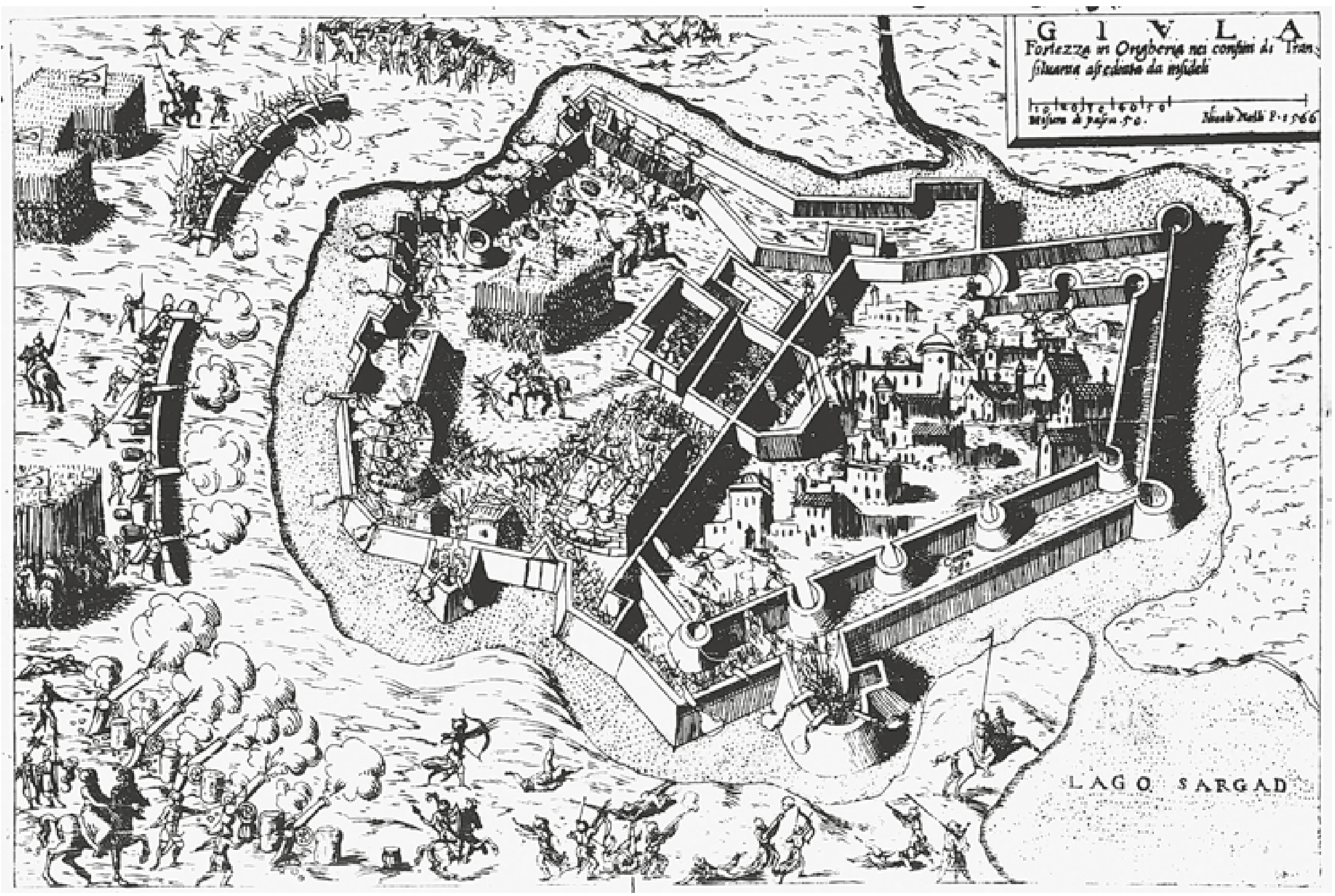




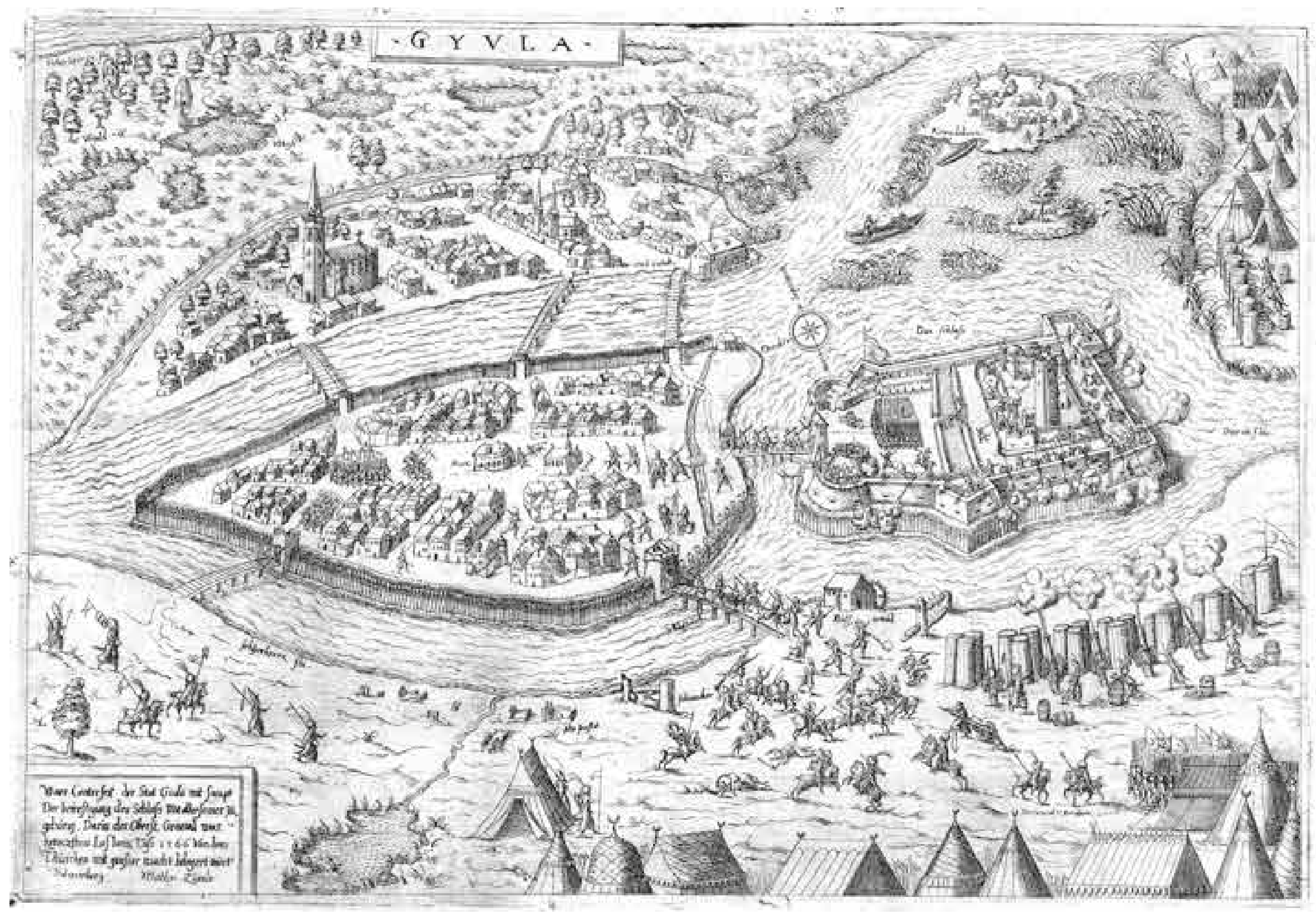




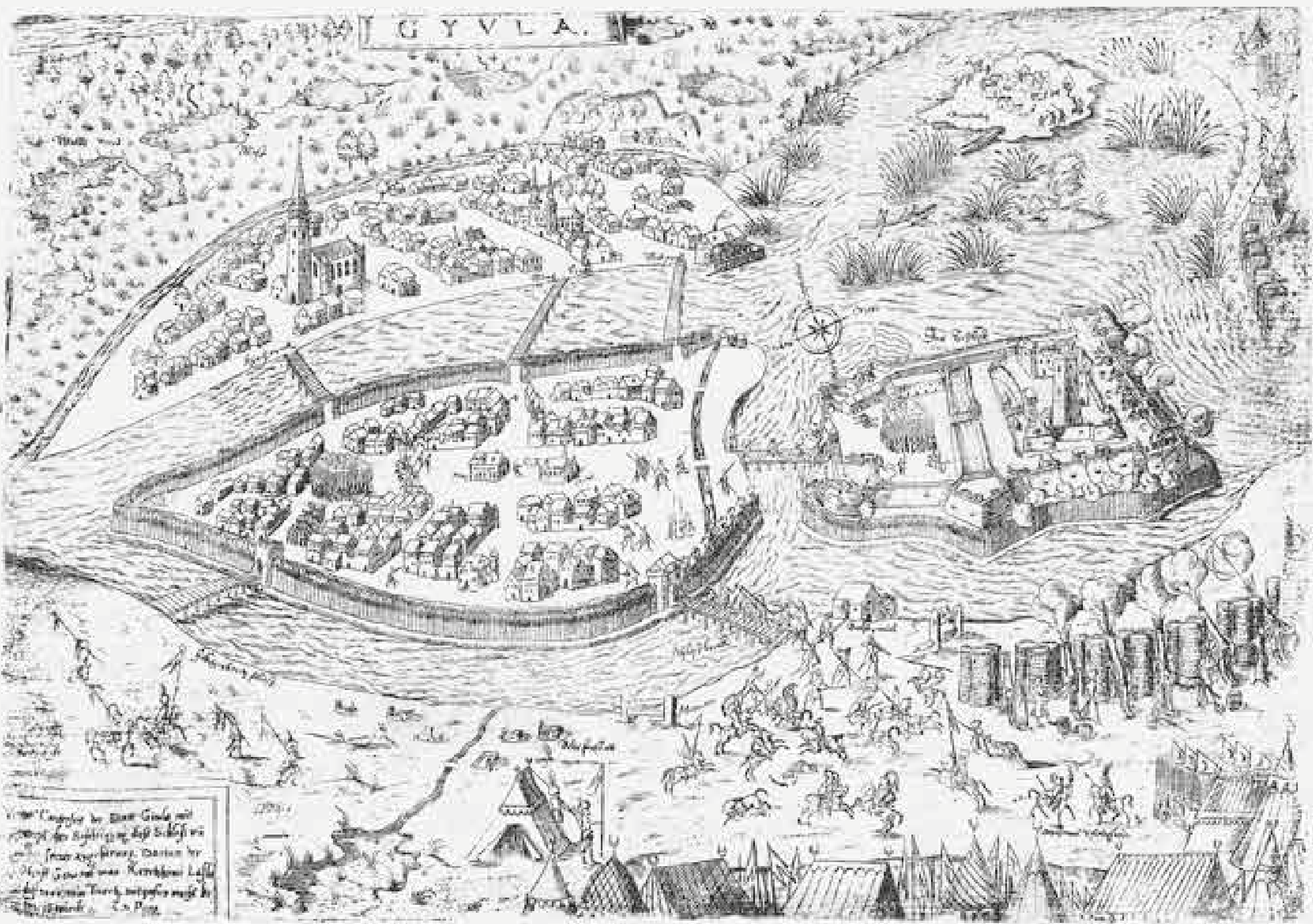




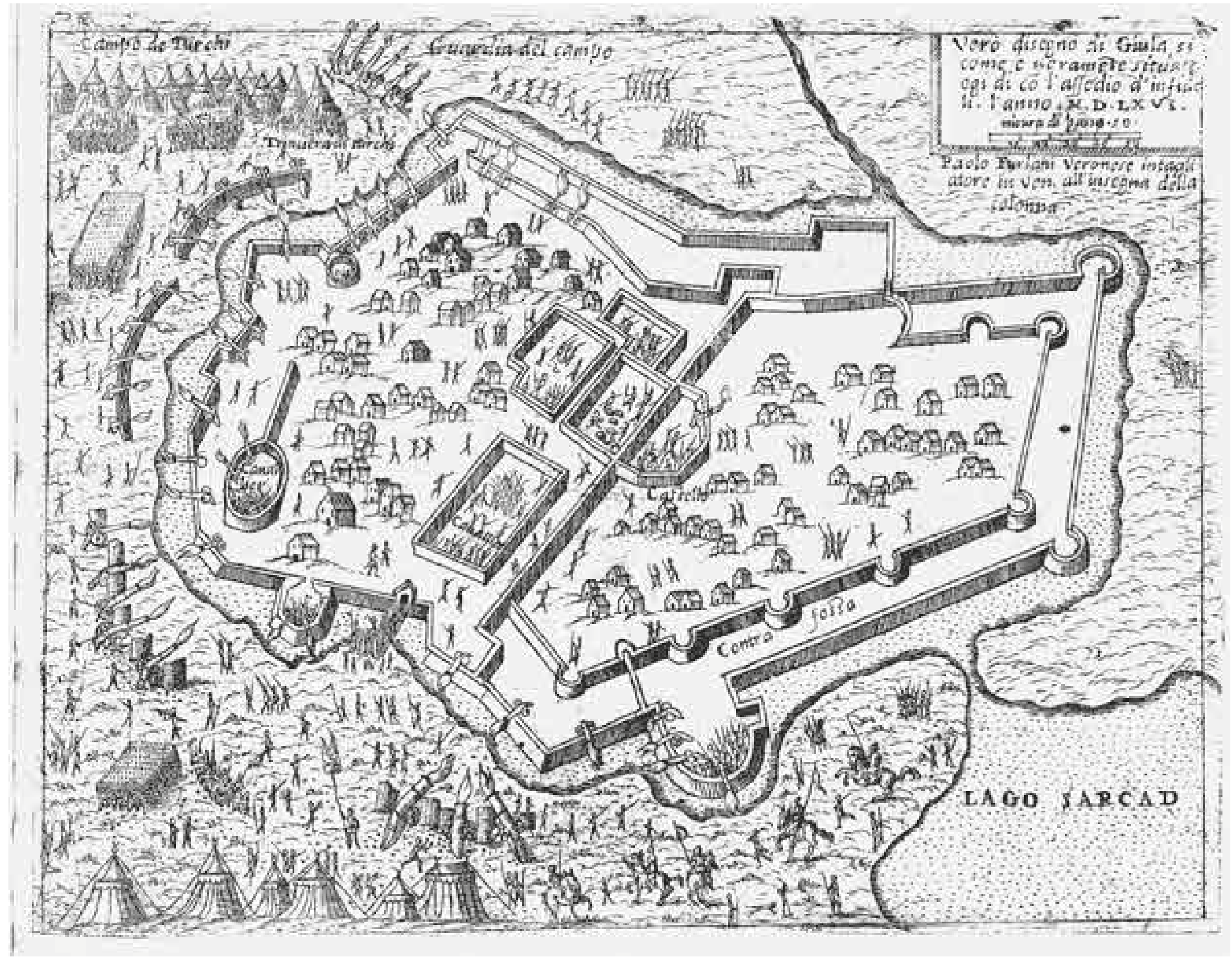




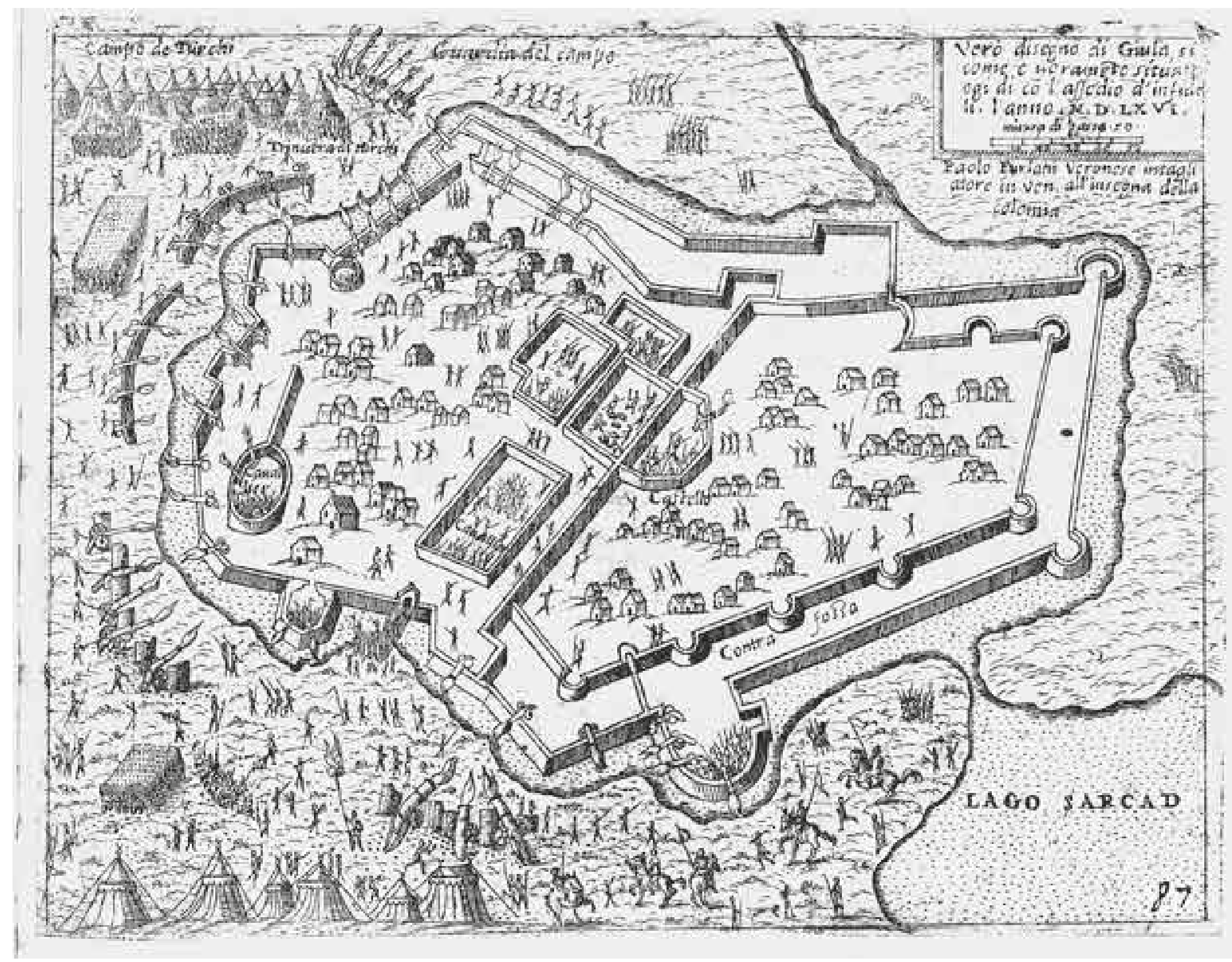




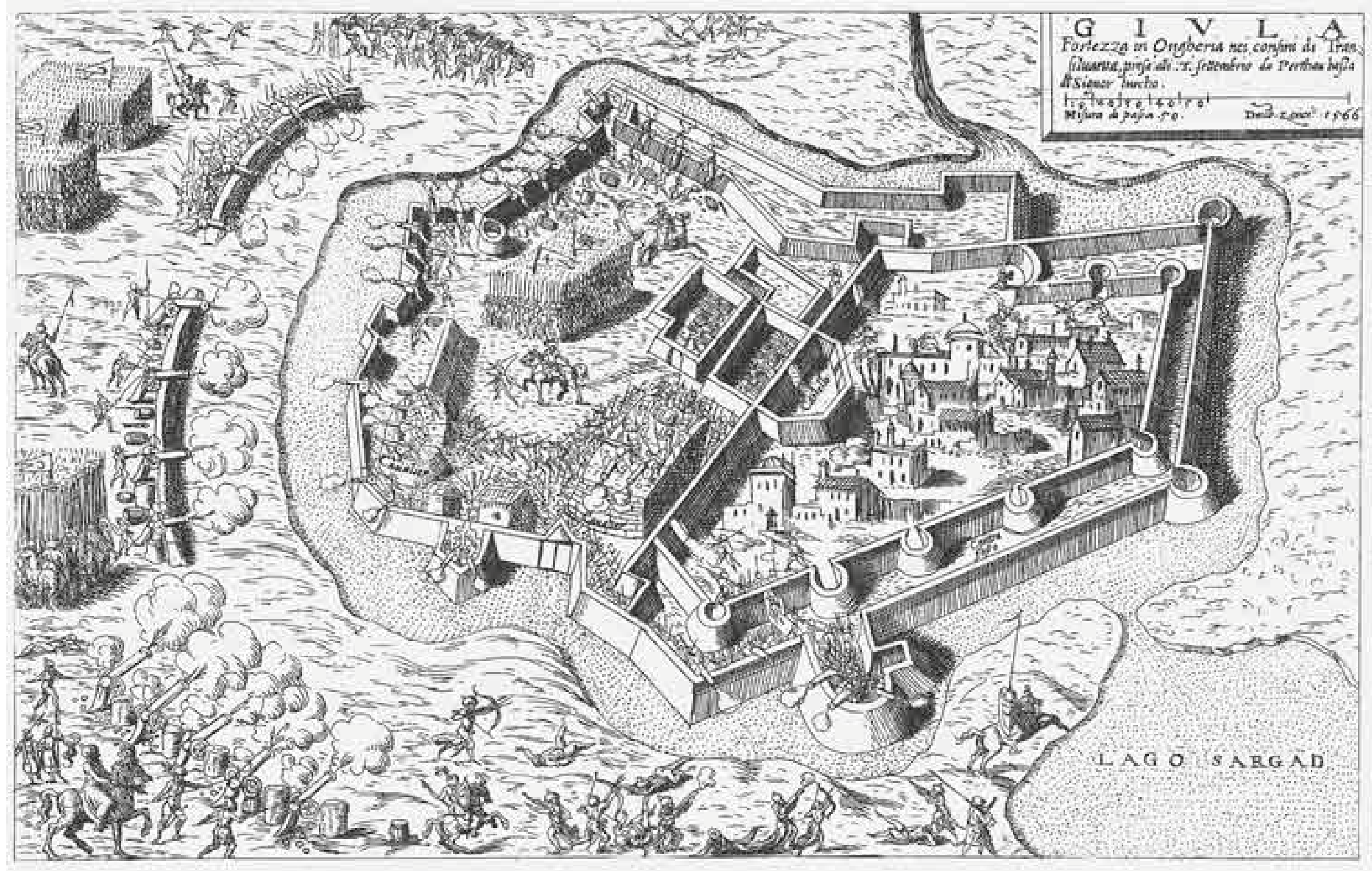




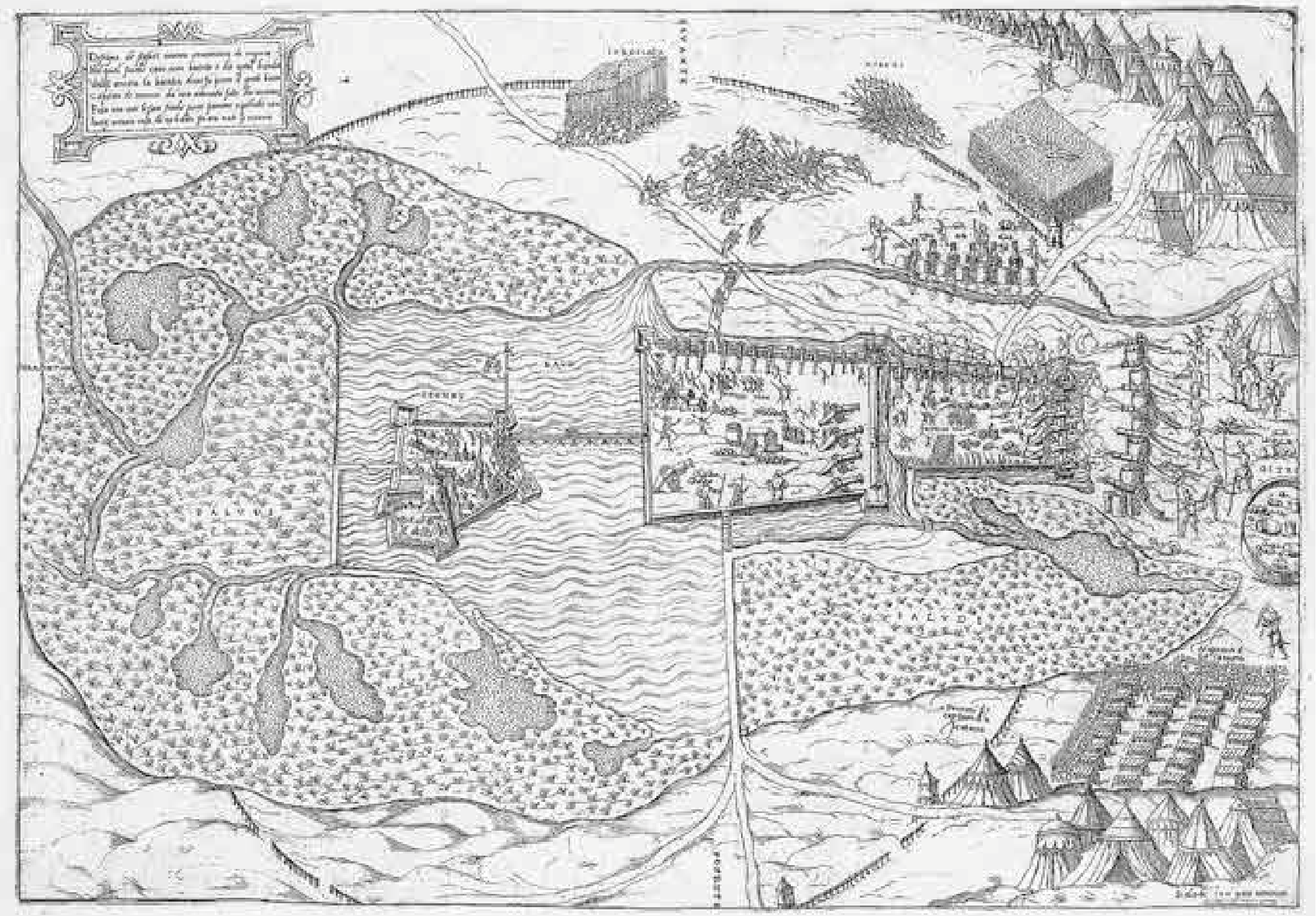




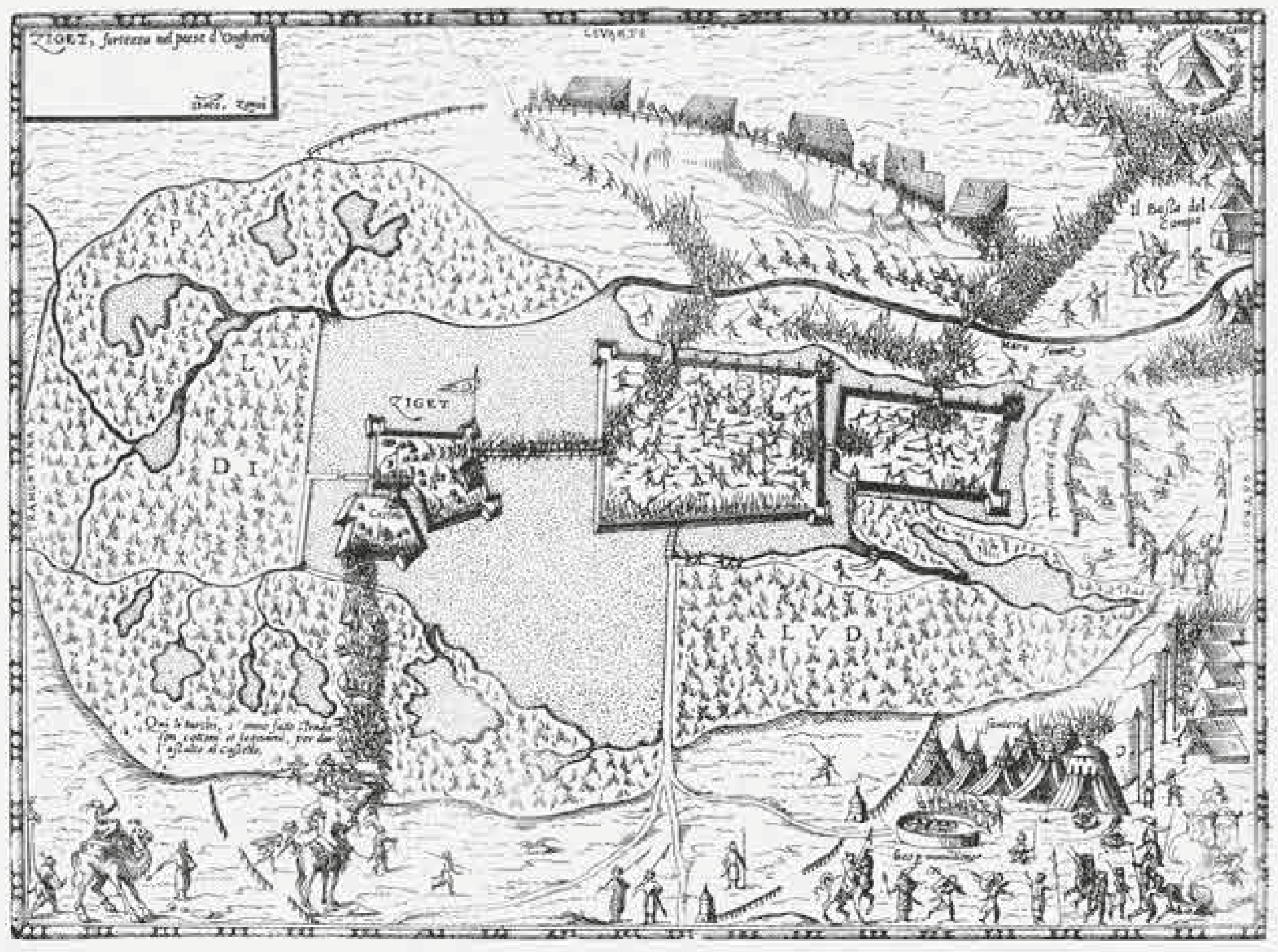




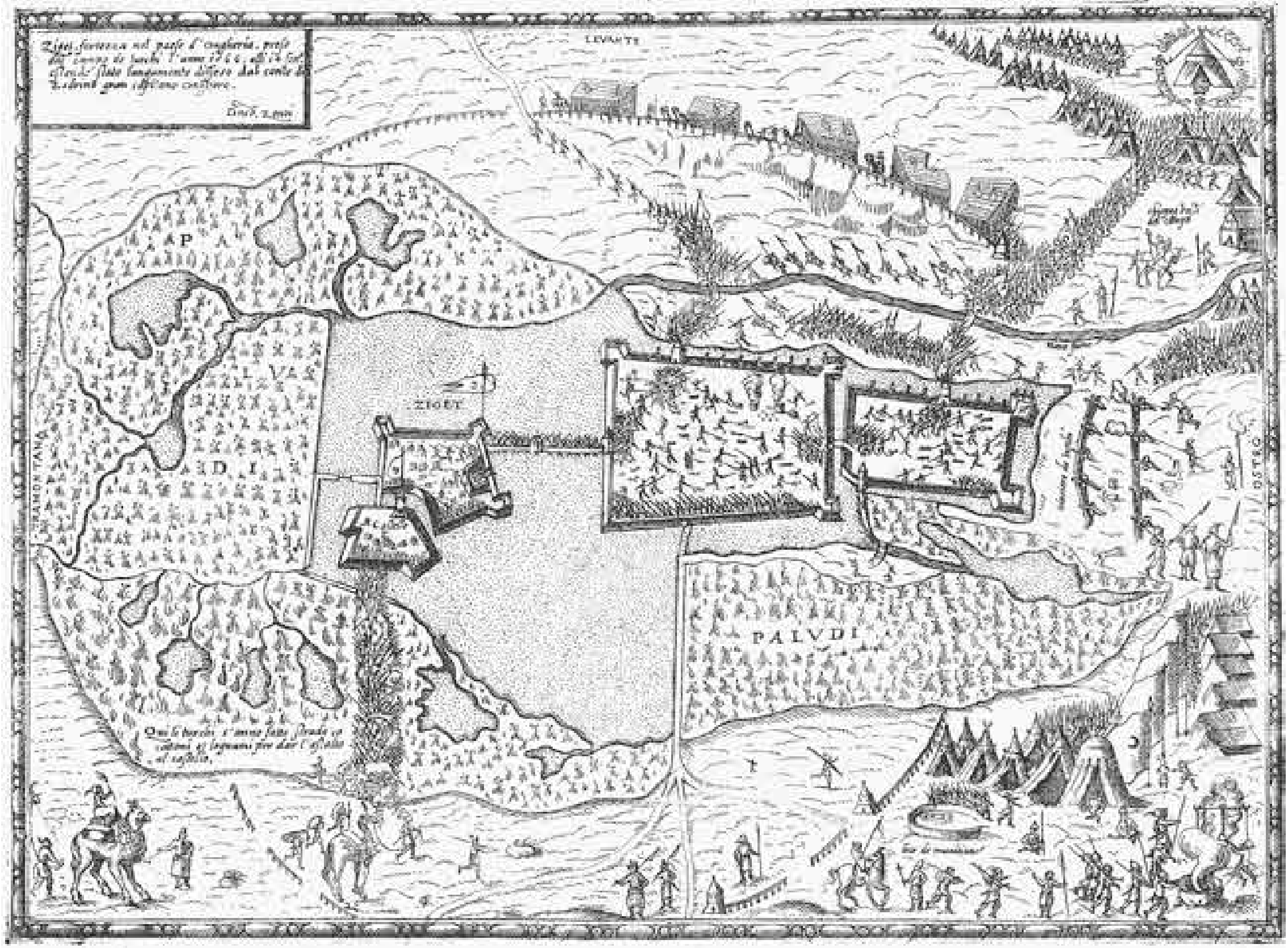




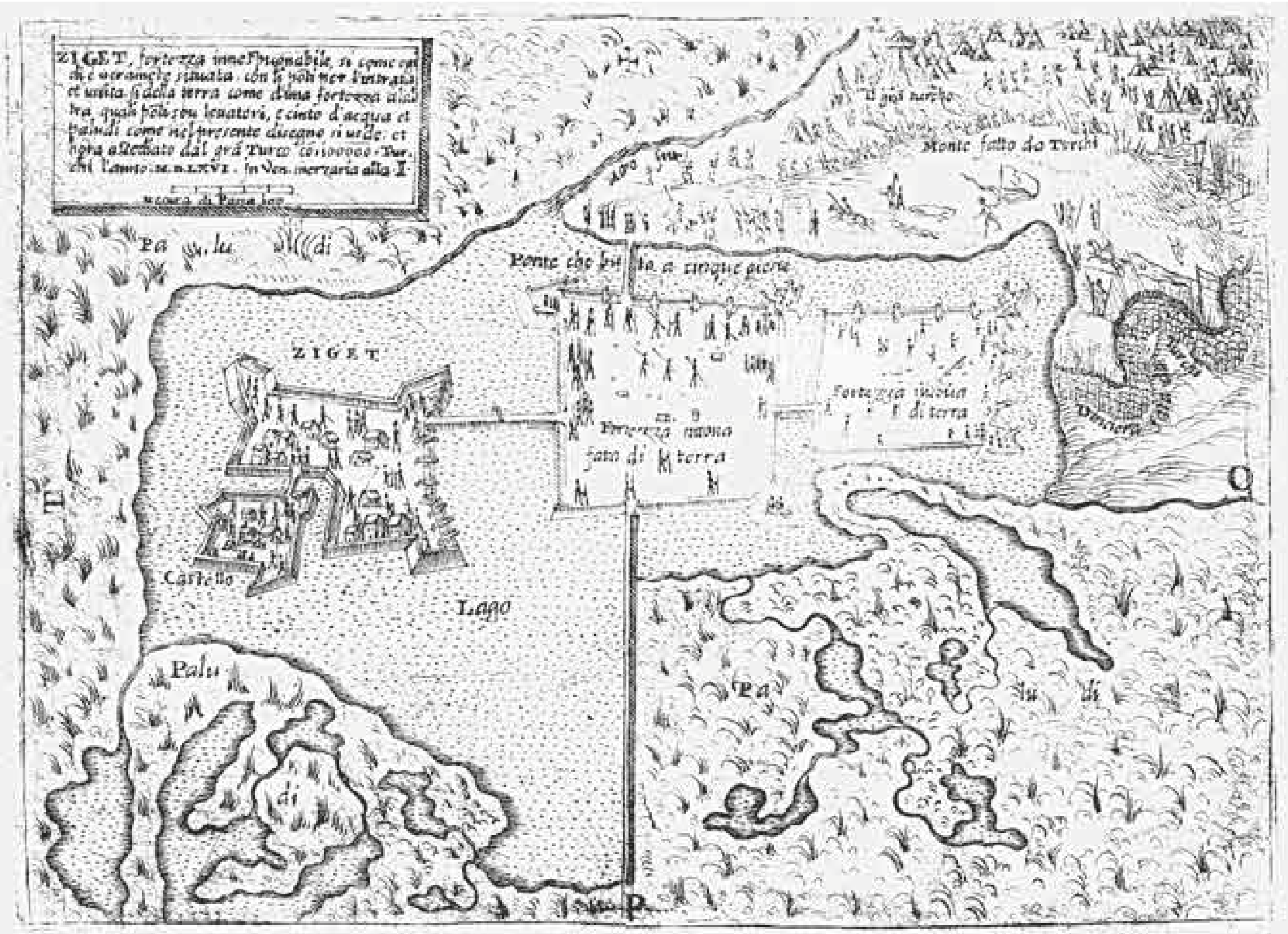




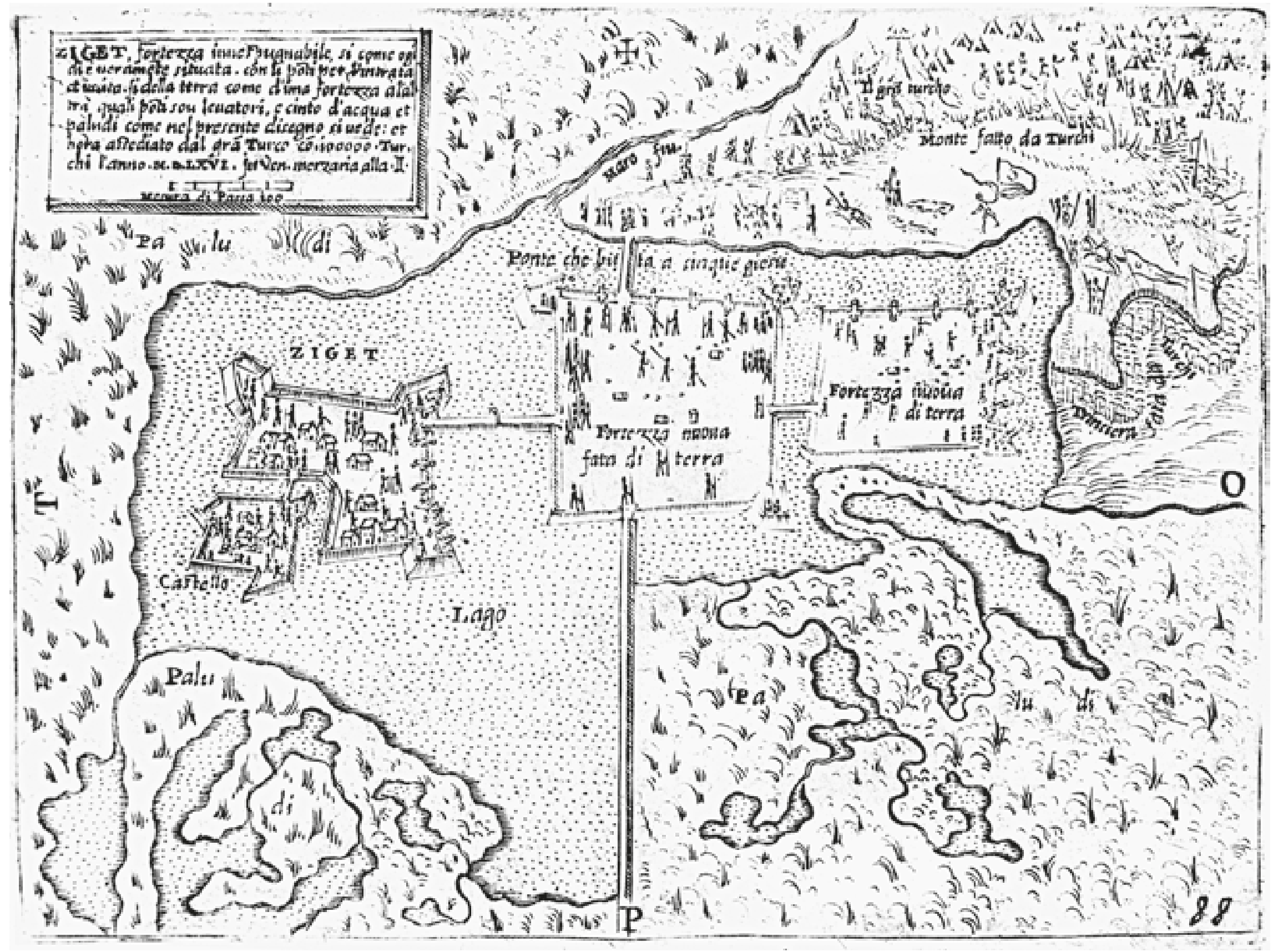




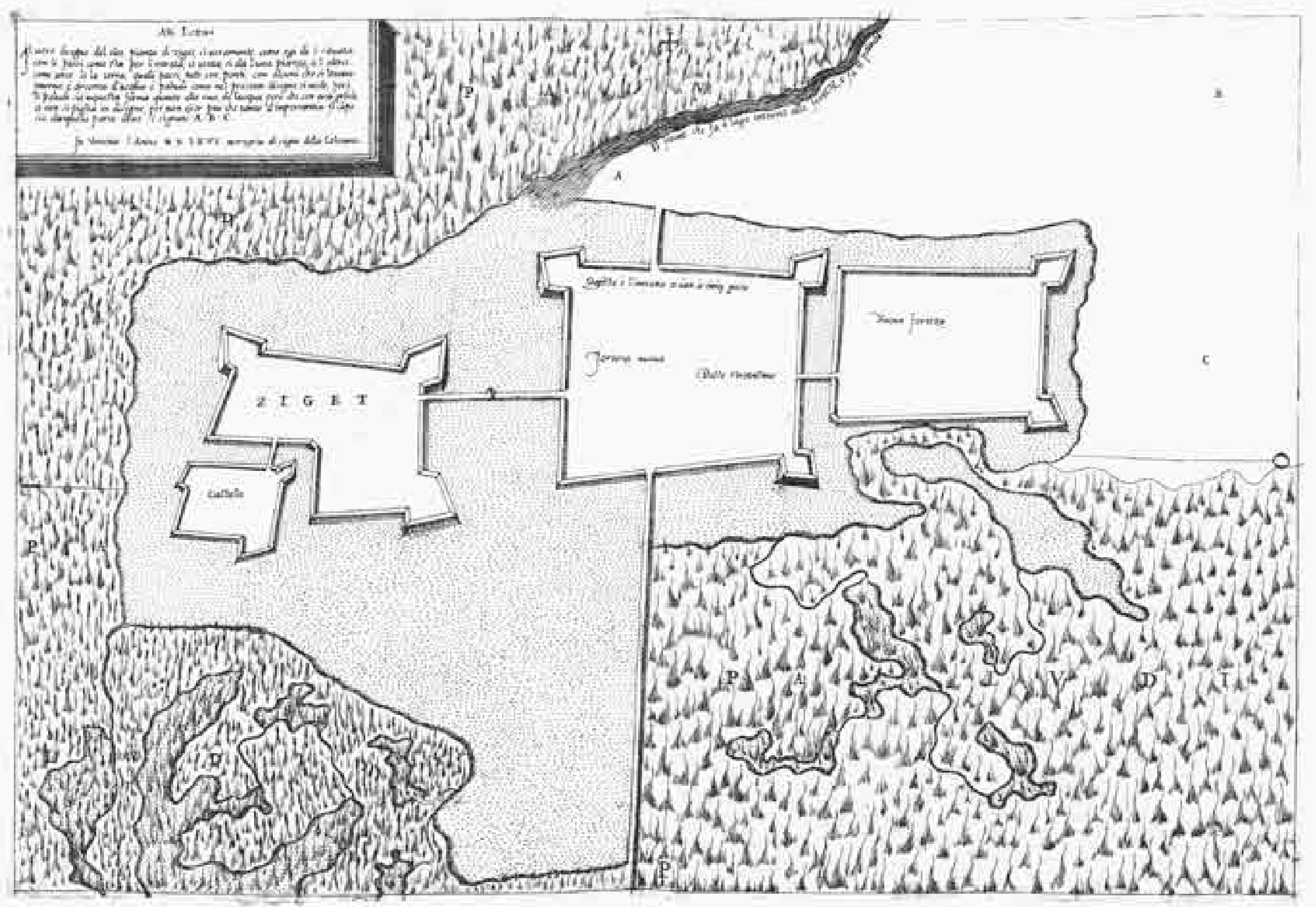




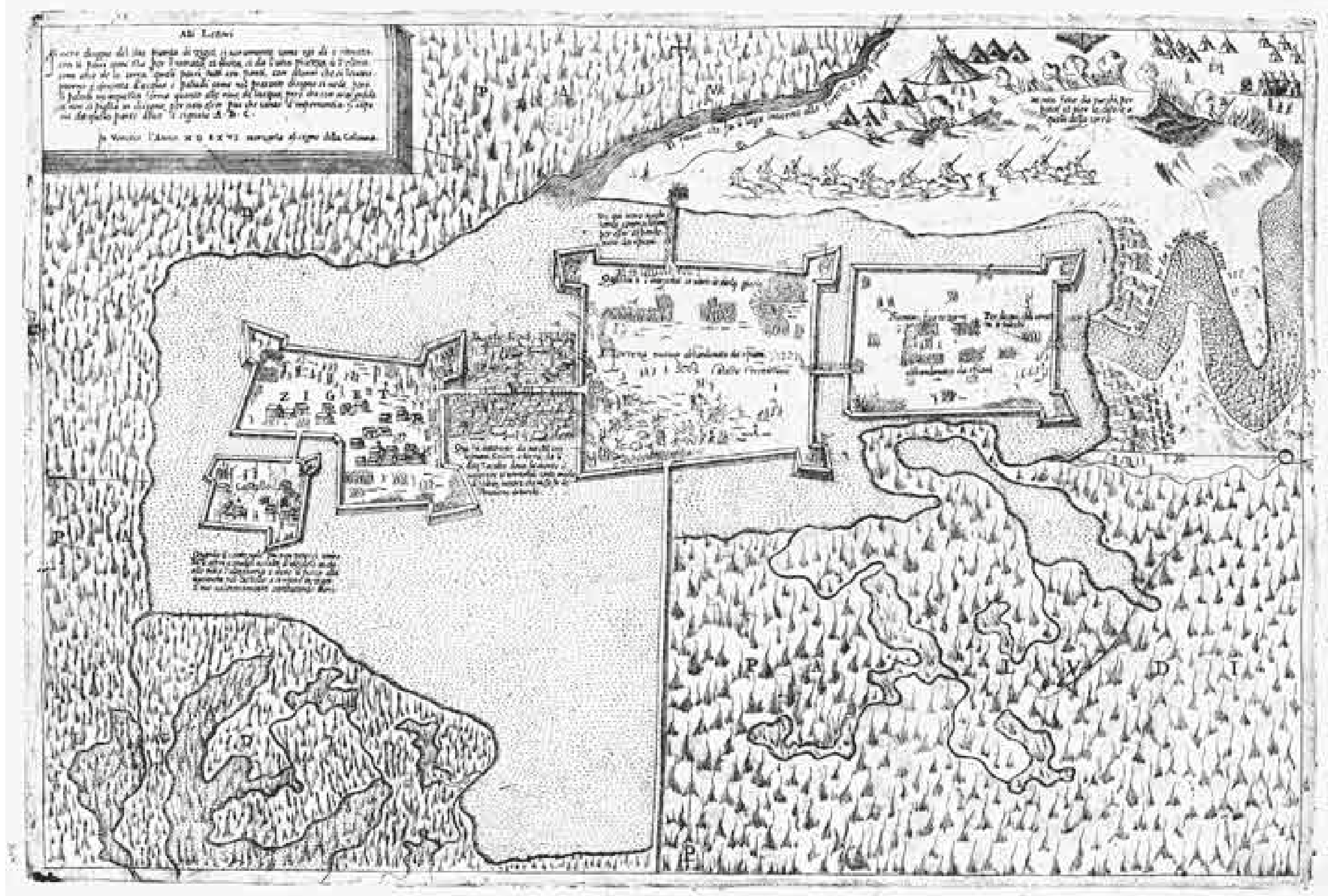




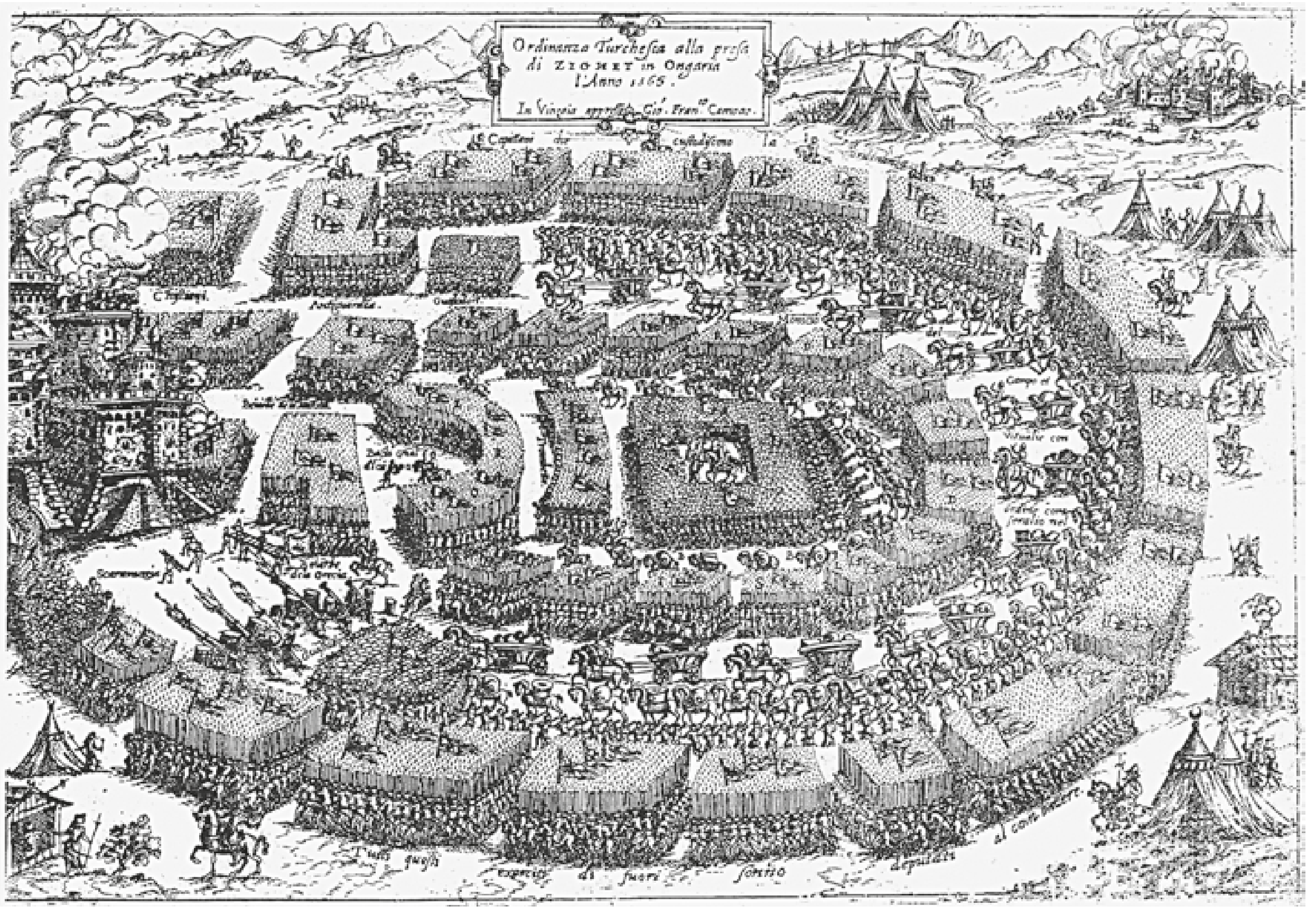




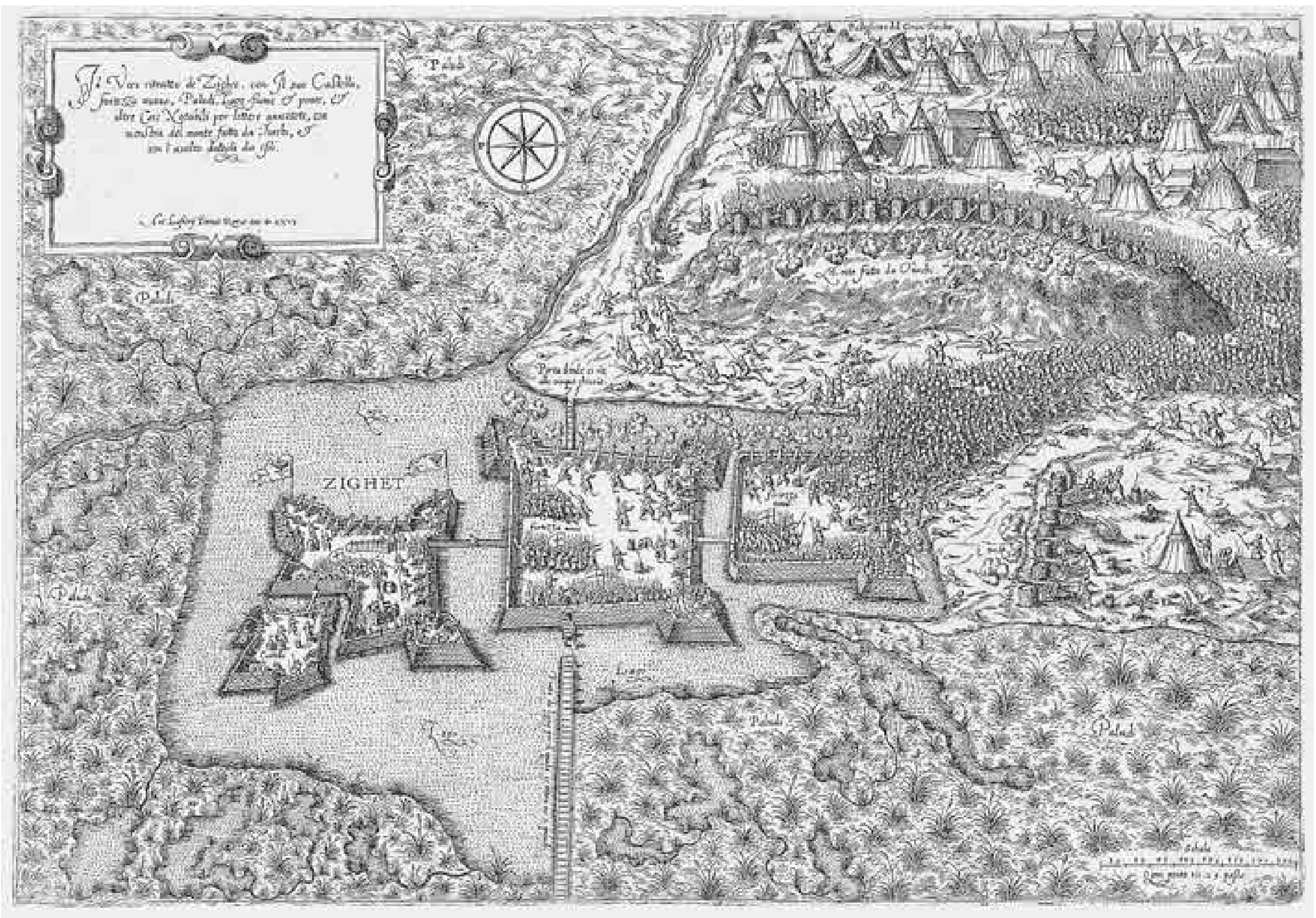




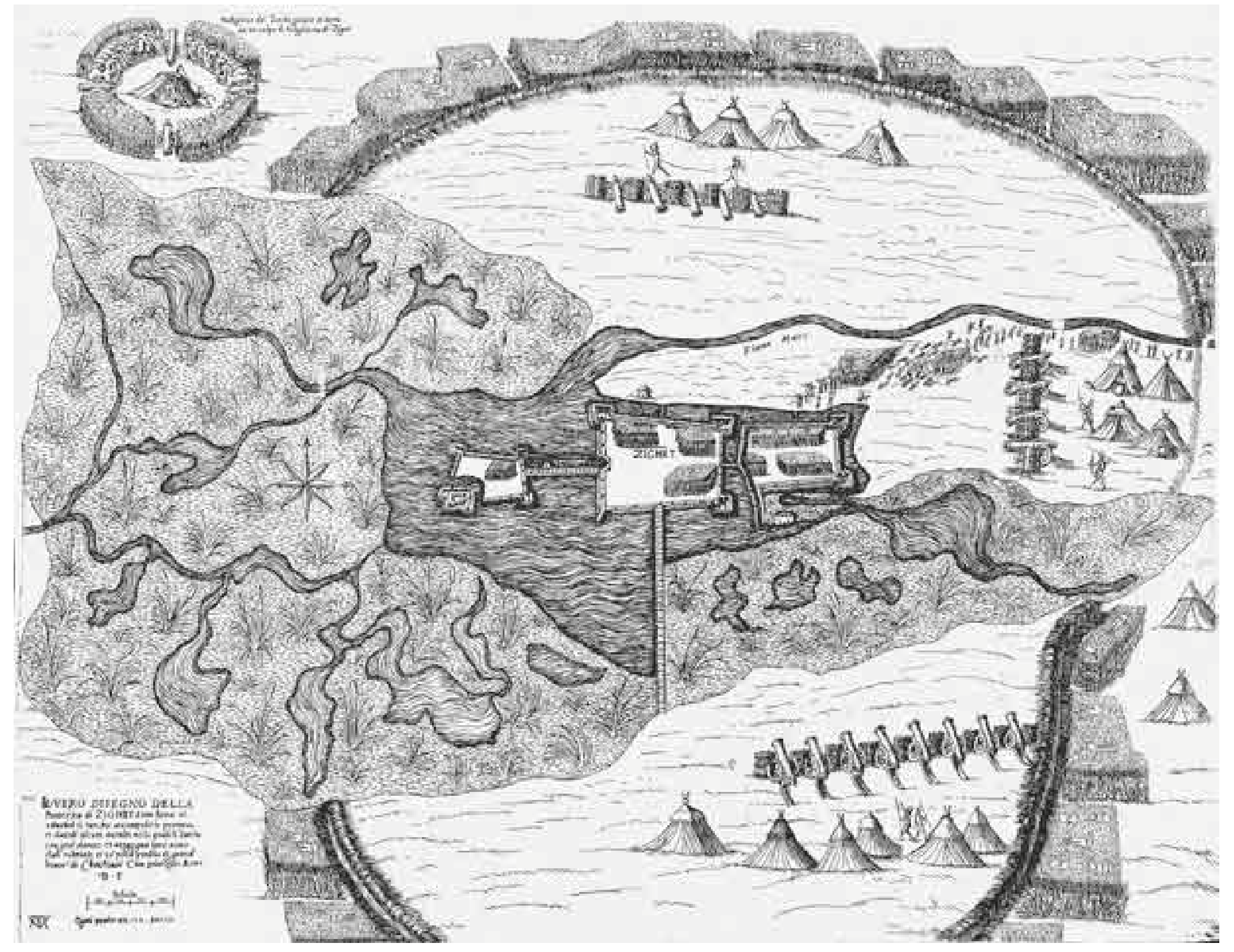


LE VRAY POVRT RAIOT DFS FORTSDE SECHIT ASSIEGEE PAR LES TVECS M D L X V I

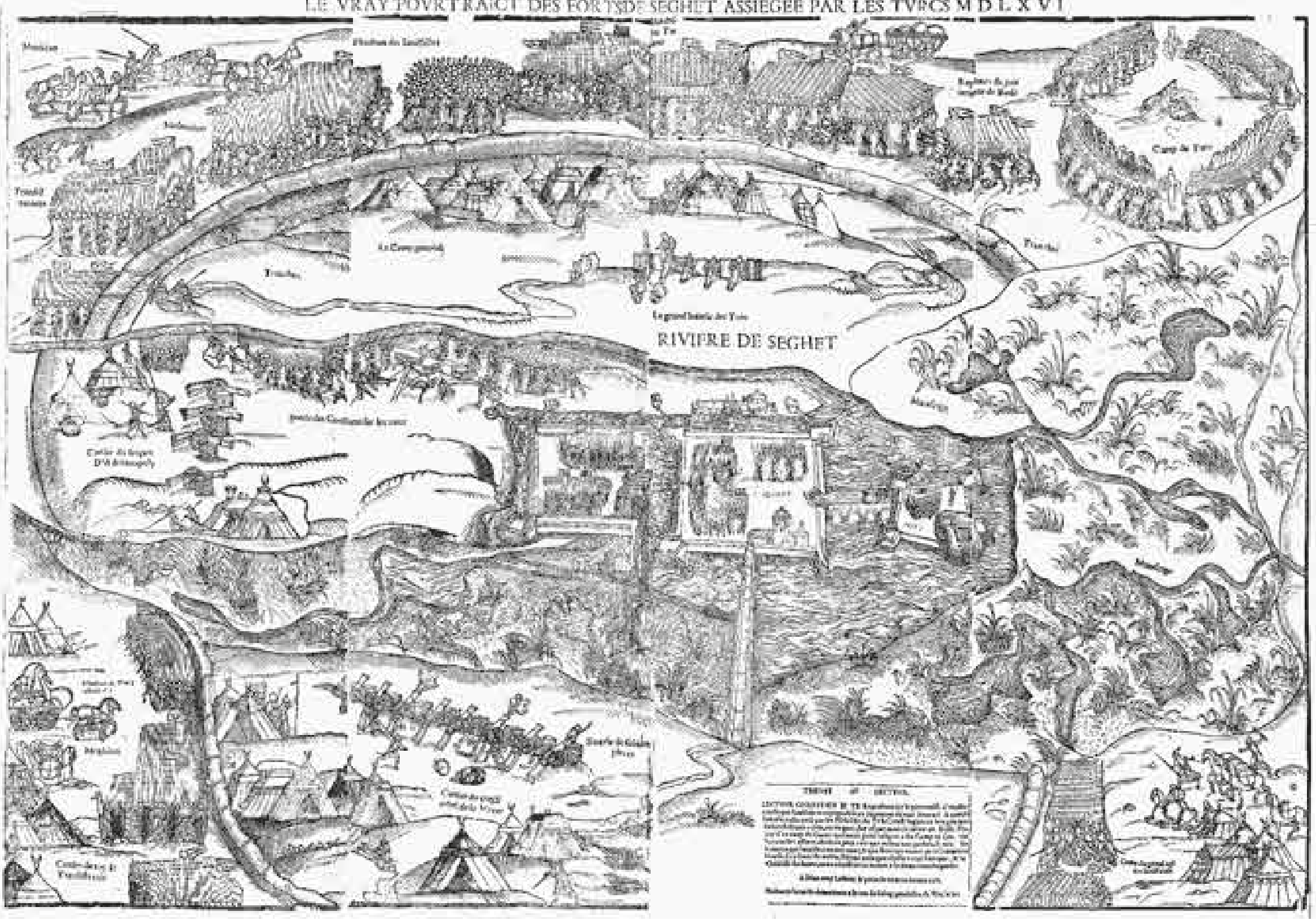




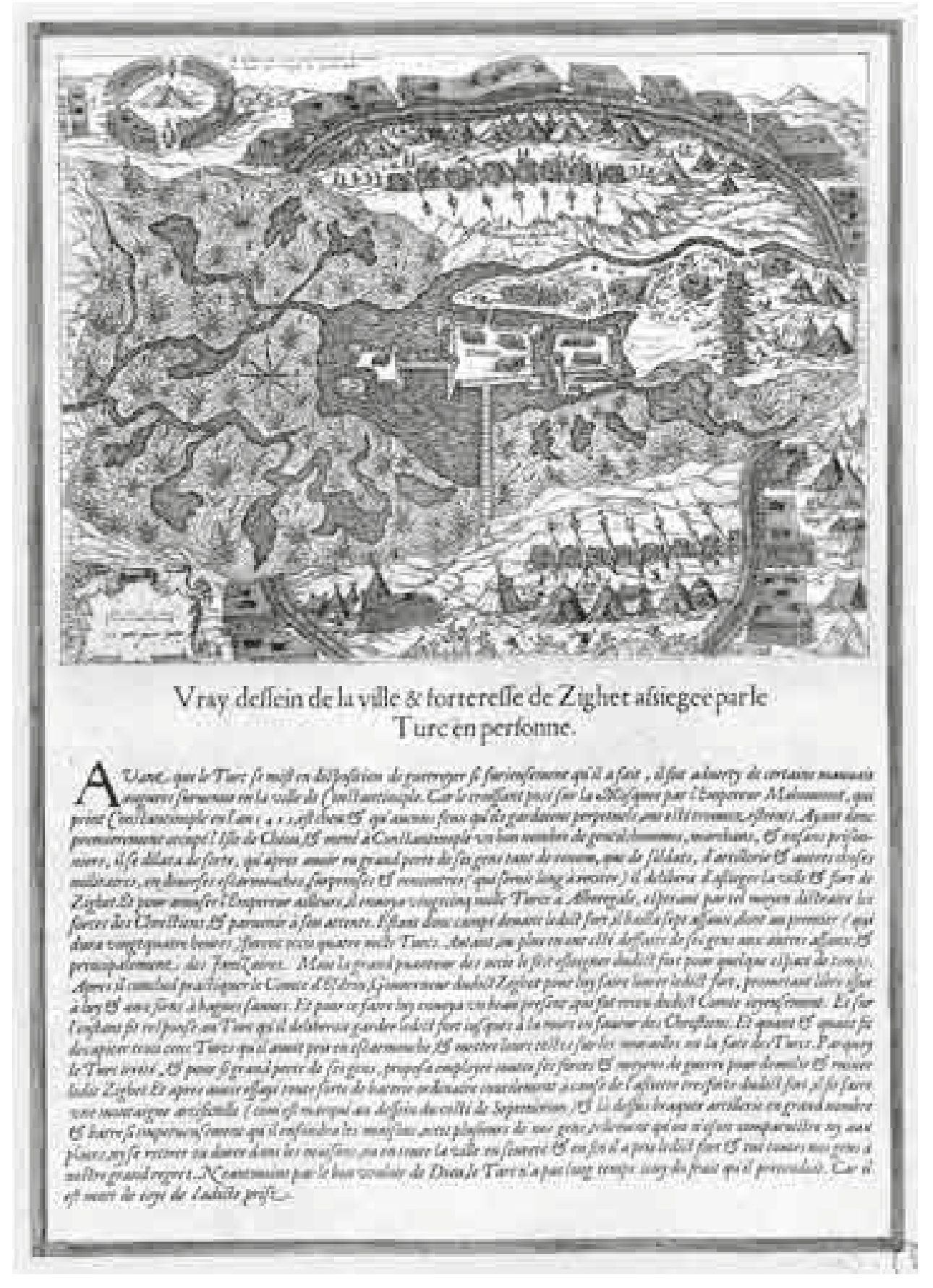




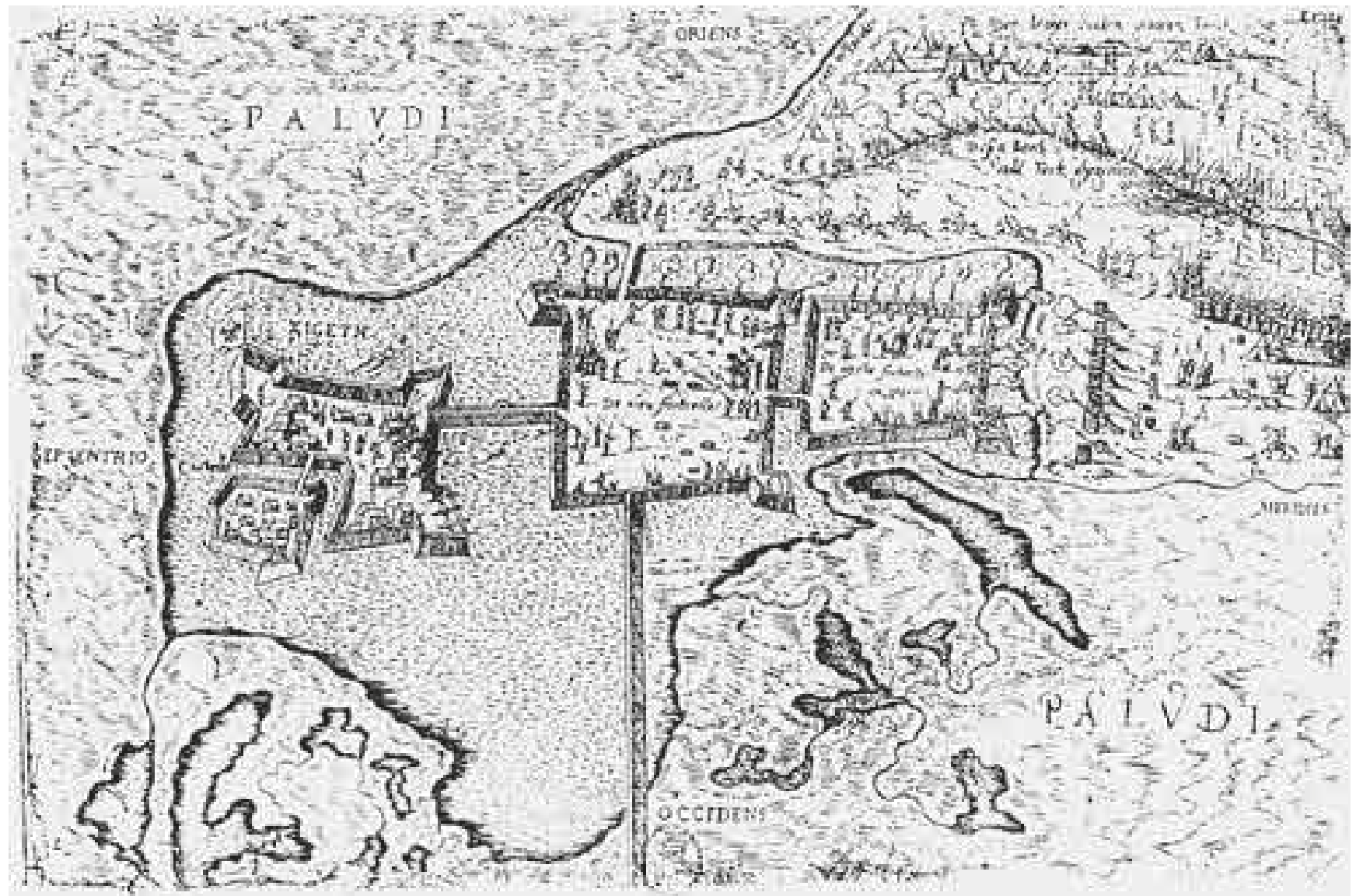

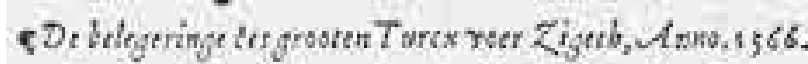

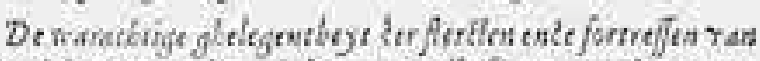

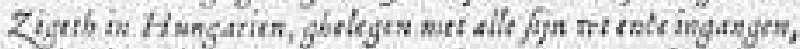

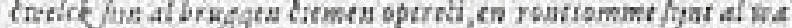

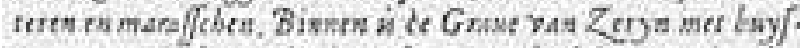

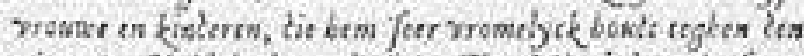

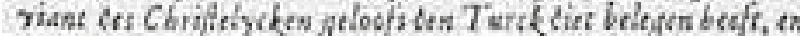

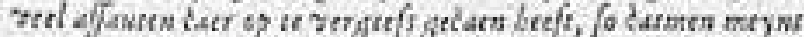

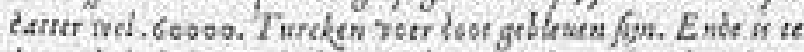

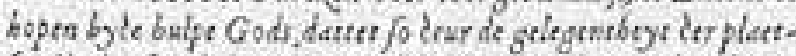

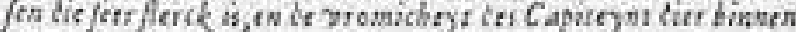

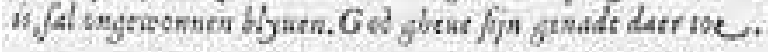

$\rightarrow$ sGeprint Thantwerpen by Hans Liefrinck.
- Ziguet affigé par le grand Tureq, Lan. igß6.

L A wave reprefentation de Ziguet, Ville, ou pluftoft for-

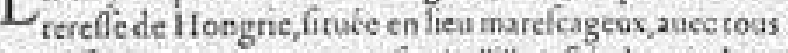
les pitfages, pour $y$ enetrer ou fortir d'ilise, foit dans on hors la ville, ou bien d'v n fort ilautre, pue manisre de pons-lewis. L.a ou fe tronue enclos le Conte de Zetiib, ausc frume \& crfins, courigeux defenteur de ceffe forte place, contre le grand Tureq, ennemy mortel de la Chreftienté, qui derant le fiege, en pluficurs affats donnez en cain, ponr le prefeot (cóne i oa diet) h ha perdu, 60000. Tures, en forte, que tane

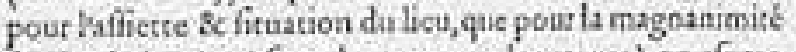
du Capitaine ( qui font deux grans adoantages) on efpere le dut Zigues pour maintenant effre garanty de la tyrannice Turquelque, A la solonté de Dieu. 


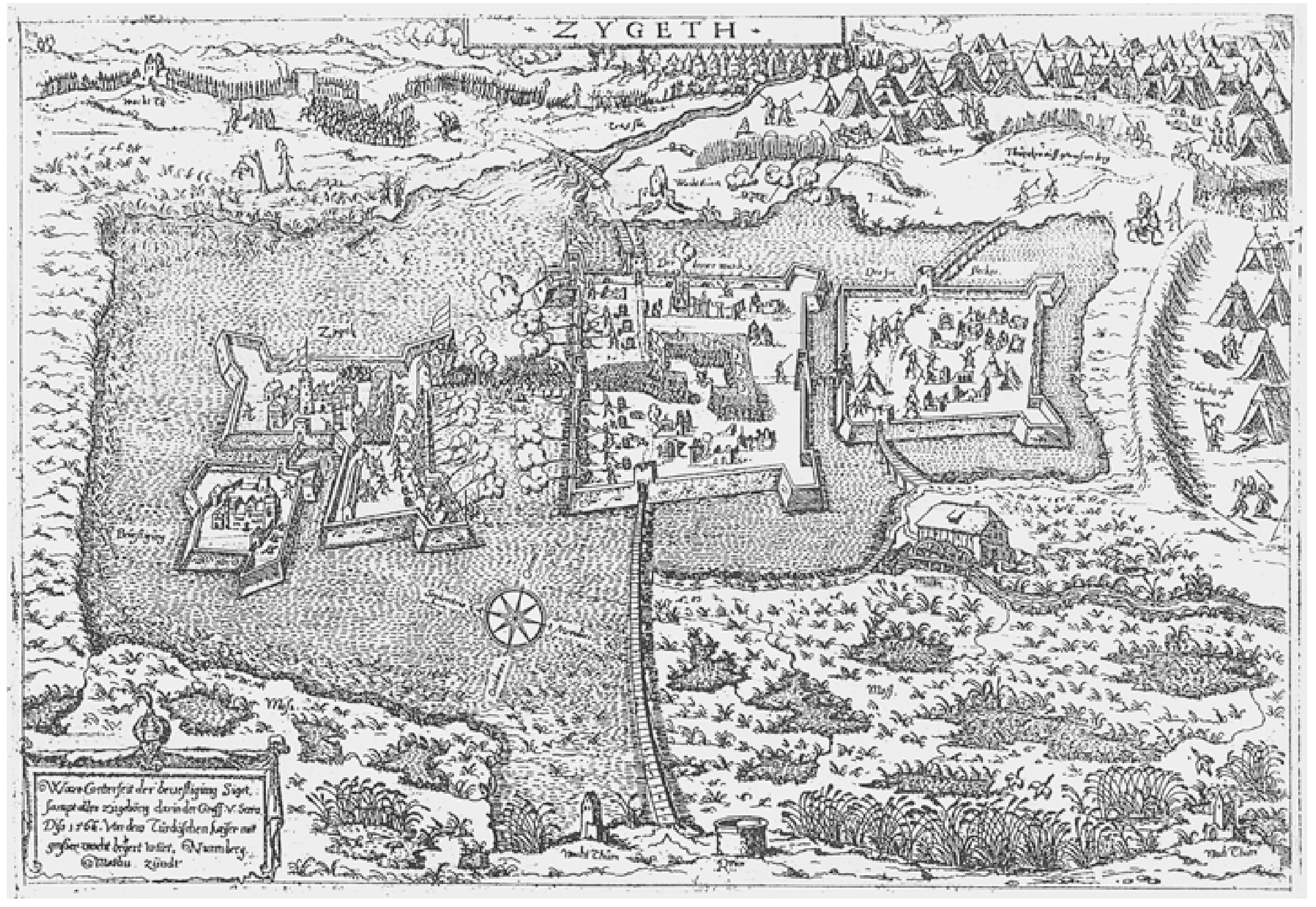




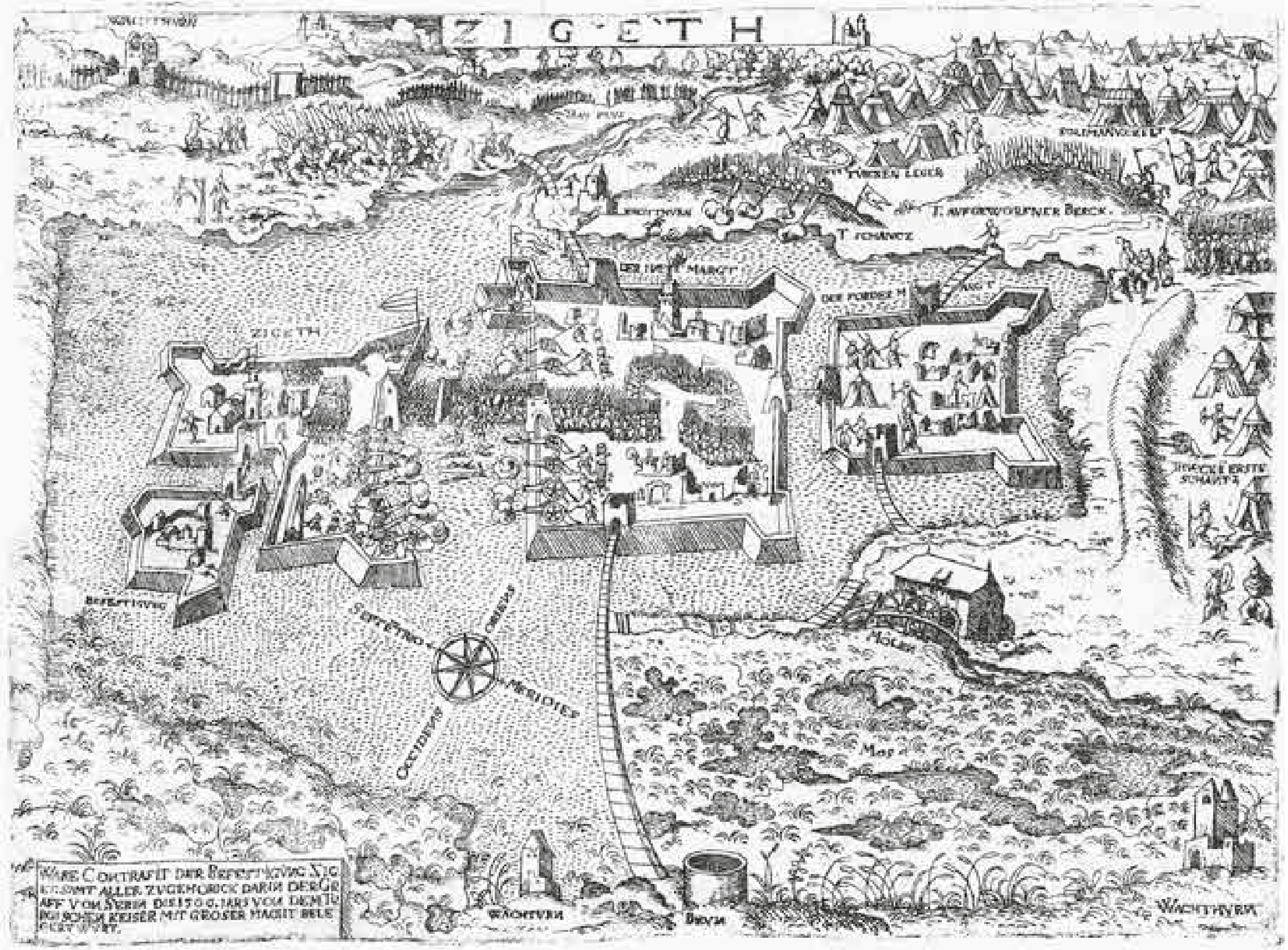




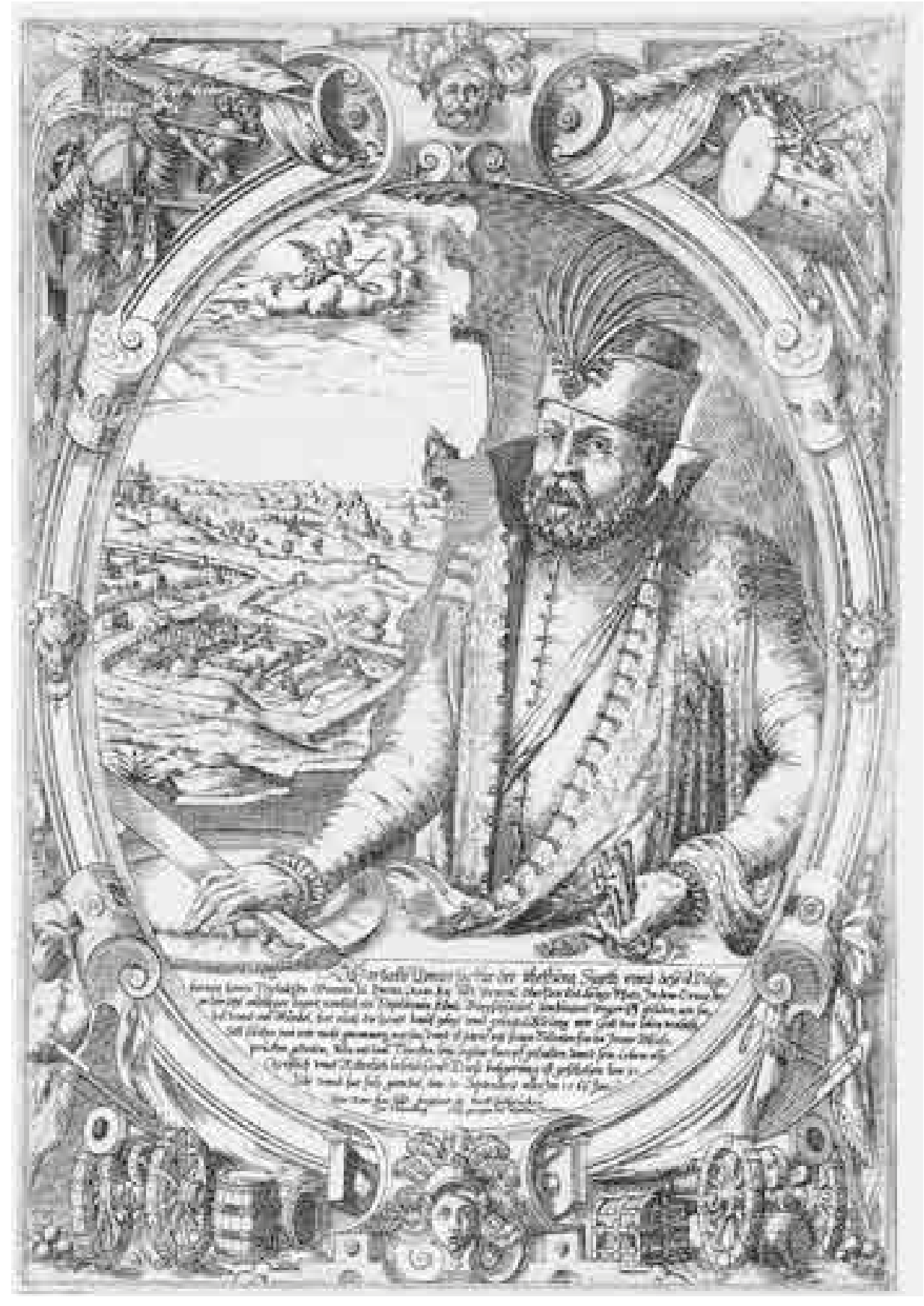




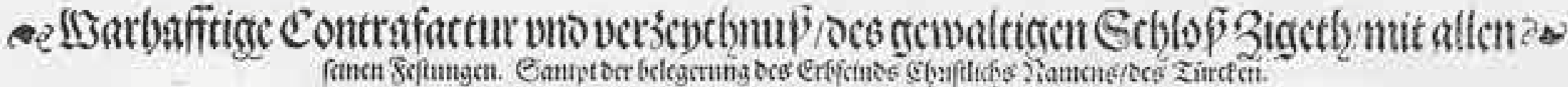

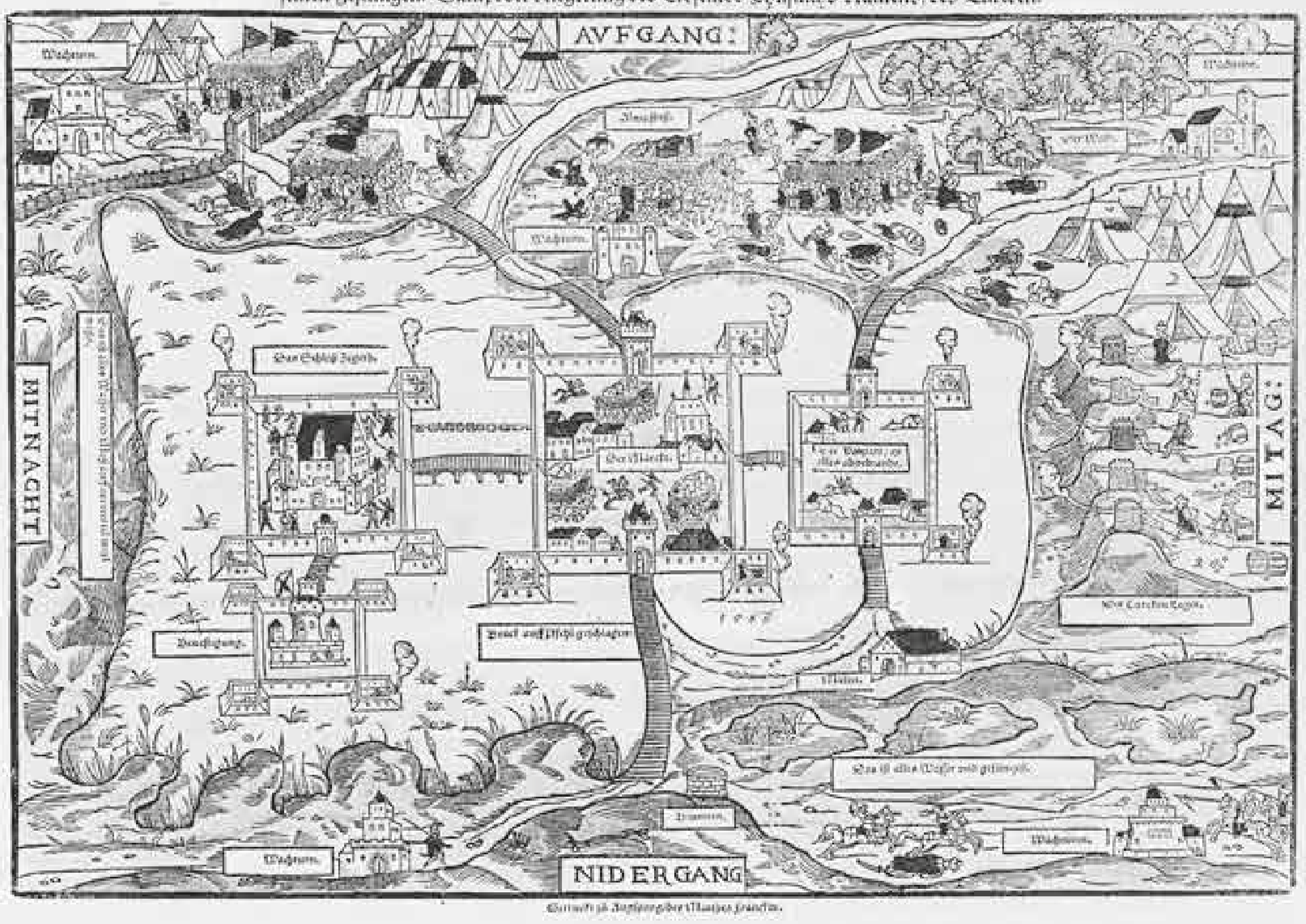




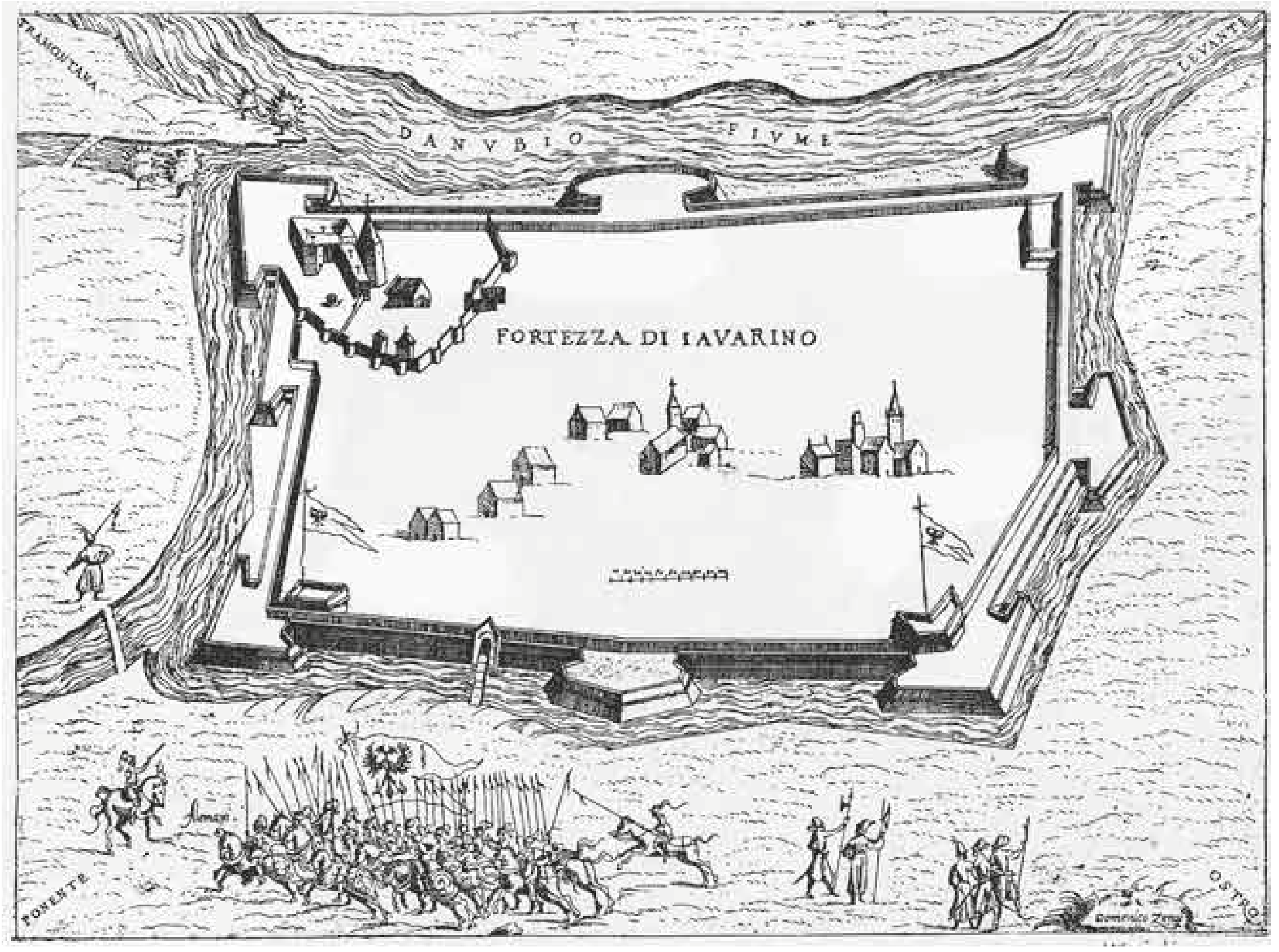




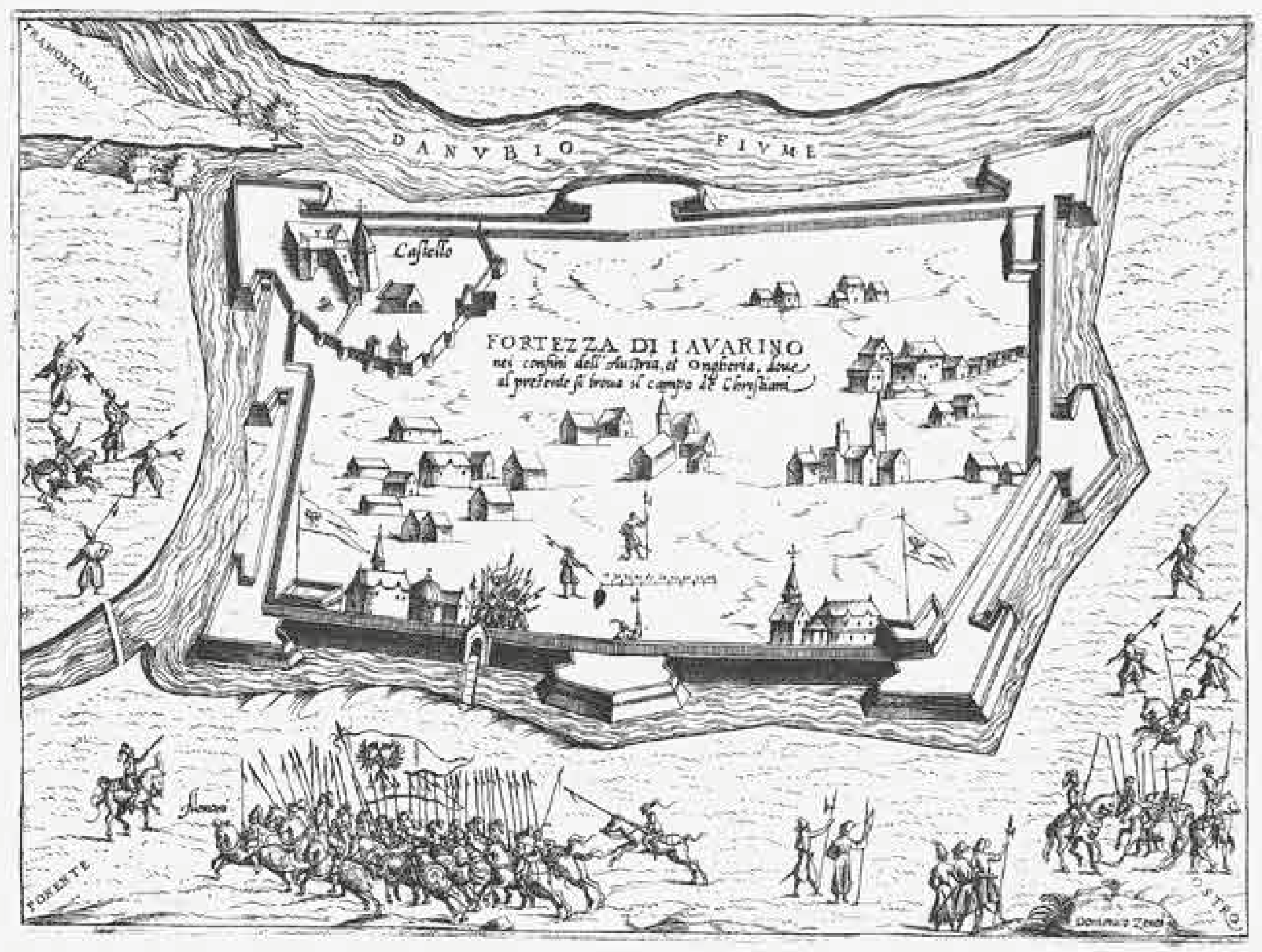




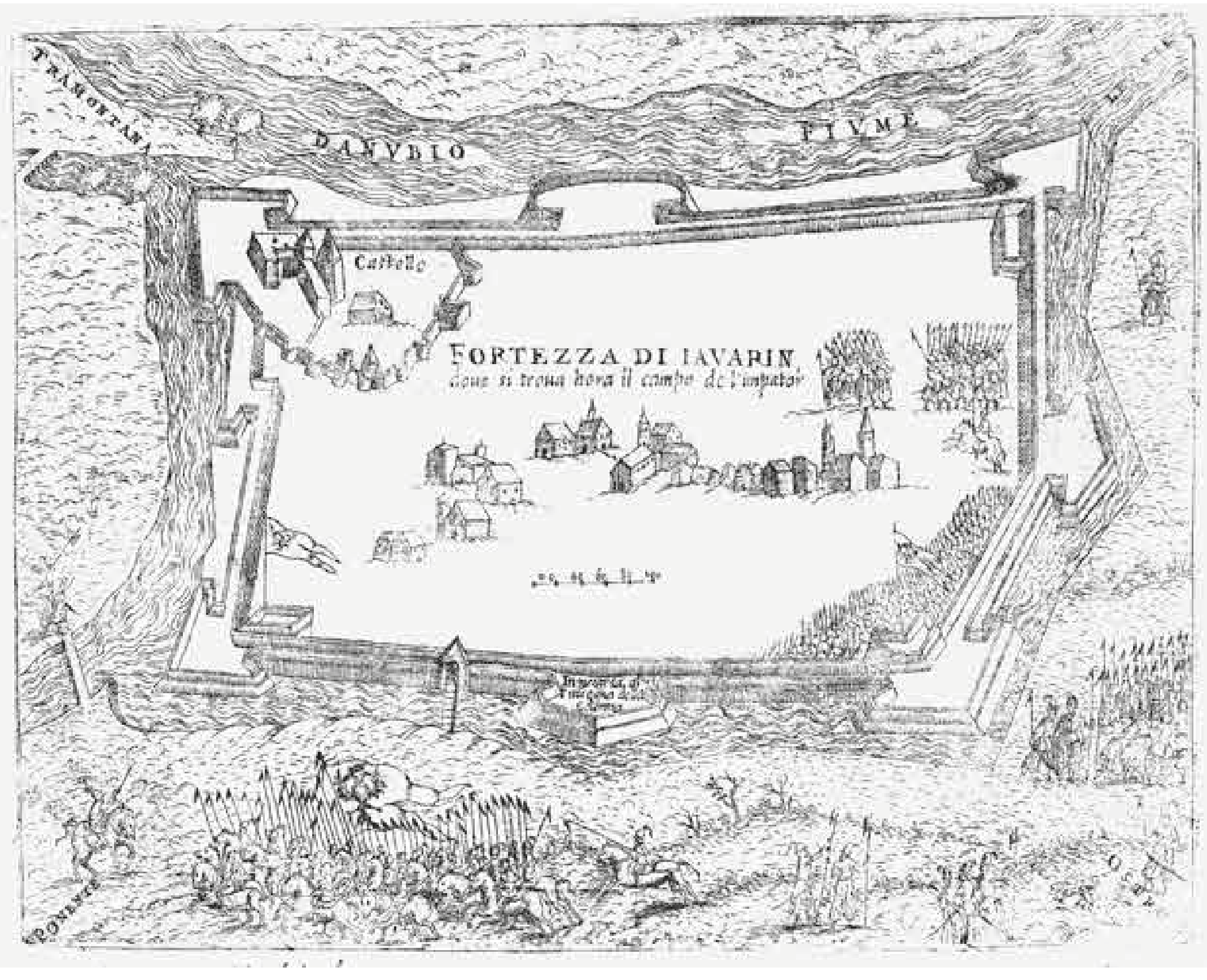




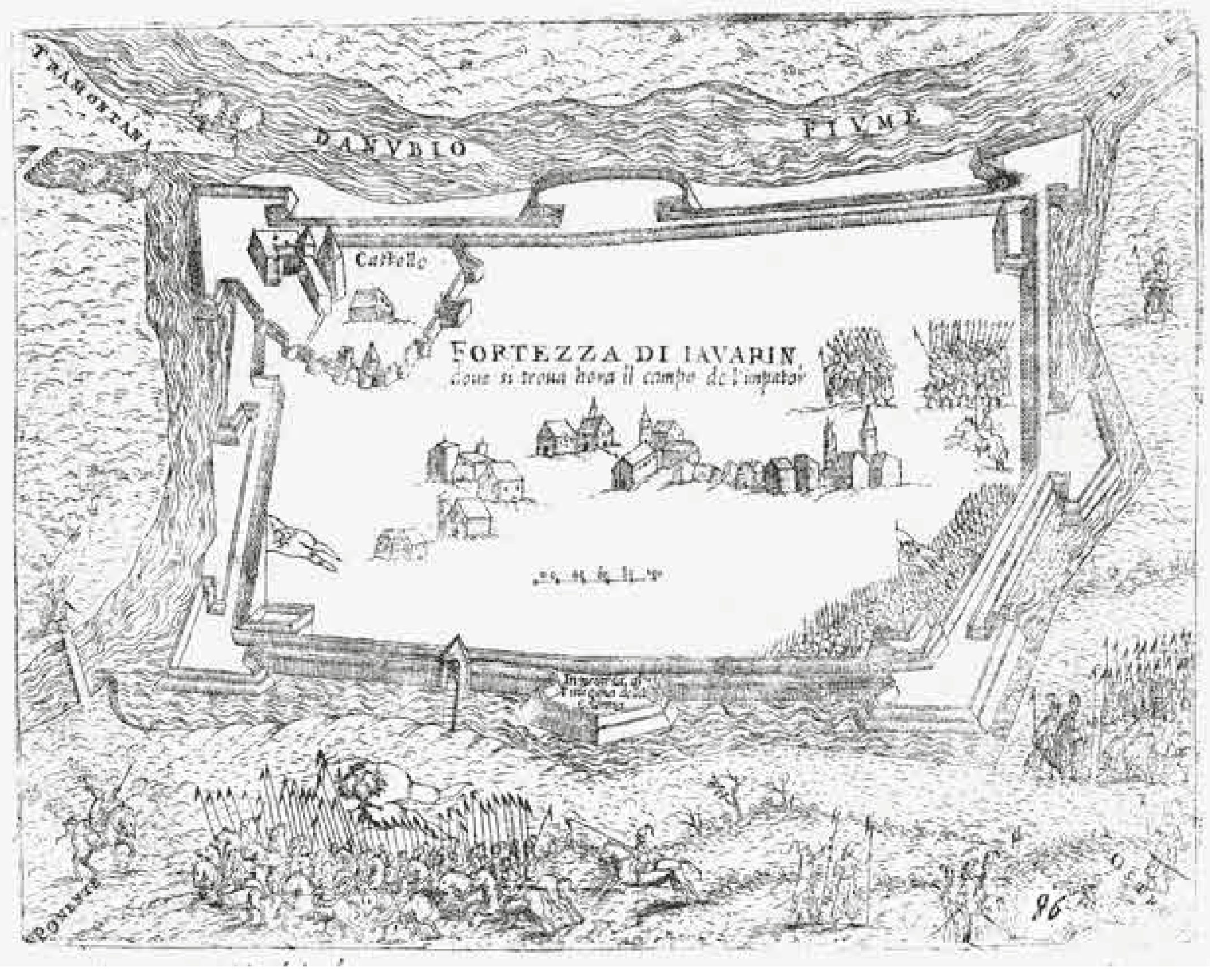




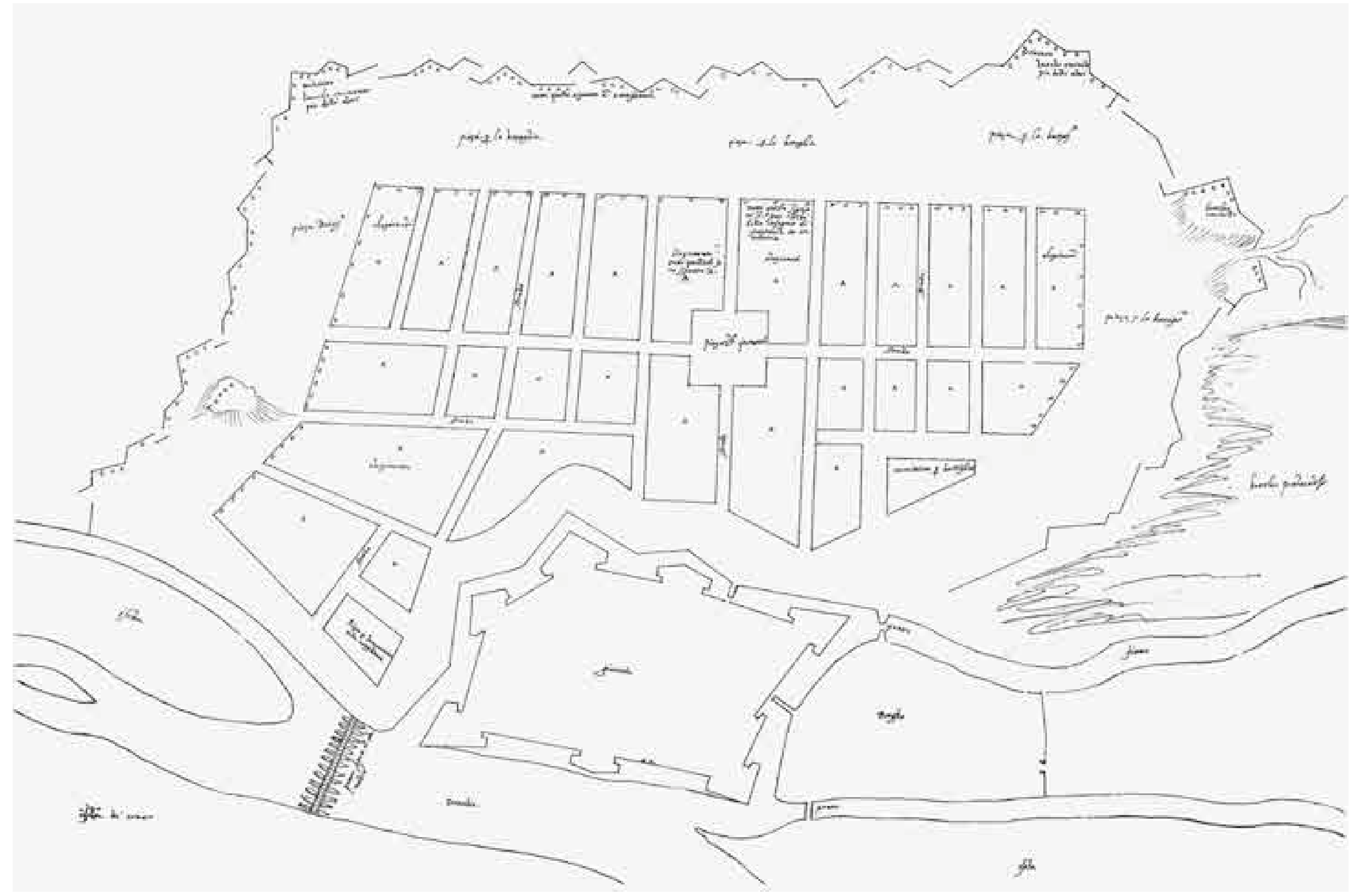




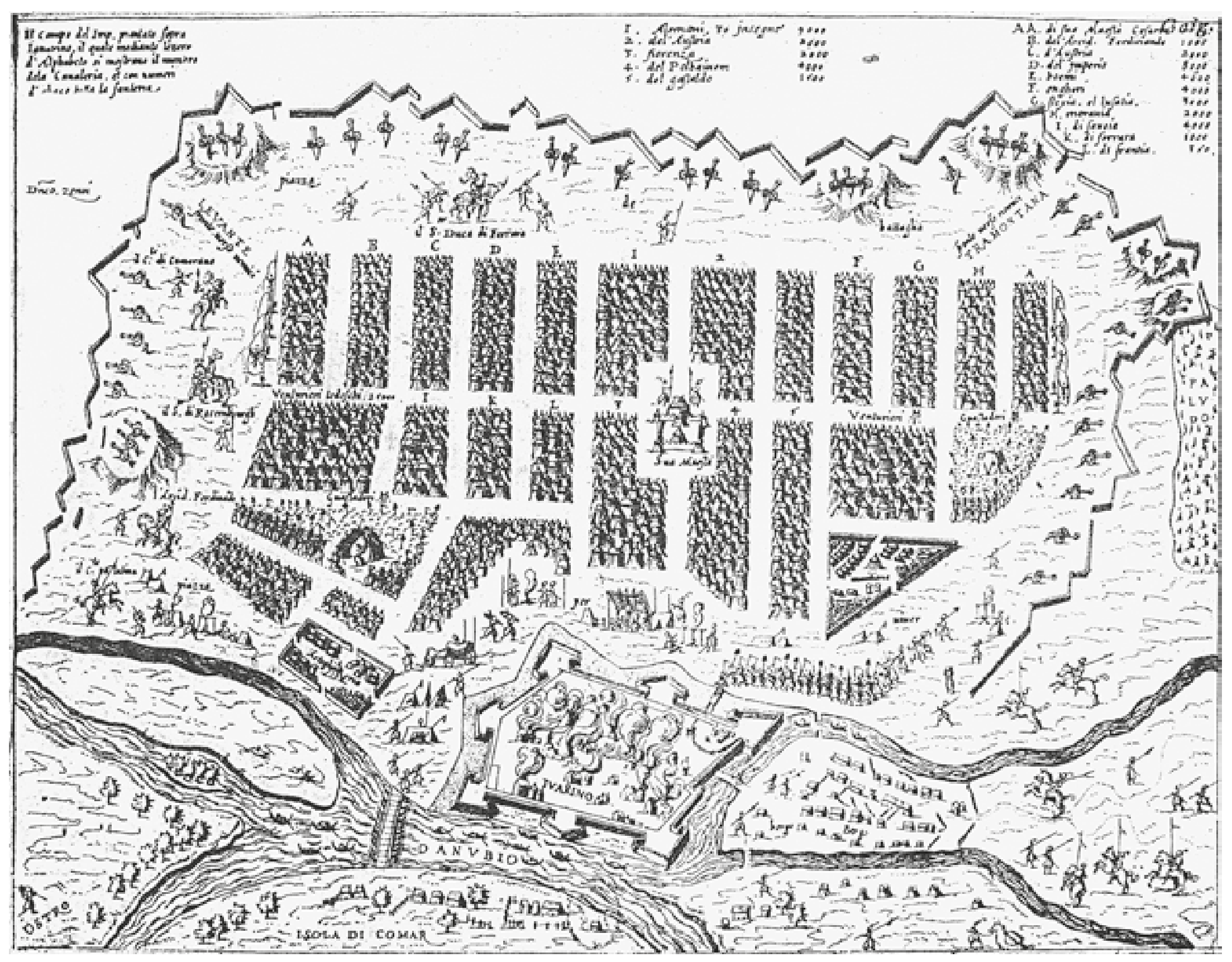




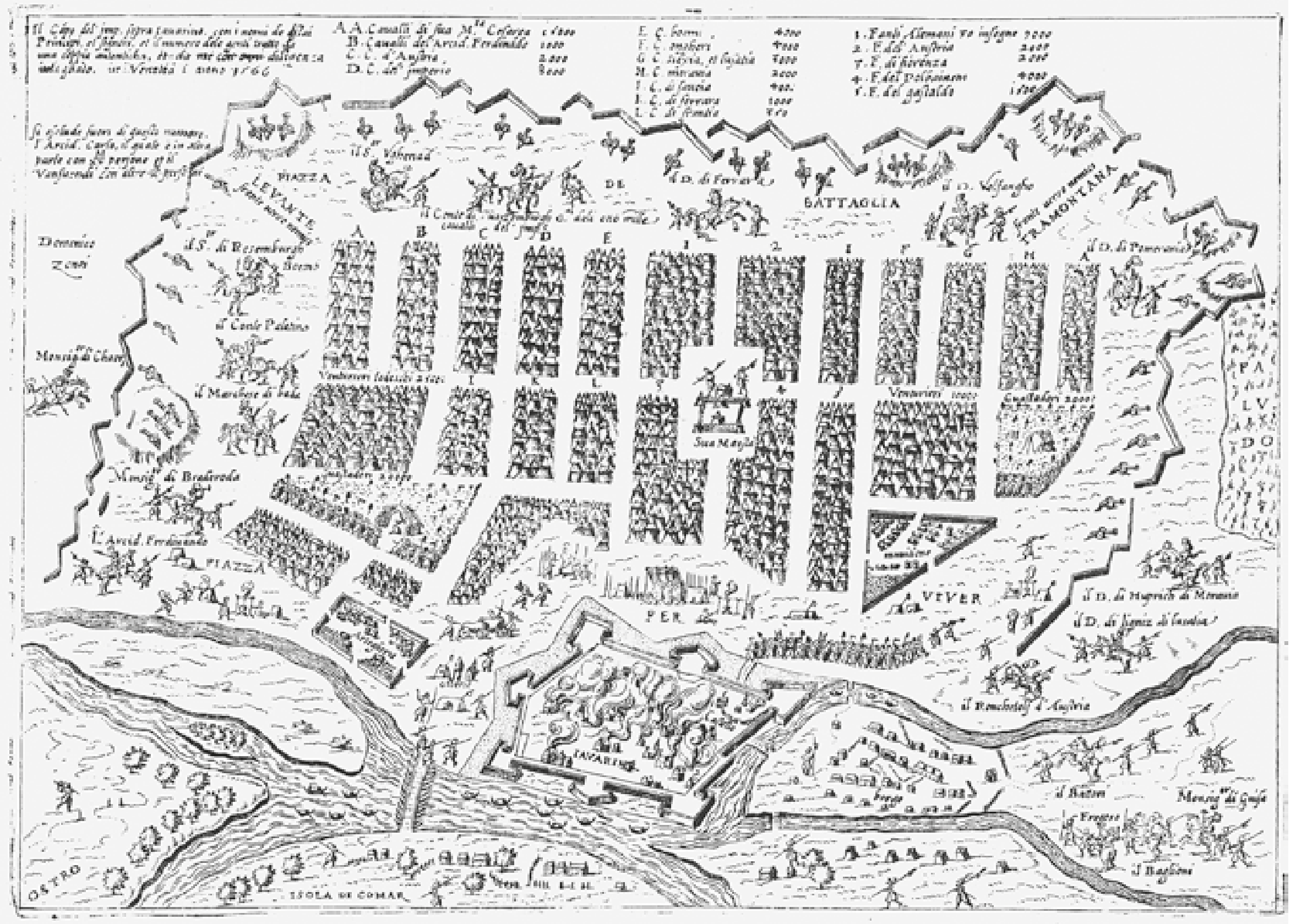




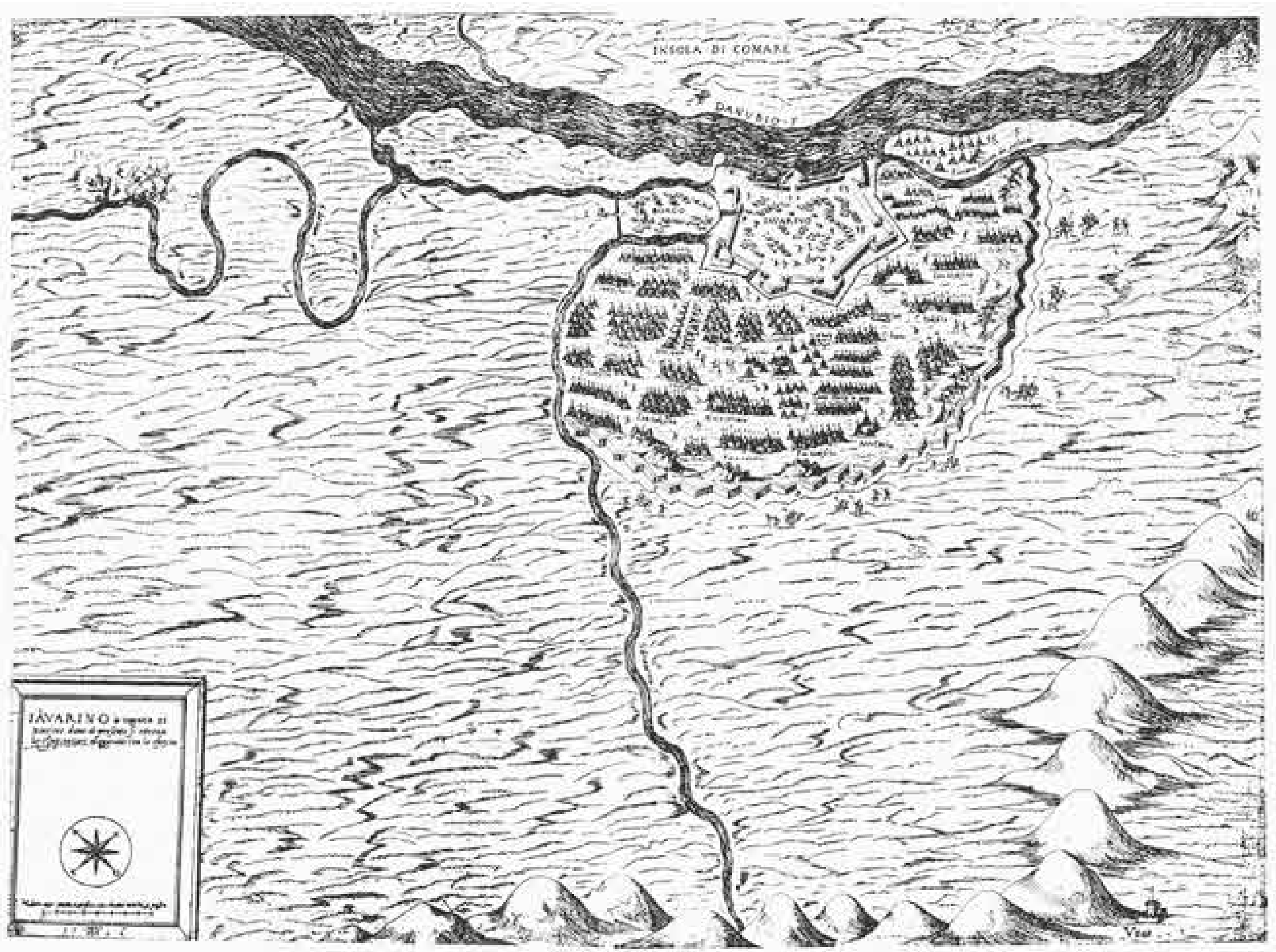




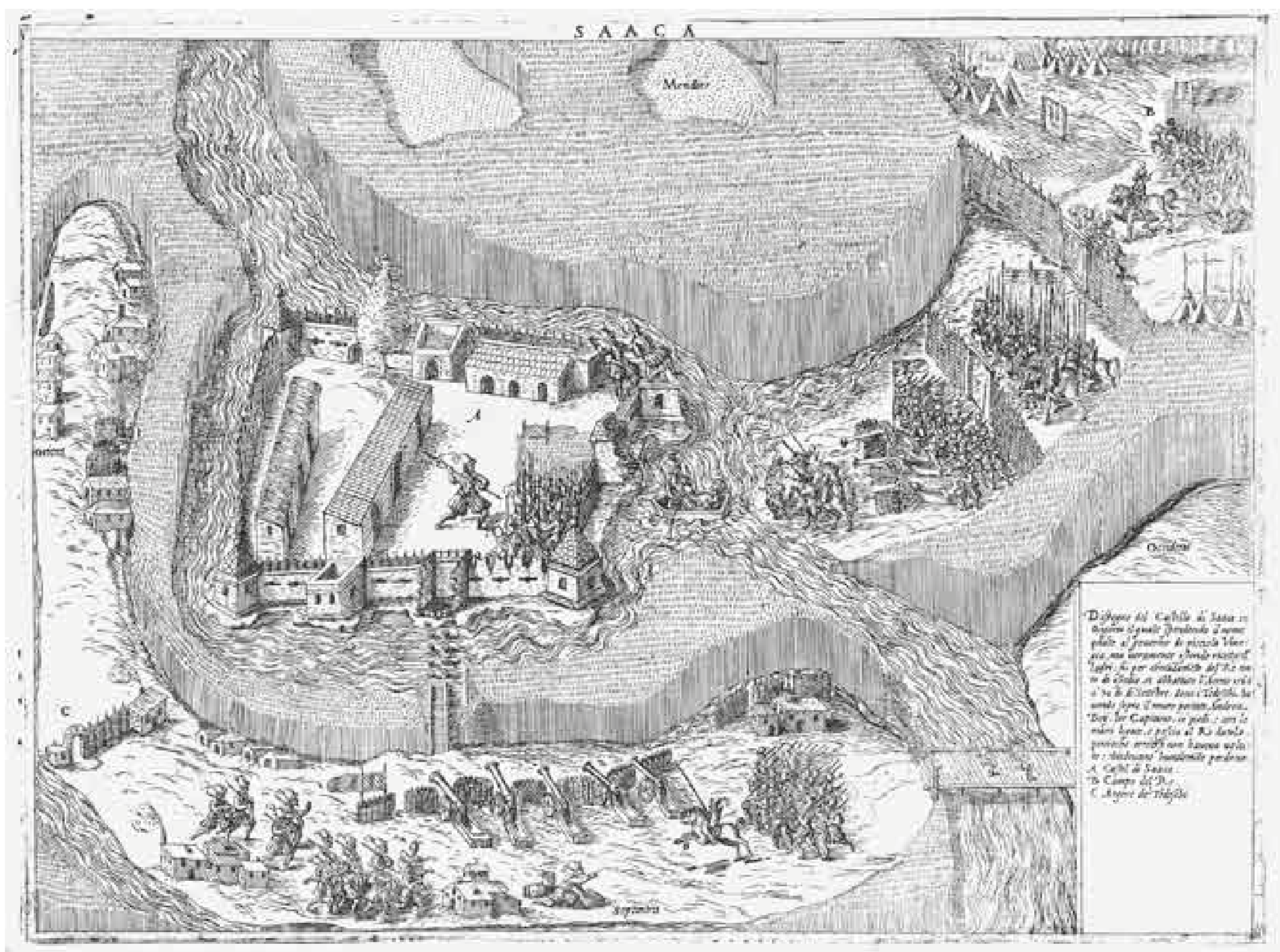




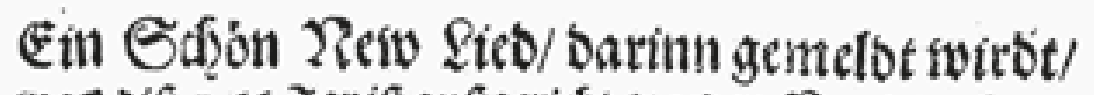

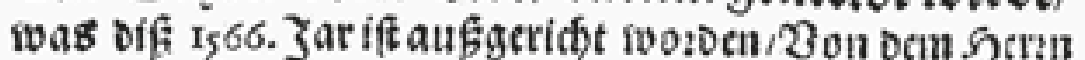

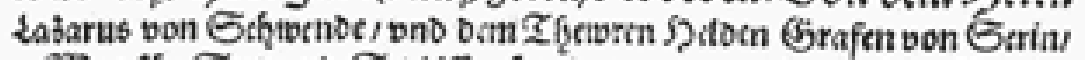

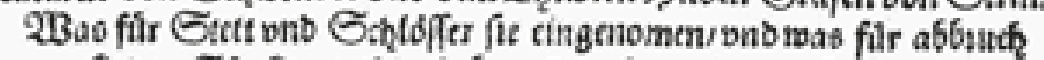

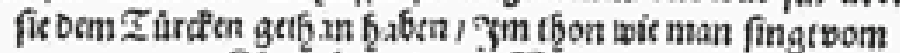
Rintg Eabtoig aub $\mathfrak{D}_{\text {ngern/ }}$ c.

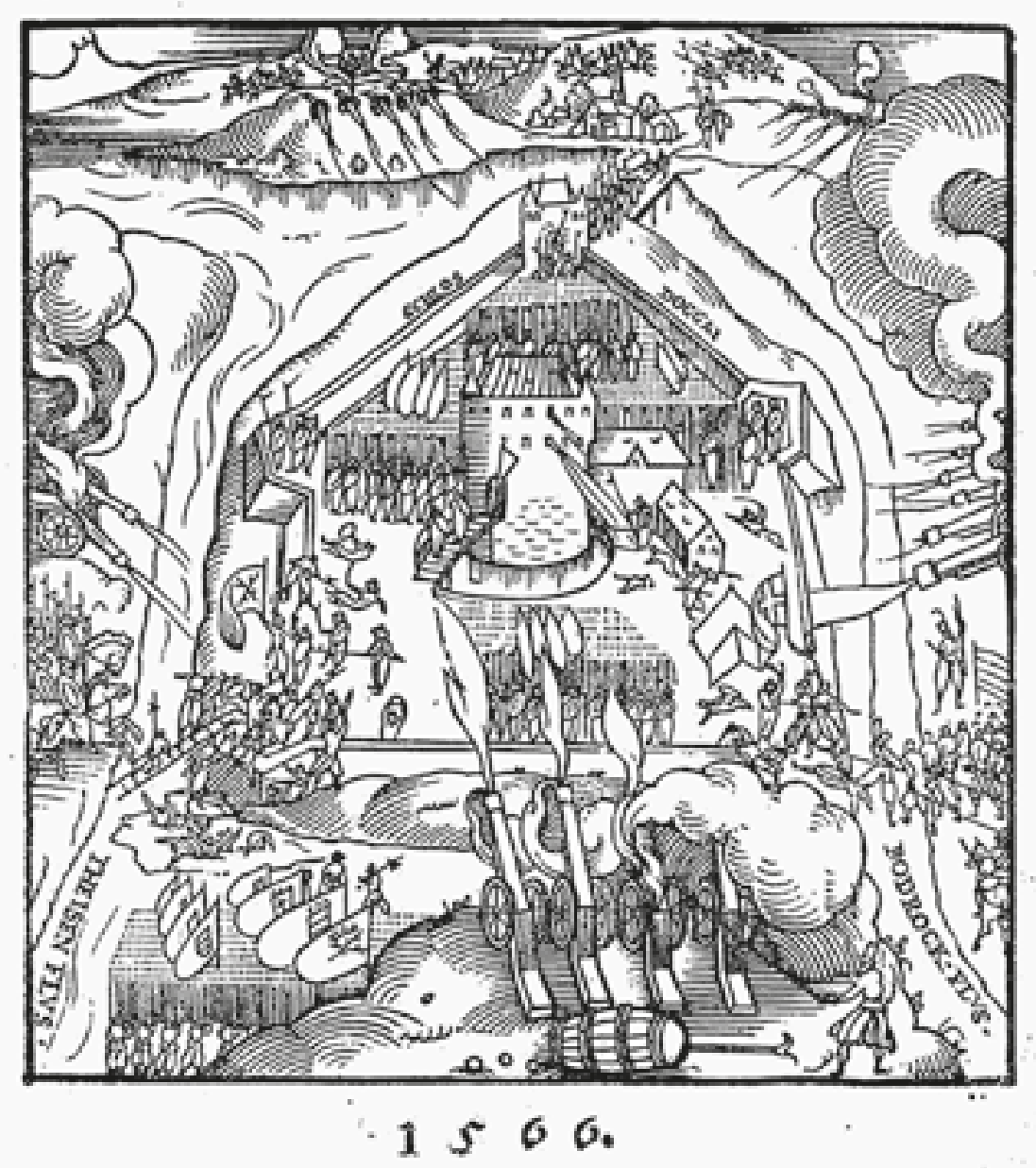




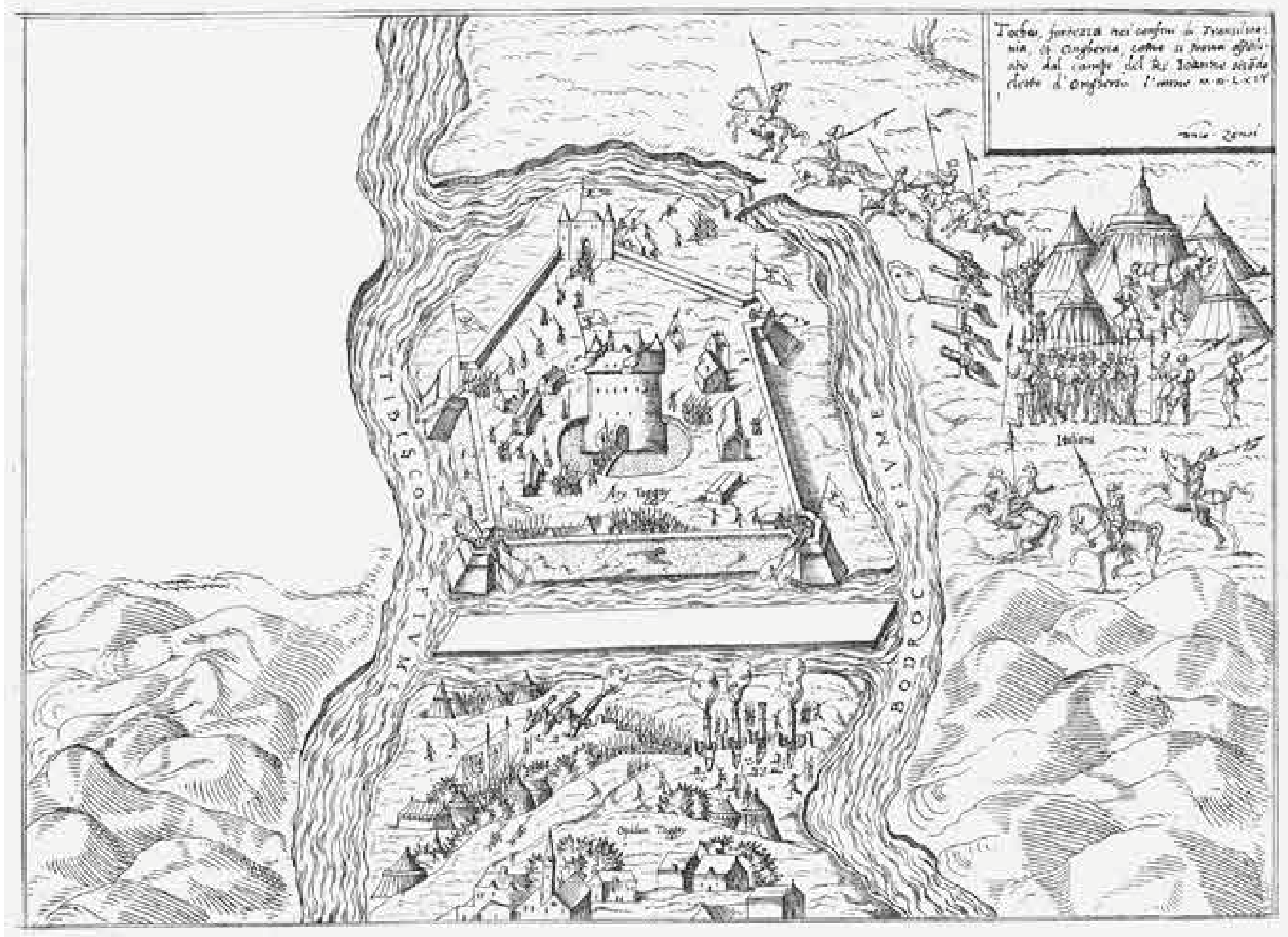




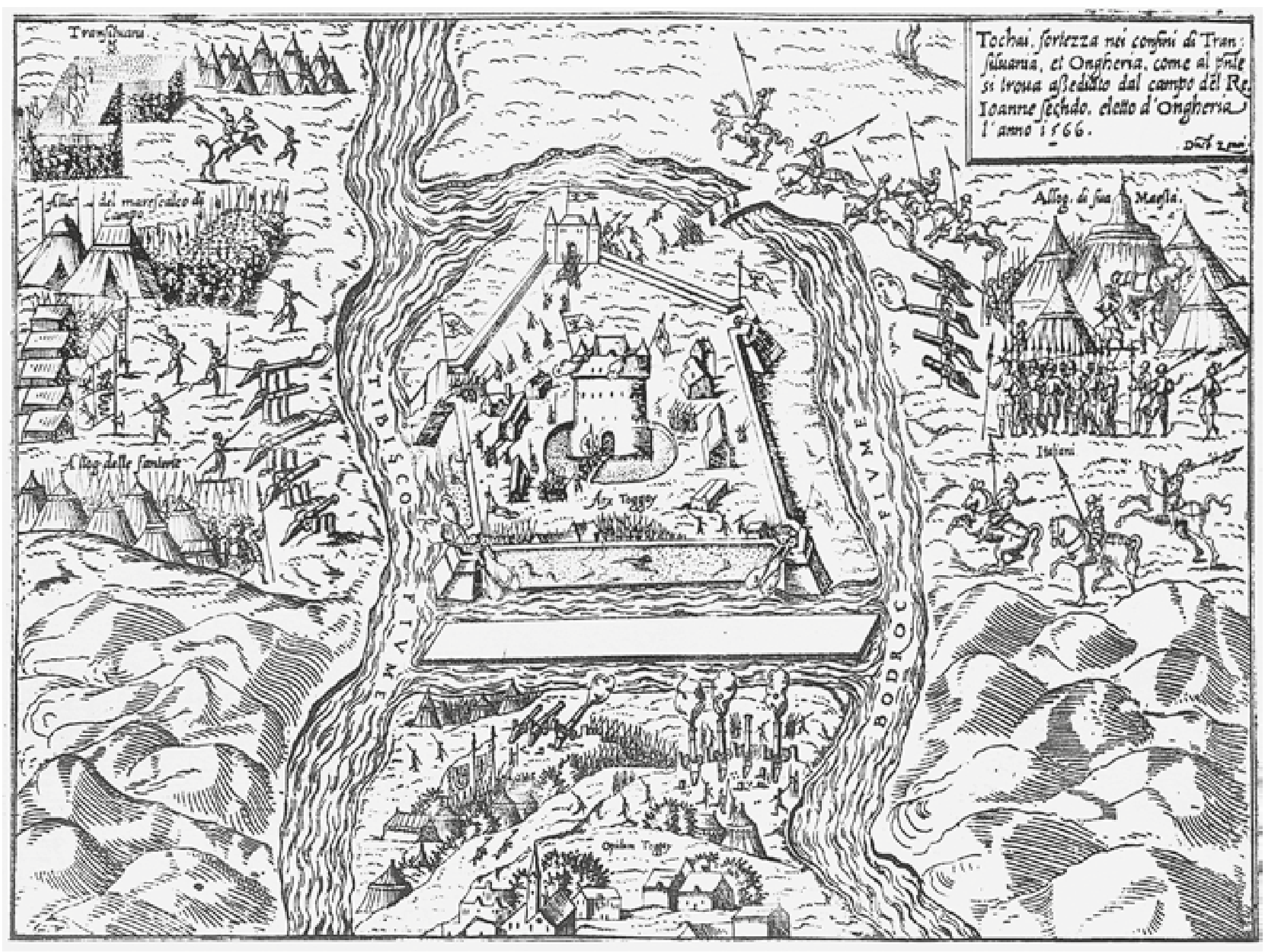




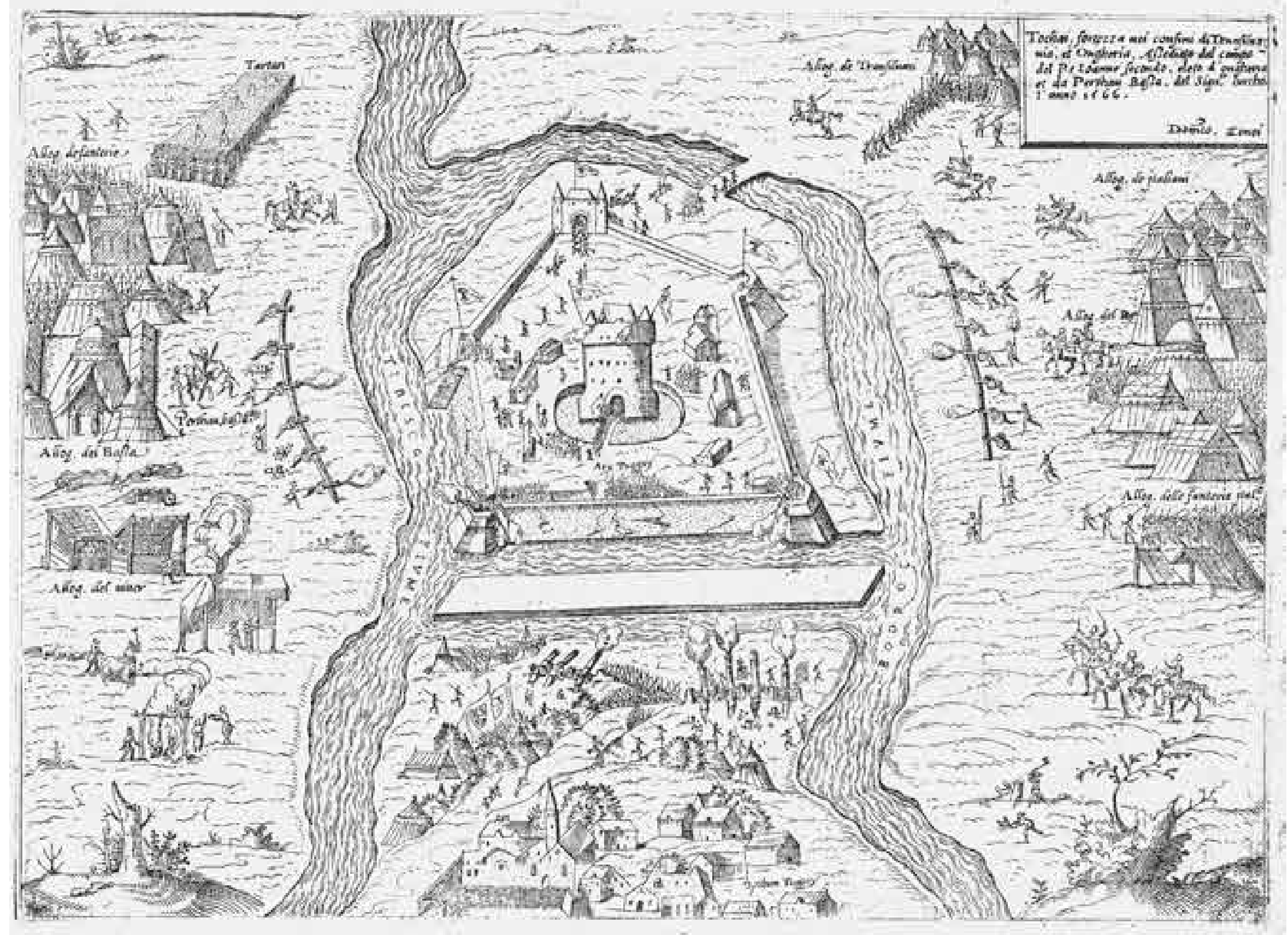




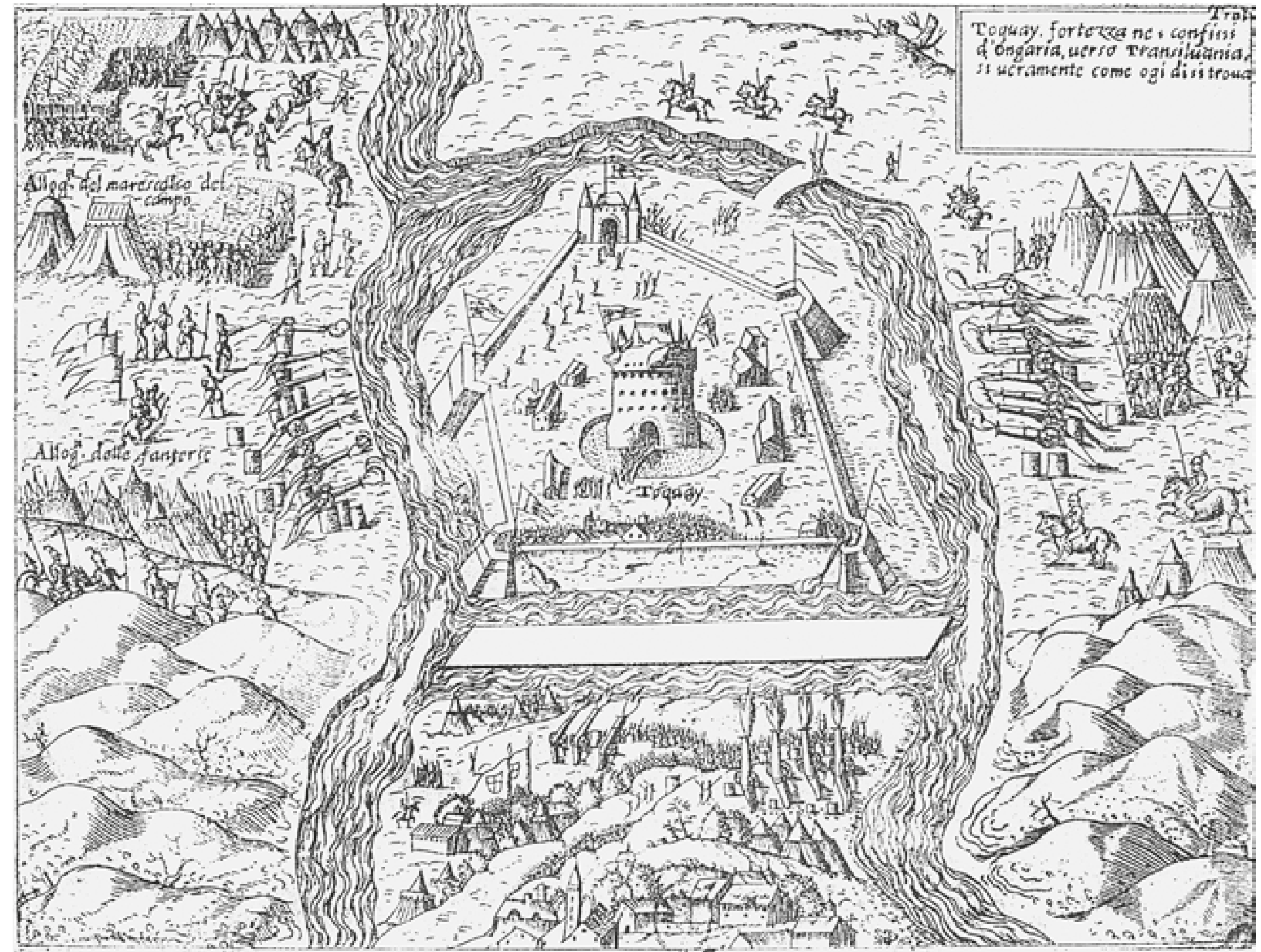




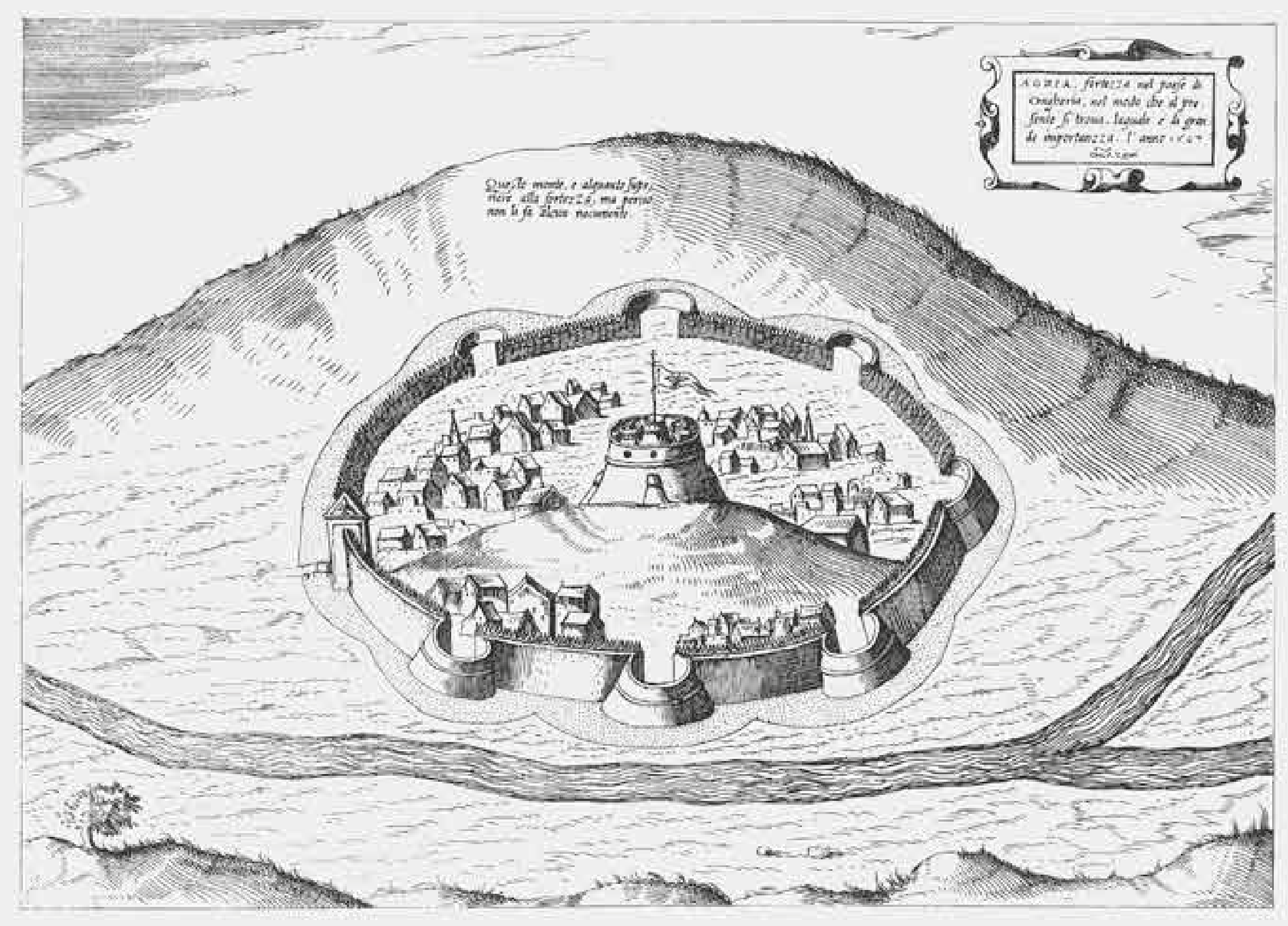




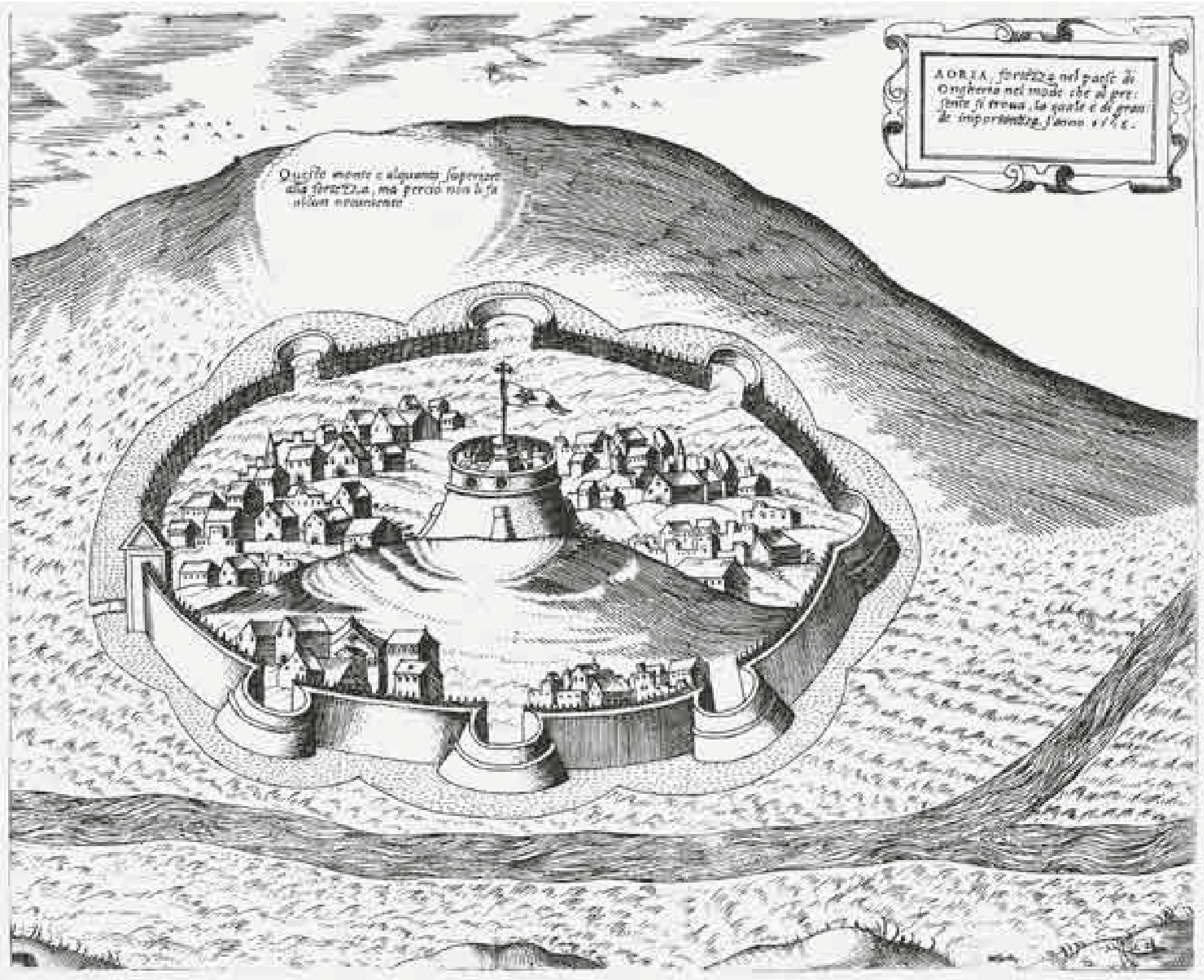




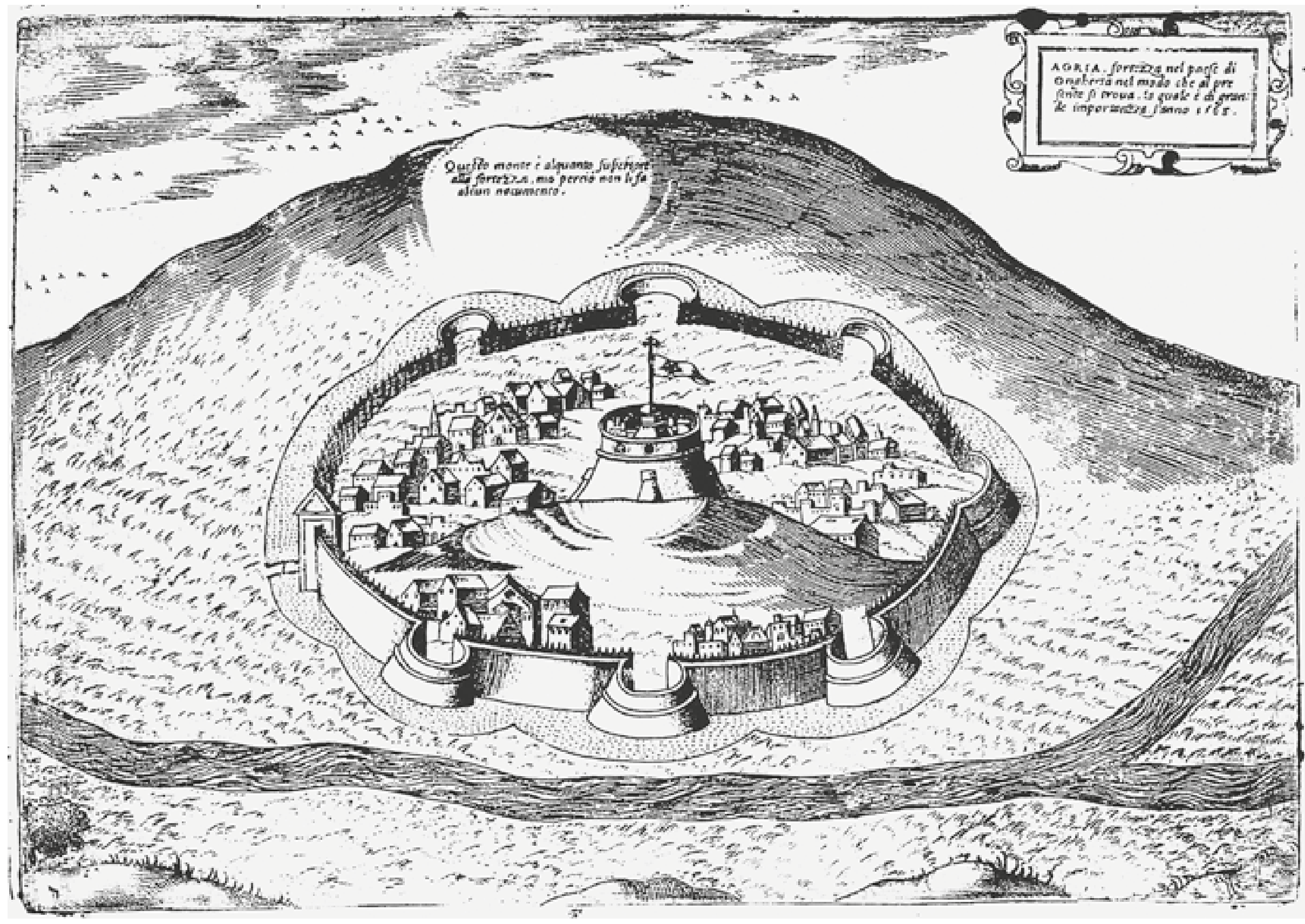




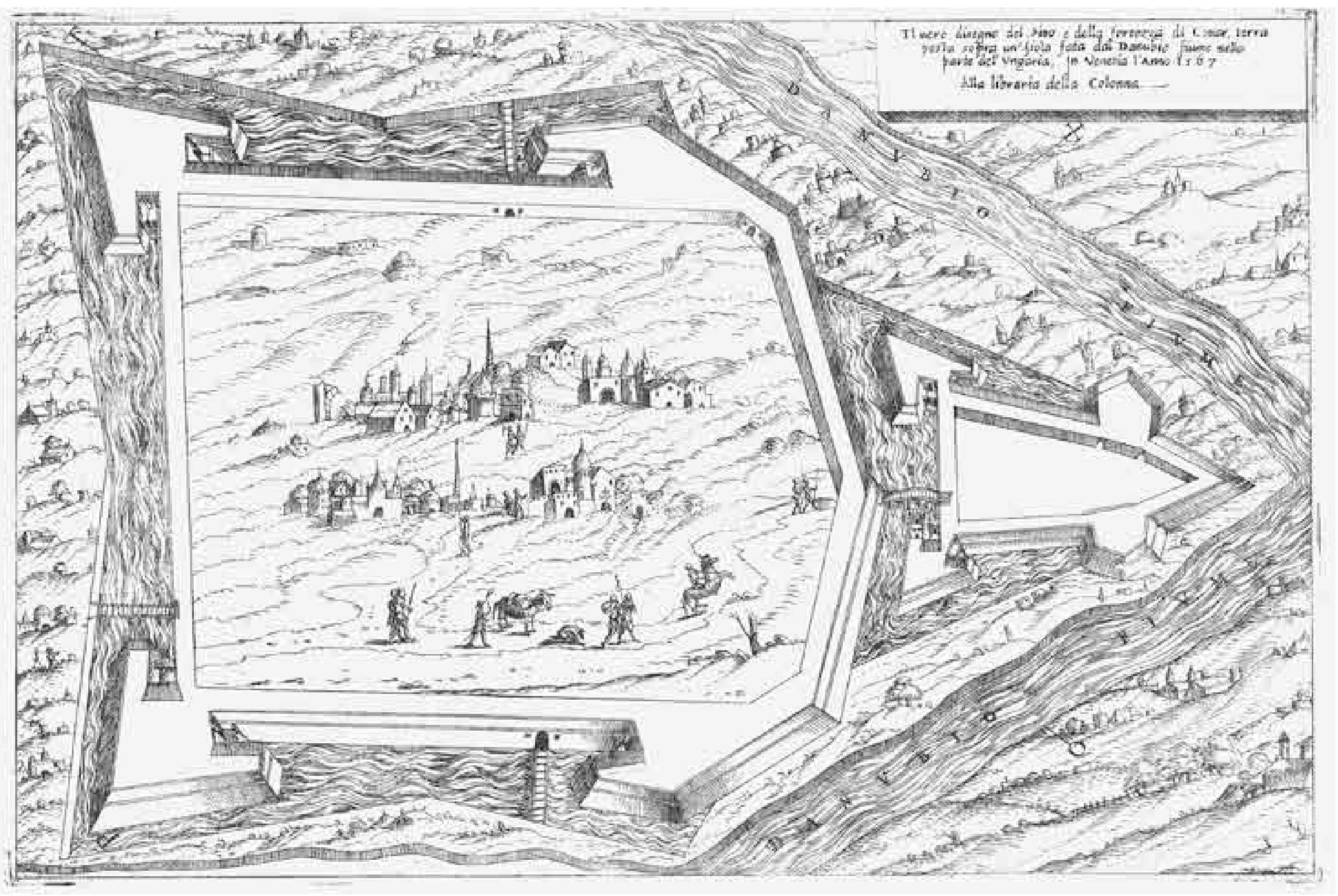




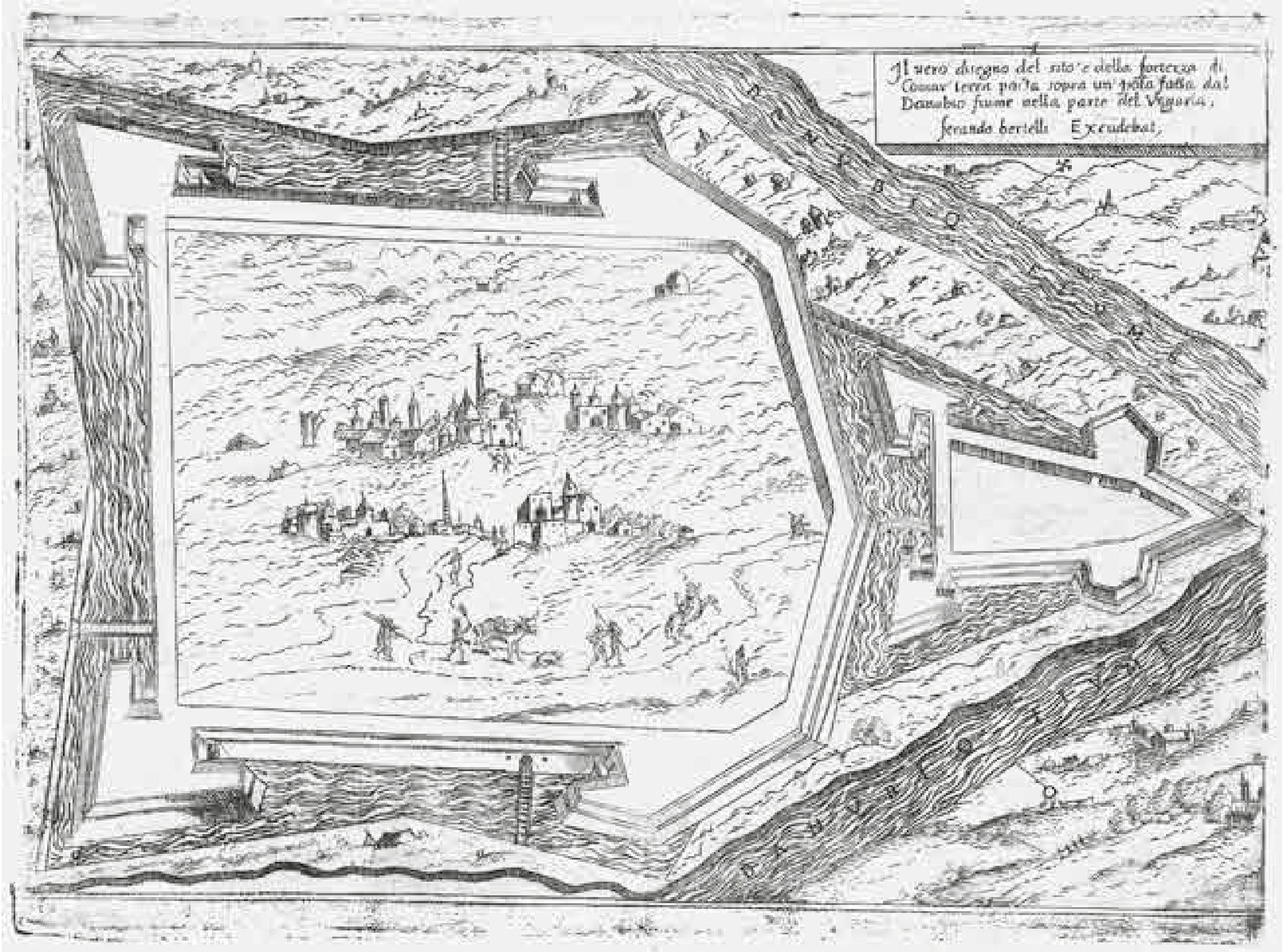




\section{Eim ver saicbmtts bondos}

Thetween Gelden6 1. dec Gazauen bon Sertit/au/ggeftanden not / in Derfelben Befertigung $j u$ Eigec/im \$ar M. D. LXVI. von feiner $\mathfrak{S}^{3}$. Eecrctarto be=

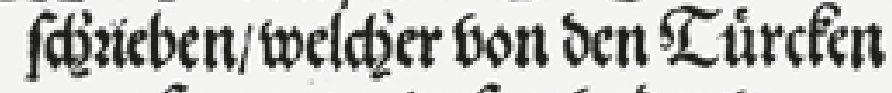
gefangen gewe $[\mathrm{en} / \mathrm{bnd}$ new $=$ lider jeit wotber erlebige wolden ift.

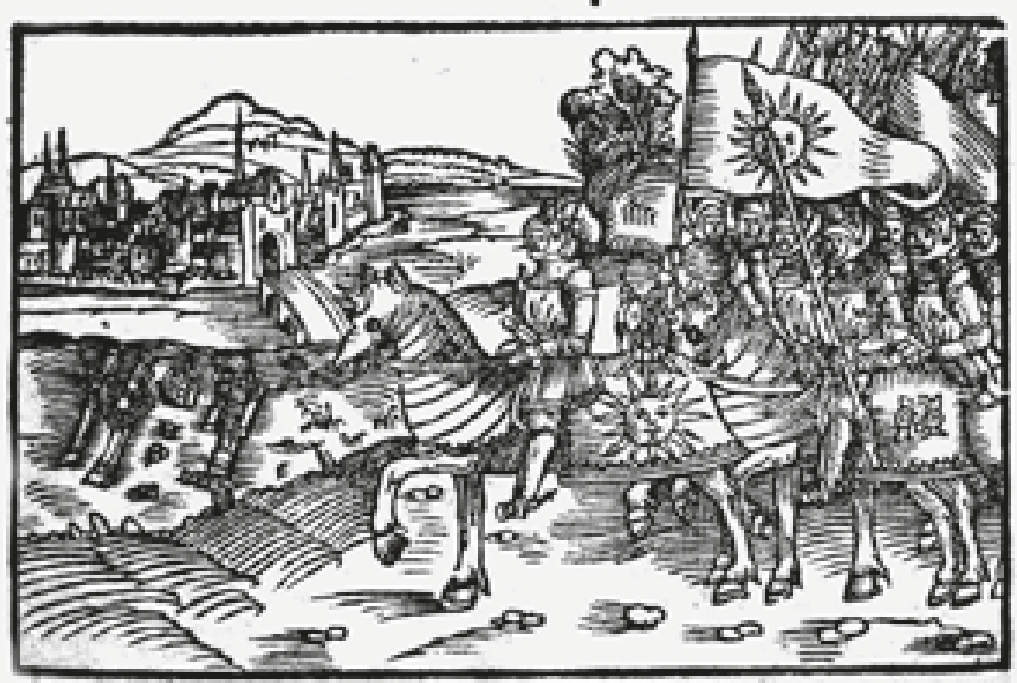

Furnberg/ M. D. LXXVI.
Ein haiplch new Cies/ Don scm Graffen/

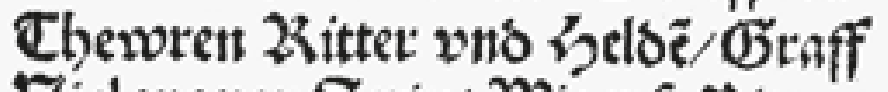

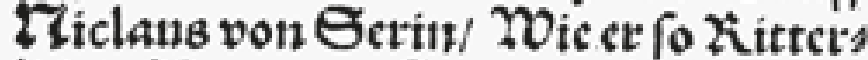
lid) in Dugern geftritten vno abanlid) gefod)tenbar/wider Den 迎 Der Chziftenbeit Den Tutectess vind /einbauffern/zc.

Im thon/ Wie man bas Iied von Slmis finge.

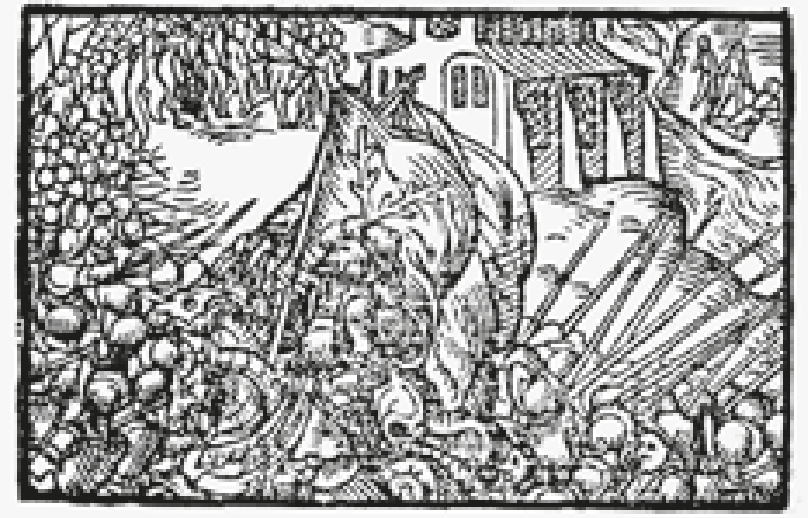

M. D. LXVIII. 


\section{cxif Befditeibung bes lecften}

Zbcontrafactur ocr 2 effung Zolay.

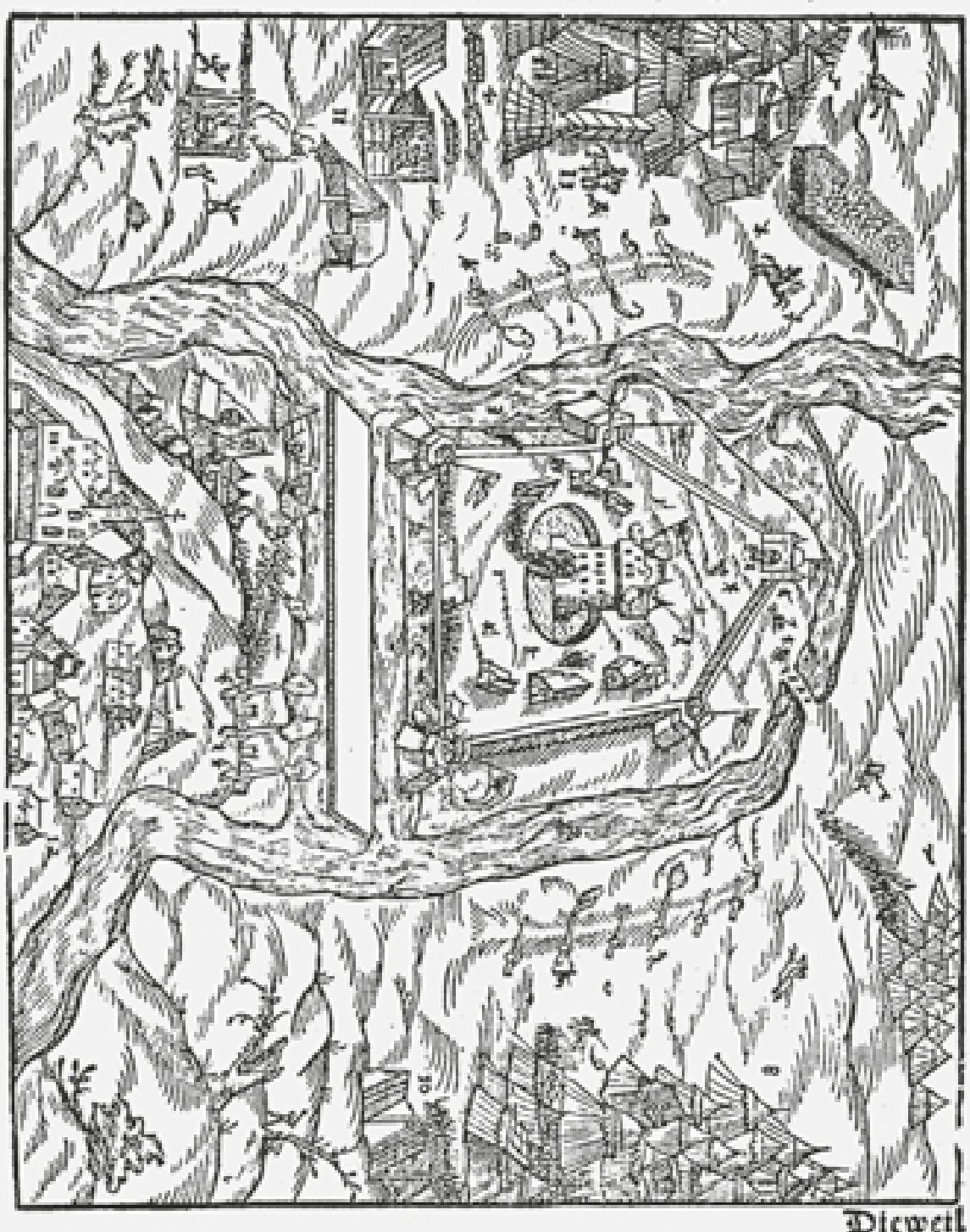

\section{Dugetifdoch Zug6. türif}

Z6contrafactur ocr gewaltigen 23etung Yula.

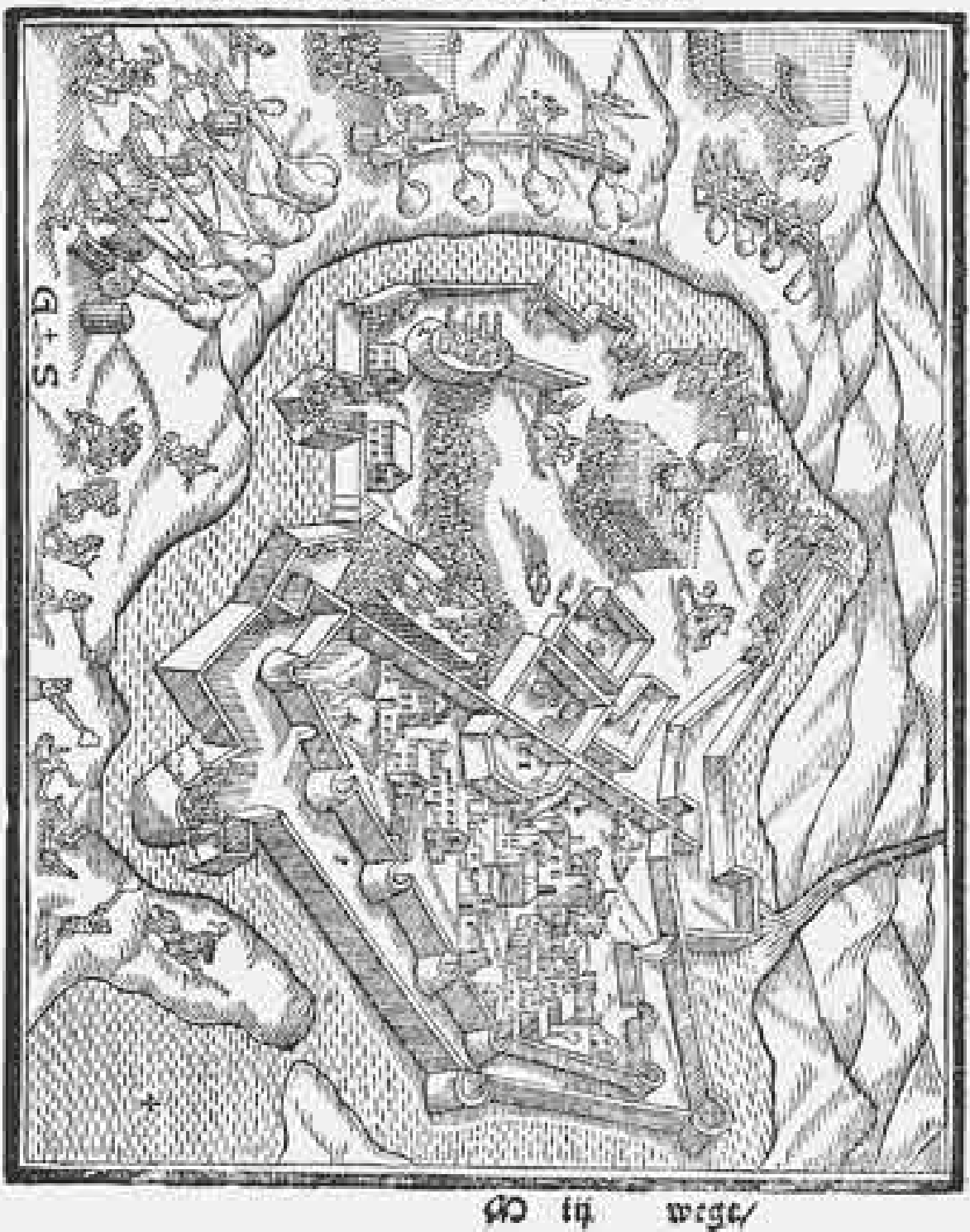


Dungetifitgen gugs. Itxwij

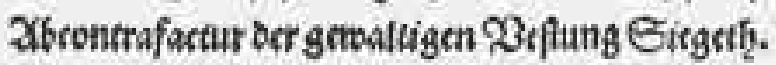

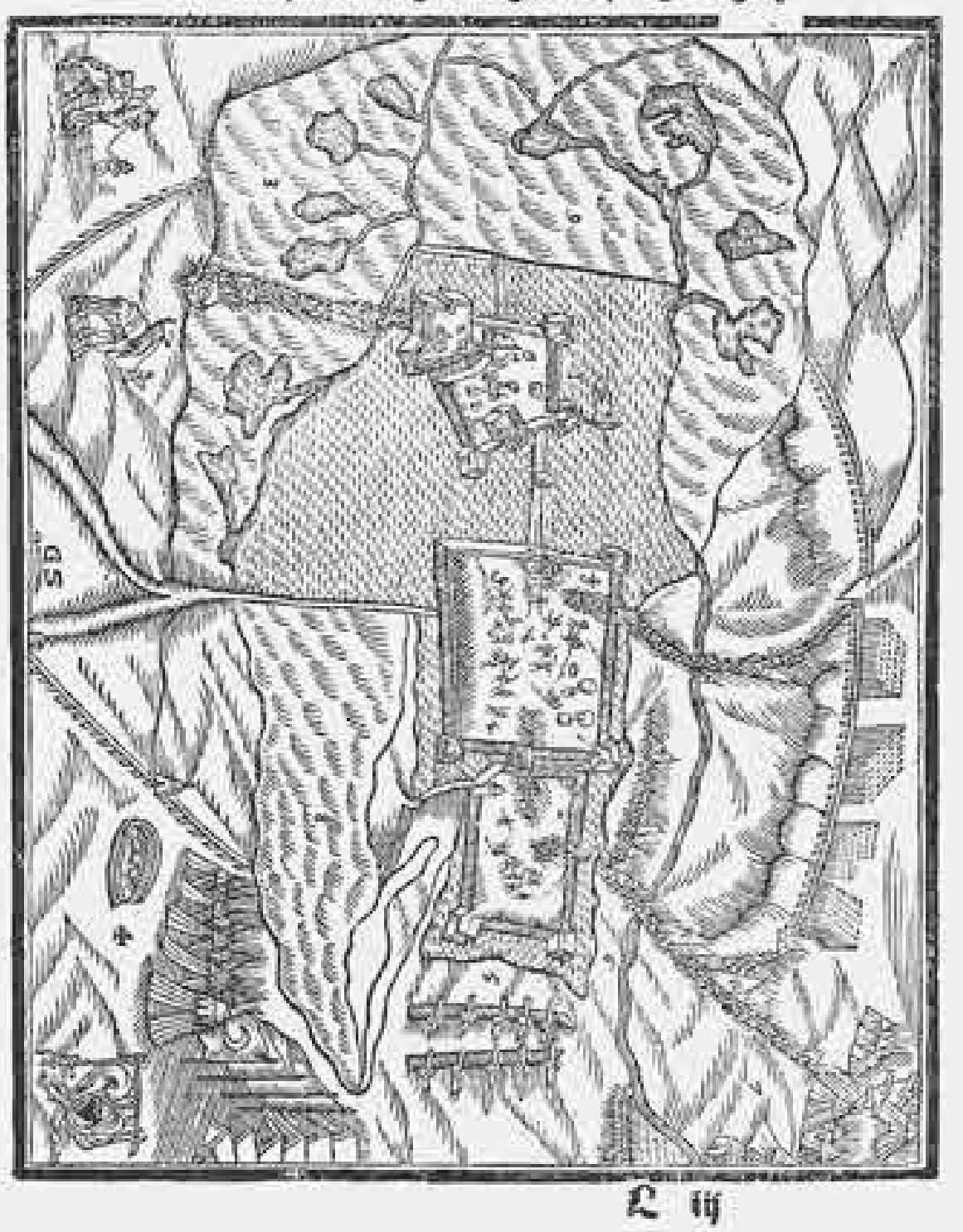

\section{Bngetifchtr gug6. Irrii}

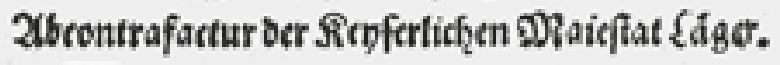

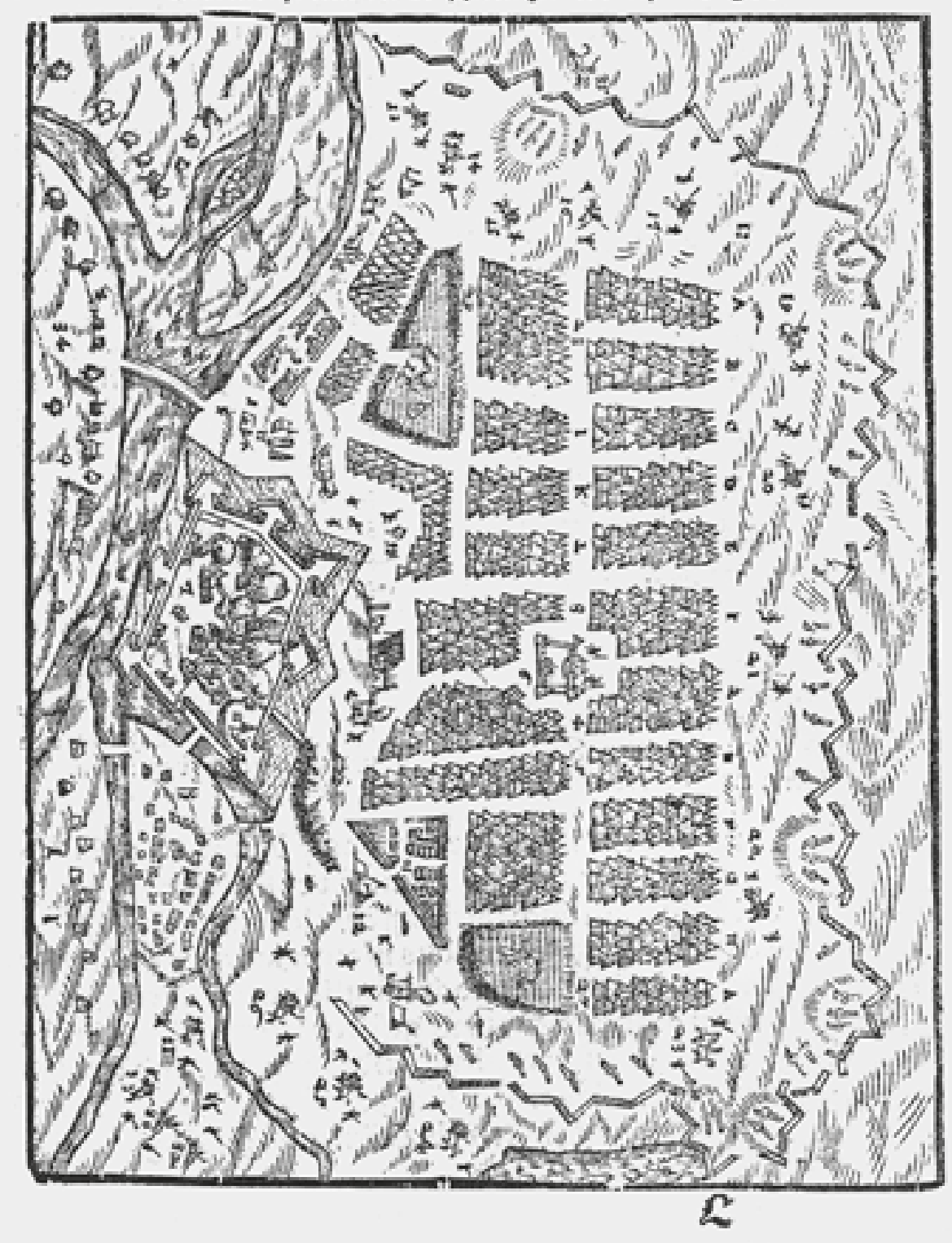




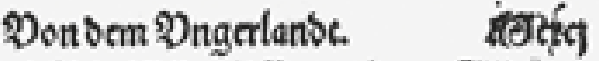

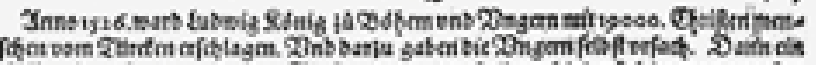

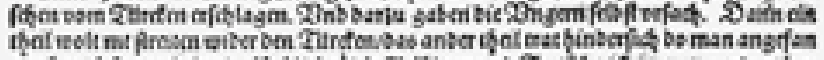

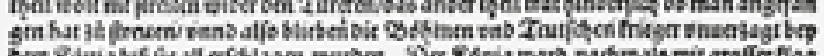

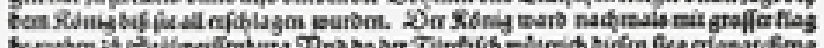

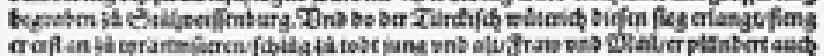

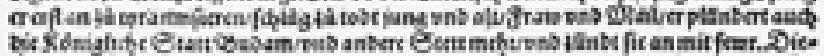

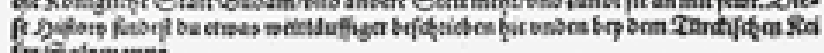
freolpuanto.

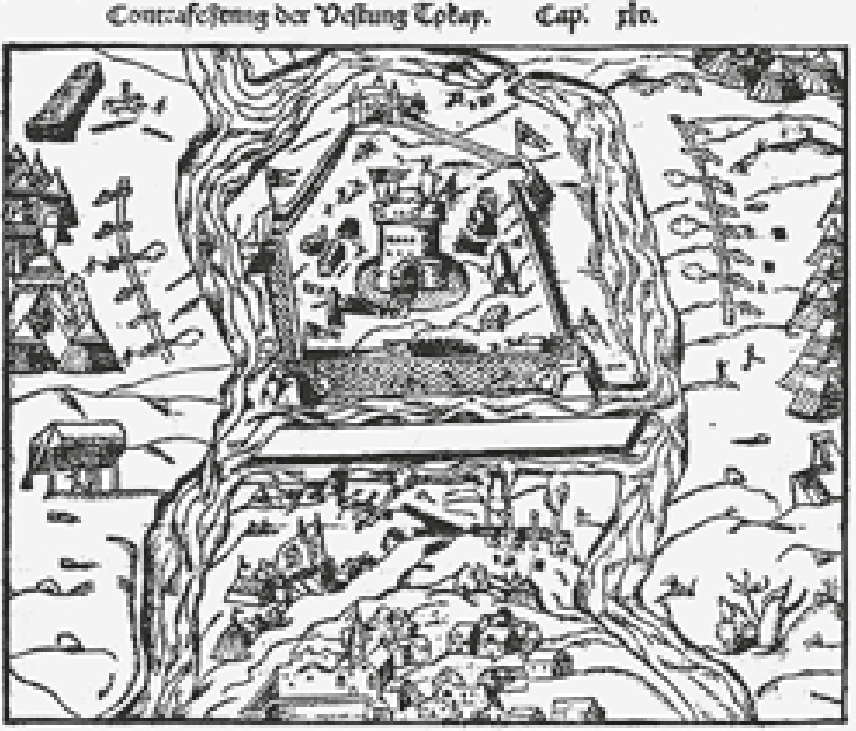

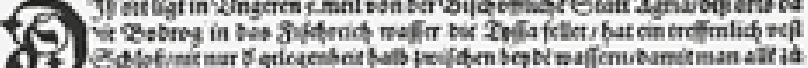

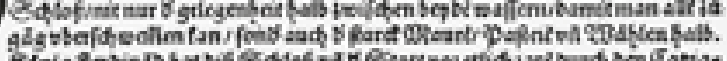

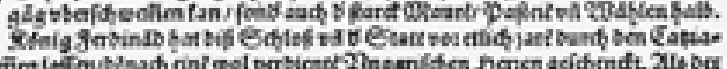
政

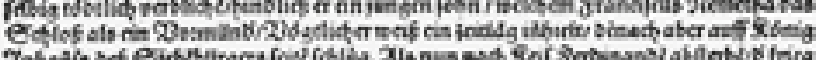

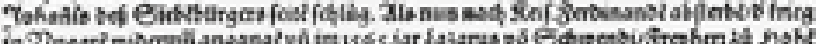

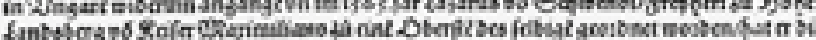

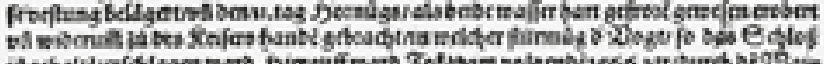

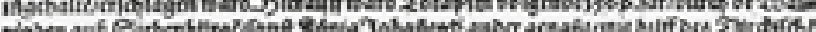

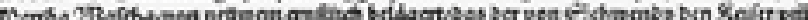

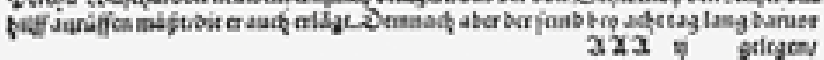

Wont $9 \mathrm{~cm}$. ngerlanbc. $\quad$ (Odrro

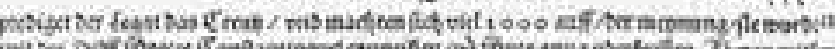

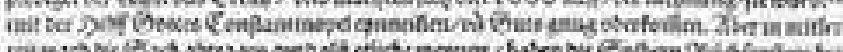

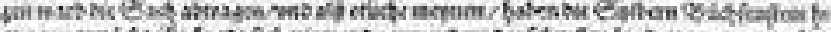

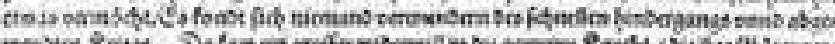

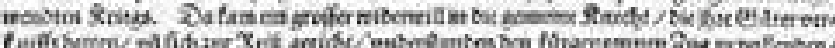

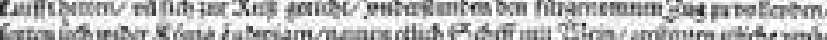

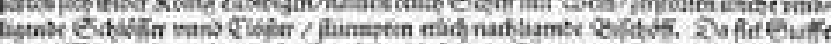

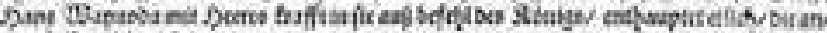

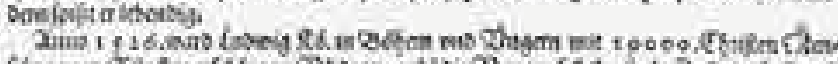

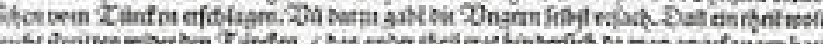

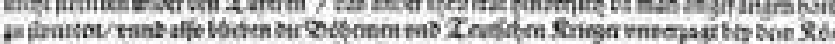

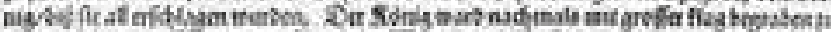

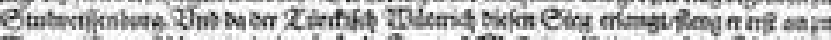

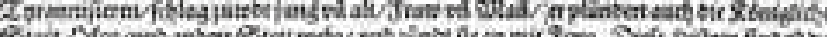
(t)

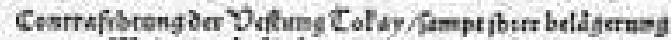

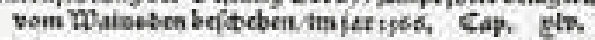

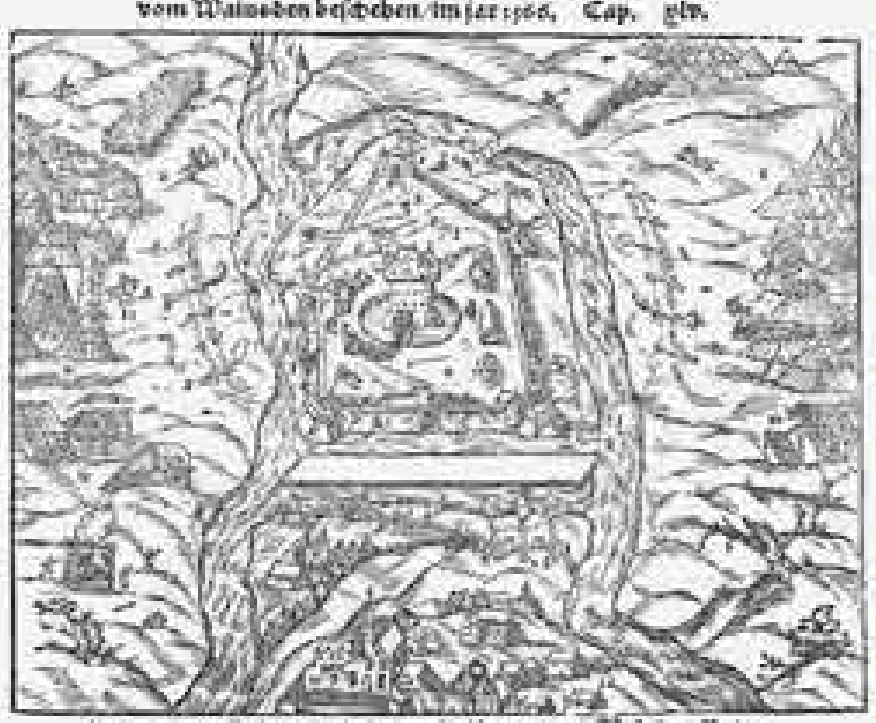

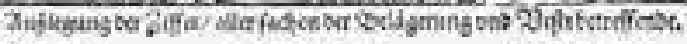

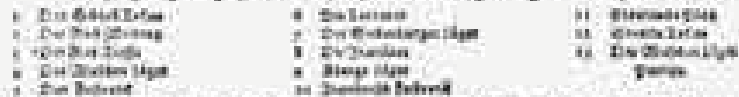

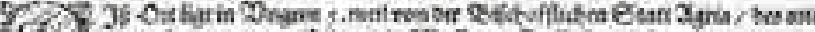

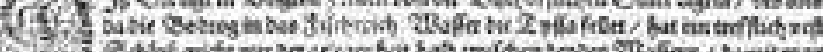

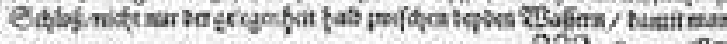




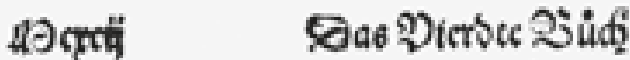

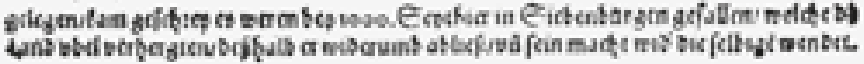

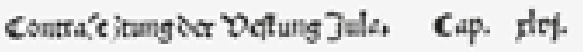

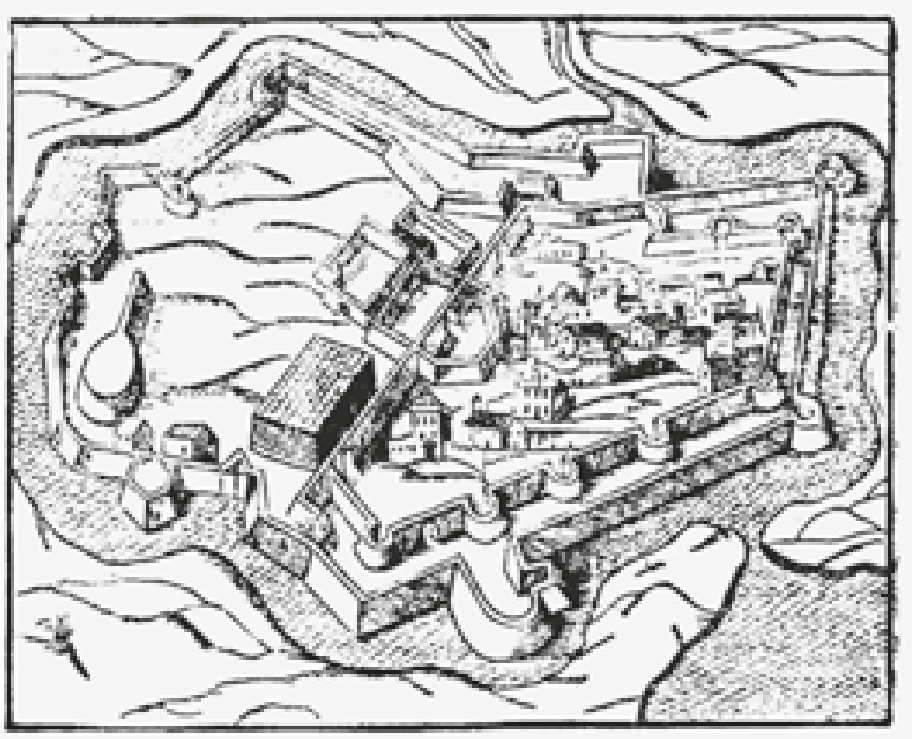

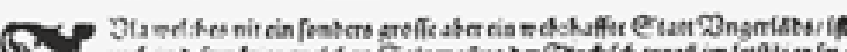

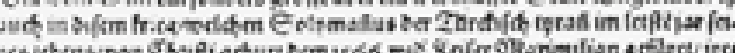

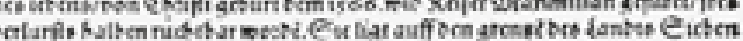

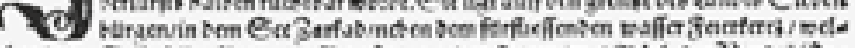

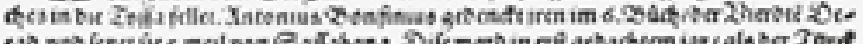

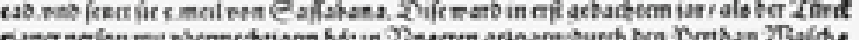

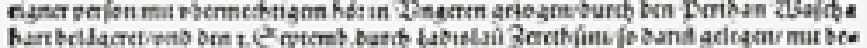

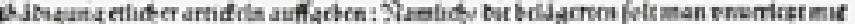

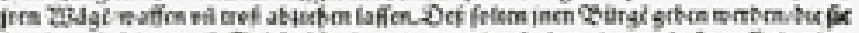

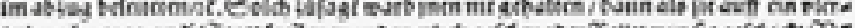

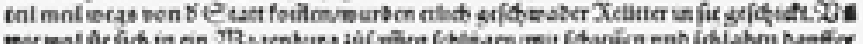
mer ar

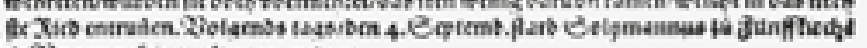

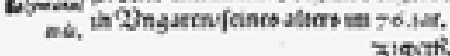

$$
\text { 3igutr, Cap. ríri. }
$$

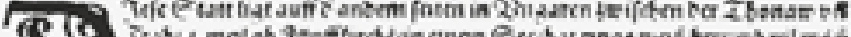

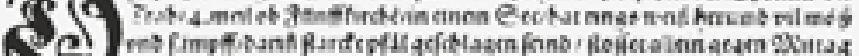

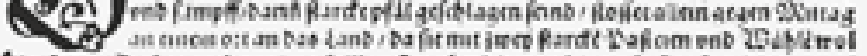

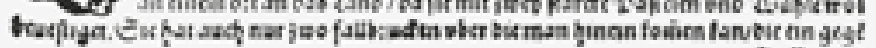

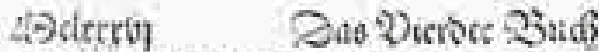

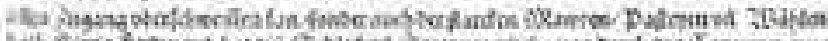
thas

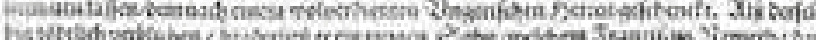

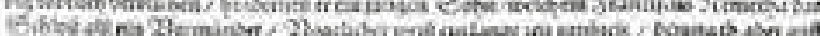

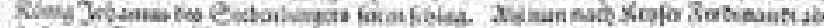

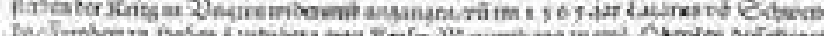

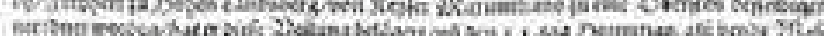

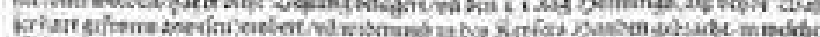

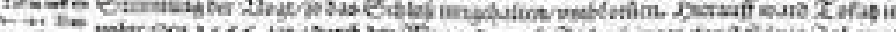

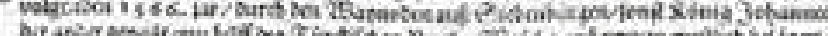

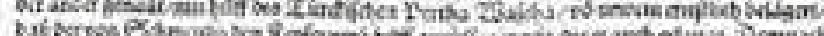

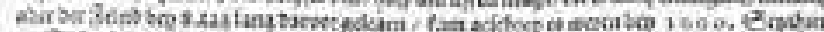

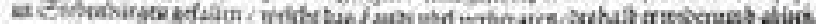

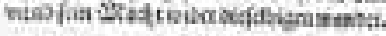

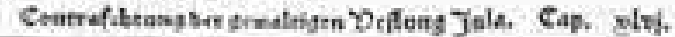

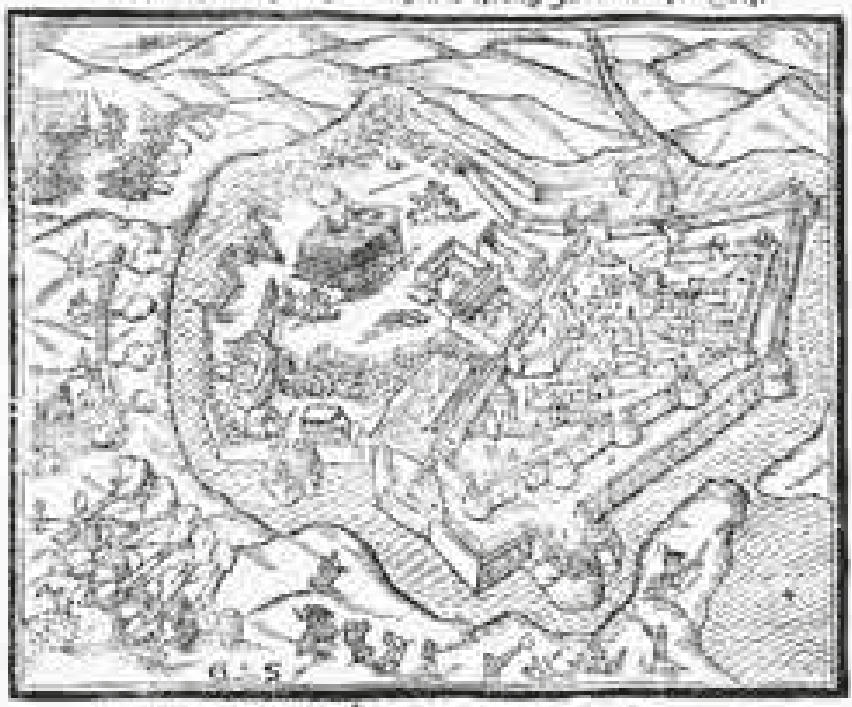

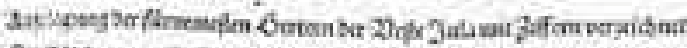

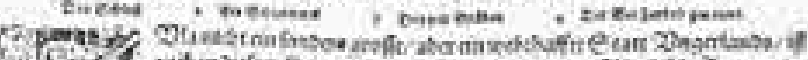

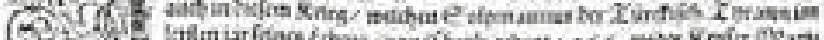

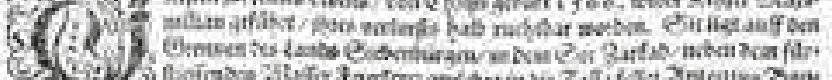

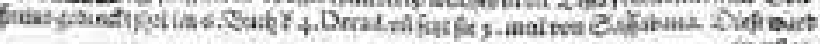


2) 4 S $9 \mathrm{em}$ 3itgerlante.

Adtreiti

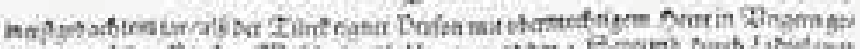

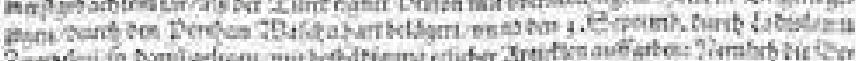

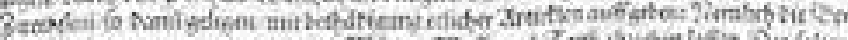

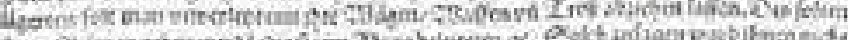

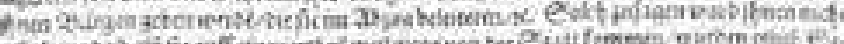

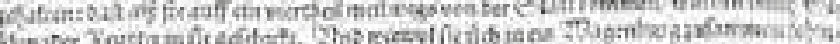

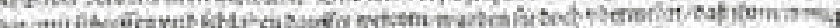

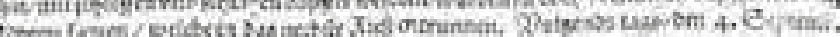

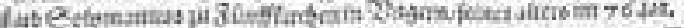

pt peo cavarian

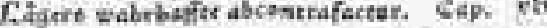

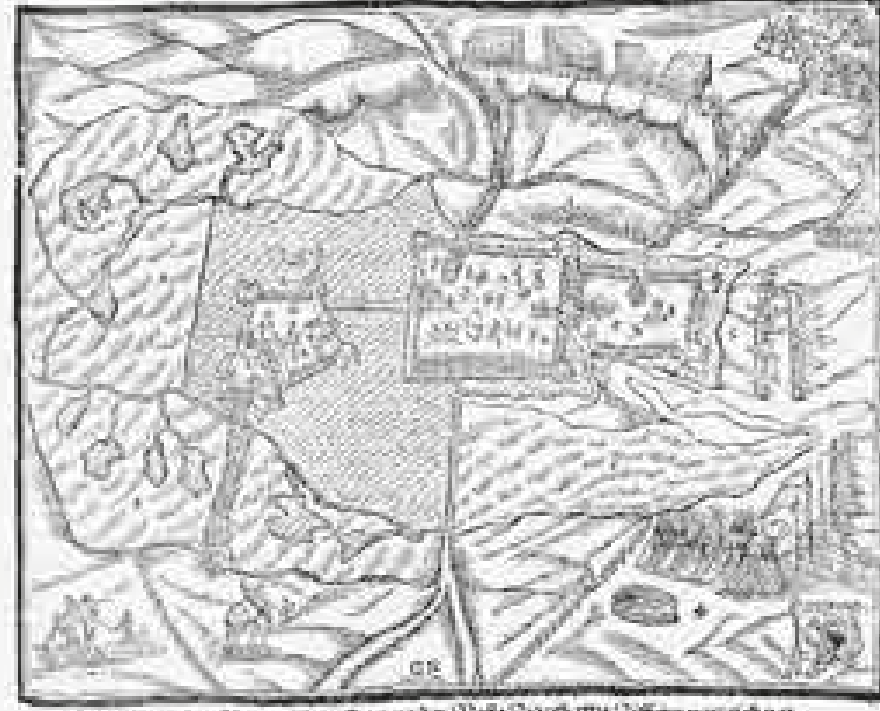

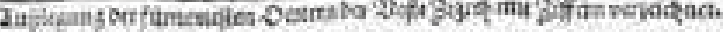
; cenared

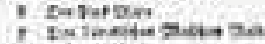

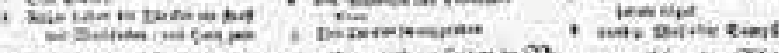

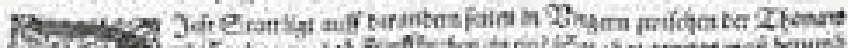

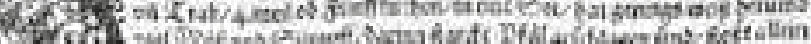

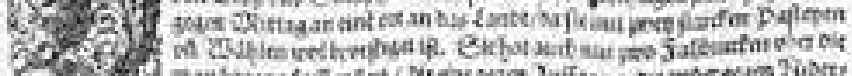
D.

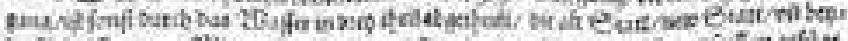
te

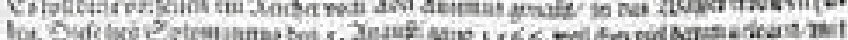

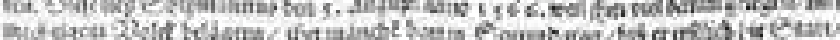

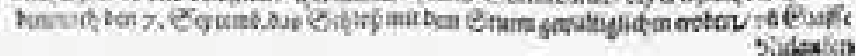

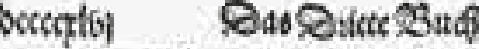

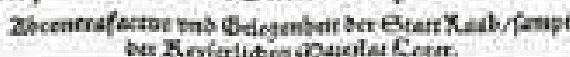

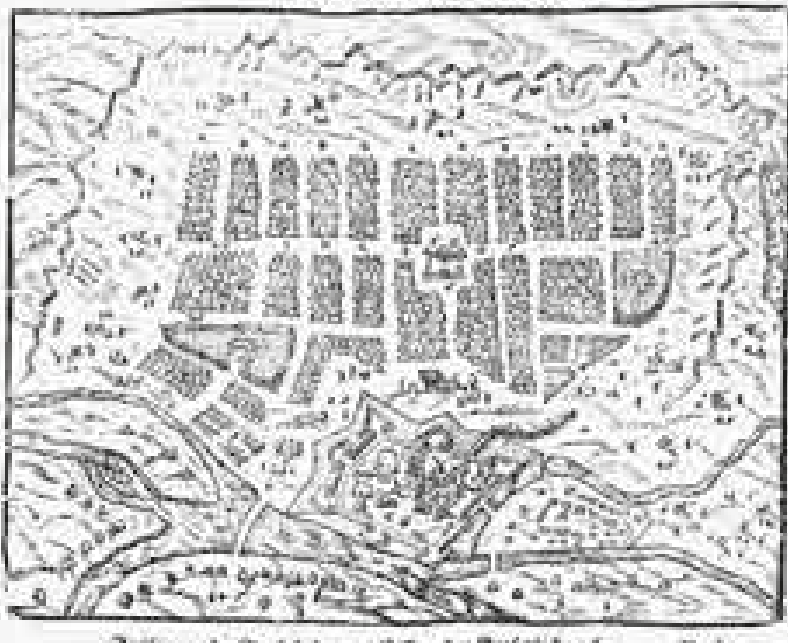

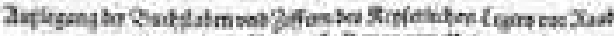

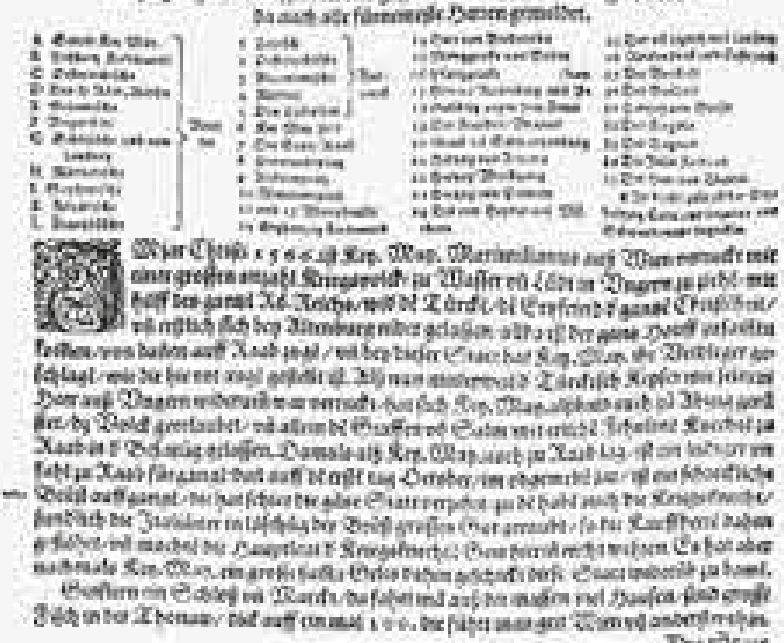

Dos Deatit 


\section{Lodrrrbif \\ Qua Pierdec Bud}

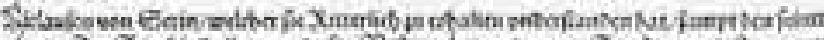

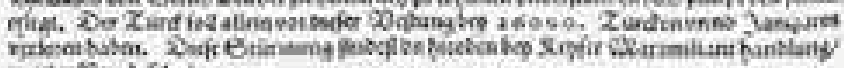
Edilnafioridiowin

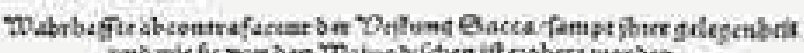

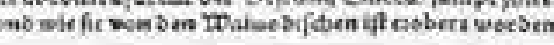

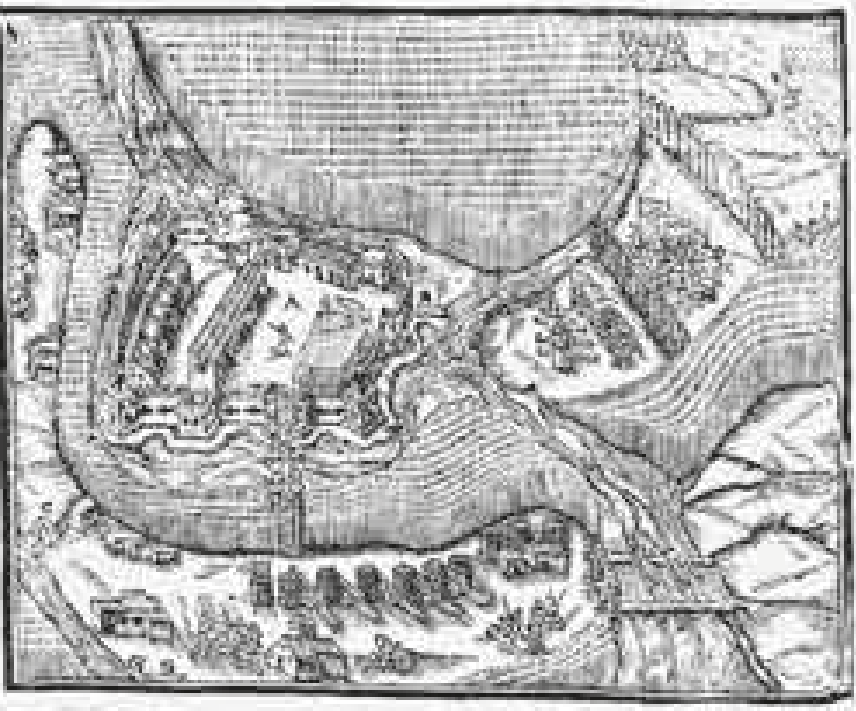

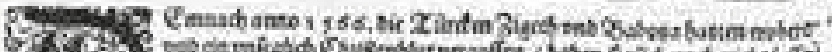

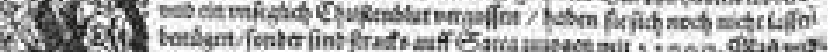

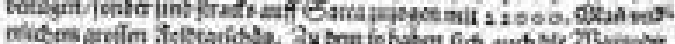

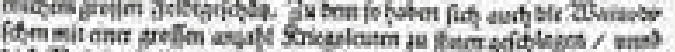

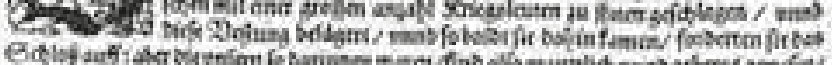

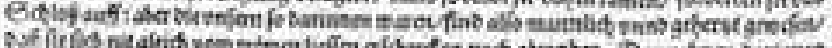

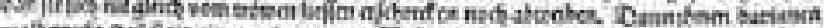

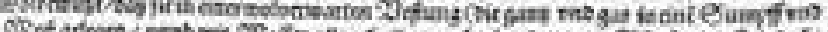
Fomids

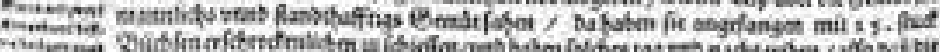

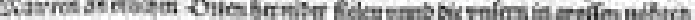

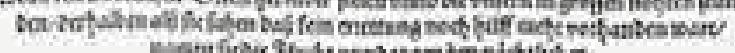

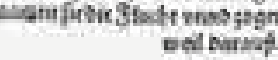

Ërnealoge
SOcclrï

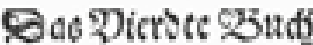

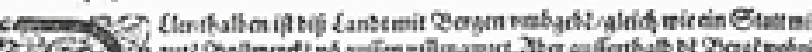

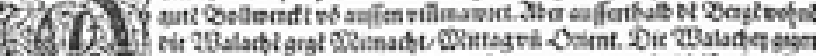

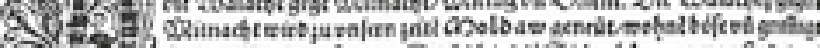

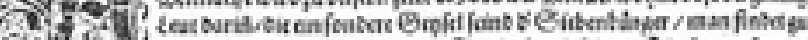

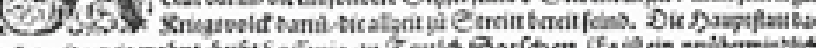

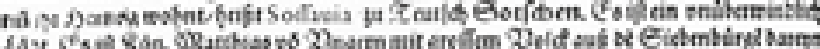
katic con 35.

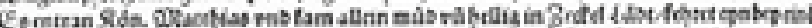

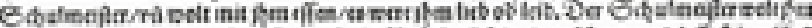

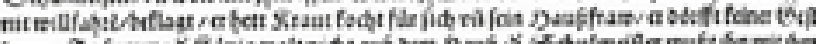

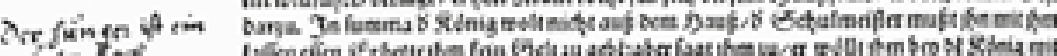

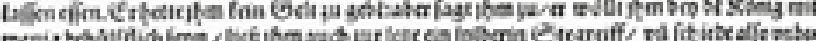

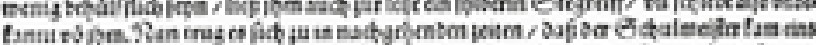

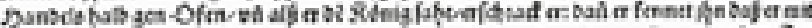

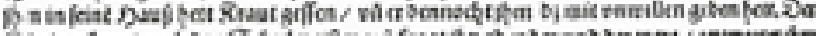

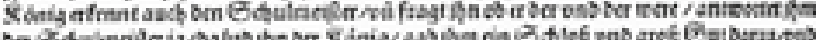

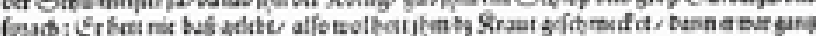

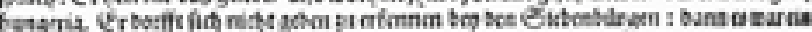

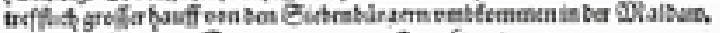

$$
\text { Don Ceculta osar gectenlanoc. Cap. sci. }
$$

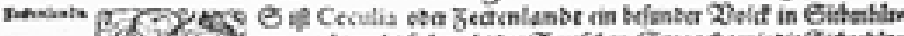

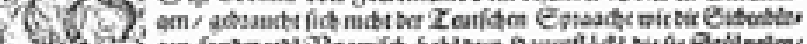

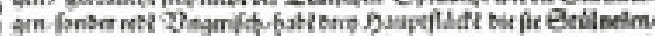

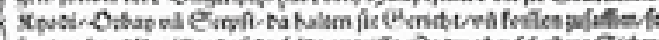

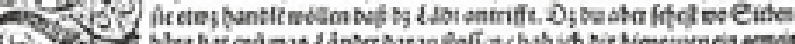

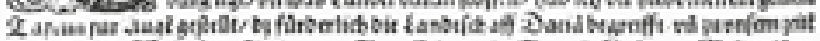

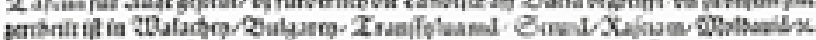

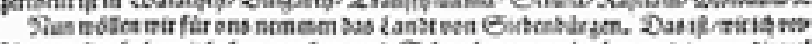

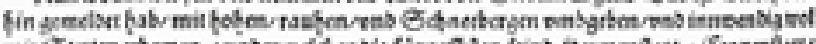

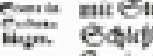

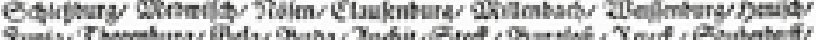

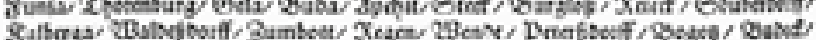

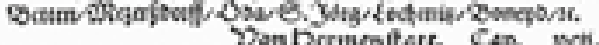

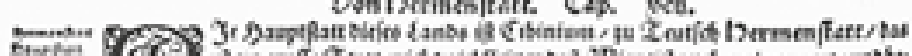

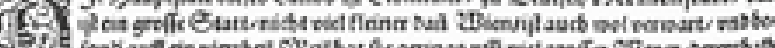

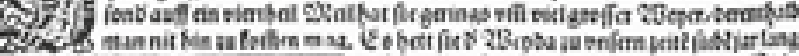

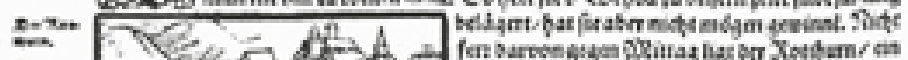

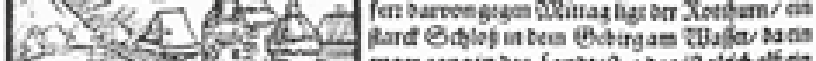

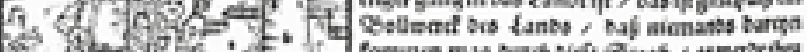
artai:

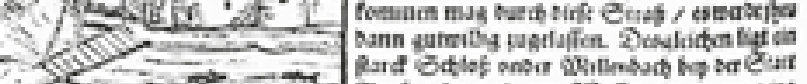

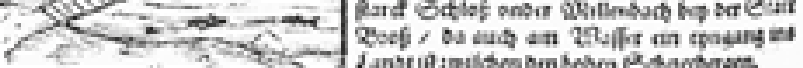

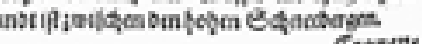




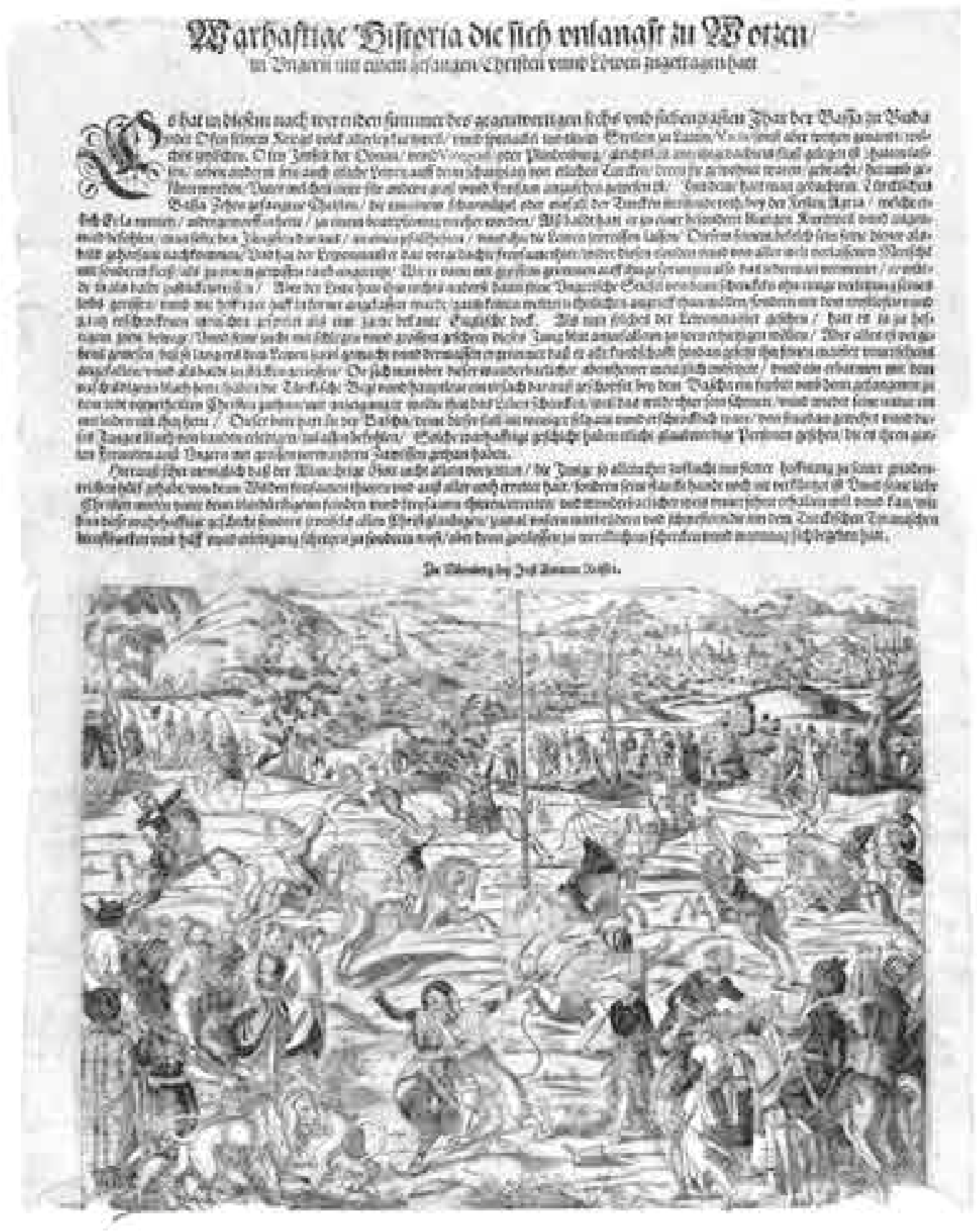




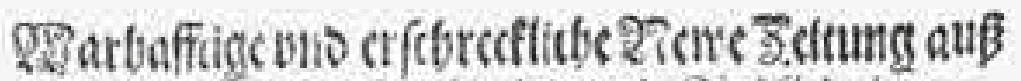

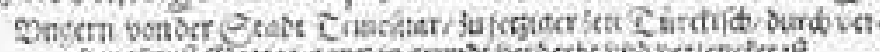

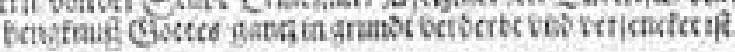

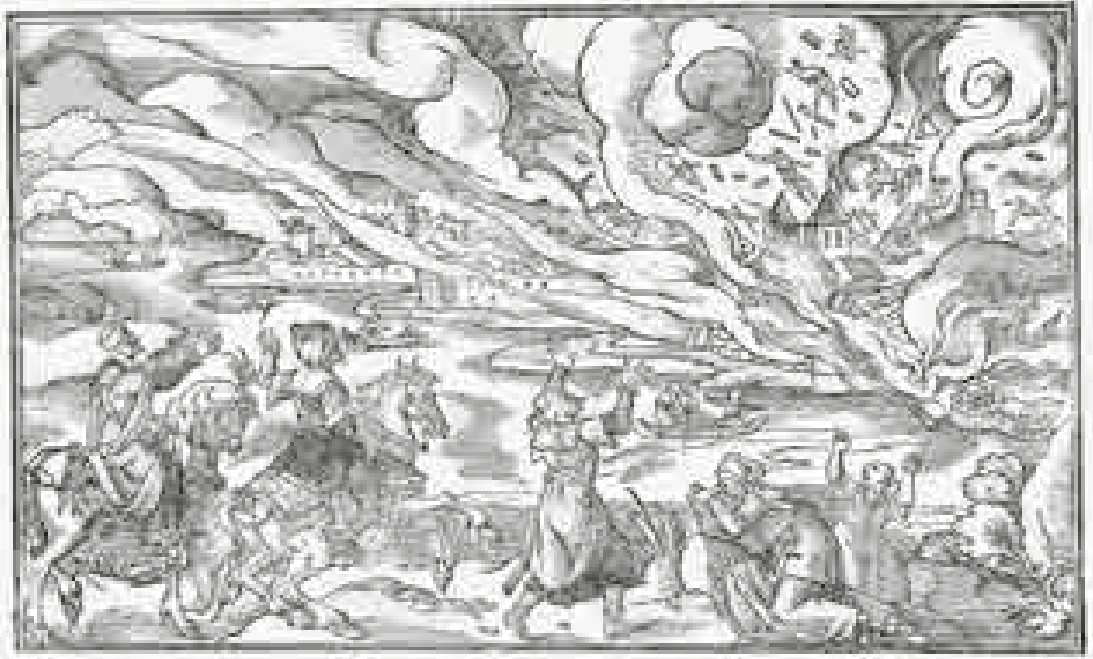

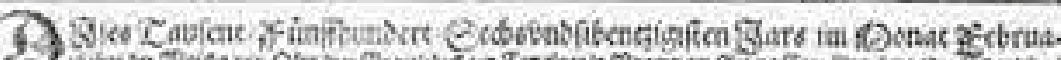

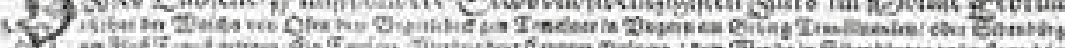

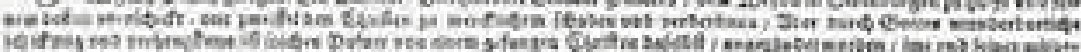

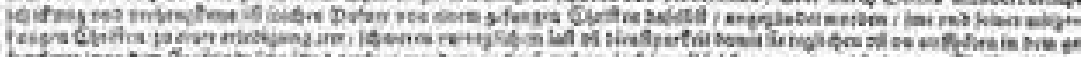

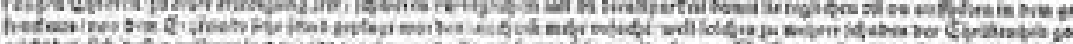

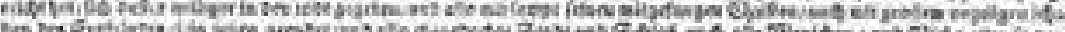

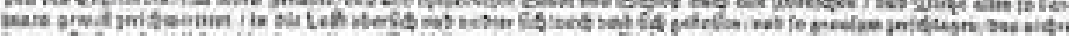

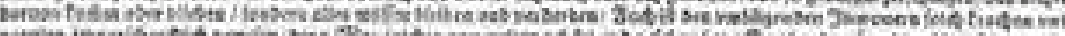

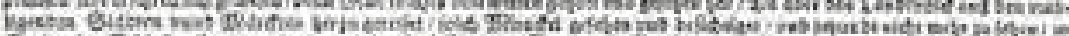

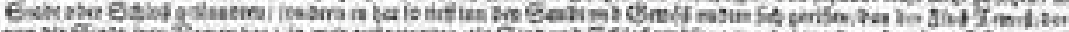

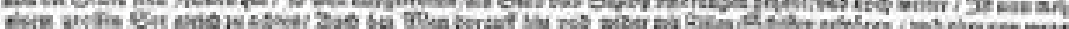

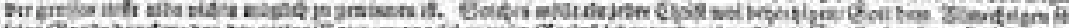

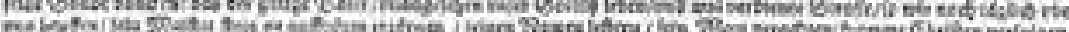

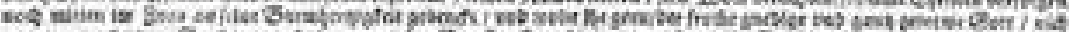

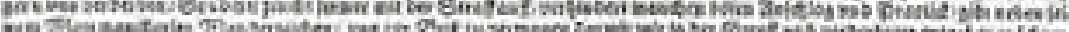

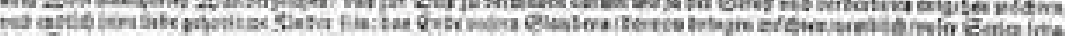

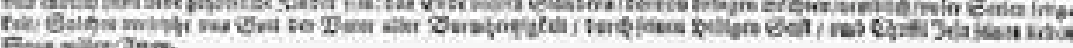

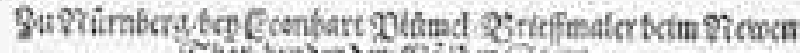

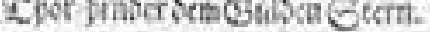

\section{Sร̧argaftitige grauta}

me vno erfocrectlidie neive jettung aus

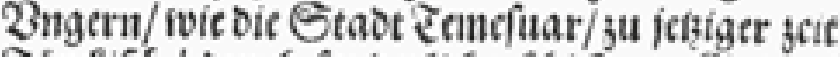

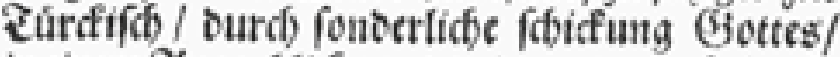
in cintent $\mathscr{Q}$ ugenblicf gants wno gar verocrbtivntb. $\mathrm{ecrt} / 3$ erfprengt vĩ veriondt ifi/aud) wo dic Stad ond Edflog geftandon/ictzit lauter waffer/ vin num incbr cintem groffar Euc gleic); a ad)= tent ift.

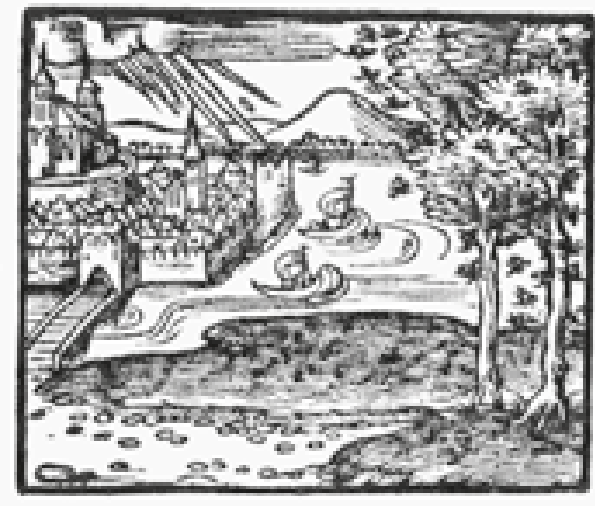

I 576 . 


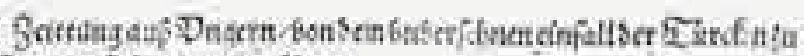

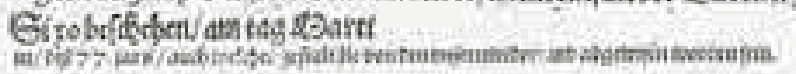

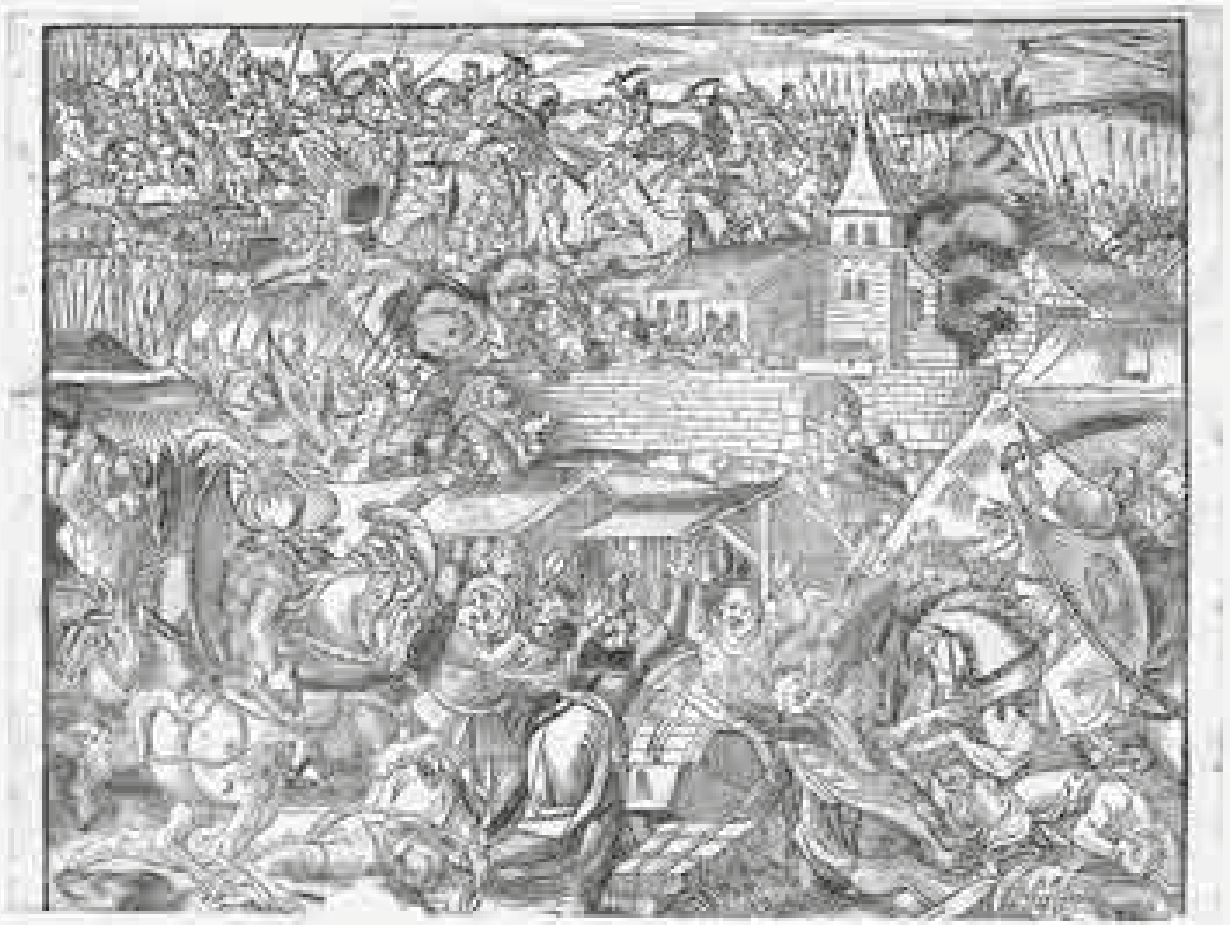

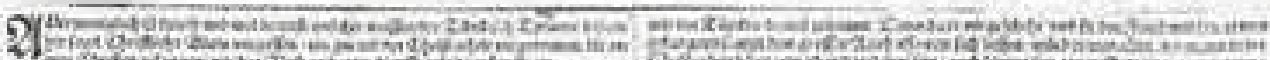

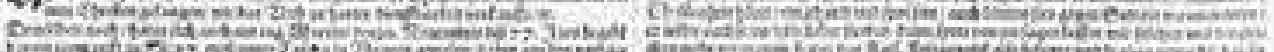

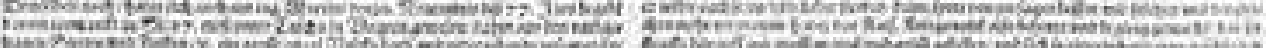

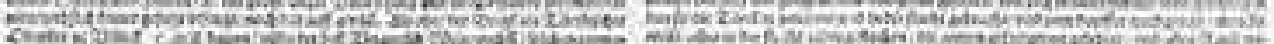

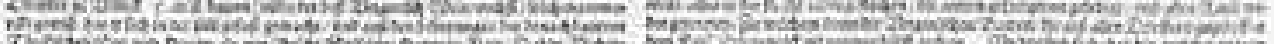

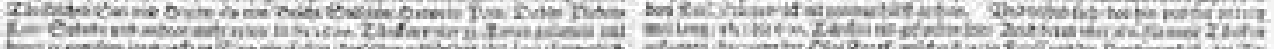

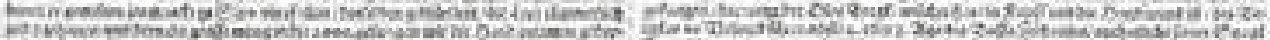

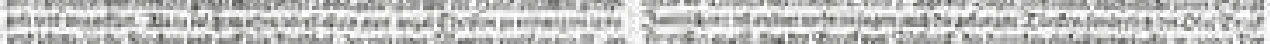

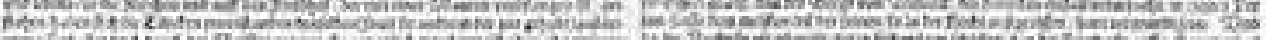

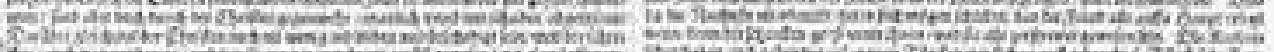

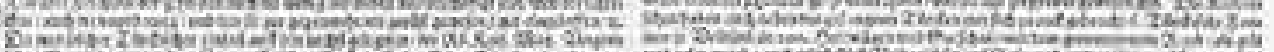

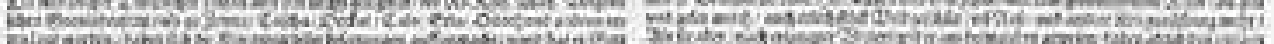

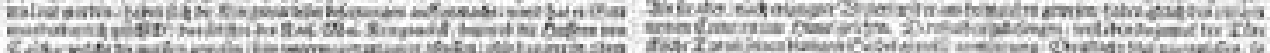

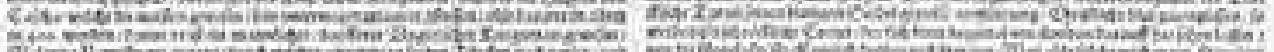

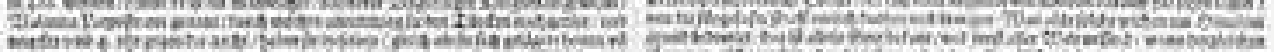

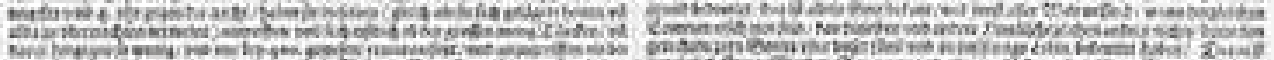

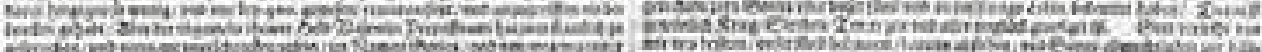

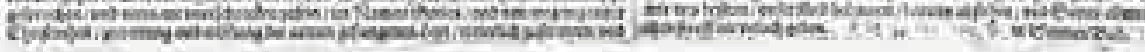




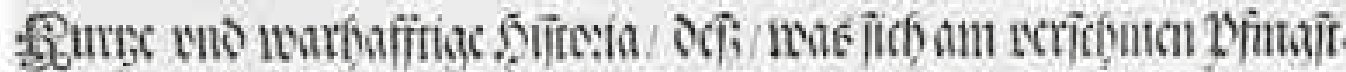

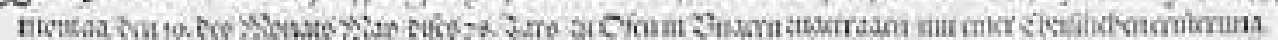

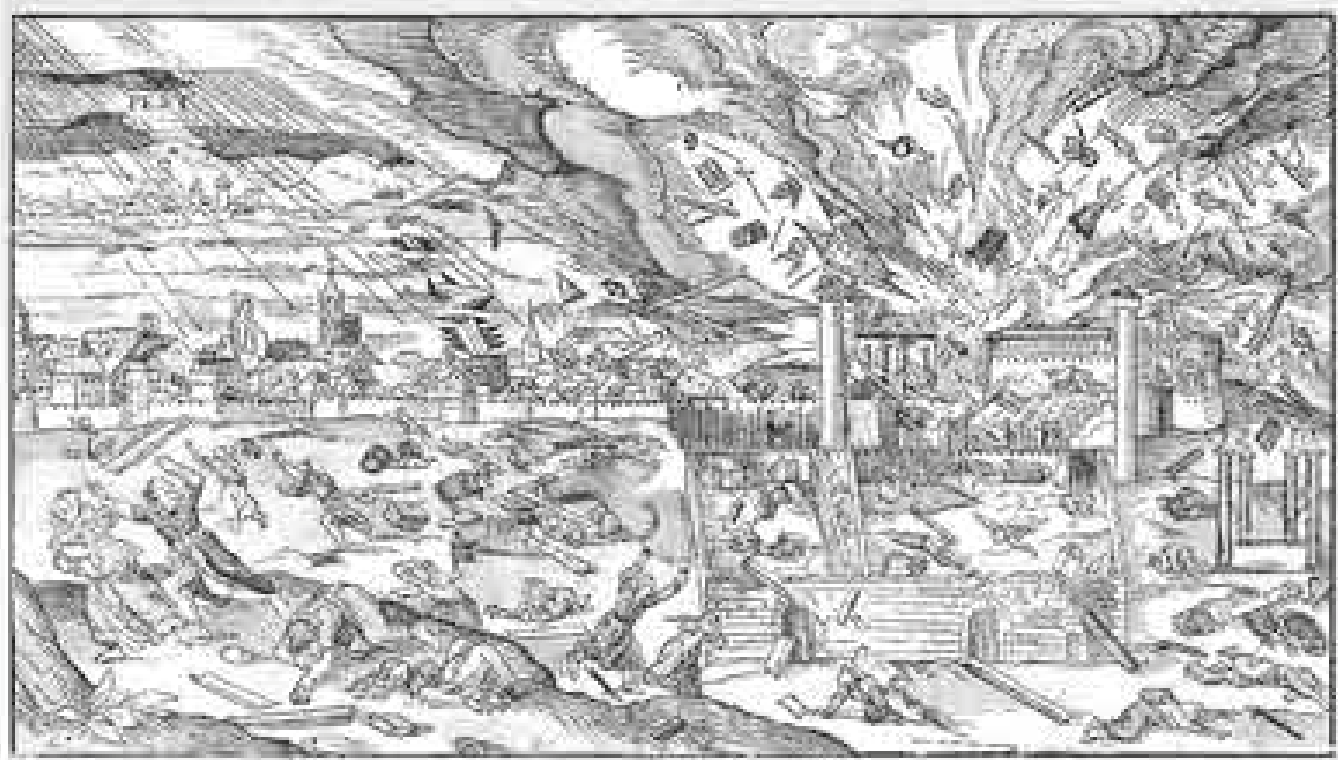

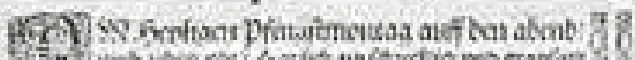

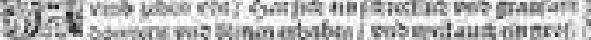

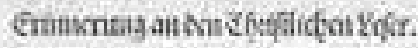

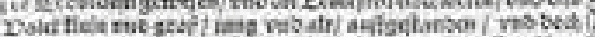

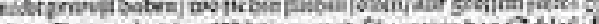

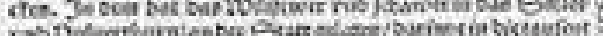

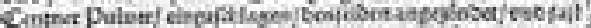

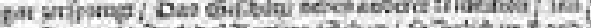

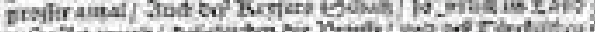

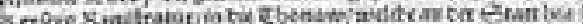

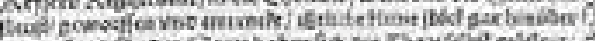

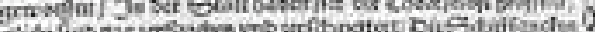

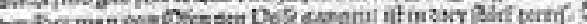

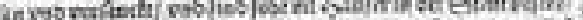

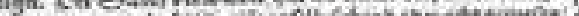

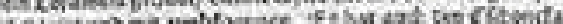

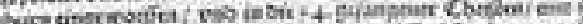

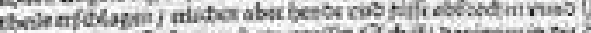

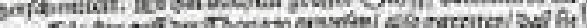

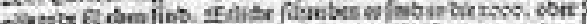

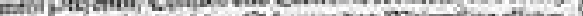

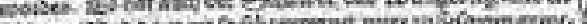

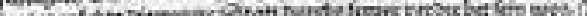

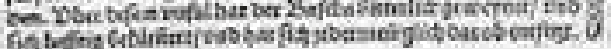

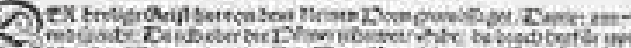

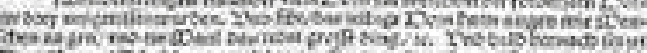

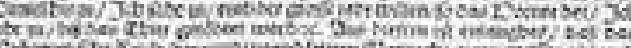

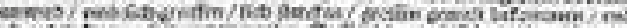
con

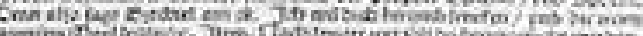

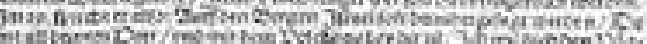

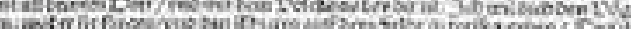

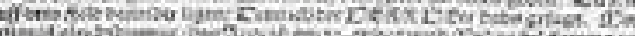

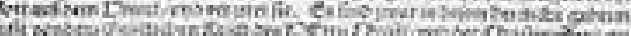

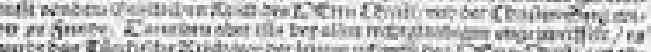

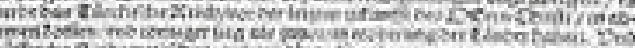

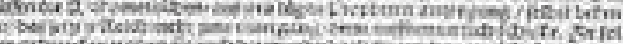

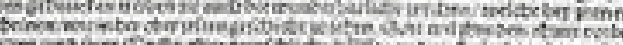

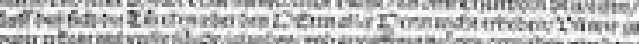

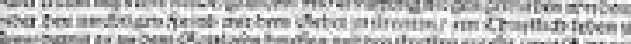

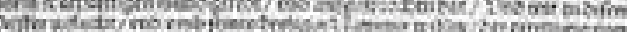

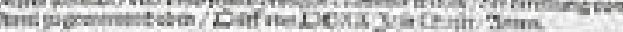

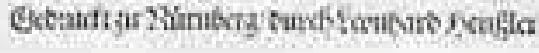




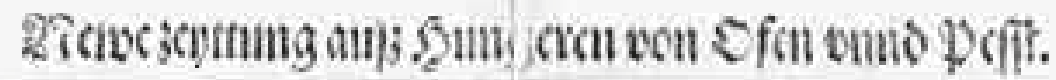
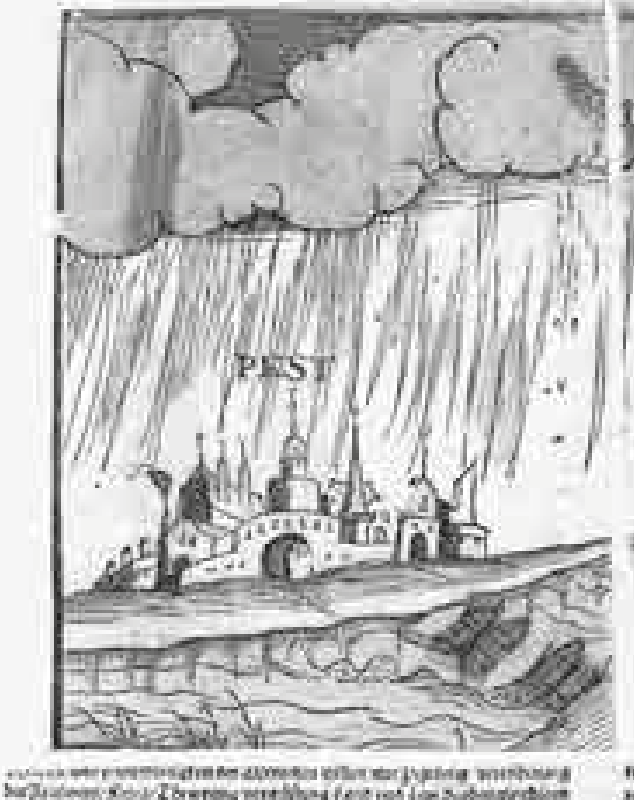

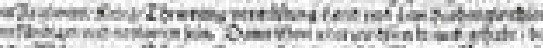

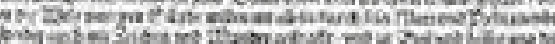

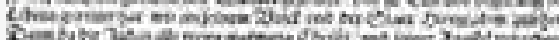

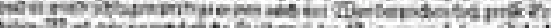

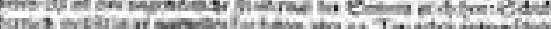

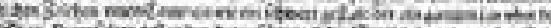

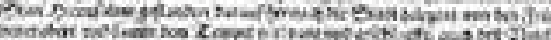

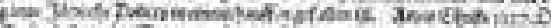
6 -

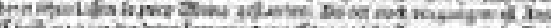

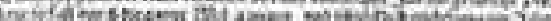
Ancon

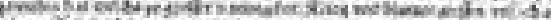

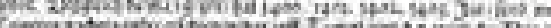

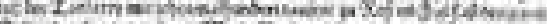

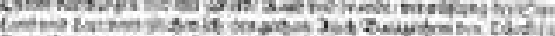
tom.

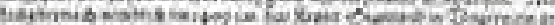
2010

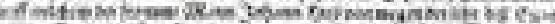
greposu. a ris

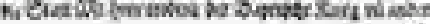

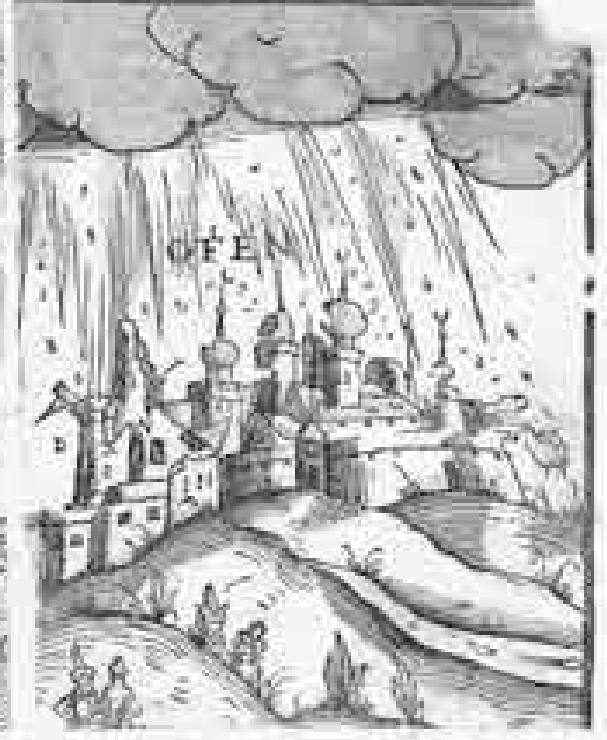

\section{0.}

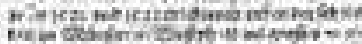

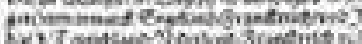
gino

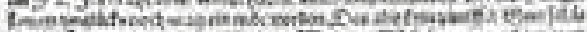

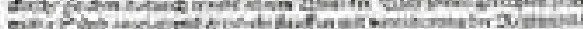

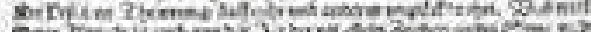

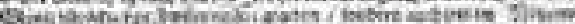

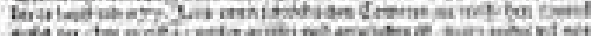

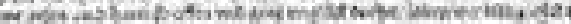
acter

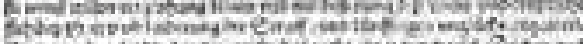
Din

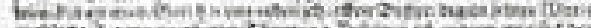
Sise

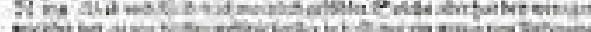

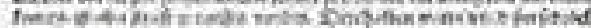

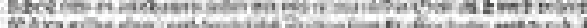

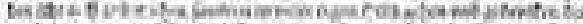

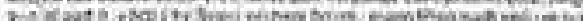

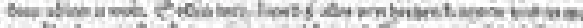

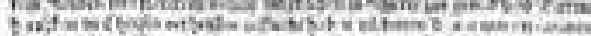

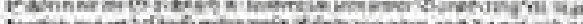

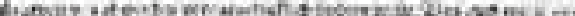

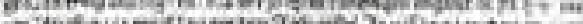

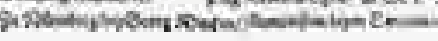




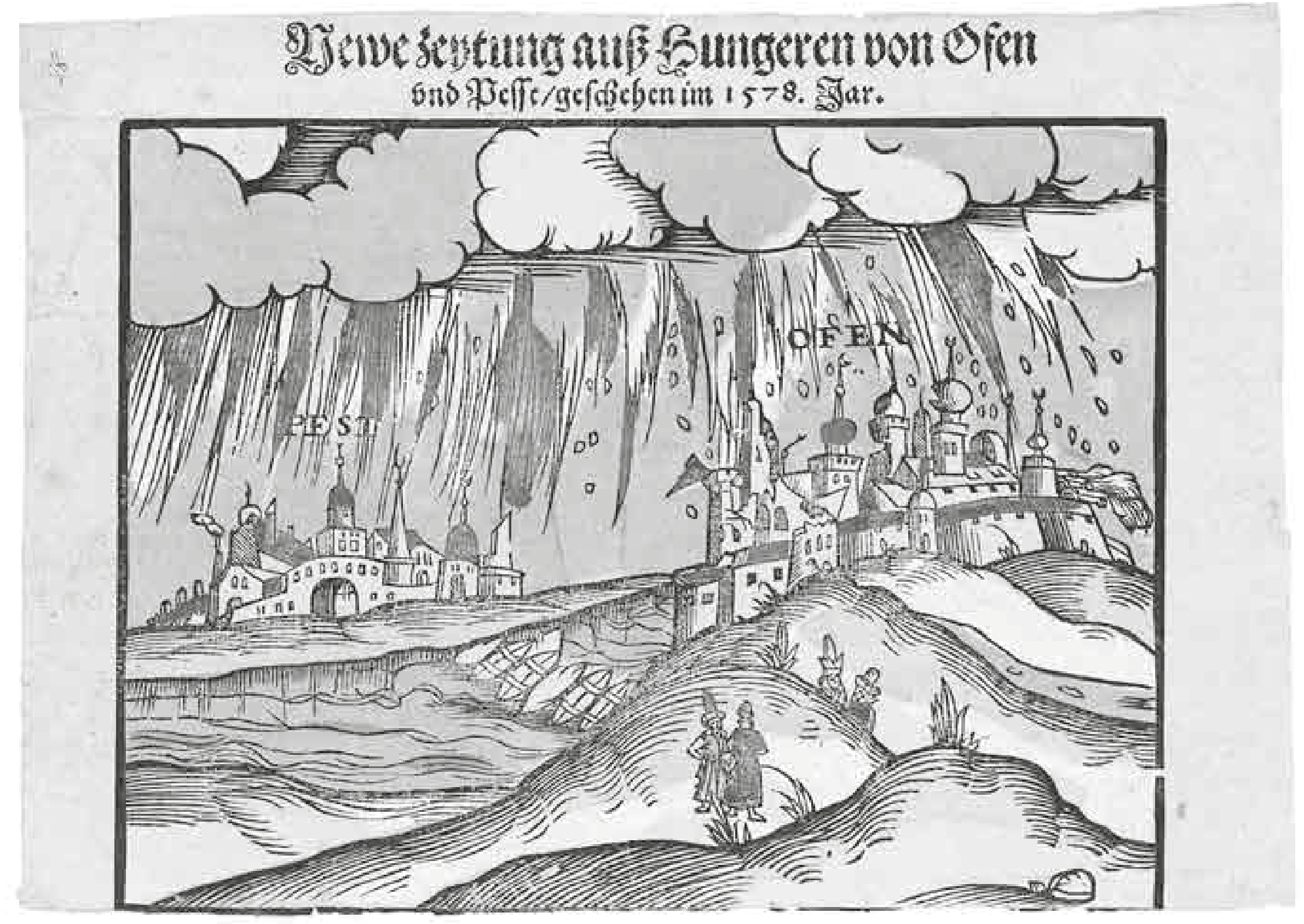




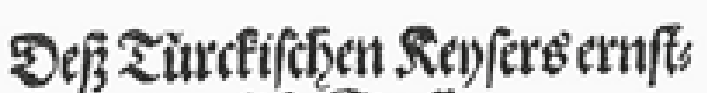
Iidue Straff.

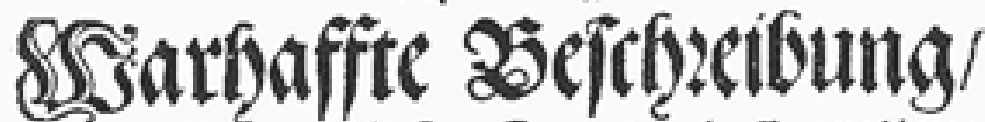

oefagroffenernftlicfern 30?ns ond Executtion/

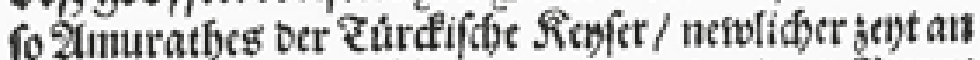

bem DRufapha Daffa bu Sfen/ vnb nod, an anoern bicyen \$etgen/

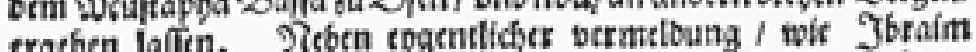
rrger bic vier gemeten Serren/ ofn alle genab ono verług Btrangulirt] bic vier genstien ferren / ohn alle genab bno bersug Strangulirt

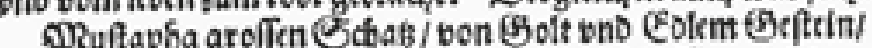

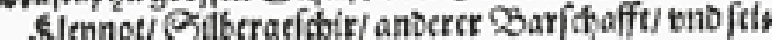
ner friegstifasing begeten vno besloffon.

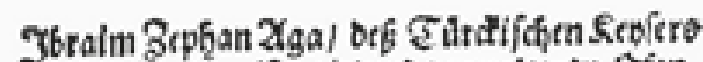

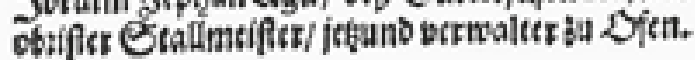

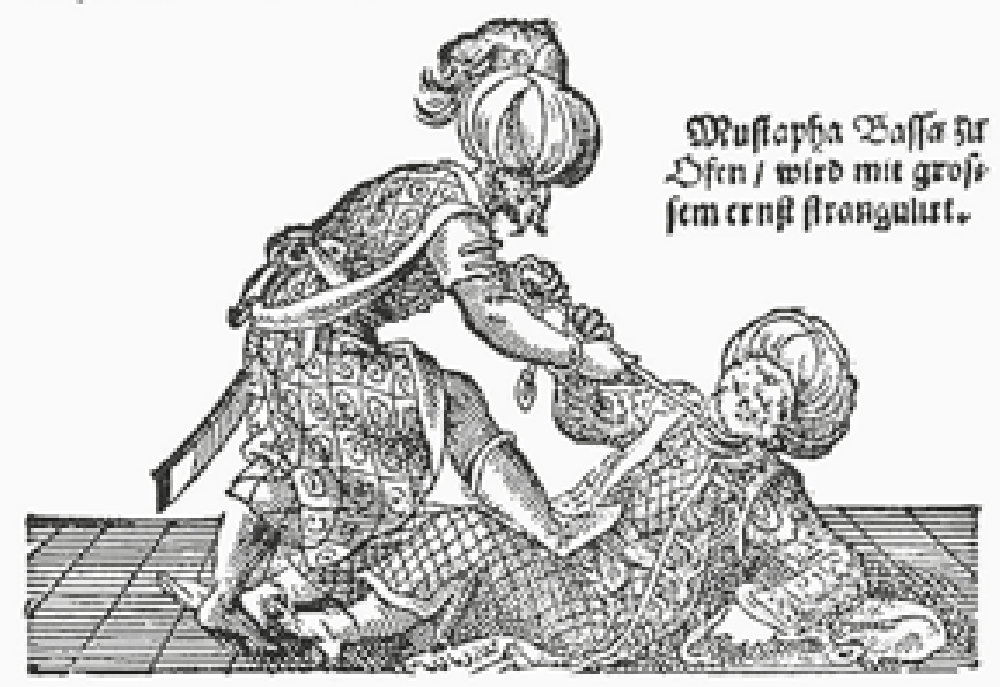

M. D. LXXIX.

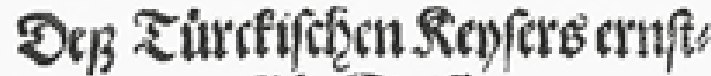 likbe Etraff.}

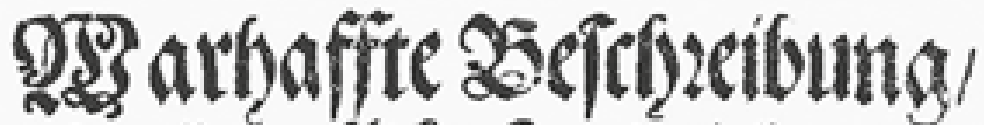

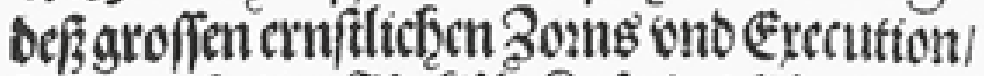

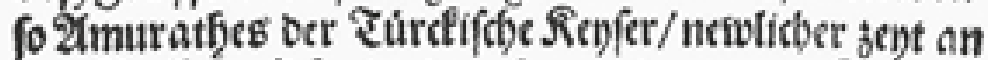

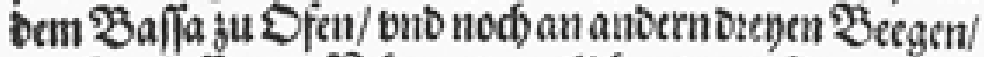
ergeben laffen. 2Reben engenticber vermeleung/ wic

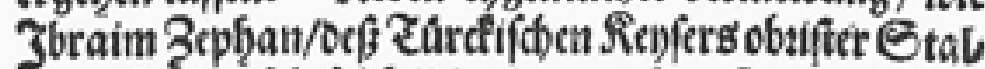
meifter/ auß befeleb/oie vier gemeiten Seerren/ ofn alle gnab vno verfug Strangulitt/ vno vom leben fum toot gebsadpt.

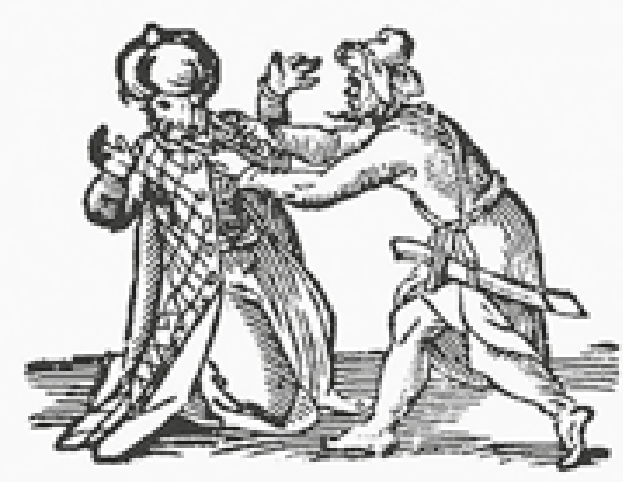

M. D. LXXIX. 


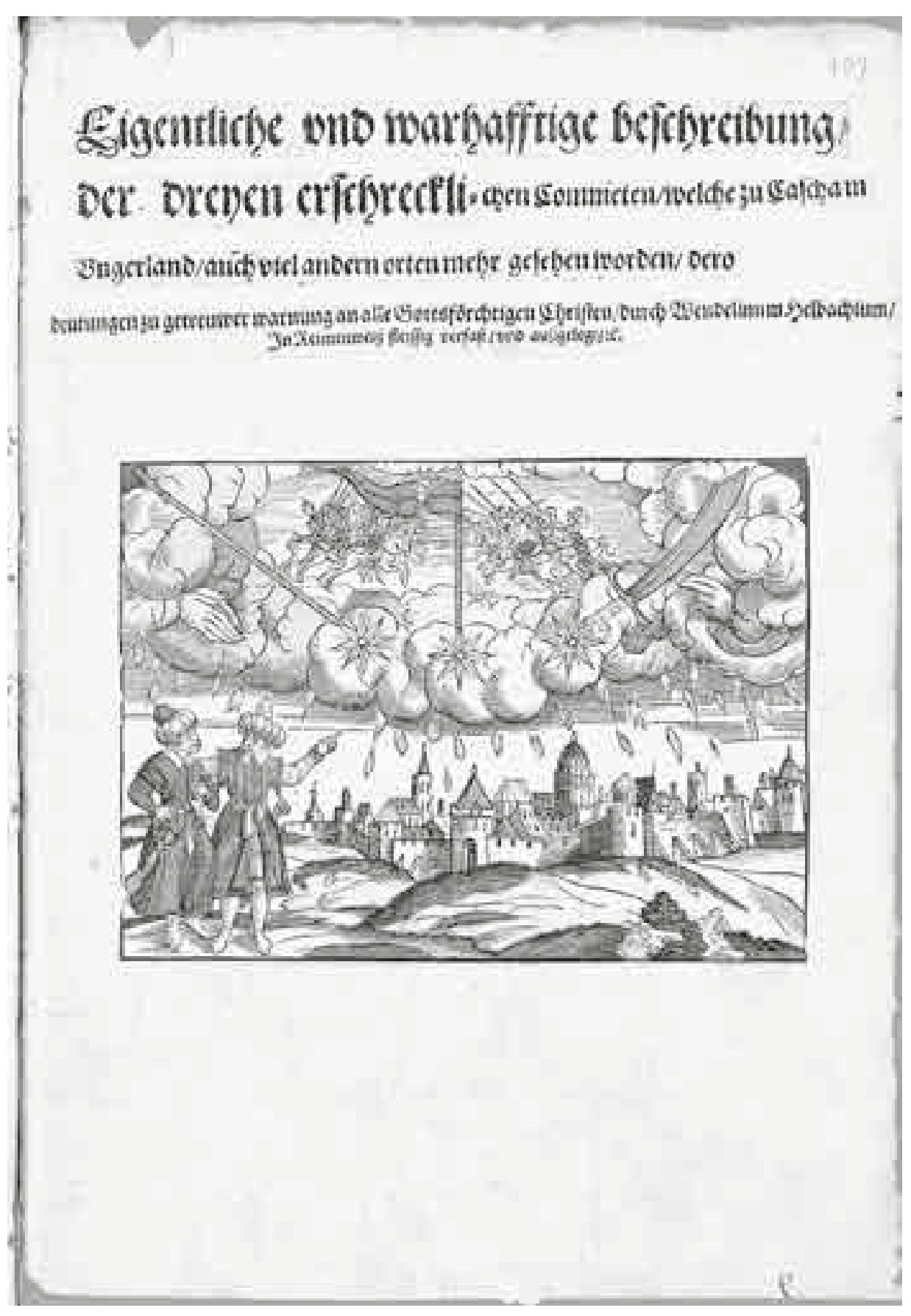


AnNo Domini 1580
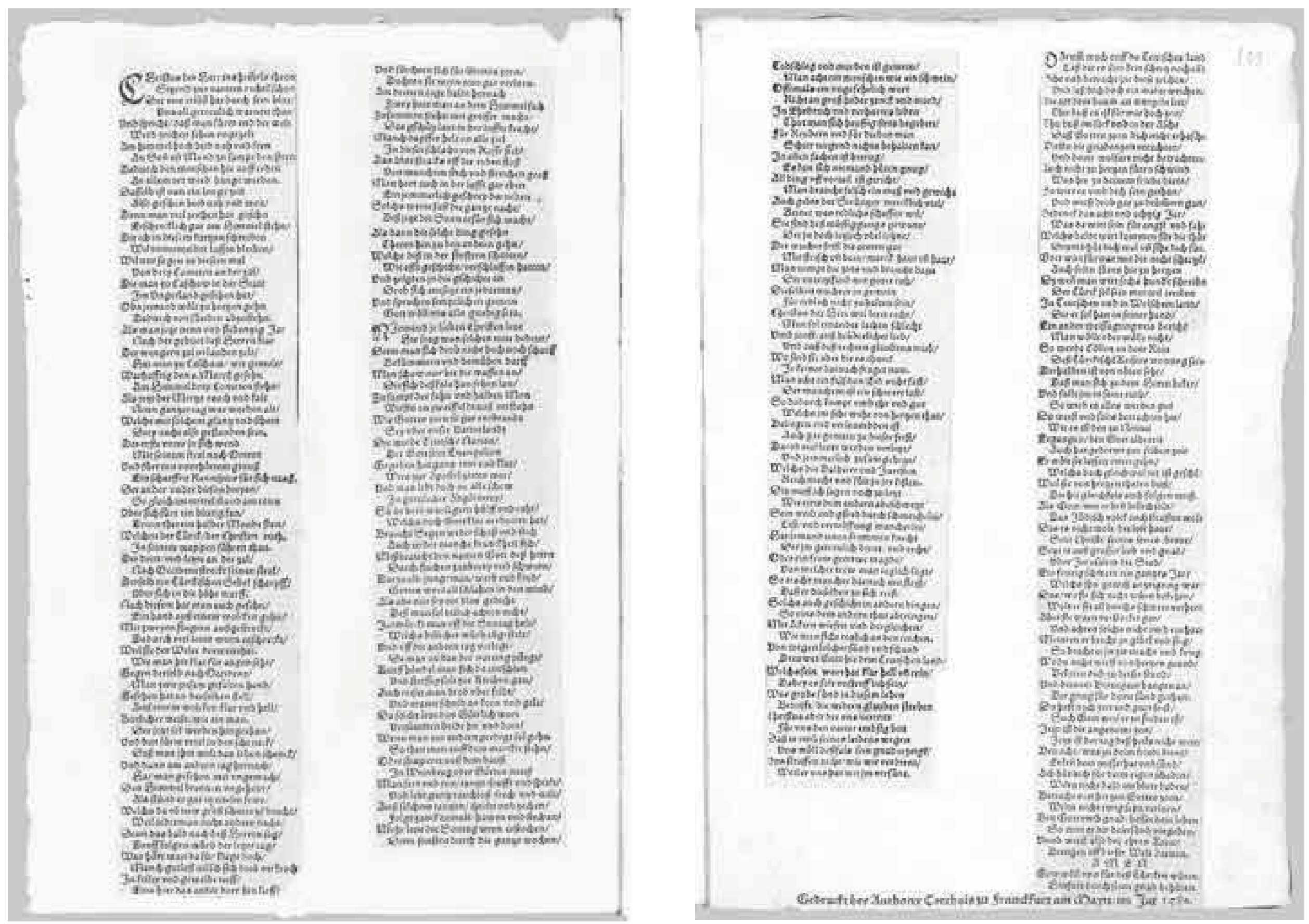

159. kép Kassa röplap szövege 


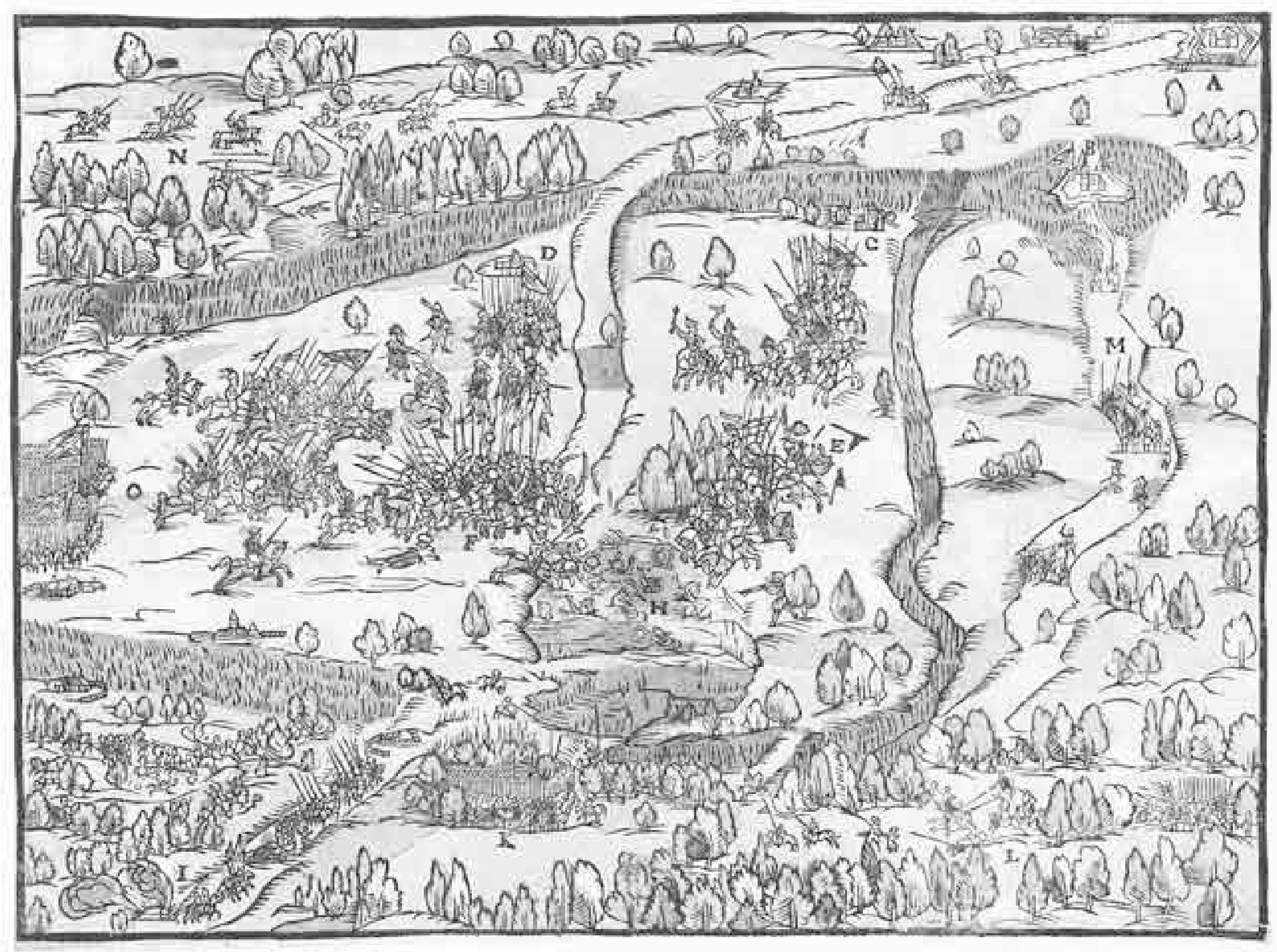




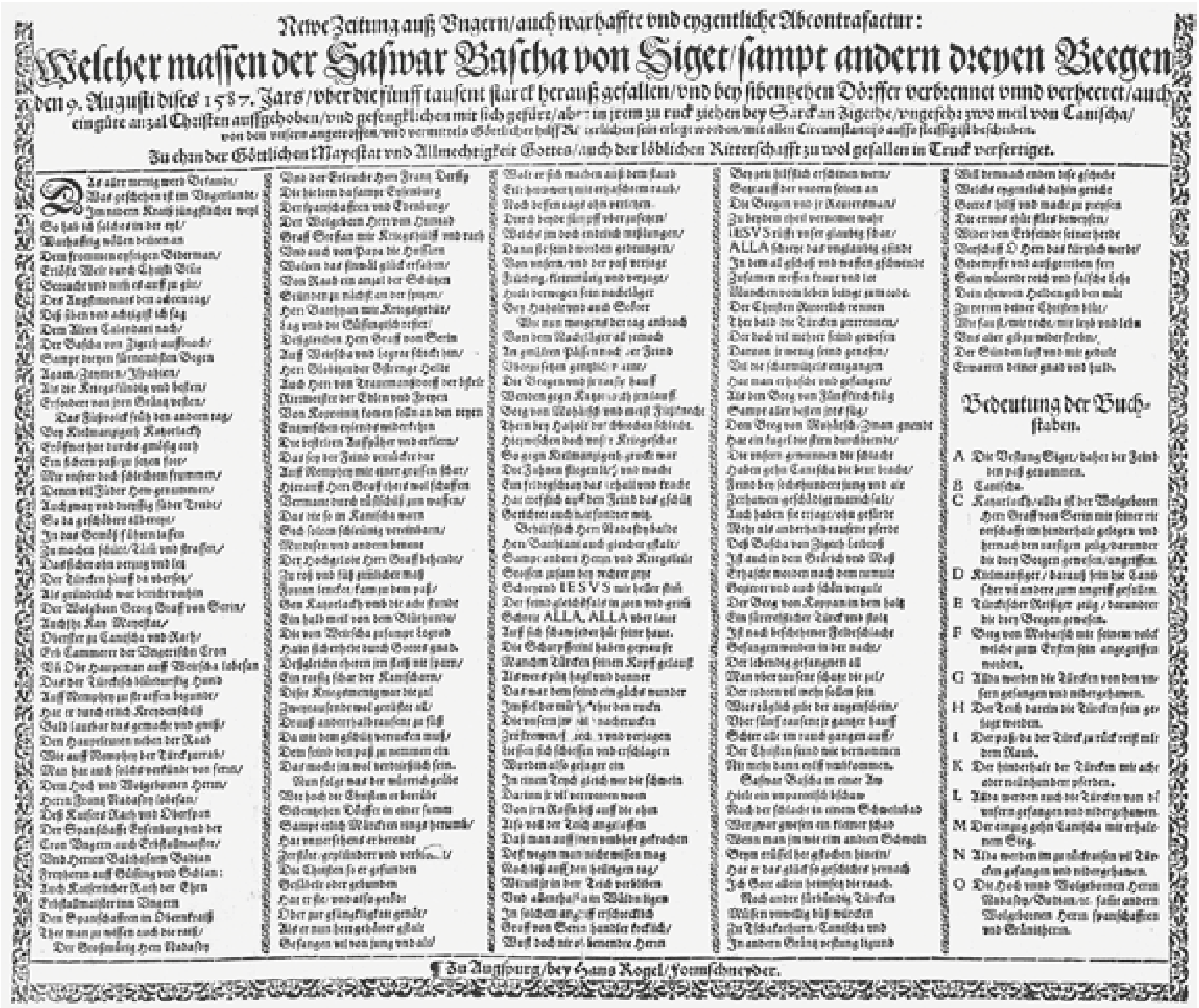




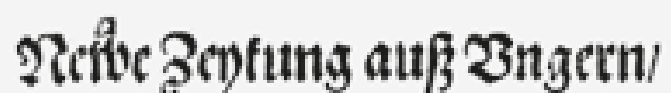

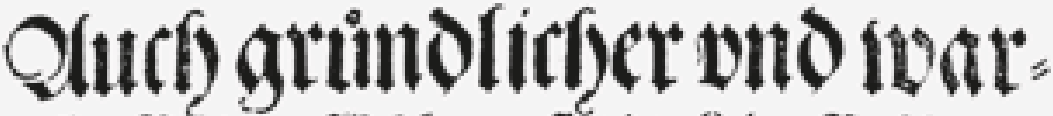

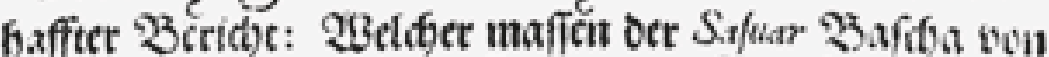
Q Xiget/ fampt anoern Dieyen Beegen, oen 9.21ugufti/ Dijes 1587. Tars/vber oie funff taufenot ftarce bcranf gefallen / pno bey Bibentzeben E daffer verbiennet vnoverberet/audb ein gate ans

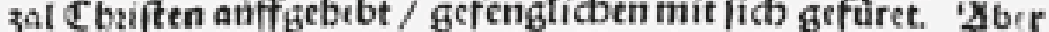
in jbem zu ruct sieben / bep Sarkan Zigethe, vngefeb: 3000 megl wegg don K anifba / von ben pniern angetroffen / vno ver. mittels (sòtttidber búlff/ Xittertíben jetino erlegt worben/mit allen circumftanti)s anffis fict)igifte befabieben.

$$
48
$$

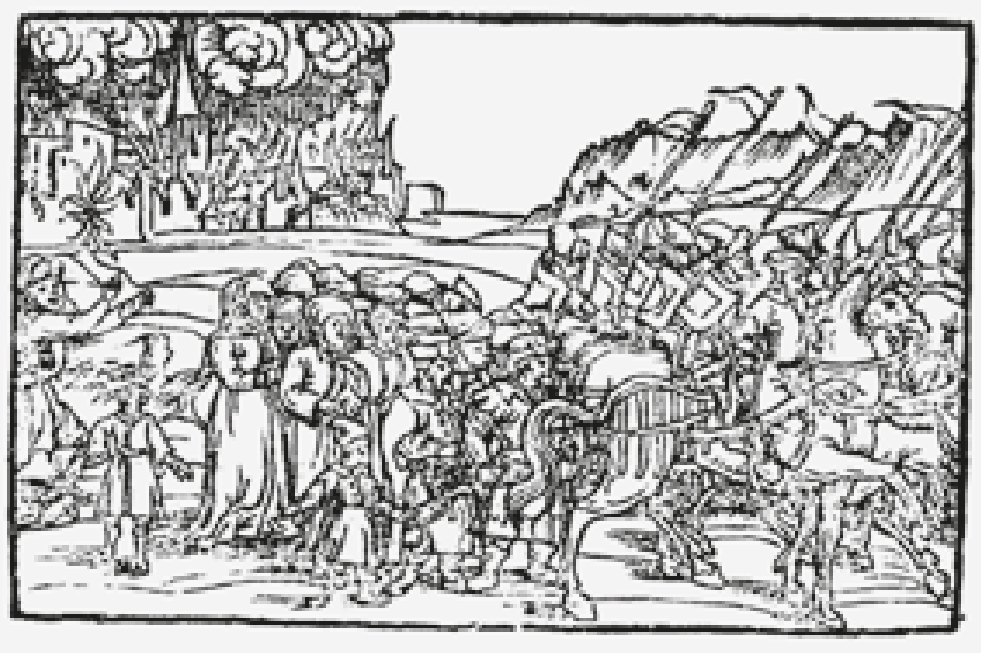

Gcosucft 孔u Rürnferg/ ourch Eecubard Spanfirr.

\section{$M$ D LXXXVII.}

\section{VICTORIA,} \$oer Zevttumtsen/fo

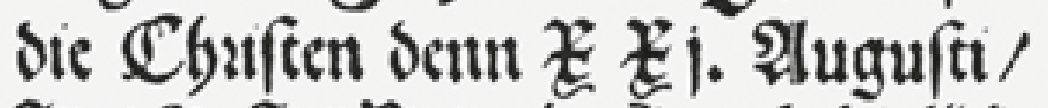
2nno 8>. Inn Dngern bey Zasertadh/glücts. lic) mit Bottes bilff oem Cutcken aberhalten/ Dergleidsen bey Mlanna geo encten nic er. bout obee gefthebct ift.

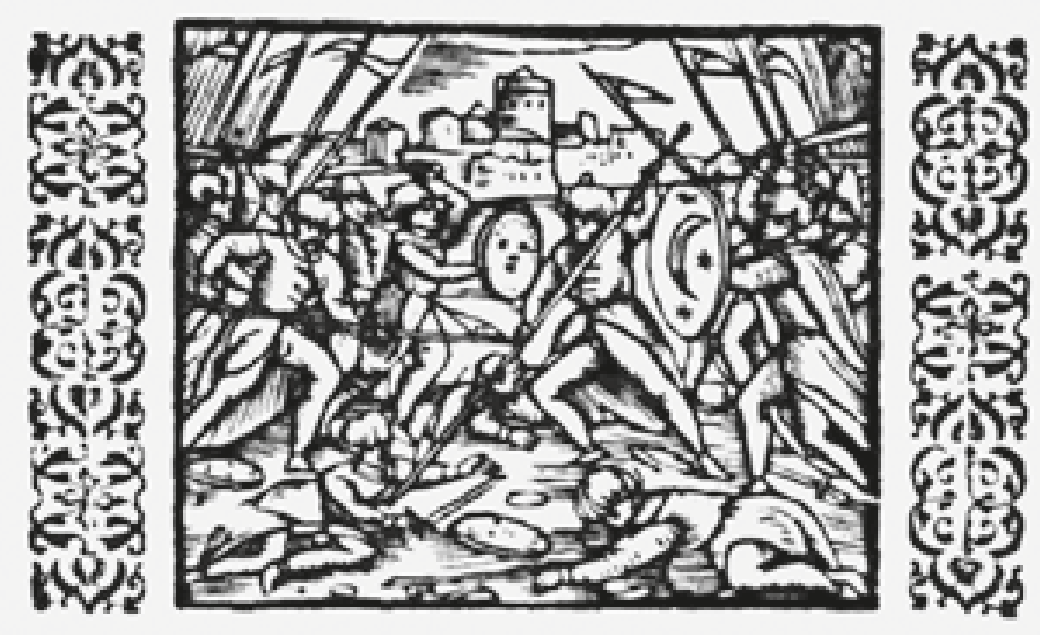

Anno Domini M. D. LXXXVII. 


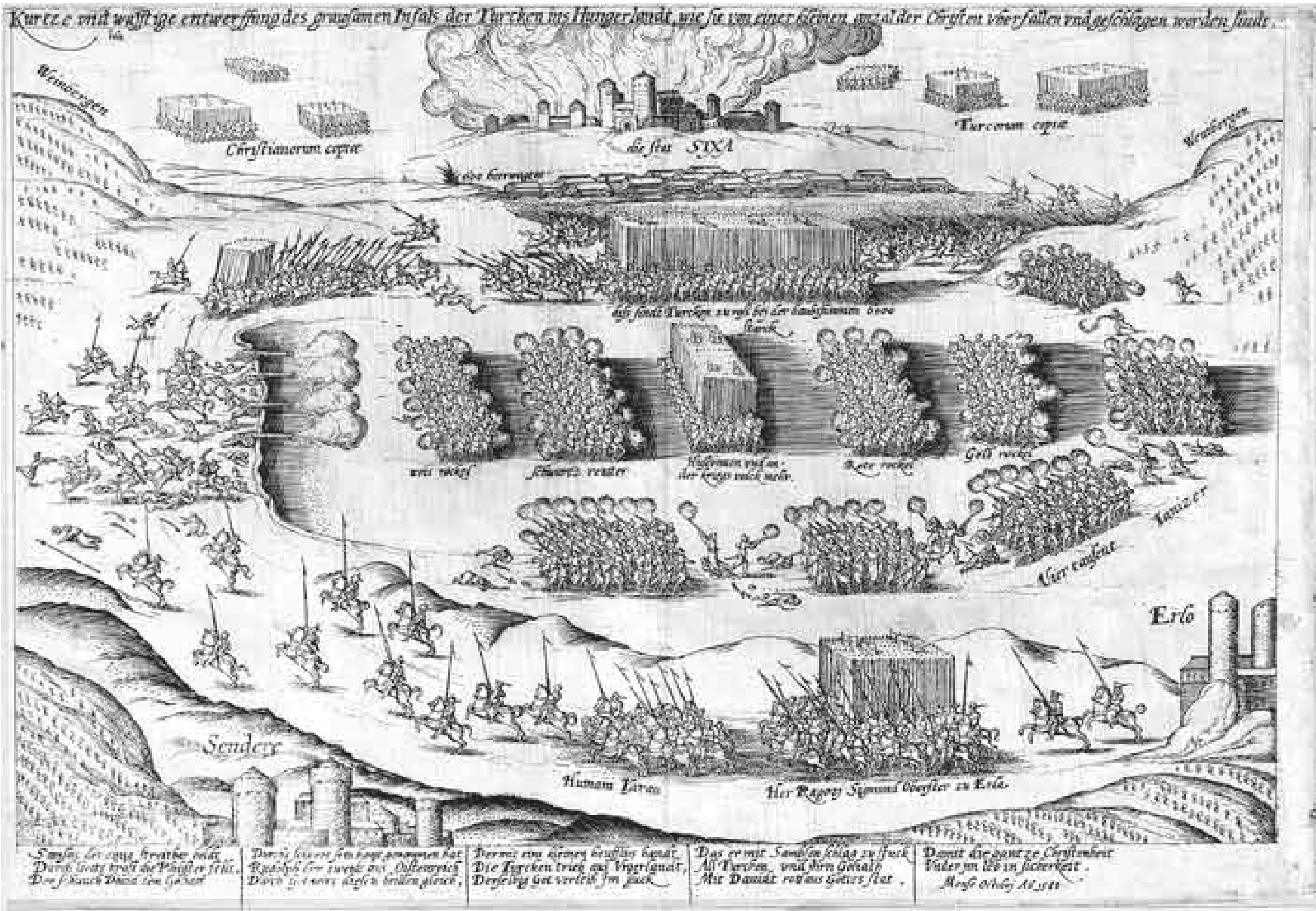




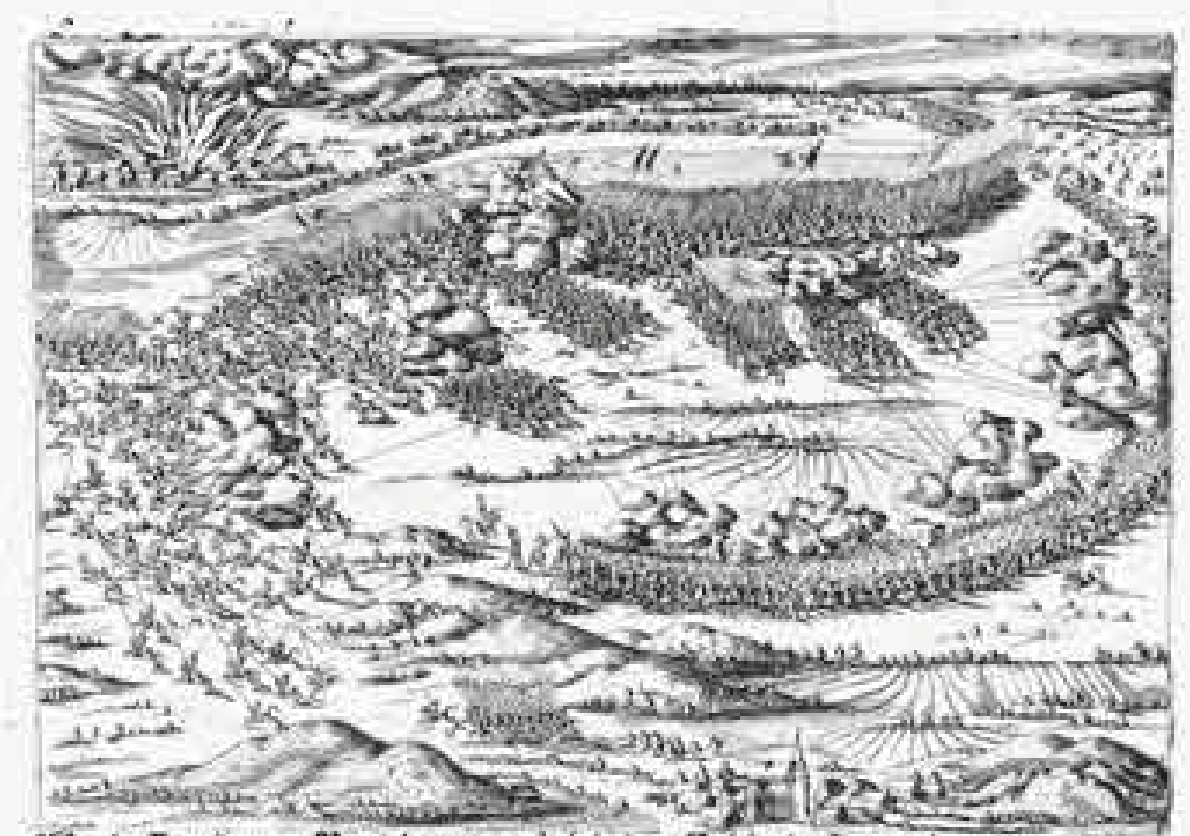

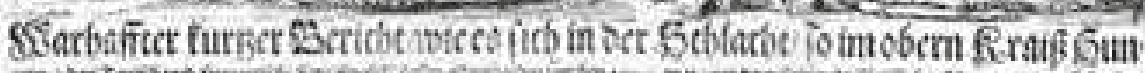

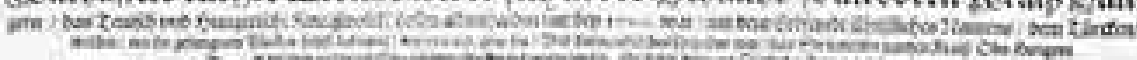

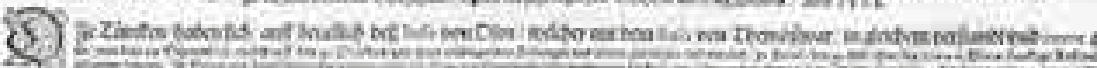

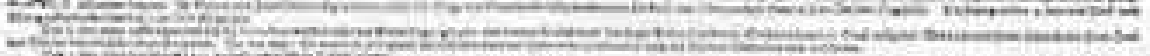

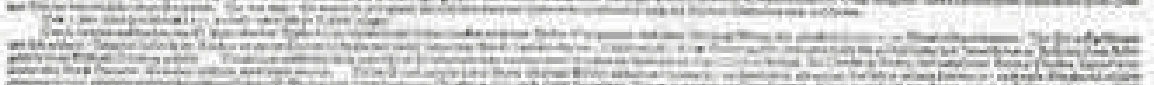

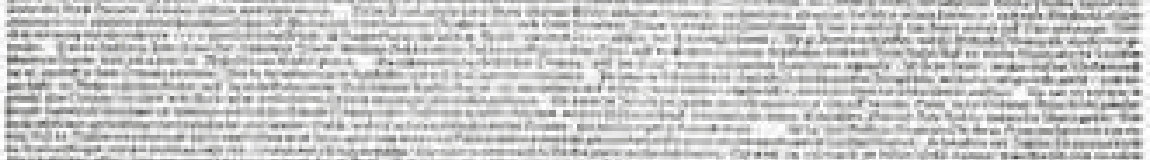

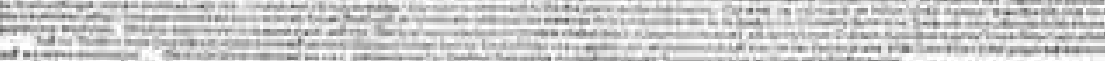

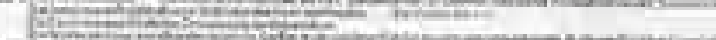

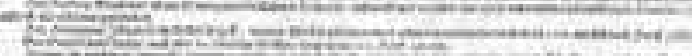

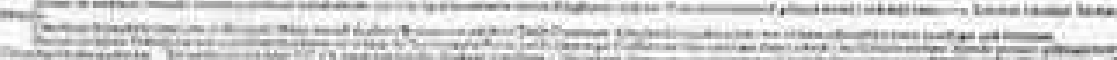

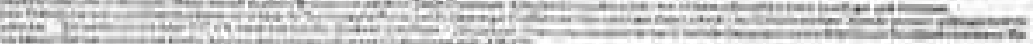

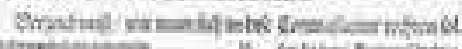

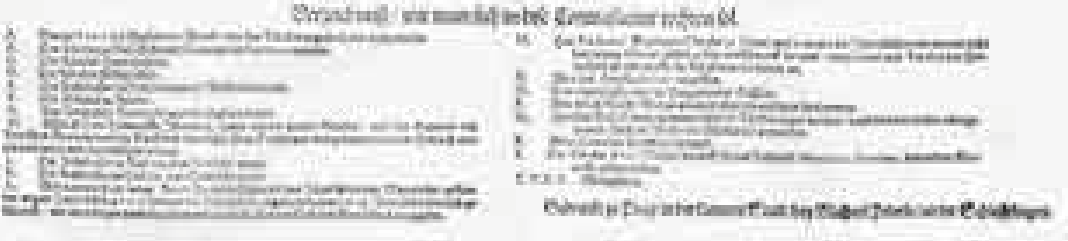




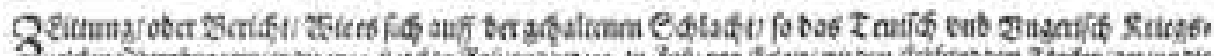

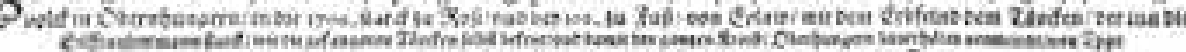

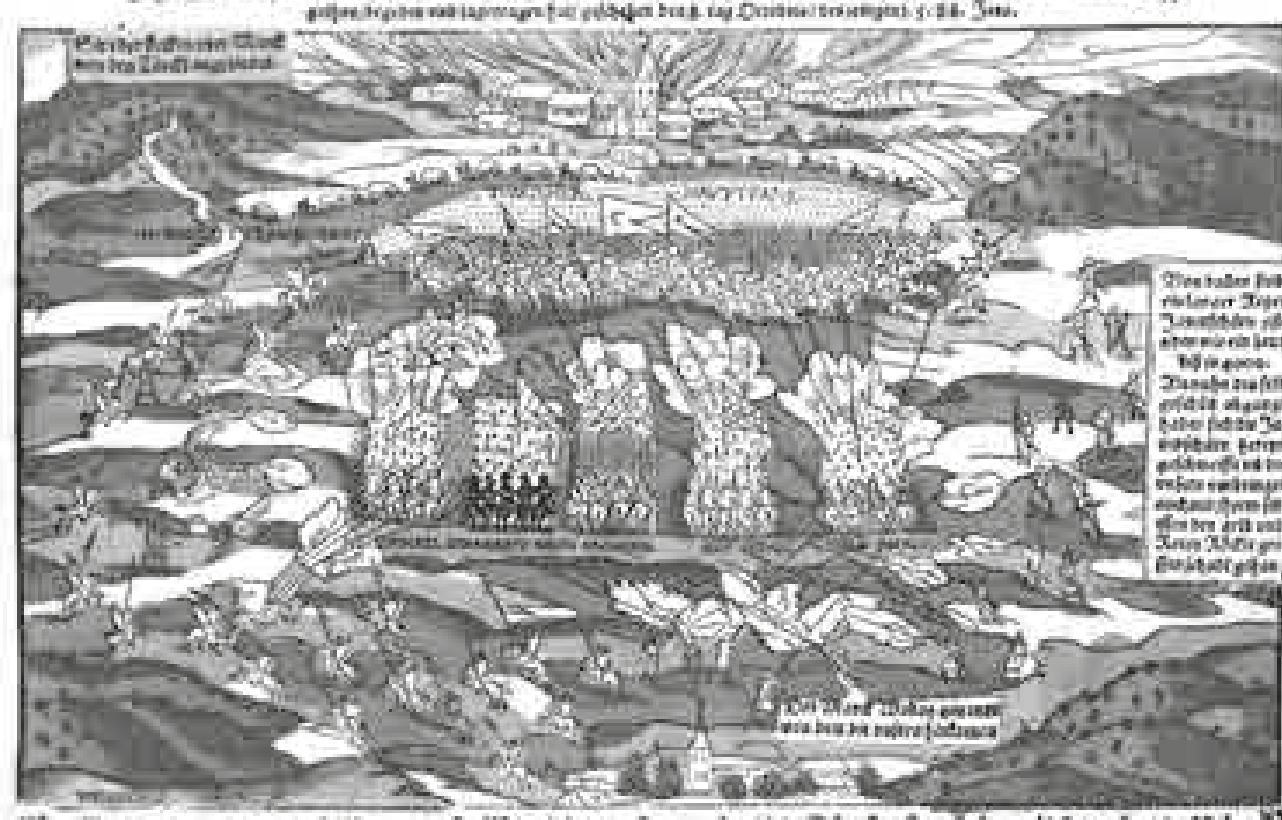

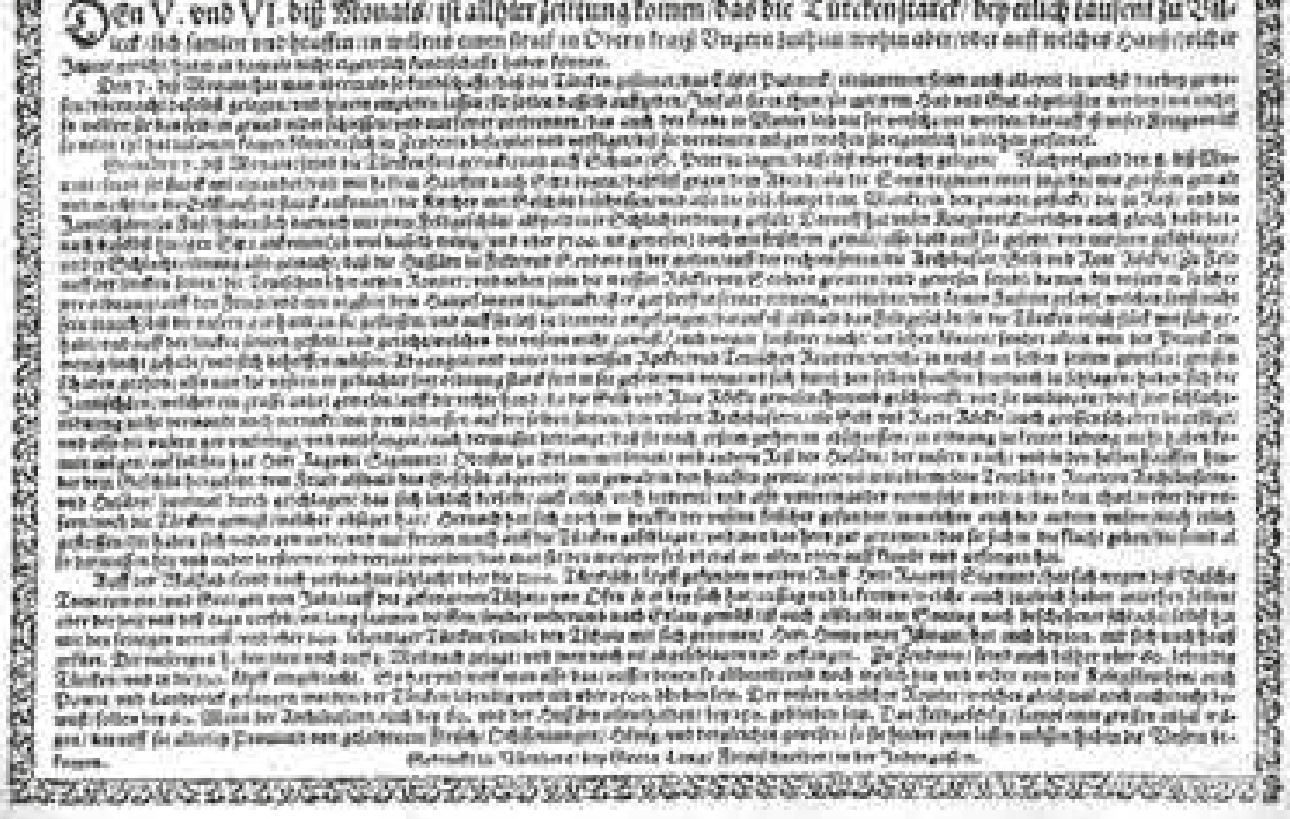




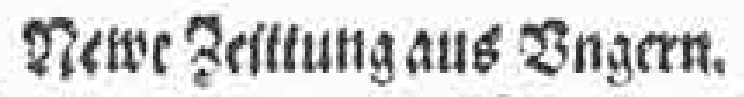 folltrect berifit oer bet bem siardt Eirom ober f̧ungern/ won

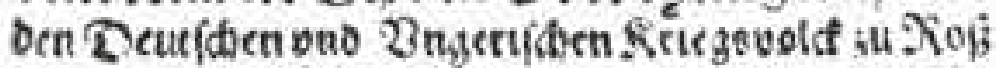

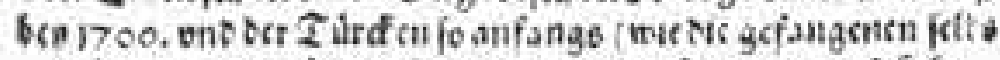

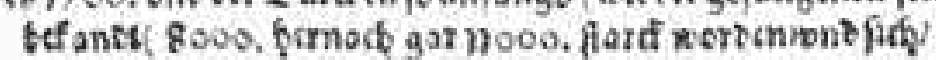

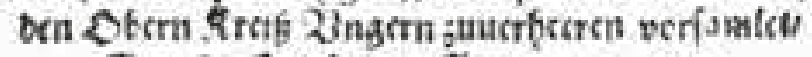 Den \&. Satobrie, Xmo is 8 \&. Brquateren Sdtacht."}

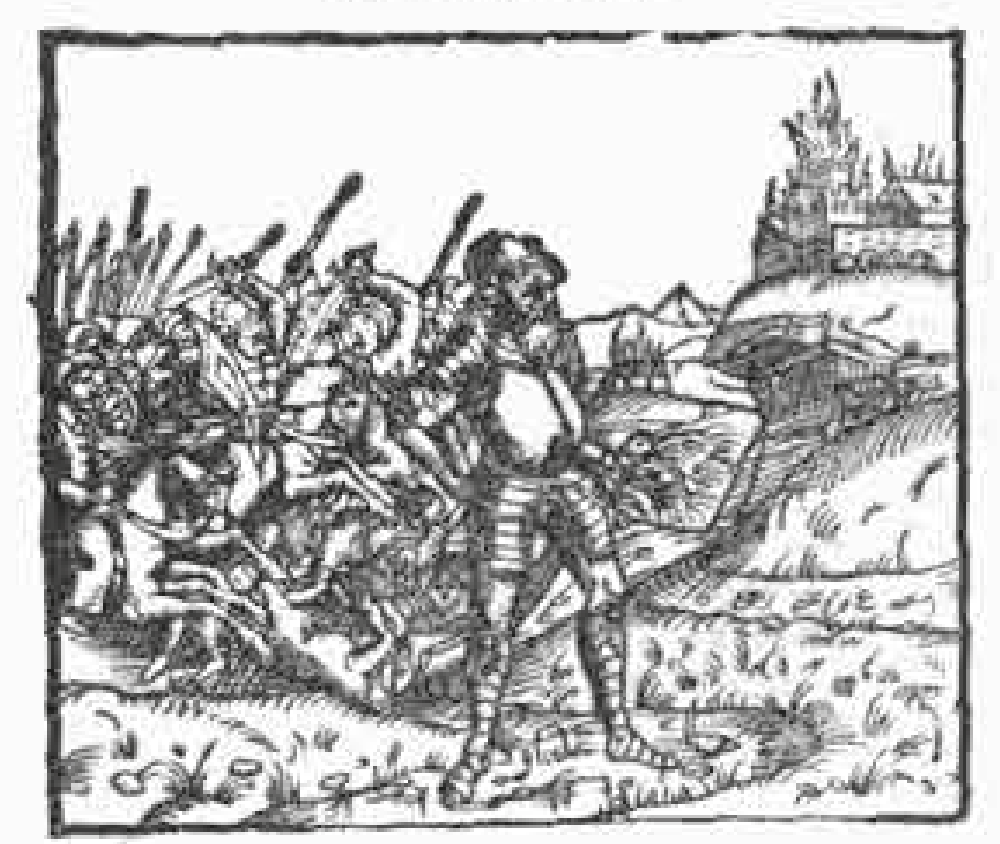

ร2. จ. 2xxxuil

\section{Tücfifdic Interlag unts 2?ciec 3eyttuny.

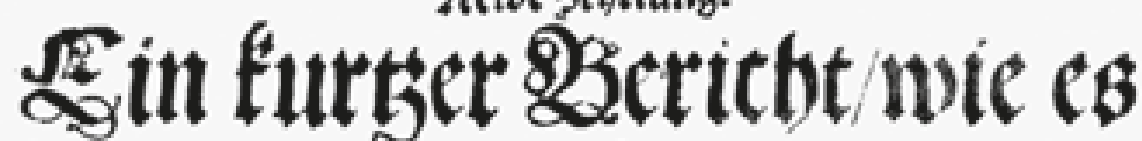
fiḑ auff Der gebaltenen Sdylaçt/ fo cas Veuts fice vno yungerif

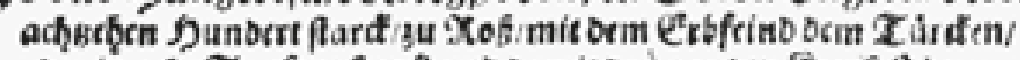

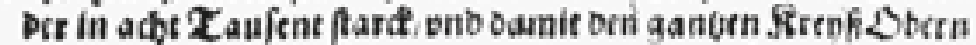
Dunacrn znuerberen orrmeine (wie bie gefangenen Surden fulbs bofenbt) 2 or Eiget gehalteny begeben bab jugetragen bit. Befobebsu oen 8. Drtobrioraniso, 5 88 .

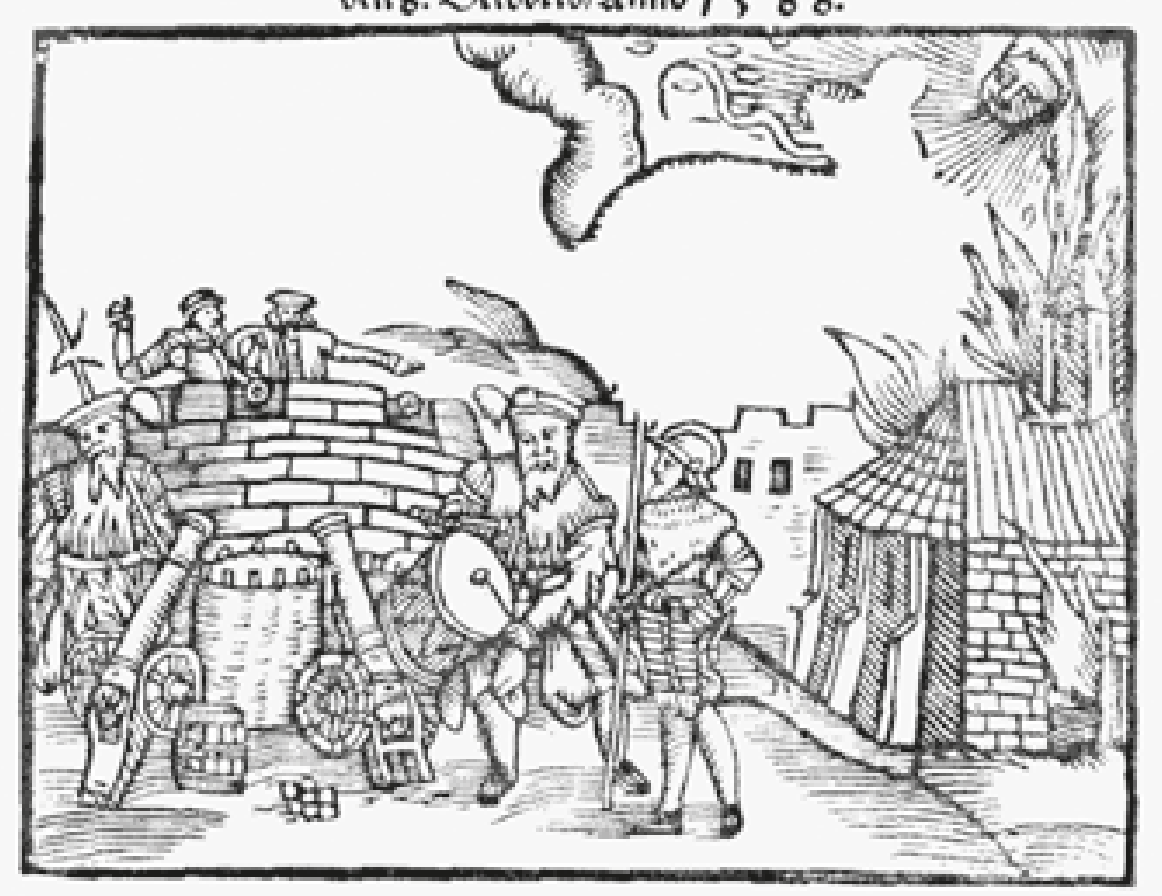




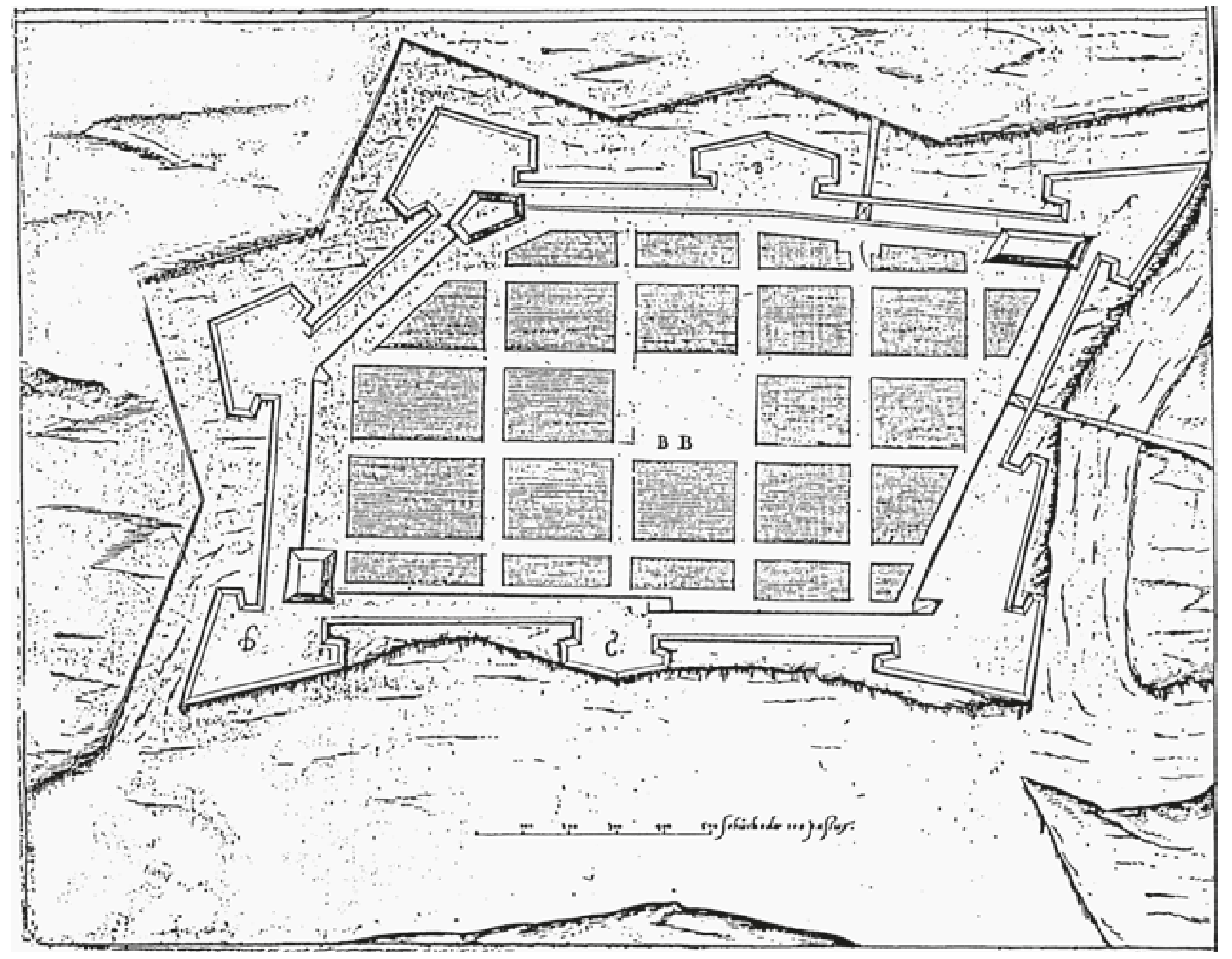


Braun, G. -Hogenberg, F.

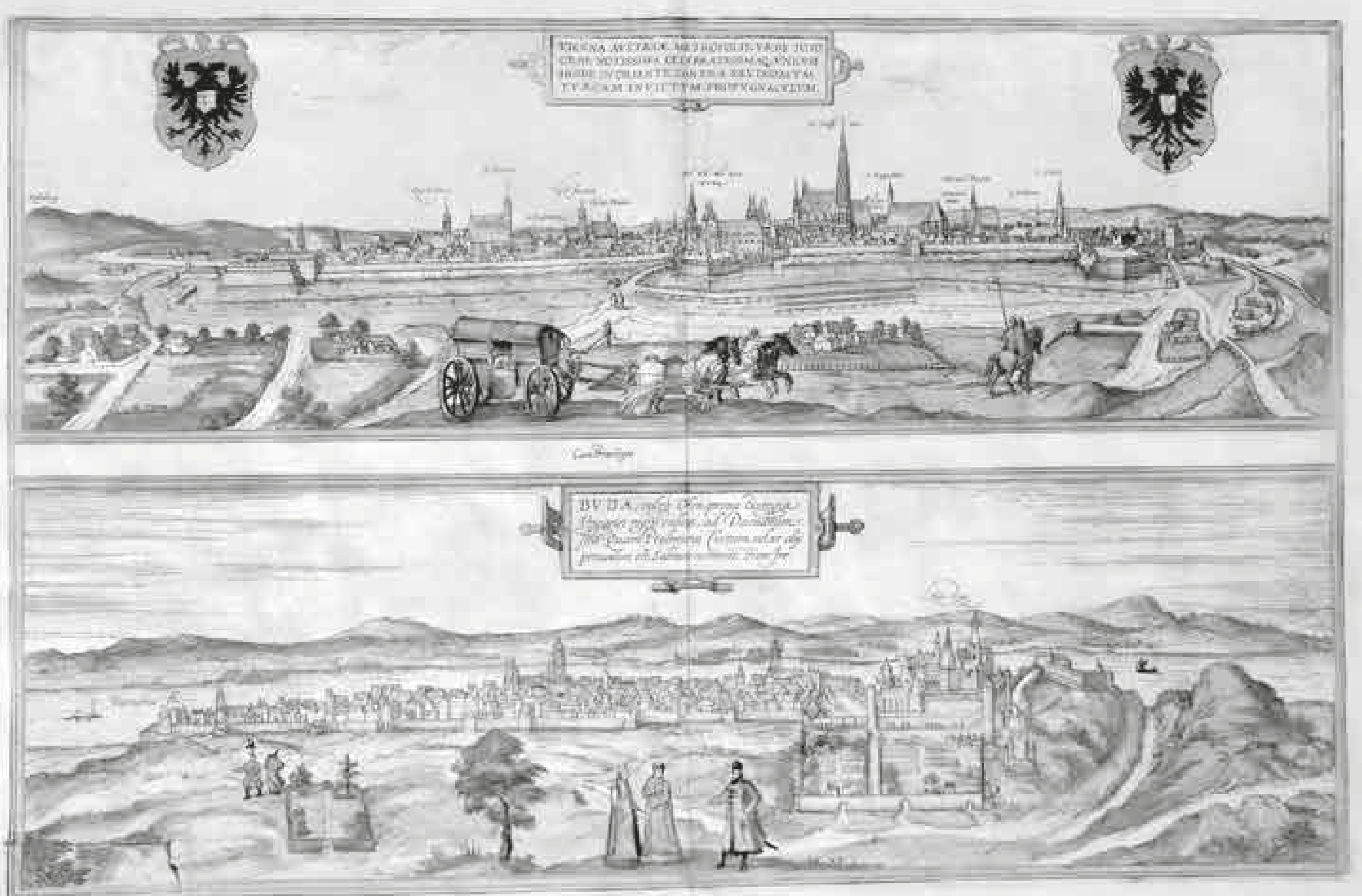




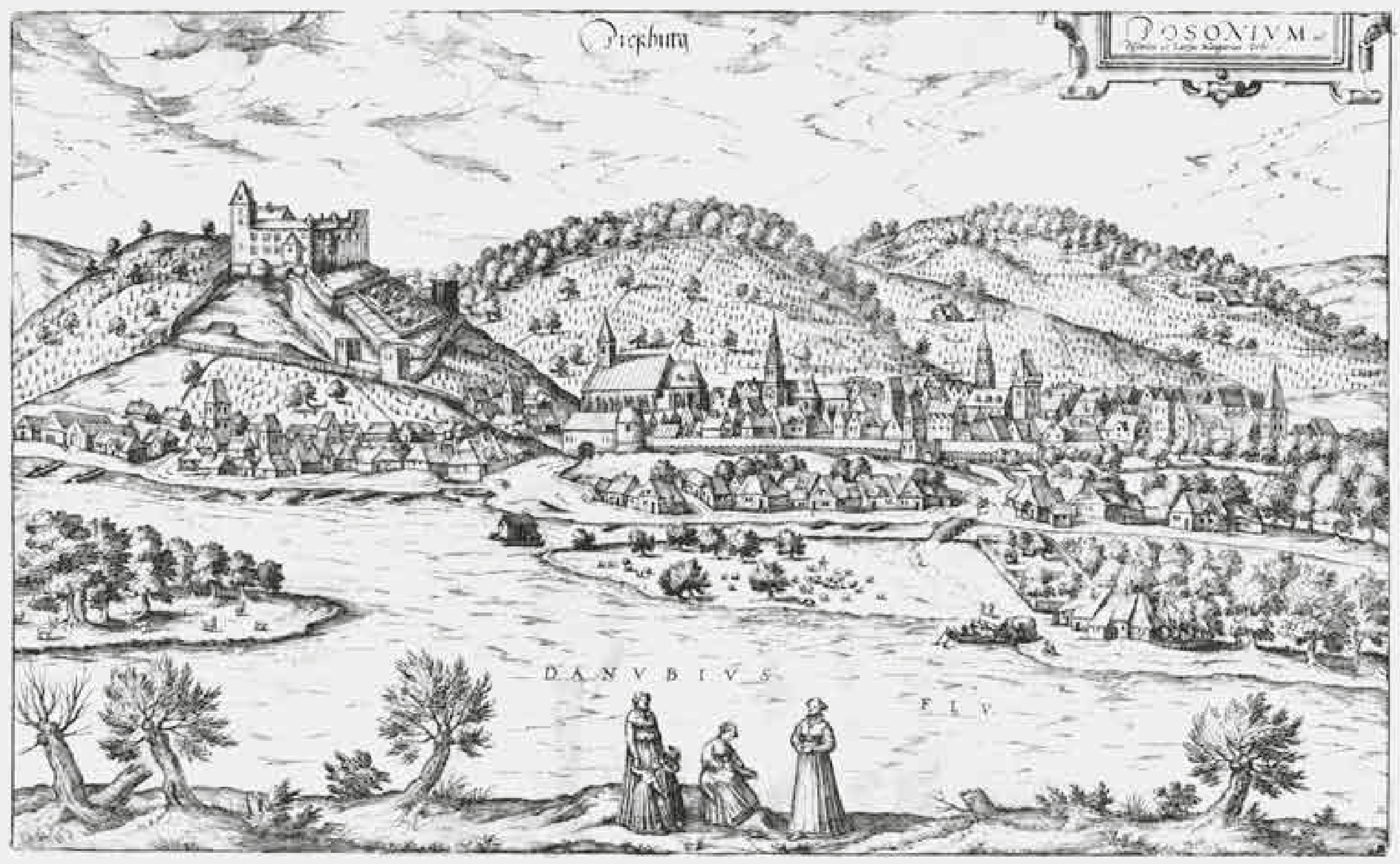




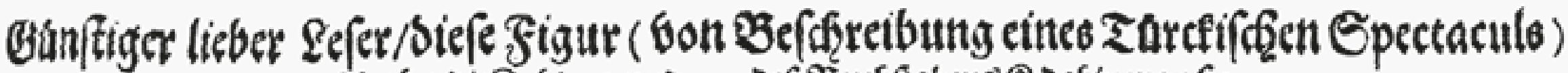

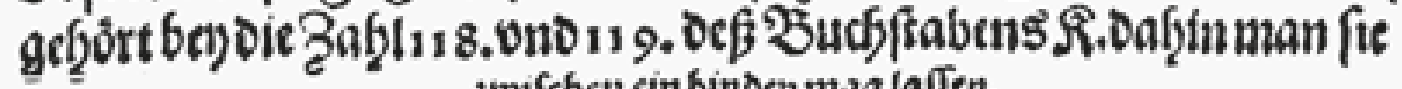 jwiftchencin binoenmag laffen.}

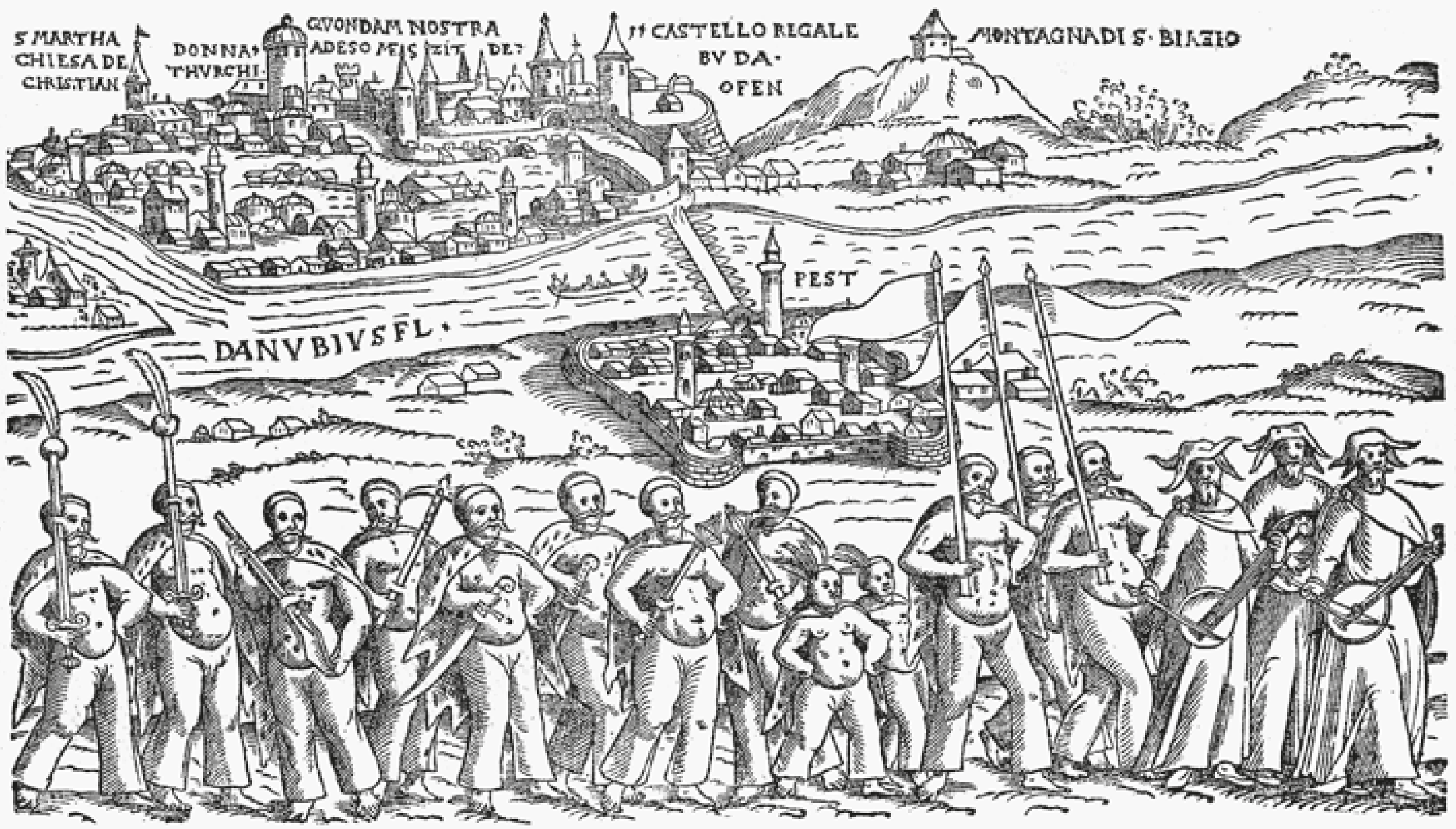




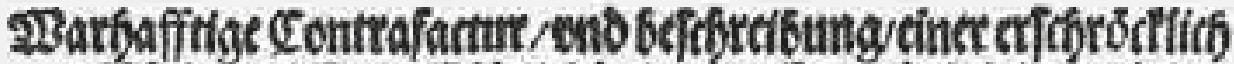

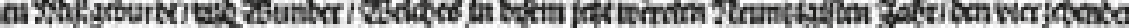

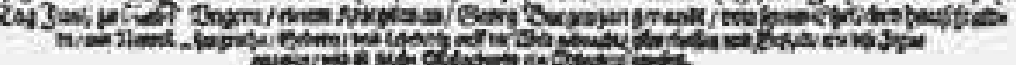

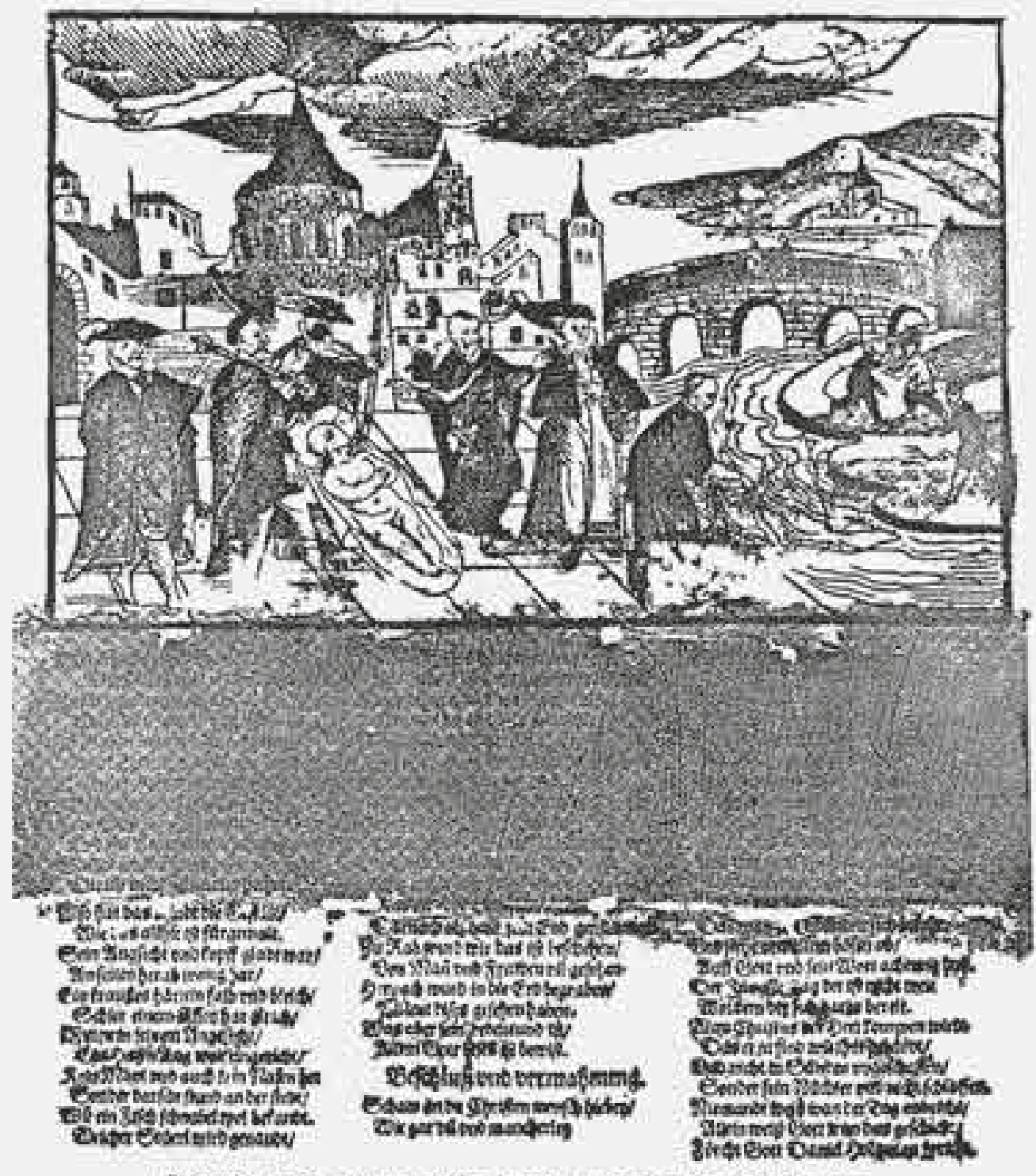

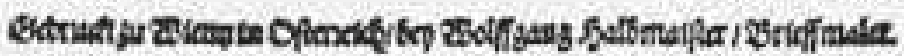




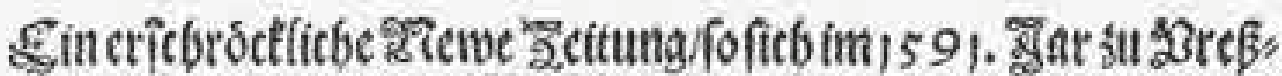

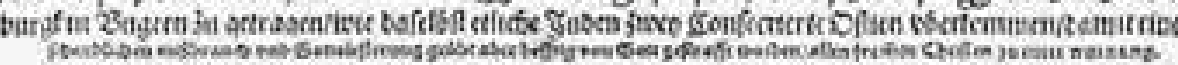

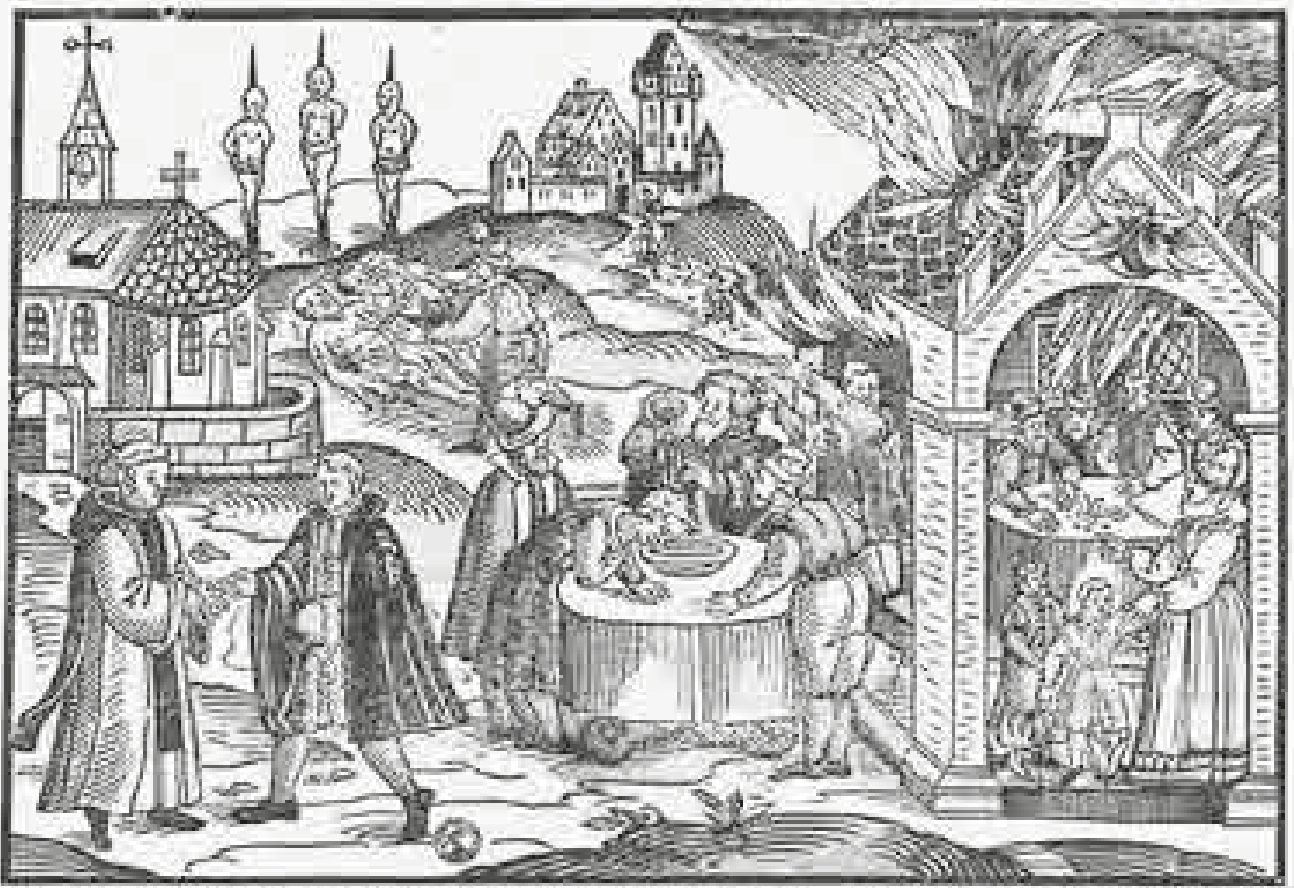

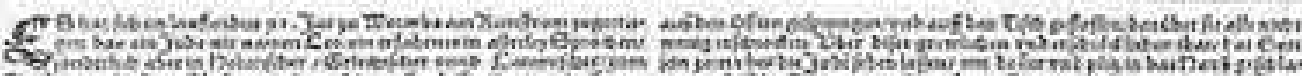

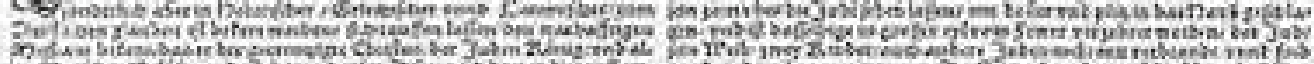

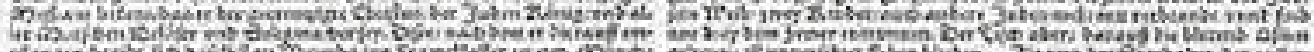

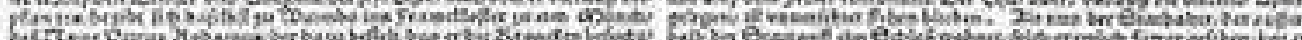

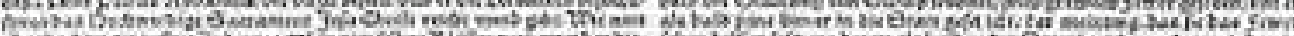

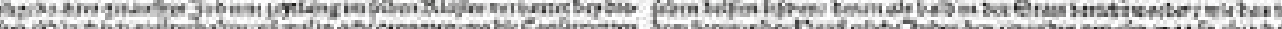
Gina

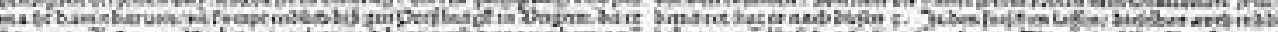
Astro

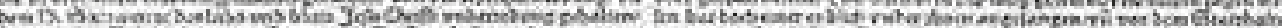
At

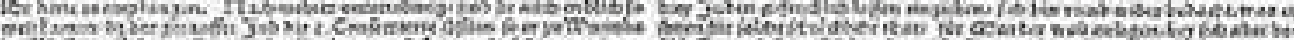

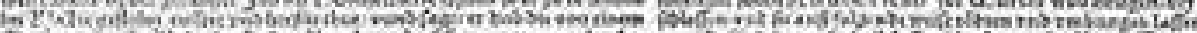
Fencine r. CrCen

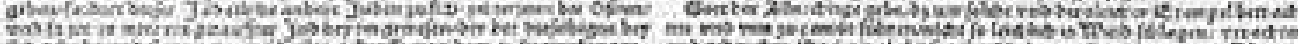

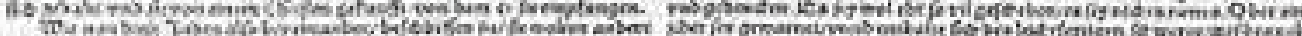
3 Min rench

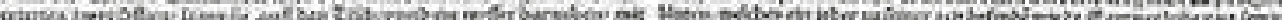

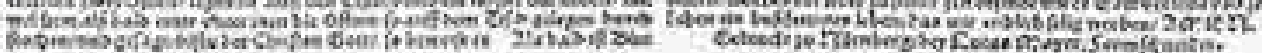




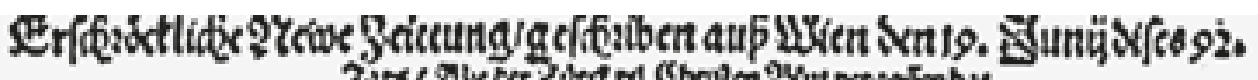

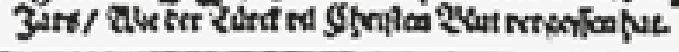

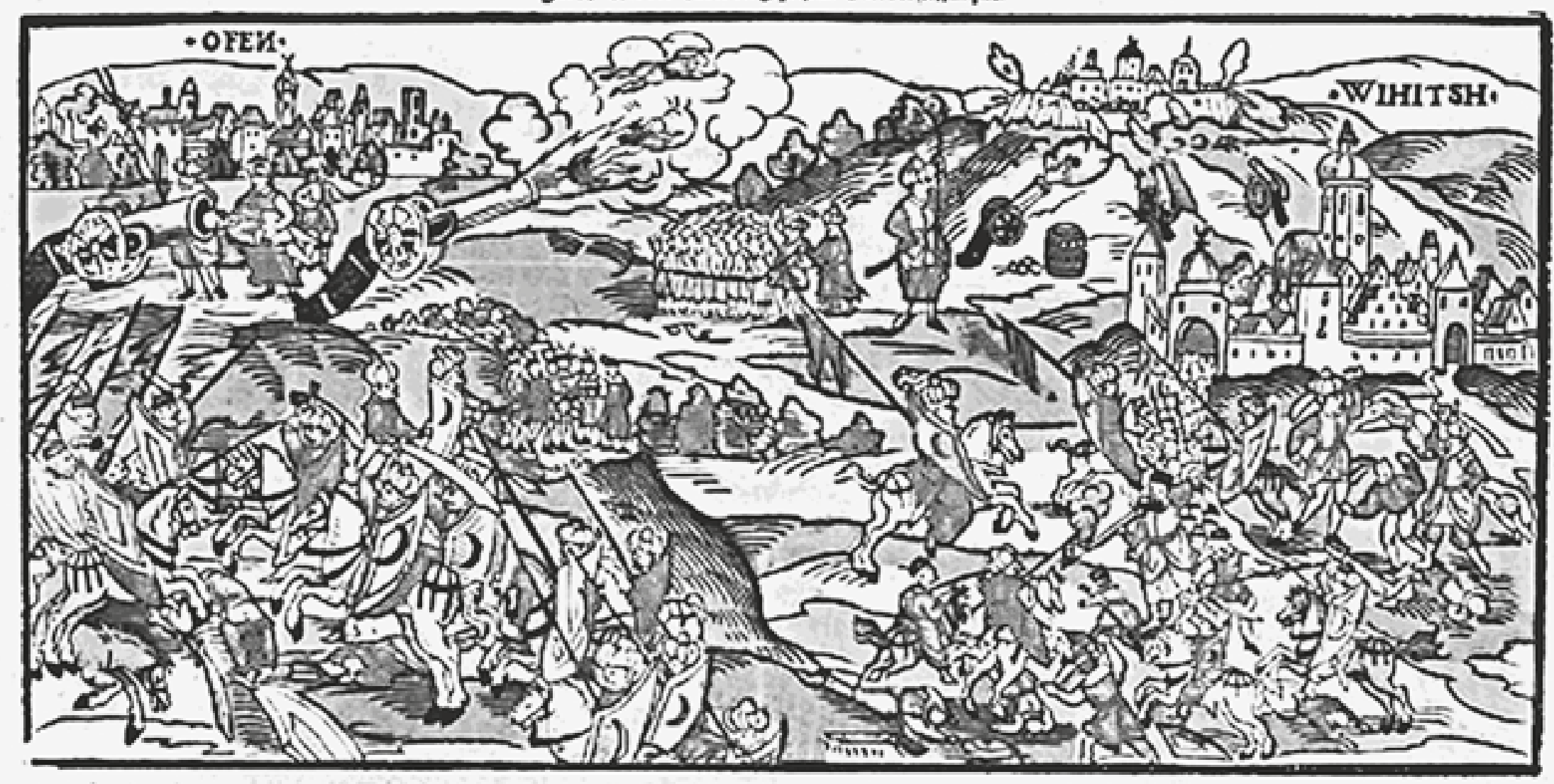

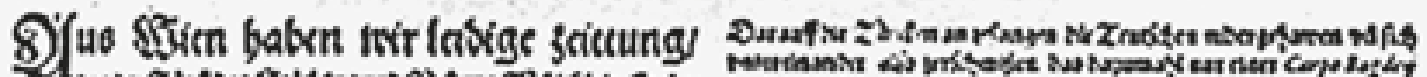

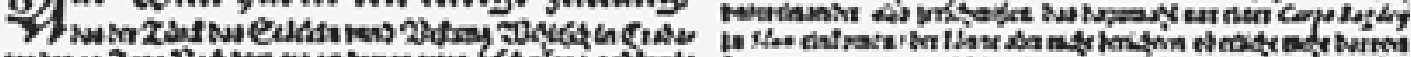

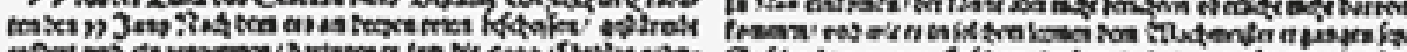

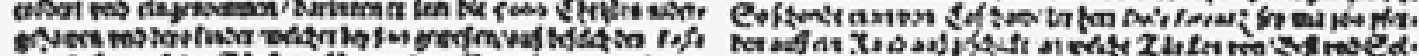

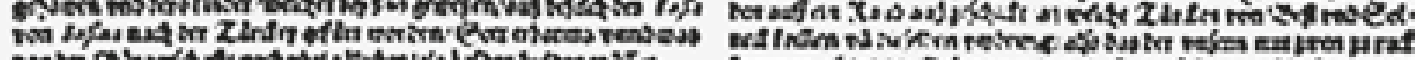

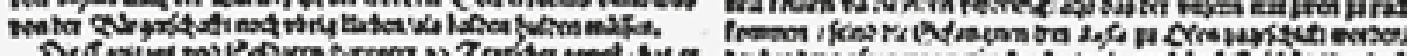

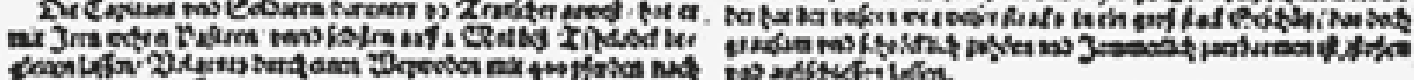

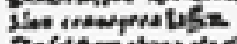

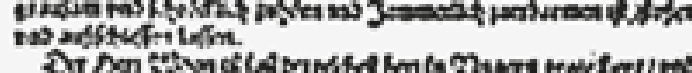

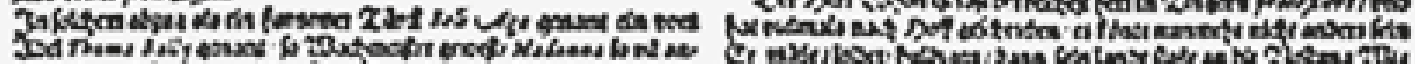

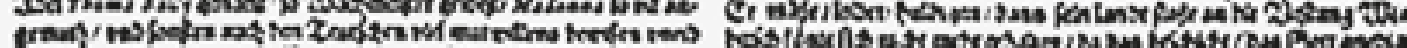

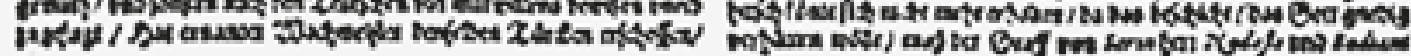

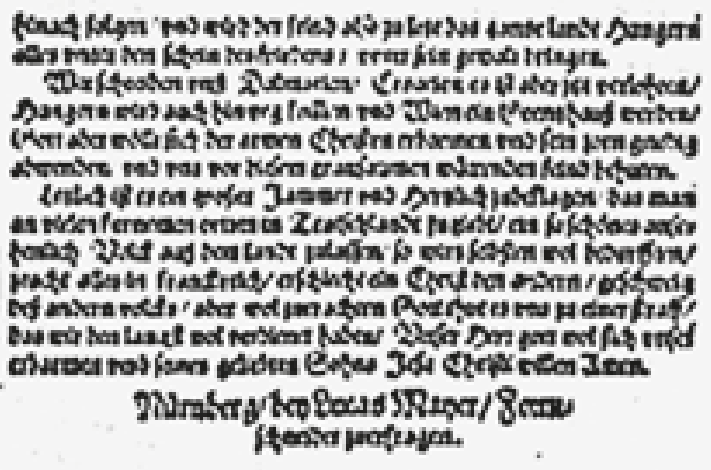
itemid postisipa. 


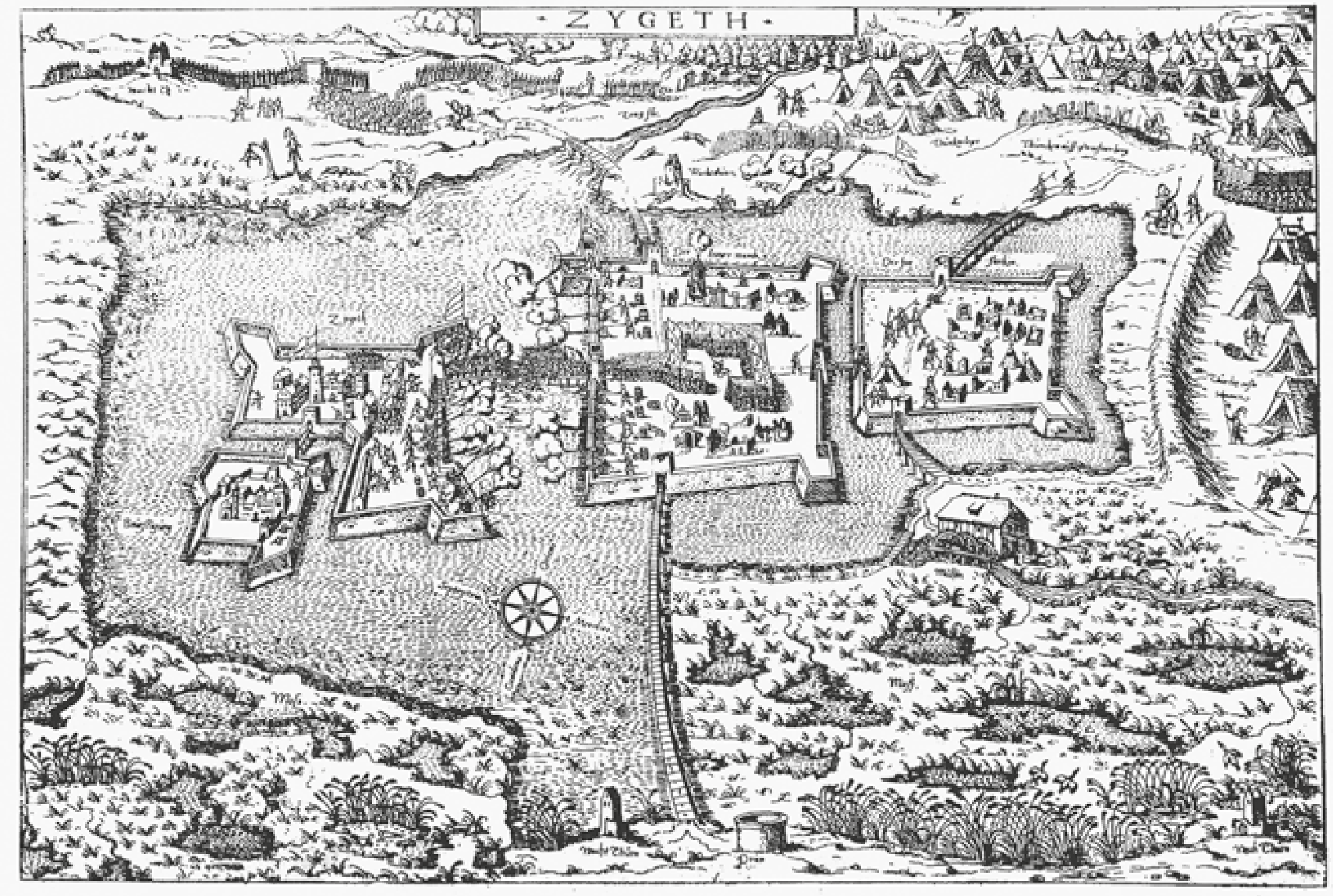

176. kép Szigetvár 1566/3 változat (lappangó)

(A metszetet csak fényképről ismerjük, annak alapján a Szigetvár 1566/3 metszet korábbi lemezállapotú változata.

Lappang, örzési helye, méretei nem ismertek) 